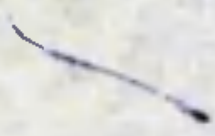

\title{
m
}

\section{CHURCH AND STATE IN ETHIOPIA}

$\underline{1270-1527}$

\section{TADDESSE TAMRAT}

A Thesis submitted for the degree of $\mathrm{Ph} . \mathrm{D}$. in the University of Iondon, February, 1968. 
ProQuest Number: 10672804

All rights reserved

INFORMATION TO ALL USERS

The quality of this reproduction is dependent upon the quality of the copy submitted.

In the unlikely event that the author did not send a complete manuscript and there are missing pages, these will be noted. Also, if material had to be removed, a note will indicate the deletion.

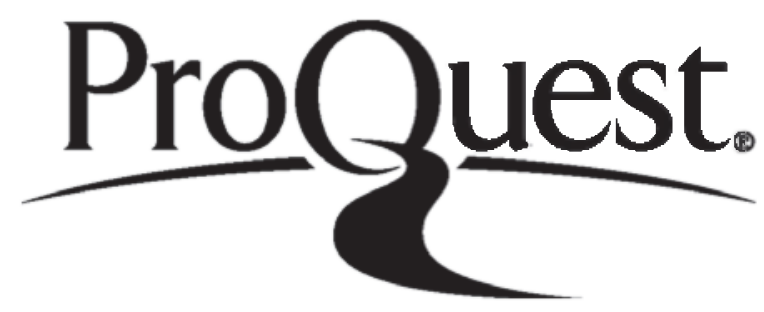

ProQuest 10672804

Published by ProQuest LLC (2017). Copyright of the Dissertation is held by the Author.

All rights reserved.

This work is protected against unauthorized copying under Title 17, United States Code Microform Edition @ ProQuest LLC.

ProQuest LLC.

789 East Eisenhower Parkway

P.O. Box 1346

Ann Arbor, Ml $48106-1346$ 


\section{ABSTRACT}

The thirteenth century ushered in an active development in both Church and State in the Christian kingdom of Ethiopia. The process had already started in the Zagw e period, but it was considerably intensified with the rise of the new dynasty founded by Yilkunno-'Amlak in 1270.

This development manifested itself in various ways in the period with which the present study is concerned. Within the kingdom itself, the power of the king over his vassal chiefs, his army, and his wealth tremendousb increased. The literary re-awakening of the Church led to the revival of monasticism and brought in a series of reform movements initiated by the new monastic leaders of the country. Of much greater importance to the history of the whole area of the Horn of Africa was the rapid expansion of the territorial limits of the Christian kingdom, and the evangelization of many of the conquered areas.

These outward movements of expansion of both Church and State were most active in the reigns of 'Ande-Sigon (1314-44) and Yishaq (1413-30), who were the most outstanding military leaders of the kingdom in the whole of our period. Their campaigns pushed the Christian frontiers far into the heart of the Muslim dominated areas beyond the Awash in the east, the rich Sidama country between the left bank of the Abbay and the lake region of the rift valley in the south, and the Agew and Felesha country consisting of Gojjam and what is 
today the Province of Begemdir in the rest and in the north-west.

The literary and religious activities of Zer'a-Ya'qob (1434-68) were essentially an attempt to stabilize the manifold conquests of his predecessors, and to give soưd institutional bases for both church and state in the whole of the Christian Empire. The relatively radical programmes which he rigorously put to effect during his reign were not continued by his successors, and with the reigns of a series of minor kings the diverse regional and religious interests fully reasserted themselves. The absence of a strong, united leadership for half a century (following Be'İde-Maryam's reign) sapped the Christian kingdom of much of itg political and military strength, and led in the end to the brilliant successes of Ahmad ibn Ibrahim, otherwise known as Gragn. 


\section{TRANSLITERATION}

For the sake of simplicity I have used the following system of transcription. With the consonant "B" as an example I illustrate below how I have represented the eeven forms of an Ethiopic letter:

$$
\begin{aligned}
& \eta=B e \\
& C=B u \\
& n=B i \\
& \eta=B a \\
& n=B E \\
& n=B I \\
& n=B O
\end{aligned}
$$

Except for the introduction of the sound ${ }^{n} w^{n}$ following the basic consonant sound, I have used the same system for the labiovelars also. Thus :

$$
\begin{aligned}
& \text { to = Kwe } \\
& \text { the }=\mathrm{Kwi} \\
& \eta \text {. Kwa } \\
& \text { ' } \\
& n=K^{\prime} I
\end{aligned}
$$


5

other sounds

$$
\begin{aligned}
\phi & =q \\
m & =t \\
\phi & =p \\
h / \theta & =s \\
F & =c h \\
\pi & =\frac{c h}{r} \\
H & =z
\end{aligned}
$$


Page

INTRODUCTION

16

CHAPTER

I ; Background to the Chriatian Kingdom in 1270

II : Intermal Conflict and Readjustment (1285-1380)

... 129

III Expansion (1270-1430)

... 227

Ir : Erangelization (1249-1430)

236

$\nabla$ : Zer'a-Ya'qob and the Growth of Religious rationaliom (1380-1477)

... 402

$V I$ : Pifty Years of Decline (1477-

$\ldots \quad 529$

HAPS

I: Routeg

... 1 ปั

2 : Egyptus Rovelo (c.1454)

… 492

3 : Fra Mauro's map (1460)

$\ldots 528$

FIGURE

1 : The Royal Court

520

SEIECT BIBLIOGRAPHY

533

ABBREVIATIONS

$60 \mathrm{~J}$ 


\section{ACKNONLEDGEMIENTS}

I am yery grateful for the excellent opportunity given to me by the British Council who have sponsored my studies here. They have also, in co-operation with the Haile Selassie University of Addis Ababa, facilitated my short field work in Ethiopia. During my flying visits to some of the medieval monasteries there the officials of the Ethiopian Church have been very helpful. I specially acknowledge the encouragement I received from His holiness, Abune Basilios, the Patriarch. His generous hospitality particularly enabled me to examine his valuable manuscript collection at Debre-Șige.

Professor Roland Oliver, my Supervisor, has been a very patient. guide, and his unfailing interest in every stage of my studies here has been a source of much encouragement. On many occasions, I have sought the advice of Professor Edward Vllendorff and he has always been most willing to help. I owe my first introduction to the field of Ethiopian History to Professor Sven Rubenson of Haile Selassie University to whom I am grateful. Inter-departmental co-operation is one of the best aspectg of the School of Oriental and African Studiea, and acknowledgement of every assistance received will make this page too long. I must, however, thank in particular 
Dr. 7. Wansbrough and Dr. A.K. Irvine, who have made themselves easily accessible every time I required their help and advice. 


\section{INTRODUCTION}

The first comfort of the student of Ethiopian history is that the ground he sets out to explore is not completely untouched. More than three hundred years of European scholarship has produced an immense literature on the languages, history, and cultures of the Ethiopian peoples. Yet, Conti Rossini's Storia d'Etiopia - written exactly forty jears ago - still remains a unique contribution in the specific field of the critical study of Ethiopian history. Ullendorff has recently furnished the book with a much needed Index which has made it more accessible to the student. But the absence of a bibliography, and of the rich annotation so characteristic of Conti Rossini's other writings, is still a serious handicap. More important still, successive volumes to Storia d'Etiopia are jet to be written.

The date 1270, with which Conti Rossini ends his book, has provided the starting point for my attempt to reconstruct, in the following pages, the more limited story of the development of Church and State in Ethiopia until the wars of Gragn. The nature of the material which I have untilized - consisting mainly of hagiographical traditions and the available royal chronicles - was a major factor in determining the topic of my thesis.

Ever since 1896, when Ignazio Guidi and Conti Rossini simultaneously published Gedle Aregawi and Gedle Tekle-Haymanot, 
respectively, the value of the lives of the local saints for the study of Ethiopian history has been increasingly recognized. Introducing Conti Rossini's Il 'Gadla Takla Haymanot' ..., Guidi had the following to say on the subject:

"Una classe di fonti molto importante per la storia dell' Abissinia sono le vite di quei santi che esercitarono qualche azione sugli avenimenti e eil progresso di quel paese : nè ciò deve recar menfiglia, se si considera l'indola piu - men teócratica del governo e la poteza del clero". 1

Following this judicious statement, many of the lives of the saints available in the Ethiopic MSS collections of European libraries have been published, translated, and richly annotated. It now seems that European libraries can yield little more of the hagiographical traditions. In Ethiopia, however, the resources of the church in this respect are almost untouched. This has already been indicated in the articles of G. Ellero ${ }^{2}, A$. Mordini $^{3}$, and R. Schneider ${ }^{4}$ for the province of Tigré. More recently Dr. Sergew Hable-Selassie of the Haile Selassie University has been engaged in a survey of the historical sources available in the libraries of the Ethiopian Church. This has taken him to many of the monasteries in the province of Tigrē, Gojjam and Shewa. His still unpublishęd list

1. MRAL, Ser.5, Vol.II (1896), p.97.

2. BSGI, Ser.7, VoI.IV(1939); RSE, I (1941).

3. RSE, XII (1953).

4. Tarik, Addis Ababa, Vol.II (1963). 
of the new documents he has uncovered (which he kindly permitted me to consult) includes many lives of saints which still await a critical study. My own short tour in Spring 1966 - of a selected group of medieval monasteries in central Ethiopia has also been very encouraging. I have listed in the Bibliography only a selection of the unpublished material I was able to utilize in these distant libraries.

The most searcining and analytical study of the Ethiopic hagiographical literature in general was made by Conti Rossini. 1 Apart from the translated lives of the saints and martyrs of the early Christian church, the hagiographies of the Ethiopian church consisto of two major divigions - namely those dealing with the local saints (a) of the Aksumite period, and (b) of the late Medieval period. All the hagiographies falling under this second category belong to the period after 1270, and it is with them that we are mainly concerned in this short introduction. To determine the historical value of such a hagiographical work, Conti Rossini has proposed a simple general rule:

"... il loro pregion, come contributo per Ia ricostruzione della storia politica ed ecclesiasti$\mathrm{ca}$, e in ragione inversa della lontananza del tempo del personaggio che intendono celebrare." 2

1. ARIV, Vol. 96, Pt. 2, 1937.

2. Ibid, p.404, n.2. 
The date of the composition of a Gedl is thus a crucial factor. But it is often very difficult to establish in precise terms. The hagiographical traditions about a local saint generally consist of four essential parts:

a) The story of his life: his evangelical work and/or his monestic pursuits in an isolated hermitage;

b) The Kidan, or pact which he receives from God in return for his endeavours. According to this the saint receives God's forgiveness of sins of whoever prays and is charitable to the poor and to the Church in his name;

c) The miracles attributed to him both in his lifetime and after his death; and

d) His Melk'王, or the short bymns composed in praise of his holy life.

Each of these sections, in part or as a whole, may be written at different periods of time and thus complicate the problem of fixing the date of the Gedl. Generally, the Melk'I and many of the miracles attributed to the saint after his death are written much later. The major purpose of a Gedl being to edify the congregation to whom it is read, and to increase the prestige of the commuity to which the saint belonged, the narrative of the post mortem miracles is often paraphrased, amplified, and occasionally re-edited. This also seems to apply, to a lesser extent, to the Kidan.

But to try to determine the chronological context of a local saint, only the story of his life and the traditions about the miracles in his own lifetime may be taken as the basic parts of the Gedl. Additional help is sometimes 
provided by the hagiographer who says whether he is writing from a personal acquaintance of the saint, or from information gathered from others, or by divine inspiration. The value of these indications by the author(s) only lies in helping one to form an initial assessment of the work. By far the most final bases of determining the date of a Gedl are its own internal evidence and the corroboration which its story may receive from other independent sources. Conti Rossini has divided the medieval lives of saints at his disposal - most of which are now published into three categories:

a) The hagiographies which are more or less biographical in character, and which bave much historical significance as such. Among some others he included Gedle Filippos and Yohannis (Bizen), Gedle Abekerezun, in this category. Or the unpublished hagiographies I have listed in the Bibliography No. 8, 9, 10, 11, 13 and all the stephanite ones belong to this major division;

b) Those which have important traditions, but who are greatly affected by their narrative of wonderous tales about the life of the saint. He included in this category Gedle Tekle-Haymanot, and Gedle Ewostatëwos, No. $4,5,6$ and $?$ in the Bibliography seem to belong here; and

c) Those which are written many years after the event they describe tends to lose much si nificance. Conti Rossini has Gedle Lalibela, and Gedle Gehre-MenfesQidus in this division, to which No. 1 and 2 of my Bibliography also seem to belong.

For the religious and political history of the country in the midale of the fifteenth century, Zer'a-Ya'qob's Meshafe-Birhan and Meshafe Milad occupy an outstanding 
place in a class of their own.

An obviously more important source of medieval

Ethiopian history are the very few available royal chronicles. For the whole period covered by my study, only the chronicles of 'Ande-ŞIyon (1314-44), Zer'a-Ya'qob (1434-68), Be'İde-Maryam, and much shorter entries about the following reigns until the wars of Gragn have come down to us. These have all been published and translated, already in the last century, and all my attempts to obtain new ones during my short visits to Haiq, Gishen, Ialibela, some of the island monasteries of Iake Tana, Dima and Debre-Werq, have been in vain, in this respect. But I was able to gather a number of small isolated notes, particularly in the form of land grants, from early manuscripts of the Four Gospels, similar to those in Conti Rossini's I'evangelo_d'aro. These notes have been of great help in forming a more complete picture of the medieval period, and they shed fresh light particularly on the chronology of the kingdom.

The new historical documents I have presented here form only a small fraction of the large collection of printed Primary Source Material which I utilize in the following pages. There is no doubt that a more complete picture of the story of Church and State in Ethiopia can only be formed after a much closer investigation of the traditions of the 
15

people and the churches considered in this study. Nothing comparable to Cont Rossini's Studio au popolazioni, Kolmodin's Traditions, and many other studies defying with the tribal groups in Eritrea, is yet available for the whole area south of, and including much of, the province of Tigre . Until this is done, the increasingly well-known history of the late Medieval period will always look like a clear incident in a hazy background. 
CHAPTER ONE

\section{BACKGROUND TO THE CHRISTIAN KINGDOM IN 1270}

South Arabian immlgrants began to settle in the hinterland of Adulis as far inland as the surroundings of Aksum before the 5 th century B.C. From then on their settlements became the spearhead of a long process of semitization in the Ethiopian region. The extensive area of North-East Africa, between the Red Sea and the Nile as far north as the first cataract and including the whole of the Ethiopian region is still predominantly inhabited by a large family of people known to anthropologists and linguistg as the Kushites. Already at the time of the South Arabian immigration it seems that the Kushites of the Bthiopian plateau consisted of three distinctive linguistic groups. The area north of the Barka-Anseba basin was the homeland of the Beja pastoralists. South of the Mareb and

1. Conti Rossini, "Sugli Habeshat" in RRAL, Ser.5, Vol. XV, 1906, pp. 45-49. Id, "Expeditions et possessions des Habeshat en Arabie", in JÄ, Ser.1l, Vol.XVIII, 1921, pp. 6-10. Id. Storia diEtiopia, 1928, pp. 102, 109.

2. Ibid., pp. 68-69. Id. Ettopia e genti d'Etiopia, 1937, pp. 123-124. Baumann, H. and Westermann, D., Les Peuples et les Civilisations de I'Afrique, 1962, pp. 274-275, 466-467.

3. Conti Rossini, Storia d'Etiopia, pp. 74-75. Id. "Schizzo etnico e storicodelle poppolazione Eritrie", in L'Eritrea economica, 1913, pp. 65,71-72. M. Cohen, Etudes 
Belesa rivers, and probably extending as far south as the Jema xiver, and from the edge of the plateau in the east to the valley of the River Tekeze in the west, there lived the Agew. The narrow wedge on the Eritrean plateau between the Beja and the Agew was apparently occupied by the QunamaBarya group, whose linguistic features represent a cross between Kushitic and a more ancient language spoken in the 2

area. The third major group of Kushites, namely the Sidama, probably occupied the extensive area south of the Jema river,

Footnote 3 cont. from previous page/

d'thiopien Meridional, 1931, p. 44. Here M. Cohen makes the point that one of the Semitic languages of Jthiopia, Tigre, which developed after the south Arabian migration, has beja substrata. E. Ullendorff, The Semitic languages of Ethiopia. 1955, p. 20.

1. Conti Rossini, "Schizze etnico", cit. p. 64; Storia d'Etiopia, p. 74. M. Cohen, op.cit..p. 44 : Ge'ezTligrigna and Amharic (particularly northern Amharic) have Agew substrata. E. Jllenforff, op.cit.. p. 28.

2. Conti Rossini, "Schizzo etnico", pp. 64, 69-70. Id. "Studi su popolazioni dell'Etiopia : IV Antiche popolazioni Nuba-Etiopiche", in RSO, Vol. VI, 1913, pp. 138141 (extract). Id. La langu des Kemant en Abyssinie. 1912 , p. 39. Here conti Rossini demonstrates that the earliest contact made by the settlers from South Arabia must have been with non-Agew speakers and probably with the Qunama or the Barya. Following Conti Rossini, M. Cohen also concludes that this must have protected Ge'ez Irom early "couchitization", op.cit., p. 44 . Cf. also Conti Rossini "Per la conoscenza della lingua cunama" in G.S.A.I.. XVI, 1903, pp. 190-191. Pollera, I Baria e i Cunama, pp. 1l-14. 
123

the plateaux of Shewa, Harar, and Bali, and extended right across the basins of the Rift Valley lakes and the Omo valley as far west as the left ban of the Blue Nile and beyond the 5

River Didessa.

1. Conti Rossini, "Su popolazioni dell'Etiopia : V Appunti di lingua Gonga", in RSO, Vol. VI, 1913, p. 153 (extract). Id. Storia d'Etiopia, p. 75. M. Cohen, op.cit., pp. 44-45. Leslau, W., The influence of sidamo on the Ethiopic languageg of Guragen in Ianguage, XXVIII, 1952 , pp. 63-65.

2. M. Cohen, op.cit., p. 45. More recently E. Cerulli definitely established that the Semitic language, Harari, has developed on Sidama substrata and that it was through the latter that it received other Kushitic influences, Studi Etiopici: I. La lingua e la storia di Harar. 1936, pp. 440-442. He closes the book with the following authoritative and cautious remarks "... I Semiti si sono sovrapposti, nei paesi dove era parlata la lingua da noi -ggi detta harari, a preesistenti popolazioni Sidama."

3. Cerulli, E., Studi Etiopici: II. La lingua e la storia dei Sidamo, 1938, pp. 1-2, 31-32.

4. Today the lake region and the middle Omo basin are the last stronghold of the Sidama, forming three major linguistic sub-groups - viz. Eestern, Central or Ometto, and Western Sidama, Cerulli, E. "Note su alcune poplazioni sidama dell'Abissinia meridionale", in RSO, Vol. X, 1925, pp. 597-598; Vol. XII, 1929, pp. 1-3. Id. Studi Etiopici. VoI. II, pp. 242, 248; Vol. III, p. 215; VoI. IV, pp. 5-10, 523, 525-526. Conti Rossini, "Contributi per la conoscenza delle lingua haruro" in RRAI. Ser. 6, Vol. XII, 1936, p. 625. Id. "Studi su popolazioni dell'ttiopia : VI. I Bambala di Amarr Burgi e il loco linguaggio", in RSO, Vol. VI, 1913, pp. 160-167 (extract).

5. Grottanelli, V.L., "Gli Scinascia del Nilo Azzure ed alcuni lessici pocco noti della loro lingua", in RSE, Vol. I, 1941, pp. 235-236. Id. "I Niloti dell'Etiopia", in BSGI, 1941, pp. 572, 574-575. Cerulli, E., Ėtiopia Occidentale, Vol. II, 1933, pp. 87-91. 
It was on this liushitic population of the Ethiopian 1

plateau that the south-Arabian settlers began to exert their pressure and to usher in an intensive cultural and political development of which the Christian kingdom in 1270 was only part of the result.

Nothing prcise is known about the nature of the initial confrontation between these settlers and the indigenous peoples of northern Ethiopia. It is apparent however that the arrival of a settler population from across the Red Sea was only the last decislve phase of the long intercourse between the Ethiopian region and the ancient civilizations of Egypt and Arabia. Strongly motivated, no doubt, by their knowledge of the terrain and of its potential resources and probably also making use of the long amicable

1. Conti Rossini had long proposed that these settlers predominantly consisted of Habeshat tribes whose original homeland he traced back to the south-western corner of the south Arabian peninsula, "Sugli Habasat", cit. pp. 39-55; "Expeditions", cit. pp. 6-7; Storia d'ttiopia, pp. 109. His location of the area whence the major South Arabian influence came to Ethiopia is still generally considered valid. But his identification of Habeshat tribes in South Arabia has been contested recently in the light of much more epigraphical material than he had at his disposal, A.K. Irvine, "On the identity of the Habeshat in the South Arabian Inscriptions," in JSS. X, No. 1965, pp. 178-196. A.J. Drewes, Inscriptions de l'Ethiopie antique, Leiden, 1962, pp. 2-5, 89-93.

2. Conti Rossini, "Egitto ed Etiopia nei tempi antichi e nell" eta di mezzo", Aegyptus, III, 1922, pp. 3-8; Storia d' Etiopia, pp. 39-54, 66; Etiopia e genti d'Etiopla, pp. 25-31. Doresse, J., I Empire du Pretre-Jean. VoI. I (1957) pp. 4-67. J. Leroy, "Les Ethiopiens de Persepolis" in AE, V (1963), pp. 293-297. B. Playne, "Suggestions on the origin of the "False Doors" of the Axumite stele", in $\underline{\underline{A}}$, 
relations they had already established with the local people, intrepid individuals or groups of individuals from south Arabia trickled on for centuries until they finally gained a permanent foothold in what are today the highland districts of northern Tigre and southern Eritrea. Ancient hunting stationg on the African coast between the straights of Bab-el-liandeb and the Dahlak islands probably served them as a spring-board for an effective penetration of the interior. From the epigraphical and archeological findings it would appear that the route from the coast leading to Adulis, Matara, and Yeha was their most important highway. They probably came in different dialectal groups. At first

Footnote 2 cont. from previous page VI (1965), pp. 279-280. Cf. also J. Leclant, "Note sur l'amulette en cornalinen, 토, VI (1965), pp. 86-87.

1. Conteson, H. de, "Les principales etapes de I'Ethiopie antiquen, CEA, No. 5-8, 1961, p. 12.

2. Conti Rossini, Storia d'Qtiopia, p. 109. Id. Etiopia e genti d'ttiopia, pp. 126-127. Ullendorff, E., The Semitic Ianguages of Ethiopia, pp. 7-8. The problem of the origin (or orlgins) of the modern semitic languages is also relevant for the direction of both the initial south Arabian migration and the eventual expansion of the kingdom of Aksum and its medieval counterpart. The view generally accepted is that the earliest immigrants probably spoke different dialects of a comon south-Arabian language of which the modern Semitic languages of Ethiopia are the distant offspring. This implies that the spread of Semitic influence in the Ethiopian region originally had northern ithiopia as a single point oi departure. While accepting this as "la plus vraisemblable" in the case of Amharic at least, $M$. Cohen has long drawn attention to the possibility that other ports like Raheita and Zeila may have also been used by south Arabian immigrants to move 
each group probably consisted of a small number of individuals who were out to Africa for specific hunting or commercial interesto, only expecting to stay there for a short time. It is most likely that it was during these early visits that they first established direct contacts with the local people. The identity and the way of life of these natives can only be surmised at this stage. Some isolated Iinguistic data seem to indicate that the earliest people they met in the Eritrean plateau were the non-Kushitic ancesters of the Qunama-Barya people. But it was with the Agew group of the Kushitic peoples of nonthern Ethiopia that the south-Arabian immigrants established a lasting relationship, and it was among them that their cultural and political impact was most deeply felt. It is most likely that at the time of their earliest contact with the South Arabians the native people were in a primitive stage of material culture, and lived in small isolated clans or groups of clans with no state or political organizations. This must have given the

Footnote 2 cont. from previous page. over to the regions of Amhara, Shewa and Harar, Etudes, cit. pp. 3-4, 38-40, 46-52. Cf. also his review of Uliendorff, The Semitic Languages, in BO, XIII (1956), pp.14$15,20 . \quad$ E. Cerulli has proposed a compromise solution, Studi Etiopici. I : La lingua e la storia di Harar, 1936 , pp. 441-442.

1. Conti Rossini, Ia langue des Kement en Abyssinie, 1912, p. 39. M. Cohen, Etudes, cit. p. 44.

2. Conti Rossini, "Notes sur l'Abyssinie avant les Semites", in Floriligium de Vogue, 1909, pp. 139-140.

3. Conti Rossini, ibid.. pp. 148-149. 
immigrants an excellent opportunity to assert themseives and easily reduce the local people to a position of political vassalage. The immigrants themselves probably consisted of amall tribal groups, each constituting a different political unit of its own. Thus the political system they introduced from the very beginning was not characterized by a large unitary state and only consisted of small unitg based on tribal groupings. This characteristic organization left an indelible mark on the political developments which their arrival in Africa must have initiated among the local people, and we shall have much occasion to see it at work in the course of this study. Each of these groups probably imposed itself on the section of the local people in whose neighbourhood it happened to settle, and began to integrate them into its superior cultural and political system. It is thus possible to imagine that by the middle of the fifth century B.C. - to which period the earliest epigraphical material seems to belong - that the Agew population of northern Tigre had already been organized into small political units with the settler population as nuclei. The formation of these urits probably followed both the clan groups of the native peoples and the tribal or

1. Conti Rossini, "Sugli Habashat", p. 57; A. Caquot et A.J. Drewes, "Les monuments recueilis a Maqalle (Tigre), AE, I (1955), pp. 26, 30; Drewes, "Les inscriptions de Melaze", AE, III (1959), p. 84; "Nouvelles inscriptions de 1'Etiopie", in BO, XIII, 1956, p. 180, n. 15. 
dialectical divisions of the immigrants.

Conti Rossini had envisaged the possibility of an initial period of direct political control of these settlements by a south-Arabian kingdom. This postulate does not geem to be necessary for the reconstruction of the history of this early period and, among the increasing amount of epigraphical material since discovered in Ethiopia, not a single sign of such a direct South Arabian rule has been procured. This seems to indicate that the South Arabian mettlements were primarily private in origin and did not represent an official act of political expansion and conquest of any state in the Arabian peninsula. Nevertheless, contacts between the two sides of the Red sea were clearly frequent; the settler population probably continued to receive a regular flow of new immigrants, and by the mid-fifth century B.C. an independent political atructure had already evolved in northern Ethiopia. By then also the political leadership was probably no longer purely South Arabian. The existence of such an early political organization in northern Tigre is attested by the recent epigraphical discoveries at Azbi-Dera and Hawlti. The earliest

1. Op.cit., pp. 57-58.

2. Cf. Drewes, Inscriptions de l'Ethiopie Antique, 1962, pp. 94-97.

3. J. Doresse, L'Empire du pretre Jean. I (1957), pp. 78-83; Caquot and Drewes, op.cit., pp. 26, 30; R. Schneider, "Inscriptions d'Enda Cerqos", 르, IV (1961), pp. 62-65. 
indication of a kingdom in this region is obtained from the Azbi-Dera inscription on a stone altar dedicated to the South Arabian god Almaqah. The anonymous king of this inscription bore a long title styling himself "King of Sr'n, Ygzyan, Mkrb of D'mt and SB..." The twin titles of Man (= King) and Morb which this sovereign held at this early stage are most significant not only in showing the South Arabian origin of the organization of state but also in pointing to the direction of the future development of the institution of kingship in Ethiopia. Mkrb was the title held by the supreme ruler of Saba in south Arabia between th 9 th and the end of the fifth centuries B.C., and it meant "Prêtre-Prince, Prince-Sacrificateur". By the end of the fifth century, it was no longer in use there, and the rulers of Saba began to assume the title of "King of Saba". On the Tigrean plateau, however, the kings apparently continued to use it together with the new title of "Mlkn". It is not known exactly when the practice started nor when it was discontinued. But the king of the Azbi-Dera ingcription appears to be neither the first nor the last to bear the title, and two other inscriptions found at Hawlti and at an

1. Doresse, op.cit.. pp. 81-83. Caquot and Drewes, op.cit. p. 30; Drewes, Inscription de I'Ethiopie antique. D. 97

2. J. Ryckmans, L'Institution monarchique en Arabie meriāionale avant IIslam, 195I, pp. 51-53.

3. Ibid., p. 101. 
unkown place probably belonged to his own sons. 1 From the epigraphic remains of the period it is apparent that the territary over which these kings maintaimed a political supremacy largely consisted of the triangle between Adulis on the coastal strip, the eastern edge of the Tigre plateau around Azbi-Dera, and the surroundings of Hawilti and Aksum. Its centre of gravity probably $\frac{1}{3}$ ay in the region of Shimezana and southern Akele Guaa. There is no need to imagine at this stage a strong unitary state. Neither the apparent dialectal fragmentations of the first South Arabian settlers (probably also augmented by their contending economic and commercial interests), nor the clan groupings of the local people on which they were superimposed, would seem to warrant such an early political development. What seems to be most likely is that there were a number of small autonomous political units sharing the same social and cultural

1. Only one letter of the king's name is intact in the AzbiDera inscription. However from the two other inscriptions referred to above M. Schneider has proposed a reconstruction of the name, and even suggests that the authors of the two inscriptions were probably the sons of the AzbiDera king, op.cit., p. 65 .

2. The first inscrigtion discovered by the German Expedition at Debre-Pentellewon near Aksum seems to bear special relations with the Azbi-Dera one, Littmann, Deutsche AksumExpedition, Vol. IV (1913), p. I; Caquot and Drewes, op.cit.. pp. 30-32; Contenson, H. de "Le principales etapes de l'Ethiopie antique", cit. p. 13.

3. Conti Rossini describes the area as "centro d'intesa vita nell' antichita", Storia d'Etiopi, p. 109. Much has been found since to confirm his verdict, Franchini, V. "Ritrovamenti archeologici in Eritrea", RSE, Vol. XII (1953), pp.8, 23-28. Irewes, "Nouvelles Inscriptions de I pthiopie" eit. p. 182 . 
heritage, among which one unit may have won sufficient economic and military prestige to enable its leader to assume royal titles such as those of the Azbi-Dera inscription. It is in fact very significant that two of the tribal groups mentioned in this Sabean inscription as the subjects of the king - namely Srin and Ygzyan - also appear many centuries later in two Ethiopic inscriptions as being engaged in rebellious military hostilities againgt King Ezana. If the dating of the Azbi-Dera king (c. 450 B.C.) is correct, eight centuries separate him from Ezana, and the feeling of self-identity and independence of the peoples of his "kingdom" could have only been much stronger. This picture of small political units, vying among themselves, may also provide at least part of the explanation for the long silence of the classical writers about any state -rganization in the region.

Nevertheless, continuously inspired by their close contacts with the Arabian peninsula, the peoples of the region seem to have gradually made their impact felt among their neighbours. The annals of this period are completely shrouded in uncertainty and a full reconstruction of its history must await further archeological discoveries in the area. But there can be no doubt that it was a crucial

1. Iittmann, op.cit., pp. 24-32. Cf. also Doresse, L'Empire du Pxetre-Jean, I, pp. 82-83. 
formative period in which the activities of the "sabeanized" inhabitants of northern Ethiopia must have produced a chain of political and social developments further inland in various directions. Hunting or commercial interests as well as deliberate attempts of territorial expansion must have spurred groups of individuals to push on into the interior. Already in the middle of the 4 th century B.C. king Harsiotef (c. 404 - 369 B.C.) of Meroe claimed to have sent a successful expedition against a town called Habasa (= ?Habasi $=$ Hebsi $)$. The inhabitants of the town are called Metit and are said to have agreed to pay tribute to Meroe. A variant of the nane Metit is also found in one of Ezana's 2 inscriptions, and with additional material from the classical writers and local tradition Conti Rossini has proposed an identification with an ancient people in the BaryaQunara area of southwestern Eritrea. The leaders of the Metit people are called Baruga and Semnasa in Harsiotef's inscription. These are South Arabian names and may very well represent the spearhead of the commercial and political

1. Cf. Budge, E.A.W., Anpals of Nubian kings, 1912, pp. 117139. Another campaign was also conducted by King Nastasen (336 - 315 B.C.). For the dates see Arkell, A.J. A History of the Sudan to 1821, (ed. 1961), pp. 155-156.

2. Littmann, op.cit., Inscription 8.

3. "Studi su popolazioni dell'ftiopia : IV. Antiche popolazioni Nuba-etiopiche", pp. 138-140.

4. Conti Rossini, Storia d'Etioph, p. 107. Doresse, J., op.cit.. p. 94 . 
activities of the residents of northern Ethiopia at the time. It is especially significant that individuals bearing South Arabian names should be mentioned as the leaders of the local Metit people. It is precisely in this characteristic pattern of a few South Arabian or sabeanized individuals moving far into the interior and assuming political and cultural leadership among the Kushitic people of the Ethiopian region that one can best envisage the origin and the eventual expansion of the embryonic state organization 1 long established in northern Ethiopia. A fragment of a Sabean inscription recently found at Hawilti makes a vague reference to "the red and the black". This clearly ethnic description is probably a reference to the crucial process of the confrontation between the culturally superior, South Arabian (or sabeanized) groups and the natives of the interior. It is impossible to say exactly how far inland this cultural influence was felt before the rise of Aksum. But the time difference between the earliest Sabean inscriptions in Ethiopia (5th C. B.C.) and the first mention of the kingdom of Aksum by classical writers (2nd C. A.D.) seems to suggest that during the long interval new ideas of

1. Essentially, the same pattern will also be seen at work in the medieval as well as the relatively modern periods of Ethiopian history.

2. Schneider, "Inscriptions d'Enda-Cerqos", cit. p. 62. See, however, Drewes' reservations as to this interpretation, Inscriptions de l'Ethiopie Antique, p. 98, n. 2 . 
oocial and political reorganization had been percolating slowly among the Kushitic tribes further west and south, beyond the sabeanized triangle of northern Ethiopia. The extensive sphere of influence of the kingdom of Aksum soon after its full emergence in documentary history is otherwise inexplicable.

Pre-Christian Aksum

Despite the clear evidence of the inscriptions for the early existence of a kingdom in northern Ethiopia, there Is no mention of an organized state in the area by the classical writers until the middle of the second century of our era. Ptolemy was the first to make an unequivocal reference to "Axume where is the King's palace". Conti Rossini has already shown the limitations of the knowledge of these writers concerning the inhabitants of even the coastal areas, and their long silence about the political situation further inland cannot be taken as absolute negative evidence. Moreover it is very clear from the compilations of both strabo (d.24 A.D.) and Pliny (d. 79 A.D.) that trade between Ptolemic Egypt and the Ethiopian region was of very long

1. The Geography of Claudius Ptolemy, ed. and tr. E. Iuther Stevenson, 1932, p. 108. Cf. Contenson, "Les premiers rois d'Axoum", cit. p. 80.

2. "Commenti e notizie di geografi classici sovra il Sudan Egiziano e l'Etiopia", in Aegyptus, VI (1925) pp. 9-10. 
standing. This trade was most active between Ptolemais (founded in about $269-4$ B.C.), and the strait of Bab-elMandeb, where a town called Deire is located by Strabo on the authority of Artemidorus (2nd C B.C.), and Eratosthenes (d. 192 B.C.). Another port, probably near the present site of Assab, was called Arsinoe after the sister of Ptolemy II Philadelphus (c. 284 - 47 B.C.), who is described by Pliny as the monarch of Egypt "who first thoroughly explored the cave-dweller country".

The port of Saba, mentioned by Artemidorus and Ptolemy, which was probably the same as the 15th c. site of Girar just to the north of Masawa, was probably founded by Sabean traders in pre-Hellenic times. Archeological studies of Adulis, first mentioned by Pliny, also indicate a much earlier pre-Hellenic date for the establishment of

1. Ibid., pp. 5-6. Crowfoot has identified Ptolemais with Akil to the north of the site of medieval Badi, "Some Red Sea Ports in the Anglo-Egyptian Sudan", GJ., 37 (1911), pp. 534-537.

2. Conti Rossini, "La citta di Deire e i due laghi di Strabo XVI, 14", RRAI, XXIX (I920), pp. 291, 295. Strabo mentions a stela erected here with hierogliphic inscriptions commemorating the conquests of Sesostris, i.e. Rames II, King of Egypt about 1333 B.C. PIiny takes the conquests of the same king as far as Mossylites Cape and Harbour, the last place he mentions near Cape Guardafui, Natural History, BK. VI, 325174 .

3. Conti Rossini, Storia d'ttiopia, p. 60.

4. Bk. VI, 32, 8 168 .

5. Conti Rossini, "Commenti e notizie di geografi classici", cit. pp. 15-17. 
1

the site. This coastal strip between Ptolemais and Deire, which classical documestary material shows to have been studded with hunting and trading stations by the middle of the 3rd century B.C., served the rich hinterland of the highland axeas of northern Ethiopia and probably also the regions further south. Pliny'o description of Adulis suggests a strong tradition of commerce in the area and the commodities are reminiscent of later, medieval times :-

"Here is a very large trading centre of the cavedwellers and also of the Ethiopians...: they bring into it a large quantity of ivory, rhinoceros horns, hbppopotamus hides, tortoise shells, apes and slaves." 2

Somewhere between Adulis and another site he calls Isis, Pliny also speaks of "a bay in the coast that has not been explored, which is surprisine, in view of the fact that traders ransack more remote districts ...". " These "remote districts" are certainly the country of "the numerous tribes of Asachae who are said to be five days' journey from the sea;

1. Conti Rossini, op.cit., pp. 17-18. Here the author Identifies Adulis with Melinos lima; Littmann, op.cit. I, p. 42. Pliny attributed the origin of the town to runaway slaves from Egyt. iie did this by attaching a Greek meaning (a-doulus = non-slave, free) to the name Adulis which may have only been Kushitic in origin, Storia d'Etiopia, pp. 104-106.

2. Bk. VI, 34, 8 172 .

3. Ibid., . 173 . 
1

they live by hunting elephants". The coastal market towns and the interior which they served had been visited by South Arabian merchants for centuries, and the GrecoEgyptian explorer-traders of the coastal areas were only following in their footsteps. Even here, however, they never replaced the local merchants. It is in fact due to the economic strength of the local traders that the direct knowledge of the classical writers concerning the region seems to have long remained defective and superficial.

But in the long-run the revival of direct Egyptian interest in the Red Sea and the eastern trade opened a new chapter in the history of the Ethiopian region, and had farreaching consequences in the political and economic development of northern Ethiopia. Before the advent of the Hellenic traders, the Ethiopian region had been a huge reserve for the economic activities of South Arabian merchants, and Ethiopian comerce had been only a small appendage to Arabian trade. The curiosities and products of the African side of the Red Sea reached the Eastern Mediterranean and even Alexandria and lower Egypt via the land routes of the

1. Bk. VI, 35, 目 191. The distance from the sea, and the name Asachae which has a slight onomatopaeic connection with Aksum, or Aksumites have to some suggested that Pliny may have been referring to the latter. Contenson, H. de, "Les Premiers rois d'Axoum", cit. p. 77. Conti Rossini only takes the Asachae as one of the tribes in northern Ethiopia of South Arabian origin, "Commenti e notizie di geografi classici", pp. 14-15. Storia d'Etiopia, p. 63 . 
1

Arabian peninsula. Local participation in international trade could have only been minimal. The hunter-traders who had settled in the Ethiopian region had only acted as distant suppliers of their African products to the agents of the commercial magnates of Arabia. Imports from Mediterranean and eastern countries could have only come through Arab middlemen and both their volume and quality were doubtless determined by them. Thus both for its cultural inspiration and its economic development the Ethiopian region had depended entirely on South Arabia. Conti Rossini's oftquoted generaiization that "la civilta etiopica non e se non un riflesso della civilta sud-arabica" is perhaps true only up to this point. The re-opening of direct contacts between Egypt and the Red Sea area under the Ptolemies drastically changed the situation. Its effects were not immediate, and much of the African trade followed the ancient Arabian routes long after the advent of the Greco-Egyptian traders. But part of the trade soon began to be diverted in the direction of Egypt, whose merchants came to the African coast and made direct trensactions with the local people. They brought with them Egyptian and other

1. Préaux, C., "Sur les communications de l'Đthiopie avec l'Egypte hellenistique", in Chronique d'Egypte, XVIII, No. 53,1952, pp. $258,275-278$.

2. Storia d'Etiopia, p. 106 .

3. Pr'eaux, op.cit., pp. 274-275. 
Mediterranean products in exchange. The items of export from Adulis listed by Pliny are repeated almost verbatim by the anonymous author of the Periplus about the end of the second or the beginning of the third century A.D. Probably, the imports were also similar at the times of the two authors. According to the Periplus, these included brass and copper objects, iron bars for making opears, and weapons such as axes, adzes and swords. The supply of these valuable goods, which helped to revolutionize their military and economic power, and the creation of an alternative market for their products no doubt impressed the local people, and probably encouraged the emergence of a new class of merchants fully committed to the development of direct trade with Egypt. This was also reflected in the economic and political life of the people, and the Ethiopian region set out on a fresh development of its own completely independent of, and often antagonistic to, its ancient South Arabian partners.

1. The Periplus of the Erythrean Sea, tr. and annotated by W.H. Schoff, 1912, $=6$, p. 24. For the problems of the dating of the Periplus see ibid., pp. 290-293; J. Pirenne, Le Royaume-Sud Arabe de Qataban, 1961, pp. 167-201. Id., "la date du Periple de la mer Erythree", JA. Vol. 249, 1961, pp. 450-455. Cf. also J. Ryckmans, La Chronologie des rois de Saba et du-Raydan, 1964. The new dating seems to have been reluctantly accepted by some scholars who are currently in very close touch with the study of the kingdom of Aksum, Contenson, H. de "Le premiere rois d'Axoum", cit. pp. 75-80. Cf. also J. Leclant's review of J. Pirenne's book, Le Royaume Sud-srabe de Qatabar, in AE, $V(1963), p p .301-303$. Drewes, A.J.' Inscriptions de I'Ethiopie antique, Leiden, 1962, p. 102. 
If the early history of northern Ethiopia owed a great deal to South Arabia, the new source of cultural and political inspiration was certainly the Greco-Roman world of the Eastern Mediterranean. Aksum rose and flourished with a Mediterranean orientation, and even when the spread of Islam interrupted its lines of commication, it was the legacy of this early cultural association which continued to give the Ethiopian region a special Christian identity throughout the medieval period.

No absolute dates are yet available for the beginning of Aksum as a political and cultural centre. As we have already seen above Ptolemy was the first to mention the kingdom of the "Axoumites" with the royal court at "Axume", and his work is attributed to about the mid-2nd century A.D. Together with Adulis which is also mentioned

1. See n.1. p.29. above. The chronology of the kingdom of Aksum had been based on the early date given to the Periplus. Very serious problems have been raised recently which lower the date of the work by about two centuries, cf. n.,p.3łabove. Thus we only have Pliny and Ptolemy as points of departure for the chronology of Adulis and Aksum. About a hundred years separate Ptolemy's work from Pliny who only mentions Adulis and "the tribes of Asachae ... five days from the sea". It is not certain if the rise of Aksum can be dated within this period separating the two authors. Ptolemy only represents perhaps the progress of Greco-Roman geographical knowledge about North-East Africa in general, and the development of closer contacts with the Aksumite region in particular. Conservative estimates recently advanced place the foundation of Aksum between the middle of the first and the beginning of the second century A.D., Contenson, op.cit., p. 80. Id., "Les principales etapes de l'Ethiopie antique", cit. p. 19. 
by Pliny before him, Ptolemy refers to two other towns, Coloe and Maste. It is however in the Periplus that we begin to see a clear term of reference for the territorial limits of the Aksumite kingdom. On the coast it extended from Ptolemais in the north to the straits of Bab-el-Mandeb. The most striking difference between the writers before him (Strabo, Pliny and Ptolemy) and the author of the Periplus is that, except for the islands of Alalai (Dahlak) he does not mention coastal towns other than Ptolemais and the port of Adulis. Unlike them, he apparently had a direct personal knowledge of the Aksumite coast and it is very significant that he should omit many of the sites reported in their works. It is most likely that this represents the growing power of the rulers of Aksum over the entire coast and the emergence of Adulis as their major port at the expense of the other coastal settlements. It is also apparent that the hinterland served by these settlements had similarly passed over into the growing political and economic sphere of influence of the kingdom of Aksum. Compared with the

1. The wordinc in the Periplus is "...from the Calf-Eaters to the other Berber country" 5 . The Calf-Eaters are elsewhere identified as one of the people who live behind the coastal strip between Berenice and Ptolemais which is also called "the country of the Berbers" $\mathrm{O} 2,3$. "The other Berber country" is a reference to the coastal region of the Horn of Africa beyond the strait of Bab-el-Handeb, 7 , See also the notes of the editor. 
pre-Aksumite (Sabean) period referred to above, there seems to have taken place a tremendous development, not only in the consolidation of the power of the kings, but also in their effective control of large territories.

The Periplus is not as useful in determining the territorial limits of the kingdom in the interior. Nevertheless it seems to offer valuable guide lines:

"... from (Adulis) is a three-days' journey to Coloe, an inland town and the first market for ivory. From that place to the city of the people called Auxumites there is a five-days' journey more; to that place all the itory is brought from the country beyond the Nile through the district called Cyeneum, and thence to Adulis."

In this passage and in the Adulis inscription "the Nile" seems to be a reference to the River Tekezze, and Cyeneum has been identified with the region of Sennaar in the 3

eastern Sudan. From these indications it seems that 4

2oskales, the king of Aksum at the time of the Periplus.

1. Schoff, op.cit., p. 23.

2. McCrindle, The Christian Topography of Cosmas Indicopleustes, p. 6I, and n.3. Ezana refers to the river by its present name, Littmann, op.c1t., Inscription ll.

3. Schoff, The Periplus, p. 61 .

4. The dates for this king necessarily depend on the dating of the Periplus, cf. p. $34 \mathrm{n} \cdot \mathrm{l}$ above. There have been attempts to identify the king with Ze-hiaqle who appears Hin the traditional lists of the kinga of Aksum, and to use his reign for dating the Periplus, Schoff, op.cit., pp. 66-68. But these lista are a much later compilation and are of little or no chronological help, Conti Rossini, "Les Iistes des rois d'Aksoum", in JA. 
was at the head of a large empire extending to the strait of Bab-el-Mandeb in the south-east and beyond the Tekezze river in the west. No specific estimates of the southern frontiers can be given at this stage of the history of Aksum; but it must be said that it is only natural for a growing kingdom in northern Tigre, which had already taken full control of the seaboard and had pushed its political and economic frontiers beyond the Tekezze, to try to expand southwards and secure a dominant position also in the region of the sources of the same river, and even further south. In his description of what can be called "the arms trade" of Adulis, the author of the Periplus reports in particular that the imported iron which was made into spears was used by the Aksumites "against the elephants.... and in their wars". These armed conflicts probably included wars of conquest undertaken by the Aksumite kingdom in the interior. 2 The ionumentum Adulitanum, and three of the inscriptions of

Footnote 4 cont. from previous page Ser. 10, Vol. XIV (1909), pp. 313-320. Zoskales is certainly a predecessor of the king of the Adulis inscription.

1. Schoff, op.cit., p. 24 .

2. For the text and description of this inscription see MacCrindle, op.cit., pp. 54-66. Conti Rossini, "Expeditions", pp. 18-25. The name of the king is rissine and no satisfactory identifications have been proposed as yet. Hia dates are however estimated to have been between 250 and 285 A.D., Contenson, "Les Premiers rois d'Axoum", p. 82. Drewes' recent attempt to ioentify him with Shamr Yuharish of South Arabia is extremely arbitrary, Inscriptions de l'Ethiopie Antique, pp. 106-107. 
1

King Ezana, are particularly concerned with such military expeditions in the region south and south-west of Aksum.

As has already been suggested above, the slow penetration of social and cultural influences into these southern areas must have started in the pre-Aksumite period. It is in fact apparent that the Aksumite conquests were only a second major wave of "Semitic" expansion into the interior of the Ethiopian highlands. The local resistance put up against the Aksumite attempts at expansion was strongly organized and suggests a fairly high degree of political evolution. It was a very far cry from the weak, disorganized clan groups which the first South Arabian settlers must have encountered in northern Ethiopia. In the Adulis inscription strong tribal leaders are presented resisting the Aksumite advances and were only reduced to tributary status by the military superiority of the kingdom :-

"Upon their submission I restored their territories to them, subject to the payment of tribute. Fiany other tribes besides these submitted of their own accord, and became likewise tributary". 3

1. Littmann, op.cit., Inscriptions 8,9 and 10 .

2. Conti Rossini, "Notes sur l'Abyssinie avant les Sémites", pp. $148-149$.

3. The Christian Topography of Cosmas, cit. p. 64 . 
According to his inscriptions Ezana also ruled over a number of tributary kings and vassal chiefs. His military expeditions were undertaken to reduce the rebellious among them and to make fresh conquests of other neighbouring territories. Many of the peoples and regions are named in both the Monumentum Adulitanum and Ezana's inscriptions and indicate an intensive prosramme of territorial expansion during these reigns. It is unfortunate that these names are still mostly unidentifiable, but there seems to be no doubt that many of them generally refer to areas south of the Aksumite region.

1. Cf. Iittmann, op.cit., Inscription 8 which mentions : SWSWT, King of the Aguezat and his people; SBI, King of Gabaz; and the king of Wylq. This place is mentioned immediately after a people called samen, no doubt the same Samenoi whose inaccessible, cold, mountainous country is aptly described in the Adulis Inscription, Christian Topography. pp. 61-62. Wylq (= welqgyt) and semen still keep their ancient appellation and are side by side just across the Tekezze from Shirē. Inscription 9 : major conflict with AbalIqIwo, king of Aguezat, who was captured with "the bearer of his throne". His territory seems to have adjoined that of Atagau, also mentioned in the Adulis inscription. It apparently bordered on Erg, also mentioned in what appears to be the first Ge'ez inscription by Gdr, nagashi of Aksum, Drewes, "Problemes de Paleographie Ethiopienne", in AE, I (1955), pp. 123-126. Inscription 10 : campaigns against what seems to mean "the kingdom of Afan", and the people called Serene, who also appear in the Azbi-Dera inscription, cf. p.24.

2. A very interesting phenomenon of the Aksumite programme of expansion is described in the trilingual, pre-Christian inscription of Ezama, Iittmann, op.cit. I, pp. 4-18. Two of the king's brothers were sent against a Beja rising which they suppressed. On their return they brought with them many head of cattle, and "six chiefs with their 
Establishment of the Church in Aksum

Aksum was at the height of its power in the middle of the 4 th century. Its military interventions in the Nile Valley had already given the tottering kingdom of Meroe" a final coup de grace, and had brought the former provinces of its old rival under its own sphere of influence. More than a century of direct participation in the local struggle for power among the South Arabian kingdoms had also brought Akgum into its first period of political supremacy in the

Footnote 2 cont. from previous page

people numbering 4400". These wer taken together and settled in one of the provinces of the Kingdom. In the Greek version the place is called "Matlia" and in the Sabean and Ethiopic it is described as "the district of B?rn". It has been proposed that this may be a reference to Begemdir which can mean "the land of the Bega", ibid., p. 13. Kammerer, A. Essai, p. 88, n.4. In the late medieval period Begemdir was a highland district separating the basin of lake Tana and the upper course of the Tekezze. Althou only two letters are common between the two names, the suggestion is very ingenuous. Strategically it makes perfect sense for Ezana to have sent a group of rebels captured in the northern frontiers and to have resettled them in the south-western corner of his kingdom. King Be'ede Maryam (1468 - 78) took an exactly similar measure against a rebellious people in Dewaro whom he transported en masse, and resettled in Gojjam, Chronique de Zar'a Ya'qob et de Ba'eda Maryam, ed. and tr. J. Perruchon, pp. 157-159.

1. Sayce, A.H., "A Greek inscription of a King (?) of Axum found at Meroe", Proceedings Soc. Biblical Archeology, XXXI (1909), pp. 180-203; Iittmann, op.cit. IV, pp. 3242; Kammerer, A., Essai,pp. 67-83; Conti Rossini, Storia d'Etiopia, pp. 201, ; Doresse, J., I Empire du Pretre Jean, I, pp.94-98, 145-149; Kirwan, I. P., "A Survey of Tubian Origins", in SNR, XX (1937), pp. 49-52; Arkell, A History of the Sudan to 1821, (1961 edt.), pp. 170-173; Shinnie, P.I., "The Fall of lieroe" il Kush. III (1955), pp. 82-85. 
1

Arabian peninsula. Its port of Adulis had developed into the most important centre of international trade on the African coast of the Red Sea, and with the decline of the land routes of Arabia much of the eastern trade was handled by Roman maritime traders with whom Aksum was on friendly terms.

It is quite clear that, from the start, these economic contacts with the Eastern Mediterranean were also accompanied by a strong cultural influence. Already at the time of the author of the Periplus we are told that king Zoskales of Aksum was "acquainted with Greek literature". No doubt this was also true of his courtiers, many of whom were probably themselves Greeks, Hellenized Egyptians or Syrians. It is most likely that such foreign advisers, who knew the king's personality at a very close

1. Conti Rossini, "Expeditions", pp. 25-36; Kammerer, op.cit., pp. 39-43; Conti Rossini, Storia dittiopia pp.139-139; Ryckmans, G., L'Institutions Monarchiaue en Arabie Ifridionale avant 1 IsIam. 1951. pp. 304-317; Doresse, op.cit., pp. 120-128; Id.". "I IEthiopie e

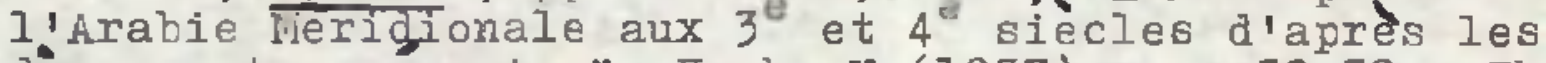
decouvertes récentes", Kush, V (1957), pp. 52-58. The chronology of these events have been drastically modified in more recent works, Drewes, Inscriptions de I'Ethiopie Antique, 1962, pp. 101-106; Ryckmans, G., La chronologíe des rois de Saba e du-Raydan, pp. 19-22.

2. Charlesworth, M.P., Trade-Routes and Commerce of the Roman Empire, 1924, pp. 58-67; Hitti, P.K., History of the Arabs (1961 ed.), pp. 58-60. Cf. also Hourani, G.r. "Dia Roman Commercial Competition ruin South Arabia?" Journal of Near and Middle East, XI (1952), pp. 29l-295. 
range, provided the author of the Periplus with his description of Zoskales as "...miserly in his ways and always striving for more, but otherwise upright". This characteristic pattern of resident merchants of Mediterranean provenance exercising a strong, permanent influence has been recently demonstrated in the case of South Arabia and the 2 eastern coast of the Red Sea. The Ethiopian region seems to have had its full share of this Mediterranean impact since the advent of the Ptolemies in Egypt. In many ways, Ezana's conversion to Christianity in the middle of the fourth century was the climax of this cultural influence.

It is probable that there were some Christians among the foreign residents of Adulis, Coloe and Aksum even before the conversion of the King. They may have also had a few converts among their Aksumite servants and commercial associates long before they could exert any influence on the royal family. Their religious propaganda must have gathered

I. The Periplus, p. 23. It seems that the passage has also been interpreted as signifying heavy custom duties (levied by the Kingdom of Aksum), Charlesworth, op.cit., p. 64 .

2. Pirenne, J., "Ia Grece et Saba; une nouvelle base pour la chronologie sud-Arabe", in Memoires Acc. Inscr.ere partie, 1960, pp. 116-120, 131, 176-191.

3. Kammerer, A., Essai, 1926, pp. 99-106; Conti Rossini, Storia dittiopia, pp. 145-156; DOresse, J., op.cit., pp. 136-139, 149-153.

4. Guidi, I., "La Chiesa Abissina", in OM., II (1922), p.124. 
momentum with the growing prestige of the Christian Church in the Roman Empire, and with the final success of the Emperor Constantine (312 - 337) against his anti-Christian rivals. It is precisely in the last decade of the reign of Constantine that the traditions seem to place the first arrival of Frematos in Aksum. The triumphant establishment of the Christian Church in the Roman Empire gave an impetus to the religious efforts of the christians in Aksum, and Ezana's conversion may not have been totally free of diplomatic and political considerations.

The first effect of the king's conversion does not seem to have opened the whole of his kingdom to the proselytizing influence of the christian zealots at his court. In fact, if one were to judge from his first non-pagan inscription, his own acceptance of the new religion was extremely

1. According to there traditions prematos first stayed in Aksum as a court official for some years before his return to his country, Syria. On his way there he called at Alexandria and told Patriarch Atnatewos (328 - 73) of the excellent prospects of the Church in Aksum appealing to him to send a bishop to guide the small congregation. The Patriarch saw the enthusiasm of the young Syrian and appointed him the first bishop of the Aksumite Kingdom, Conti Rossini, "A propos des textes ethiopiens concernant Salama (Frumentius)", in sethiope, I, 1922, pp. 2-4, 17-18; Kammerer, op.cit., p. 101. Patriarch Atnatewos suffered a number of exiles in his term of office because of the Arian controversy, and it appears that it was on his second return to his seat $(346-57)$ that prematos was ordained. Wgr. C. Lagier, I'Orient Chretien, Vol. I., 1935, p. 138.

2. Halevy, J., "I'alliance des Sabeans et des Abyssiniens contre les Himyarites", RS., IV (1896), p.64; Guidi, I., "Bizanzio e il regno di Aksun", in Studi Bizantini, 1924, p. 137; Kammerer, op.cit., pp. 102-103. 
equivocal and he may have had to contend with anti-christian 1

conservative forces in the Kingdom. It seems therefore that at first Bishop Fremmatos' congregation consisted only of a section of the Royal Court and the foreign resident merchants and their households. In Aksum and other centres of population along the major routes to the coast former temples were converted into churches, and new places of Christian worship erected. Because of the lack of books in Ethiopic at the time, Greek was probably the major language of the church. Nost of the clergy may also have been of foreign provenance. Thus, although its position as the royaI cult may have added much prestiege to Christianity in the country, its scope for expansion after Ezana's conversion was extremely limited. It is in fact more than a century after Erana's conversion, with the advent of groups of Syrian missionaries - the Sadgan, and the Nine Saints - that the traditions of the church show definite signs of progress in the Kingdom of of Aksum.

1. Cerulli, Storia della letteratura etiopica, 1956, pp. 20, 21.

2. Doresse, op.cit., pp. 190, 230-239.

3. The hagiographical traditions about these early missionaries have been studied by various authors, Geale krafawi. ed. and tr. in part Guidi, I., in riRAL, Ser. V, Vol.II, Pt. 1, 1896, pp. 54-96; Conti Rossini, L'Omelia di Yohannes, Vescovo di Aksum, in Onore di Garima, in Actes du XI Congres des Orient, Paris, 1897, pp. 139-177; Id., Acta Yared e Pantalewom, in CSCO, script. Aeth. Series iltera, t.XVII, 1904; Id., Storia d'stiopia, pp. 156-163; Horesse, J., Iitmpire du Pretre Jean, I, pp. 182-189; 
The episode of the Sadqan and the Nine Saints is placed towards the ond of the fifth century, and may have been connected with antimonophysite persecutions in the Byzantine Empire after the Council of Chalcedon. Before the advent of these clerics in Ethiopia, it seems that the effective sphere of influence of the Church was limited to a narrow corridor between Adulis and Aksum along the main caravan routes. But they established permanent outposts beyond these frontiers and the monastic communities attributed to the Nine Saints alone extend from the River Mareb north of Aksum as far as the district of Ger'alta in central 2

Tigre. The other group, collectively known as Sadqan, are said to have settled and taught in the district of Shimezana. A much more productive career seems to have been that of Abba Meta who is renowned for his evangelical activities in the region of Baqla in northern Eritrea, in Serawē and Shimezana, where his famous church of Debre Libanos was still the centre of a powerful community in the

1. Guidi, "Ia Chiesa Abissina", p. 126; Kamerer, op.cit., p. 104; Conti Rossini, Storia d'Etiopia, pp. 162-163.

2. The most northerly community was Abba Alef's at Beesa, overlooking the Mareb river from the south; Yém'ata went southwards, crossed the $R$. Wer'i and established himself in Ger'alta. The rest of the group settled between these limits : Iiqanos and Pentelēwon near Aksum, Afsē at Yeha, Aregawi at Debre-Damo; and Gerima north of Adwa, Conti Rossini, Storia d'Etiopia, pp. 158-161; Doresse, J., op.cit., I, p. I'85.

3. Ibid.. p. 187; Conti Rossini, op.cit., pp. 156-157; Anfray and Schneider, loc.cit. 
fourteenth century.

The efforts of these men brought the church deap

into the interior and the traditions of their conflicts 2

with the local people probably represent pagan resistance to the fregh incurgions of the new religion. It seems that, more than in anything else, the importance of these commurities lay in serving as permanent centres of Christian learning. No doubt the first thing these Syrian monks set out to do was to translate the Bible and other religious books into Ethiopic. Although Ethiopic was already in use as a written language, their literary activities further enhanced its development and facilitated the teaching of the Chriatian religion in the country. Many of the local people joined the communities, received enough religious training and provided a growilng number of reoruits for the church. Many of them opened their own little schools in their parishes and offered educational facilities for the members of their congregation who cared to send their children to school. The kings watched the development very closely and

1. Conti Rossini, op.cit., pp. 157-158; 1d., "I'evengelo d'oro di Dabra Libanos", RRAL, Serv.5., Vol.X (1901), pp. 177-180; Doresse, J., op.cit., pp. 187-188.

2. Gedle Aragawi, cit. p. 64 .

3. Cerulli, Storia della letteratura Etiopica, 1956, pp. 2333. The tranglation of the Gospel of St. liatthew is especially attributed to Abba Meta'i, Conti Rossini, Storia d'Etiopia, pp. 157-158.

4. See Drewes, Inscriptions de I'Ethiopie Antique, pp. 94 97, 101-103. 
encouraged it. This gave much prestige and economic benefit to the clerical profession and no doubt attracted many individuals to it. Two basic problems - lack of trained candidates for the services of the church, and the absence of books in Ethiopic - had faced the church in its programme of evangelization. The initiative generally attributed to the Syrian monks seems to have done a great deal to alleviate these problems and to strengthen the position of the church in the country.

Chrigtian Expansion in the Agew Interior

Except for hagiographical traditions - which in their present form cannot be dated earlier than the 13 th century - there are practically no contemporary a ources for the story of the evangelization of the kingdom of Aksum. It is quite clear, however, that by the beginning of the 6 th century the church had made tremendous progress, and Cosmas included the kingdom among the countries where

"there are everywhere churches of the Christians, and bishops, martyrs, monks and recluses where the Gospel of Christ is proclaimed".

This was no doubt true of northern Ethiopia, incluaing much of the province of Tigre, the whole of the Eritrean plateau, and the coastal settlements. The effect of these developments must have also been felt in the more distant parts of

1. The Christian Topography, p. 120.

2. Conti Rossini, Storia d'Etiopia, p. 163. 
the kingdom, particularly along the major trade routes and wherever military outposts had been established. It may be that Cosmas was also making a reference to the interior districts of the Aksumite Empire when he reported that Christianity had spread "in Ethiopia and Axom, and in all the country about it". Such active expansion of the church into the Aksumite interior tallies very well with the strong position held by the kingdom in the 6 th century as a champion of Chriatianity in the whole of the Red Sea area. The crusading activities of King Kaleb against the persecutions of Christians in South Arabia, and the second Aksumite occupation of the peninsula that followed his military intervention are very well documented. It is also apparent that within his own kingdom his reign was marked by a major progress in the spread of the Christian religion among the Agew tribes of what are today the districts of Wag and Lasta. Iocal traditions collected at Lalibela attribute a number

1. The Christian Topography, p. 55; Moberg, A. , The Book of the Himyarites, 1924, pp. 134-135, 138, 140-142; Procopius, History of the wars, tr. and ed. Dewing, H.B., 1914, Vol.I, pp. 179-195; Gedle Pentelewon, ed. Conti Rossini, pp. 52-56 (text); Halevy, "L'alliance des sabéans et des Abyssiniens contre les Himyarites", RS, IV (1896), p. 86; Kammerer, op.cit.. pp. 107-117; Ryckmanns, G., Institutions Monarchiques pp. 320-325; Doresse, op.cit., pp.154-197. 
of churches to him in the region of the sources of River 1

Tekezze.

At the time of Kaleb's expedition to South Arabia the region of Wag and Lagta was already an integral part of the Aksumite kingdom. Cosmas provides an important documentary confirmation for this. He makes a reference to the governor of Agau, who was entrusted by the king with the protection of the vital long-distance caravan routes to the gold mines of Sassou. These gold mines have been identified with the region of Fazogli on the Blue Nile just to the west of the present border between the sudan and

1. The churches include Iyela Miska'ēl, Dībīsa Giorghis, and Merora Maryam. My informant was Megabi Tegegne, an elderly member of the Community oI Lalibela, who was specially recommended to me by the Abbot, Memhir AfeWorg. Presented to him by the Memhir, I found Megabi Tegegne an inexhaustible source of oral traditions about his native Province of Lasta in particular. Hio-fos-

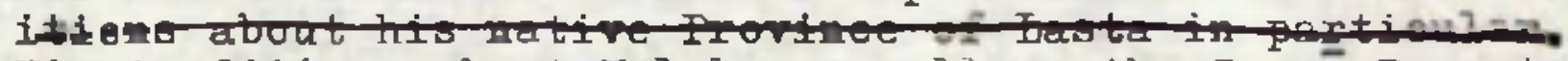
His traditions about Kaleb, as well as the Zagwe Dynasty (see pp.120, and 127, below) have a definite local orientation. According to him, for instance, Kaleb was a man of Iasta and his palace was at Bugna where it is known that Lalibela had later established his centre. The relevance of this tradition for us is the mere association of the name of Kaleb with the egangelization of this interior province of Aksum. Cf. Alvarez, The Prester John of the Indies, Vol. I, pp. 200-201.

2. The Christian Topography, pp. 52-53. 
Ethiopia. If this is correct, the caravan routes from Akeum probably ran southwards to the present district of Wag, where they crossed the Tekezze, and thenproceeded in a south-westerly direction across Dembya, north and west of Iake Tala to the gold producing area of Fazogli. In the region west of lake Tana the territory traversed by these routes is dissected by many rivers flowing westwards to join the Blue Nile, and Cosmas" geographical notes on the region tend to make the above identification very secure :

"... the sources of the river Nile lie somewhere in these parts, and in winter, on account of the heavy rains, the numerous rivers which they ${ }_{2}$ geinerate obstruct the path of the traveller".

Apart from showimg the extensive sphere of Aksumite commercial activities il the reign of Kaleb, these notes of Cosmas are also invaluable as providing the earliest account of the western limits of the Kushitic peoples of the Ethiopian plateau. In the late medieval period much of the area through which Cosmas' caravan routes travelled was imhabi-

1. Conti Rossini, "Notes sur l'Abysinnie avant les Bemites", pp. 147-148. He seems to have changed his views later in favour of a more untenable identification in Welega, Storia d'Etiopia, p. 169; Wainwright, G.A., "Cosmas and the gold trade of Fazogli", in Man, Voli.42 (1942), No. 30, pp. 52-58; Arkell, A.J., "Cosmas and the Gold Trade of Fazoglin in Man, Vol. 44 (1944), No. 24, pp. 30-31.

2. McCrindle, op.cit., p. 53.

3. Infra, pp. 383-7. 
trict of Agewmidir has a dwindling minority of Agewspearing families. Cosmas mention of the governor of Agau as being in charge of the caravans atrongly indicates that already at the beginning of the sixth century, the western frontiers of the Agew people extended towards the region of lake Tana and the sources of the Blue Nile. Hil description of the "silent trade" also inaicates that a major linguistic frontiex had to be crossed before reaching the gold-mining areas.

There are local traditions of Agew migrations from north-east into the rich country of Gojjam south of Lake Tama : the Awiya-speaking tribes of Agew-midir derive their origin from lasta. The original inhabitants of the area appear to have been ancestors of the Gumuz, who still occupy the territory west of Achefer and Agew-midir and extend beyond the Ethiopian-Sudanese frontier. The Agew call them Shanqilla and relate that they originally conquered the land from them. No chronolygical deductions can

1. Conti Rossimi, "Popoli dell'Ethiopia Occidentale : i Gunza ed il loro linguaggio", i直 RRAI, XXVII (1919), pp. 252-254; Grottanelli, V., "I Niloti dell Etiopia allo Stato attuale delle nostre conoscenze", BSGI, 1941, pp. 567-568; Cerulii, E., Peoples of South-west Ethiopia and its borderlands, 1956, p. 12 .

2. Beke, "Abyssinia, being a continuation of routes in that country", JRGS, XIV (1844), p. 10; Conti Rossini, "Appunti sulla Iingua awiya del Danghela", GSAI, XVIII, 1905, pp. 122-123; id. "Popoli dell'Etiopia Occidentale : i Gunza", cit. p. 257. 
be made from these traditions as such, but Cosmas' report of the caravan routes protected by the Agew implies that the migrations into this area were well underway by the first half of the sixth century. Between this date and the beginnimg of the fourteenth century (when hagiographical traditions become available) the process was already complete, and Agew predominance in Dembya and east of the headwaters of the Dinder, Balas, and Dura rivers in Gojjam was a fait accomplie. It is apparent that, in the end, not the Shanalliah but the unfagourable climatic conditions of the regions further west put a limit to this continuous process of territorial expansion which had already started before the time of Kaleb's governor of Agau.

The Agew language and people consist of a number of dialectical groups presently found in small pockets spread over a vast territory extending from Bogos in Eritrea to Agew-midir in Gojjam. In all their traditions of origin they indicate Lasta as the area of dispersal. Conti Rossini has explained this as being a general tendency of the Agew to show a common origin, and to associate

1. Collt Rossini, La langue des Kemant en Abyssinie, 1972, pp. 25-34; Tubiana, J., Note sur la distribution geographique des dialects Agaw", in CAA.. No. 5, 1955, pp. 3-12.

2. Conti Rossini, "Racconti e Canti Bileni", Actes, $14^{e}$. Congres Inter. Orient., 1907, pp. 332-334; id., "Stüdi su popolazioni dell'Etiopian, pp. 53-54, 82 (extract). 
themselves with the political fortunes of the Zagwe 1

Dynasty. His explanation is quite acceptable in the case of the lesser, and relatively more recent migrations auch as those of the Zagwa and Adkeme-Melga of Eritrea. For the western and southern Agew, however, the insistence on their traditions of lasta origin seems to refer to a period much earlier than the Zagwe Dymasty. Aksumite attempts to expand southwards had been long and persistent, and were most active in the second half of the third and the beginning of

1. "Appunti sulla Iingua Khamta dell'Averghelle", ir GSAI, Vol. XVII, (Pt.2, 1905), p. 190; id. "Apputi sulla lingua awiya del Danghla", GSAI, Vol. XVIII (1905), p. 122.

2. On the Zagwa and the Adkeme-Melga see p. $12 \boldsymbol{\delta}, n \cdot 1$ It is very unlikely that any migrations from the south were at ali involved in the case of the Bilen (Bogos). Conti Rossini has taken the legendary episode of Gudit (loth C.) as a point of departure for their migration northwards from Lasta, "Note Etiopiche", GSGI.. X, 1897, pp. 153-156; "Raconti e Canti Bileni", cit. pp. 336-337; Storia d'Etiopia, p. 286. But he himself has sugested a Damoti (Sidama) origin for the queen whose anti-Christian activities in the loth $\mathrm{C}$. are attested by Christian and Muslim sources. It is most improbable that the actions of this Queen of the South could have resulted in such a major population movement in the northern part of the kingdom, cf. pp.74-5,78-4,97,100. Unlike the Zagwa and the Adkeme-Melga who have lost their lamguage in the process of their migrations northwards, the Bllem still speak a dialect of Agew which, Conti Rossini has himself shown, preserves many archaic forms - Ia langue des Kemant. cit. p. 27. It is more likely that the Bilen are the descendants of the original Agew inhabitants of borthern Ethiopia who, in the period of the early South Arabian migrations, were pushed northwards and isolated from their southern kinsmen by an expanding "semitic" wedge which stretched from the coast to the region of Aksum. 
the fourth centuries of our era. Both the flomunentum Adulitanum and one of the inscriptions of Ezana make a I clear reference to the people of $\Delta$ th agau, and both seem to locate them in the region east of the River Tekezze. In these documents the Agew are presented as the object of intengive wars of conquest led from the north against them, and it is apparent that by the middle of the 4 th century, already before Ezana's conversion to Christianity, a decisive break-through had been achieved by the kimgdom of Aksum into the very heart of their country east of the River Tekezze. Naturally the Aksumite pressure was strongest on the fromtier districts of Aberghele, Seloa, and Bora, and the centre of Agew resistence seems to have moved to the area south of the River Selleri, in Wag and Lasta. Two centuries after Ezana's conquest, when the region was well-established as a tributary Province, Kaleb's governor of Agau probably has his seat of government in this area (which also served later as the cradle of the Zagwe dymasty). From here he protected the caravan routes west of the Tekezze, where some Agew tribes may have already begun to settle. Probably subsequent migrations also followed the same direction, thus

1. The Christian Topography, p. 61; Iittmann, op.cit., IV, pp. 24-28. For the identification of the rame with Agaw see - Conti Rossini "Appunti sulla lingua Khamta", cit. p. 183, . 1 . 
giving rise to the Awiya tradition of Lasta origin.

The traditions of vigorous evangelical activities by the Aksumite church in the interior, during the reign of King Kaleb, only reflect a general phenomenon of the sixth century, which was marked by an active expansion of the Christian Church in North-East Africa. The three pagan kingdoms of Nobatia, Mukurra and Aloa were converted between the yea.s 543 and 580, and the temple of Isis on the island of Philae was at last converted into a church. It was apparently an official policy of the Byzantime Empire to evangelize these areas in an attempt to stop the recurrent border clashes on the southern frontier of Egypt. A simiIar programme preoccupied the minds of the Christian kings

1. Canti Rossini sees a possible reference to this lasta origin in the name Dahema or Dahma given to the sgew by the Gumuz of western Gojjam; the mame may be a derivation from Dahna, a place mame which he locates in weatern Lasta, "Popoli dell' Etiopia occidentale : I Gunza", cit. p. 258. Dehana is today one of the three districtw of Wag, Journal of the Ministry of Interior, Vol.I, No. 3 (1962) p. 8. The Chronicler of IAdme-Siyon also makes a reference to the "governor of Dahma" next to the "governor of Wag", Histoire des guerres d'Amde-Siyon roi d'stiopia. ed. and tr. Perruchon, J., in J.A. Ser. 8, VOI. XIV, Pp. 293, 384

2. Kirwan, I.P., "A contemporary account of the conversion of the Sudan to Christianity" in SNR., XX (1937), pp. 289295; Ugo Monneret de Villard, Storia della Nubia Cristiana, 1938, pp. 53-70; Latourette, K.S., A History of the Expansion of Christianity. Vol. I (1953), p. 194 .

3. Arkell, A.J., A History of the Sudan to 1821, (ed. 1961) pp. 179-181. 
of Aksum. It has always been assumed that the original 1 group of Syrian missionaries came to the kingdom on their ow initiative, or, as the hagiographers have it, by divine inspiration. It is more likely that there was an official encouragement of clerical immigrants in Aksum, possibly accompanied also by a programe of careful recruitment and selection by the (Monophysite) Patriarchate of Alexandria. In those days, when religious controversies ran very high, it is unlikely that the Patriarch would have left the prosperous diocese of Aksum to slip out of his hands. Indeed, even in the very early history of the Church, it is a sign of the great influence of the Patriarch that there is a Byzantine tradition of a vain attempt by the Enperor Constantius $(337-61)$ to convert the Aksumite Church to his Arian persuasions. The dangers were as great in the sixth century. John of Ephesus's story of the intrigues and intensive competition between the Jacobite and Orthodox factions in Constantinople on the occasion of the conver3 sion of Nubia was characteristic of the whole period. Aksum seems to have participated actively in this struggle for episcopal influence, and the earliest Christian missionaries

\section{1. $\mathrm{Pp} \cdot 46-48$.}

2. Kammerer, Essai, pp. 105-106.

3. Kirwan, op.cit., pp. 290-214. Monneret de Villard, op.cit., pp. 60-64. The latter author the story of early monophysite successes in Nubia reported by John of Ephesus. 
in the kingdom of Aloa are believed to have been Aksumite. Within the realm of Aksum itself, it is very clear that, from the start, the kings and bishops encouraged the advent and settlement of Chriatian missionaries. The programme was probably intensified towards the end of the 5 th century, when, as we have seen above, the traditions place the advent of the Nine Saints and the Sadqan. In these traditions the kings are closely associated with the conduct of the religious activities of the period. They assigned the new arrivals to suitable areas, they made generous endowments to the communities and religious schools established by them, and protected them from local anti-Chrlstian ill-treatment. They probably made recruits from among the young atudents of these communities, had them ordained, and seat them to gtaff new parishes established further afield. Similar encouragement was probably practised at the local level in the courts of the king's officials. This probably coutinued until the prestige of the church was sufficiently established for the local people to enter the ministry of their own accord. We have practically no documentation for the details of the life of the church in this period. But

1. Ibid., p. 69; Doresse, op.cit., p. 193.

2. Gedle Penteliēwon (text) ed. Colli Rossini, pp. 44, 52-56, 59; Gedle Aragawi, ed. Guidi, pp. 68-69, 74. There is an echo of the royal protection given to these early missionaries against local ill-feeling in the legendary campaign conducted by Kaleb in the district of Bur in support of the Sadqan, Schneider, "Une page du Gedle Sadqan". cit. pp. $168-169$. 
it is quite clear that the eseential doctinal and liturgical traditions were securely established in the first four centuries of the history of the Aksumite church. It is indeed due to the strength of these traditions that the Ethiopian church was able to survive a long period of only intermittent contacts with Alexandria.

Islam and the Decline of Aksum

Kaleb's intervention in South Arabia was mainly undertaken at the invitation of the Patriarch of Alexandria and the Emperor Justinian. However, Byzantine interest in the peninsula was not limited to the establishment of the Church there. The protection of the eastern trade from Persian monopoly constituted a major factor in Justinian's policy of securing the alliance of Aksum and her South Arabian dependencies. Aksumite readiness to co-operate in this was helf-hearted, and proved completely ineffective

1. Commenting on the obscure period of Ethiopian history before the l3th century Professor Cerulli makes the following valuable remark, "... a mio parere, quel vuoto di secoli che divide le iscrizioni del re Daniele e le opere del primo Trecento ... non e che apparente e non significa, communque, altro che una lacuna nella trasmissione dei codici...", Storia della leterattura Etiopica, p. 35 .

2. Procopius, History of the Wars, I, 20 : 9-io; Cf. S. Smith, "Events in Arabia ir the sixth century A.D.", in BSOAS, XVI (1954), pp. 425-427. 
against the superior economic and military prowess of the Persian Empire. But it probably gave the Persians and their allieg enough reason to strike hard at the maritime trade of Aksum in the Red Sea. Iocal traditions among the inhabitants of the islands and coastal settlements - formerly under Aksumite rule - refer to a period when they were dominated by a people called Furs, to whom many wells are attributed. This is probably a reference to the Persians. It is apparent that the first serious blow to Aksumite economic and political interests in the Red sea was inflicted by the Persians during their ephemeral auccess over the Byzantine Empire, Nascent Islam continued on this course, and in time ensured a more permanent withdrawal of effective Christian power from the coastal areas.

The amicable relations between the Prophet and the kingdom of Aksum during the period of his exile which have been preserved in Muslim traditions were only short-lived, and hostilities seem to have started already before his death in 632. Many incidents of maritime conflict between the Aksumites and the Muslims marked the whole of the geventh century. At first their longer experience in naval

1. D'Abbadie, A., Géographie de I'Éthiopie, 1890, Vol.IF pp. 24, 328; Basset, R., "Ies Inscriptions de l'Ale de Dahlak" in JA. Ser. 9, Vol. I, 1893, p.13. Conti Rossini, Storia d'ttiopia, pp. 196-201; Doresse, J., I'timpire du Prêtre Jean. Vol. I, pp. 193-195; Trimingham, J.S., Islam in Ethiopia (ed. 1965), p. 42.

2. Conti Rossini, Storia detiopia, pp. 207-2ll; Trimingham, op.cit., pp. 44-46; Doresse, op.cit., Vol.II, pp. 3-5. 
warfare apparently gave the Aksumites an advantage over their adversaries. It was not until the advent of the Ummayyads and Mu'awiyya's organization of a strong Muslim naval force that the balance of power began to change in favour of the Muslims. Soon afterwards, at the beginaing of the 8th century, the Dahlak islands were annexed, and began to serve as a distant place of political aile for prominent prisoners of state during both the Ummayyad and Abbasid Caliphates. Even after this major defeat, however, the ksumites seem to have continued the struggle and we have references to maritime conflicts as late as 770 A.D. But this was a hopeless struggle. During the period between the beginning of the seventh and the midile of the eighth centuries the Christians seem to have lost gradually their control of the maritime trade. The Byzantine merchants

1. For these early conflicts see Conti Rossini, op.cit., pp. 211-214; Trimingham, op.cit., pp. 46-47; Hasan Yusuf Fadl, The Arabs of the kastern Sudan. (Ph.D. Thesia,

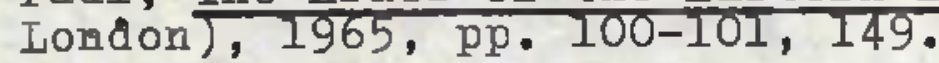

2. Basset, R. "Ies Inscriptions de l'Âle de Dahlak", cit. pp. 89-90; Rossi, E. "Sulla storia delle isole Dahlak (Mar Rosso) bel medioevo", in Atti del $3^{\circ}$ Congresso di Studi Coloniale, 1937, Hed p. 367; Irimingham, op.cit., p. 45, n.1. There seems to be a reference to this historic role as a place of exile in an inscription dated 1225 A.D., which de日cribes the ruler of the islands as "the refuge of the weak and disgraced; the shelter of strangers and exiles", Wiet, G., "Roitelets de Dahlak" in BIE, tome $34(1951-2)$, pp. 94-95.

3. Hassan, op.cit., p. 101 . 
Who resided in the Aksumite kingdom, on whom much of the international trade depended, probably left in the early stages of the conflict. The coastal settlements and other centres of trade declined, and the Aksumite kings seem to have stopped issuing coins towards the middle of the eighth century. Once again the control of international trade in the Ethiopian region passed into the hands of the dominant group in the Red Sea area. Only this time it was the Muslim merchants who benefited by the change of the political situation.

There are no historical documents which can help us study what exactly was the effect of this development on the kingdom of Aksum itself. It is apparent, however, that, despite the reverses suffered on the coast, the kingdom held its own on the mainlaind. It is significant that the earliest tradition of a Muslim exile in the Red sea area is that of Abu Mihgan banished to the port of Basa' (= Badi) by Caliph

1. The presence of such resident merchants in the kingdom is quite clear from the Periplus. Philostorgius refers to a Syrian colony near Akgum in the 4th century, quoted by Doresse, op.cit.. I, p. 189. Cf. McCrindle, The Christian Topography, p. 56. According to Procopius, King Kaleb'g governor of South srabia, Abrham, was originally a slave of a Roman residing in Adulis, History of the Wars, I, 20 : 4.

2. Contt Rossini, Storia dittiopia, pp. 213-214, 217; Contenson, "Le foullles a Axoum en 1957" in AE, III (1959), pp. 32-34; Id. "Les principales étapes de ITEthiopie antique", cit. p. 22; Id. "Les fouilles a Axoum en 1958", AI, V (1963), pp. 13-14. 
Umar in 634 A.D. In an important article crowfoot has identified Badi with a site near the present port of Aqiq just to the north of Ras Kasar, which is the frontier between Eritrea and the Sudan. This tradition of a Muglim exile at Badi during the Orthodox Caliphate may define the northern limits of the Aksumite kingdom at the time.

Similar traditions for the Ummayyad and Abbasid caliphates refer only to the Dahlak islands. Thus the direct relevance of Islam as a politiolal factor in the mainland districts of the kingdom was minimal in this early period. Ethiopic inscriptions which Conti Kossini dates to the seventh century indicate the presence of effective Christian power in the hot lowlands of the Barka 3

Basin. The traditions collected by Munzinger of an ancient monastery (= agere-nagran) in the region of Baqla

1. Conti Rossini, op. cit., p. 212.

2. "Some Red Sea Ports" in GJ, XXXVII (1911) pp. 542-547. Cf. also Crowfoot, OGS, The Fung Kingdom of Sennar, 1951, pp. 104-107; Hasan, op.cit., pp. TOI, 149-150; Conti Rossini insists in equating Badi with Massawa, op.cit., pp. 212, 214, 273-274. The historical reasons for his identification are not apparent and it seems to depend on a lgth C. Tradition collected by Munzinger, cf. AlUmari, Masalik el absar fi mamalik el amsar. Vol. I, 1927, tr. Gaudefroy-bemombynes, p. 19, n.2. I bn Haukal locates Badi on the African coast, at least four days' distance north of Dahlak and an equation with Massawa seems quite impossible, Configuration de la Terre, tr. G. Wiet, Vol.I, 1964, pp. 41-42.

3. "Documenti per l'archeologia eritrea nella bassa valle Barca", RRAI, Serv. 5, Vol. XII (1903), pp. 139-147. 
in northern Eritrea probably belong to this period, when the inhabitants were still predominantly Christian. Nevertheless, the loss of the maritime trade must have reduced the wealth and power of the Aksumite kinga and gradually slackened the effective control of their provinces. This 2 probably led to local revolts, and weakened the defence of the northern frontiers with the pagan Beja who appear to have gradually pushed their way into northern and central 3

Eritrea.

1. Quoted by Crqwfoot, op.cit., pp. 104-105. The monastery is said to have been on the pilgrimage route to suakin. Hagiographical traditions about 14 th $\mathrm{C}$. and 15 th $\mathrm{C}$. pilgrims to Jerusalem do not refer to such important Christian sites north of the Bogos and Marya districts. It is also difficult to imagine a post-l5th C. foundation for the monastery, in this distant northern region.

2. Three inscriptions by an Aksumite king allude to such troubled days. Two of them bear the name of the king Hasani Daniel, son of Debre-Ferén. One of these mentions armed revolt of the "people of Welqayt" (already annexed by Ezaxa) who are said to have even marched against Aksum. The King and his troops suppressed the rising, which appears to have been widespread, Littmann, op.cit., Inscriptions 12, 13 and 14. Cerulli very cautiously dated these inscriptions between the 7 th and 12 th centuries, Storia della letteratura Etiopica, p. 22. He does not give his reasons for this. But his views may have been influenced by the famous traditions of the pagan queen Gudit and the political decline attributed to her revolt dated to the loth century, which nevertheless seems too late a date for the general historical context of the ingcriptions of Hasani Daniel.

3. Conti Rossini, Storia d'ttiopia, pp. 267-276; Bewbold, D., "The Beja tribes of the Red Sea hinterland", in AngloEgyptian Sudan from withir, ed. and tr. J.A. de C. Hamilton 1935, pp. 148-151; Crowfoot, op.cit., pp. 102, 104-108, 118-122. For the background of the Beja see Monneret de villard, op.cit., pp. 24-60. 
Christian Expansion in the Regions of Amhara and Shewa

As we have seen above, the Christian kingdom and the Aksumite Church had already been securely established in the heart of the Agew country in the first quarter of the 1

sixth century. It was in this direction that the centre of gravity of the kingdom now began to shift. This development is quite apparent from an early Muslim tradition about the Aksumite king who was contemporary with the Prophet. His name is given as EI Asham, son of 'Abdjar, and father of King Arma. NI-Asham, the Negashi, had welcomed the companions of Muhammad whom the latter had sent to Aksum to take refue from anti-Mulim persecutions in the Hijaz. When the news of the death of King EI-Asham reached the Prophet in $630 \mathrm{~A} . \mathrm{D}$. he is said to have remembered him with affection and pronounced some prayers for him. This has apparently created the tradition that the king was in fact a convert to the new religion, and the tradition has in the end led to his being considered as a Muslim saint. In the 16 th century, when Gragn's triumphant army was on its way from Tembēn to Agamē, the elated Muslim troops asked for their leader's permission to visit the tomb of this friend of the Prophet. His name is here given as Ashamat En-Nedjachi

\section{Pp.49-56. Sxpres.}

2. Conti Rossini, op.cit., pp. 210-211.

3. Trimingham, op.cit., p. 46, n.2.

4. Futuh al-Habesina, tr. R. Basset, 1894, pp. 419-420. 
(certainly a variant of Tabari's El-Asham) and the tomb seems to be near Wiqro where there is still a site remembered 1 as such by the local people. The significance of this is that we should have a tradition of the tomb of an early seventh century king (d. before the end of 630 A.D.) of Aksum outside the ancient capital. WIqro is about rixtyfive miles south-east of Aksum and the tradition of El-Asham's burial there is strongly indicative of a general southward movement of the centre of gravity of the Christian kingdom already in the seventh century. It is impossible here to follow this southward expansion of the Kin dom and the Chruch in great detail. This must await a close investigation into the traditions of the churches and their congrgations in the crucial area of southern Tigre, Lasta and Angot. From about the first quarter of the ninth century, however, both the fragmentary Arabic refereaces to the Ethiopian region and the traditions of the Church show the kingdom definitely established well beyond the central highlands of Angot which serve as a great water divide for the

1. Guida dell'Africa Orientale Italiana (ed. 1938), p. 300. The name of the king has apparently undergone an onomatopoeic transformation into Ahmad Negash but the reference is to the same person. Doresse has found many traditions of acient royal tombs in the region of Ger'alta, I'Empire du Prêtre-Jean, I, p. 185. For the genealogy of King EI-Asham by Fuslim writers and for attempts to identify him with some of the names in the traditional lists of Aksumite kings cf. Hartmann, M., "Der Nagasi Asham und sein Sohn Arma", in ZDMG, Vol. 49 (1895), pp. 299-300; Basset, op.cit., p. 419, n.2. 
three major river systems of the central plateau of Ethiopia. Here rise the upper waters of the Tekezze, the Bashilo (which is a major tributary of the Blue lile) and numerous other rivers flowing eastwards into the basin of the Awash. Strong traditional data show the Christian kings activeiy engaged in military campaigns of territorial expansion south of this central region in the ninth century. The traditions centre around a "king of Aksum" remembered under the name of DignaJan :-

"During his reign he (who) led 150 priests from Aksum to Amhara and assigned them (to teach?) there. As he came out of Tigre he camped at Weyna Dega (and had) with him 60 tabots ... When he counted his troops there were found (among them) 180,150 dressed in coats of mail. Takin these he went to another country in Enerya, one month's journey away..." 1

Dïgna-Jan is noted for having ruled over a vast Empire and he is elsewhere referred to as having travelled "from horizon to horizon" in the course of a royal tour of his

1. Tarike-Neghest, MS. Dima, f.43a. D'Abbadie collected a shorter variant of this tradition in Begemdir, Conti Rossini "Il libro delle leggende e tradizioni Abissine dell'teciaghie Filpos" in RRAL, Ser. V, Vol. XXVI (1917), pp. 706-707. The local orlentation of the recital is clear from the location of the camp at Weyma-Dega in Begemdir. No other places are mentioned between Tigrē and Amhara, and this is no doubt due to the dominant pootZagwe traditions of the Amhara Christians claiming direct descent from ancient Aksum. The specific mention of Enarya definitely shows that the tradition has been affected by events in the late medieval period and the exaggerations of the strength of the army are quite obvious: For all these, however, the essential value of the tradition as an indication of southern expansion remains atrong. 
1

klngdom. It seems possible to obtain a chronological

framework for this vigorous movement of territorial ex-

pansion and evangelization from a comparative study of the available traditions. According to the Life of Tekle-

Haymanot (c. 1215-1313) the advent of his ancestors to Amhara and Shewa is connected with Dígna-Jan's programme of evangelization of his southern provinces. The reference to the king in this tradition may be related with the earliest of the saint's ancestors to settle in Amhara eighteen generations before him. 2 This brings Dígna-Jan to the first half of the ninth century. It is also sbout the same time

1. Gedle Yared, ed. Conti Rossini, p. 23 (text).

2. The Iife of Takla-Haymanot, ed. E.A.W. Budge, p. (text). Here the king is mentioned only with YIdla, the first ancestor of pekle-Haymanot who is said to have settled in Shewa ten generations before. In this hagiographicai tradition, which is essentially of Shewan origin, there is a clear tendency to emphasize the importance of the Shewan branch of the family, and the association of Yĩdla with Dígna-Jan may very well be an alteration of a more ancient tradition. Moreover in both the versions of the tradition about the king quoted above ( $.6 \%$. 6 . there is no mention of Shewa at all.

3. It is interesting to note that there is a reference in the IIfe of Patriarch Yosel (830-49) to an Ethiopian king at the time being engaged in a military expedition which kept him away from his court for some time. During the king's absence the Queen and her courtiers are said to have dismissed the Egyptian Bishop, YohannIs, who had already been in the country before Yosef's accession to the episcopal seat of Alexandria, Sawirus, History of the Patriarchs of Alexandria, ed. and tr. in P.0, $\boldsymbol{X}$, (I915), pp. 508-509, Cf. also Renaudot, E., Historia Pafriarcharum Alexandronum, 1717, pp. 273, 283. 
that local traditions refer to the foundation of the famous church of Debre Eqzi-labhēr on the mountaintop overlooking Lake Haiq in the North-East. Two apparently independent traditions are preserved in Gedle Iyesus-Mo'a about the date of the foundation of this Church. According to one of these traditions, the church was built by King Dilna'od and the Egyptian bishop Abuma Selama II, who is said to have come to Ethiopia 618 years after the advent of Selama I (Frematos), the first bishop sent to Ethiopia by the Patriarch of Alexandria. The other tradition dates the event at 6362 year of Creation. The two dates are rewardably ciose to each other, and both take the foundation of Debre Egzi 'abhēr to the third quarter of the ninth century. The chronicler of Ahmad Gragn also collected a similar tradition that the Church was built 720 years before the Muslims burnt it to the ground in 1531 A.D., which, however, makes it about

1. Gedle Iyesus-No'a, ed. and tr. S. Kur, in C.S.C.O. Vol. 259, script. Aeth. t.49, 1965, pp. 18-19. The advent of Selama I is a reference to the establishment of the church in Ethiopia, which Ethiopic chronolgical tables usually place at 245 E.C., cf. S. Gebrant, "Table du Calcul", in R.O.C.. I $(1918-9)$, p. 325. Thus the selame is equivalent to $870 / 1$ A.D. 6362 Year of the Creation is also equivalent to $869 / 70$ A.D. Conti Rossini's copy of the Gedle probably omitted some words in the phrase "618 years after Selama I" and he has adlopted a much earlier date, Storia ditiopia, pp. 262-263. Little credence can be given to the actual names of either the king or the bishop. The prelate is called after the first Bishop to Ethiopia in an obvious attempt to emphasize the expansion of the church at his time. 
half a century older than in the above traditions. All these isolated notes add up to show that the ninth century was a crucial period of expansion for the christian kingdom. They also find full confirmation in contemporary Arabic sources. Immediately after his description of the five Beja "kingdoms" in the north, Yaqubi (fl. 872 A.D.) gives short but invaluable notes on the extensive limits of the Christian kingdom :-

"It is a spacious, important country. The capital of the kingdom is Ku'ber. The Arabs still go to it for trading and they (the Ethiopians) have mighty cities and their coast is Dahlak. As to the kings in the land of al Habesha, they are under the control of the great king (the mehashi) to whom they show obedience and pay taxes. The Nejashi is of the Jacobite Christian faith. The Zenj are the last of the Habesha; they extend to
sind".

1. Futuh al-Habasha, ed. Basset, pp. 231-232 (text). It geems that here the translation of d'Abbadie and Paulitschke is more accurate, Futuh el-Habasha, Paris, 1898, p. 266. The difficulty arose from Gragh's chronicler who combines two different traditions in the same passage.

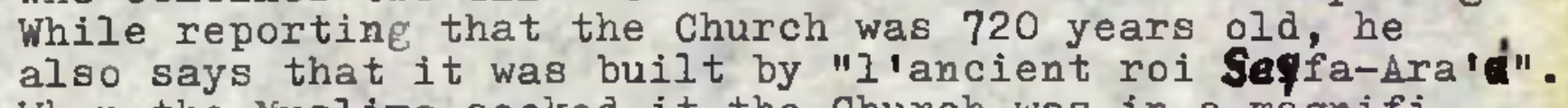
When the Muslims sacked it the church was in a magnificent condition : "Elle resplendissait d'or... (des) plaques d'or... couvraient entièrement le toit et 1 ' intêrieure de l'eglise." It is apparent that as such it was rebuilt by Seyfe-Ar'ad and its position as an important church and royal treasure probably started from his reign. Apparently to reconcile the two traditions, $R$. Basset made Seyfe-Ar'ad the founder of the church in 720 A.H., which he equated with 1342 A.D., p. 329 and n.I. However this king started his reign in 1344 , and $720 \mathrm{~A} . \mathrm{H}$. is only equivalent to $1320 / 1$ A.D.

2. Historiae, ed. Houtsma, 1883, I, p. 219. 
It is quite clear from these notes that, the obscure period of Ethiopian history between the middle of the seventh and the ninth centuries was in fact marked by a continuous expansion southwards. The ancient city of Aksum was then almost at the northerm end of the expanding territory and it was no longer the seat of government. Significantly, a hagiographical tradition connects the transfer of the capital with the royal founder of the church of Debre igzi'abher :-

n... in the seventh year of his reign...the (centre of the) kingdom moved from Aksum to the country of the east". 1

One of the most characteristic aspects of this process of expansion had been the establishment of military colonies in the newly conquered territorles. It has been said at the beginning of this chapter that the Agew were

1. Gedle Iyesus-Mo'a, p. 18 (text). It is not clear what is meant exactly by "the country of the east". The phrase may only be a reference a general direction southeast of Aksum. Arabic sources of the ninth and tenth centuries give a still unidentified site, Kuber, as the capital, cf. Yaqubi, loc.cit., Masudi, Les Praire日 d'or, ed. and tr.deMeynard and Courteille, Vol. III (1844), p. 34. The editors' identification of the site with Ankober (which was the capital of Shewa when their book was published) should not be taken seriously. Conti Rossini thought that Kuber coyld be a mistake in the MSS. for Ksum - Aksum, "Les listes des rois d'Aksoum", cit. p. 263, n.l. This is rendered even more improbable by the tradition quoted above. It $1 \mathrm{~s}$ most likely that an identification of Kuber is to be sought in the region of southern Tigre or Angot. The tradition of the transfer of the capital is not at all comected with the Zagwe Dymasty, as Cerulli seems to think, cf. his introduction to Gedle Iyesus-Mo'a, tr. pp. III-IV. 
the native inhabitants of the Ethiopian plateau north of 1

the River Jema. The immigrants from South Arabia settled In the northern part of this region and lived among the Agew population, who gradually adopted the language of the settlers. These linguistically semitized natives later constituted the dominant section of the peoples of Aksum. As the kingdom acquired additional territories, large groups of these people were apparently recruited and settled in distant frontier stations. Here they intermarried with the local people and formed yet another semitized zone in the interior of the Agew country, wlich was gradually passing into the sphere of Aksumite political influence. It is apparent that all the semitic linguistic groups south of the Tigre region had a similar origill. The Amara tribal group is the most northerly of these communities and was probably the earliest to be established as such. Traditional material on the Amara is lacking and it is impossible here to give any specific dates for their origin. It is most likely, however, that it belongs to the pre-Christian period of Aksumite history and as we have seen above the expansion of the kingdom in this direction was already in full swing during the intensive military activities of King Ezana.

1.P. $17 \cdot n \cdot 1$.

2. See p. 40 . 
The earliest recorded tradition of Christian settlement in the region indicates that there was already a distinct Amara population occupying the upper basin of River Bashilo, The tradition seems to belong to the first half of the ninth century, eighteen generations before the days of Saint Tekle-Haymanot. These later Christian immigrations further enhanced the semitization of the area between the Bashilo and the Jema rivers. The story of Digna-Jan quoted above strongly implies that the expansion of the kingdom was undertaken as part of a definite programme of Christian settlement and evagelization. The kings built churches and established military colonies in their newly acquired provinces, and by the tenth century contemporary writers describe the kingdom as controlling a vast territory between the Dahlak islands and Zeila on the coast, and from the upper basins of the Anseba-Barka rivers to the central Ethiopian plateau itself this territory was much larger than in the Aksumite period. A new ethnic and linguistic group of people had also been added within the sphere of

1. Gedle Tekle-Haymanot, ed. Budge, p.3-5 (text); ed. Conti Rossini, p. 102 .

2. Masudi, op.cit., III, 34. Ibn Haukal, op.cit., pp. 16, 20, 22-23. Conti Rossini, Storia d'Etiopia, pp. 281-283. uliendorff, E., The Ethionians, (ed. 1965), p. 60. Trimingham, op.cit., pp. 50-5I. 
Chrietian military control. It is apparent that the Sidama, who were probably the original inhabitants of the Shewan plateau, had already become tributary to the christian kings by that time.

Pagan Resurgence in the Shewan Region

The History of the Patriarchs of Alexandria makes

a reference to a pagan queen of the Bani al-Hamwiyah who led her people against the christians in the tenth century. Conti Rossini has proposed the reading al-Damutah for the name of the people, and indicates that she was probably of Damoti (Sidama) origin. Her hostile activities are repre-

1. See p.18,n.1.

2. Sawirus, op.cit., p. 171 .

3. Storia d'Etiopia, p. 286. There are other references to female rulers in the sidama region, cf. Behayle-Mika'èl, Meshafe-Mistire-Semay Wemidr, ed. in part and tr. Perruchon, J. In PO, I (I904), p.25. Budge, The Book of the Mvateries of Heaven and Earth, (complete ed. and Fr. 1935, p. 31 (tr) - Cf. also Cerulli, E. "II sultanato dello scioa nel secolo XIII", in R.S.E.. I (1941), p. 22. Zorzi collected a tradition in 1523 about the Province of Wej, "where the inhabitarats would have none but a queen to govern them", Crawford, O.G.S. Ethiopian Itineraries c.1400-1524. Hakluyt Society, 1955, p. 161. This mention of the province of we $j$ is particularly interesting in this context. According to the chronicler of Ahmad Graen there lived in the vicinity of Weja tribe of formldable fighters called El-Maya. A small administrative unit in the district of Che bo and Gurage still bears the name of Ameya, Journal of the Ministry of Interior, Vol. I, No. 2 ( $1 \overline{961})$, p. 14. 
sented as a revolt of a vassal ruler and they had a particularly religious undertone. The queen and her pagan followers destroyed churches and killed Christians. The Christian king himself probably lost his life in the conflict, and the queen appears not only to have restored the independence of her people from Christian rule but also to have been widely known as the most powerful ruler in the Ethiopian region for a long time:-

"Lef pays des Abyssins est gouverné par une ferme depuis de nombreuses années : celleci a tué le rol des Abyssins, qui s'appelait, Hadani. Jusqu'à maintenant elle règne en toute indépendance sur son pays et les alentours du. territoire de Hadani, dang le sud de l'Abyssinie."I

There are specific indications of internal conflict and general decline in the first half of the tenth century which seem to account for the dramatic reversal of the fortunes of the Christian kingdom in the days of Ibn Haukal (fl. 943 - 77 A.D.). It is about this time that we have the earliest recorded struggle for the succession of the Christian throne in which even the Patriarchate of Alexandria seems to have actively participated. The story is related by the hagiographer of Patriarch Cosmas (933 - 42)

1. Ibn Haukal, op.cit., p. 56. The location of her centre of activitieg "in the south of Ethiopia" according to Gaston Wiet's latest translation of Ibn Haukal's work, is very interesting and goes to confirm Conti Rossini's proposed identification of the queen's origin. 
and the episode appears to have practically rent the country 1

in two contending factions. The Patriarch sent a new Egyptian bishop, Pētros, to Ethiopia. The anonymous king who welcomed him was apparently an old man and died soon after the bishop's arrival. The succession was contested by two of his sons, and Pētros gave his blessing to the younger brother. Two other Egyptian monks, Minas and Fiqitor, who were in the country at the time, disagreed with the bishop and joined the other prince. As part of the propaganda warfare that followed, they produced forged letters from the Patriarch supporting the principle of primogeniture in the royal succession and declaring that Fētros had come with false credentials. Minas claimed that he was himself properly ordained as bishop of Ethiopia. This weakened the other party and the army rallied around the elder prince who was thus able to defeat his brother and cast him into exile. Pētros was also banished from his seat. In his place Minas was declared Metropolitan of Ethiopia. When the news reached the Patriarch, he excommunicated Minas for his uncanonical assumption of the ecclesiastical power. Anxious to make amends for these irregularities, the new king arrested Minas on the arrival of the Patriarch's letter and executed him. Then he ordered the return of

1. Sawirus, op.cit., pp. 118-120. cf. Renaudot, op.cit., pp. $339-3 \overline{41}$. 
Petros to his rightful chair. But it was soon found out that Pētros had died in exile. It is apparent that the king asked for enother bishop. The situation was clearly too embarrassing, and the Patriarch refused to respond to his requests. Relations between the Patriarchate and the royal court became very tense. Faced with such a deadlock, the kin made an arbitrary decision to force a young (Egyptian) follower of the late metropolitan to fill the vacant seat in which he remained until the reign of Patriarch Filatewos (979 - 1003). 1

It is quite clear that the episode created much conflict and bad morale in the country. In Alexandrian circles the king was apparently held responsible for the death of Abune Pētros. The hagiographer of Filatewos later accuses him for "his fallifications and his fraud". No doubt his political enemies at home also made recourse to the same argument. Public dissatisfaction within the Church and at the court probably received ample expression in the guise of continued loyalties to the Patriarch of Alexandria. This weakened the power of the king, and from the available

1. The story is given in the Ethiopic Synaxarium with a number of interesting alterations clearly intended to absolve the Egyptian Christians from any responsibility in the episode. Thus the two monks Irinas and Fiqtor are said to be Syrian renegades who had already bên dismissed from the famous monastry of St. Anthony in the eastern desert. Cosmas' refusal to ordain a new bishop in Peter's $\mathrm{pl}_{\mathrm{a}} \mathrm{ce}$ is also denied and blamed on his successors, the Book of the Saints of the Ethiopian Church, tr. Budge, III, 1928, pp. 666-668.

2. Sawirus, op.cit.. p. 171. 
chronological data it even appears that the revolt of the queen of the Hamwiyah took place towards the end of his 1

reign. His own death in the conflict and the military reverses of the kingdom were taken as divine retribution for the sufferings of Abune Pētros. In such an atmosphere of public apathy the pagan resurgence in the southern provinces against Christian rule was a complete success. The struggle against the pagan revolt in the south and the discontinuation of spiritual links with Alexandria had tremendously weaken the kingdom. The letter to King George of Nubia pathetically underlines the dangers for the very existence of the church in Ethiopia at the time :-

"...lest the Christian religion pass away and cease among us, for lo, six patriarchs have sat (on the Throne) and have not paid attention to our lands, but they (the lands) are abandoned without a shepherd and our bishops and our prieste are dead, and the churches are ruined..."2

Through the good offices of King George of Nubia, Patriarch Filatēwos accepted the entreaties of the Ethiopians and sent them a new bishop, Daniēl. He was received with much joy

1. As we have seen above, he was the contemporary of Patriarch Cosmas (933-42). Ibn Haukal, who wrote his book in about $977 \mathrm{~A} . \mathrm{D} .$, speaks of the queen in the following terms: "nenos jours elle (i.e. Ethiopia) est gouvernée par une reine depuis une trentaine d'années ...", op.cit., p. 16. This brings her assumption of power to c'. 945 A.D. It was probably an immediate successor of her adversary who wrote to hing George of Nubia asking for his help in restoring relations with Alexanaria broken by "the king who (was) before him", Sawirus, loc. cit. It seems that the letter was sent in C.980A.D.

2. Ibid., pp. $171-172$. 
and the hagiographer adds that "God... put an end to the affairs of the woman who had risen up against them". The establishment of normal relations with Alexandria no doubt restored public confidence among the Christians, who could probably withstand more effectively the anti-Christian activities of the queen of the Hamwiyah. But it does not appear that there vas an immediate return of Christian control over her southern dominions. The only remnants of former Christian supremacy in these parts were a number of advance groups of Semitic-speaking military colonies. Effectively isolated from the kingdom in the north, these military gettlements maintained their linguistic identity in a completely Sidama environment and seem to provide an adequate explanation for the origin of the modern Harari, Argobba, Guragé, and Gaffat.

Trends of Muslim Expansion in Ethiopia

For about a century and a half after the episode of the queen of the Hamwiyah the effective political frontiers of the Christian kingdom were probably limited to the

1. Conti Rossinj aptly described these groups as "etniche e linguistiche sovravvinze delle antiche conquiste", Storia d'Etiopia, p. 282 . 
area north of the Jema River. During the whole of this period relations with Egypt were close and regular. The Chroniclers of the Patriarchate of Alexandria took these contacts for sranted and, unfortunately for us, they mentioned Ethiopian affairs only when conflicts arose or something unusual took place. In Ethiopia itself material for the study of the eleventh and twelfth centuries is almost lacking. No doubt a close examination of local traditions in Angot, Lasta and Northern Amhara - the central parts of the kingdom at the time - will help fill the lacunae. However, despite the apparent weakness following the pagan reaction in the south, the general picture of the kingdom that emerges from the isolated references in the History of the Patriarchs id one of steady development and reconsolidation. Even the Coptic myth that the Ethiopian state was a strong champion of Egyptian Christiandom finds its earliest expression in this period. And towards the beginning of the twelfth century there are definite signs of the expansion of the Ethiopian church. In the reign of Patriarch Gabriel (1131 - 45) the request of the Ethiopians for more than the usual number of bishops provided a new source of conflict between them and the Patriarchiate. It is also about this time that we

1. $P .93 \cdot n \cdot 1$.

2. Renaudot, op.cit.. pp. 510-513. Budge, The Book of the Saints, cit. pp. 800-801. 
find the Christian $/$ engaged once again, in an active process of territorial expansion in the Shewan region. A Muslim chronicle belonging to the region of eastern shewa preserves the tradition that early in II28 A.D. the Amhara led an unsuccessful expedition in "the land of Wejín". This is the first reference to the Werjih, a pastoral people who had apparently lived in the vast semidesert lowlands of the Hawash valley east of the Shewan plateau. The Chronicler of King Amde-Sīyon (1614-44) locates the Werjin and Gebel nomads "between the frontiers of Fingate and Bĩqul-zar". Finsate $\bar{e}$ is mentioned here for the first and last time and cannot be identified. Biqqulthe first and last time and cannot be identif zar was, however, east of the River Hawash and it was probably in this region which was predominently inhabited

1. Cerulli, E. "Il sultanato dello scioa nel secolo XIII", in R.S.E.. I (1941), p. 10 and n.4, and p. 18. The actual wording in the chronicle is "E fu la fuga degli Amhara dallaterra di Wargih..."

2. Perruchon, Historie des guerres d'Amde-Sīyon, p. 284 (text). The Werjih are specially mentioned $(p .282)$ as "keepers of cattle" and camels."

3. Cf. Ibid.. pp. 283, 432. The Chronicler of Ahmed Gragn late $\frac{1}{r}$ placed it more than two days journey east of the Hawash, Futuin al-Habashe, tr. Basset, p. 94 . 
by the Werjin and the Gebel in the reign of Amde-Siyon.

In the beginning of the twelfth century, when the armed conflict with the Amhara took place, the Werjin probably inhabited a more extensive area as far west as the foothills of the Shewan plateau. It is not certain if they had already become Muslims at the time. There is however a tradition of the conversion to Islam of a still unidentified people called Gbbah towards the end of the year 1108 A.D.,

1. This seems to be quite clear from the Chronicle itself. Immediately atter locating the Werjîh and Gebel between Finsate and Biqulzar the author goes on to say that the land between the Hawash and Zebir was a Muslim area, op.cit., p. 284 (text). Zebír was apparently a locality on tne eastern edge of the plateau near Ifat, p. 292. Thus Amde-Siyon's chronicler seems to make a distinction between the more dedentary Muslims occupying the land from the west bank of the Hawash to the north eastern edge of the Shewan plateau, and the completely nomadic peoples east of the River. In the long list of Muslim rulers who leagued and fought against Amde-Siyon are also mentioned the "mulers of Zellan", and the "rulers of Gebel", pp. 322-323. It is most likely that here the Werjîh are meant by the Zellan who, together with the Gebel, are located east of the Hawash.

2. Cerulli, op.cit., $p, 10$ and $n .3$. The similarity of sound between Gbbah in Cerulli's Arabic text and Gebel in 'Amde-SIyon's chronicle is very tempting and suggests a possible identification. No serious topographical difficulties preclude the identification. If this is correct, the Werjîh nomads could have also been under strong Muslim influence when they repulsed the Amhara expedition in the Ir country in Il28 A.D., only twenty years after their neighbours, the Gebel, had formally adopted Islam. 
and it is very clear that Island was becoming an important political factor in the area.

We have seen above that Aksum had already lost to the Muslims the control of the maritime trade in the Red Sea by the middle of the eighth century A.D. The spread of Islam in the Ethiopian region must have already started by then. On the mainland, the process was most active where Christian power was felt least - that is, in the coastal settlements and among the pastorial peoples of the vast semidesert between the Red Sea coast and the edge of the plateau. Thus from the start Islam in Ethiopia was particularly associated with trade and nomadism. Muslim traders operated freely throughout the Chrlstian kingdom, and in time they completely replaced the former Byzantine merchants. At first they were probably of foreign origin. Al-Yaqubi specially

\section{1. $\mathrm{Pp} \cdot 59-62$.}

2. Early references to the peoples of this lowland region are few and fragmentary. It appears, however, that the sharp difference between their nomadic life and that of the inhabitants of the plateau had taken shape already before the beginning of our era, cf. Strabo, Georaphy, c1t. 16, IV, 17. The author of the Periplus refers to them as Berbers in general, and, in the hinterland of the coast of the Gulf of Aden, he specially contrasts the political organization of the kin their decentralized local democracy, Schoff, op.cit., pp. 25,27 . The inscription of Adulis mentions two unidentifiable tribal names which seem to belong to this region : "The tribes of Rhansi I next brought to submission : a Barbarous race spread over wide waterless plains in the interior of the frankincense country. (Advancing thence towards the sea) I encountered the sollate, whom I subdued, and left with instructions to guard the coast", McCrindle, op.cit.. p. 63. 
1

mentions Arab merchants, and by the time he wrote his geographical treatise (c. 889 A.D.) commercial relations between the Ethiopian region and the centre of Islam in Iraq were well-established. Similar relations with Yemen were particularly strong, and probably most of the Arab traders came from there. Their local partners were probably recruited from among the inhabitants of Dahlak and the coastal settlements. With these and a large group of caravan slaves they frequented the trade routes and the numerous village markets in the whole kingdom. Along these routes and in the market villages they established friendly relations with the local people and probably stationed their

1. Historiae, ed. Houtsma, 1883, Vol. I, p. 219.

2. Iivre des Pays, tr. G. Wiet, 1937, p. 4.

3. Ibn Haukal, op.cit., pp. 22-23, 54. Masudi, op.cit., p. 35. Umarah, Yamañ its early mediexal history, ed. and $t r$. H.C. Kay, $1892, \mathrm{pp} .8,143$.

4. When the islands of Dahlak were annexed in the early 8th century they were apparently part of the Governorate of Medina, Conti Rossini, Storia detiopia, p. 213 . Afterwards relations with the Hijaz and Yemen were regular Basset, R. "In inscriptions de l'Ale de Dahlak", cit. pp. 17-20.. The rulers of Ifat and Adal later derived their origin from the Hijaz, Maqrizi, Historia Regum Islamiticorum in Abyssinia, ed. and tr. F.T. Rinck, 1790, p. 17. Cerull1, E. "Documenti Arabi per la storia del_l'Etiopia", in M.R.A.I. Ser. 6, Vol. LV, I931, p. 43.

5. For the routes and major items of trade involved, see pp. 152, etc.

6. "...and they have mighty gities", Yaqubi, Historiae, cit. loc.cit. "Les Etats (du Nédjachi)...renferment un grand nombre de villes", liasudi, Praires dior, Vol. III (1841), p. 34 . 
agents at regular intervals. The kings and their local officials encouraged these profitable commercial activities in the country and the Muslin traders no doubt enjoyed official protection. It is apparent however, that complete freedom of worship was not granted to the Muslims within the Christian provinces.

It seems that the problem became very acute with the conversion to Irlam of an increasing number of local people in the important market places. This was particularly the case after the advent of the Fatimid Caliphate in Egypt. Their meticulous organization and efficient system of religious propaganda had brought the Fatimida to absolute power in Egypt in 969 A.D., and, for the first time since the Roman conquest of the Ptolemies, Egypt acquired a completely independent political status in the Eastern Mediterranean. This marked the beginning of a new period and the centre of gravity of Islam in the Red Sea area shifted once and for all from the region of ancient Mesopotamia to the Delta of the Riverile. It is a reflection of this general phenomenon that Islam in Ethiopia grew particularly militant after the tenth century.

1. See Ivanow, W. "The organization of the Fatimid Propaganda", in the Journal of the Bombay branch of the R.A.S., IV (1939), pp. I-35. Canard, M. L'imperialisme des Fatimides et leur Propaganda, in A.I.E.O.. VI (1942-7), pp. 156-193. 
The whole region of the Near and the Middle

East had gcquired an unprecedented unity with the Arab conquest of Egypt and the eastern seaboard of the Mediterranean. The economic warfare between the Byzantine and Persian bmpires hod become a thing of the past. The gradual movement of the centre of the Muslim Empire from the Hijaz to Damascus and then to Baghdad had also reduced the relative importance of the Red sea as the thoroughfare of the eastern trade. It is even apparent that the economic and political decline of Aksum was occasioned not so much by the anti-Christian activities of the Muslims as by the sudden change in the value of the Red sea trade with the eastern Mediterranean, on which the Aksumite state was essentially based. In the second half of the tenth century the eatablishment of the independent Fatimid Caliphate in Egypt completely reversed the situation, and the old struggle for the control of the eastern trade began to be played in an essentially similar fakhion as on the eve of the rise of Islam. This tremendously enhanced the re-emergence of the Red sea as a major channel of commerce. It is ironical that, in the area with which we are presently concerned, the end result of this vital development was not only the rapid

1. Lewis, B., "The Fatimids and the Route to India", in Revue de la Faculté des Sciences Economiques, University of Istanbul, Vol. XI, (1949-50), pp. 50-54. 
expansion of Islaw but also the steady revival of the Christian Kingdom of Ethiopia.

Like the Ptolemies and the Romans before and the Namlukes after them, the Fatismids took a keen interest in both the Arabian and African coasts of the Red Sea. Before their advent to power Kolzum had become the chief Egyptian port to the Red Sea, and both pilgrims and the supplies of grain to the Holy Cities left for the Hijaz from there. With the increased volume of trade in the Red Sea, however, the Fatimids extended their frontiers further south and the port of Aydab developed under their auspices as a major entrepot 1 of the eastern trade. Their political and religious envoys were very active in the Yemen and they finally succeeded in establishing the pro-Fatimid Sulaihi and Zura'i dynasties, which successively dominated the political scene from about 1037 to Saladin's annexation of Yemen in 1173. Unlike Saladin, the Fatimids did not annex Yemen but only encouraged the establishment of a strong pro-Fatimid atate which would not only undermine the Caliphate in Baghdad but also facili-

1. Lewis, op.cit., p. 52. Hasan, The Arabs and the Eastern Sudan, cit, pp. 155-I57.

2. Umarah, op.cit., pp. 15-34. Khazraji, History of the Resuliyy Dynasty of Yemen, ed. and tr. J.M.Reahouse, Vol. III No. I, (tr), pp. 10-18. See also Encyclopaedia of Islam, 4st edition, under Sulaihi. 
tate Egyptian commerce with the East. They supplemented this by organizing a special fleet to protect the regular flow of trade in the Red sea.

It is apparent that this gave a fresh impetus to the Muslim commercial activities that had been going on in the interior of the Ethiopian region. Just jlas in the Mamluke period some two centuries later, Fatimid protection was also extended to these inland traders. In this respect the spiritual dependence of the Christian kingdom of Fthiopia on the Patriarchate of Alexandria often created embarrassing situations. The increasing number of Ehtiopian converts to Islam mainly along the trade routes and in the market towns demanded complete freedom of worship in the Christian provinces. They pointed out that throughout the Muslim world, and in Egypt in particular, Christians were tolerated and even protected a Dhimis. They claimed similar rights of public worship within the realms of the Ethiopian Kingdom. It seems that these requests were met with the adamant refusal of the Christian kings and the tenacious opposition of the local clergy. Naturally the Ethiopian Muslims approached Cairo through their commercial associates and appealed to the Fatimids to put some pressure on the ringdom

1. Hasan, op.cit., p. 161 . 
to grant them reciprocal rights of worship as were enjoyed by the Copte. Thus there began the historic role of Egypt as the champion of Islam in Ethiopla, a position first assumed by the Fatimid Caliphate, and which has characterized Ethio-Egyptian relations throughout the centuries.

To carry out their responsibility to the Muslims in Ethiopia, the Fatimids hit hard on the most sensitive chord in Ethioplan Christindom. Not only did they press the Patriarchs to send messages enjoining the Ethiopian kings to protect Muslim rights but also interfered in the actual selection of the Egyptian candidate to be ordained as Metropolitan of Ethiopia. An important incident related in the Fistory of the Patriarchs indicates that the problem has assumed a serious character in the second half of the reign of Caliph Al-Mustangir $(1035$ - 94). Badr al-Jamal, the Armenian, whom the Caliph had appointed Amir al-Juyugh in 1073, was the most central figure in the incident which took place between this date and 1089 A.D.

Not long before 1077 the Egyptian bishop in Ethiopia, Fiqİtor, died, and another Egyptian called Abdun presented himself at the Ethiopian court pretending that he was sent by the Patriarch to succeed him as Cyril, Metro-

1. The story is told by the hagiographer(s) of Patriarchs Christodulus (1046-77) and Cyril (1077-92), Sawirus, op.cit.. II, Pt.3, pp. 316-317, 329-330, 347-351; Renaudot, op.cit.. pp. 443-444, 453-454. Budge, the Book of the Saints of the Ethiopian Church, pp. 994-5. 
politan of Ethiopia. It had been customary that, on the death of a Metropolitan, the King should send an official delegation to Egypt asking for a replacement and the process usually took a long period of time. The sudden dispensation of this age-long convention, and the unexpected arrival of the pretender probably aroused suspicions in the court and among the Ethiopian clergy over the chims of Abdun. An Ethiopian delegation was probably sent to Egypt to obtain a more tangible proof for Abdun's chims. Abdun also sent his own agents with the delegation and made secret representations to Badr al-Jamal through a man named Ali al-Kifti. He requested the Amir al-Juyush to command Patriarch Christofdulu to confirm the episcopal seat on him. In return he promised to send a handsome annual tribute in gold, and to improve the conditions of the life of the Muslims in Ethiopia. This greatly impressed the Amir al-Juyush and forced the Patriarch to accord to the wishes of Abdun. Even the method used for his intended ordination was unorthodox :-

"...there had been arranged the journey of $\mathrm{Abba}$ Mercurlus, bishop of Wisim, to the lands of Abissinia with a letter from the Patriarch and one of his vestments to clothe the aforesaid Cyril, and to make him metropolitan, and the father, the Patriarch, had wept when he was obliged (to do) thia..."I

1. Sawirus, op.cit., p. 317. 
Unfortunately for Abdun, just on the eve of the departure of this mission to confirm him, his arch-supporter at the Amir's court, Ali al-Kifti, was disgraced for another intrigue in which he was also involved regarding Nubia and summarily executed. This brought the Patriarch back to the Amir's favour and "the affair of Cyril was cancelled". The self-styled Metropolitan was the only looser in this drama. Badr al-Jamal $h_{2} d$ no intentions of withdrawing the favourable conditions proposed by Abdun during his short misadventure. He imposed them on the next bishop, Sawiros, properly ordained and sent to Ethiopia by Patriarch Cyril (1077-92). Sawiros was a nephew of Fiqitor, the deceased Metropolitan, and he had been brought up by him in Ethiopia. He knew the country very well and had probably

1. Together with his protestations in favour of Abdun, Ali has also accused the Egyptian bishop in Nubia of antiMuslim acts. Enraged at this Badr al-Jamal cast the Patriarch into prison until another of his engoys returned from Nubia and reported the falsity of Ali's charger, ibid., pp. 316-317.

2. Abdun remained in Ethiopia until the arrival of the rightful metropolitan, Sawiros. Then he fled to the Dahlak islands, where he was taken prisoner by the local Muslim ruler, who confiscated all hï possessions and sent him to Cairo. There he was condemned and executed at Badr alJamal's orders, probably in 1086 A.D., ib1d., p. 329. Renaudot, ov.cit., p. 453. I have here given preference to Renaudot's date of the execution. It is probable that there was a difference in the MSS. consulted by him and those used by the editors of the History of the Patriarchs. where the date is $1143 / 4$ A.D., half a century after the death of Badr al-Jamal himself. 


\section{2}

established close friendly relations at the royal court during his stay there with his uncle. He is also described as "a learned man" and all these characteristics probably 1 gave him much influence both in Ethiopia and at the Patriarchal court in Cairo. For the purposes of Badr al -Jamal he was apparently thought to be the best candidate and was recomnended to the Patriarch for the ordination. On this occasion he is said to have made many promises to the Amir al-Juyush, "...that he would continue (to supply) him with presents from (Ethiopia) and would allow the kings to obey him". In October 1088 the bishop sent his brother, Rigal, to Egypt with a gift to the Amir al-Juyush. The Amir was not impressed by it and threw Rigal into prison. Then he angrily summoned the Patriarch and the other bishops who were in Cairo at the time, and reproached them for what he called the bad faith of the Metropolitan of Ethiopia. He accused him on three major charges: that he failed to raise the stipulated amount of tribute; that he did not build mosques for the Muslims in Ethiopia; and that he did little to protect the traders in that country where "they have begun...to waylay the Muslim merchants and others than them".

1. This may have facilitated the reforms in the matrimonial customs of the people which he enthusiastically reported to the Patriarch, ibid., pp. 329-330. 
The Amir demanded that the Patriarch send a delegation of two bishops with an official letter ordering the Ethiopians to fulfil all the above requirements. Until the Eatriarch and his assembly of bishops agreed to do this he put them under house arrest. It is apparent that they courageously resisted his wishes for a long time. It was not until February 1089 that they agreed among themselves to despatch the two bishops with a Patriarchal letter. We are not told of the contents of the letter, but the Amir is said to have been pleased with it, and he had it sent to Ethiopia together with his own. The Amir's message was short and poignant :-

"If thoud dost not do thus and thus, I shall demolish the churches which (are) in the land of Egypt."

It seems, however, that the delegation came to nothing, and the Ethiopian king is said to have replied in similar vein to the Amir's threatening letter.

1. The tradition of this exchange of messages is given, ibid.. p. 35l. The Ethiopian king's reply is said to have been "If thou demolish a single stone of the churches, I shall carry to thee all the bricks and stones of Mecca, and I shall deliver all of them to thee, and if a single brick of it (Mecca) is missing, I shall send to thee its weight in gold". Although there is no doubt that the terms of Badr al-Jamal were rejected at the Christian court in Ethiopia, the tradition of the language of this reply seems to have been strongly affected by the apparent belief of the copts that they had in the Ethiopian state a strong champion of their faith. The theme recurs throughout the medieval period. 
The Egyptian bishop in Ethiopia held a difficult position. Technically he was a subject of the Muslim rulers of Egypt. Every act, unfavourable to Muslim interests in his diocese with which he might be charged closely affected the Patriarch and the Christian community in general and $\mathrm{h} \pm \mathrm{s}$ own relations in particular. There was besides an apparent misunderstanding in Cairo of the extremely limited powers of the metropolitan. In Ethiopia, the bishop was naturally expected to provide a strong leadership for the religious feelings of his congregation. Any sign of weakness or moderation would cost him not only his reputation among the influential clergy but even his episcopal seat. When the problem involved Muslim interests in the country, his views would be received with apparent suspicion and would carry very little weight. This delicate situation in which their envoys to Ethiopia had to live was clearly understood by the Patriarchs, who persistently disclaimed any responsibility for the political acts of an independent kingdom of which they were merely the spiritual heads. When Badr al-Jamal reproached him for the alleged insecurity of luslim traders

1. Cf. p.68 n. 3 . The temporary dismissal of bishop Yahannis was apparently occasioned by a controversy on the institution of circumcision, Sawirus, op.cit., pp. 508-511. Renaudot, op.cit., pp. 273, 283-288. Later in the reign of Patriarch lilkièl (1092-1102) Bishop Giorgis was dismissed for apparently more serious charges of "infamous affairs and... vile deeds (which) did not become his rank", Sawirus, op.cit.. p. 394. 


\section{5}

in Ethiopia, Patriarch Cyril meekly replied, "O my lord, what have I to do with waylaying? Am I a watchman (Khafir)?" In Ethiopia too, it seems quite clear that the rings had given much cognizance to the sensitive position of the metropolitan, and had exempted him from direct public involvement in their strong anti-muslim policies, particularly after $1270 .{ }^{2}$ Even for the difficulties of the expansion of Islam in Ethiopia the metropolitan could fully declare his innocence and blame them on the religious fanaticism of the people. This seems to offer an explanation for the unlikely story reported in the History of the Patriarchs that Bishop Sawiros had built mosques for the Muslims in thiopia sometime before 1089. At the audience he granted the Patriarch and his bishops in February 1089, Badr al-Jamal asked Rigal why his brother, Bishop Sawiros, did not build the four

1. Ibid., p. 349.

2. This point emerge日 from the fact that neither the available chronicles nor the hagiographical traditions about armed conflicts with the local Muslims make any reference to the part played by the Egyptian bishop. The important role of praying for the aruy when it set out on an expedition is assumed in these traditions by the local saints, cf. Acta Sancti Marcurii, ed. and tr. Conti Rossini, in C.S.C.O., script. Aeth. Ser. altera, t.XXII, pp. 38-39 (text). Gedle Samu'el. (Waldebba), ed. and tr. B. Turaiev in his Monumenta Aethiopica Haglologia, Fasc. II, 1902, pp. 14-15. Les Chroniques de Zar'a Ya gob et de Ba'eda Maryam, ed. and tr. J. Perruchon, pp. 90, $133-134$. 


\section{6}

mosques he had agreed to erect in Ethiopia before his ordination. Rigal replied :

"O my lord, he built seven mosques in the places where it was possible to build (them), and... the Abyssinians demolished them and wished to kill him, and... when the news of this reached the king, he arrested the Metropolitan and imprisoned him."I

Egyptian protection of Muslim interests was only a myth, and did not constitute a crucial factor in the expansion of Islam in Ethiopia. Their own economic strength, arising from their almost complete monopoly of long-distance trade, gave the Ethiopian Muslims a growing influence in the Christian kingdom, and eventually led to the establishment of small Muslim principalities in the peripheral areas in the south.

Except in the islands of Dahlak, the growing political significance of Islan in the Ethiopian region was a posttenth century development. Masudi (fl. 946 - 56) clearly indicates this situation in his short description of the land of the Habeshi :-

"Les familles musulmanes qui y résident sont
tributaires des indigênes." For over three centuries after the rise of Islam and the establishment of the extensive Muslim Empire from the Atlantic

1. Sawirus, op.cit., p. 350.

2. $\mathrm{P} \cdot 61$.

3. Ies Praires d'or, cit. III, p. 34. 
to Central Asia, this remained the political status of Islam in Ethiopia. As we have seen above, their commercial activities in the region constituted the raison d'etre of these Muslin families. By the second half of the tenth century their important role as a link between the region and the outside world had already been recognized, and no doubt through their agency the Ziyadite rulers of Yemen had contracted treaties of commerce and friendship with the 1

Christian kingdom on the one hand and with the pagan peoples in the south on the other.

Muslim penetration of the pagan south became a new and dominant factor in the political history of the region after thig period. We have already referred to the withdrawal of effective Christian power from the Shewan region following on the successful pagan revolt led by the queen of the Bani al-Hamwiyyah. Ibn Haukal's invaluable information about Ethiopia at the time also indicates that the queen had established amicable relations with the Ziyadite ruler of Yemen :-

1. Masudi, op.cit., p. 35. The only ruler mentioned here by this author is the Christian Nelashi who had trade agreements with Ibrahim b. Ziad, chief of Zebid : "En vertu du traité d'amitié qui unit les deux pays...". For the year 366 A.H. (= 977 A.D. ), Umarah also refers to the Christian king's relations with the ruler of Zebid: "The kings of the Abyssinians, on the further side of the sea, sent him offerings of presents and sounthis alliance". Yaman, its early Medieval History, Eit. p. 8 (tr.). 
"Ia reine d'Abyssinie lui envoie aussi des prèsents et des cadeaux bénévoles, qui lui sont offerts en permanence."1

Al-Yaqubi considered the Dahlak islands as the major outlet of trade of the Ethiopian region, and only makes an incidental reference to the port of Zeila in his geographical treatise written two decades later. It is apparent that in the days of Masudi and Ibn Haukal the importance of Zeila had considerably increased, and fresh lines of communication had been opened between the interior of southern Ethiopia and the Gulf of Aden. The new direction of contact was characterized by the extensive, hot, lowland plains between the Ethiopianplateau and the sea coast. It is certainly to this tract of land that Ibn Haukal refers as "des solitudes et des déserts difficiles à traverser". 4

The indefatigable Muslim traders crossed these difficult roads and began the commercial exploitation of the rich natural resources of southern Ethiopia. We have no means of following in greater detail the activities of these

1. La configuration de la terre, tr. G. Wiet, Vol. I (1964), p. 23 .

2. Historiae, cit. p. 219.

3. Livre des Pays, tr. G. Wiet, 1937, p. 159.

4. Op.cit., p. 56. It is quite posaible that he obtained his notes about the queen "in the south of Abyssinia" through these new routes, and he seems to have had more information about her thas he cared to relate : "On racconte sur elle des chose curieuses", Ibid., p. 16. 
traders and the early development of Islam in the region. The earliest Muslim tradition in eastern Shewa is a record of the death of an apparently pagan ruler, queen Badit, daughter of Maya, in 1063 A.D. The prevalence of female rulers in the few available traditions about the region has already been referred to, and even the genealogy of this ruler seems to recall to mind the queen of the Bani alHamwiyyah mentioned in the History of the Patriarchs. It is most likely that the mention of the daughter of Maya in Cerulli's document refers to a period when the Muslim traders were attached to the courts of the iocal pagan rulers and mainly engaged in commercial activities. In the main centres of these economic activities they probably gained, from among the local people, an increasing number of followers who gradually adopted their religion. It is clearly part of this development that they should have an early tradition of a major conversion to Islam in the land

1. Cerulli, E., "Il sultanato dello Scioa", cit. p. Io, n.l. According to the same chronicle the socalled liahzumite Dynasty is said to have ruled from the end of the ninth century until its final overthrow by the Walasma ruler of Ifat, Ibid.. pp. 13, 35. The contemporary Arab writer, Masudi, clearly underlines, however, that before the riddle of the tenth century, the Muslims were living in the region as clients of the local (pagan or Christian) rulers, op.cit.. III, p. 34.

2. Supra, p. $74, n \cdot 3$. 
of Gbbah at the beginning of the twelfth century. 1 Significantly this glmost coincided with the renewed christian attempt at southern expansion. Thus began the long struggie between the Christians and Muslims for the control of southern Ethiopia.

The Muslims entered the struggle at a disadvantage. The prestige of the Christian kingdom as the strongest power in the Ethiopian region since the Aksumite period was alreaciy established. Much of the area had been under its control in the ninth and early tenth centuries. In the whole of this period the Muslims had only been active as long distance traders, with little or no political influence of their own and often under the protection of the Christian kings and their local vassals.

Even after the queen of the Bani Hamwiyyah won back her independence from the Christians, the dominant section of the remnanats of the former military colonies ${ }^{2}$ no doubt continued to look towards the Aksumite kingdom as a place of their distant origin. It is in fact apparent that, at least in the region of eastern shewa, the descendants of these ancient Aksumite colonies provided the most impor-

\section{Supra, p. $6 h, n \cdot h$ \\ 2. Supra, pp.73-4,79.}


tant settled community in which Islam began to flourish. Islam was a late-comer in the area, and even after the establishment of a number of Muslim principalities, it could never get rid of the stigma of being a second-rate power in the Ethiopianregion.

Moreover, the twelfth century, which is the period of the earliest traditions of active Muslim proselytization in southern Ethiopia, was also marked by the revival of the Christian kingdom in the north.

The Zagwe Dynasty : A Period of Christian Revival

After the decline of Aksum, the Christian kingdom 3 had centred around the region of southern Tigre and Angot. It spopulation consisted mainly of the rigre and Tigrigna speaking tribes in the north, the Christianized Agew of Lasta and Wag, and the Amhara who inhabited the expanding zone in, and south of, Angot. At this stage of the history of the

1. From an analysis of the names of the princes Prof. Cerulli has made an interesting conclusion that a Semitic Ethiopian language was spoken in the region of Ifat and eastern Shewa, "Il sultanato dello scioa", cit. pp. 32-34. Cf. also his Studi Etiopici : Vol. I. Harari, p. 19. Although he also states that at least fifty difierent languages were spoken in the whole of the Ethiopian region, Al-'Umari nevertheless gives, in the case of Ifat, a number of still recognisable words, Masalik cit, pp.8, n.2; 9, n.5; p. 10, n. 7; $1,2.2 ; 21$.

2. This status of the Muslims in the area was also recognized by the Mamluks in Egypt ang according to Al-1Umari "la chancellerie $n^{\prime} a$ jamais ête en correspondance avec les sept rois musulmans; il n'y a donc point de protocole", ioid., p. 33 .

3. Supra, pp.71-3. 
kingdom the main difference between these people was perhaps only linguistic. The northern people, who spoke Tigre and Tigrigna, constituted the dominant section of the population in the Sabean and Aksumite periods. It seems that during the expansion of the Aksumite kingdom into the Agew plateau south of Tigre, a narrow semitized corridor had been created in the region of Angot. It consisted of the great waterfohed between the basins of the Tekezze and the Hawash, and was apparently used as a major passage to the region of Amhara. Immediately to the west of this corridor lived the Agew people of the broken country of Wag and Lasta. It has already been suggested that Aksumite pressure of expansion on this area had started early, and King Kaleb's governor of Agew mentioned by Cosmas probably had his headquarters there. It is apparent that, despite the early progress of the church among them, the compact and inaccessible nature of the area, which is almost totally enclosed by the rivers Selleri and Tekezzēe, had preserved the tribal and linguistic identity of the local people. This appears to have been the case long after the spearhead of the Aksumite expansion had outflanked these people and almost encircled them with a semitized zone extending from

\section{Supra, p.55}


southern Tigrē through the highland districts of Angot, and stretching across the basin of the river Bashilo south of the upper Tekezzē. However, with the decline of Aksum and the establishment of the centre of the kingdom in the region of Angot, it is clear that the Christian Semitic pressure on Wag and Lasta became all the more redoubled, and the local chiefs were completely integrated with the royal christian court. After more than three hundred years of such a close association with the descendants of tie ancient Aksumite kings, a new Christian dynasty emerged in the first half of the twelfth century and took control of the whole kingdom, deriving much of its political support from Lasta.

It has been known in traditional history as the Zagwē Dynasty and it has already been critically examined on many occasions specially by Conti Rossini. The circumstances of the advent to power of the Zagwe kings are very uncertain, and the traditions of the event that have survived are only brief and incomplete. An interesting version attributes the dynastic change to a marriage between a daughter of

1. Perruchon, J., "Notes sur l'Histoire d'Ethiopie", in RS, I (1893), pp. 364-372; Id., "Les Pays de Zague", in $\underline{\underline{R S}}$, $\vec{\nabla}$ (1897), pp. 275-284. Conti Rossini, "Appunti ed osservazioni sui re Zague et Takla Haymanot", in RRAL, ser. 5, Vol. IV (1895), pp. 144-159; Id., "Lettera a J. Halểvy sull caduta degli Zague", in RS, X (1903), pp. 373-377; "Lettera... sullo stato attuale della questione degli Zague", RS, XI (1903), pp. 325-330; Storia d'Etiopia, 1928, pp. 303-321. 
the last Aksumite king and one of his generals who came from Bugna in Iasta. The general rebelled against his father-in-law, killed him in battle, and usurped the throne. 2

This is apparently a non-official version, and clearly underlines the continuity of the Ethiopian political tradition even in the ewergence of the Zagwe Dynasty. The rise of the Zagwe Dynasty did not represent a break in the Aksumite tradition. For over three centuries the centre of the Christian kingdom was on the doorsteps of Wag and Lasta and it was from here that it controlled its extensive sphere of influence in the ninth and early tenth centuries. The local traditions already referxed to indicate that the earliest attempts to evangelize in the area may have started 3

in the sixth century. Within this long period the church was securely established in Wag and Lasta, and it is apparent

1. Conti Rossini, "Il libro deļle leggende e tradizioni Abissine dell'Ecciaghié Filpos", R.R.A.L.. ser. 5, Vol. XXBI, 1917, p. 707. Storia d Etiopia. pp. 304-305; Doresse, J., L'Empire du Pretre Jean, II (1957), pp. 50-51.

2. Four of the Zagwē kings, Yimrha-Krkstos, Ialibela, Ne'akutoLe'ab, and Yitbarek have hagiographies, two of which are still unpublished. None of these works mentions the above tradition of matrimonial connections. All of them were composed after the downfall of the Zegwe Dynasty of which the origin is simply attributed to the wrath of God on an excessively arrogant Aksumite king, Gedle Yimrha-KrIstos, MS. Lalibela, Bete-Maryam, ff. 40-42. Cf. also Gedle Yared, ed. Conti Rossini, p. 23 (text). The tendency in these later official traditions is to show that the Zagwe kings were of a completely alien family who usurped power from the rightful princes of the "House of Isra'el", Gedle Yimrîha-Krîtos, $f .42^{\circ}$; Gedle Lalibela, ed. and tr. In part Perruchon, 1892, p.6 2 . 
that by the eve of the rise of the Zagwe Dynasty many of the local people had already taken active a part in the religious, political, and military leadership of the kingdom. A close review of the few available historical notes on the period shows no signs of a sudden and dramatic advent to power of a completely new cadre of leadership in the country. It rather seems that the assumption of royal powers by the princes of Bugna was only the culmination of a natural political development within the Christian kingdom of which the central parts had long consisted of the crucial area of the headwaters of rivers Tekezze and Selleri.

Conti Rossini used an incident preserved in the History of Patriarch Yohanis (1147 - 67) as part of his evidence for dating the rise of the Zagwe Dynasty. An Ethiopian king wrote to the Patriarch and the Egyptian vizir Ali ibn Sallar (d. 1153), asking for the replacement of the aged Metropolitan, Abba Mika'el. The vizir authorized the Patriarch to send a new bishop. But the Patriarch refused, on the grounds that it was not canonical to ordain a replacement for a living Metropolitan, and he was imprisoned for it. The hagiographer also adds that the actual

1. Renaudot, op.cit., p. 525; Conti Rossini, "Sulla dinastia Zague", cit. p. 148; "Lettera a J. Halevy", (1903) cit. p. 328; Storia d'Etiopia, p. 303. 
reason for the Ethiopian request was not that Mika' $\overline{\mathrm{e}} \mathrm{l}$ was too old for his office but that he had refused to recognize the king who was an usurper. Conti Rossini took this as a reference to the first Zagwe king, and used it as confirming the date of the advent of the Dynasty in about 1150 A.D.

1. There are two conflicting traditions for the duration of the dynasty. The more comon version is that it lasted for 333 years until the advent of Yîkunno-Amlak in 1270. The other version gives it only 133 years. Conti Rossini prefers the latter, essentially because it can easily be reconciled with the short list of Zagwe kinge given in the traditions, cf. "Il libro delle leggende", cit. pp. 707708. In two important land grants Ialibela gives his genealogy as "Son of Morara, son of Zan-Sïyum, son of Asda", Id. "I'evangelo d'oro di Dabra Libanos", R.R.A.I... Ser. 5, Vol. X, 1901, pp. 186, 189. Merara is elsewhere said to have been the first Zagwe king, Gedle Yared, ed. Conti Rossini, p. 23 (text). The name oI the general who married the daughter of the last Aksumite king and who founded the new dynasty is usually given as fiera-TekleHaymanot. It is very likely that both this name and Merara refer to the same person. It is apparent that the curious system of succession to the throne has been the reason for the long list of Zagwe kings available in some traditions, cf. Conti Rossini, Storia d'Etiopia, pp. 305306. Zēna-Genete Maryam. MS. Debre-Sige, p. 2I. It seems that the throne rarely passed from father to son but either from brother to brother or from uncle to nephew, cf. Gedle Ialibela, ed. and tr. Perruchon, pp. 32, 40 Gedle lie'akuto-Ie'ab, ed. and tr. Conti Rossini, pp. 114I16, 147-148, 150. However, some lists also include the princes who did not occupy the throne. It seems possible now to provide a tentative genealogy of the princes with the help_of additional notes from the unpublished Gedle Yimrha-Kristos, ff. 2-4. In the following table the names of the crowned princes are in capitals. The numbers signify the order of succession :
(1) MERARA = ? Mesobe-Werq

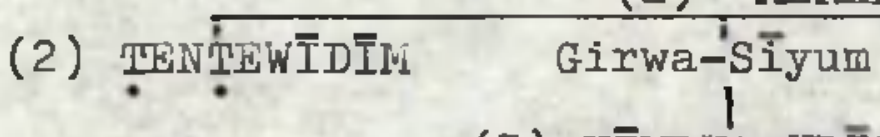
(3) YIMRHA-KRĪSTOS
\begin{tabular}{ll} 
(4) & \multicolumn{1}{|}{ (5) LALIBELA }
\end{tabular}
(6) INE' $\triangle K U T O-L E^{\prime A H} \sim(7)$ YITRAREK 
But there is no evidence for a "strong resistence ... at first offered to the new dynasty by the clergy under Abuna Mika'ēl". The metropolitan was probably sent to Etuiopia in the first years of the reign of Patriarch lleqarios (1102-31), and had become very old by the middle of the century. He had also been an object of a controversy already before a replacement was asked for. In the reign of Patriarch Gabriel (1131 - 45) the Etriopian king asked Abba Mika'el to ordain more than the prescribed number of seven bishops in Ethiopia, But the Metroplitan declined to do this without Patriarchal authorization from Cairo. The Caliph apparently agreed. However, Patriarch Gabriēl explained to the Caliph the implications of the Ethiopian church having more than seven bishops. If the number reached ten the Ethiopians would in future be able to appoint their ows Metropolitan, or even a Patriarch, and would thus be completely independent from Egyptian influence. When he heard this the Caliph reversed his decision and agreed with the Patriarch in his refusal to let the Ethiopians have any

1. Trimingham, Islam in Ethiopia, p. 56.

2. Renaudot, loc.cit. About the end of the reign of Patriarch Mika'el (1092 - 1102) Biship Giorgis had been sent to Ethiopia and had been deposed soon afterwards, cf. p. 94 n. 1 . It is probable that Bishop Mika'el was his immediate successor, ordained soon after the accession of Meqarios. 
more bishops. Thus both his old age and the earlier controversy surrounding his name were sufficient reason ior the Ethiopian request to replace Abba Mika'èl. The incident certainly indicates that there was a succession struggle at the advent of the new King. But it had none of the drastic effects of the conflict between the two brothers who fought for their father's throne in the reign of Patriarch Cosmas. The new king referred to may have been the firgt prince of Bugna to occupy the throne, but there is no sign of a dramatic episode at the time of his accession. Like all Ethiopian monarchs before and after him, he had a local 3 base for power. The region of Lasta, from which he derived

1. Renaudot, op.cit., pp. 510-511. The story is altered in the Ethiopic translation, which was undertaken at the auspices of the Egyptian bishops. Here the role of the Patriarch in the reversal of the Caliph's decision is suppressed. On the contrary he is said to have been willing to grant the permission, were it not for the courtiers of the Caliph who opposed such a measure, Budge, The Book of the Saints of the Ethiopian Church. pp. 800-801.

\section{2. $\mathrm{P} \boldsymbol{\beta} \cdot 75-9$.}

3. This seems to be quite clear right from the Aksumite period, Many of the kings specifically mention what appear to be their regional or tribal origin in their inscriptions and coins, Littmann, Deutsche Aksum Expedition, Vol. I, pp. 46-47; Vol. IV, Inscriptions 8, 9, 10 and 11; Kammerer, Essai, pp. 154-159. 
much of his support, differed from the rest of the central parts of the kingdom in one important factor. The local people, although as much Christian and part of the Aksumite cultural tradition as the peoples of Tigre and Amhara, had apparently preserved their linguistic identity and used Agewigna outside the church. Essentially based on this linguistic difference, the Zagwe kings have been dismissed, in the dominant traditions of their political enemies, as an alien and impious group of adventurers. This has long obscured what is perhaps the richest and most artistic period of Ethiopian history since the conversion of Ezana. The advent of the Zagwe Dynasty brought in fresh developments in the revival of the Christian kingdom for which there are noticeable indications at the turn of the twelfth century.

Relations with Egypt and the Patriarchate were not affected by the Mika' $\bar{l} l$ incident and there was a regular supply of Egyptian bishops to Ethiopia. Abba Mika'ēI apparently remained in the country until his death, and

1. This is reflected even in the names of the princes, particularly Merari, Tentewĩdim and lalibela, Conti Rossini, "Appunti ed osservazioni", cit. p. 355. The following exclamation appears ds having been pronounced by the people at the coronation of Yimrha-Krístos : "Hawisa, Hawisa, King of Ethiopia; Hawisa, Yimrhanne-Kristos Hawisa", Gedle Yimrha-Kristos, $f .28 \mathrm{~b}$. The word huwash appears in Conti Rossini'g Kimant-French vocabulary and it means to annoint, La langue des Kemant En Abyssinie, p. 209. Yimrha-Krigtos father is called Girwa-Siyum. In conti Rossini"s vocabulary again gerwa means a virile man, Ibid., p. 201. 
must have had a,t least one successor before the end of the century. An Ethiopian delegation sent with a letter and presents to Caliph Al-Adid (1160-71) was later received in 1173 by Salah-al-Din who was greatly impressed by the presents. The Arab historian is silent about the purpose of the delegation. But an interesting passage in the Iife of the third Zagwe king probably reiers to the same period :-

"And.... Yimrha sent a message to the king of Egypt saying "Send me the wooden door which is in your Great Hall so that it may serve me for (building) the House of God'. And he sent him much gold. When the king (of Egypt) saw the gold... he sent him the dogr (which was cut out of the tree of Iibanos)."

1. In 1I99/1200 A.D. a delegation arrived in Cairo announcing the death of a metropolitan and asking for a new one, Abd al-Latif, Relation de l'Egypte, tr. M. Silvestre de Sacy, 1810, p. 334. This cannot be a reference to Mika'el's death since he was already too old in c. 1150.

2. Maqrizi, quoted in Conti Rossini, Storia d'Etiopia, p.306.

3. Gedle Yimrha Kristos, f.39. It is apparent that the first European who saw a copy of this Gedl was Alvarez, who gives a brief but accurate description of it, The Prester John of the Indies, ed. Beckingham and Huntingford, 1961, p. 204. Marianus Victor had also been given some excerpts of the Gedl by his informant Abba Tesfa-SIyon (d. 1550) in Rome. In his list of Ehhiopian kings he gives another version of the passage quoted above, cf. J. Perruchon, "Notes pur l'histoire d'Ethiopie", R.S., I (1893), pp. 368-369. of all the known hagiographies of the Zagwe kings this Gedl is most interesting for many of the historical traditions it preserves. Alvarez' testimony indicates its pre-l6th $\mathrm{C}$. composition, and internal evidence shows that it was written after 1270 . The MS. I could consult in Lalibela was however a recent (probably 19th C.) copy. King Yimrha was probably reigning at the end of the Fatimid Caliphate and in the early years of the Ayyubids. Abu Salih, who refers to events 
Yimrha inaugurated the Zagwe tradition of building rockhewn churches, and his communication with the ruler of igjpt about building material probably indicates a fresh revival of the long and close cultural contacts between the two countries. There are further references to a number of foreign ecclesiastics who went to Eth1opia in Yîmrha's Ethiopian pilgrims to the Holy Land also seems to have increased. In 1189, at his triumphant occupation of Jerusalem, Salah al-Din is said to have given many sites to the Ethiopians there. We still know very little about the cultural and religious impact of this two-way traffic on athiopia. But at no time does the Holy Land seem to have captured the imagination of the Ethiopians so much as in this period,

/Footnote 3 cont. from previous page

in $1173 / 4$ as having occurred in his own life time, reports that Ehtiopia was ruled by kings who were also priests, The Churches and Monasteries of Egypt, cit. pp. $X, 286$. In Ethiopian traditions this description only fits Yimrha, who was ordained a priest before his Coronation and continued to celebrate mass after his accession, Gedle Yimrha-KrIstos, ff. 8 - 10, 30b; Alvarez, op.cit., p. 204 .

1. Gedle Yimrha-Krístos, f.35. Here they are called "Romans". Alvarez was told that one of the tombs beside the king's belonged to a "Patriarch of Alexandria", loc.cit. He also says that the local people told him that the rock churches of Lalibela were built by Egyptian masons, op.cit., p.227.

2. Cerulli, Etiopi in Palestina, Vol. I, 1943, pp. 33-37. 
which Conti Rossini so aptly characterizes as "I'alba del nuovo periodo della letteratura abissina". "The beautiful churches of Lalibela were in fact a deliberate attempt to reproduce the Holy City of Jerusalem in the mountains of Wag and Lasta.

It is no doubt a reflection of the close and regular contacts with Egypt at the time that we should have a remarkable corroboration between the historical notes about King Lalibela in his own land grants ${ }^{3}$ and in the History of the Patriarchs. ${ }^{4}$ His reign marked the apex of

1. Storia d'Etiopia, p. 306 .

2. This is represented in the hagiographical tradition that Christ was revealed to Lalibela before he started building them. He than took him on a round trip of the churches of Jerusalem describing to him tie significance of each and inspiring him to build similar sites in his kingdom, Gedle lalibela, ed. and tr. Perruchon, p. 88. This is particularly true of the Church of Golgota where there is even a representation of the Holy Sepulchre, cf. Alvarez, op.cit., pp. 207, 221.

3. These have been publiahed in an important article of Conti Rossini, "L'evangelo d'oro di Dabra Iibanos", in R.R.A.I. Ser. 5, Vol. X, 1901, pp. 186-193.

4. Perruchon, J. "Notes pour 1'Histoire d'Ethiopie : Extrait de la vie d'Abba Jean, $74^{\circ}$ Patriarch d'Alexandrie", ed. and tr. in R.S.. Vol.VI (1898), pp. 267-271, 365-372 and Vol. VII (1899), pp. 76-85. Cf. Renaudot, Historia Patriarcharum Alexandronum, 1713, pp. 554-67.

5. According to the king lists he ruled for 40 years. It is impossible here to determine when the reign started, but he was certainly on the throne between 1205 and 1225, Perruchon, op.cit., pp. 79, 82, 84-85. Conti Rossini, op.cit., pp. 188, 191. The references to Ialibela in the History of the Patriarchs belong to 1205 and 1210 A.D. 
the Zagwe dynasty. The Zagwe kings had their capital at a place called Adefa, just outside the present site of the Lalibela churches. In Lalibela's reign the Metropolitan also lived at a site nearby, in a special "palais episcopale" where the king often went to see him. Thus Bugna had become the centre of the religious and political life of the kingdom. Many of Lalibela's courtiers were drawn from the same district and held very high ecclesiastical and administrative positions. A brother of Queen Mesqel-Kíbra, Hirun, had been ordained a bishop by Metropolitan Mika'īl (1205 1209) through the insistence of his royal sister. Soon

/Footnote 5 cont. from previous page

and contain no mention of the rock churchea. It is likely that they were not built as yet. Tradition has it that they took 24 years, cf. Alvarez, op.cit., p. 227; and Lalibela was probably still alive as late as c.1235 A.D.

1. It is first mentioned in 1210 by the Patriarchal envoys to Lalibela, Perruchon, op.cit., pp. 84-85. Since it was not mentioned elsewhere, many ingenuous attempts have been made to identify it, mainly by suggesting various readings for the Arabic name. Conti Rossini identified it with Adwa and supported his view with a quotation from Abu Salih "Note etiopiche", in G.S.A.I., X (1897), p./48, n.5. Esteves Pereira rejected this with convincing arguments, but he suggested a curious identification with Yifat (in Shewa), of which the reading he altered into Adefat or Ayfat, Perruchon, op.cit., pp. 86-87. The accuracy of the Egyptian envoy Is now fully confirmed by the hagiographer of King Yimrha, "They received him (with acclamation) from the district of Say (in Bugna) to the land of Adefa and here he sat on the throne and ruled all (the people) according to the apostolic conons....", Gedle Yimrha-Kristos, ff.28b-29a. A local man casually pointed at a small site still bearing the name of sdefa, near Medage Abbo among the western foothills of Mt. Asheton overlooking Lalibela on the north.

2. Perruchon, op.cit., pp. 78-79. 
afterwards the Metropolitan left for Egypt complaining that limu had challenged his authority. There is a constant mention of "the great men of Bugna" in the land grants of the King. The Abbot of the important monastery of DebreLibanos of Shimezana, Yīrdíanne-Krīstos, also came from Bugna and held office between 1225 and 1268 an the eve of the fall of the Dynasty. Lalibela had a Iarge army, and probably much of its leadership and the economic patronage deriving from it were also predominantly enjoyed by his Bugna courtiers. Zagwe power had been firmly established everywhere and the dominance of Lasta in the political and religious life of the kingdom was complete. It is apparent that towards the end of the eventful reign of Lalibela conflicts were beginning to flare up and the Semitic-speaking peoples of Tigrē and Amhara were organizing a strong political reaction. The characteristic weakness in the system of Zagwe succession to the throne greatly facilitated the anti-Lasta movement.

It is apparent that succession to the throne among the descendants of Merara, the founder of the Zagwe Dynasty,

1. Ibid., p. 79 .

2. Conti Rossini, op.cit., pp. 187, 190, 192, 193.

3. The patriarchal envoys estimated it at 60,000 mounted soldiers without counting the numerous gervants that followed them, Perruchon, op.cit., p. 83.

4. P.106 $\mathrm{n.l}$. His reign is sald to have been very ghort, Gedle Yared, cit. p. 23 (text). 
was determined by the same rules as those of inheritance of family property in lasta. Two legal pronouncements attributed to King YImrha by his hagiographer seem to offer a useful clue to the problem of succession among members of the Royal Family :-

"(King Yimrha) decreed saying, 'If there are two or three brothers, born of the same father and mother, and if one becomes rich and the other poor, let the poor man share the property of his rich brother. For both are the fruits of the same womb'."1

It seems that the descendants of Merara considered the Christian throne on precisely the same terms. Each of the princes of Bugna apparently claimed rights of succession to the crown and, despite the hagiographical traditions of divine intervention, the problem was probably decided every time by force of arms. The trouble had already started in the reign of the second Zagwe king, Tente-widim. He had two younger brothers, GIrwa-Sīyum and Zan-Sīyum, respectively, and ho is presented as being worried about the prospect of being succeeded by Girrwa's son, Yimrha :-

1. Gedle Yimrha-Kristos, f.29b. On another occasion the King was presented with tine case of two brothers who had become deadly enemies on land dispute. He called them to his presence and reconciled them by ruling as follows: "Divide all your property into five parts. Let two parts go to the elder brother, and the rest to the younger. The residence of the (deceased) parents shall also belong to the younger", Ibid., f.26a.

2. In a curious passage Yimrha describes himself as follows "I am the son of Girwa Siyum; my bigger father is Tentewidín and my younger father, Zara-Siyum". f. 27 a. One may easily point out that a word is omitted in each case and that the underlined words stand for brother of my father. 


\section{1 it}

"(Yïmrha) stayed with him (i.e. the King) for a week. When (Tentewidim) saw him among his own sons he becamé jêalous saying, 'He is going to reign, and my own sons will be his soldiers'... and he wanted to kill him.... But his sorcerers told him 'send him to his mother so that he does not learn the secrets of your kingdom. Instead he shall grow with shepherd boys and herdsmen'. He was pleased with this advice and sent ( $Y$ imrha) to his father's hous and he grev there."I

Struggle for succession is a common theme in zagwe royal traditions. During the reign of his brother, Lalibela was an outlaw and wandered in self-exile for many years; and his half-sister almost poisoned him to death. The events which led to his eventual advent to power are difficult to decipher. But since he acceeded to the throne in the life-time of his brother it was probably achieved by force of arms. The humble condittons with which King Harbē welcomed his

/Footnote 2 cont. from previous page

But since lalibela is also referred to as the father of Ne'akuto-Le'ab, I have preferred to keep to the original which probably indicates a clamish cohesion in the family, at least in times of peace, cf. Gedle Ne'akuto-Ie'ab,

pp.119 (text): Lalibela referred to as Mhis father in the flesh and in the spirit".

\section{Gedle Yİmrīha-Krīstos, f.5.}

2. Gedle Lalibela, ed. Perruchon, p. 82. She is described as "his sister, born of the same father". This probably means that they had different mothers. Her attempt to kill him were undertaken in favour of their brother, King Harbe, who may have had the same mother as herself. Polygamy was common among the secular families of Christian Ethiopia despite the attempts of the Metropolitans, Sawirus, The History of the Patriarchs, cit. pp. 329-330. Among the legal reforms attributed to King Yimrha, a veritable PriestKing himself, was his insistence on ruline the country accordin, to the apostolic canons, "Let every man live with one wife, anc every woman with one husband", Gedle Yimriha-Kristos, ff. $28 \mathrm{~b}-9 \mathrm{a}$. 
triumphant brother "... on his feet... while his soldiers implored him to mount (the Royal irule)..." also lead to the same conclusion. This hagiographical tendency to alter historical traditions is even more problematic in the last years of the Dynasty.

The Patriarchal envoys to his court in 1210 reported that Ialibela had two sons : Itbarek and Ie'ab . The second name, Le'ab, most probably stood for the much longer name of Ne'akuto-Le'ab, which the Egyptians hed obvious difficulty in remembering. Ne'akuto-Le'ab was a 4 nephew of King Lalibela, and was brought up at the royal court. The story of his career, as given by his hagiographer(s) may be summarized as follows. Ialibela'g queen,

1. Gedle Lalibela, pp. 108-109. Cf. also Gedle Ne'akutoLe'ab, ed. Conti Rossini, p. 106.

2. That Ialibela had a son is also mentioned in his Gedl, ed. Perruchon, p $\mathbf{5}$-51-5k. But his name has been suppressed in both passages and only appears in what may be called unofficial king lists, cf. Conti Rossini, "Il libro delle leggende e tradizioni", cit. p. 708 .

3. Perruchon, op.cit., p. 85. The name is given here as Atyab, (Inab or itab). The Arabic can also be read as Le'ab. I am very grateful to Dr. Wansbrough for this important correction.

4. Gedle Ne' akuto-Le' 'ab, pp. 114, 129.

5. Ibid., pp. 1187119, 125, 128.

6. Ibid., pp. 126, 146-151. 
Mesqe -Kíbra, requested her husband to abdicate in favour of the promising young prince. The king hesitated at first but he eventually agreed to crown his nephew who began to rule the kingdom from a nearby capital of his own. Only eighteen months later, however, his soldiers mtreated a simple farmer by taking away his only cow for the royal tables of their young master. This displeased the saintly queen. She complained to Lalibela, who summoned Ne'akutoLe'ab at once and took back the crown from him. The young prince meekly accepted the verdict and lived in absolute obedience until Lalibela's death, when, once again, he ascended the throne and ruled for forty-seven years. This is an unlikely etory and has undergone a deliberate process of transformation of which the major purpose seems to have been the exclusion of Lalibela's own son, Yîtbarek, from the official record of succession. The envoys of Patriarch Yohannis to Adefa in 1210 had no doubts of the precedence of Yitbarek's position and they listed his name with much accuracy, prior to that of his "brother" Ne'akuto-Le'ab, of whom they had only an imperfect memory. We'akuto-Ie'ab was probably the son of King Harbe, ${ }^{1}$ who had been deposed by Lalibela. The young

1. The tradition collected by Antoine d'Abbadie clearly states this, also giving the other name of the king, Gebre-Naryam, Conti Rossini, "Il libro delle leggende e tradizioni Abissine", cit. p. 708. His own hagiographer(s) give another name, Gebre-Mesqel, for the prince's father, op.cit., p. 115 . 
prince was taken to court where he grew with Yitbarek. Towards the end of Lalibela's reign probably the two princes were each given a governorate to administer. As the son of a former king, Ne'akuto-Ie'ab was no doubt a rallying point for dissatisfied elements in the country and was deeply mistrusted especially by Queen Mesqel-Kibra, who considered him a serious threat to the career of her own son. Thus he was probably under close watch and was not allowed to move very far from the royal capital. 'Yitbarek on the other hand seems to have had a greater freedom of movement and was probably given, at one time, the command of a military contingent sent out to suppress a rebellious

1. This emerges clearly from the contradictory roles she is said to have played in the career of Ne'akuto-Le'ab in ph. $117-8$. above. Her strong, practical influence in her husband's reign is quite evident in the land grants. One of the main reasons for which bishop Mika'è (1205 - 9) claimed he had to leave the country was the Queen's interference with Church administration in favour of her brother whom she had raised to a bishopric, Perruchon, op.cit., p. 79 .

2. His name has always been associated with a place called QeghInna, about three hours by mule east of Lalibela, on the other side of Mount Asheten. It is there that Lalibela gave him leave to establish his official residence, Gedle Ne'akuto-Le'ab, pp. 147-148. It was also there that, dismissed from office at the insistence of the queen, he returned and continued to live, ibid.. p. 150. At present there is a natural cave at the foot of Mt. Asheten, on the eastern side, in which a pretty littie church has been constructed in his name, ibid., p. 173. 
1

governor. His name is also associated with Tigrē where

he may have had some responsibility. It is most likely that

on the death of Lalibela there was an armed struggle for the

1. A tradition of local rebellion (no place names are given) against which Lalibela sent "his son" is still preserved in Gedle Lalibela, p. 117. The name of the "son of the kin $\bar{g}^{\prime \prime}$ is however suppressed. What seems to be the same incident is also ment oned in Gedle Ne'akuto-Le'ab, pp. 14l142, 146. The rebel here is however said to have been Sere-Qimis of Gojjam, and Lalibela sent Ne'akuto-Le'ab against him. What makes this very dubious is the complete absence of Ne'akuto-Le'ab's name in Gedle Lalibela both in this connection and in general. It is apparent that the author(s) of Gedle Lalibela, although forbidden to mention the name of Yitbarek were unwilling to substitute Ne'akuto-le'ab and simply referred to "the son of the king".

2. There is a curious composition entitled Gedle Yítbarek of which I was able to consult a paper MS. at Lalibela. Since its existence was unknown, the Abbot, Memhir AfeWerg, drew my attention to it and obtained the MS. for me from liegabi Tegegn (see p. $50 \mathrm{n} . \mathbf{l}$ ). It is said to have been a copy of which the original is found in a monastery dedicated to Yîtbarek in Tigre at a place called Mekane Satwa. It is a collection of numerous anachronisms and contradictory traditions. It seems quite clear, however, that its general theme is Yitbarek's dispossession of his rightful place in lasta tradition. The book opens by stating that Lalibela and Mesgel-Kibra forced him to go to Tigre and live in very poor circumstances, Gedle Yîtbarek, paper MS, Megabi Tegegu, pp. I - 3. St the time of my visit there was much controversy about the book in the Lalibela community, which did not give official recognition to the work. Yîtbarek's connection with Tigre is also referred to in the tradition of mi grations of the Adkeme-Melgä of Serawe : Yîtbarek was grandfather of Amotager first ancestor of the tribe, Conti Rossini, "Studi su popolazioni dell'ttiopia" cit. p. 82 (extract). 
succession between the two princes, in which Ne(akuo-Ie'ab was victorious at first and probably acceeded to the throne for a time. Soon afterwards, however, Yĩtbarek seems to have taken over his father's throne. His own hagiographer seems to refer to this final defeat of Ne'akuto-Le'ab :"There was a man in the land of Ambagē. He went and entered the King's palace. He met the King and accused (Neakuto-Le'ab) saying, 'He took your kingdom before, and now he is hiding in a cave with your tabot of S'yon'..."

Ne'akuto-Le'ab's interregnum probably lasted for a short time, and in an early tradition of the period only Yítbarek is referred to as "the Zagwe king who is reigning in the 2 place of lalibela".

Anti-Zagwē Movements in Tigrē anà Amhara

The internal conflicts of the Zagwē princes greatly strengthened the political movement against them. The earliest sign of anti-zagwe feelings amolng the semiticspeaking Christians of Tigre and Amhara is provided by the tradition about the first Arabic copy of the Kíbre-Negest

1. Gedle Ne'akuto-Le'ab, p. 173. The reference is to the cave church of Qoghinna, cf. p.llq, $\boldsymbol{n} \cdot \mathbf{2}$.

2. Gedle Iyesus-Mo'a, ed. and tr. S. kur, p. Is (tr-) That the reference is to Yitbarek is clear from another passage which states that the saint settled at Haiq in Yítbarek's reign, Ibid., bo.lo, 26.df. also Conti Rossini, "La Caduta della dinastia Zague", cit. pp. 282, 285, 287, 289.

3. Gedle Ne'akuto-Ie'ab. p. 109. 
in Ethiopia. We are told that the first Arablc copy of the book was translated from the Coptic in 1225, at the time of 1

Lalibela and Bishop Giorgis in Ethiopia. Nevertheless, an Ethiopic version could not be made right away because, as the scribe has it "It went out in the days of Zagua, and they did not translate it because this book says : 'those who reign, not being Isra'ēlites, are transgressors of the Law'". Anti-Zagwe feelings were probably widespread in Tigre, where Lasta power was firmly established. For the same reason too the emergence of a strong anti-Zagwe leadership was practically impossible there and the initiative seems to have passed to the region of Amhara.

The Amhara had long been the advance guard of Chriatian expansion in the south. We have already referred to an early Muslin tradition of the armed conflict between them and the Werjīh pastoralists in the Shewan region, in 3

1128 A.D. There are traditions of a slow movement of isolated Christian families from Amhara to the region of 4 the Shewan plateau.

A military expedition by a Zagwe

1. Bishop Giorgis is also mentioned in a land grant of Lalibela's in the same year, 1225, Conti Rossini, "L'evanelo d'oro", cit. pp. 189-191.

2. Budge, E.A.W., The Queen of Sheba and her only son Menyelek, (ed. 1932), p. 228 .

3. Cerulli, "Il Sultanato dell Scioa", cit. p. 10, m. 4 . sortor.

4. See pp. 228-30. 
monarch into the "kingdom of Jamot" is also referred to elsewhere. It is apparent that by the first half of the thirteenth century a large number of Christian familes had already settled in the pagan dominated area of the Shewan plateau north of the Awash. The Muslim principalities established in the region only affected the eastern sections of the Sidama area south of the Awash, and in the hot, lowland basins of the western tributaries of the Awash in eastern Shewa. The Muslim kingdom of Ifat, which was the strongest among them, was itself only tucked into the north-eastern corner of the edge of the shewan plateau. This was no doubt due to the earlier establishment of Christian comunities in the area. The Christian families in the sêwan region were subjects of the Zagwē kingdom. In a tradition about the district of Tegulet in the thirteenth century, a salt trader is made to say "The King of Roha in Angot,... he is king over us in this period".

1. Gedle Yared, pp. 22-26.

2. This is quite evident, even from the place names in the important document published by Prof. Cerulli, op.cit., pp. 5-42. Many of the identifiable place names were still lluslim in 'Amde-Síyon's reim, ibid., pp. 25-32. And in that period the referred to the hot lowlands east of the Shewan plateau.

3. Gedle ewístos, MS. Debre-Iibanos, f. 57. A more uncertain tradition attributes a church on Debre-Fentalie (eastern Shewa) to a local chief who lived in the retgn of Ne'akuto-Le'ab, Ibid., ff. 99-I00. 
With the development of the commercial activitiea of the Muslims in the Shewan region and the growing importance of the port of Zeila, the region of Amhara was of vital significance for the Christian Kingdom and its Zagwe rulers. Whe major routes to and from Lasta passea through it, and it is apparent that very close contacts had been established between this province and the GuIf of Aden. In an early MS. at the library of Haiq Estífanos there is an interesting genealogy of a Jewish family that immigrated from Aden and settled in Amhara :-

"In the period of the Zagwe rings, there came out a n, a Jew called Yosef from the country of Aden .... He was a very rich and respectable man, This was probably a family of Jewish merchants and may not have been the only one. No doubt much of the economic and political benefits accruing from these developments were shared by the local people, particularly the ruling families. There are many reasons to show that Yînuno-Amlak and his supporters owed much of their success to the new situation.

1. Compendium of the Prophets and the Book of Enoch. MS. Haiq, Colophon. Then Iollows a genealogy of eight generations. None of the names is identifiable as yet; but the MS. itself seems to belong to the first half of the 15th century. 
Yikunno-'Amlak : Founder of a New Dynasty

The origins and early life of Yíkunno-'Amlak

still remain very obscure. On his father's side tradition makes him a descendant of Dilna'od who is said to have been the last Aksumite king deposed by the zagwe. ${ }^{1}$ His mother is nevertheless said to have been "one of the slaves" of a 2 rich Amhara chief in Segerat. This connection with a local chiefly family in Amhara is more significant in his career. He grew there with the chilaren of his master and he is also said to have obtained some religious training with them. More important still another tradition reports that he was later imprisoned by King Yitbarek in Melot from where he managed to escape. ${ }^{3}$ He was probably involved in the struggle for succession between Yitbarek and Ne'akuto-Le'ab.

1. Gedle Iyesus-Ho'a, p. 21 (tr.); Conti Rossini, "La Caduta della dinastia Zague", cit. pp. 282, 287. The tradition that Dilna'od was the name of the last Aksumite king is by no means secure. Another version calls him Dignazan, Gedle Yared, p. 23 (text).

2. Conti Rossini, op.cit., pp. 283, 287; Segerat is on the main road from Lake Haiq to Begemdir.

3. Ibid., pp. 284-285, 289.

4. This is probably the origin of the tradition of an amicable settlement of the dynastic problem between Yikunno-'Amlak and Ne'akuto-Le'ab accordin to some versions of the traditions about the advent of the new dynasty; cf. Bruce, Travels to discover the Sources of the Blue Nile, Vol. I, 1790, pp. 532-535. Among the zagwe of the Eritrean region who have a tradition of migrating there from lasta on the 
It is interesting that the most important part of his activities against the Zagwe are attributed to the period after his escape from Yîtbarek's prison. It is in this period that he is said to have made a religious pact with Iyesus-Mo'a of Debre-Haiq. YTikunino-'Amlak seems to have organized an effective military revolt against king Yitbarek within the crucial area of Amhara and the Shewan plateau. We find him in communication with the Yemenite Kingdom and the Mamlukes of Egypt inmediately after his success over the Zagwe. It is probable that this started much earlier. On the eve of the downfall of the Zagwe Dynasty, YIkunno-'Amlak had apparently established a virtually independent kingdom of his own comprising Amhara and the Christian communities of Shewa.

/ Pootnote 4 cont. from previous page occasion of the fall of the Zagwe- dymasty there is also another tradition which accuses Ne'akuto-Le'ab of killing many of their ancestors and forcing the rest to migrate northwards, Conti Rossini, "Studi su popolazioni dell/Etiopia", cit. pp. 53-54, 72, 79 (extract).

1. Gedle Iyesus-ivo'a, pp. 20-2l (tr.). Much later tradition have ascribed this religious role to Tekle-Haymanot of Shewa, Conti Rossini, op.cit., pp. 299-311. Conti Rossini has made a critical study of these traditions and has conclusively shown that Tekle-Haymanot does not seem to have played this role, "Appunti ed osservazioni sui re Zague e Takla Haymanot" in RRMI, Ser. 5, Vol. IV (1895), pp. 444468. A cloae study or the life and religious career of Tekle-Haymanot fully confirms this conclusion, see pp. $30 \%$ etc.

2. Mufazzal, Histoire des Sultans Mamlouks, cit. pp. 383-387 Maqrisi, Histolre des Sultans Namluce, tr. Quatremere, Vol. II, Pt. 2, p. 122, I. 15I. 
Marianus Victor collected a pre-sixteenth century tradition that, in his strugcle against Yítbarek, YIkunno'Amlak obtained military assistance from Shewa. Conti Rossini has more recently published an interesting document which confirms the tradition :

"And when he went (for a Battle)... with his warriors, the seven Gwidem whose names were, Wegda lialezay, Dínbi Debaray, Muger Eindezabi, Wereb Enekafe, Sïlalīsh Enegafe, (and) Mwal Awjajay ..."

With these and his Amhara troops Yîkunno-'Amlak attacked the 3

Zagwē king, killed him, and declared himself King of Ethiopia.

The title was probably only nominal for some time. Leading members of the zagwe army and their followers appear

1. Quoted in Perruchon "Notes pour I'histoire d'Ethiopie", in 토, I (1893), p. 368.

2. "La Caduta della dinastia Zague", cit. pp. 296-297. the place names appear in the documents since the 14 th century. Mugar Endebazé is mentioned in a slightly different form in Gedle Samu'el (Wegeg), MS. Debre-Iibanos, f. 9a. There is also a reierence to the "chlef of ti.e seven GWĩdim" in Gedle Nerha-Kristos, (16th C.) MS. DebreLibanos, pp. 28, I89. The people of Mwalu are mentioned in Chrouiques de Zar'a Ya'eqob, ed, and tr. Perruchon, p. 85 .

3. As we said above the name of Yîtbarek had been systematically suppressed in the official hagiographical traditions. In the story of the struggle he is given an esotertc name and is simply called Ze-timekoun, "The Unknown, the hidden one". In many cases his name Yitbarek is also given; cf. Conti Rossini "La Caduta della dinastia", cit. p. 299. In Lasta, however, the esoteric term has become a useful escape mechanism in denying that the king killed by Yikunno-1Amlak had anytining to do with Iasta. Megabi Tegegn vehemently stated that Ze-Elmeknun was only a rebel in Wadla! 
to have left Lasta and moved northwards into Tigrē. There they joined hands with the Zagwe provincial officers and put up a hard resistance. In 1268 an interesting land grant to Debre-Libanos of Shimezana indicates that the Zagwe had crowned another king, Dîlanda, and apparently organized themselves under a council of six military leaders. Two years later, in 1270, another land grant to the same monastery is signed by "King Yīkwinat" and all the various offices held by a completely different group of people. Yīkunno'Amlak founded a new Christian Dynasty in the Kingdom. Common resentment of Lasta domination probably brought him much support in Tigre, where the Amhara tradition of Tigrē origin strengthened his position as against the Zagwe. The predominantly Agew rulers of the Christian Kingdom were deposed, and the throne was once again occupied by a Semitic-speaking monarch. Only in this sense was the advent of Yīkunao-'Amlak a restoration.

1. The Zagwa and Adkeme-lielga in Eritrea have traditions of migration from Lasta as a result of an invasion from Shewa, Lonti Rossini, "Studi su popolazioni dell'ttiopia", cit. pp. 53-54, 60-6i, 82 (extract).

2. Conti Rossini, "L'evangelo d'oro", cit. p. 193. Together with the king's name there is a reference to "the six strong men" which probably indicates a council of leading generals to look after the hostilities.

3. Ibid., p. 196. This curious form of the king's name also appears in another contemporary tradition, Cerulli, E., "Il sultanato dello scioa", pp. 13, 19. 


\section{INTERNAL COIFFLICT AND READJUSTMEENT $(\underline{1285-1380)}$}

rany problems awaited the new dynasty

founded by Yikunno-Amlak. For more than a decade after the end of his reign the rivalries among his own sons ${ }^{l}$ presented the dynasty with its most serious danger. Yagb'a-Síyon was probably the eldest and took over as King of Ethiopia on his father's death. In a land grant to Debre Iibanos of Schimezana, a certain Yagb'a-siyon is mentioned as one of the officials of Yikunno-Amlak. The name appears onfy next to the King's and it may very well be that it represented his son. 2 In fact, probably because of the position of authority wilch he held already before the death of 'hisfather, Yagb'a-Síyon's

1. All the available sources agree that Yagb'a-Sìyon and Tidim-Re'ad were his sons. According to Bruce, however, the five princes who succeeded Yagb'a-Síyon were also his brothers, iravels to discover the source of the Nile, II (1790), pp. 4-5. Basset's text makes tilen his sons, Etudes, cit., pp. 10-11. Bruce's source for this was probaly the game as that of D'Abbadie who collected a similar tradition, Conti Rossini, "Il libro delle leggende", RRAL, 26, 1917, p. 709. The tradition is confirwed elsewhere in the case of one of the princes: $K \bar{i} d m-\dot{s} e g i d$ was also Yikunno-Amlak's son, Gedle Beselote-liika'el, p. 29 (text).

2. Conti Rossini, "I'evangelo d'oro", cit. p. 194. 
successiod does not appear to have been contested at firgt.

Nevertheless there are clear indications of political unrest and internal conflict in wich the church was also involved. In 1290, some five years after his accession, letters from Yagb'a-Sĩyon to the Sultan of Egypt and the Patriarch of Alexandria requesting the appointment of \& new Egyptian bishop, reached Cairo. ${ }^{1}$ the letters contain some interesting information about new developments that had been taking place in the Ethiopian church since the dynastical change. Yagb'a-Síyon compleined to the Patriarch John VII (1262-8; 1271-93) about the serious difîculties raised by the presence in Ethiopia of "Syrian lietropolitans":

"Ces metropolitains syriens qui résidaient dans l'Abyssinie, se sont attirés notre haine. Uniquement attachés au patriarchat de L1 Egypte, nous $n$ 'avons pas souffert que ces etrangers exercessent plus long-temps les fonctions episcopales, et nous les avong chassés de leur sièges, ou il ne s'etaient waintenus jusqu'alors que par la protection de notre pere..."

In the hagiographical and other clerical records of the Ethiopian church no reference to such Syrian

I. Luatrevère, Æ. Mémoires géographique et historiques sur I'Egypte, II (1811), pp. 268-73.

2. Ibid, p. 271. 
prelates has yet come to light. At the beginning of Yikunno-Amlak's reign, Abba Qerflos is mentioned as "Archbishop" in Ethiopia, in a land grant dated 1269-70.1 Three years later, probably because Qerilos had died in the meantime, Yikunno-Amlak wrote to Sultan Baybars (1260-77) asking for a new bishop. ${ }^{2}$ From the text of the letter it appears that he had already been expecting the arrival of the bishop for some time then. He reminded the sultan, that, although he had already received an envoy from the Mamluk governor of Kus, no bishop had come with him as expected. Despite this second appeal, however, the king did not succeed in obtaining a new bishop from Egypt. This may have induced him to look for a prelate from elsewhere. Already in the letter of 1273/4, he mentioned the purpose of the Mamluk delegation from Kus as having been "au sujet du moine qui est venu nous trouver". It is not clear what this refers to exactly; but Yagb'a-Siyon's letter

1. Conti Rossini, op.cit. p. 196. The title "Iige papasat" is quite unusual. But a bishop of his name is also remembered elsewhere for the same period, Gedle Tekle-Haymanot, ed. Conti Rossiniti p. 104. Gedle Zena-Margos I. $7^{2}$. Gedle Gewistos, ff. $44 \mathrm{~b}-78 \mathrm{a}$.

2. Mufazzal ibn Abil-Fazail, Histoire des gultans lamlukes, ed. \& tr. i. Blochet, in PO,XIV, pp. 383-7. Fiaqrizi, Histoire des sultans Mamluks, tr. Quatremere, Vol. II, pt. 2, p. 12k, n.15I. 
in which he tells Patrianch Yolannis that his father "n'avoit auprès de lui aucun evêque de votre choix" makes it most likely that Yîkunno-Amlak had accepted a prelate whom his son later called"a syrian". It is apparent, however, that the king did not maintain "the Syrians" out of mere defiance of the Alexandrian Patriarchate. The implications of Yagb'a-Síyon's letters are that these clerics had come to the court with uncertain credentials and were accepted by YÍkunno-Amlak without the full consensus of the Ethiopian church. When doubts about the credentials were raised, Yǐkunno-Amlak probably felt it unnecessary to refer the matter to Cairo, where his previous requests had been given only the slightest attention. Soon after his death, however, opposition to the "Syrian" clerics had flared up once again, and the new king very wisely espoused the strong party still loyal to Alexandria.

To offset the recurrence of similar uncertainties about the credentials of the new bishop, the king suggested to the sultan some precautionary measures:-

"Je voulais en changer mon député Yusus; mais je me suis vu constraint de différer, a, cause du metropolitain Syrién, qui a boulversé mon pays, sous le règne de mon pềre qui étoit enemie des 
qusulmans. Je desire que le nouveau métropolitain se rende dans mes états, accompagnể d'un ambassadeur du sultan, et mon député. (Ceci) calmera les troubles de l'Abyssinie et rendra la paix aux musulmans et aux chrétiens."

Thus, Yagb'a-Siyon had brought an end to the Syrian Interlude by a royal decree, but he did not succed in obtaining a new bishop. Unrest among the clergy and their lay supporters probably continued to the end of his reign. This may have contmoted to the last struggle far power in which we find him engeged, with what appears to be another group of his ow family. The incident is related in an interesting contemporary note at the library of Debre Haiq:

"I, Yagb'a-Sìyon, whose regnal name is Solomon, addrned this Book of the Four Gospels with gold and silver in 478 Year of Grace and gave it to (the church of St.) Stephen. Aiter that, there came $Y^{\prime} i q e b e n n e$, and he wanted to take away my throne; but I defeated him and destroyed him with the power of Christ, my God."

The date is equivalent to $1293 / 4$, and

Yagb'a-síyon died soon afterwards. 3

1. Quartrenère, op.cit., pp. 268-9.

2. The Pour Gospels, MS(III), Haiq, f. $339 \mathrm{~b}$.

3. Yikkunno-Amlak died in June 1285, and Yagb'a-Sìyon reigned for nineyears. His death must therefore have occurred in the first half of 1294. 
But the struggle among the descendants of YikunnoAmlak seems to have continued for sometime, until the final accession to power of King Widim-Re'ad. There are in fact many uncertainties about the events that took place after Yagb'a-Siyon's death. The identities of the power groups involved in the struggle and the names and mumber of the princes who occupied the throne between the reigns of Yagb'aSĩyon and Wĩdî-Re'aà are still very doubtful. Iater compilations of the royal chroniclers only give them a bare mention:

$$
\begin{aligned}
& \text { "Sinfe-Arad, HIzbe-Asegİ, Gidme-Asegid, } \\
& \text { Zan-Asegid, and Seb'a-Asegid, the five sons } \\
& \text { of Yagb'a-Siyon reigned for five years. } \\
& \text { Nothing is knowm about them". }
\end{aligned}
$$

As we have seen above, Bruce's story that they were all the sons of Yîkunno-Amlak finds support elsewhere in the case of Qídme-Asegĩ. 2

1. Zotenberg, H., Catalogue des lanuscrits éthiopiens de la Bibliotheque Nationale, Paris, 1877, No. 142, section I, Bascet's publication of this text has a misprint at the relevant section wich is however rendered correctly in the translation, Etudes sur l'Histoire d'Ethiopie, cit., pp. 10, 99. Accordin to another list, the first two of these princes reigned for three years and the remaining three for two, Wright, W. Catalogue of the Ethiopic l"anuscripts in the Britisli useuri, Loncion, 1877, Or. 817, I.3.

2. Gedle Besolete-íika'êl, p. 29 (text) 
Another list of the kings of the new dynasty, which is probably the oldest list available, only gives four of the names without their filial connections. I These contradictory notes clearly indicate an obscure period of some five years during which the succesaion was contested among the princes, including the sons of both Yíkunno-Amlak and Yagb'a-Síyon. Widím-Re'ad, the latter's younger brother, finelly emerged victorious in the struggle. With his accession to power, the dynastical conflict among the descendunts of Yíkunno-Amlak seems to have come to an end, and the succession went to Wídim-Re'ad's branch of the family once and for all. But the incident became a bad precedent for future generations and, as we shall see in the course of this study the absence of a definite rule of succession was a continuous source of strife among the numerous sons of the medieval kings of Ethiopia. 2

Consolidation of the Dynasty in the North.

The immediate result of these early conflicts was to weaken the power of the new dynasty

1. Wright, op. cit., Or. 818 , f. $46 \mathrm{~b}$. Zotenberg, op. cit., 10. 146, section I. Seb'a-Seged is left out in both these snort lists. Cf. also Conti Rossini, "Pergamene di Dabra Damo", in R.S.O. XIX (1940), P.47

\section{Infra, pp. 541-3, etc.}


within the Christian kingdom itself. At this stage of the history of the dynasty the most important parts of Christian Ethiopia consisted of Tigre, Lasta and Amhara. As a result of Yikunno-Amlak's successful revolt, Lasta had not only losts its primacy in the kingdow but also much of its leadership. This left Tigre and Amhara as the two outstanding parties in the Christian power structure. The claims by Yỉkunno-Amlak and his Amhara troops of Tigrè (Semitic) ancestry had been central in their movement against the Zagwe, and it is apparent tint they got much support from the Tigrigna-speaking population. In fact it seems that a new cadre of local governors took over the leadership of Tigre immediately after Yíkunno-Amlak's accession to power. ${ }^{I}$ The most important among these new local leqders was the "Governor of Entertan who also held the titles of Hasgwe and Aqabe-Sensen. The latter title, "Aqabe-Sensen" was apparently of ancient Aksumite origin, and gave a particular significance to the position of this official throughout Tigre. ${ }^{2}$ Engida-Egzi', who

1. Conti Rossini, "L'evangelo d'oro", cit. pp. 194, $196,197-8,199-200$.

2. During the formal coronation of Ser'a-Ya'qob in Aksum, the Governor of Tigre, also beld the title of Aqabe-Sensen (=the keeper of the fly whisks), Perruchon, J. Les Chroniques de Zar'a Ya'eqob. p.50. 
belonged to a local chiefly family, ${ }^{1}$ held the office in the reign of Yíkunno-Amlak, and, like the king himself, he was also succeeded by his own son TesfaneEgz1'. It is apparent that in this initial period of the new dynasty, ana especially at the time of the internal struggle of the sons and grandsons of Yỉkunno-Amlak, the family of Tingida-Egzi' gathered a considerable influence in tine area as a whole and held an almost independent power over its own province of Enterta in particular. In a land grant dated 1305, Tesfane-Egzi' already refers to his province as "wy kingdow". 2 Yagba'-Síyon and Widim-Re'ad had little power to control the situation and were both apparently satisfied with a distant recognition as King of Ethiopia. Only 'Amde-Sĩyon could mustreinough strength to bring to an end this new development which threatened the unity of the Christian kingdom.

Before he turned his attention to pigre, ' Amde-Síyon had accomplished his early campaigns against Hadya, Damot, and Gojjam, and his conquestr

1. He calla himself in the land grant "Son of KulAsgede". This strongly suggests that the famils had a local importance already before the aynastical change.

2. Conti Rossini, op. cit. p. 199 
in these regions ${ }^{1}$ placed him in an excellent position to impose his will on his provincial governors. He comemorates his success in Tigre in a land grant to the island monasty of Debre-Haiq:

"God delivered into my hands the ruler of interta with all his army, his followers, his relatives, and all his country as far as the Cathedral of Aksum" .

The governor of Enterta at the time was Ya'Ibike-Egzi, and his land grant of $1318 / 9$ does not even mention the King. He apparently had a firm control of northern Tigre, and his following included both secular and clerical leaders in the area. The two influential aubots of Aksum and Debreatamo were among his prominent courtiers. there are also traditional indications that he had invited the governor of Tembien to join him in his rebellion against 'Amde-Siyon. 3 He is said to have failed to enlist the support of this official, but it appears that his revolt was fairly well organized. 'AmdeSiyon's action against him and his followers was equally rutiless:

1. Infra, pp. 256-7, 370-1.

2. The Four Gospels, Ms.(IF), Haiq, f. $25 b$.

3. Wright, op. cit., or. 695 , ff. $38 \mathrm{~b}-40 \mathrm{a}$. Conti Rossini, "Note di agiografia etiopica:y AbiyaEgii', in RSO, XVII (1938), pp. 419-21. 
"...Wien Ya'ibike-Egzi and Engīda-Egzi rebelled, King 'Amde-Síyon decreed and deposed them, and destroyed these rebels. loreover to eliminate the pride of their hearts and to efface their (traditional) honours, (the king)appointed over their country men who were not born from Adar and Eve wilo were called Halestiyotat..." I

The multiple offices held by Habike-Egzi and his predesessors were given to different individuals, and what appears to have been a military colony of troopg from outside Tigre was stationed at Amba Senayet, which was the centre of the rebellion. The king at first entrusted the ofice of the Governor of interta to one of his own Queens, Bilen-Seb'a who was apparcntly herself a Tigre lady. ${ }^{2}$ With her a new group of subordinate officials was appointed for the various districts. The Queen's administration of her province was probably indirect and there is an early tradition of sore local displeasure with her complete dependence on her local agents and advisers. 3

1. Liber Aksumae, ed. \& tr. Conti Rossin1, pp. 30-1 (text). "Halestiyotat" literally means "bastards of mixed or low origing", and its use here certainly reflects the unpopularity of the military colony established by King Amde-Síyon

2. Conti Rossini, "I'evangelo d'oro", cit. pp. 204, 206. Id., "Raconti e cauzoni bileni", in Actes du 14 ème Congrès. Intern. Orient., Paris, 1907, p. 335 .

3. Wright, op. cit., Or. 695, ff. 36-37a. 
Probably because of this, one of the king's sons, Bahr-Sēqēd, was soon given charge of a highly cent tralized administration in Tigre. ${ }^{1}$ A new feature of this appointment in 1328 is the inclusion of the maritime provinces under the combined government of his son.

The term lialikele-Bahr, one of the titles held by tinis prince, probably referred to these maritime provinces, which apparently included the whole region between the Mareb and the Red sea. ${ }^{2}$ It has already been mentioned in the last chapter that the replacement of the Zagwe by the new Ambara Dynasty had sparked off a series of population movements from the Lasta region to north-eastern Tigre, Akele-Gruzay, Hamasēn, and Seraē. 3 This had resulted in a struggle

1. Conti Rossini, "I'evangelo d'oro", p. 208.

2. The title of lia'ikele-Bahr (lit. "between the riverg or seas") was already used in the Zagwe period, Its application 18 very uncertain, and Conti Rossini has suggested that it could refer to either the recion between the Tekeze and the Red Sea or the Nareb, Ibid. pp. 190, 194, 208. The limitation of the term "Bahr" to mere rivers in such a pompous title is improbable, and Ma'ikele-Bahr was apparently a title held by officials wioge special duties concerned relations with the coastal areas and their immediate hinterland. It was probably the precursor of the title Bahr-Negash, cf. Perruchon, J. Histolire des guerres d'Aude-Sdyon, p. 293 (text). Acta Sancti liercuri, ed. \& tr. Conti Rossini, $\overline{p .26}$ (text).

3. Supra, pp.125,n.4., $128, n \cdot 1$. 
for power between the newcomers and the original inhabitants, and in the eventual transfer of political suprewacy from the Christian Belew tribes to the Adkeme-Melga who constituted a major part of the new Christian settlers in the area. The Belew tribes were of Beja origin and before the end of the 13th century they dominated the region of the Eritrean plateau, including probably some of the districts south of the Mareb also. Their downfall in the hands of the Adkeme-Melga created a new power vacuum in the area, and gave their Iormer vassals a last chance to agsert their independence before the Adkeme-lielga consolidated their power. It is about this time that the traditions of the Christian tribes of Deqi-irina'ab indicate an intengive period of territorial expansion from their traditional centre of Gishnasilim, north-west of Asmara.

They have a tradition that their ancestors originally came from Dembya north of Lake Tana. 1 However, a close examination of this tradition slows a rather recent formulation, and it appears that the

1. Kolmodin, Traditions de Tsazzega et Hazzega $\operatorname{Tr}_{5} \operatorname{Tr}_{7}-\operatorname{Tr}_{8}$ These traditions, like many others in north Ethiopia, are closely related to the legend of the Queen of Sheba. Minab, the ancestor of the Deqi-Iinab, is said to have been oneoof the cmipanions of Menelik I on his way to Ethiopia from Jerusalem. 
Degi-Mina'ab were probably one of the original inhabitants of the Eritrean plateau, no doubt considerably affected by fresh population movements from the north and south. ${ }^{1}$ like all the other tribes around them, they were under the general political supremacy of the Belew. ${ }^{2}$ Between the end of the 13th century and the first years of the 14th century gowe branches were moving into what are today the districts of Gameshim, Dembelas, and Ackele-Guzay, and already in 1328 two officials in Hamasēn are mentioned among the influential local rulers. ${ }^{3}$ The present triballonfiguration of the rest of the Eritrean plateau was also taking ahapo about the same time. In the narrow lowland strip to the east, representatives of the Hazo-Teroa group of the Soho had already moved northwards into Samhar, and further inland on the plateau to form the Mensa and Haria aristocracies immediately to the north of the area occupied by the

1. Conti Rossini, "Schizzo etnico e storico delle popolazioni Eritree" in L'Eritrea Economica, Novara, 1913, pp. 78-9. "Studi su popolazioni dell'Etiopia" in $\underline{\text { RSO }}$, Vols. III - VI (1910 - 1913), p. 2 (Extract)

2. Kolmodin, op.cit. Tr6

3. Conti Rossini, "I'evangelo d'oro", cit., p. 209. 
Bogos (or Bilen) people. ${ }^{1}$ Except in the coastal strip, where the predominantly soho population were under the increasing religious influence of Islam, all the sundry tribes in the plateau were Christians. The most important Musim influence in the region came from the small sultanate of the Dahlak archipelago. Although the Christian inhabitants in the plateau maintained their old commercial relations with the Muslems, the Chrigtian kingdom had long logt direct control of the coast. Tine military colonies establighed on the way to the anctent port of Adulid had already been disrupted by the northward movements of the Soho.? But this had only been a measure of the internal weakness of the Christian kingdom, and did not at all represent an organized attempt gt luslim expansion. The situation basically characterizes the relative position of Islam and Christianity in

1. On his way to Jerugalem about 1337 Ewostatéwos is said to have vigited first the Bogos, and then "the two Maria", Gedle Ewostatewos, pp. 72-3. Despite this, however, Conti Rossini estimates that the iormation of the lilense and Maria aristocracies was "verso la seconda meta del secolo XIV", "Tradizioni storiche del Mensa" in GSAI, Vol. XIV, 1901, p. 43. Cf. also, Id., "Studi su popolazioni dell'Etiopia", cit. p. 6 (Extract).

2. Conti Rossini, "Al Ragali", in Boll. Soc.Ital. d'Espl. Geog. \& Comm., 1904, fasc. II, p. 22. Id. "Studi su popolazioni dell'ptopia", cit. pp. 4-5. 
northerm Ethiopia since the 8 th century A.D. Although the presence of Islam in the Dahlak islands by far the earliest and most important liuslim centre on the Eritrean seaboard - is well attested since the first century of the Hejirah, its influefice as a base for the propagation of Islam into the interior remained minimal until the end of our period. Only a section of the Soho nomads wandering about in the lowland strip could be affected in a religious sense, the inhabitants of the plateau were Christian, and even mogt of the people of the samhar, were either still Christians or pagans, as la te as the fourteenth century. The political and economic importance of the Muslim settlements on the lnainland and in the islands nearby had nevertheless been much more significant than their missionary value for Islam. Just as in the southern provinces of Shewa, Ifat, and Hadya, 'Aude-Sỉyon was deeply concerned about the dangers of the development of luslim power on the Eritrean seaboard. He fully realised that the restoration of Christian supremacy in the Ethiopian region would only be complete if its impact was felt by the coastal risilim settlements. His recent campaigns geaingt the Muslims of Ifat and easterm Showa were doubtless resented by their co-religionists in 
the north, who hay have co-operuted with the rebellious army in northern Tigre. This may have furnished 'Amde-siyon with the immediate reasons for his expedition in the fritrean region:

"I, King 'Amde-Sīyon, went to the sea of Erityrea. When I reached there I mounted on an elephant and entered the sea. I took up my arrow and spears, killed my enemies, and saved my people".

There is also a reference to this successful expedition in the hagio-graphical traditions about the life of Ewostatēwos, whose monastic activities in Sera' $\theta$ about the same time inaugurated a parallel revival of the Ethiopian church in the Eritrean region.?

1. The Four GospeIs, is. (I:), Haiq, f. 25b. The word used here Ior elephant is Harmaz, the same word wilch appears on the inscription of Cohaito, Iittmann, Deutsche Akgur-Fxpedition, Vol. IV (1913), p. 70. It is also interesting to note tuat a similar use of elephants was made by the King of Yemen in 1309, A.D during a visit to the coast, on the opposite side of the Red Sea, "The Supreme cortege proceeded to the sea of 'Ehwa'd, the sea coast of qebid... (The Sultan) mounted an elephant when he entered Faza...", \&IKhazraji, ilstory of the Resulid Dynasty, ed. \& tr. J.W.Redhouse, III, i. p. 288 .

2. Gedle Ifwostatêwos, p. 53. The passage has hitherto been completely neglected and was a parentiy thought of as a nere clerical eulogy of the king. But the essential basis of the tradition - i.e. 'Amde-Síyon's personal campaigns in Eritrea - finds an important confirmation in the contemporary historical reference quoted in the last rootnote. The wording of the passage is however hagiograpinical in character: "(The King) travelled from sea to sea, from one end of the Eritreas sea to the other, fighting the infidels who are strong and who put their trust on astrological devinations; and he defeated the enemies of Crrist, 
The major obstacles to a much bolder action against the coastal Muslims and Soho nomads had always arisen from the internal weakness of the Kingdom itself and, unlike the regions south of Amhara, they seem to have offered little resistance to the revival of Christian power over them. This was considerably promoted by the absence of a united front among the Muslim powers of the Red Sea area. Since the emergence of the Rasulid dynasty of Yemen, Egypt hadlost direct control of its south Arabian province with the strategic port of Aden. Yemen was in fact becoming a strong rival of Mamluk Egypt in the control of the Red Sea trade. ${ }^{1}$ Relations between the two states were very tense, and the kings of Yemen showed no more than an attitude of formal respect to the superior force of Cairo. In the last two reigns of the Mamluk, sultan Al-Nagir Muhamad b. Qalawn, there were very clear attempts at the reconquest of Yemen. On one of these occasions,

/Footnote 2 cont. from previous page.

and reduced inis enemies with the power of God...". Ewostatewog $1 \mathrm{~s}$ also said to have met the $\mathrm{King}$, ibid, pp. 52-4. This probably took place when the court was in Northern Ethiopia. Ewostatewos was in Armenia when the King died in 1344, and he is said to have been deeply upset by, the news, Ibid, p. 108.

1. Wiet, G. MLes marchands d'épices sous lé sultans lamiuks" in CAH. HIS. EGY, VII (1955), p. 88. 
in 1307, the king of Yemen "prohibited the spicemerchants" until agypt undertook to stop warlike preparations at the Nile River port of Qus, where ships were being built for the invasion of Yemen. 1 An uneasy peace was apparently concluded, and the spice trade continued to flow to the egyptian dominions via Yemen. But the occasional arrival of large numbers of Egyptian troops for the annual to pilgrimage/lecca, which was in Egyptian hands, brought fresh dangers of an ultimate confrontation between the two powers. The King of Yemen was at one time (in 1352 A.D.) carried away to Cairo and detained there for fourteen months. ${ }^{2}$

The special concern of the Mamluk sultans of Egypt with the uninterrupted flow of the eastern trade also brought them into conflict with the unruly Arab and Beja tribes inhabiting the desert area between 'Aydab and the Nile river ports of Aswan and Qus.

1. Al-Khazraji, History of the Rasulid Dynasty of Yemen, cit., III, i, po. 285-6. Cf. Wiet, G. op. cit., p. 93. Sultan Al-Nasir of Egypt reigned on three occasions, 1293-4, 1298-1308, 1309-40. His reign wals one of the most prosperous periods of Egyptian history, Wiet, G. L! Egypte Arabe 642-1517, pp. 489-90; Hitti, P. History of the Arabs (ed. 1961) pp. 679-81.

2. \$1-Khazraji, op. cit.. III, pt.2, pp. 27-9; 69-75; 100 . 
In $1316 / 7$ A.D. these nomads attacked a Yemenite

delegation and a number of merchants on their way to Cairo from 'Aydab. The sultan sent a punitive force against them, which had only a temporary success. Only three years later, in $1319 / 20$ A.D., the Arabs and their Beja allies sacked 'Aydab itself and killed the Egyptian inspector stationed there.

A stronger force was now sent, and 'Aydab was more effectively annexed. A Mamluk governor was stationed there with an impressive garrison to deal with any Iuture recurrence of local revolt. I Furtier south, the island of Swakin was similarly dealt with, ${ }^{2}$ and a more distant but nevertheless dependent political relationship created between the rulers of the island and sgypt. In $1316 / 7$ the island sultanate dewonstrated its likaluk loyalties by coroperating with the Egtian army in pursuit of the tribesmen wro had attacked 'Aydab. 3 The Dahlak islands were even less relevant than Swakin to the exstern trade, and the Mamluk Sultang had nothing to fear from them. A mere diplomatic

1. Quatremère, Et. Memoires, II, pp. 170-1. Cf. also Hasan, Yusuf Fadl, The Arabs and the Easterb Sudan, Ph.D. Thesis (Iondon, 1964), pp. 169-71.

2. Ibià, pp. 179-81.

3. The lamluk army of 500 used a roundabout route on that occasion; starting from tQus they went to 'Aydab, thence to Swakin and then southwestwards. They crossed the Atbara, went a distance of three days journey upstream where they met the Halengo tribe which offered a weak resistance. From thence they trevelled back down the Atbara to the Dongola and Qus op. cit. pp. 169-71. 
warning in $1265 / 6$ had sufficed to stop anti-Egyptian piratical activities based in these islands. ${ }^{1}$ This cautioug attitude of t..e inhabitants of Dahlak towards the growing power of the Mamluks in the Red Sea completely preciluded Egyptian intervention, and helped them to preserve their complete independence from Egyptian overlordship. But it also tweakened their position vis è vis a strong Christian power in the Ethiopian hinterland. Wile the ports of Badi, 'Aydab, and Swakin had always depended for their existence on trade with the interior of what is today the eastern Sudan and the Nile valley, the Dahlak islands had likewise succeeded ancient Adulis on the Eritrean seaboard, and their raison d'être consisted of their commercial relations with the Ethiopian plateau. 2 But, unlike their northern counterparts, they did not serve as point of Arab penetration into the interior, nor did they lead to the development of liuslim commities of any political significunce in northern athiopia. The Arab tribes who poured into the hinterlands of Bad1, 'Aydab and Swakin, had been lured by the mines

1. Al-Khowayter, Abdul Aziz, A Critical edition of an unknown source of the life of hl-lialik gt- Zuhir Bavbars. Ph.D. Thesis (Lonúon University, 1960), Vol. I, p. 285, Vol. II, p. 498, Cf. also Hassan, op. cit. pp. 179-8I.

2. Crowfoot, J.W., "Some Red Sea Portg", in G.J. Vol. 3F (191I), pp. 547-8. 
of gold and emeralds for which the reion had long been held in repute. ${ }^{1}$ The hinterland of Dallak did not offer such possibilities. The very rough physical characteristios of the edge of the plateau overlooking the narrow coastal strip opposite the Dahlak archipelago also kept the interior much more inaccessible than in the region north of Ras Kassar. But the most important reason for the considerable limitation of Malim expansion in northem Ethiopia is to be sought in the strength of the Church, even when the central ower of tile kingdom had reacled its lowest ebb. The reion of northern Ethiopia centring rouna Aksum and the monastic establishwents of the nine saints had long been tine cradle of Etriopian Christiandow - since the mid-4th century, in fect, - and its religious churacter long survived the politicil decline of the Christian kingdom. We have alreay seen ${ }^{2}$ how the Beja contributed to the decline of Aksuw for whose political supremacy in the region of the Barka Ansebe basin they lad largely substituted tineir own. In so doing, lowever, they were in time linguistically and even ethnically assimilated, so that by the end of the thirteenth century tine belew princes of

1. Guatremêre, op. cit. p. 141. Hasan, op. cit, pp. 101, 146-152.

2. Supra. p.64,n.3. 
the Eritrean region were apparently Christian and spoke either Tigre or Tigrigna. ${ }^{1}$ Indeed during occasional periods of revival of the Chrtstian kingdom they were even brought under its political overlordship, and by the middle of the thirteenth century the Belew governors of what are today the province of Seraie and Hamasèn seem to have been under the suzerainty of the Zagwe kings. ${ }^{2}$ Despite the vicissitudes of the central power of the kingdom, therefore, the Christian character of nortiern Etiopla was preserved throughout the centuries after the advent of Islam. As we have suggested above tilis development was further enhanced by the economic dependence of the islands of Massawa and Dahlak on tireir Christian hinterland, and their solitary politicel position in relation to other liuslim countries in tha Red sea area. Until they were finally amnexed by the Ottomans in the second half of the l6th century, these islands remained in the backwaters of liuslim expansion, and their only importance to the luslim world lay in serving

1. Conti Rossini, Etliopia e genti d'etliopia, pp. 45, $126-9$.

2. The Belew rulers who were aisplaced later by the Adkemè - Melga were subjectg of the Christian Kingdom, Conti Rossini, "Studi su popolazioni dell 'Etiapial", cit. pp. 82-83. Cf. also Kolmodin, Traditions de Hazze a et Tsazzega, Tr. 6, Tr. 25, A 29. 
as the outlet for the products of the Christian hinterland. Their value to the Christian kingdom also consisted in maintaining the longtdistance conmercial contact with the Musim powers of tigypt and srabit, which firmly controlled the profitable trade of the Red sea. The need to share in this lucrative traffic between the fthiopian interior and the Red Sea provided 'Amde-Siyon with sufficient economic reasons to demonstrate his military power in the Erttrean region.

Trade and Trade Routes.

It is significant that 'Ande-Siyon conducted this expedition immediately after his punitive campaigns against the rebellious governor of Enterta in Northern Tigre. In these northern provinces as well as in the very rich areas south of simbara, tile king's militar activities were essentially motivated by economic considertions. It is quite clear that his aim was to bring the net-work of trade routes in the whole Ethiopian region under his own control. From a close study of secular and haglographical traditions it is possible to determine the major routes which traversed the country in the fourteenth century. Since the emergence of the new dynasty and particularly after the conquests of 'Amde-Siyon in 
the first two decades of the century, the heart of the Chriatian kingdom had consisted of the high ridge forming the watershed of the rivers Nile and Awash. On this central crescent, stretching from the River Bashilo in Amhara to the headwaters of hliluger and Awash in the Shoap pleteal, converged all the major routes coming from different directions.

From the northern provinces came two wore or less parallel routes. The first of these ran from Lalibela, tile capital of the Zagwe dynasty, northwards across the difficult country of Lasta and Wag, across the River Selleri, and apparently through the western parts of the Tigre districts of Tembien and Ger'alta to the region of Aksun. Frow tisere it continued northwards across tine River llereb to Serawe, Hamasēn, Bogos and larya, whence, passing through the district of Bagla, it merged with the Swakin-lile caravan routes!

1. A combination of itineraries point to this route. Abba Aron travelled part of it from Tembien to Lalibela soon after 1341 A.D., Gedle Aron, pp. 133-4. Yafgirenne-Egzi' (in the beginning of tie I4th century) and Samu'el after him, probably followed this route right from Axum soutiwards on their way to the Lake Tane region for reasonsiven elsewhere, ef. pp.372.38s-8. Tìe northern part of this road was used by Ewostatewos on his way to Egypt in about 1337 A.D., Gedle Ewostatewos pp. $\$ 62-3,72-3,78-9,83$; Contí Rossini, Storia d'Ftiodia. p. 255. His disciples probably returned on the same route and one of them, Gebre Iyesus, travelled all the way to Bnfraz, east of lake Tana, via Tigre, most likely also via Wag (his place of origin accordine to some traditions) ana Lalibela, Conti Rossini, "Note di agiografia...Gebre-Tyesus," RSO, XVI, 1938, pp. 441, 444 . 
This road appears to have been nost popular during the Zagwe period, when the province of Lagta was the foicus of political and commercial activities. But it traversed extremely difficult country and, already before the end of the Lasta Dynasty, it wag giving way to the second of the northerm routes, which cut through the whole length of the kingdom from the region east of the upper course of the River Mareb in Hamasen and Bur, via easterm Tigre, the Doba country, Angot, Amhara and further south to the Shewan plateau. ${ }^{1}$ At ita

1. Already in the Zagwe period there is a tradition of this route from Shewa via Menz, Amhara and Angot. Here a branch left north-eastwards to Lalibela, and another went directly northwards through Angot to E. Tigre, a road aready frequented by the Salt traders, Gedle Qewistos, ff. 54, 57. Filippos of Debre Agbo was banished to Tigre in 1341 along this route, of which the identity seems quite secure by the mention of the pass of Qorqwara which also appears in the 1454 map of kgytus Novello at precisely the same spot: "the country of the nomads who were pagans and they kill all men they encountered" - an unmistakeable reference to the Doba people; Gedle Filippos, pp. 219, 220. Cf. also Crawford, op. cit. p. 14. Abbe Aron also seems to have gone to Tigre via this road, described as "the road of Angot", Gedle lron, p. 133 . On his way back he took the western route as mentioned in the last footnote. It is most likely that after the beginning of the Ambara dynasty the "road of Angot" became increasingly important as the easiest and most direct route to the north. 'Amde-Siyon's troops, and those of his descendants, moving to Tigre and Eritrea and vice - versa, doubtless used it. It is to tis route that Al-'Umari refers, Ifasalik, pp. 19-20. It is precisely this route, which runs, as it were, along the backbone of the kingdom, that is most carefuly plotted in medieval maps of the Cliristian kingdom, and frequented by the available itineraries. Cf. Crawford, op. cit. pp. $14,21,42-5$. 
northern end this route apparently had two branches: one of these joined up with the main route to Swakin somewhere around Asmara, $I$ the other went in a north easterly direction down the edge of the Eritrean plateau to a mainland port called 'Aouan probably facing the island of Masawa.?

Another major route ran inland from the port of Zeila. This appears to have been the wost important direction of Islamic penetration in the Ethiopian region, and already before the mid-fourteenth century all the Muslim seztlements were known in Egypt and Syria by the collective name of "the Country of zeila". 3 Tre main road ran in a soutw-westerly direction, traversed the districts around the present sites of Harar and Diredawa, ${ }^{4}$ and continued eastward,

1. This is represented by the Latin itinerary of the anonymous traveller who visited ethiopia in the reign of King Dawit (1380-1412), Jorga, N. "Cenni sulle relazioni fra l'Abysinia e l'suropa cattolica nei secoli XIV - XV con un itinerario inedito del secolo XV" in Centenario líchele Amari. Palermo, 1910, pp. 146-147. Crawford op. cit. pp. 28-39.

2. Ibn Said (1214-74) gives the best description of lAouan whicll was already luslim in his time, Abulfida, Geographie, p. 212. Muffaddal also mentions it as an Abysingan port, north of the district of Sahart, and from which the main route to Amhara started, Historre des Sultans Mamluks, p. 223. 'Amde-Sīyon's expedition to the coast probably took this road. After the establishment of the monastry of Bizen in $1388 / 9$ A.D. the community kept its commercial relations with Masawa and Dahlak along this route, Gedle Filippos (Bizen) p. 106.

3. Al-iUmari, op. cit. p.4.

4. A group of Muslim tomb-stones with Arabic inscrip$\mathrm{r} /$ note cont. 
probably keeping on the northern side of the range of mountaing which divide the basing of the Hawash and Wabi Shebelle rivets. ${ }^{l}$ As it approached the Hawash crossing, it probably divided into two: one branch took off in a south-westerly direction to Dewaro,? the other crossed the Awash, and then branched off once again into two main roads. One of these proceoded in a slightly north-easterly direction across

/Footnote 4 cont. from previous page.

tions have been found at Chelengo and lasto, west of Harar, R.P.Azais et R. Chambard, Cing Années de Rocherchés irchéologiques en Ethiopie po. 125, 129. Two of the insciptions of lasto beer the dates $1267 / 8$ and 1276 A.D., ibid., pp. 288-97, 308 .

1. This seems to be the case particularly because of the otriking similarity between the geographic conditions of the itineraries of 'Amde-Siyon in his campaign againgt Adal in 1332 A.D. and those of - Ahmed Gragn in his invasion of the Chrigtian kingdom two centuries later. cf. especially Perruchon,J. Histoire des guerres d'Ande-Siyon, pp. 317, 432; Basset, R. Futuh al-Habasha, pp. 84, 94. Both armies moved in the semi-dedert regions on the north side of the Harar Plateau.

2. It was apparently along this branch of the eastern route on his returm march from Adal, and immediately after his visit to Bíqulzar, thet 'Amde-sîyon led his punitive expeditions against the people of Diphoya, Deg'u, the Wergih, Dewaro, Eehla and Sarka, who had been molesting his line of communicationg while he was in Adal, Perrucion, op. cit. pp. 432-8. Ahmad Gragn was also camping at Biquizar, about two days east of the $R$. Awash, when he explained to his generals "..the route to Dewaro is nearby and here is another route which will take us to the city of the Christian dog Wenag-Seged". Basset, R. op.cit. p. 174 . 
a difficult country in the eastern slopes of the Shewan plateau to the Muslim principality of Ifat. ${ }^{1}$ The second branch probably passed near mount Fentale, and climbed the plateau directly westwards."

Otker routes doubtless connected the Christian

1. Sebre-Din apparently fled to Dewaro along this route in 1332, and the Christian Army sent againat him in Ifat probably travelled the same way to join 'fmdeSîyon east of Awash, Perruchon, op.cit. pp. 290-1, 302-3. Gragn's first raid on the kingdom west of the Awash was also conducted along this route and his army penetreted as far as Gindēbèio, Basset, op. cit. pp. 53-66. This is doubtless the route to Zeila reported in 1523 by "Brother Antonio" Crawford, op. cit. pp. 173-5. Crawford identified this with a roundabout route from Zeila via Aussa to Gendebellu, ibid, pp. 95-6, and fig. 20. This was based on his assbintion that Genasere may have been in Aussa. But "Djanasir" was a place in the Harar region, probably further east, Basset, op. cit. p. 146. The climatic descriptions in Zorzi's notes fit the area perfectly.

2. This was apparently the road 'Amde-Siyon himself took in his 1332 campaigns when he is clearly said $t$ to have followed "le chemin de droote", Perruchon, op. cit., p. 340. In the area between the edge of the plateau and Mount Fentale the community of Abba Qêwistos at Nígge was consolidating its religious influence, and the same route was probably used in the local Christian-Muslim conflicts pregerved in the hagiographical traditions, Gedle Uewistos, ff. 94 - lola. Ahmad Gragn's forces used this route on their way to Badeqe on the eve of the battle of Shimbra-Kurē in 1529, Basset, ep. cit.. pp. 95 - 116. All these three branches of the eastern route to Zeila are vividly described by an Ethiopian Chronicler in his report of the flight of the Christian troops after Gragn's first success against Degelhan in Hubat, "...Chilandd per la via del Dawaro, Chi per la via del Fatagar, chi per la via d'Ifat e de Gedem;...", Conti Rossini, "Storia de Lebna Dengel re d'Etiopia", in RRAL, sec. 5, Vol. III (1894), p. 637. 
kiggdom westwards with Damot, ${ }^{1}$ and southwards with Gurage--land and with Hadya. 2 It is also apparent that some branches of the Eastern Route from Zeila proceeded in a soutl-westerly direction to eastern Dewaro, Bali, and furtherinland to Hadya and the lake region. It is most likely that these different roads branched off from the tain route somewhere around the Harar-Diredawa region and served as the lines of further penetration into the rich interior of south-eastern Ethiopia where small and mutually independent fuslim settlements had already been flourishing in the first half of the fourteenth century. 3

1. In 'Amde-Sìyon's campaigns to Damot no itinerarie日 are given. Among the Provinces of the Kingdom in 1332 Damot, 'Areb (=Wereb ?) Bndegebtan, Wege (=Wej ?), Muger are enumerated, Perruckon, op. cit. p. 280. From the hagiographical traditions about the 14 th century access to Damot also seems to have been via the region where the rivers Muger, Awash, and Guder have their headwaters. The military colonies in this region were most likely connected with the protection of this western route to the rich pwovince of Damot.

2. Alamale (= Aymellel) in northern Gurage-land is specially mentioned as one of the southern provinces of the kingdom in 1332, Perruchon, op. cit.. p. 280. It may be that it was via this district that 'ArdeSijyon's campaigns against Hadya were conducted, Infra p.156-9.In the beginning of the l6th century Alvarez witnessed Royal troops passing to and from Hadya precisely in this direction, The Prester John of the Indies, pp. 427, 430, 434-6.

3. See pp. 263, etc Zeila was the port used by all, and this common dependence on the easterm route gave them somo measure of unity. Accarding to Al-'Umari Ifat, 


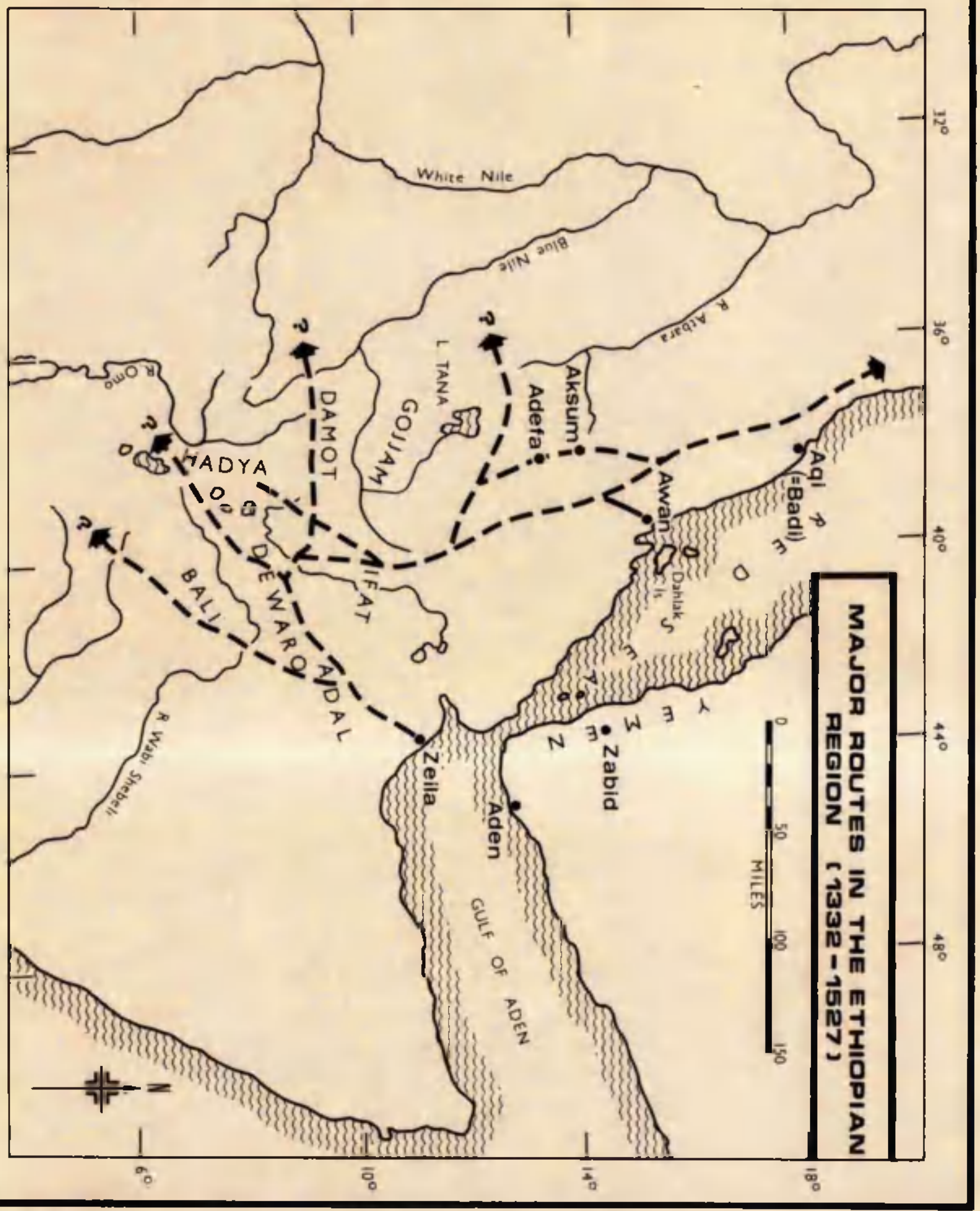


These were the life-line s of the Ethiopian region and wuch of the conflict between the luslims and the Christians on the one hand, and the local princes and the royal court on the other, involved the control of the commercial traffic conducted along these major routes. Yikunno-Amlak seems to have drawn much of his success in the dynastical struggle from his apparently very close contact with the luslim merchant comunities in Arahara and Shewa. ${ }^{1}$ His grandson, 'Amde-Síyon translated this economic cooperation into strict political and military dominance and soon emerged as the richest and most powerful gingle ruler in the ḱt iopian region.

Between his accession to power in 1314

and the Muglim wars in 1332 'Amde-Siyon's energetic campaigns throughout the country hadbrought him full control of the different trade routes and the interior provinces which they served. His most important demand on the Muslim communities was to recognize

/Footnote 3 cont. from previous page.

which controlled Zeila and the main route, enjoyed some kind of political supremacy over them, op. cit. p. 5, 19. There are later references to direct routes from Hadya via Dewaro and Bali to the Harar region. Perruchon, Chroniques de Zarfa Ya'ecob pp. 17-21, 58-60. The same routes were also used by the invading army of Ahmad Gragn, Besset, R. Futuh al-Habash (fr.) pp. 132-70. 
his overlordship as "the king of all the Muslim reala of Ethiopia". I In economic terms this meant a complete freedom on his part to participate in, and to control, their lucrative comercial activities. It is clear that already before 1332 the king was not only levying tribute and taxes on his Muslim subjects but he had also organized a strong commercial concern of his own. One of his grievances againgt Sebre ed-Din of Ifat in 1332 was the latter's interference with the royal caravang operating along the eastern route:

"You took away the commodities belonging to me obtained in exchange for the large quantit. of gold and silver I had entrusted to the merchants. And you imprisoned the traders who did business for me."

Many of the ivglim trsders "did business" for him, and their tributes to his treasury consisted of the items of trade they obtained from Egypt; Yemen and Iraq. 4

1. Perruchon, op. cit. p. 304 (text)

2. Ibid, pp. 298 (text), 344 (tr). Perruchon did not understand the passage very well. He could not see the obvious mistake made by the copyist in writing the word Nedayan for Negadyan which makes all the difference between "the poor", and "merchants". Even in the altered text, however, there is the word for "sale" at the end of the sentence which is silmply omitted by Perruchon in his translation.

3. Ibid, p. 304 (text) 348 (tr.) Here again Perruchon iissed the point about trade contained in the passage to which Huntingford has recently done more justice, Tie Glorious Victories of 'Amde-Siyon, p. 67, 11.15-16.

4. Al-'Umari, op. cit. p.2. 
Evidence for the exact nature of the items

of trade is very hard to come by. But some general conclusions can be formed. An essential basis for the commercial activities of the fuslim traders in the Ethiopian region seemg to have been the supply of domestic slaves to the Hear and Middle East. Ethiopian slaves were highly priced in the Muslin world, ${ }^{1}$ whither they were transported in considerable numbers through the principal ports of Dahlak ${ }^{2}$ and Zeila. It appears that they were originally obtained from all of the non-ruslim districts, and cases of Sahart (= Tigre) and Amara slaves are reported in Yemen. 3

1. Aboulfida, Geographie, p. 226. Al-'Umari, op. cit., pp. 30-1.

2. It seems that this island port supplied particularly Yemen with Nubian and Ethiopian slaves. It is reported for the year $976 \mathrm{~A} . \mathrm{D}$. thet an annual supply of 1000 slaves, of whom half were Ethiopian and Nubian females, used to be sent to the ziyadite rulers of Yemen, Umarah, Yaman, its early medieval history, ed. and tr. H.C.Kay, 1892, pp. 8, 143. The practice probably continued even after the fall of the Ziyadites when the "Habesh slaves" exercised power in the coastal strip of Yemen for an almost unbroken period of over a century $(409-533$ A.H. $)$, ibid, pp. 15-6, 81-93.

3. Ibid, pp. 15, 104, 117. Faraj as-Saharti and Surur gg-Amhari ruled one after the other as Wazirs of Zebid between 1133 and 1157 A.D. Another tribe represented as having come from the Ethiopian region is called Jazali and furnished the Banu Najah slave dynasty of Yemen; Ibid, p. 96. In a short list of Ethiopian tribes Dimashqi also has "DJazl, qui se distinguent par leur belles formes", Manuel de la cosmographie du moyen Age, tr. H.A.F. Fiehren, 1874, pp. 388-9. The name is otherwise still unidentifiable. 
With the revival of Christian political power the number of Christian men and women thus recruited for export into Arabia must have been drastically reduced. But even after 1270 , isolated cases of Christians being carried away are available in many traditions. 1 It was mainly from among the pagan communities, however, that most of the slaves were obtained. The vast region of southern Ethiopia wasparticularly rich in this comodity.

Hadya was an important centre of trade in the south. Ibn Said (1214-74) was the earliest Arab writer to mention the place as such, and he mentioned It in connection with the slave trade. ${ }^{2}$ Here the slaves collected in the surrounding area were prepared

1. Perruchon, op. cit. p. 314 (text); sometime before $1337 \mathrm{Abba}$ Ewostatewo $\mathrm{s}$ is said to have quarelled with his fellow countrymen of Sera'e whom be blamed for "the sale of Christians", Gedle Ewostatewos. p. 35. Occasional raidsalso seem to have affected the Ethiopian anchorites in Waldîbo. Gedle Samuel p. 24. Wright, Cetalogue or 595 , f. 5 Ia. Tio security of the young comminity of Blzen was overshadowed by the slave-lifting practices of the coastal lusliws in the life-time of its first two abbots, Il 'Gedle Filippos' e il 'Gedle Yohannes' de Bizen, ed. Conti Rossini, DD. 106. 144. There are also later traditions of miracles about christian sloves thus taken away, Gli Atti di Abuna Yonas. ed. \& tr. Conti Rossini, pp. $24 v-3,245-7$. It is most interesting, however, that all these incidents refer to frontier areas.

2. Abulfida, op. cit. p. 220. 
for exportation. liang of them were rendered eunuchs at a neighbouring place called Washilu, ${ }^{l}$ and brought to Hadya for medical treatment, after wich they were sent to $\mathrm{Zeila}{ }^{2}$ It is apparent that the vast region south of the organized states of Damot, Hadya and Bali was a particularly rich field for continuous slave raids undertaken by the Muslim merchants and their local partners. Large scele wars of conquest such as those of King $\mathbf{A}$ inde-Siyon also yielded a vast quantity of fresh supplies.

Some hagiographical traditions tend to rule out Chrigtian participation in the slave trade which is considered to have been an exclusively Muslim affair. At one place a group of excMuslims converted to the church are made to gay:

"We no longer sell slaves...(like the Juslims)... after being baptised in the name of Christ".

This probably represented som monastic

1. Ibn Said does not name the place and only calls it "un village voisin"., loc. cit. The name is first given by AlciUmari, op. cit, p. 16. It was probably south of Hadya but no specific identification is now possible. The best is still Arab Faqih's "rashiloh, in the frontiers of Ganz", an area whicis Wis to the south-west of Hadya in the 16th century, gutuh al-Habesh, tr. Basset, p. 201 and $n .5$. Cf. also, pp. $33, n .2,377-90$.

2. Al-'Umari, op. cit. pp. 16-7. Meqrizi, Historia Regum Islamaticorum in Abyssinia. pp. 14-5.

3. Gedle Zena-Marqos. f. $69 a$. 
reservations about slavery in general. I But in fact many Christian fatiles, including those of the local saints, had numerous slaves. ${ }^{2}$ Gifts of slaves were even made to prowinent monks. 3 The numerous captives taken during military campaigns were usually reduced to slavery. The terma used by 'Amde-Siyon's ctroniclers in describing bis successes clearly indicate that slave-raiding was an Improtant by-product of many of his canpalgns:-

"He went to the country of Hadye and killed (many of) the people of that land... and the rest he made captives with their king, great (men) and small, men and women, old and young, and transported them into his kingdom". of the destination of such ceptives of war

'Amde-Siyon is made to say elsewhere "I deported them to another country". ${ }^{5}$ A large part of these was

1. Such reservations are apparent in sove scattered references, Wright, Catalogue, Or. 719, f. $44 a$. Gedle Yafgirenne - Egzi . Pp. 82-6 (text). Gedle swostatewos, p. 35 .

2. Abundant references slow this. Together with his owmership of 300 bee-hives, the father of Abba Merha-Kristos (d. 1497) was noted for his numerous slaves, Gedle Merha-Kristos MS. Debre-Libanos, p. 82.

3. Gedle Yafgirenne-Igzi', p. 82.

4. Perruchon, p. cit. p. 287 (text), Cf. also pp. 294, 434-8.

5. The Four Gospels, HS (IY), Halq, f. 25b 
doubtless atteched to the royal court itself and fumished new recrults for the king's army. Many of them ended in private families and it is most likely that others passed into the hands of Muslim merchants engaged in the long-distance trade. In this period of great expansion of the kingdom the need to ensure the full recognition of the growing power of Chrigtian rule offered the king's troops invaluable opportunities for raids and counter ralds which constantly supplied the slave markets with yet more recruitg from the frontier.

Ivory was another important item of trade. The valleys of the Tekezze ${ }^{1}$ Barks and Anseba rivers, and other provinces of the kingdom, ${ }^{2}$ were very rich in elephants and other wild animals. It is apparent that the kings undertook the systematic hunting of elephants, the tusks of which they entrusted to their comercial agents. A hagiographical trudition about the Fourteenth century gives an interesting picture of the comercial exploits of the Chrigtian kings:-

1. Gedle Abiye-Egzi, ff. 49b-5la. Gedle SamuēI (waldibba), p.22.

2. Al-'Umari, op. cit, p. 28. Gedle liergorewost pp. 30-31 (text). Crawford, O.G.S. Ethiopian Itineraries, pp. 143, 145, 177. 
"(The líuslim traders) did business in India, Egypt, and among the people of Greece with the money of the King. He gave them ivory, and excelkent horses from Shewa and red, pure gold frow Enarya....and these Muslims.... went to Egypt, Greece and Rome and exchanged them for very rich damasks adorned with green and scarlet stones and with the leates of red gold, which they brought to the king".

The Ethiopian interior also seems to lave supplied the coastal towng probably on both sides of the Red Sea with fresh fruits and cereals. ${ }^{2}$

This was the general pattern of trade in the fourteenth century and it seems to have shown no appreciable changes throughout ourperiod, between the thirteenth and sixteenth centuries.

\section{The Royal Court was the busiest centre of} trade, and the kings benefited most from it. of all his predecessors on the throne since 1270, 'AndeSiyon's Empire was by far the largest and he was first among them to reap econonic fruits from the

1. Gedle Zena-liarqos, ff. 69b-70a. Cf. Al-'Umari, op. cit. p.2. According to the latter, gold was obtained from Damot, 0.13 . In the 12 th century Idrisi considered that gold was rare in kthiopia and that gilver and slave constituted the most important exports of Zella, op. cit. po. 29-30. Cf. also Crawiord, op. cit. pp. $\overline{149,151}$ and n.2. Alvarez, The Prester John. p. 455-7. Basset, op. cit, pp. 70-1. The Portuguese Expedition to Abyssynia in 1541, tr. by R.S. Whiteway, Hakluyt Society, IInd series, No. 10, 1902, pp. 234-9. For gold obtained frow Enarya in the 17 th century see Almeida. Some Records, tr. Beckingkam and Huntingford, pp. 85 149. Al-'Umari'g mention of Narya and Ganj seems to suggest also that these areas were already in 'Amde-Siyon's hands, op. cit. pp. 23-4. 
growing power of ti:e kingdom. This dramatic change in the political and economic status of the Christian kings wag not lost to 'Amde-Sĩyon's chroniclers, who epitomised his reign with the following generous compliment:-

"...sous son rēgne, I'or et l'argent abandaient commes les pierres, et les vêtements du luxe étaient aussi nombreux chez lui que les feuilles sur les arbres (et) l'herbe dans les champs." I

'Amde-Siyon used his fabuloug wealth in building his huge army and consolidating his power throughout the Empire. His military exploits became widely known in the Mulin world, and the Mamlluk chancery called him "la gloire de la religion chrétienne..., le gardien des régions méridionales, le successeur des apôtres, des docteurs et des saints, l'honneur de l'église de Siyon, l'unique des rois jacobites". 2 Iike Yagba' Silyon before him, he had a Syrian secretary, who came from a well-known Cluristien fanily of Damascus, 3 and he kept a close touch with developments in the Near and riddle East. He raised public morale among his Christion subjects and ambitious young men rallied

1. Perruchon, op. cit. pp. 289,(text), 337 (tr.). The word in parenthesis is my owm wodification.

2. Al-'Umari, op. cit. p.33. Conti Rossini, "II libro de conoscimento e le suo notizle suli 'stiopia" inVI (1917), p.671.

3. Al-'Umari, 으. cit. p.32 Infra, p. 246,n.3. 
around his court in search of wealth and adventure. The most successful Musiin Entrepreneurs offered their services to him, and the newly conquered pagan communities provided an inexhaustible source of manpower for his growing army.

The Christian Army.

Like many other institutions of his Empire, the organization of 'Ande-Siyon's army was a direct replice of that of the Kingdom of Aksum at the time ot its greatest splendour. The description of the Aksumite army in one of Ezana's inscriptions makes it strikingly similar to thet of the medieval tmpire. An essential common feature was the regional (or tribal) character of the military organization in both cases. I It seems clear that the Christian army under 'Amde-Sīyon had two basic elementa. Firstly there was an effective striking force closely attached to the Royal Gourt and nay thus be called the central

1. For the text of the inscription see Deutsche AksunExpedition. IV, p.32. A French version is available in Kamerer, A., Essai sur l'histoire antique d'Abyssinie, Note pp. 95-7. Erana's amy consisted of contingents of Mahaza, Hara, Danawa, Falha, Sera, Halew, Laken, Sabarat. These names have not jet been identified, but they almost certainly stood for place nawes or peoples. Halen, for example, was robably the place of origin or tribe of King Ezana iniself. In his inscriptiong ana coins he styles himself as "Ezana, the man of Halen...", ibld.pp. 89, n.2; $90, \mathrm{n.1}$; and 157-9. 
army of the King. Secondly, in times of national or local crises, the monarch raised a huge local militia from the Christian provinces. These kept their local character and served in different contingents such as those from Tigre, Lasta (Bugna), Amhara and Shewa. ${ }^{1}$ They were again sub-divided into smaller units each comanded by its own lockl chieftain. ${ }^{2}$ A substantial part of the Chrigtian army during major expeditions consisted of these local units, but the control over them exercised by the monarch was often minimal. The tug-of-war between court and Country had been a constant factor in ethiopian political and wilitary history, and whIl be referred to below. ${ }^{3}$ It must be said her, however, that 'Ande-Síyon's reign opened up pew period in the relations between the monarch and his vassals, and the balance of power decisively swung over in favour of the kings and basically remained so for over two hundred years. 'Amde-Siyon's best remedy for the

1. Perruchon, op. cit., pp. 293, 382-2, 399.

2. Ibid, p. 293 (Text), 340 (tr.). We have here an example of such organization. The "i"ekwanint" and "Shums" cited in connection with the places quoted represent the wosaic of local chieftaincies in the kingdow.

3. See pp. 180, etc. 
centrifugal forces of his kingdom was the effective central army he had successfully built around his Court. The nucleus of this army consisted of a number of special contingents mainly organized in two different ways. First of all there were a number of mutually independent regiwents, each copmanded by an officer directly responsible to the King himself. Every such regiment was given a symbolic name, and maintained an egprit de corps of its own. These picked warriors included the regiments of QesteNihb, Tekula, and Hareb-Gonda. ${ }^{1}$ They vied with one another ${ }^{2}$ to fulfil the king's orders, and to please the monarch who "raised us (from childhood) and fostered us to die (with him)" 3 Their comanders were absolutely loyal to him, and some of them are specially mentioned as having been very intimate

1. Perruchon, op. cit. pp. 382 (text). Qeste-Nîhb literally means "the sting of the bee"; Tekula means "jackaI".

2. Ibid, p. 290 (text). of all the troops sent out toget er against sebredin in Ifat the regiment of Tekula distinguished itself by being the first to arrive in, and attacked. Ifat despite the difficulty of the road.

3. Ibid, pp. 410 (text) 
friends of the king. ${ }^{1}$ Some were probably his relations. Among the prominent officers of the army in 1332 for instance were Amde-Sĩyon's own son, SafAsegid, and also one of his brothers-in-law. ${ }^{2}$ The rank and file of these regiments probably consisted of the best men recruited from different parts of the country, and professional soldiers of fortune who had joined tre court in gearch of wealth and adventure. ${ }^{3}$ These men had tied up their fortunes with that of the king and served hin with complete devotion in various assignments. They formed the hard

1. SImİshehal commanded Qeste-Níhb, ibid, p. 382 (text); and he is mentioned with his colleague knze-Aygeb as "most beloved" officers of the king who was greatly distressed when they were wounded at the Battle of Hagera, pp. 428-9. Finz-Aygeb is almost certainly the same "officer of the king'g troops" whose name is a little differently given as Yenz-Aygeb, p. 289 (text).

2. Ibid, pp. 400,419 (text)

3. 'Amde-Síyon was apparently very generously disposed towards his warriors. He occasionally gave them handsome presents and many of his followers possessed numerous male and female slaves, no doubt obtained from the large number of captives in his wars of conquest, ibid, pp. 289. 416 (text). 
core of the fighting force in his expeditions against rebellious governors and in his wars of conquest in Muslim and pagan areas. He mace use of them whenever swift and effective actions had to be taken. Sometimes, when emergency action was required, he sent his loyal officers on frovincial assignments as local Governors. Digna, the right-wing commander of the mounted regiment of Korem in 1332, was at one time given sucl: an assignment in Tigre soon fter the abortive revolt of the governor of Enterta. 1

\section{Another part of 'Ande-Sĩyon's central axmy} geems to have been organised on a regional basis. Men of the same linguistic and tribal area were grouped together to form a separate contingent such as that of Korem, Barya, Gojjam, Gonder, Damot and Hadya. ${ }^{2}$ A comon feature mong most of these tropps was that they were recruited from frontier areas newly conquered by the king. It seems mott likely that they were mainly draw from the numerous prisoners of war. Some of these passed into private hands, others were exported through slave markets, but a large proportion must have been recruited for the

1. Ibid, pp. 289,382 (text). Conti Rossini, "I'evengelo d'Oro", pp. 206-7. Semay who appears in the same list of officials as the new Ma'ikele-Bahr may bave also been 'Amde-Siyon's favourite comander of QesteNibb referred to above. Even in the chronicle his name appears variously as Semey ( - shehel), and Símíy (shihal), Perruchon, op.cit. pp. 382, 428 (text).

2. Ibid, pp. $293,382-3, \overline{399}$ (text), 
service of the Royal Court. Of these some were adopted as mere domestic slaves in the huge court, but the wost promising young men were probably grouped together, trained and organised into military units. Originally their commanderg may beve also been of the same provenance, but they were probably men who had long proved themselves in the king's service and had won his confidence in the meantime. Each of these contingents was probably large and divided into smaller unita. Thus in 1332 a section of the contingent of Damot went with the army sent gainst the Felasha wille another participated in the Mulim wars in Adal. I These territorial contingents probably constituted the largest aection of the central army and continuously received fresh reinforcements after evexy successful war of conquest. They also probably served as a training ground for the more prestigious reginents mentioned in the last paragraph and to which only the most tried soldiers were recruited. A brilliant young man who may have started his career as a mere slave in the royal court could thus emerge as one of the king's most favoured 
officers of the court. ${ }^{1}$

'Amde-Síyon's central army wainly con-

sisted of these two types. Although no numerical

estimates have survived, the army must have been

very large, at any rate the largest and most effective single army in the whole Ethiopian region. ${ }^{2}$ It was also relatively well-armed. Both his chronicler and Al-'Umari give a strikingly similar account of the weapons used by the king's troops:-

1. The immediate reason for 'Amde-Siyon's armed conflict with Hagedin was the latter's detention of "one huble slave called Tiliyintey", ibid. 283 (text). It may be that Ti'iyintey was for 'Amde-Si yon just what Mehari-Kristos was for King Be'ede-haryam (1468-78). Originally a slave of the young prince, Mehari-Kristos was cruelly tortured when his master was suspected of a plot against his father Zera'-Ya'qob. When the puince eventually took the tirrone his former slave became one of the higiest offlcials in the kingdom. Perruchon, Chronique de Be'ede-liaryam, pp. 107. I64, 180-1.

2. Al-'Umari estimated the troops of Ifat and Hadya as 20,000 and 40,000 respectively, op. cit. pp. 6, 16 . But he also stated that 'Amde-siyon was much stronger than all of them, pp. 19, 24. The easy superiority of the Christian army can also be inferred from the fact that the king could send a large force for the suppression of local revolts in Felasha country and Tigre on the eve of his more important liuslim wars in 1332 , on which he himself set out with the rest of his troops, Perruchon. Histoire des guerres d'Amde sīyon... pp. 289-90, 293- 4 (text). Some of his predecessors were also noted for maintaining large armies; Lalibela had 60,000 in c.1210, Perruchon, "Extrait de la vie d'Abba Jean", cit. p. 83. Yikunno-'Amlak claimed to have had more tian 100,000 troops, Ifufazzal, op. cit. p. 384. 
"Leurs armes de combat sont l'arc avec des flèches ressemblant au nussab, le sabre, le javelots et les lances. Dés guerriers combattent avec des sabres et des boucliers longs et ftroits; mais leur arme princinle est le javelot qui ressemble à une longue lance. Il en est qui, avec un arc long qui ressemble à l'arbalete, lancent des traits qui sont de comtes flèches."

However, it ap pears that the superiority of the Christian army over that of the luslims in 'Amde-Síyon's reign was mainly numerical. In the passage quoted above, al-'Umari added "On dit que les fleches des guerriers de la 'bordure musulmane' sont plus grandes." This may not have been altogether a case of patriotism on the part of his liuslin informants. 2 'Amde-Síyon's chronicler also indcates a marked difference in the kind of weapons used by the two adversaries. This, whereas "swords, daggers, iron sticks (= dimbus) and armah" are invariably mentioned in connection with the luslim troops 3 the first two items only appear in special prestigious cases in the Cliristian amy; 4 and the rest are never

1. Al-'Umari, op. cit. pp. 25-6. Perruchon, Histoire des guerres, pp. 309, 313-4, 382-3 (text) 352, $355,441-2$ (tr.)

2. He specifically mentions a certain Sheikh 'sbalalah ezZeila' $i$ and his companions as his informanta, op. cit. pp. 2-5. Another ifuslim merchant El-Hajj Farej elFuni, and the Éyptian (Jacobite) Patriarch Benjamin (1327-39) also supplied him with some information; pp. $16-7,27$.

3. Perruchon, op. cit. pp. 285, 394, 400 (text) 3,4, 449-50, 454 (tr.) Tie invariably renders "armah" with "lances".

4. Ibid (tr.) pp. 306, 309, 312, 313, 383 (text), 349, 352, 442 
included in the list of Christian weapons in the hostilities of $1332.2^{2}$ Although the chronicler degcribes "Amde-siyon as having been armed with "a sword", it is significant that throughout the narrative be only referg to the king's dexterity in the use of the shield, bow, arrows and spears. ${ }^{2}$ The mogt accurate description of 'Amde-Siyon's army at this stace was perhaps "mounted and footmen armed with arrows and spears", a description also given by the chronicler himself. 3

It is apparent that arawing very heavily from the experiences of their brothers in the Near Middle East, with whom they always kept a close contact, the liuslims of the Ethiopian region were better off inthe variety of their arms. But this only gave then some advantage in casea of military engagements at very close range, wilich the Clristians avoided, 4 and for wlich they more than made up by

1. Thev appear, however, in hagiographical descriptions of the court where the only seem to have been employed for purposes of poppous display, Gedle Beselotepika'el. p. 27. Gedle 'Aron, p. 140

2. Perruchon, op. cit. pp. 306, 307, 308, 401-3, 428 (text), 349, 350-1, 454-456, 474 (tr.).

3. Ibid, p. 383 (text), 442 (tr.)

4. The Chrigtiang seen to have been at a disadvantage when engagements were too close. The king was almost killea on one occasion. His uslim assalant used a sword while the king only employed a spear with which he barely saved his life, Ibid.p. 307 (text), 350 (tr.). 
their superiority in numbers. Even in this difference of military weapons, however, 'Amd-Síyon had al ready macie considerable strides in bridging the gap. As we have seen above swords were already being used in his army to some extent. They were probably nostly obtained from abroad through Muslim traders thewselves, and by the year 1332 King 'Ande-Sĩyon had created a separate group of warriors specially armed with swords. ${ }^{I}$ Together with tilis group is mentioned another of which the warriors are called "carriers of slields". Since eveny soldier arved with bows, arrows, and spears also carried a shield, the need for such a special group of "carriers of shields" would seem rather superfluous. It is apparent, however, that here again 'Amde-siyon was actively improving the effectiveness of his army. The clue to tinis seews to be in his chroniclerla conplimentary description of the fighting skill of Adali warriers of whom he says at one place:

"There are among them who shoot with arrow, and others protect them with shields".

It is most likely that with the organisation of the

1. Ibid. p. 383. The nave of the comanding officer was firurb-'Asmi'a.

2. Ibid, 427 (Text), 474 (Tr.). 
"carriers of shields" 'Amde-Sĩyon had also started adopting similar tactics of warfare.

King 'Amde-síyon was thus at the head of a large, well-organised central army witir which be effectively ruled his empire and undertook successful wars of conquest in the whole of the Ethiopian region. The pattern of the organisation of the army was most favourable for the concentration of power in the person of the monarch. 'Amde-Síyon's army did not have a monolithic organisation wizerein the line of comand ran from the king tirough successively subordinate officers down to the ordinary soldier. It was rather - group of mutually independent contingents commanded by numerous officers of equal rank, each responsible to the king himself. This made the king the sole waster of his forces and tile emergence of a warrior leader with sufficient influence in the army to challenge the king's position was quite impossible. Menever one of the regional hereditary chiefs grew too powerful, the king relentlessly used his central army to impose bis will in the provinces. The constant state of mobilisation throughout his reign during which the kingdom was undergoing an active expansion in Muslim, pagan and Felagha areas, also gave an additional impetus to the 
aonsolidation of the personal power of the king.

Administration of the Kingdon.

'Amde-Siyon's conquests covered a very wide area, and, as we shall see in a subsequent chapter, the administration of the new provinces perfected itself only later under his fifteentin century successors. ${ }^{1}$ But already in his own reign it had started to adopt the pattern of the feudal organiation of the northerm provinces. We have made a brief reference above to the general tendencies in these areas towards local autonomy. ${ }^{2}$ This was quite inherent in the administrative system long developed in the Christian kingdom. It seems that there had been two layers of local administrative officials. The first consisted of a series of hereditary chiefs whose position of authority was originally derived from the royal court. But possessed of local power for many generations they seem to have in time developed traditional rights of hereditary rule. Each of tiese local chiefs generally held the title of Sîyum wich clearly indicates a royal

\section{Infra, $p p \cdot 479-80$. \\ 2. Sittre, pp. 135, etc.}


appointment at least in origin. ${ }^{1}$

These small chieftaincies were the basic units of the whole political and military structure of the medieval Empire, and they served as a launching pad for the emergence of the leaderslip of Christian Ethiopia. A close study of the traditions of different royal dynasties often indicate their ultimate origin in these small local cieftaincies. A number of local traditions illustrate the characteristic pattern of this development. In many cases a prospective leader started his career at the court of a local chief to whom he may have been a relative or just a follower. While in this humble position he distinguighed bimself with bravery and other traits of leadership in the local feuas of his clief with other neighbouring districts. Thus he gradually acquired considerable influence, and became a focus of much interest among the followerg of the clief. When the chief died he assumed power, by legitimate succession if he was a

1. There are many references to such local officials with the tita of "Síyum", and "lísokin" in many land grants, in 'Amde-Siyon's chronicles and in the lives of the saints of tile period under review, Conti Rossini, "Ir'evangelo d'oro," cit. pp.Lor-p-Perruchon, Histoire des guerres, cit. p. 293. Gedle BeseloteMka'el, p. 24; Gedle Filippos (Asebo) 0.220 ; Gedle Ewostatewos, pp. 38-4I, 62,72 . The hereditary character of the e offices is also implied, ibid, pp. 52-3; Wright, op.cit. OR. 695, ff.38-40. 
son, or otherwise by a simple act of usurplition of power, sowetimes committed even in the life-time of the chief. Once in the saddle of local power the new ruler subsequently aproached the royal court with such demonstrations of loyalty that he was in time confirmed in the office which he had already made his ow by force of arms. He could even grow further in prestige, / with the King's favour, acquire a prestigious title granted by the monarch, and be given charge of a larger political unit, including his own. ${ }^{1}$ Under favourable circumstances such a resourceful local prince could easily grow into a serious rival of the monarch himself. 2

A local ruler who acquired power in these ways fully exercised tile Kine's authority in hisc ow province. When tlie power of the kings was weak there was little or no interference in his local adwinigtration by the royal court. For all practical purposes he

1. For examples of this vital development see Conti Rossini, "Studi su popolazioni dell'Etiopia", cit. pp. 82-4, 87-89, 90-92; Garrone, V., "Gli Atcheme Melga", cit. pp. 997-8.

2. The case of the powerful rulers of Finterta before the reign of 'Amde-Siyon has been considered suprä, pp.135-37. Basicelly the emergence of Yikunno-Tini to power followed the same patterm, supra, pp.25, de. have to be looked at in the sane light. 
maintained a virtually independent local court modelled on thit of the Kings themselves. On his death he was normally succeeded by his own son who would get full royal confirmation as long as he continued to show the traditional signs of his loyalty to the king. These gigns of loyalty consisted of two acts, both of cardinal importance: the coliection and submission of the king's tributes accruing from the region ${ }^{l}$ and the readiness to contribute an adequate fighting force to the king's army during a national crisis or to send contingents against local rebellions in the nare of the king who called upon him to do so. ${ }^{2}$

I. Failure to bring his tributes was given as tre reason of ' $\Delta$ me-Síyon's campaigns against his vassals, Perruchon, op. cit, pp. 286,298 . In a higiographical tradition a local saint miraculously intervenes in favour of his congregation threatened with an iminent punitive campaign if they failed to pay tribute to the king, Gedie Zena-l:arqos, $f$. $78 b$.

2. 'Amde-Síyon used local forces to suppress local revolts, Perruchon, ㅇp. cit. p. 293. Hamasen troops roturning from war in wich they had served in the $\mathrm{king} \mathrm{\prime}^{\mathrm{s}}$ army visited a Tigrè saint on the way, Gedle 'Abiye-'Efzi OR. 695 (BN), f.22b. The rulerg of Serate and Bur reported to be at the royal court in Sinewa, Gedle Ewostatewos, pp. 38-4l (tert). King Dawit sent his governor of Tigre to suppress a local rebellion in Felasha country, Gedle Yafqirenne-Egzi', ed. Waijnberg: pp. 56-8 (text)? Conti Rossini, Mppunti de storia e ietteratura Falascia", in RSO, VIII (1920), pp. 572, 577. 
This extremely locul orientation of the structure of the Christian kingdom tended to make it a loose confederation of regional princedons. It was particularly so at a timerof a general decline in the power of the kings. This appears to have been the case in the final years of the Zagwe Dynasty and Yikunno-Ablak took full advantage of the situation. the first two decades of the new dynasty also saw local rulers trying to reassert themselves.

It is apparent that, to offset this chronic tendency towards local autonomy, the kings had instituted an altogether different layer of local officials appointed by them and made in cirazge of large polltics units. These officials were given a series of royal titles which signified the responsibilities of their position. The titles of Aqabe-Sensen. Ila'ikele-Bahr', Na'IkeleTewazat, ${ }^{3}$ Hasgwa, ${ }^{4}$ and Sehafe-Lam, ${ }^{5}$ apparently belonged

1. For tils title see p. $136 \mathrm{n} \cdot \mathbf{2}$.

2. $\mathrm{P} .140 \mathrm{n}, 2$.

3. This title is first mentioned in the reign of 'Amde-Siyon, Perruchon, op. cit, p. 293 (text). Conti Rossini, "L'evangelo d'oro", cit. pp. 208, 210. It seems quite clear that it referred to one of the northern provinces, and since it was once held by the king's son it appears to have been of considerable ingortance.

4. References to tisis title are found since 1225 A.D., Conti Rossini, op. cit, pp. 190.194,199, 208. Gedle 'Abiye-Egzi, f. $27 a$, Whe an official of tris title is seen apparentiy colilecting the king's tribute in Tëbea.

5. First wentioned in Lalitela's reign with no regional pt. note cont. on next page. 
to this second category of officials. These were the king's nowinees and, as long as he mustered enough political and military strength, they were completely dependent on his power. He re-shuffled them according to his wishes and his needs. Thus be tween 1322 and 1328, the titles of Ma'Ikele-Bahr and Hasgwa were each held by at least two inaividuals. ${ }^{l}$ Even at a time when his wilitary power was considerable, however, this absulte discretion of the king to transfer his officials probably did not apply to the hereditary rulerg of these areas. Except in cases of open rebellion when a military showdown was unavoidable, it was always impolitic to interfere in their local affairs, and the kinfs seem to have left them in full possession of their traditional rights of leadership.

The centrifugal forces in the kingdom arose mainly from this dual system of local administration; and it was precisely this system that 'Amde-Siyon began

/Footnote 5 cont. from previous page. references, Conti Rossini, op. cit, p. 190. Officials of the same title for Amhara and Qida appear in the reign of 'Amde-Sĩyon, Perruchon, op. cit, p. 281

1. Conti Rossini, op. cit., pp. 204,206, 208. Gedle 'Abiye-IEzi, loc.cit. 
to apply in his newly acquired provinces. In a long list of local governors in 1332, his chronicler significantly uses the titles of Negasi and liesfin for the verious local officials in Gojjar, Shewa, and Damot. ${ }^{1}$ It is most likely that the titles refer the descendants of the former rulers of these areas before their annexation by the Christian kingdom. With the gradual removal of the centre of the kingdom to the Shewan plateau ${ }^{2}$ the regions of Amhara and Shewa acquired a special status and became direct apanages of the royal court. In the outlying provinces, however, the traditional system of local adminiatration fully obtained, and the king's intervention largely consisted in making sure that the lnereditary succession of $10 \mathrm{cal}$ power passed to favourable candidstes. Al-'Umari's account of the king's control of the Muslim areas' ${ }^{3}$ also applied to the Empire as a whole.

1. Perruchon, op. cit., pp. 280-2 (text), 329-30 (tr.). Only the ruler of Gojjar is given the title of Negasi here. Elsewhere the rulers of pre-conquest Hadya and Damot are also referred to by the same title, ibid. pp. 286 (text), 335 (tr.). The Four Gospels, MS(I), Haiq, f.25b. Cf. also Gedle Yafcirenne-Egzi, pp. 16,24 .

2. Infra, $p .539 \mathrm{n} .1$.

3. Op. cit. p. 19 . 
The economic basis for the power of the Christian monarcla lay in his traditional right to distribute fiefs in return for military or other services. The ideological background for this was ultimately derived from the theory that all land within his dominions belonged to the king. This constitutional theory was certainly antecedent to the new dynasty and it also appears in the traditions about earlier Ethiopian monarchs. The bagiographer of the Zagwe king, Lalibela, compliments him for paying for the land on which he boilt his churches. He attributes this to the king's special sense of piety and saintliness and asks fa rhetorical question to demonstrate the traditional power of the monarch: "Who would have forbiden the king if he had decided to take the land (without purchase)?" I In his famous conflict with the monasteries, wich we shall consider below, 'Amde-Síyon is said to have demanded their absolute obedience to him because they lived "on the land of the king"." His son and successor SeyfeAra'd is also said to have made the claim that "God gave

1. Perruchon, đ. Ia vie de Lalibela, . 123. Cf. also Gedie Yïrrihanne Krïtos, lis. Lalibela, St. Mary'g Iibrary,1.30a.

2. Gedle Aron, p. 130 . 
(all the) land to me". ${ }^{1}$ A more practical example of this royal prerogative over land is furmighed by the abundant records of land grants made by the kings and in their nove to cilurches and individuals.

The vast tracts of land thet had recently come into their possession by conquest provided 'AmdeSiyon and his successors with the real basis for their political and military power. In tris they were merely following the precedents of earlier dynastiea of the Christian kingdor. All the Christian provinces in the north were originally acquired by wars of conquest. 2 It is apparent that every such conquest was followed by allotments of land being distributed in fief among the king's followers and heavy dues being imposed on the conquered people. Witiz the passage of time, however, the conquerors and the conquered becare religiously and ethnically assimilated anci developed a single, slbeit tribally diversified, Christian identity. It was precisely the same historical process that was being replayed in the recently acquired provinces under the new dynasty. The juridical effect of a fresh

1. Ibid, p. 149. Gedle Filippos, p. $242,243$.

2. This seevs to be very clear from the inscription of the early Axumite kings, particularly that of Adulis, first reported by Cosmas, MlacCrindle, The Christian Topography of Cosmas, an Igyptian monk. 1897, pp. 57-c6. E.Littrann, in Deutsche Aksum-Expedition, Vol. I,p.42. Conti Rosaini, "Expeditions et possessions des Habashat on Arabie," in JA, Ser. 11, Vol. XVIII, 1921 , of. 5-36. A. Kariarer, Dśai sur lisistoire antique d. Abysinie. pp. 56-60. 
military conquest was to reduce all the conquered people and their entire belongings to the king's absolute power. He appropriated all the people and their land, and reserved every right to dispose of them according to his wishes. He executed all resistance fighterg who fell into his hands, and reduced to slavery other captives of war. The conquering army tinen raided the country burning and looting and taking away the cattle, horses, and other possessions of the local people. These acts of cruel repression were deliberately committed not only to replenish the ever-failing provisions of the huge army, but also to force the people to surrender, and to give them a terrible example of the destructive force of the Chrigtian army in case of further revolts. ${ }^{1}$ At first sucil military conquests did not apparently lead to a large-scale occupation of the area by Christians. Ag goon as the people surrendered they were offered peace terms and allowed to live under such members of their troditional chiefly fomilies as were prepared to accept the christian king as their overlord. These vasal princes were then

1. On the eve of the warg of 1332 'Amde-Siyon reminded Sebreddin of the destructions that befell Ifat and its dependencies when hia predecessor Haqeddin provoked the Christian kingoom, Perruchon, op. cit. 282 74 (text), 332-3 (tr.). References to similar havoc cormitted bjo the Christian army are also abundant, ibid, pp. 287, 294, $425,429-30,434-8$. The Four Gospels, Ms (III). Haiq, f. $25 b$. 
required to appear at the royal court and submit their occasional tributes in person ${ }^{l}$ and protect the king's Christian sub, ects ${ }^{2}$ within their jurisdiction. It appears that at first the tributes thus deminded were collectively reised by the people and passed over to the Cinistian court through their local rulers. Gradually, however, as the power of the kingdom consolidated, military colonies were established.in the new areas and large scale Christian settlements encourided. The regions most affected by tilis new development in the period under review were particularly those in Shewa, and in Damot.

By the end of the 13 th century there were only small, isolated Christian settlewents in the central Shewan plateau. 3 On the advent of the new dynasty, and particularly after the extengive conouests of 'AmdeSi yon, however, this vast territory became the very centre

1. Sebredin's revolt in 1332 received its higliest exmression in his message to 'Amde-siyon saying "je ne me rendrai pas à ton palais, je ne me presenterais pas devant toi...", Perruchon, op. cit. pp. 285 (text), 334 (tr.) The king of Hadya is also presented as having rebelled by listening to the advice of a Muglim cleric w.o told him: "Ne te rengs pas pres du roi de Siyon et ne lui donnes aucun présent"; ibid. pp. 287 (text), 335 (tr.).

2'Amde-Siyon's quarrels with both Haqeddin and Sebreddin were partly because they interfered with the freedow of movenent of his subjects, ibid. pp.283, 289 (text), $332,344(t x$.$) .$ 
of the Christian kingdom. Besides its own abundant agricultural resources, Shewaccupied a strategic position at the heart of the Ethiopian region, and served as a valuable gateway to the rich areas beyond the upper course of the Awash and the southern tributaries of the Blue Nile. The rich districts of Wej, Nar'it, Fndegebtan, Wereb and Damot were soon made the objects of an intensive programe of Chrigtian settlement. ${ }^{1}$ The most important beneficiaries of this deliberate programe were no doubt the members of the king's army. It is apparent that 'Amde-Sĩyon and his immediate successors distributed allotments of land in these areas among their followers in return for specific services. It is not quite clear exactly how this was undertaken, nor is $1 t$ possible here to determine in precise terms the relationship between the newcomers and the local people. But from many of the available records of land grants made by these early kings it seems possible to give a tentative recongtruction of the nature of these fiefs.

The technical term for these land grants is Gult, and it had specific political and economic Implications. A church or an individual wiro received

1. It was also in these areas tlat the Egyptian bishop Abune Ya'iqob (c. $1337-44)$ organised an active programme of evangelisation. See pp.377, etrd land grant made by 'Amde-Siyon to one of his courtiers indicates these regions as haying been most affected by this

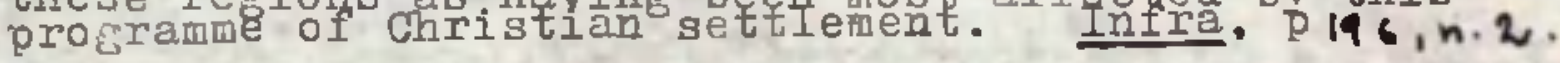


a piece of land as GuIt by a royal decree enjoyed a number of rights in relation to the peasants living on the land. These mainly included rights to collect monthly and/or amnal tributes from the . The tributes thus collected were not necessarily produced on the Gult land itgelf. They were only determined to meet the daily needs of the grantee and had to be collectively raised by the peasants. In a group of early land grants attributed to King 'Amde-Sĩyon there are preserved some particulars about the general items of which these tributes consisted. They included specified amounts of home-made cloth, bushels of grain, honey, bars of salt, hoads of cattle and sheep, and even simple implements such as axes and aickles. ${ }^{1}$ The peasants were thus obliged to provide the owner of the Gultwith the simplest of his needs, and their relationship with him was of the nature of an extended household. Although the land grants did as a rule make the minfmur specifications of the amount and tvpes of tributes, it appears that the demands of the grantee on the peasants and their families were in fact arbitrary and largely depended on the kind of relationships that developed between tiem. The tributes due from

1. Wright, op. cit., Or. 481, ff. 124, $208 \mathrm{a}$. 
the peasants could be exacted in kind, or in personal services, or in both. I It seems that particularly in areas ricently annexed the exactions on the local people were invariably heavy and entirely depended on the discretion of the individual concerned.

The owmer of a Gult, who was termed a Bale-Gult was basically different from a landlord in that he had originally no rights on the land itself, but only on the peasants living and working on it. The ownership of the land remained in the hands of the lacell people, who passed it on to their descendants according to their own local customary laws. It seems that the Gult system was essentially a rationalization in peacetime of the emergency meagures taken during military expeditions. When an army was sent out on a campaign it collected its provisions from the country through which

1. The only bases for these conclusions are the particularg given in the available land criats attributed to the medieval kings. A useful guide for the svstem of land tenure and taxation in Ethiopia was published recently by a senior public servant who made use of existing Government archival material and local traditions. Although it deals only with the period since the end of the last century, the book also provides an excellent introdution even for earlier centuries, Gebre-Veld Fngidawerq, Land and Taxation in Ethiopia (Ambaric), Addis Ababa, 1956. See pp. 15, 17-19 about Gult in particular. Cf. also Conti Rosini, "I Loggo e la Legge dei Loggo Sarda", in GSA., XVII (1904), pp. 31-33. Examples or more recent military colonizations wirich are no doubt based on medieval parallels can also be observed in the 19 th $\mathrm{C}$. 
it happened to varch. I It is apparent that, to avoid conflicts among the regiments on such occasions, a number of homesteads were evenly distributed among the different sections of the army who obtained their provisions from the people as long as they remained in the area. At the time of such expeditions this only arfected the people living on the main roads or within easy reach of the military camps. When an effective and a more permanent occupation was intended however, the same arrangement was simply extended far and wide, and the occupied land was divided into a number of Gults eaci assigned for the laintenance of an officer and his dependents.

The Gult system was much more than an economic arrangement. It occupied an important place in the adrinistration and the defence of the whole Empire.

Footnote 1 cont. from previous page. expansion of Christian thiopia, Cerulli, E., Etiopia Occidentale. I, 1933, pp. 133-4, 233-8. D.N. Levine has a short but precige definition of Gult, Wax and Gold, 1965 , p. 306.

1. In 1332 'Amde-Síyon's troops suffered a number of casualties while thus collecting provisions in the hostile resion of 'Adal, Perruchon, op. cit. pp. 430-1 (text), 476 (tr.). 
A Bale-Gult was also the local representative of the king, and he exercised much authority within his territory. He was responsible for the maintenance of law and order there, be led the local comandos organized to innt down local criminals, and he was also responsible for the local prisoners. ${ }^{1}$ Together witil his superlors in the region, he also raised and commanded local contingents in times of hostilities with external forces. He washelped by the traditional hierarchy of the local people in the execution of these responsibilities. In the absence of the Bale-Gult at the royal court or elsewhere his representative acted for iim in keeping peace. Every part of the kingdom was thus divided into numerous Gults whicin were also administrative units at the headof wilich were placed a hierarchy of the king's poldtical and military officials. This organization served a double purpose. On the one hand it provided an excellent weans of maintaining a large territorial army, and on the other it considerably simplified the rask of governing the expanding empire by dividing it finto small, easily manegeable units.

1. The monks exiled to the provinces of 'Amde-Síyon and Syfe-Ar'ad seem to have been in the custody of such officials, Gedle Beselote-lika'el, pp. 23-4. 30; Gedle Filippos,pp. 214, 220; Gedle inorewos, pp. 8990. Gedle iron, pp. 138-40, 145 . 
Gults were originally given to a person in

return for specific services to the monarch. The

services were generally military ${ }^{l}$ but numerous re-

tainerg of the royal court could also obtain pieces

of land as Gults for sundry reasons. ${ }^{2}$ The tenure of

the Gult was at first strictly personal and did not

entail hereditary rights. Wven during the lifetime

of the Bale-Gult,his tenure only lasted as long as

he properly executed tle responsibilities for wich

he was given the land. This insecurity of tenure

1. It is interesting that al-'Umari uses the same term for 'Amde-Síyon's troops as is emloyed in Mamluk Egypit to denote the soldiers who were given fief"s in return for military services, op.cit.p. 25, note 1 . In his description of the Muslim army of Ifat, bowever, he maintained that no suci land grants were given to the soldiers, pp. 13-14. The editor's note (p.13, n.6) contradicting this is based on the assumption thit this last description was tiat of the Christian Army. It is apparemt, nowever, that the author meant to underline the difference in the organization of the two armies.

2. An interesting land grant to a resourceful courtier Irom Hadya made by 'Ande-Siyon towards the end of his reign is preserved in Tarike-Negest, OR. 821 Mis. (Bi.), ff. $106 b-107 a$; WS. vruce 88 Bodl. ff. $33 b$ - 34a. The Hadya courtier was surprised at the great expense incurred by the king in purchasing wules, and suggested they could be bred in a geries of royal stables in the country. The King was delighted and said to him "Chooge any'Gulta! and he ohose Metemet in Fetegar, Elqiar in Farít Ser in Dinbi, Diwan and Bhortin in Wereb, Haweyet Amba and "Algot in Ambara", where royal stable were successfully established. 
was very convenient for the maintenance of effective control by the royal court over the activities of the provincial officers. Gults were a medieval substitute for salaries and provided the king with a ready meang of rewarding his loyal servants. It is apparent, however, tilat with the pacification of the newly conquereed areas and with the consolidation of the Empire, the Gults gradually assumed an hereditary character so that they could be inherited together with the responsibilities attached to them. In fact it seems that the land holdings known as Rist,or hereditary estates, in the more ancient parts of the Christian kingdom were also in origin GuItg ${ }^{I}$ and their transformation into Rist was only a measure of the degree of religious and etınic equilibrium long created in these areas since the Aksumite period. The mainstay of the Gult systen was the difference between the conquerors and the conquered. At the initial period of the expansion of the Kingdom the general picture that emerges is one of two layers, of which the botton layer consisted of the local subject people. Over and above them came the conquerors with their

1. Cf. Conti Rossini, "I Ioggo e la legge dei Loggo Sarda", cit., pp. 33-35. 
nuwerous ellotments of Gults wilich entitled then to use the local people as no more than domertic servants. Gradually, however, with an increased socisl contect and intermarriages between the two classes, the difference between them became less and Gults were transformed into hereditary holdings. Wherever this developeent was impeded by deep religious and ethic prejudices, the Gult system maintained its original character, and the power of the Christian kingdom alwaya remained alien and only skindeep.

\section{The Royal Court.}

The rost important centre for this transformation was the Royal Court 1tself. Being at the pinnecle of the military and administrative organisation, it was a perfect model of the whole Empire. Its internal structure saw its fullest development in the first half of the fifteenth century, and a detailed atudy of its characteristic organisation and its place in the administration of tize kingdom will have to be deferred to subsequent pages. I It suffices here to sketch a broac outline of its basic elements for the purposes of this chapter. It seems possible to consider the Christian court during the period under 
review as consisting of two major sections:

(a) a large number of civil, clerical, and wilitary functionaries pertornentiy attached to the court, and

(b) a floating population occasionally coming to court for sundry reasons.

According to an early tradition, King ' AndeSiyon is said to have formally organised in his court fifteen "lsouses" each of wiich had its own special responsibllity. I At the head of each "house" were appointed a chief and an assistant chief who were directly answerable to the king for carrying out the gpecific responsibilities asalgned to their house. It is interesting to note that the dutios assigned to then also reflect the king's increasing wealth, and his particular concern with military activities - at least seven of these "houses" were paced in charge of his special tressures of gold and vestments of honour,?

1. The tradition is preserved in Tarike-Neghest, MS. Bruce, 88, Eodl. f. 32b, This rS. is described in Dilleann, Catalogus Codicum Manuscriptorum Bibliothecae Bodelianae Oxoniensis Pars VII. Codicis aethiopic: oxford, 1848, 110.29. Cf. also Wrisit, op.cit. Or 821 , ff. $103 \mathrm{~b}-4$.

2. Miny of the words used for the sundry objects kept by these "houges" are archeic and their specific meanings are difficult to decipher. But from the recognisable names in the list it seems quite possible to determine the nature of the responsibilities of eacls loouse. The seven "houses" referred to above included Gimja-Bet, lijle-Bet, Mereba-ket, Werq-Bet, Be'ale-Siri Fizt-Bet, Qesiy-Bet and Metelat-Bet. It seens that it is to F/note cont.... 
and three of then looked after his defensive armour, his various other weapong of war, and the fittings of the horses of the right and of the left. ${ }^{1}$ The eatabIlshment of these "houses", with their speclal dutieg seevs to provide an interesting clue to the organisation of the whole court. It is ap parent tiat the rest of the numerous retainers of the king and his family were also similarly organized in separate groups accordIng to their respective functions. Outside this inner circle of courtiers, whoge special duties were mainly to look after the personal needs of the royal family, there came the political and military officials of the king with their numerous followers consisting of the royal guards and the various contingents of the army. Each of these afficials and their followers were also accompanied by their own families and other dependents. In a short description of the court during the hostilities of 1332 in 'Adal, reference is made to "the wives, children and the male and ferale slaves" of the troops

/Footnote 2 cont. from previous page.

these "treasure houses" that the king's chronicler also makes \& reference when he says of 'Ande-Siyon "He took out of his treasure houses (much) gold and gilver and vestments of honour... and conferred them upon his soldiers", Perruchon, Histoire des ruerres, p. 289 (text) and cf. also p. 337 (tr.)

1. These included Harb Bet, Dir'i Bet and Tíqaqin Jir'i-Bet. 
es having constituted a substantial part of the court. ${ }^{I}$

It no doubt mainteined a similar pattern in relatively more pegceful times. Its gize fluctuated with the seasons. In the dry season, when local officials and vassal rulere normally brought t..eir tributes, the court received luge reinforcements from the provinces. Another occasion wilen it was at its greatest was on the eve of najor military expeditions, when provincial

governors joined the court with their regional forces. ${ }^{2}$ During the raing season many of the King's court officials and their followers went to their home districts or to their official stations, and the court was reduced to its smallest size.

The court itself appears to have been continuously moving from one province to another. It seews that it was to this aspect of the court that Al-'Umari made a reference when he wrote:-

"On dit que ce roi et les soldats de son arnée ont degstentes qu'ils transpgrtent avec eux dans leur marches et leurs déplacements".

1. Perruchon, J. op.cit., p. 415 (text), Cf. also pp. 416 (text), 465-6 (tr.).

2. Ibid. pp. 293 (text), 339-40 (tr.). llany of the governors of the northern provinces of the kingdom are here mentioned as having been at the court on the eve of 'Amde-Síyon's campaigns to 'Adal.

3. on.cit. p. 25 . 
The statement did not refer only to the movements of the army during military expeditions. Traditions of many sites of the Clristian court also provide an apple confirmation for its mobile character in peaceful times as well. I Thus it was not only that the king's subjects came to his residence, but also that his court actually. changed its location at regular intervals. This two-wiy traffic between court and country played a great role in stablising Christian power in the new areas. The appearance of the court in a region was a drametic representation of the presence of the Christian kingdom. During the first years of conquest and expansion in any new region it brouglit with it utter destruction and havoc to all the local people. Once Christian overlords ip was accepted, however, members of the local ruling families were gradually drawn into the court and into the feudal system of the Christian administration. fit first they were probably kept at court as mere hostages for the good behaviour of their relatives and their subjects. After a period of readjustrent at court they were brought forward as favourite candidates for the leadership of their people. A typical exdmple of tis

\section{Infra, p. 539 .}


pattern of development was the relationship between the Welasma ruling house of the Muslim state of Ifat and the Christian court. ${ }^{1}$ The chronicler's description of the first conquest of Hadya also points to the same conclusion:

"('Ande-SIyon) fit un grand carnage des gens de ce pays, tuant les uns à la pointe de l'épée ou les massacrant, et emmenant en captivité, avec leur roi, les autres, grands et petits, homves et femes, vieux ot jeunes, qu'il transporta dans sa capitaln.

We are not told here or elsewhere what happened to Amano, the king of Hadya, after his capture and detention at court. But the power of the kingdon in his country remained cuite secure after that, and it seems possible to suppose that 'Ande-Síyon and his immediate successors pursued an exactly similar policy towards him and his famly as with the Iuslin Welasme princes in Ifat. The sane case no doubt aplied to the leaders of other communities recently brought under the suzerainty

I. On his victory in Ifat in 1332 'Amde-Siyon appointed as "King of all the liuslim districts" Sebrin's orother, Jiwaldin, who was apparently in prison before the war. Perrucion, op.cit. pp. 301 (text) 346 (tr.). When later he proved to be unco-operative another brother, Nasreddin, was appointed instead, ibid, po.323-4, 432-4 (text) 362, 478-79 (tr.) King Seyfe-'Ar'ad (1334-71) also kept Sabradin'g son AlI and his fauily at kif court and appointed the in turns as vassal rulers of Ifat, Marizi, Historia cit. pp.18-2l.

2. Perruchon, op. cit. pp. 335 (tr.) 287 (text). Cf. also The Four (3ospela, MS (Ii), f. $25 \mathrm{~b}$. 
of the kingdom. The historic role of the court was to serve as a vast training ground for loyal district officers and provincial govermors.

'Amde-Siyon was the most important architect of this dynamic system of Christian expansion, and it is ironical that his nawe should be an object of hostile monastic propeganda in the hagiographical traditions of the Ethiopian church. Yet, even this was an essential by-product of the intensive development which the church was undergoing, particularly in the period of his reign. The traditions of his violent conflicts with the monastic leaders are only an indication of the growing importance of monasticism in the organization of the Church.

Revival of Monasticisw in Ethiopia.

Despite its early introduction in the 6 th century with the advent of the Nine Saints, ${ }^{l}$ monasticiaw could assume a dominant position in the sthiopian church only geven centuries later. Ethiopian monastic traditions before the last quarter of the thirteenth century revolve around Egyptian and "Roman" founders, and they are, as a whole, extremely defective and fragmentary. This is 
quite clear from the spiritual genealogies given for the two dominant monastic "Houses" of the Ethiopian church, namely those of Tekle-Haymanot of Shewa (d.1313), and Ewostatēwos of Sera'e- (d. 1352). l The emergence of militant national leaders in Ethiopian wonasticism was a post-thirteenth century development, and the church seens to have been dowinated until then by the secular clergy. This was particularly so in the regions of Amara and Shewa, where the new-born monasteries seem to have made a strong bid for influence as champions of better moral standards in the adwinistration of the church, and in the daily lives of the Christians, including the wonarchs themselves. The opposite sides taken by the secular clergy and the monks in subsequent conflicts were determined by their respective positions in relation to the Royal Court.

1. Both these "Houses" derive their origin from the Nine Saints. But Tekle-Haymanot and Ewostatewos are placed only eight and thirteen generations after st. Antiony (d.356), respectively - Conti Rossini, II 'Gedle Filipos ed il Gedle Yohannis' de Bizen, in MRAL, ser. 5, vol. III (1901), p. 156. How much defective monastic traditions before the $13 t$ ta $c$. are, can better be illustrated in the genealogical tables for 'AbiyeEgzi who lived in the first half of the 14 th c. Whereas as many as 8 generations are given between him and the wars of Gragn (1527-42) only 9 separate him from St. Anthony, Gedle 'Abiye-Egzi, Or. 695 (BM), Conti Rossini, "Note de agiografla etiopica: 'AbiyeEgzi", in RSO, XVII (1938), Pp.416-7. 
The hierarchy of the coptic clurch consisted of elght orders. ${ }^{1}$ only five of these are represented in the traditions of the sthopian ciarch. ${ }^{2}$ The lighest of these five orders, nawely that of the Metropolitan, was always conferred on an igyptian nionk who was chosen by the Patriarch in Cairo and sent to Ethiopia? Next

1. Ibn Saba (Yuhanna ibn Zakariya), La Perle précieuse Traitant des sciences ecclésiastiques. ed. \& tr. Jean Perienr, in PO, XVI (1922), pp. 661-4. Wansleb, J.M, Histoire de l'Eglise d'Alexandrie, I677, р. $33-8$.

2. The orders which are not represented in the Fthiopian church are those of the Patriarch, Sub-deacons, and 'Agnostes' (or Readers). There are sowe differences between Ibn Saba, who wrote in the end of the 13th century, and Wansleb ( 17 th century) in the number af orders. Whereas the foraer referred to Metropolitans and Bishops as being of the same grade, the latter took them a different. In another passage where he compares the orders of the church with the 'seven celestial orders', Ibn saba roduced the number to seven by arguing that Patriarcis, Metropolitans, and Bishops were in fact the same grade, op. cit. pp. 660-661. At the end of Wansleb's lists is a church functionary be calls "Sacristain" or "Zeiin". He defines his duties as being llmited to guarding and taking care of the precincts of the church in general, op. cit. p. 38 .

3. Instances of Egyptian resistance to the ordination of ithiopians to this order are avallable in the Ilveg of the Patriarchs, Budge, E.A. W. The Book of the Saints of the Ethiopian Church, III, pp. 198801; Renandot, Historia Patrarciorum Alexand rinorum, pp. 273. 283. In a conflict between Patriarch Cyril III of Alexandra (1235-50) and Ignatius II of Antioch, the latter nominated an atriopien monk in Jerusalem, Abba Tomas, as Bishop for Ethiopia in 1237. Pressed by tile Dominicans in Palestine, who were anxious not to displease the Egyptian Sultan, Ignatius backed down and Tomes did not take his seat, ibid, pp. 579; Cerulli, is. gtiopi in Palestina, I, pp. 62-66; Neal, J.1. History of the Patriarchate of ilexandria, 1847, II, p. 31 
came the order of the Epis-qopos to which Ethiopians also could be raised. ${ }^{1}$ Below these ecclesiastics came the priests, archdeacons ${ }^{2}$ and deacons. These last three orderg nade up the backbone of the church and thev consisted of botli the secular and monastic clergy. The difference between these two elements of the ethiopian churcli was fundamental. The most distinctive aspect of the monestic clergy was that they entered into special oaths of celibate life, and their activities wore Inmited to their monasteries. Very little ia known about the organization and discipline of the wonasteries before the widdle of the

1. Three rthiopian ecclegiastics are mentioned as having held this title in the relgn of lalibela, Conti Rossin1, "L'evangelo d'oro", pp. 187, 190. In the sare reign an Egyptian bishop is said to have consecrated an Ethiopian "Izveque" at the king's request, Renaudot, op. c1t. pp. 554-67; Perruckion, "Extrait de la vie d'hbba Jean", in RS. 1900, p. 79. This is curious because according to the customs of the Coptic cluncin a vetropolitan or a bishop cannot ordaín "un evêque", Ibn Saba, op. cit, p. 746. It seems that the term "Epis-Qopos" was used in Ithiopia as equivalent to hegoumenos which was the inferior title next to that of the bishop, ivid. p. 665; 0.H.E. Khs-Burvester, "The Canons of Cyril III ibn Laklak", in Le ruséon. Vol. pp. 170-111.

2. The position of the Archdeacon was very important in the Coptic Church, Ibn Saba, op. cit.,665-6; Wansleb, og. cit. pp. 36-7. It also appears to have been of special importance in sthiopia and the title is given in early lists of influential officials on very solem occasiong, Coni Rossini, "I'evangelo d'oro", pp. 187, 190; The Four Gospels. IIS. (II), ff. $22 b, 345-6$. 
thirteenth century. It is however considered that the liver of St. Paul the Hemit and St. Anthony and the Rules of St. Pacomius were translated from the Greek into Ge'ez already in the Aksumite Period. I There is no doubt that this monastic literature provided the earliest guide-lines, and the monasteries were probably organized accordine to a simple application of the Rules of St. Pacomius with wiom the Nine Saints are traditionally connected. At the moment, an examination of the traditions about the establisaments of new commanities since the middle of the thirteenth century is the only way of attempting to reconstruct the development of monastic institutions in Ethiopia. At the beginning of this period references to monastic comalunities are limted to some of the ancient establisiments of the Nine Saints, ${ }^{2}$ and other sites incidentally mentioned as

1. Cerulli, E. Storia della letteraturi Etiopica, 1956 , pp. 25-29. The thlopic version of tlie Rules of St. Pacomius was translated by $R$. Basset in his collection Les Apocryphes bthiopiennes, 10 Vols., 1895-I915.

2. As the origin of the most dominant monastic group in the 15th century Debre-Damo is represented best in these traditions, Gedle AEegawi, ed. I. Guidi, in ARAI, 1896, Ser. V, Vol. TI, pt. I, Memorie, pp. 54-96; Gedle IyesugMo's, ed. \& tr. S. Kur, pp. 9-13 (text); Conti Rossini, II Gedle TaklaHaymanot', in ARAI, 1896, Ser. $\nabla$, VoI II, pt. 1, Meworie, pp. 107-8; Budge, E.A.W., The Life of Tekle-Haymanot; pp. 72-3 (text); Gedle Beselote-i.ika el, ed. \& tr. Conti Rossini, p. 19 (text). The wongstery 
monastic retreats in the Iegion north of Amhara. ${ }^{1}$ A more complete picture of the rapid development of monasticism emerges only after the middle of the tirirteenth century. The trends of this development are represented by the traditions of the "Eouses" of TekleHaymanot and Fwostatēwos.

For aly the differences wlich subsequently developed between these two groups, ${ }^{2}$ their early traditions represent the same phenomenon of monastic revival in the Ethiopian church. In its early stages the movement was characterised by 1 ts simplicity and proverbial sense of independence, both of wrich found their fullest expression in the background of the political and wilitary revival of the Christiun kingdom in the whole of the Ethiopian region. While the growth of the Tekle-Haywanot group of monasterieg followed on the most decisive

/Footnote 2 cont. from previous page.

of Abba Gerima at liedara is also referred to, Gedle Gerima, Or, 702, I.S.Bl. ff 128b -38; Aedle vewistos. FS. Debre-Iibanos, ff. 17-24. Since Pentelewon and Afsè also bave their Gedles, comiled probatly in the 15th century, it may be surmised tirat the comunities they had established were still intact at the same time. Debre-Iibanos of Scimezana wilch belongs to about the same period as the Nine Saints was apparently the nost important commity towards the end of the Zagwe Period, Conti Rossini, "I'evangelo d'oro, cit. pp. 177-93.

1. Cf. Budge, The Life of Tekle-Haymanot, pp. 73-4 (text); Gedle Beselote-Mikalel, pp. 19.

2. Infra, pp.442-53,523-6. 
directions of the expansion of the kingdom, the increasingly militant attitude of the Christian tribes of Serawē and Hamessēn towards their liuslim and pegan neighbours, ${ }^{1}$ was also reflected in the intensive monastic activities of the House of liwostatēwos. Nowhere was this parallel religious and political development of Ethiopia brought into more direct fonfrontation then in the regions of Amhara and Shewa, which had become the centre of the political and military activities of the Cinristian kings. It was also in these parts of the kingdom that the militant leaders of the new monastic wovement came into open conflict with King' 'Amde-Sĩyon and his successor SeyfeAr'ad.

The earliest traditions of monagticism in this region at our disposal go back only to the widdle of the thirteenth century, when Iyegus-ijo'a settled at the island church of St. Stephen in Lake Haiq. In about 1249 he left his monastery of Debre-Damo and started school at Haiq where many students from Ambara and shewe joined him. ${ }^{2}$ He conferred the wonstic habit on many of them, and some subsequently left

1. Supra, pp.140-2.

2. Infre, $\mathrm{pp} \cdot 301, \mathrm{etc}$. 
Haiq to establish their own comunities. TekleHaymanot left for his native land of Shewa, ${ }^{1}$ and others appear to have dispersed in the province of Amhara. 2 Within a short tive of his advent at Haiq, Iyesus-lio'a had firnly established the position of monasticism which was to be the most effective vehicle for the expansion oif the church.

This vital development was greatly enhanced by the simplicity of the process of establishing a monastic comunity. Iyesus-1.0'a himself settled at a very well-established centre of Christian population where his special role as a teacher was apprectated, and he was not faced with the initial problem of starting a new community frov scratch. Hig disciples who left hin to live on their wn were not as fortunate. A monastic comunity normally started by beine an isolated place of private retreat for its founder. 3 Alone, or

\section{Infra, pp. 308 , ete.}

2. Anorewos 'the Priest', the spiritual father of BeseloteMika'el (d. before 1337) was apparently one of these early disciples of Iyesus-Ilo'a, Infra, pp. 345-7.

3. Conti Rossini, II 'Gedle Takle-Hayganot' D. 109; Budge, The Life of Takla-Hevmanot. p. 79 (text); Gedle Beselote-llka'e1. . 14; Gedle Yafqirenne-Eqzi, p. 26, 36, 38, 40; Gedle Samu' el (Waldibba), p.9; Gedle Tädewos, ed. \& $t r$. K-de Santis, in Annali Lateranensi, Vol. VI, 1942, pp: 34-35. 
accompanied by a few followers, the founder of the commity pursued a strict life of extreme ascetism, in an almost complete seclusion. Inaccessible hillsides, forest or sem-desert areas, were most popular as the sites of a young comunity. At times they were apparently very far away from where even cirurches could be found. I Contact with neighbouring settlements was kept to a minimum at first, and when some of the inmates of such a secluded community ventured out to gather food supplies the task usually fell on the junior members. 2 The leader of the conmunity remained inside and his followers nade use of their meagre contacts with the surrounding people to spread the news of his monastic renown. 3 The reaction of the local people to the earliest signs of the existence of sucl a combunity largely depended on their religious loyalties. In

1. The nearest church where Abba Samu'el of Waldibba could receive Holy Comounion was at a distance of three days, Gedle Samu'el, p. 23. A similar story is told of Abba Tadewos of Iartarwa and his fol owers, who travelled all the way to Aksum irom remben until tisey finally built their owm ciurch, Gedle Tadewos, 1oc. cit.

2. Ibid, pp. 33-4

3. In a chronologically untenable reference to the visit paid by Tekle-Taymanot to Beselote-Mika'el on his way to filq he meets onew the latter's disciples who tells him of the monastic exploits of his master, Budge, op. cit, pp. 60-1; Cf. Conti Rossini, "Liagiografia Etiopica e gli Atti del Santo Yafqirenne-Eqzi", in ARIV, Sc. lett. ed arti, 1936-7, Vol. 96, Pt. 2, p. 408 . 
predominently Christian areas the news was generally welcome and the young community received fresh reinforcements. ${ }^{1}$ In frontier areas the reaction was one of hostility, and acts of outright persecution were attempted until local Christian officials came to the aid of the monks. ${ }^{2}$ Gradually, as the monastic prestige of the leader became establighed among the neighbouring people, wore people joined him, and the economic and religious organization of the comunity began to take shape.

At first the suall comunity lived a very simple life by gathering wild fruits for their daily needs ${ }^{3}$ and by hiring their services to the nearest farming villages at harvest time. ${ }^{4}$ When the comunity got bigger, it looked around for a suitable site, built a small church and a number of little huts for their abode:-

1. Conti Rossini, II 'Gedle Takle-Haymanot' pp. I15, 138; Gedle Filippos, pp. 187-8; Gedle Anorewos, p. 68; Gedle sivostatewos, p. 29.

2. Gedle Yafgírenne-Iigzi, pp. 24-6, 50-8; Gedle ZeyohannIg,

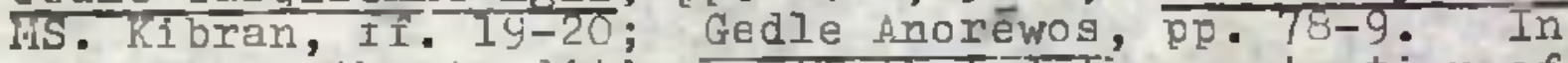
some cases the tradions attriouted the protection of the young communities to God's wiraculous intervention, Budge, op. cit., pp. 79-81; Gedle Samu'el, p. I8.

3. Conti Rossini, II 'Gedle Takla-Haymanot', pp. 112, 115; Gedle Samu'el, p. 31 .

4. Gedle Tadēwos, pp. 33, 48; cf. Gedle Abekerezun, p. 13. (Text). 
"And they built a small ahelter, they placed the 'tabot' of St. llary (in it) and celebrated mags there. And they planted some 'Dagussa' and 'Hihigo' for the purposes of the church... And (Tadewos) sent (a disciple) one day to clear a piece of (more) land (for cultivation)..."

The religious influence of the group soon spread among the neighbouring villages with whow more frequent contacts were established. The people came to pray and to ask for the prayers of the monks, and they brought various gifts wits ther. ${ }^{2}$ The monastic exploits and sanctity of the founder became widely accepted, and stories of estounding wiracles were built around his name while atill alive. ${ }^{3}$ Canonization in Ethiopia was a sirple act of public recognition of the saintly

1. Gedle Tadewos, p. 35; Cf. also Budge, op. cit. p. 219; Conti Rossini, op. cit. pp. 112, 1.15; Idem, II

2. Gedle Yafqirenne-Egzi, pp. 58,62, 64, 66; Gedle Filippos (Asbo), pp. 22I-2. Ewostatewos, is said to have prohibited his followers accepting gifts from unworthy people or from non-believers. He enjoined them to live_on the fruitg of their own labour, Gedle swostatewos, pp. 32-3. His descendint Filippos of Debre-Bizen also confirued this, Conti Rossini, op. cit. p. 96 .

3. A study of the miracles offerg a useful means of understanding the life and beliefs of the people in the medieval period. They are of special interest since they deal with the day-to-dey econowic and social problems of the region in wlich the memory of the saint is associated. 
pursuits of a monk wio soon emerged as a patron saint of the area in which he conducted his monastic labour. 1 Firmly established in such a small locality, the prestige of the saint later spread further afield and similar recognitions were given to him by neighbouring districts, who asked for his prayers and spiritual protection. He soon became a rallying point for the sick, who came to him in search of miraculous cures, and the poor, wio saw an economic and social security in the growing influence of the comunity. Thus, between the middle of the thirteenth century, when Iyesus-Ho'a had opened his monastic school at the island of Lake Halq, and the reign of 'Amde-Siyon (1314 - 44), many such comunities had been esteblished in Anhara and Shewa. Tile most notable among these were the corimunity of Debre-Asbo in Shewe founded by Tekle-Haymanot in c. 1284,2 and Debre-Gol in southern Ambra which was originally a private retreat of "Anorewos the priegt" and later developed into an important comunity under his remarkable disciple Beselote-Mika'ell. 3 At tlis

1. Gedle Tadewos, p. 43 .

2. Infra, pp. 327, ek ther commities had also been established in Shewa besides Debre-Asbo, Gedle Zena-ilargos, ff. $14-15$; Gedle vertatos, ff. 101b- 102a.

3. Infra, pp.345-7. Here also there are references to still other comunities, Gedle Beselote-ílika'él, pp. 8-10. 
stage of their development an esgential feature of these comunities was their complete independence from the kings and their local representatives. They enjoyed this position of economic freedor in striking contrast with the secular clergy, who had always been dependent on the Royal Court and the politico-military structure of the kingdor.

The secular clerdy consisted of the married priests, the deacons and other functionaries of the church. Before the development of monastic communities they alone provided for the routine religious needs of the Christian communities. It seems that the priestly families constituted a special class of society with special rights of succession to the clerical progression. Despite the tendency of Ethiopian hagiographers to connect this hereditary systew with the muc! diffused legend of the Queen of Sheba, ${ }^{1}$ itg origin may have only been an ancient custom of the Coptic cliurch concerning the secular priesthood, later confirmed by the cunfons of Patriarch Cyril III $(1235-50)$ in $1238 .{ }^{2}$ The purpose of

1. This relates to the trudition of the Jewish arigin of the Ethiopian kingdom, and the priestly class derived its origin from Azaryas, son of Badok, King Solomon's High Priest, who accompanied llemelik I to Aksum, Budge, The Queen of Sheba and her only son Memelik I, 1832, pp. 61-63. Cf. also The Life of Tedle-Haymanot, I, p.5

2. O.H.E. Khs-Burmester, The Canons of Cyril III ibn Laklak, cit. pp. 132-5. In a congregation of a church precedence is here given to sons of Priests (a) over sons of deacons, (b) over sons of priests of other churches, and (c) over sons of laymen. 
such a stratification of a congregation may have only been administrative in origin. In vedieval Ethiopia, however, it appears that it had resulted in the creation of a different caste of people in whom rishts of the priestly function were exclusively invested. References to "the parentage of priests", as a separate, elevated class, are available in the hagiographical traditions about the origins of some local saints. It also appears that members of this priestly class enjoyed distinctive marks of respect in their relations with the local people:-

"(Young Begelote Mika'el trode over the chains of the king's mule wlile passing by, and (the keepers) caught him and took him to their chief. And their chief saw the tunic (slung) on the shoulders of the child and said to them, 'Leave him alone because he is of the parentage of priesti, and do not beat hin '."

In the stratified society of the priod the priestly clase came next only to the class of local rulers. The two clasaes, whose relationship is aptly described in the traditions of Menelik I and his high priest Azaryas, were always very close and complementary. The secular

1. Gedle Beselote-ika'ēI, p. 5. The distant orisin of this rered respect and consideratle sanctity surrounding the priestly function may in fact be found in the pre-Christian and Kushitic religious practices of ancient Ethiopians, cf. Conti Rossini, Storia Iitiopia, pp. 78-79, 81 .

2. Ibid, p.9. In the text tire word Priest is used in place of the phrase underlined, so that ".. because he is a priest" would be a wore literal translation. But since he was still a swall cild the hove rendering is probably preferable for the context. 
clergy lived in society and only looked after the routine services o- their local churcbes. The progremes of relifious training whicil they underwent at the beginning oi their career ${ }^{1}$ were probably sinort and only Iimited to reciting sowe prayers, singing the hyuns, and reading some selections of the Bible. This only enabled them to practise and preserve the liturgical traditions of the clurch. Probably very few among them went beyond these limits. But this was not an important part of their difference to the monastic clergy, of whom the majority were probably in the same position. The basic difference between them arose in that the aecular clergy lived in, and completely depended on, so ciety, of which they constituted an in由egral part. This complete dependence on society denied them the economic and spiritual freedom which enabled the monks to be fully engaged in religious pursuits and to pose as champions of a more rigorous observance of the rules of the Church.

1. These were provided by a local priest who taught his own children and probably also some of his relatives, Budge, The Iife of Takle-Iavmanot. P. 20, (text); Gedle Qewistog, f. 44a; Gedle Peselote-iniak, P.6; or by a cleric attached to a local chorch, Gedle Anorewog, p. 68; Gedie Filippos, p. 175; Gedle Sandel, p. I; or mere tiey were available, by monastic commities, Gedle Ewostatewos, pp. 7-8. 
Reforw Movewents in the Church.

A youthful monastic militancy swept twrough the second generation of the descendants of Iyesus-ilo'a in frhara. It seems tirat their first aim was to bring about basic reforms within the church itself. Beselotelikika'el, ${ }^{l}$ who apparently led the movement, first accused the Egyptian bislop Abune Yohannis of practising simonj:"Beselote-rika'el went to the priests of the Royal Court and asked them to take him in to the King. And they told the King (about it) and took him in. He said (to the King) '...the Apostleg excowmunicated those who received money in return for either baptis or ecclesiastical ordinations. But this bishop contravenes their order; he orduins and receives money'..."

1. Infra, $\mathrm{pp} .345-7$.

2. Gedle Beselote-Mika'ēl pp. 22-3. Beselote-lika'ēl is reputed in these traditions to have been a very learned man, ibid, pp. 19-20. The quotation here of the Canons of the Apostles is interesting because it seems to show an intensive liter ry development in Ethiopia. 'Amde-Siyon's chronicler, who must have written his work between 1332 and 1344, also quotes the Canonsoi the Apostles, Perruclion, Histoire des guerres, cit., pp. 310,312 (text), 352354 (tr.). This monestic movenent of reform may have been a result of increasing contact with Arabic Christian literature in sgypt. It is remarkable how the above quotation is an almost verbatin repetition of a similar accusation made in śgyt on Patriarch Shenuti, Sewirus, History of the Patriarchs of Alexendria, Vol. II, pt. 2, p. 233. See also pp. 136, 150. At the Council of 1238 held in Cairo Patriarch Cyril II had also condemed simony in his Cinons, 0.H.F. Khy-Eurmester, op. cit. pp. 105-6. Cf. Conti Rossini, "II 'Senodos' btiopico" in RRAI, 1924, p. 44. 
The Egyptian bishops in Ethiopia were very well provided for, and it is curious that Abuna Yohannis should be accused of aimony. In the reign of Lalibela the metropolitan Abuna Hika'el is said to have had numerous servants and a fief of forty "villages" for his maintenance. ${ }^{I}$ It is most likely that with the expansion of the kingdom and the gradual increase of the wealth of the monarchs, the retropolitan's possessions also became more substontial. It is possible, however, that in the days of Beselote-Mika'èl, which wa period oI active expansion of the church, the monks may have been presented with some difflculties at the episcopal residence in their increasing demand for more ordinations. That tisis was in fact a serious problem at the tice is suggested in another passage where a young wonk is said to have assuried the functions of a priest on his own accord without being ordained.2 However, the king was not apparently impresged by the accusation against the bishop and he is said to have exiled Beselote-likika'el to Tigre instead. 3

1. Perruchon, J. "Extrait de la vie d'Abba Jean", cit. pp. 79-80.

2. Gedle Beselote-Mika' $\overline{\mathrm{e}} \mathrm{l}$, p. $4 I$

3. Ibid, p. 23-4. 
Beselote-Mika'èl returned to Amhara two years later and started a series of reforms in the monastic practices in Amhara. Nonasticism was only a recent developgent in Mhara and Shewa, and this lack of experience was seriously showing in the organizational difficulties of recently established commities. One of the most serious problems was the difficulty of effectively separating the living quarters of the male and female members of a monastic community. The traditions of monesticigm in Tigre indicate that convents usually grew beside important monasteries, ${ }^{1}$ and by the thirteenth century there were very weli-established convents. ${ }^{2}$ In Amhara and Sheswe, however, the custom had spparently developed for botk monks and nuns to IIve together. ${ }^{3}$ Beselote-Mika'ēl fiercely attacked this custom and is said to have obtained a royal decree againgt 1 t. 4 Abba Anorewos, a senior disciple of

1. Gedle Aregawi, ed. Guidi, p. 64.

2. Lalibela and his queen, ilesqel-KIbra are said to have made a number of land grants to sucl convents in the region of Scimezana, Conti Rossini, L'evingelo d'oro, pp. 186-9. In the tradition about the life of Lalibela himself, his wife is said to have waited for hiv in a convent, where men had no access, until his return from his alleged visit to Jerusalem, Gedle Ialibela. pp.

3. Conti Rossini, Il 'Gedle Tekle-Haymanot', pp. 115-6. Gedle Beselote-Iika ${ }^{\top} \mathrm{I}, \mathrm{pp} .36,40-41$.

4. IbIㄹ. 36 . 
Tekle-Haymanot, and a grest adnirer of Beselote-iika'ēl, is also said to have effected similar reforns at DebrAabo in the life-tive of his waster for wilich he became extremely unpopular among his colleagues. 1

Beselote-lika'ēl next came into open conflict with King 'Amde-Sĩyon whom he denounced for his nonChristian matrimonial habits:-

"God has ordered us, Christians, not to marry two wives nor buy (lit.) concubines, nor sleep with the wives of otherg. But you have broken aII (these) orders of God. And worse of ill, you married the wife of your father; and you did not desist from keeping nuwerous other woven (of pagan origin)..."

The matrinonial habits of Ethioplang had already been brought to question before. In the reign of Patriarch Cyril (1077 - 92) the getropolitan Sawiros reported

1. Gedle Anorewog, pp. 71-2. Anorewos is said to have been "Deconowe" of the comunity in Tekle-Haymanot's lifetime and was apparently tipped for the succession. He falled to get the succession and left for Tigre imediately after tho death of his master. Ibid, p.75. His reforms may have played a part in this. Fi met Beselote-lika'el in Tigre, and probably stayed with him until his death. Later, after 1337, Nnorewos returned to shewa and seems to have played a leading role in Abune Ya'iqob's reorganization of the monasteries there, Infra, pp. 351 , ete.

2. Gedle Beselote-ika'ēl, p. 29. That the king did in fact liave more $t$ an one wi e and wany concubines is also confirmed elsewhere, Iistoire des guerres d'Amde Sîyon, cit., po. 326, 387- 9 . Conti Rossini, "L'evangelo dioro", cit.'p. 202. But imde-siyon deniéd trat he had married his father's wife. He declared that Widitretad (1299-1314) was not his father. The sceptical monks retorted that he was only creating excuses based on tine rumours that he was the issue of ar illicit affair between Widi-Re'ad's queen and Qidne-Seged, his brother, Gedle Beselote-lika'el, loc.cit. 
that he had succeeded in pusuading the kinc's courtiers to live each with only one wife. The king inimself also agreed to drop wany of his concubiues and to keep only two wives. ${ }^{l}$ What is most significint in the fourteenth contury is thet the movement for reform was no longer initiated from Cairo, and indicates the tremendous development which the stiniopian clurch had undergone at the time. Abba twostatēwos of Ser'ē is also reported in the same period to have demanded similar reforms from the local rulers. ${ }^{2}$ But the movenents of the Ethiopiun monks were no more successful then those of Bishop Sawiros in the llth century. Beselote-lika'el was beaten and disgraced at court and exiled once again, apparently back to Tigre where he died at Gīlo-liekeda. ${ }^{3}$

1. Sawiros, History of the Patriarch of Alexandria, Vol. II, pt. 3, p. 339. Characteristically, the vthiopic version reports that the bishop's efforts were an unqualified success and the king also dropped all but one of his wives, Budge, The Book of the Saints, cit., p.995. It is stated elsewhere tliat one of the Zagwe kings was an ordained priest and that he decreed a strict monogany in his kingdow, Gedle Yimriha-Krístos, IIS. Lalibela, ff. $28 b-29 a$.

2. Gedle Ewostatēwos, p. 35 .

3. Gedle Beselote-Mika'ēl, pp. 29-30, 47-5l. 
The question was re-opened once again on the advent of Abune Yaqob, the new grgytian bishop, in c. 1337 after the death of Beselote-Iika'èl. Ya'qob added a new dimension to the movement. His predecessor, Yohannis, had been unpopular among the new monastic leaders of the country by mintaining the traditional close contact with the Royal Court and the secular clergy. He now reversed tilis policy and establishod excellent relations with not only the descendants of Beselote-ríka'ēl but also with the growing comunity of Debre-Asbo in Shewa. His first attempt was to organize a successful programe of evangelization in tile pagan and luslim provinces of the kingdom. ${ }^{l}$ He probably tried to persuade the king in privete to reform his matrimonial habits. When these quiet protestations falled, he openly sided with the ronks, and excomanicated the king.' 'Amde-Sîyon

\section{Infra, pp. 337, etc.}

2. Gedle Aron,pp. 129-30. It is probably this inEernal religious conflict that led to the rumours about the king's religious convictions recorded by Al-'Umari, "On nous a rapporté que la souversin aujourathui régnant s.'est fait secretement musulman et qu'il ne continue a pratiquer le C ristianisme que pour conserver son royaume", op. cit., p. 32 and n.l A hagiographical tradition also accuses in of being indfferent to the conversion of Muslins to the Courch. He is once said to have dismissed some of Beselotelika'el's converts wit. the following instruction. "Go and live according to the rules of your forefathers", Gedle Beselote-lika'êl, p. 31. (text) 
threatened to expel the bialiop, flogged his monestic allies and dispersed the into exile. ${ }^{1}$

When 'Atide-siyon died three years later, Ya'qob is said to have made an agreement with the new king thut he would recall all the exiles and keep only one wife. ${ }^{2}$ But he soon went back on his words and married three wives. Ya'qob and tie monks protested once again but it was all in vain. The bishop was finglly deported back to Egypt, and the recalcitrant monks sent out to the southern parts of the kingdor in exile. ${ }^{3}$

The difficulties wilci befell these wilitant leaderg aparently created diviaions in the wonastic movement. Many of the monks are accused of having accepted land and money from the kine, to live with hin on his own terms. ${ }^{4}$ others refused to give even

1. Gedle Filippos. pe. 206-15. Gedle Aron. pp. 131-2.

2. Ibid, p. 85. Gedle Filippos, p. 224.

3. Ibid. pp. 226, 23--6; Gedle Anorewos, pp. 89-90; fedle ron, pp. 141-9. Infra, pp.

4. Gedle Beselote-l'ika' ek pp. 45-6. 
a temporary shelter to the king's opponents. ${ }^{1}$ A new period had started for the monasteries, and the will of the king had been triamphant over their epheweral puritanical movements. To a very large extent, the first major Ethiopian attempt to reform the spiritual life of the church had thus become a failure.

1. Filippos was turned away from the gates of DebreAgbo and liekane-Serebt, Gedle Pilippos. p. 241 


\section{CHAP'PER THREE \\ EXPANSION $(1270-1430)$}

The Christian kingdom at the time of Yỉkunno'Amlak's accession in 1270 apparently extended to the region of Shime-Zana and the Mareb river, in the north; the Tekezze river, Southern Begēmdîr, and the upper basins of the eastern tributaries of the Blue Nile, in the west; the edge of the plateau from northern Ethiopia down to the Shewan region, in the east; and the northern part of the Shewan plateau, in the south.

A large section of the army which Yīkunno-'Amlak led against the last Zagwē king came from the Shewan region. It is most likely that in the Shewan districts which contributed these troops a number of Christian families had

1. Debre-Libanos of Shimezana has a tradition of land grants by Yíkunno-'Amlak, Conti Rossini, "L'evangelo d'oro", cit. pp. 194-195, 196. The Adkeme-Melga who have traditions of migrating from Lasta as a result of a Shewan invasion settled in Sera'e, and the incident was probably related to the fall of the Zagwe, Conti Rossini, "Studi su popolazioni detiopia", cit. p. 82 (extract). Garrone, V., "Su gli Atchểmé-Melgà", cit. pp. 997-999.

2. Marianus, V., extract quoted by Perruchon, J., "Notes pour I'histoire d'Ethiople", in RS, I (1893), p. 368. Conti Rossini, "La Caduta della dinastia Zague", cit., pp. 295-296. The Shewan districts mentioned as having contributed these troops are Wegea, Dinbi, Muger, We.j, Silalish, and Iwal, collectively referred to as the Seven GWIdam (三 Gidim?). 
already been living for many generations. In hagiographical traditions about the thirteenth century, it is reported that small and isolated Christian communities were to be found unevenly scattered in the pagan dominated districts of SIlalish, and Nuger on the Shewan plateau. Wegda, at the edge of the plateau overlooking Tegwilet and Moret, is on the way to both Muger and Sillalish from Amhara, and txaditions of the Debre-Libanos cycle indicate that it was a christian area by the middle of the thirteenth century. Christian immigrants had long been moving from Tigre in the north to the region of Amhara, and further south to Shewa. It appears that this process was in full swing

I. Tekle-Haymanot's ancestor, Yíla, is believed to have settled here ten generations before the saint, Conti Rossini, Il 'Gadle Takla Haymanot', cit. pp. 102-103. Budge, The life of Takla Haymanot. pp. 5-6 (text). Gedle zena-Marcos, f.T. Its location had been uncertain ever sijuce Conti Rossini placed it, for unknown reasons, in Shewa "towards the Nile", op.cit.. p. 125, n.4. But it is an ancient name for Etisa which is still a popular centre of pilgrinage as the birth place of Tekle Haymanot, cf. Tekle-Sadiq Mekurya, History of Ethiopia (Amharic), Vol. II, p. 20.

2. This still survives in the name of the river Muger flowing into the Nile, west of Debre-Iibanos. Anorewos (d. 1374), a disciple_ot' rekle-Haymanot, was borm in this region, Gedle Anorewos, p. 67 (text): Filippos (d. c.1349), second successor of Tekle-Haymanot as abbot was also born at a place called Zím, a day's journey west of the monastery, Gedle Filippos, pp. 175, 187 (text).

3. Gedle QewIstog, ff. $2,4^{b}, 68^{\mathrm{a}}$. Gedle Zéna-Marqos, 
by the ninth century. This slow population movement

cannot be fully documented, but from the available traditions about the genealogy of Tekle-Haymanot it seems possible to infer the gradual Christian settlement in Amhara and Shewa. The essential value of these traditions only lies in showing that for many generations before our period a chain of Christian settlements had been forming from the northermmost fringes of Amhara to the south-eastern corner of the Shewan plateau. However, these early population movements brought only a handful of Christian families to the pagan south, and only served as a pointer to the direction of the eventual expansion of the Christian kingdom. And despite the clerical bias of these traditions which give a missionary origin to the migrations, more than eight generations

1. Supra, pp.67-72

2. This genealogy is given in both versions of the life of the saint, and in some other related hagiographies, Conti Rossini, II 'Gadla Takla Haymanot', cit. p. 102. Budge, The Iife of lakla-Haymanot, pp. 3-5 (text). Gedle Qewistos if. 19-23. Gedle Zena-Marqos, ff. 13-18.

3. The ancestors of Tekle-Haymanot are said to have moved to Shewa in three different stages: Hizbe-Barīk a Tigre cleric, first settled in Dawint (Amhara), 18 generations before. His grandson, Asqe-Lewi, is said to have moved further south and "baptized the people of Weleqa, Amhara, Merhabite, and Nenzih". One of his descendants, Yída, ten generationsbefore Tekle-Haymanot, migrated still further soutil to Silalish in Shewa.

4. According to some versions of the tradition of Dignajan, King of Aksum, the ancestors of Tekle-Haymanot are said to have been sent to Amhara and Shewa with numerous other priests to evangelize the region, Budge, loc.cit. cf. supra, $19.67, n \cdot 1$. 
passed before any appreciable evangelization was carried out. When this was at last started it was inextricably connected with the vise of the new dymasty in the Christian kingdom.

Both Christian and Muslim traditions indicate that the whole of the shewan region was dominated by a strong pagan kingdom - the Kingdom of Damot $\stackrel{1}{-}$ before the last quarter of the thirteenth century. According to Christian tradition, Motelami, a legendary monarch of Damot, invaded the shewan region as far north as the Jema river, and almost completely annihilated the small christian communities in the area. He is said to have conducted these invasions on two occasions : sometimes before the birth of Tekle-Hay2

manot, and when the saint was a fully grown young man of

1. Until the Muslim invasions of the sixteenth century, Damot referred to the region immediately south of the Blue Nile and west of the sources of the Awash river. Its limits are indefinable, but it may have extended asfar west as the Didessa, and as far south as the region of Ennarya. To the east it probably bordered on Hadya, and Conti Rossini thinks that the region of Welamo may have also been included in it, cf. Futuh al-Habesha, tr. Basset, p. 54, n.2. Conti Rossini, "postile ai "Futuh al-Habasah", in Le Museon, 59 (1946), pp. 180-181.

2. Conti Rossini, II 'Gadla Takla Haymanot', cit., p. I02. Budge, on.cit., pp. 8-15 (text). Gedle Qewistos, ff. $5-7$. 
twenty-five. If the chronology of the life of Tekle-Haymanot (1215-1313), transmitted by the hagiographical traditions, is correct, the invasions of Motelami must have taken place in the first half of the thirteenth century. This tallies very well with the period of the revival of the Christian kingdom in the north, and with the local traditions of renewed Christian attempts at southern expansion. About two centuries after the queen of the Bani alHamwiyyah had successfully got rid of Christian overlordship in the Shewan region, the Christians of Amhara are reported

1. Conti Rossini, op.cit., pp. 105-107. Cf. also Budge, op.cit., pp. 45-53. According to the Waldîbban version edited by Conti Rossini Tekle-Haymanot was himself taken prisoner to Damot on this second invasion, and there he preached until he succeeded in convertiqlotelami. In the much paraphrased text published and translated by Budge, however, Tekle-Haymanot apparently made the trip on his own accord to preach the Gospel. In both versions, however, Motelami's power wa strongly felt in the whole region of Shewa.

2. The saint is said to have died in the 14 th year of the reign of Widim-Re'ad (1299-1314), Basset, R. Etudes sur l'histoire d'Ethiopie. p. 99 (tr.). This alsofits other comparative chronological notes. Thus, Filippos, who succeeded the saint as abbot of Debre-Asbo, only three months after his death, had occupied the chair for 28 years, whell he was exiled to Tigre by 'Amde-Siyon in 1341, Gedle Filippos, pp. 192, 246 (text). Tekle-Haymanot is said to have been 55 years old when Yikunno-'Amlak acceded to the throne in 1270, Basset, op.c1t., pp. 98-99 (tr.). He lived for just over 99 years, Budge, op.cit., p. 96 (text).

3. Supra, pp.74-75 We have seen the persistent traditions about strong female rulers in the shewan region, supra, p. $74 \mathrm{n.3}$ It is interesting to note in this connection that the genealogy given about the legendary King of Damot 
as having been in military conflicts with their southeastern neighbours - the Werjin pastoralists - in the second quarter of the twelfth century. Probably, similar moves were also directed towards the northern districte of the Shewan plateau where a new wave of Christian settlements were apparently established. The tradition of the military expedition of a Zagwe king into Damot may belong to this period. Christian pressure in the area probably increased over the years and the traditions of Motelami'g invasions may only represent a strong pagan reaction against this process of expansion.

The story of Yîkunno-'Amlak's revolt against the Zagwe indicates - as mentioned above - that he procurfed substantial military support from shewa. In the traition, the troops who served under him on that occasion are referred to as "his warriors", and this most likely means that all the seven districts from which they were recruited.

/Footnote 3 cont. from previous page Motelami, oaly refers to his mother: Motelami, whose mother's name was Eslandene", Budge, op.cit., p. 21 (tr.).

1. Cerulli, E. "Il sultanato di Scioa", cit. p. 10, and note 4. Cf. also supra, pp.81-83

2. Gedle Yared, ed. Conti Rossini, pp. 22-26.

3. Supra, fo. $127, n \cdot 2$. 
had already become tributary to him. No doubt his success against the Zagwe, and his assumption of the Christian throne also enhanced his power in shewa. For the period after the overthrow of the Zagwē, both Christian and Muslim traditions are unanimous in showing that Yīkunno-'Amlak conducted a strong offensive against the pagan "Kingdom of Damot" which gave the Christian kingdom, once and for all (until the end of our period), a dominant position in the shewan plateau. According to one version Yíkunno-'Amlak "appointed (Motelami) King of Ennarya ...
and gave him the land beyond the Gíne river." This only means that Christian military success in the Shewan plateau forced the withdrawal of the centre of Damoti resistance further south, and as we shall soon see it was not until the reign of King Amde-Siyon that pagan Damot was effectively reduced to a vassal state. But the most valuable account of the conquests of Yikunno-'Amlak in the Shewan region which was once under Damoti overlordship is by the Arab historian Ibn Khaldun (1332-1406) :-

1. Guidi, I., "Strofe e brevi testi amarici", in MSOS, Vol. X (1907), pp. 180, 182. The tradition is here given as part of a compilation of historical notes made in the middle of the nineteenth century. Just as in the dynastical atruggle between Yikunno-'Amlak and the Zagwe, Tekle-Haymanot is said to have intervened to effect amicable relations with Motelami also.

\section{Infra, pp. 256-7.}


"A l'ouest des états de ce roi (d'Abyssinie) est située la ville de Damout. Un grand chef y regnait autrefois et possedait un grand empire. Au norā des mêmeg (états) se trouvait un autre roi appartenant à la me race et appelé Hack ed-Din ibr Muhammad ibr Al1 ibn Oulasma. Il habitait la ville d'Oufat... Comme son aieul Oulasma avait reconnu ITautorite du roi de Damout, El-Hati en fut offensé et lui enleva son royaume." 1

Walasma, also called 'Umar, was the first historical ruler of the Muslim principality of Ifat, ${ }^{2}$ and just like Yikunno'Arlak he flourished in the lagt quarter of the thirteenth century. The last part of Ibn Khaldun's passage is clearly a reference to that period. At that stage of the history of the region, therefore, the principal contenders in what appears to be the control of the Shewan plateau were the Christian kingdom and the King of Damot, and the outcome of the conflict was a Christian success. Iocal Christian traditions also report that already at the time of Yirunno'Amlak, the Shewan plateau north of the Awash river was

1. Histoire des Berberes, tr. de Slane, New Edition, P. Casanova, Paris, I927, Vol. II, p. 108. Cerulii, E. "I'Etiopia Mediovale in alcuni brani di scrittori arabi", in RSE, III (1943), p. 284. Trimingham, J.S. Islam in Ethiopia (ed. 1965), p. 59.

2. Maqrizi, Historia Regum Islamaticorum in Abyssinia, tr. F.T. Rinck, I790, pp. 17-18. Cerulli, E., "Documenti arabi per la storia dell'Etiopia", in MRAT, ser. 6, IV (1931), pp. 42-43. Id., "Il sultanato di scioa", cit., pp. $15-17$. 
under Christian administration. I To a very large extent this is confirmed by Ibn Khaldun's story quoted above, and written only about a century after the events took 2

place. Maqrizi also refers to this early predominance of Christian power in the Shewan region already by the second half of the thirteenth century. According to his informants who were Muslims themselves, even 'Umar Walasma owed much of his power to the Christian king. He speaks of the reign of this founder of the ruling house of Ifat and Adal in the following terms :-

"This man administered for a long time with great power the government of Awfat and the country subject to it which he had received from the Heti.

1. Gedle Qewistos, ff. 1-5. Gedle Zēna-Marqos, ff. 2-3. According to these traditions the districts of Wegda and Keteta, Muger, SIlalish, Fetegar, and even Dewaro were ruled by christian chiefs. 'The pagan King of Damot, always referred to by the legendary name of Motelami, was the most dominant power south of the Awash. In their details these traditions are hagiographical in character and cannot be accepted literally. Their reference to Dewaro at that early period is particularly dubious. North of the Awash, however, they seem to have been based on early historical recollections.

2. The effect of Ibn Khaldun's invaluable reference to this early confrontation between the Christian kingdom and the Kingdom of Damot is considerably obscured by his attempt to round off a long history in a relatively short passage. Thus immediately after his reference to the period when the Walasma was tributary to Damot he jumps to the long drawn armed conflicts between the christian kingdom and the descendants of Umar Walasma. Cf. The Translations of the passage quoted in Cerulli, $\mathrm{E} .$, I' Itiopia Nediovale", cit., p. 284. Trimingham, op.cit., p. 59. The Arab historian simply passes over the crucial developments transmitted in the document published by cerulli in his Il sultanato di Scioa, and in the Chronicles of 'Amde-Sīyon. 
According to Masudi the Muslims in the Ethiopian region were still living as clients of the native inhabitanto in the middle of the tenth century. It Ibn Khaldun's description of the ruler of Ifat as an autonomous vassal chief, tributary to the king of Damot, provides another stage of development in the political status of Islam in the area. By the second half of the thirteenth century, a chain of Muslim commercial settlements and principalities had already been established along the major routes from Zeila to the interior of the Ethiopian plateau. The most important among these were the principalitieg of Ifat and eastern Shewa. Both Maqrizi and the chronicle of the Walasma dynasty give a Quraysh or Hashimite origin for IUmar Walasma.

1. Les praires d'or, III, p. 34. Cf. also supra., pp.96-97

2. Apart from the royal chronicles of the Christian kingdom our knowledge of the seven luslim "states" in the region mainly comes from Al'Umar's work, later almost completely reproduced by Maqrizi with some additions. Recent investigation has brought to light the short chronicle of the Walasma Dynasty of Ifat and Adal of which the translation was first published by Paulitschke and later by Prof. Cerulli with many useful notes and additions. A stili more recent find has been the chronicle of the socalled "Sultanato of Shewa" edited and translated also by Cerulli. On the other six "states" mentioned by ald'Umari and Maqrizi - Dewaro, Bali, Hadya, Arababni, Sharkha, and Dara - we still have no additional material. All of these placea, except Arababyi, are later mentioned as outlying provinces of the kingdom in the royal chronicles.

3. Maqrizi, op.cit., p. 17. Cerulli, "Documenti arabi per la storia d'Etiopia", cit., p. 43. It is interesting that Al-iUmari does not mention the Arab origin. According to Ibn Said (1214-74) "Ia population de Vefat est 
According to Naqrizi the ancestors of 'Umax Walasma first settled in Jabara (or Jabarta) a region which he says belonged to Zeila; they gradually moved further inland and occupied Ifat also. But Maqrizi gives us no information on the rulers before 'Umar Walasma; nor does the chronicle of the Walasma dnasty, despite the long genealogy it gives for 'Umar, who in fact assumes the characteristics of a legendary figure.

The traditions of the "Sultanate of Shewa" take its origin back to the end of the ninth century, ascribing it to a ruling house of Arab origin, this time fror the family of the Mahzumi Khalid b. 'Al-Walid. Its annals

/Footnote 3 cont. from pervious page très-mélangée", Aboulfeja, Géographie, tr. Reinaud, M., Vol. II, 1848, p. 229. For Ibn Khaldun the Walasma family belonged simply "à la même race (i.e. Habasha) ... islamisme à une époque que nous ne aaurions designer", op.cit., p. 108. Cf. also supra, p.101,n.l

1. Maqrizi, loc.cit. Ibn Sald says that Ifat was also called Djabara, Aboulfeda, loc. cit. For the general connotation which the term Jabarti later acquired, see Bruce, I, 'lravels to discover the source of the Nile, London, 1790, Vol. II, pp. 8-9. Trimingham, op.cit., p. 150 notes 1 and 2 .

2. He lived for 120 years, and ruled for 80 . He had 300 sons and 360 daughters, Cerulli, "Documenti arabi", cit., p. 43.

3. Cerulii, "Il Sultanato di Scioa", cit. pp. 15-16. Cf. also supra $p$. n. The specific meaning od Shewa as appliea to this Muslim principality is very uncertain. In Christian documents the name applied to the whole 
before the middle of the thirteenth century consist only of an incomplete record of successive reigns. After 1234 its history describes continuous internal conflicts among the different branches of the ruling house until 'Umar Walasma gives it a coup de grace in 1285 by finally annexing it to his own kingdom of Ifat.

/Footmote 3 cont. from previous page

plateau south of the Wenchit-Addabay gorge and extending as far south as the Awash river. There is nothing tangible to show that the luslim "Sultanate of Shewa" ever included any of the districts in the highland area west of the edge of the plateau. All the identifiable place names in Prof. Cerulli's document were still Muslim in 'Amde-Siyon's reign, Ibid., pp. 25-32. And in that period they clearly referred to the hot lowland areas east of the Shewan plateau where the "Sultnate of Shewa" must also be sought. For Al-'Umari "Shawa" was one of the "mother cities" of Ifat together with Bīqulzar, Sime, and Adal, op.cit., pp. 8-9. By the time he wrote (I342-9) it cannot have referred to the Shewan plateau which was securely in the hands of 'Amde-Sîyon and Seyfe-Ara'd. Among the different contingents that joined Gragn at Biqulzar his chronicler mentions a group recruited from a liuslim tribe called Shoa together with those of Hargaya, and Gidayah, Futuh al Habasha, tr. Basset, p. 173. In the Ethiopian Chronicles Hariaya and Gidayah are mentioned in reference to Muslim districts east of Awash and Dewaro, cf. Perruchon, J., Histoire des guerres d'Amde-Siyon, pp.283,318, 321 Les Chroniques de Zar'a Yareqod, cit.. p. 166. Guidi, I., "Le canzonl geTez-Amarigna", cit., p. 63, x. Probabiy the Muslim tribe of Showa also referred to the same region. Hore interesting still, a district of Scioa is mentioned among the other Adali districts of Sim, Nagab, Gidaya and Dakar in a document about the sixteenth century, CeruTI, E. "Documenti arabi", cit., p. 57, and n.6. 
The motive behind the actions of the Walasma was clearly to consolidate the conflicting interests of the Muslims into a strong political power in the area. Before this attempt at a united Muslim political front the nature of the penetration of Islam was still essentially commercial and the small "Sultanates" were conterminous with the trading interests of each. The internal conflicts among the different family groups in the thirteenth century do not represent a period of decline of Muslim political power, which was still in its early stages. This was only inherent in their competitive trading concerns in the interior. The policies of the Walasma were directed at this essential weakness of Islam as a political force in the Ethiopian region. Looked at in another way, 'Umar Walasma was doing in the Muslim communities exactly what Yîkunno-'Amlak had just accomplished in the Christian kingdom, and is is more than a coincidence that the military and political activities of both were in full swing during precisely the same period of time. Ifat was evidently resplonding to the revival of the Christian kingdom and its growing involvement in the south. As it

1. A chronological study of some of the events that took place in the two communities suggest this. For instance: Yîkunno-'Amlak became king in 1270. Marriage relations between the reigning sultan of Shewa and a daughter of the Walasma are contracted in 1271. The Walasma's first visit (probably hostile) to Eastern Shewa happened in 1277. His oon burnt what appears to be the capital of the viahzumite sultanate in the same year. The deposed Mahzumite ruler took refuge in Yikunno-'Amiak's court in 1278/9. cf. Cerulli, op.cit.. pp. 11-14. 
happened, however, this Muslim bid for political supremacy in the shewan region came rather too late in time and the initiative was soon lost in favour of the Christians. In the early part of his reign, Yīkunno-'Amlak was friendly not only with the local Nuslims, but also with the rulers of Yemen and Egypt. A letter he wrote to Sultan Baybars (1260-77) of Egypt, asking for a new bishop, reached Cairo in 1273/4 accompanied by a coveriag letter from the then ruler of Yemen, Al-Malik al-Muzzaffar (1250-95), through whom the message had been sent. After the usual humble protrstations Yīkunno-'Amlak declared his friendly sentiments to all Muslims :-

"Tous les musulmans qui viennent dans notre royaume, nous les protègeons, et nous leur permettons de voyager dans nos Etats à leur guise."I

The letter also sugge日ts that there was an earlier exchange of messengers in which the Mamluk Governor of Kug had sent an envoy to smhara where he was taken ill at the time of writing. Yīkunno-'Amlak apologises in adition for not having sent "the ambassadors" back as soon as he would

1. Mufazzad, op.cit., P.0. XIV, pp. 384-385. Maqrizi, Histoire des sultans mamlukes de l'Egypte, tr. Quatremère, vol. I, I partie, 1840, p. 122, n. 151. Abdul Aziz alKhowayter, A critical edition of an unknown source of the life of ai-Malik al-Zahir Baibars, Ph.D. Thesis (London University) 1960, vol. II, pp. 8I5-816. 
have liked, because he was engaged in a campaign elsewhere. Finally Yīkunno-'Amlak informs the Egyptian ruler that his large army included a hundred thousand Muslim cavaliers and a still greater number of Christians. This number is almost certainly an exaggeration, but the essential part of the message - that his troops included some Muslims - is not hard to accept.

In the later part of his reign, however, Yíkuno'Amlak was definitely taking offensive action againgt the Muslims. This was partly a result of the failure of his mission to Cairo, which was largely due to the apparent lack of full co-operation on the part of the ruler of Yemen. Yîkunno-'Amlak had sent his envoys, charged with the letter to Baybars, via Yemen. He expected that the ruler of Yemen would send them on to Cairo as soon as possible and also facilitate their return with the new bishop by the same route. Yíkunno-'Amlak promised to send the presents to the sultan of Egypt, usual on such occasions, upon the arrival

1. E. Blochet thinks this may be a reference to envoys previously sent by Baybars to Ethiopia, cf. Mufazzal, op.cit., p. 384, n.3. It was in Baybars' time that Egypt took a nore decisive action against Nubia, and the sultan took a special interest in ensuring the safety of the DahlakSawakin-Aidab-Kus route. Yikunno-'Amlak contacts with the governor of Kus, and Baybars must be seen against this background. Cf. Al-Khowayter, op.cit., Vol. I, pp. 283-285, Vol. II, p. 498, p. 580I

2. In an Ethiopian MS. at the B.M. there is a representation of Yíkuno-'Amlak seated on his royal dais and surrounded by kuslim ambassadors and servants. The inscription reads: "Muslims and slaves", Wright, Catalogue, cit., Or. 503, ff. $75 b-76$. 
of the bishop in Ethiopia, through the good offices of the ruler of Yemen. The latter, however, detained the envoys at his court, alleging that he would have to ask for the authorization of the sultan before sending them to Cairo. He then sent the king's letter to Baybars together with his own request for permission to send the envoys also to his court. This is clear from Baybars' reply to Yīkunno-'Amlak :

"Quant à la demande de I'evêque, que nous $\mathrm{y}$ voyons formulée, personne n'est venu à notre cour pour nous entretenir de la part du roi sur ce sujet, de telle sorte que nous ignorons entièrement ce que vous attendez de nous. Bour ce qui est de la lettre du sultan al-Malik alMuzaffar, elle nous est arrivee, nous expliquant que ce souverain a reçu du roi d'Abysoinie une lettre et un courrier, qu'il a, gardé auprès de sa personne, jusqu'au moment ou il a répondu a sa lettre.ni

It is not known if this reply ever reached Yikunno-'Amlak. We only find it sent back to Cairo in 1288 enclosed in another letter from his son and successor, Yagb'a-Sīyon (128594). From this second letter it is clear that Yīkunno'Amlak did not succeed in obtaining the bishop he asked for. Yikumo-'Amlak resented the serious limitation Imposed upon him by the fact that he was dependent on the goodwill of neighbouring Muslim states, even for the religious needs of his kingdom. This feeling contributed to

1. Mufazzal, op.cit., p. 386. Maqrizi, Histoire des sultans mamlukes, loc.cit. 
to his growing anti-Muslim activities and probably led to armed conflicts also. His son's letter referred to these hostilities from which he was clearly anxious to dissociate himself :-

"...mon père... était enemie des musulmans... Pour moi ... je ne ressemble nullement à mon père; mais je protêge les musulmans, dans toute l'etendu de mon royaume"r

Yīkunno-'Amlak'g policies were directed towards creating a united kingdom, militarily and politically dominant throughout the whole Ethiopian region. This would give him the necessary control of the lucrative trade of the Muslims in the interior and eventually ensure their complete dependence on his kingdom. This would, in turn, make its bargaining power vis a vis the sultans of Egypt much more effective.

In the shewan region his policy took the form of active political intervention in the local rivalries of the Muslim princes. In one such conflict Dil-Marrah, the Mahzumite sultan of Shewa, whowes also the son-in-law of the Walasma, escaped from his enemies and took refuge at the court of Yīkunno-'Amlak in December - January 1278/9. He apparently remained there until his return in April -

1. Conti Rossini, "Marco Polo e l'Ethiopia", in Atti della Reale Istituto Veneto, Vol. 99, 2a partie 1940, pp. 10241028.

2. Quatremère, Et., Ilémoires géographiques et historiques gur l'Egypte et sur quelques contrés voisines (recueilils et extraits des Mss Coptes, Arabes etc. de la Bibliotheque Imperiale) II, 1811, p. 268. 


\section{4}

May 1280. Probably enraged by this unpatriotic act of his son-in-law, Walasma sent his son Ali to joln hands with Dil-Marrah's local rival, Dil-Gamis, to fight against another prince Abdallah b. Ganbah and to resist the possible counterattack of Dil-Marrah from the Christian court. At the beginning the league failed in both these missions: Abdallah succeeded in taking power for a short time and DilMarrah was able to return to Abut in Shewa. Dil-Marrah was probably accompanied by a few Christian troops on his way back and was able to resist Ifati hostilities for three years. By then, however, the Walasma himself had come to Shewa once more and has assumed full powerd in the region. He led what appears to have been punitive expeditions against many areas, in one of which Dil-Marrah was captured and executed in May 1283.

The ruler of Ifat now began consolidating his power against Shewa. In July - August 1285 he captured all the contending Mahzumite princes and massacred them to a man. In their place he nominated a certain Mr(?) and returned to Ifat feeling assured that, with the removal of the traditional rulers, the last vesti es of Shewan resistance to his power were destroyed once and for all. He was

1. Cerulli, E., op.cit., pp. 12-13 and pp. 16-17. 
soon disappointed in tis. No sooner did he return home than Mhz himself led a rebellion in an attempt to regain Shewan independence. The Walasma invaded Shewa once more, and furiously pillazed the country and its allies of Gidaya and Haddimorra. It appears that this determined move on the part of Ifat to control all the Muslim regions brought about much local resistance and it was necessary for the Walasma to send campaigns against each. Mora, Adal, Hobat, Zatanbar were each attacked and occupied. The predominance of Ifat in the Muslim regions was now talking shape.

After the return of Dil-Marrah to Shewa from his court it is not clear what Yîkunno-'Amlak's role was in these local conflicts. It is, however, unlikely that he could have been indifferent to these events in Shewa. The fact that the chronicles of Shewa found it necessary to record his death strongly implies that the king had always maintained a close contact with developments in the south. Yagb'a-Sīyon began his reign on friendly terms with

1. As will be seen below, Al-iUmari reporta in the first half of the fourteenth century this predominance of Ifat among the Muslims in the Ethiopian region as a whole, and in the corridor between Zeila and Shewa in particular. It is very likely that the emergence of Ifat as a strong power started with these early actions of the Walasma against his neighbouring luslim principalities. cf. Al-'Umari, op.cit., p. 5.

2. Cerulli, op.cit., pp. 13, 19. 
1

the Muslims. As mentioned above, he confirmed this to the sultan of Egypt and requested him to hold a similar attitude towards his Christian subjects :-

":.je protège les musulmans, dans toute l'etenâu de mon royaume; et je désire que le sultan notre maitre en use de meme a l'égard des chrétiens de ces états, afin qu'une amitié inalterable règne entre nous deux, et se soit cimentié par des ambassades mutuelles." 2

Yagb'a-Șīyon had a Christian (Egyptian ?)

secretary, called Daud ben Azz, who wrote his letters for him in Arabic and had the title of "visir du roi". He was thus in close touch with developments in the Near East. Very little internal (Ethiopic) material for this reign is as yet available, and the king's name is only barely mentioned in the lists of kings. However from his letters to the sultan, to the Patriarch of Alexandria Abuna Yohanneg (1262-8; $1271-93$ ) and to the Ethiopian community in Jerusalem, he emerges as one determined to maintain friendly

1. His father died in 1285. His letter reached Cairo in 1240 only five years after his accession to power, and it may have been sent from Ethiopia even earlier. cf. also supra, pp.

2. Quatremere, op.cit., p. 268.

3. Ibid., pp. 270-271.

4. This is the first time we have an official royal message to the community. This in itself indicates that the king was able to command considerable goodwill among the Muslims. 
relations with the Muslims both at home and abroad. His envoys to Cairo were led by an Ethioplan Muslim called Yusef Abderrahman who died in Cairo. On his death another member of the delegation whom the Arab chronicler calls "an Abyssinian" assumed the position of ambassador and submitted to the sultan both the letters and the presents sent by Yagb'a-Sĩyon.

This policy of co-operation with the Muslims was not, however, a renunciation of Yİkunno-'Amlak's intentions of makilig the Christian kingdom the strongest single power in the area. In fact, as we have seen from his letter to Qalawu, Yagb'a-Siyon was giving a new dimension to the growing power of his kingdom by posing as the protector of his fellow Christians in Egypt. That he could do this with sufficient confidence only less than five years after his accession to power shows how much the prestige of the kingdom had been enhanced in the momentous reign of his father. This special concern for the Christiang of Egypt, which Yagb'a-ȘIyon initiated, would henceforth be invoked time

1. This probably means a Christian Abyssinian. That Yuse was also Ethiopian ig suggested by a cousin of his who vent a note to Cairo about Yusef's death from Aidab where he had just dieembarked on his way back to Ethiopia from Mecca. Cf. Quatremere, loc.cit.

2. These consisted of a eunuch and "une pique dorée servant en guise de lampe", ibid., pp. 268, 270-271. 
and again by his descendents in their relations with both Egypt and their Muslim subjects and neighbours at home. It is possible, however, to detect a gect deal of internal weakmess in Yagb'a-SIyon's unreserved declaration of friendly sentiments towards the Muslims in his letters to Cairo. The policy of strong Christian offensive against Damot and the Muslims in the Shewan region was seriously interrupted by the intermal conflicts following the death of Yîkunno-'Amlak. These dynastic problems only came to an end with the accession to power of WİIm-Re'ad (1299-1314) ${ }^{1}$ which introduced a new period of protracted hostility between the Christians and the Muslims.

\section{It is apparent that this started with a deter-}

mined Muslim offensive against the Christian districts on the eastern borders of the shewan plateau. A certain Sheikh Muhammad, also called Abu-Abdallah, is reported to have gathered a huge following in 1299 in an attempt to lead a Jihad against the Christian kingdom. Wĩdim-Re'ad intervened, we are told, by intriguing through his agente in the Sheikh's camp, and manaced to persuade many to forsake the

\section{Supra, pp.133-5}

2. Mufazzal, Histoire de Sultans Nanlukes, ed. and tr. Blochet, in PO, XX (1929), pp. 56-58. Cerulli, E., "I'Etiopia Medievale in alcuni drani di Scrittori Arabin, in RSE, III (1943), pp. 281-284. 
cause of the sheikh. Faced with these mass desertions, Abu-Abdallah had to conclude an honourable peace with the Christian king :-
"...le seigneur de l'Ambara avait envoyé une ambassade au Sheikh Abu-Abdallah, et il lui avait concedé plusierls districts frontieres de l'Abyssinie, formant un territoire, ou lui et ses compagnons pouraient s'établir, ž la condition formelle qu'ils n'exigeraient rien de plus du prince de l'Amhara, lequel s'engagait à leur donner ce dont ils avaient besoin jusqu'a les satisfaire entièrement, et qu'ils reconnâit- raient sa suzerainté." 1

We are not told exactly where the camp of the sheikh was. The only definite thing that can be said from the text about the centre of the Muslim movement is that it was east of the Blue Nile. The Christian king sent his envoys to Sheikh Abdallah "du côté du Nil". It appears that the

1. Mufazzal, ㅇ‥ cit., p. 58.

2. The name of the Sheikh may also give an additional clue to the area of the conflict. In the district of Kesem, on the eastern edge of the shewan plateau, there is still a locality known as Abdallah. The Church of St. George there is called Abdalla Gijorgis. This is most probably the area where wídin-Re'ad allowed the sheikh and his followers to settle. It fits the historical topography of the period very well. In the hostilities of 1332 a certain Abdallah was killed in Adal. The Christian Chronicler refers to him as "their ruler whom they revere like a bishop" Perruchon, Histoire de guerres, cit. p. 422. This took place only tliree decades after the attempted Jihad, and in the reign of Widim-Re'ad's son and immediate successor. Al-'Unari also had an informant in Cairo whom he calls, "le pieux Cheikh 'Abd Allah-ez Zeila'i", op.cit., p. 3 . 
incident represented a further stage in the consolidation oi the power of Ifat. We have already seen that the Walasma had unified the Iuslims of eastern Showa under his own leadership about 1280. Encouraged by the internal difficulties of the descendants of Yīkunno-'Amlak, they were now making a bid for the control of the shewan plateau also. Nevertheless, although the story had a Muslim origin, Sheikh Abu-Abdallah's adventure shows the essentlal weakness of Islam as a political force. Abdallah's followers displayed very little unity of purpose, and the Christian king had a great influence in the rank and file of the Muslim commity. The incident also indicates, however, Wídim-Re'ad's internal problems which did not permit a more decisive solution to the new Muslim challenge. Both Wỉim-Re'ad and Sheikh Abu-Abdallah concluded their agreement of 1299 from a position of relative weakness. It is most likely that, in the military engagements that must have followed the disclosure of Abdallan's plans, the two parties reached a stalemate which could only be decided by the conclusion of an agreement. This is indeed what is implied in Nufazzal's own passage :-

"... ils avaient envoyé du côté du Nil des missions pour arrêter les termes d'une 


\section{convention, et cette situation s'était} prolongee pendant six mois."1

We have no further information on Wídìm-Re'ad's relations with the Muslims after this incident. It seems, however, that in the following fifteen years of his reign, he had considerably improved his position, and that his control of the Shewan plateau had become secure. This is quite clear from the relative ease of military superiority which Amde-Sĩyon enjoyed from the very beginning of his remarkable reign.

'Amde-Sïyon inherited the military and political problems of the turbulent reigns of his imnediate predecessors. These included the final conoolidation of the powers of the new dymasty in all the Christian provinces; prourames of expansion into the Agew districts in the north-west, the kingdom of Cojja, in the west, and Damot in the south-west; and the more important struggle with the ruslims in the east and south-east.

A state of uneasy peace with the Muslims seems to heve existed at the time of 'Ande-Sīyon's accession to power. One of the most important reasong for Christian-Muslim conflicts was the need for the kingdom to ensure a free and

1. Mufazzal, loc.cit. 
unmolested passage of its nationals or agents to the Red Sea and beyond. This had already created the difficulties between Yikunno-'Amlak and the ruler of Yemen. The rame consideration motivated the attempt to create a spirit of co-operation based on mutual respact between the Muslims and the Christian kingdom in the reign of Yagb'a-síyon. The Muslims had always enjoyed an almost complete monopoly of long distance trade in the whole region. Sometimes they acted as the agents of the christian kings, sometimes as independent traders. In either case Muslim rulers were masters of the areas through which the main trade routes passed. This technical dependence of the Christians on the service and goodwill of the Muslims was easily liable to be used for political purposes especially in times of hostile relations. This appears to be the immediate reason which sparked off the first major military encounter between 'Ande-Șiyon and the ruler of Ifat.

'Amde-Sĩyon complained that Haq ed-Din, the ruler of Ifat, had arrested a certain subject of his called TítEyintay, who had probably been proceeding on a mission to the coast. He answered this offence with an all-out attack against Ifat and the Muslim regions in the south. Taken by

1. Perruchon, op.cit., p. 332 (tr.). 
itself the Tíleyintay incident was a miror one. The king himself describes Haq ed-Din's Christian captive as nore of his least servants". But it touched a sensitive chord in Christian-louslim relations in the area, and precipitated a series of military encounters which changed the balance of power in the Horn of Africa in favour of the Christians for more thar two centuries.

At this time 'Amde-STIyon was at Shagura, a place in the immediate neighbourhood of Ifat, probably to the north-west. He marched south and attacked Ifat, which aeems to have been quite unprepared for the encounter. The Christian army scored an easy success; they pillaged the country and sacked the town of Ifat itrelf. 'Amde-Síyon's description of this town gives an impression that it was a great centre of trade and Muslim political power :-

"...mon armée est venue me rejoindre et a ravagé (Ia grande ville) que l'or nompe

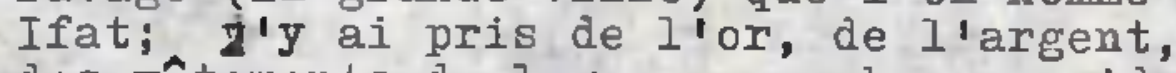
des vêtements de luxe, en nombre considerable, de I'airain, du fer et du plomb en abondance." ?

The implications of this description are remarkably gimilar to those of Ibn-Said's description of the same town in the

1. Ibid., loc.cit., n.l. and p. 339 (tr.). Cf. also Gedle Abekerezum, ed. and tr. Conti Rossini, pp. 25-26 (text). Segura is here mentioned as being near Diror in Ifat and zega. The saint was travelling to Tigre from the south.

2. Perruchon, op.cit., p. 332 (tr.). 
thirteenth century wich confirms its position of great importance as the citadel of Islam in the region :-

"Ie palais du roi a étè bâti sur une colline; il en est de même de la citadelle. La ville est à une grande distance de la mer; elle oe trouve à l louest par rapport a Zeyla ${ }_{1}$.. ses habitants professent I'Islamisme .... ${ }^{1}$

It was here that 'Umar Walasma had consolidated his power and extended it over the other luslim principalities from Shewa to Hubat, near present-day Harar, in the last years of the thirteenth century. Its destruction was a major blow for Islam and opened the way for a more effective Christian control of the districts to the east and south-east.

After his signal victory over Ifat 'Amde-siyon continued on his path of success by sending his troops to the other Muslim establishments in Kulgore, Gĩdeye, Kubat (Hubat ?), Fedīsē, Qedīsē, Hargay, Bíquizar and eastern Shewa beyond the edge of the plateau. The reference to the burning of "strong forts" in these places confirms the respectable stage of development reached by these Muslim settlements at this time. These early advances of 'Amde-Sīyon do not seem, however, to have resulted immediately in a direct control of the conquered places.

1. Aboulféda, op.cit., p. 229. 
Iike other engagements at the time, they were largely occasions for plunder and a show of force. But they were an unmistabable pointer to later political developmenta, and their immediate result was to make the military might of the kingdom more closely felt by the distant Muslim districts.

The implications of this Christian success were clearly understood by the Muslims, who immediately organized a strong resistance which at first seemed to reverse the situation. They rallied around Haq ed-Din's son, called Deradir. The new leader furiously attacked the southerneastern districts of the kingdom with what appears to have been a large army consisting of Werjîh pastoralistg of eastern Shewa and the regions east of the Hawash.' AmdeSïyon himself bemọns his own defeat which followea in no flattering terms to himself :-

"The people called Werjih and Gebel, who are experts in killing and war, came to fitht me from the confines of Fingete to the frontiers Bíqulzar. From the river of Hawash to Zebir (were) also Muslims. And the land of the Christians was destroyed, and the land of ziga and Menzih. All these leagued agrainst me and surrounded me."3

It is not clear for how long this military superiority of

1. Haq ed-Din may have lost his life in the previous hostilities.

2. Cf. supra, pp. 81-83

3. Perruchon, op.cit., p. 333 (tr.). 


\section{0}

the Muslims lasted. The Christian chronicle which is the only source for these hostilities, reports that 'Amde-Sīyon soon resumed his victorious position and later developments confirm it. Deradir himself was captured and killed. This probably resulted in the immediate disbanding of the largely tribal Muslim forces. The morale of the resistance was seriously damaged and it appears that for most of the period before the advent of Sabr ed-Din, 'Amde-siyon's adversary in 1332, Ifat was ruled alternately by a series 1 of usurpers and military adventurers. This state of affairs may have been promoted by the increasingly more direct intervention of 'Amde-Sĩyon.

One of the earliest campaigns of 'Amde-Sijyon was conducted against Damot and Hadya. It took place in 1316/7 A.D. and the king commemorates his success in a contemporary note in an early Ethiopic manuscript at the library of the island monastery of Haiq :-

1. The chronicle of the Walasma Iynasty has eight short reigns between Haq ed-Din and Sabr ed-Din, only two of which belonged to the grandsons of 'Umar Walasma. The origin of the rest is not given. Maqrizi does not even mention these eight intervening reigna, most probably because of the unstable political conditions into which Ifat had fallen at the time. It also seems to be the reason why he assumed too early a date for Sabr ed-Din's accession to power; he also makes him die at a very advanced age, Maqrizi, op.cit., pp. 17-18. Cerulli, "Documenti arabi per la storia dell'Etiopia", cit., pp. 43-44. 
"( In 1316/7) I went on an expedition .... and God delivered into my hands all the people of Damot, its king, his princes, and all his officials. And of the peoples (of the king of Damot) I trassported innumerable men and women to another area. And after that God gave me all the people of Hadya, innumerable men and women

These early victories had given the king a great source of wealth and manpower in the rich interior south and south-west of the River Awash. At first the king's control of these areas seems to have been minimal and limited to levying occasional tributes from the local rulers. This appears to be the case with Hadya in particular. Al-'Umari mentions Hadya as one of the "seven Muslim states" in the Ethiopian region placing $1 t$ west of Bali. It is not clear from his work when exactly luslim influence became predominant in Hadya. The Christian report of 'Amde-SIyon's successful campaign in Hadya about $1316 / 7$ does not at all imply that the king was fighting against lifuglim troops. Al-'Umari's "Muslim state of Hadya" may have been in fact a pagan kingdom in which a growing number of Muslim merchants had been settling; they had probably also collverted some of the local people. But it does not seem that in 'Amde-Siyon's time the rulers of the country were as

1. The Four Gospels, MS (IM), Haiq, f. $25^{\mathrm{b}}$.

2. Al-'Umari, op.cit., pp. 15-17. 
1

yet Muslims. It is quite clear, however, that the influence of the Muslims in the area was very strong, and they used it to underinine the consolidation of Christian power there. Just belfre 1332, 'Amde-Sỉyon led another expedition against the kingdom of Hadya to offset such hostile activities.

According to his chronicler, the ruler of Hadya, called Amano, refused to come to the king's court and submit the usual tributes. He was encouraged in this by a Muslim "false prophet". 'Amde-SIyon's response to this was swift. He led his army into Hadya, pillaged the country, and took many prisoners including Amano. The Muslim preacher himself fled to Ifat." 'Amde-Silyon seems to have made a thorough job of his reconquest of Hadya which soon became an inportant source of manpower for the Christian army, of which contingents from Hadya would

1. Hadya is first mentioned by Ibn Said (1214-74), Aboulfeda, op.cit., p. 229. Although he specifically describes Ifat as wuslim in the same passage his reference to Hadya has no political or religious connotations. On the slave trade see supra, pp. Prof. Cerulli's article in which he discusses all the available historical and traditional material on Hadya is still the best on the subject, "Note su alcume popolazloni Sidama dell'Abissinia meridionale", in $\underline{\text { RSO }} \mathbf{X}$ (1925), pp. 599-610.

2. Perruchon, op.cit., pp. 286-287 (text). 


\section{5}

henceforth form a considerable part.

With Hadya and the regions immediately to the north and west under his control 'Amde-Șiyon was now within measurable distance of achieving his initial programme of controlling the inland trade of the ruslims. Ilhe reconquest of Hadya in particular dealt a hard blow to the slave-trade for which it had long been the richest single market. It was largely on this trade that Muslim activities in the area were based, and the effect was felt, not only by the local traders of Hadya and their immediate nelghbours, but by all the chain of Huslim settlementa as far as the Red Sea coast. Noreover, Christian power and influence was fast growing in the newly conquered regions, and it looked as if it would soon extend further afield. The future of Islam per se was threatened as it had never been threatened before.

The response of the Muslims to this new challenge was equally striking. Until now the different settlements had been operating largely independently of one another, and the attempt of Ifat to create a united Muslim front

1. Ibid., p. 293. Already in 1332 a contingent called Hadya was sent as part of the Christian troops to suppress a Felasha revolt in Wegera. 
had been only partially successful in its immediate neighbourhood, and even that had already been seriously damaged by the early successes of 'Ambe-Sijjoll. Now, however, the ground was ripe for a united action againgt the Christian intruder. 'Amde-Sīyon's dauntless campaigns in areas hitherto unknown to Christian troops further shook their sense of security, and made the need for a league even stronger.

Once again Ifat took the lead in the ensuing hostilities. Sabr ed-Din was the ruler of Ifat at the time, and he seems to have been at the centre of the new movement for which he was perfectly suited as the son of the great 'Umar Walasma. Although evidence is lacking to determine the intellectual or doctrinal content of this movement, there are references in the chronicles to religlous leaders helping in its organisatio. One of these is the "false prophet" of the Christian chronicler, who fled to Ifat on the Christian conquest of Hadya. He appears to have continued his hostile propaganda in Ifat also where he is represented as one of the advisers of Sabr ed-Din :-

"Ie faux prophete s'enfuit alors dans la province d'Ifat, ou il continua a propager ses doctrines errones ... Lorsque Sabr ed-Din... interrogea ce devin, il lui repondit : Le regne des chretiens est fini; leur royaume 
nous sera donné; tu régneras sur sīyon. Va livrer bataille au roi des chretiens, tu le vaincras et tu assujettiras son peuple. $" \perp$

There is also another religious leader referred to in the chronicles this time in the Adal-Mora region :-

"...leurs princes et gouverneurs furent rassemblés par un chef nomme Saleh, ayant le titre de Cadi, analogue à celui de pontife, que les priuces et les gouverneurs Yénéraient et oragnaient conme un dieu et

The Muslim league against 'Amde-Síyon had therefore assumed the characteristics of a Jihad. Its purposes were very ambitious and not limited merely to regaining the provinces reeently lost to the Muslims. It aimed at a complete takeover of all the Christian provinces in order to remove the Christian threat once and for all. It appears that the political and military moves of Sabr- ed-Din and his allies were extremely well planned.

Sabr ed-Din declared hostilities in the first 3

months of 1332. Together with the news of the Muslim

1. Perruchon, op.cit., pp. 287-288 (text) 335-336 (tr.).

2. Ibid., pp. 358-359 (tr.). Elsewhere there are passing references to Sabr ed-Din's religious programmes after his victories, pp. 328-329; and those of the "king of Adal", p. 363. Cf. also Sheikh Abdalla's religious movement, supra, pł $248-51$

3. Ibid., p. 327(tr.), where it is said that hostilities started in 516 Year of Grace, in the 18th year of the reign of 'Amde-Sijyon. 'Amde-Sĭyon's reign started in 498 Year of Grace, The Four Gospels NS (IM), Haiq, $f .25^{b}$. Yekatit, 516 Year of Grace is equivalent to 1332. 
risings in the east, 'Amde-Sïyon also received reports of rebellions in the northern provinces of his kingdom. It is not impossible that Sabr ed-Din deliberately cinose the timing so that 'Amde-Sỉyon's huge army could be diverted elsewhere. This in fact suited the grandiose intentions of the ruler of Ifat.

According to the chronicler, one of the earliest steps taken by him was to nominate his own Muslim governors for all the provinces of the Christian kingdom. He accordingly divided his army into three : the first part was to march due north to the province of Angot, the second due north-west to Amhara, and the rest led by himself was to march on Shewa, where 'Amde-Siyon was camping. 'AmdeBìyon was apparently warned of these plans and mace a swift move to frustrate them. He sent a large force to attack Sabr ed-Din and his army at their headquarters in Ifat before they could move to their several assignments. The mission had the intended result. The Muslim army was defeated, Ifat sacked once again, and Sabr ed-Din narrowly

1. Perruchon, op.cit., pp. 339-340.

2. Ibid., pp. 280-28I (text), 328-330 (tr.).

3. Ibid., pp. 288 (text) 336 and $n .1$ (tr.). Shewa here doubtless refers to the central shewan plateau where 'Amde-SIyon was camping. "... and to ascend to the country of Shewa", left out in Perruchon'g translation, clearly indicates the direction of the hostilities. 
escaped, probably to Dewaro in the south-east.

'Amà-Síyon sent some contingents of his army to the rebellious provinces in the north, and himself marched to Dewaro to follow-up the success of his troops in Ifat. He had more than one reason to march in this direction. Despite the religious and political overtones of the Muslim movement led by Sabr ed-Iin, the immediate reason for the hostilities in 1320 क was exactly similar to the Tì' eyintay incident at the time of Haq ed-Din. Sabr ed-Din's interference in the free movement of the $\mathbf{k i n g}^{\prime} \mathrm{s}$ commercial agents still held an important place in ' Sijyon's multiple grievance against the ruler of Ifat. 'Amde-Síyon's pre-occupation with the safety and freedom

1. Ibid., pp. 338-339 (tr.).

2. This is the first time we have a reference to Dewaro. Neither the chronicle of the "Sultanate of Shewa", nor that of the House of Walasma mention it. Al-immari later makes it one of the "Muslim states" in the region, op.cit., pp. 14-15. It occupied the north-eastern section of the Harar plateau throughout our period, Perruchon, Chroniques de Zara ya eqob, etc. pp. 15, n.7, 133, n.l. Futuh al-Habasha, tr. Basset, pp. 16, n.2, 30, 55. A small administrative district in central Farar still bears the name of Dewaro, Journal of the Ministry of Interior, Addis Ababa, Vol. II, No. 5, 1964, p. 6. It is probable that most of the inhabitants in the area were of Sidama origin, Cemlli, E., Studi Etiopici, I : Ia lingua e la storia di Harar, pp. 6-14.

3. Perruchon, op.cit., pp. $298,344$.

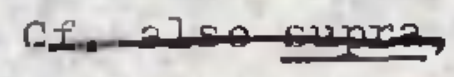


of the trade toutes was quite central to these conflicts, and was a prime factor in determining the direction in which the campaigns had to be conducted.

It will be remembered that soon after his victory over Haq ed-Din, 'Amde-SIyon had sent troops to other Muslim districts such as Kulgor, Gideye, Kubat, FediseQedíse, Hargay and Bíqalzar. Most of these areas were originally conquered and annexed by the Nalasma at the end of the thirteenth century and, having conquered Ifat, 'Amde-Siyon was also indirectly the master of these districts. It is hard to determine in precise terms the actual nature of the political relationship between the christian kindom on the one hand and Ifat aad its satellites on the other. Nevertheless, it seems clear from the chronicles that occasional tributes were collected through the ruler of Ifat and that the freedom of movement of both Christiana and Muslims in these areas was ensured. 'Ande-Sïyon's growing control of the interior and

1. Huntingford has recently proposed a different route for these campaigm, The Glorious Victories of 'Ama Seyon, 1965, pp. 36-38. This is completely uacceptable and it has been considered in a short review of the book in the Journal of African History, VII, (1966), pp. 512-513. Maxy of the place names and tribal Eroups referred to in the chronicle are also mentioned in other documents in connection with the area of the Harar Plateau, east of the Awash and Dewaro. Cf. supra, p. $237, n \cdot 3$. 
his military prestige in the whole Ethiopian region had also obtained for him the respect and willing co-operation of the rulers of the communities where Ifat did not have direct political influence such as in Dewaro and Sarka. This was important for the security and prosperity of trade in the area and was promoted by the Muslim traders who had considerable influence at the kins's court and in those communities. All these areas loy along the main routes to Teila which had long been the chief outlet of trade for the region. As long as the safety of these routes to his Christian and huslim agents were enoured, 'Amde-Síyon appears to have been satisfied with distant but friendly relations with these provinces. With the organisation of Sabr ed-Din's resistance, however, all these Muslim areas

1. 'Amde-Síyon's chronicler later accuses "the ruler of Sarka" "of having co-operated with the Muglims of Dewaro against the Christian army. The king led a punitive expedition againgt Sarka immediately after passing through Dewaro, Perruchon, op.cit., pp.436-437. According to Al-'Umari Sharkha was a small Nuslim state bordering on Hadya, op.cit., p. 17. Just like 'Amde-Sîyon's army Gragn's troops also raided Charkha after having passed through Dewaro, Futuh al Habasha, tr. Basset, pp. 190-193. It seems therefore that it was to the north-east of Hadya, and on the western borders of Dewaro. There is still a small adwinistrative unit called Shirka in eastern Arussi, Journal of the linistry of Interior, Vol. I, No.12, 1962 , p. 15 . 
were persuaded to join hands in an attempt to abolish the growing Christian control of their old commercial and political activities in the interior. Their success in this disastrous plan could have reversed the political situation back to its original position at the end of the thirteenth century and could have made the Christian kingdom entirely dependent on the luslim principalities for its commercial needs and its external commications in general. It was to solve these essential problems that 'Ande-SYIyon personally led his army to Dewaro, Mora, and Adal.

He fortified his mundane reagons for these campaigns with sufficient religious motives and could thus more effectively inspire his troops with a crusading spirit. "You fought for my sake in the past" he told them "and now fight for Christ". He doubtless had the full support of the leading churchmen of his kingdom in this. He specially received a message from a local saint, Amanu'el, which message the king quoted in his speech to his troops :-

"... le règne des musulmans est fini. Voilà longtemps que tu combats pour la royauté passagère, pour l'or, pqur l'argent et les vêtements de luxe; 2

1. Perruchon, op.cit., pp. 340-341, 358-363, 478-482.

2. Ibid., pp. 353-354. For a possible identification of this saint cf. infra, p. $365^{\circ}, \mathrm{n} .4$. 
The campaigns of 1332 were long and difficult. They were conducted in regions completely hostile and apparently uaknown to the Christian troops. The heat and the scarcity of water in the semi-degert regions, where the fighting largely took place, were intolerable to the highland troops, and the whole campaign was overshadowed with constant threats of mass desertions which were only averted by the king's determination and by the possible dangers that awaited such recalcitrant soldiers on the long way home. Despite these difficulties the campaigng were a brilliant success. Sabr ed-Din surrendered and was imprisoned together with his friend and ally, Hayder, king of Dewaro, and his own brother Jemaldin was appointed "King of all the Muglims". The other members of the league in Mora and Adal further to the east were similarly attached and defeated one by one.

I. Although most of the place-names mentioned in the chronicle cannot be precisely identified as yet, it seems clear that the campaigns followed more or less the same line as the Addis-Jibuti railway along the northern slopes and foothills of the Harar plateau. It carnot be determined here how far east 'Amde-Siyon led his troops, and it is uncertain where Bruce got the idea that the king actually entered Zeila. The chronicle, of which Bruce's chapter on the reign is a very free translation has "the king of Zeila" as one of the nembers of the liuslim League against Amde-Síyon. Bruce may have got the idea from this, cf. ibid.,"p. 359 (tr.) Bruce, op.cit. (II, 1790) p. 45.

2. Perruchon, op.cit., pp. 347-348, 351-355, 465-469.

3. Ibid., pp. 343-347.

4. Ibid.. pp. 346-347, 349-351, 354-363, 455, 470-474, 477- 
It appears that this superiority of the christian army lay in its characteristic organization, consiating of numerous contingents recruited from the different provinces of the kingdom, each with its own commander and under the united leadership of the king himself at the top. That the campaigne took place in distant, very hostile regions was also an important cohesive factor in 1332. The Muslim troops on the other hand largely consisted of elusive nomadic tribes of the area who were only suited to making occasional surprise attacks and immediately retreating into the bush after causing considerable damage in the Christian camp. This may have made the casualties very high among the Christians but it was not suited to pursuing the campaigns with the necessary tenacity and single-minded continuity which characterized 'Ande-Sĩyon's leadershlp. This weakness was further aggravated by the lack of essential unity in the Juslim league. This, indeed, seems to have been the key to 'Amde-Șiyon's success in those areas at a considerable distance from the centre of his kinedom. The political superiority of the kingdom, which was now an accomplished fact after these campaigns, also drew its
1. Cf. вupra, pp.161-75
2. Ibid., p. $349,356,358$. 
strength very largely from this basic disunity among the Muslims.

The political control of Ifat in the districts originally conquered by the Walasma - Mora, Adal, Gideye was only minimal. What seems to have resulted from the se early conquests was, at best, a loose confederation of the old trading settlements, with the ruler of Ifat at it head, largely because of his military prestige and his strategic position at the heart of the trade routes from Zeila to Angot, Amhara and Shewa. And much of this early political influence was already lost to Ifat with the growing importance of the Christian kingdom.

South of this east-west corridor from Zeila to Ifat, which was apparently limited in the south by the northern slopes of the Harar plateau, there throve another chain of liuslim commercial states along the routes from Zeila to the south-east, namely Dewaro, Sharkha, Bali,

1. Unlike Dewaro and Sharkha, Bali is not mentioned in the long list of liuslim areas whrchought against the Christian army in 1332. But the songs about 'Amde-Siyon refer to it as one of his conquests, Guidi, I. "Le Carzoni", cit. p. 53 ,etk. It is not clear when the Christian conquest was first undertaken, but by the time Al-'Umari wrote it was one of the vassal inslim kingdoms, very rich in its resources, op.cit.. p. 18. Maqrizi, op.cit., p. 15. The Webi shebelle separated it from Dewaro in the north, and Adal in the north-east, Futuh al-Habasha, tr. p. 68, n.3.; p. 132, n.1; p. 152 . Its original inhabitants were probabiy Sidama, of the eastern group, Cerulli, Studi Etiopici, Vol. II, 1938, pp. 1-2, 3I-32. 
Dara, Arababni, and Hađya.

The commercial nature of all theae states and their vulnerable positions vis à vis a strong power controlling the rich interior made complete unity among them an impossibleicieal. Faced with the considerable army of 'Amde-ȘIyon the initial warlike preparations inspired by religious and economic motives virtually flickered out of existence. The league was already seriously weakened at the beginning of the war when 'Amde-Siyon first attacked Ifat, as it appears, before the numerous "kingdoms" and "principalities" could send their share of the army to Sabr ed-Din. This does not seem to have been due to the king's strategic moves any more than to the deliberate delay on the part of Sabr ed-Din's allies. Even after the hostilities were iu full swing, divisions of interest

\section{Infra, $p \cdot 367, n \cdot 1$.}

2. Arababni is not mentioned as such in Christian or Muslim documents other than Al-'Jmari'g work. It has therefore been imporsible to susgest any specific identification. It is clear, however, that 'Umari placed it between Dewaro and Hadya, south of the Awash, in the region of what is today Arussi province, op.cit.. p. 15, and n.I.

3. The chronicler gives a long list of 16 "kings", and 2712 "princes" who fought 'Amde-Siyon after the defeat of Ifat, op.cit., pp. 359-362. 
seriously affected the efficacy of the Mulim strategy. These fraternal divisions oeem to have furnished 'Amde-Sīyon with sufficient allies among the Muslims themselves. This is clearly brought out throughout the struggle, and provides a more logical reason for his success in these distant regions. It will be remembered that one of the major immediate reasons for the conflicts of 1332 was the seizure of the king's commercial agents and their detention by Sabr ed-Din. These merchants were most probably Muslim themselves, and the incident was a clear case of jealousy by the more distant lifuslims of the large profits such royal agents were doubtless making, protected as they were by the political and military power of the king. It is unlikely that these Muslim commercial interests strongly organized around the Christian court were immediately disbanded on the declaration of war between the communities. These traders, like many of their Christian counterparts, were no religious crusaders and would, at most, only try to make the best of the two worlds. Rival members of the

1. Ibid., pp. $381-2$.

2. There seems to have been a strong buslim pressure group in the Christian court anxious to see hostilities discontinued and peace resumed. The earliest such instance is when the Queen was made to intercede for Sabr ed-Din on the occasion of his surrender. 'Amde-Siyon persistently refused to accept such half-measures; many requests were submitted to him during the course of the campaigng to return to his kingdom. cf. ibid., pp. 342-343, 347-348, 471-473. 
ruling families among them also seem to have offered themselves for nomination as new governors of the districts 1

conquered from their brothers. Such rivalry among local princes for the royal favour was not unique in the Ethiopian policy and it was the mainstay of the Medieval Empire as a whole. What is new in the case of Ifat and the Muslim provinces is that the principle was also being more boldly extended to then despite their former political and economic importance and the religious difference with the Christian kings. The dependent status of the Muslim provinces became an accomplished fact after the conquests of 1332, and by the time Al-iUnari was writing, this relationship between the kingdom and the liuslim states was definitely eatablished :-

"Bien que tous les souveraing de ces royaumes se trangmettent le pouvoir héréditairement, nul d'entre eux n'a autorité propre que s'il est investi par le souverain de 'Amhara. Quand I'un de ces rois vient à disparaitre et qu'il reste de males de a famille, ils se rendent tous auprès du souverain de 'Amhara et ils emploient tous les moyens possibles pour gagner sa favour, car c'est lui qui va choisir celui suquel 11 confiera le pouvoir .... car c'est lui qui a sur eux I'autorité suprêre

1. Ibid., pp.422-6. 
et ils ne sont devant lui que des lieutenants."I This policy of "divide and rule" was specially directed to the family of Sabr ed-Din, and was in the end responsible for the militant members of the family moving their headquarters from Ifat further to the east and continuing the struggle throughout the period.

'Amde-Siyon's conquests of 1332 did not bring about a permanent settlement to the Muslim question. It has already been mentioned that, soon after Sabr ed-Din's defeat, 'Amde-Sĩyon appointed his brother Jamaldin in his place. Jamaldin was himself in prison before he was elevated to this office. This probably means that there had already been a reaction in the Walasma family to the growing Christian dominance since Deradir's defeat, and the king may have consequently held some of the princes in custody either as hostages or virtual prisoners. Like many

1. Op.cit.. p. 19. Al'Umari (1301-49) wrote in the years between 1342 and 1349. But much of the material for his book seems to have been collected in 1329-37, when he assisted his father who was head of the chancery in Cairo. He mentions Patriarch Benjamin (1327-39) as one of his informants on Ethiopia (p.27). Much of his work is therefore contemporary with Amde-siyon and the relationships which he gives between the two communties were characteristic of that reign and the years immediately following it. By the time Maqrizi wrote $(1435 / 6)$ however, the situation was different, although he simply copies al-'Urari in ennumerating the seven "Iuslim states". As is clear from his own story of the subsequent wars, Ifat was no longer the centre of inslim resistance, and the other Muslim "states of Bali, Dewaro and Hadya were integral parts of the kingdom. 
individuals under similar circumstances, these princes reconciled themselves (at least temporarily) with their positions and could later be used as tival nominees of the king for the leadership of their people specially in times of hostilities. This may have been the case with Jamaldin as it would soon be with the son and grandsons of Sabr ed-Din. However, although he accepted the office of his brother, Jamaldin did not intend to be a passive agent for the king's expansionist policies. At first he requested him to relinquish his intentions of continuing war further east to Adal. When 'Amde-Síyon rejected this idea, Jamaldin began secret arrqngements with the king of Adal and his allies to take concerted action against the christian aring and attack them on two flanks. The plan failed because continued his hostile intentions, and 'Amde-sīyon found it necessary to imprison him once again and appoint another brother in his place on his way back from Adal. The immediate reason for his dismissal was his failure to bring to the king's court all those Christians living in the realm of Ifat who had been converted (or reconverted?) to Islam during the war. He alleged that "the son of fuis brother"

1. Ibid., pp. 362-363, 441 . 
prevented him from doing so. This presumably means Sabr ed-Din's son, and implies that although 'Amde-Síyon may have appointed his own governors over Ifat, the legitimate ruler was still Sabr ed-Din's son. This in fact seems to be the case since, according to both Maqxizi and the chronicler of the house of Walasma, Sabr ed-Din was succeeded by his gon Ali, who was the contemporary of SeyfeAr'ad, son and successor of 'Amde-Síyon.

$$
\text { Seyfe-Ar'ad }(1344-71)^{2} \text { continued his father's }
$$

military policies towards the Muslims. It appears that his was a policy of maximum intervention in the local affairs of Ifat, undertaken with the view of incorporating it completely into the system of his medieval empire. He went further in this even than his father, and his direct attempts at assimilating the ruling house of the Walasma created a split in the family, the more militant group moving further east and eventually emerging as the undisputed champions of Islam in the region.

1. Ibid., p. 479. Maqrizi, op.c1t., p. 18. Cerulli, E., "Documenti arabi", p. 44. It is significant that the chronicler of 'Amde-Siyon does not say what happened to "the son of his brother" when Jamaldin was cast into prison. This may very well represent the position of strength which the son of Sabr ed-Din enjoyed at the time vis a vis the wishes of the conqueror.

2. Bruce reports that Saye-Ar'ad had accompanied his father on the 1332 campaigns, op.cit., (II, 1790), p. 60. He probably misread the name of another son of the king, called Saf-Seged, who did take part in the Adal wars, Perruchon, op.cit., p. 400. 
Ali ibn Sabre ed-Din was, according to Naqrizi, nthe first to revolt from the customary allegiance to the 1 Hatin. Since llaqrizi does not refer to the war of 1332 this appears to mean that, after 'Amde-Sịon's military display of power, the ruler of Ifat and his followers showed no more resistance to the demands and political domination of the Christian kingdom until after the death of the conqueror himself in 1344. This was sound policy, since the damage done to the economic life of the Muslim regions in the long and desperate campaigns of 1332 , and the military presti fe of 'Ande-sĩyon himself, could not have been favourable to another series of hostilities. 'Ali therefore seems to have given a breathin space to his people before summoning them to help him reatore their independence. The accession to power of a new king was probably thought to have created the necessary conditions for a new rising. But Sayfe-Ar'ad took stern action against such a move, and popular feeling in Ifat was not favourable to Ali's rebellion since, according to Faqrizi, "they not only disagreed with his action but rebelled against it".

This popular complacency towards Christian rule in these Muslim regions, a thing which is lamented by both 
Al-'Umari and Naqrizl, was of course merely the result of the considerable loss they had already suffered in the earlier hostilities. It was also a result of the difference in the relative position of the two communties. For the Christians, led by their warrior kings, it was a period of conquest and expansion when they were almays on the offensive. Possessed of a huge army and a mobile destructive power, they had much less to lose in the conflict than their Nuslim counterparts, in whose territory the campaigns were conducted, with all their disruptive effect on the trade-routes and the marginal agricultural economy of these areas. The location of Ifat itself, which was its greatest asset in the thirteenth century, as the speerhead of Muslim expansion in this direction, was now becoming a liability, since physical continguity with the centres of the Christian power offered much scope for direct political and military intervention by the royal court. The overall result of these unfavourable circumstances doubtless fell heavily on the influential merchant clase which probably helps to explain their apparent reluctance to engage in further hostilities.

This strengthened Seyfe-Ar'ad's position. He

1. Al-'Umari, op.cit., p. 2. Maqrizi, loc.cit. 
imprisoned Ali ibs Sabr ad-Din together with his sons, except for Ahmad with whom the king was on very good terms. Ahmad was appointed governor of Ifat in his father's place. Eight years later his father, Ali, was set free and reinstated. He was apparently released together with his other cons and he nominated them to positions under himself. He excluded Ahmad from these nominations and the king's personal intervention was required for him to be given a district to rule. Ahmad was alienated from his family for his friendship with the Christian king. When he died, his children were looked upon as outcasts of the Walasma family, and excluded from local government posts.

A bitter struggle for power started between Ahmad's children on the one hand and their grandfather, Ali, and his sons on the other. Among Ahmad's sons were Haq ad-Din and Sa'ad ad-Din. The latter was actually born at the Christian royal court, and probably Haq ad-Din also accompanled his father during his sojourn there. But despite their father's apparent friendship with KIIg

1. Maqrizi, op.cit., p. 18. Maqrizi says elsewhere (p.27) that Ali was in prison for 30 years and died there in the reign of Sa'ad ad-Din. This would mean that he was imprisoned more than once. The Chronicle of the House of Walasma also gives him a long reigin of 40 jears which is, however, followed by that of Ahmad, who is given only two years. But we know from Maqrizi that Ahmad died before his father, and the succession was not as neatly legitimate as the official Walasma chronicler has it. Cf. Cerulli, "Documenti arabi", pp. 44, n.5, and 45, n.l.

2. Maqrizi, op.cit., p. 19. 
Seyfe-Ar'ad, both Haq ad-Din and Sa'ad ad-Din grew up to be the strongest champions of Islam in the Ethiopian region. Their father Ahmad represented a major success in the king's deliberate policy of dividing the House of Walasma. But it is ironical that the deadiest enemies of the Christian kingdom should have come from his branch of the family.

Haq ad-Din, the elder of the two of Ahmad's famous sons, was in fact the founder of the kimgdom of Adal as we know it in its protracted struggle with the christian kingdom from the last quarter of the fourteenth century right to the end of our period. Maltreated by his grandfather and his uncle, Mola Asfah, Haq ad-Din started his career as an outlaw. He apparently had a great deal of Islamic leaming, and, unlike his father, he was completely reluctant to use the goodwill of the Christian king in regaining his rights as the son of Ahmad. He took the opposite course, gathered a large following around him, and rebelled against his grandfather and his uncle both of whom he forced to identify themselves with the much hated Chrigtian kingdom. Accusing them of being the puppets and vassal chiefs of the Christian king, Haq ad-Jin assumed the sole leadership of militant Islam in the region. No doubt the religious leaders of the luslim communities approved of his action and probably encouraged many to join him. 
Thus surrounded by numerous followers Haq ad-Din declared war on his grandfather and his uncle. They asked seyfeArtad for Christian assistance against the rebel liuslin prince. In a series of military engagements Haqad-Din was victorious afainst the combined force of his relatives and the Christian army. His greatest enemy and uncle, Mola Asfah was killed in action, and the breach inthe family feud grew even wider. Haq ad-Din triumphantly entered Ifat where hig gradfather resided. He was magnanimous to the old man and confirmed him as titular ruler of the old city. However, he established his own capltal at another site, in "the land of Sawa", according to Maqrizi, "where he built the town of wahal".

It is very uncertain what haqrizi meant by "Sawa" in this context. Almost certainly, however, the name cannot be a reference to any of the districts of the Shewan plateau, which was definitely a Christian province at the time. Most likely, it was in the region south-east of Ifat, and east of the edge of the plateau, just like the "Sultanate of Shewa". Haq ad-Din's change of his capital was the

1. op.cit., p. 21 .

2. Supra, p.237 n. 3. It is interesting that Maqrizj Iocates Sa'ad ad-Din's centre of military activities at twelve days Journey fxor Bali, op.cit., p. 25. This is most likely a reference to the Harar region, and probably Wahal was also in the same general direction, as Dakar and Harar, cf. Cerulii, "Documenti arabi", pp. 42, …, 50, 32.1. Hutuh al Habasha, tr., pp. 24, 67. 
most drastic action taken by the luslims since active struggle with the Christians started, and the establishment of a new centre of Muslin resistance marked a new chapter in the relations between the two communities. Haq ad-Din inaugurated a new and uncompromising spirit of liuslim leadership in the area which was no longer satisfied with a mere local autonomy. The prime motive of his new move was to be completely independent of the christian kingdom. For this he needed to acquire much of the mobility and warlike character of the Christian kings themselves, and his emergence to power was a clear case of self-adaptation to the Christian challenge.

Accordinf to Maqrizi, Haq-ad-Din began his reign in about 1363-4 A.D. His advent to power was preceeded as we have seen, by a series of armed conflicts which seriously disturbed the process of quiet assimilation that formed the cornerstone of Seyfe-Ar'ad's Muslim policy. It seems

1. Ibid., p. 22 : "...he fell in the Year 776 A.H., the tenth year of his reign." His reign was probably considered as having started on his successful take-over of Ifat, although his grandfather was still alive util after his own death, cf. supra, p.278,n.1.According to the Chronicle of the Walasma Family "(Haq ad-Din) ...inizio il cammino della guerra santa per la via di Dio durante dieci ani". This description of his life tallies with Maqrizi's reports about him. But the chronicler gives his dates as 1376-86 A.D., Cerulli, "Documenti arabi", cit. p. 45, notes 2,3 and 4. These dates are too late by about twelve years since, according to liaqrizi, Haq ad-Din was already active in the reign of seyfe-Ar'ad $(1344-71)$. 
reasonable to suppose that it was also about this time that Seyfe-Ar'ad is reported to have taken desperate repressive measures against hiv Muslim subjects. The new upsurge of hostilities damaged the business and security of the merchants to such an extent that they appealed for help to the gultan of Egypt. In Egypt itself Muslim popular feeling had flared up against the copts, and relations between the two commurities were extremely 1 tense. This probably induced the Sultan and his court to give a special sense of urgency to the petition of the Nuslims in Ethiopia. Patriarch Marqos (1348-63) was summoned at once, and ordered to send a delegation asking the King of Ethiopia to stop his hostile actions against the Muslims :-

"At that time ruled a king called seyfe-Ar'ad ... He killed many of the Muslime who rebelled againgt him. There were also some whom he expelled from his country. These went to the king of Egypt and appealed to him. They told him : The King of Ethiopia destroyed the Iuslims : Some of them he killed, and some he made Christiang'. When the king of Egypt heard this he was greatly concerned for his religion and forced the Patriarch to send prominent persons ... (to) the king of Ethiopia.., about the remaining Muslims in his kingdom." 2

1. Quatremère, E., Mémoires géographiques et historiques sur l'EEypte, Paris 1811, pp. 250-257.

2. Budge, E.A.W., The Book of the Saints of the Ethiopian Church, 1928, pp. 177-179. Cf. Basset, Etudes, 1. 93. 
It is not clear what exactly were the results of the embassy, but the delegation, which conolsted of the Coptic Archbishop of Jerusalem and the Bishop of Ahnas, was not allowed to leave the country. Seyfe-Ar'ad doubtless realized that the Patriarch was only induced to send such a delegation by forceful means, and probably distrusted 1 them as a result. Armed hostilities continued with Haq ad-Din until he was killed in action in 1373-4 A.D., in the reign of Nêwaye-Haryam ( $1371-80)$, the sone and immediate successor of Seyfe-Ar'ad.

1. The reason given by the hagiographer for the detention of the delegates is the kine's "great admiration of their holiness". Cf. also infra, pp-463-5.

2. Maqrizi, op.cit., p. 22. Here liaqrizi calls the Christian king in whose reign Haq ad-Din lost his life, Dawit. But this is an obvious error since he himself says that the Muslim prince fought until the death of Seyfe-Ar'ad "who was succeeded by his son Dawtt." This no doubt refers to the immediate successor of Seyfe-Ar'ad who was also his son, but his name was Niweye-Maryam which liaqrizi took for Dawit ( $1380-1412$ ), probably because of the more widely known exploits of the latter. Professor Cerulli bases his defence of the dates of the Walasma Chronicle on this error of the Arab historian. Consequently he alters many dates given by Maqrizi and partly confirmed by Ethiopian sources - mamely, that Haq ad-Din began his reign in the days of Seyfe-Ariad; that he was killed in the reign of his immediate successor; that Sa'ad ad-Din who succeeded him died on the occasion of the Christian invasion of Zeila in the reign of Dawit, in 1402-3 A.D. He alters all these to establish the validity of the Walasma dates of which the reliability is also questioned sometimes by himself, Cerulli, "Documenti arabi", p. 45, notes 2,3 and 4 ; and p. 46 notes 1,2 and 3. Cf. also Gedle-Mergorewos, ed. Conti Rossini, p. 38 (text). Basset, R., Etudes, notes 90, 93. 
The power of resistance of the Muslim kingdom of Ifat had already been exhausted by the second half of the fourteenth century. A hundred years of continuous warfare with the much stronger Christian kingdom had sapped its economic and military strength, and it had been reduced to a position of a provincial governorate. As such it was no longer of much use as a platform for organizing and leading a political and religious warfare against the Christians. Haq ad-Din and his rilitant followers understood this, and they displayed a remarkable sense of realism in moving their centre of hostile activities away from the expanding Christian Empire. Thus on the one hand,

1. This transfer of political centre also represents, it seems, the vast displacement of peoples which always accompanied the expansion of the kingdom in every direction. In the Adal region, the hot lowland plains were largely inhabited, it appears, by the Eastern Kushitic group of people represented today by the Soho, Afar, Sonali and Galla. An interesting theory on the origin of these people has recently been proposed, Iewis H.S., "The Origins of the Galla ard Somali", in IAH, VII (1966), pp. 27-46. Most likely, the pastoral tribes to which references are made in the chronicles belon to this atock of people. It seems possible to detect, after 1270, a general eastward movement of a section of these people. The relative positions of the Harla in the fourteenth and sixteenth centuries seems to illustrate the general phenomenon. Ibn Said (1214-74) mentions the Karla as as important people in the Ethiopian region, Aboulfeda, Geographie. cit. pp. 225-226. Mufaddal (wrote before 1358) makes them one of the subject peoples of the Christians, Histoire des Soultang Niamlouka, cit. p. 386. 'Amde-Siyon's chronicler describeg tieir hostile action against the king's army in the region between 
Haq ad-Din's transfer of the centre of Islam in Ethiopia from Ifat to Wahlal, probably located much further to the south-east, represented a major success in the expansionist policies of the Christian hings since the days of Yíkunno'Amlak. But it also brought new darerg to the kingdom. Ifat had always been within a tolerable distance from the highland Christian provinces, and it was more vulnerable to swift punitive expeditions sent out againat it. But the kingdom of Adal which sprung up in its place, after the eventful career of Haq ad-Din II (1363-4 - 1373-4 A.D.), was very remote, and it had at its command an extremely mobile and elusive force, considerably more destructive than what Ifat could ever have at its disposal. It also held a strategic position on the major eastern route to Zeila. The region of Harar, where the new Muslim centre seems to have been established, was the focal point for all the trade routes from the eastern provinces of the Christian kingdom - namely, Ifat, Fetegar, Dewaro, and Bali.

/ Footmote I cont. from previous page

Bíqulzar and Dewaro, Hidtoire des guerres, ed. Perruchon, p. 435 In the time of Gragn, however, their habitat seems to have been east of Harar, Futuh al-Habasha, tr. Basset, pp. 149-150, 170-171. Azaiz and Chambara collected some vivid traditions about the early importance of the Herla in the Harar region, Cinq Annees de Recherches Archeologiques en Ethiopie, 1931, pp. 33, 35-36, 132-133, 139. Conti Rossini, "Postile al Futuh alHabasha", cit., pp.181-182.

1. For the first Haq ad-Din see supra, pp 2.52-5.

2. For these routes see supra, pp.152-9. 
Islam was the dominant religion in all these eastern provinces. This gave the successors of Haq ad-Din II additional power and influence within the boundaries of the Christian Empire itgelf. The political loyalties of the inhabitants were seriously divided, and often changed sides with every shift in the balance of power between the Chriatians and the Muslims. The new Muslim kingdom of Adal fully exploited thèse favourable circunstances, and begar to harass the long frontier lines of the Christian kingdom from the outskirts of Ifat in the north to the left bark of the Webi-Shebelli in the south.

\section{Haq ad-Din II was succeeded by his brother}

Sa'ad ad-Din who continued the aggressive policy of his predecessor. Both Christian and liuslim sources are unanimous in reporting his milltary successes against the Christian army in the early part of his reign. An Ethiopic hagiographical tradition relates that "a rebel called Se'aledin... gon of Hageledin, in the country of Adal..." fought against $\mathrm{King}$ Dawit whose army he easily destroyed.

1. Instarces of thif unstable situation in the froptier districts are abundant throughout our period, Perruchor, op.cit., pp. 433-434, 478-479. Les Chroniques de Zar'a ra'egob et de i3a'eda-Maryan, pp. 16-2I, 58-60, 45-46, 157-158. Conti Kossini, "La storia di lebna Dengel", cit. pp. $623,628$.

2. Ibn Khaldua, Histolre des Berberes, cit. p. 108. Maqrizi, op.cit., p. 22. Cerulli, "Document arabi", p. 46.

3. Gedie Merqorēwos, ed. Conti Rossini, p. 38 (text). The Christian scribe has slightly altered the names of the princes, and has considered Sa'ad ad-Din as the son of Iad ad-Din, presumably because he was his immediate successor. 
Ahmad al-Qalqashandi (d. 1418), the Egyptian encyclopaedist, also describes Sa'ad ad-Din as the rost successful Muslim prince in his resistance against the Christian kingdom which nevertheless maintained ito position as the strongest power in the Ethiopian region :-

"Ie Hati, roi d'Abyssinie, après l'arnée huit cent, conduisit les chrétiens dans la plus grande partie de ces provinces, gu'il devasta et dont il tua les habitants, brulant leur livres saints et obligeant la pluspart d'entre eux à se convertir à le religion chrétienne. Des rois musulmans, il n'est resté que Ibn Mismar, dont le pays fait face à liffle de Dahlaq et qui, sous l'obéissance du hati... lui paie un tribut fixe; et que le sultan Sa'd ed Din, spuverain de Zeila' et dependances, qui résiste et lui refuge obéissance; il y a des guerres contiguelles entre eux, et la pluspart du temps c'est, au sultan Sa'd ed Din que rest la victolre."2

The success of Salad ad-Din arter this Egyptian report were only short lived. The christian kingdom had taken up the challenge brought about by the emergence of the new state in Adal, and had considerably strengthened the military colonies stationed in the eastern provinces. The locations of King Dawit's favourite camping sites are particularly expressive of his special preoccupations with the Muslim threat from Adal. One of these sites was at a

1. $800 \mathrm{~A} \cdot \mathrm{H} .=1399-1400 \mathrm{~A} \cdot \mathrm{D}$. The Hati at the time was King Dawit (1380-1412).

2. Quoted in Gaudefroy-Demombyne's translation of Al-'Umari, Nasalik, cit., p. 37, 1.1. 
place called Tobya in north-western Ifat where the king apparently settled for a long period of time. Tobya lay in the most important pass which led to the highland Christian districts of Menz and Gishe, and further north into Amhara. The so-called Ifat route from Zeila passed through it, and it was precisely this road which Ahmad Gragn later followed on hil way to Amhare. Gragn actually camped at Tobya for a time. The other site where Dawit established his court was at $\underline{1} \mathrm{I} l \mathrm{q}$ in Fetegar, and it also looked towards the eastern frontiers. The Christian court was apparently maintained here for many years: Zer'a-Ya'qob (1434-68), and his grandson Eskindir (1478-94) were bork at Tilq, and Be'ìde-liaryam $(1468-78)$ also spent much of his childhood 3 there. King Dawit had also stationed numerous troops in

1. Les chroniques de Zar'a Ya'eqob et de Ba'eda llaryam, ed. and tr. J. Perruchon, p. 152. Dawit apparenty IIved here for a fairly long period ot time. The Chronicler geems to suggest this when he says: "Previously our King Dawit had lived in t.is land, and had planted many trees in it." Perruchor's translation, and his proposed pusctuation are imperfect.

2. A renegade Christian governor of Ifat defected and joined Gragn at Tobya, Futuh al-Habasha, p. 272, cf. also pp. 56-65.

3. Les Chroniaues de Zar'a Ya'eaob, cit., pp. 67, 91-92, 155. 
Bali, ${ }^{1}$ Dewaro and Hadya who fought against the Hualims with a varying degree of success. The elusive character of Salad ad-Din's army presented the settIed Christian military colonists with serious tehnical problems. Sa'ad ad-Dir only launched a series of raids which had little or no motive of actual Empire bullding such as characterized the early struggle between 'Amde-Șiyon and Sebr ad-Dir. His raiding parties descended upon the frontier districts by surprise and, when successful, they did considerable material damage on the local people. The liuslim troops never followed up their occasional victories with a more settled military occupation. By the time the local Christian troops were re-organized for another round of hostilities the

1. Maqrizi, op.cit., p. 24.

2. Ibid., p. 35. Zer'a-Yaqob's chronicler complains that the military colonists settled here - apparently before the king's reigh - and called ZameHasena, had become insubordinate, and often took refuge in the Muslim kingdom of Adal whenever measures of discipline were taken against them, Ies Chroniques, cit., pp. 45-46. other colowists were organized and settled there.

3. Sa'ad ad-Din also fought against "Amano the Hati's emir in Eadya", Maqrizi, op.cit., p. 23. This"is a reference to the hereditary king of Hadya. He was definitely Muslim himself in the reign of Zer'a-Ya'qob who married his daughter, Les Chroniques, cit., pp. 16, 59 .

4. Maqrizi, op.cit., pp. 23-25, 
Muslim army would disappear from the area taking away Its spoils, usually consisting of many heads of cattle and mumerous slaves. It was this characteristically nomadic aspect of the ruslim army that distinguished it from that of the Christians, and gave a special sense of urgency to the Adal question. King Dawit himself led his army into Adal on more than one occasion. In the final encounter Sa'ad ad-Din was pursued by the king's troops as far as Zeila where he was captured and killed in 1402/3. Ethiopic clerical traditions also make a reference to this victory as one achieved through the special favour of God.

This is the first Christian invasion of Zeila on record in our period. It is indicative of the pergistence of the struggle with Sa'ad ad-Din and of the degree of the resultant weakness of the Phuslim forces. With Sa'ad ad-Din's death, liuslim power in the Ethiopian region reached its lowest $\mathrm{ebb}$, and remained so for a lone time.

1. A land grant attributed to him refers to at least two such campaigns he personally led to Adal, Wright, Catalogue, cit., or. 481, f. $154^{\circ}$.

2. Maqrizi, op.cit., pp. 26-27. For the date see supra, p.283, n. 2 .

3. Gedle Samu'el, ed. and tr. B. Turaier, 1902, pp. 14-15 (text). Gedle liergorewos, ed and tr. Conti Rossini, pp. $40-4 I$ (text). 
But the ephemeral auccess of King Daw1t's army in Adal did not lead to a permanent settlement. Dawit's immediate successors - Tēwodros (Oct. 1412 - June 1413) and Yİshaq $(1413$ - 30) - persistently continued their father's aggressive policy towards Adal, and probably, both of them lost their lives there. When Salad ad-Din was killed, his sons had been exiled in Arabia, and Christian superiority was assured in Adal which was occupied for a time :"...the strength of the Muslims was abated. For the Hati and the Amhara having acquired this country settled in it, and from the ravaged mosques they made churches. The Muslims they harassed for the space of twenty years..."12

On the return to Adal of Sa'ad ad-Din's soms, the struggle

1. Ethiopic hagiographical material indicates that the body of tewodros was brought from beyond the Rive Awash for burial in Amhara, extract published and translated in Sapeto, G. Viaggio e Missione Cattolica fra : Mensa, Roma, 1857, pp. 437-438. Cf. also supra, p. Maqrizi reports that Yishaq was killed in action. op.cit., p. 39. There seems to be no reason to contradict the story. In the royal chronicles and other traditions for the period one can detect a deliberate attempt to suppress the violent end of Ethiopian kings in the hands of their enemies. Cf. infre, p.552, n.l.

2. Op.cit., p. 27 .

3. Maqrizi does not specifically state how long they had remained in Arabia. But he says that the Christian superiority lasted for twenty years after Sa'ad ad-Din's death in $805 \mathrm{A.H}$. He is also very consigtent, for the next date he gives is $825 \mathrm{~A} . \mathrm{H}$., when Sabr ad-Din died a natural death apparently after one year of armed struggle with the Christians settled in Adal, ibid., pp. $28-30$. 
started once again, and Fuslim raids and counter-raids followed one another in a monotonous regularity, right down to the end of our period. Of the Christian kings at the time Y'ishaq was most successful in his Adal policy. He had reorganized his army and the administration of his kingdom with the help of Egyptian advisors. It il apparent that he particularly made use of these new developments in his characteristic attempt to solve the Adal question once and for all. 2 Haqrizi seems to refer to this desperate policy when he describes a Christian attack against Adal "with the object of rooting out utterly all the Muslimg living in Abyssinia."

But Adal could never be an integral part of the Medieval Empire of Christian Ethiopia. This was unwittingly

1. Maqrizi, op.cit., pp. 6-8. Fthiopic traditions also seem to confirm Naqrizi's report about this, and a royal panegerist refers to Yishaq as follows: Your wisdom is that of Egypt, and your strength is that of India", Guidi, I., "I Canzoni", cit., pp. 54-55. It ig also interesting to note that Maqrizi's account of the king's pompous appearance on oolem occasion is remarkably similar to the story reported by Pietro, the Napolitan, in 1432, Le voyage d'outremere de Bertrandon de la Brocquiere, ed. Scheler, ch., Paris, 1892, p. 147. cf. also infra. p. 475 .

2. Maqrizi, op.cit., pp. 8, 3I. The royal songs also mention a number of tribal and place names in Adal, Guidi, op.cit., p. 57 .

3. Op.cit., p. 33. Cf. Yíshaq's similar policy towards the relasha, infra, $p \cdot 391-4$ 
prevented by 'Amde-Sīyon already in 1332, when he appointed a descendant of the Walssma as "King of all the Muslims". His own intention was to centralize Muslim affairs in Ethiopia under one person with whom he could deal more effectively, and a friendly member of the house of Walasma was, of course, most suited for the post. But this tremendously helped the process of the final emergence of the Sa'ad ad-Din branch of the family as a champion of Islam in the whole of the Ethiopian region. Haq ad-Din II and his successors had been successful in establishing complete independence from the Christian kingdom. Yet as the descendents of Walasma the price they paid for this was very high : by relinquishing Ifat as their traditional centre, they gave up all their advance positions, and their more direct political influence, in the interior. Ifat, the whole of Shewa, Dewaro, Hadya, and Bali were now integral parts of the Christian kingdom. The almost regular frontier conflicts and political intrigues, in which Adal was always involved, were no longer relevant to the Christian control of these very rich areas.

For a period of just over a century and a half after the establishment of the new dynasty in 1270, the

1. Perruchon, Histoire de guerres, cit. p. 301 
Christian kingdom underwent an intensive process of expansion throughout the Ethiopian region. In the south, with the early conquest of Damot and Hadya - the strongest political units beyond the fwash - the presence of the kingdom was strongly felt in the predominantly Sidama country of the basins of the Gibe, Gojeb, and Ono rivere.

1. The southern frontiers of the kingdom are more difficult to determine in precise terms. It is possible, however, to detect in the chronicles an increasing amount of knowledge about the Sidama region over the centuries. Most likely this represents a closer contact, probably also a more direct military control of the area. 'Amde-Síyon's panegyrist only sang of the king's exploits in Damot, Genz, Hadya, and Bali in this direction, Guidi, I., "Le_Canzoni", cit., pp.53, ete. In the case of king Yíshaq, a century later, mumerous recognizable tribes of the Gibe - Gejeb - Omo basia are listed, ibid., pp. 56-57. Zer'a-Ya'qob married a Hadya princess, and his chronicler ene entumerates many tribal groups in Hadya, Les Chroniques, cit., pp. 16-18. At one time, this kirg is believed to have established his court on the hill of Djibat which is part of the high ridge dividing the highwaters of the Gibe, and Gudru rivers, Annequin, G., "Notes on Djibat and Adadi Maryam", in AE, VI (1965), pp. 13-16. Zer'a-Yaqob still has an Important place in the traditional recollections of the people of this area, Haberland, E., "The influence of the Christian Ethiopian Empire on Southern Ethiopia", in Journal of Semitic Studies. IX, (1964), pp. 235-238. It is most likely that the chain of Sidama aristocracies in the whole of this area were originally formed under the stimulus of the Christian expansion, Conti Rossini, "Sui linguaggi dei Nar e det Chimira (Sce) nell'Etiopia meridionale", in RRAJ, Ser. 6, VoI. I (1925), pp. 612, 616, 633-636. Id.," II popolo dei Magi nell'Etiopia meridionale e il suo linguaggio", in Atti del 3 ' Congresso studi Coloniale, Vol. VI (1937), pp. 108-118. Ia. Etiopia e Eenti detiopia, 1937, pp. 369-371. 
In the north-west the Felasha country was gradually brought under Christian control, and King Yïshaq (1413-30) probably sent his troops in the country of the sof-called Shangilla west of Agew-Mĩdir in Gojam. These military conquests throughout the Ethiopian region opened up a vast field for the expassion of the church.

1. Inera, pp. 391-4.

2. Cf. Guidi, op.cit., p. 55. 
CHAPTER FOUR

$$
\text { EVANGEIIZATION (1249 - 1430) }
$$

The evangilization of the Ethiopian regton followed very closely the expansion of the Christian state. The fourteenth century, which wes marked by the maximum expension of the kingdom, was also the period when the Ethiopian Church exerted its pressures most on the pagan peoples in the area. The Shewan plateau, which had increasingly come to be the most important theatre for the military activities of the Christian army, also assumed a key position as the centre for propagating Christian teaching among the conquered peoples.

It is apparent that the presence of isolated Christian families in Shewa preceded the establishment of effective Christian political control of the area. These early Christian immigrants in Shewa apparently lived in a pagan country, under pagan chiefs. Despite the tendency in the hagiographical traditions to give them a long clerical background they were probably mostly lay Christians who were anxious to maintain peaceful co-existence with their pagan neighbours. 
They kept contact among themselves and with their distant kinsmen in Amhara and Tigre. Their long distance contacts probably gave them an advantage over their locally orientated neighbours, and many of these families appear to have lived a relatively comfortable life with numerous slaves and substantial farms. 1 Some of these communities probably built small churches in their respective areas. These churches were staffed by a handful of clerics, who provided the most primary religious needs of the Christian families. The long distance from the court of the Egyptian bishops, and from the centres of Christian learning in Tigre must have always kept the number of the clergy to a bare minimum. Some rudimentary teaching may have been given by very few local priests to their own children, who woild almost invariably succeed them in their clerical posts, and to some other children entrusted to them. 2 These meagre educational facilities may

1. Such traditions of material wealth are told about the families of many of the early church leaders, and they may not have been completely unfounded, cf. Budge, The Life of Takla Haymanot, pp. 28-30 (text). Gedle Anorewos, p. 67 (textl.

2. Budge, op. cit., p. 20. Gedle Filippos, p. 175 Gedle gewistos, Ms. Debre-Libanos, f. $44^{\mathrm{a}}$. 
have been strengthened from time to time by the arrival of clerical reinforcements from the north. ${ }^{1}$ Some of the more adventurous members of these early Christian communities may have also travelled all the way to Tigre in order to obtain a clerical education. On their return home they, no doubt, established their own schools among their relatives, whose children they helped to educate. 2 But such educational enthusiasm does not seem to have been a general characteristic of the Christians in the south and, before the advent of the new dynasty, the picture of the Church that emerges from a study of these early traditions is one of precarious existence. These early Christian settlers were no religious crusaders, and it would seem that in general they participated in the ordinary life of their

1. Gedle Anorewos, p. 68. Anorewos is here said to have been instructed by one Harankis who seems to have entered his parents' service.

2. Gedle Gewistos ff. 17-24. Here is given the tradition about the lifo of Hîwet-Bine-Besigon, great-grandfather of Tekle-Haymanot. He is said to have travelled to Aksum and Debre Gerima where he was educated. On his return he opened a school in Shewa. This tradition is almost certainly an attempt to increase the importance of the Saint(s family. But the essential part of the story, that some of the distant Christian settlers used the educational facilities of Tigre, is not minconceivable as a general pattern. 
pagan neighbours. Even the hagiographer(s) of TekleMaymanot inadvertently point to this conclusion in the story of his wild youth:-

"He learnt riding horses, hunting wild animals and using arrows and other implements .... And his arrow never missed, and was always smeared with blood".

They had reached a modus vivendi with their environment and were generally reluctant to disturb their amicable relations with their neighbours. The same conclusion emerges from the attitude of cautions opposition assumed by the older generation of Christian settlers against the more militant anti-pagan activities of the younger men in the traditions concerning the last quarter of the 13 th century. We have one such tradition in the story of the early life of Filippos of Debre-Asbo. His father is represented as punishing him for his hostile actions against a local witchdoctor, and he thus explained his position:-

"I punished you so that the people of this country may not kill you, and confiscate our belongings".?

This cautious attitude seems to have chara-

1. Budge, op. cit. p. 24 (text).

2. Gedle Fillippos, pp. 182-3. 


\section{0}

cterized the life of the Christian settlers in the south for many generations.

The province of Amhara was exposed to Christian influences much longer, and the Christians were clearly dominant by the beginning of the 13th century. Even there, however, the politically dominant position of the Christian Amhara does not seem to have been accompanied by a similar development of Christian learning and a Christian zeal for evangelization. As among the Christians of Shewa, there were only small secular churches serving the daily needs of the local congregation. The growing political importance of the Christian Amhara may have increasingly drawn to the church many of the non-Christian groups in the area. But even clerical traditions are lacking about any Christian centres of learning and monastic activities in the area until the middle of the 13th century. The cultural centre of the Ethiopian church still remained in Tigre, particularly in the centres of the monastic activities of the Nine Saints established over seven centuries before. The story of monasticism in Amhara and Shewa, and systematic evangelization of the newly conquered areas only starts with Iyesus-Mo'a of the island monastry of 
Debre Haiq.

Iyesus-Mo'a

Iyesus-Mio'a $(\mathrm{d} .1292)^{1}$ was born at Dahna

of a Christian family. Very little is said about his early life in his native land. He may have received some primary religious education in his home district as his hagiographer reports, no doubt with much exaggeration. 3 But the turning point in his religious career only occured when he decided to travel to Tigre in about 1242 and join the famous monastery of Debre Damos

1. The date of his death is given as 477 Year of Grace, The Four Gospels, MS. (IM), Haig, f. $24^{\mathrm{a}}$. He is said to have been 81 then, Gedle Iyesus-Mola, ed. and tr. S. Rur, in CSCC, Vols. 259-260, Script. Aeth. Tom. 49-50, 1965, p. 35 (tr.). The date is also given according to another system of calculation at 6786 Year of Creation, 402 Year of Grace, Ibid., p. 4l. This is equivalent to 1293 A.D. But I have given preference to the much earlier MS. of the Gospels. Prof. Cerulli's proposed corrections do not seem at all necessary, Cf. Ibid., pp. II-III.

2. The hagiographer locates this place in Begëmir Ibid., p. 5 Amde-Sijyon's chronicler speaks of a "Governor of Dahina" together with the "Governor of Mag", Histoire des guerres, ed. Perruchon, p. 293. Cf. also Supra, D. 54, n.1.

3. Ibid., p. 7 . 
of which the abbot at the time was Abba Yohanni. I

Iyesus-Mo'a was a young man of about thirty when he joined the monastry, and he was given arduous assignments by the abbot:-

"(Yohanni) ordered him ... to travel much (on the business of the monastry) ... and he thus travelled for a long time and by the will of God he returned to his master Abba Yohanni ... and delivered to bim the things for which he was sent ...".

Apart from thus "fulfilling the orders of his master" he devoted much of his time to learning and solitary contemplation. The most important art he acquired here was that of writing:-

"He learnt how to write and lived on his

1. Very little is known about him. There is a short hagiographical notice about his early life, Ibid., pp. 16-17. A still more uncertain tradition about him is that he is said to have been the 7 th abbot of Debre-Damo after Aregawi, one of the Nine Saints of the 6th c., Gedle Aregawi, ed. Guidi, I., pp. 85-86. This is chronologically impossible and it may be that by the time the Gedl was written many of his predecessors were forgotten.

2. Gedle Iyesus-Mo'a, pp, 10-1l (text). The translation (p. 9, and $n .1$ ) does not appreciate the practical aspect of Iyesus-iro'a's travels. It was usual in the monasteries for young novices to be given such business assignments on behalf of the community, cf. Gedle Filizppos (Bezen), ed. Confi Rossini, pp. 97-8. 
own (in a cell) on the precipice and wrote the Four Gospels there" . $^{1}$

His sojourn in Debre-Damo lasted about seven years after which he travelled south and settled on the island of Lake Haiq. His advent to Lake Haiq was a turning point for the history of monasticism in Ethiopia, and for the story of evangelization with which we are specifically concerned here.

It does not seem that Iyesus-Mo'a's final choice of Lake Haiq as a place of settlement was motivated by a need for a solitary retreat, as some traditions have it. His own Gedl transmits the tradition that a church dedicated to St. Stephen had already been built by an Aksumite king and an Egyptian bishop of his time four centuries before. ${ }^{2}$ For a long time before the advent of Iyesus-Mo'a the lake side region seems to have continued to be one of the centres of Christian population in what is now the rich district of Tehulederē. Besides Debre-Equiabhër and the island church, there were apparently other churches in the neighbourhood. Iyesus-Mo's himself stayed in a church dedicated to Saints Peter and Paul,

1. Gedle Aregawi, p. 86.

2. Gedle Iyesus-iuo'a, pp. 18-9 (text). Cf. also Supra, p. 69, n.1. 
apparentiy on the western shore of the lake, for six months before being admitted to the island. ${ }^{1}$ In the island itself lived Christian men and women clustered around the secular church of St. Stephen. Having a long tradition of royal foundation the island church may have been associated with the local Christian chiefs, and even with the power groups in Amhara claiming descent frow the ancient royal house of Aksum. Debre Damo itself where IJesus-ho'a obtained his monastic instruction in Tigre had always cherished its ancient associations with the Aksumite kings for which it was apparently neglected by the Zagwe kings.? It appears that Iyesus-Mo'a also found in Haiq a viable Christian commuity with respectable connections which offered tremendous possibilities for further development. Like many of the churches in Amhara and Shewa at the time, Haiq Estifanos was

1. Ibid., p. 22 (text).

2. Cf. Gedle Aregawi, pp. 71-73. Liany of the land grants to Debre Libanos of Shimezana in the Zagwe period make no mention of either Aksum or DebreDamo. No sooner was the new dynasty established by Yíkunno-Amlak than both these communities begin to assume particular importance, cf. Conti Rossini, "I'evangelo d'oro di Dabra Iibanos", cit., pp. 194-201. 
was insufficiently supplied with priests and deacons, and probably had no adequate schools of its own. This last need was now amply provided by Iyesus-Mo'a on his advent there about 1249 .

According to a tradition in his Gedl, the community in Haiq was so greatly impressed by his general conduct that they soon asked for his promotion as head priest of the island church. But apart from the monastic virtues of humility and pious devotion to the services of the church, emphasized by his late 15th century hagiographer, Iyesus-Mo'a's growing importance in the island community resulted very largely from his great learning which was unequalled by any of his contemporaries in Amhara. $\mathbf{A}$ living testimony of this is still seen in the precious folios of what is believed to be his own manuscript of the Four Gospels, which is one of the most treasured objects kept at the monastry of Debre-Haiq:-

$$
\begin{aligned}
& \text { "I, Iyesus-Mo'a, sinner and unworthy, an } \\
& \text { exile (in Christ), had this Book of the } \\
& \text { Four Gospels... written in } 465 \text { Year of } \\
& \text { Grace. I I... gave this Book to Stephen } \\
& \text { of Haiq". }
\end{aligned}
$$

1. The Four Gospels, MS (TM), Haiq, $f .23^{\mathrm{b}}$. The date corresponds to $1280 / 1$ A.D. This makes the MS the oldest Ethiopic MS. known. Its folios are full of precious notes of invaluable historical interest. 
This note is immediately followed by a list of many books left by Iyesus-Mo'a on his death in $1292 .^{\text {I }}$

The advent of Iyesus-Mo'a to Haiq opened new opportunities of learning for the Christians in Amhara and Shewa, and many appear to have taken full advantage of this. The first to do this were probably the young men in the local communities. Hirute-'Amlak, the future founder of the island monasthry of DagaEsțifanos in Lake Tana, was one of his early disciples.? Ze-Ijesus, who succeeded Iyesus-Mo'a as abbot of Haiq was apparently a secular priest, who had already settled

1. Ibid, $f .24^{\mathrm{a}}$

2. There is a note about Iyesus-Mo'a designating him for Daga Estifanos at the early date 237 Year of Grace, ibid; f.llb. The first figure of the date is almost certainly a mistake for the figure '4' and the date seems to be 437 YG. This is equivalent to $1252 / 3$ and it is quite possible that Hirute'Amlak was in Haiq then. His own Gedl is lost, But the traditions of Daga-Esథifanos also confirm his advent there: The Gospels of St. inatthew and St. Mark, MS. Daga, f.Ib; The Book of the Miracles of St. Mary, MS, Daga, end of IIS. Although nothing is said about Hirute-'Amlak, we know that there were monks living on Daga island already in the early part of the reign of Amde-Sijyon (1314-44), Gedle Yafqirenne-Egzi'i, pp. 32,'34. 
in the island even before his master's arrival. Many others who formed the nucleus of the followers of Iyesus-Mo'a were probably of the same provenance. But his fame must have spread throughout the Christian communities in Amhara and Shewa and many came to join him from far afield. Abba Begi'u, whose monastic ascetism is proverbial in Ehiopian clerical tradition, appears to have come from the region of Gỉim and died on the island before Iyesus-Mo'a. It was also at

1. Ze-Iyesus survived his master for only four years and was already dead at the end of 1296 A.D. The circumstances of bis death are curious. He lost his life somewhere outside the island "with his son Buruk", and a special permission of king WedimRe'ad (1299-I314) was required to bring their remains back to the island, The Four Gospels, cit. f.3a. Those years were marked by an internal feud among the descendants of Yikunno-'Amlak and ZeIyesus may have been involved. Descendants of his "daughter" appeal elsewhere for the restitution of land of which they were long dispossessed, ibid. f.268 . This picture of Ze-Iyesus as a man, probably of a more secular background and extremely familiar with local political conditions is completed by a note we have elsewhere about him relieving Iyesus-Mo'a of his administrative duties already before his death, Gedle Iyesus-Mo'a, pp. 31-2 (text).

2. I have been able to consult two MSS. of his Gedl: one at Daga (15th - 16th C. 1HS), another at Haiq (late 19th C. MS). His hagiographer claims to have been his contemporary Gedle Begi'u, MS. Haiq, $f .83^{\circ}$. The Gedl is as a whole of little historical interest. He was not an abbot of Haiq and is only remembered 
this crucial period that Tekle-Kaymanot of Shewa came to join the monastic school of Haiq.

\section{Tekle-Haymanot}

Tekle-Haymanot was born about 1215 at Șílaliss in Zorere, in what is today the district of Bulga. As we have seen above tradition derives his origin froll an ancient clerical family who had settled in Shewa for over ten generations. ${ }^{1}$ His own father is presented as having a priest who served in the church of Sillalish. He is also said to have given Tekle-Haymanot his first religious instruction and to have even taken him to the court of the Egyptian bishop, Qerilos, for ordination as a deacon while still a joung boy.? This is quite

/ footnote 2 cont. from previous page

for his monastic reputation. Conti Rossini's note on him should be revised, cf. Gedle Filippos (Bizen), p. 166. Cerulli has followed this, and has also added his own chronological contributions which should also be modified, Gedle Iyesus-Mo'a p. XV (tr.). That he lived and died in his master's lifetime is clearly given in his Gedl, MS. Haiq, ff. $85^{\circ}, 95^{\circ}$. It is also implied in Gedle IyesusNio'a, p. 49 (text).

\section{Supra, pp. $67-69$}

2. Budge, op. cit., pp. 20-2l. Cf. also, Conti Rossini, Il 'Gadla Takla Haymanot', p. 128, n. 5. Gedle Gewistos, ff.440-5Ia. 
possible in the light of our attempt above at a reconstruction of the small Christian communities of Shewa based on the early traditions. There also seems to be an additional factor that may help in unaerstanding the background of Tekle-Haymanot's later activities. Te have already alluded to the persistant traditions that strong anti-Christian manoeuvres were undertaken by the pagans in Shewa between the last years of the l2th and the first quarter of the 13 th centuries. In Tekle-Haymanot's Gedl and in related hagiographies of the Debre-Iibanos cycle these pagan activities are said to have been led by the legendary Motelami, King of Damot. ${ }^{1}$ The immediate effect of this reaction on the Christian communities in Shewa appears to have been disastrous. Churches were burnt down, and Christian homesteads destroyed. ${ }^{2}$ This must have created a great

1. Supra, pp. $230-1$.

2. Budge, op. cit., pp. 8-9. Gedle cewistos, ff. 4-5. It is probable that the traditional founder of the Zíqwala community, Gebre-Menfes Qidus, belongs to this early period. A hagiography, which is still unpublished, is available about his life and activities in Ethiopia. The date of its composition is very uncertain, Wright, ... Catalogue, Or. Fll. Conti Rossini once thought that it may have originally been written in the reign of King Dawit, "Appunti 
strain on the still modest position of the church at the time, and must have further weakened the religious life of the Christians. It is this picture of general decline of the Shewan church that seems to offer a reasonable background for the religious career of Tekle-Haymanot which finally resulted in the regeneration of the church in the south.

The Waldebban version of his Gedl explicitly states that he had already been ordained a priest, and had officiated as such in Shewa, long before he joined

/Footnote 2 cont. from previous page ed osservazioni sui re Zague", in PRAL, IV (1895), p. 444. Gebre-kenfes-Qidus is believed to have been an Egyptian who came out to Ethiopia in the reign of lalibela, Wright, op. cit., Or. Fll, ff. $2^{b}, 63^{b}-64^{a}$, F8-F9. Evangelical activities are attributed to him in the region of $\mathrm{Ziqwala}$ and immediately south of it is "the land of Kebd", Ibid., ff. 18-21. All these are very uncertain, and the saint is not at all mentioned in the traditions of Debre-Iibanos which became the dominant monastic group in the area after the 14 th $\mathrm{C}$. Frobably, Gebre-lienfes-Qidus_only represents the beginnings of Christian Zagwe pressure on Shewa, soon repulsed by local pagan reaction, which may also explain the uncertainties of the traditions about him. It is interesting to note that a place name, Lalibela, is reported by Gragn's Chronicler, not far from Ziqwala, Futuh al-Habasha, tr.. Basset p. 112 . 
Iyesus-lí'a in Haiq. ${ }^{1}$ But it is difficult to give much credence to these later hagiographical assertions of which the motive is clearly to show the importance of Tekle-Haymanot and to minimize his dependence on his monastic associations with Haiq and Tigre. But it is apparent that he joined Iyesus-Mo'a when he was already well over thirty years of age.?

Tekle-Haymanot's advent at Haiq is of great significance for the important role that his community of Debre-Asbo would soon play in the expansion of the church, particularly after his death in the 14th century. But despite later traditions that grew around his name, his own arrival at the monastic community of Iyesus-ino'a did not create a sensation, and his life in the island is not even mentioned in the contemporary notes of Debre-Haiq. These notes are not a complete record of every aspect of the island community, and this negative evidence does not at all invalidate the historicity of

1. Conti Rossini, Il 'Gadla Takla Haymanot', p. 104. The same point is also made in the Debre-Libanos version which describes (in even greater details) his alleged missionary activities even before joining Iyesus Mo'a. Budge, op. cit., pp. 25-59 (text).

2. Iyesus-hio'a himself came to Haiq in about 1249 and it seems that TeklefHaymanot joined him when he was already well established in the island and well-known in the area. 
Tekle-Haymanot's sojourn there. What it does is to underline his rather modest position in those early days and to offer a basis for a historical reconstruction of the gradual development of his religious career.

Very little is known about his life in Haiq, ${ }^{l}$ but he no doubt made use of his stay with the widely travelled Iyesus-Mo'a to improve his knowledge of the Scriptures, Church History, and monastic traditions. Contacts between Tigre and Haiq were probably frequent, and Tekle-Haymanot may have collected further information about the ancient centres of Ethiopian Christendom and the monastic communities long established by the Nine Saints. This appears to have increased his

1. I am adopting here his itinerary according to the Jaldebban version of his Gedl, Conti Rossini, op. cit., p. 107. The Debre-Libanos version, due to what appears to be a much later addition, relates that he stayed for 12 Jears with Beselote-Mika'el of Debre-Gol before going to Haiq, Budge, op. cit.. pp. 60-69 (text). But according to his own Gedl, Beșelote-Mika'el lived much later and was still a young boy at the time of Wedim-Re'ad in whose reign Tekle-Haymanot died at a very advanced age, Gedle Beselote-lika'el pp. 8-9. Gedle Iyesus Mo'a, which is a much later work than the Debre-Iibanos version of Gedle Tekle-Haymanot, also refers to Beselote-rika'el as the senior of Tekle-Haymanot. The passage which is strongly polemical also contains other anachronisms, Gedle Iyesus-Lo'a, pp. 28-3I (tr.). 
curiosity, and he decided to have a more personal experience of these places. After nine years in Debre-Haiq, therefore, Tekle-Haymanot left for Tigre. 1 At this stage he apparently concentrated on his own personal salvation, and does not seem to have been contemplating evangelical activities in his native land of Shewa. More than anything else, his departure from Haiq was motivated by a desire to make a pilgrimage to the holy places of Tigre, and even further to Jerusalem.? Tekle-Haymanot doubtless visited Aksum and the other monastic centresof the Ethiopian church; but it was at Debre Damo, Iyesus-Vio'a's old monastic school, that he finally settled. Iyesus-Mo'a's spiritual father, Yohanni, was still alive and welcomed him to his fold. Here again we know very little about his activities in this community. Tekle-Haymanot was now a middle aged man with many jears of monastic labour behind him. His origin in distant Shewa, from where he had long banished himself in the name of Christ, must have further enhanced his reputation among his

1. Conti Rossini, op. cit., p. 107; Budge, op. cit., p. 72 (text).

2. Gedle Aregawi, pp. 85-86. Tekle-Haymanot does not seem to have succeeded in going to Jerusalem, despite the apocryphal traditions to the contrary. 
fellow monks. This may have attracted many close friends and younger followers to him. This personal following may have substantially increased over the years, and it may be in this period that Ar'ayeneŞeggahu, Medhanine-Egzi' and Bertelomēwos joined him. 1

All the available traditions of the church are unanimous in attributing a great monastic influence totakle-Haymanot while he was still in Tigre, and they even make him personaliy responsible for the establishment of many communities. ${ }^{2}$ It is more probable, however, that such communities only developed later after his own return to shewa. It is important to appreciate, nevertheless, that the development of monasticism in Ethiopia was extremely personal in character, and a monastic leader with sufficient hagiographical and religious reputation could always draw man disciples. Monastic loyalties always transcended regional considerations. It was within this framework that Tekle-Haymanot could gather a number of followers around him in Tigre, where

1. Wright, Catalogue, Or. 769, $\$ .4$ : Budge, op. cit., pp. 74, 77 (text). Basset, R. Studes, pp. 10-11. 99-100.

2. Conti Rossini, op. cit., pp. 107-8. Budge, op. cit., p. 75 (text). Cf. also Gedle Aregawi, p. 86 . 
some of them remained. Each of them appears to have established his own community on Tekle-Haymanot's return to his native land of Shewa. The period in which he stayed in Tigre saw a tremendous revolution in the history of monasticism in Ethiopia in general. In the long period between the 6 th and the mid-13th centuries Ethiopian monasticism had always reyolved around the old establishments founded by the nine saints. Together with the secular churches which enjoyed royal or local princely patronage, they alone provided the cultural leadership which kept Ethiopian Christiandom alive. Apart from some individuals who may have abandoned their homes to wander freely in isolated woods and desert regions, no independent monastic communities seem to have been established before the middle of the 13th century. This age-old convention was now seriously compromised. We have already seen how Iyesus-Mo'a started his own community in distant Iake Haiq about 1249. In the north, Abba Dani'elof Debre-Maryam in Gere'alta, the spiritual father of Ewostatewos, was similarly developing his 
own community. ${ }^{1}$ It is this picture of an intensive monastic development at the time which explains the religious career of Tekle-Haymanot both in Tigre and back to Shewa.

Tekle-Haymanot returned to Debre Haiq before be finally went back to Shewa. His encounter with Iyesus-Mo'a on this second occasion is shrouded with uncertainties in the traditions, and has become one of the most controversial points in Ethiopian ecclesiastical history. The controversy basically revolves around the mutual claims of seniority later advanced by Debre Haiq and Debre-Libanos for their respective founders. As such it is of a relatively recent origin, and concerns the rules of investiture of monastic habits in the Ethiopian church.

Four elements constituted the essential parts of the Ethiopian monastic habits. These were the

1. Gedle Ewostatewos, ed. B. Turaiev, Fetropoli, 1905, pp. 7-8. Gedle Filippos, (Bizen), table facing p. 156. Conti Rossini, "I 'evangelo d'oro di DabreIibanos" in RRAL, 1901, p. 179. A parallel revival of Ethiopic literature is also seen in this period and is closely related with these monastic developments. The Ethiopian church was just beginning to share in the renaissance of Christian Arabic literature in Egypt, Conti Rossini "Il 'senodos" etiopico", in RRAI, 194.1, pp. 42-3. Cerulli, E. Storia della literatura etiopica, 1956, pp. 
Gemis, ${ }^{1}$ Qinat,? Qob ${ }^{3}$ and the Askēma ${ }^{4}$ which were formally acquired by the novice at different stages of his career. On the first occasion the novice was given the gemis and the ginat. Then after a further period of reexamination and preparations he was invested with the gob. The last and highest stage, that of the Askēma was only open to the most saintly and the most tried members of the commuity. 5 It appears, however, that these specific rules of gradual investiture were of a relatively recent date.

Most of the hagiographical traditions available for our period do not mention these different stages of

1. A long (cotton or leather) cloak worn by the monks. It is usually white in colour, but some monasteries prescribe yellow cloaks, cf. Alvarez, The Prester John of the Indies. p. 70.

2. The leather belt worn over the cloak. Guidi's definition is curious: "... Corda benedetta che il monaco mette al collo ...", Vocabolario AmaricoItaliano, Roma, \$901, Col. 283.

3. The head piece of a monk.

4. Adequately defined in Guidi, op. cit. Col. 445-6; Kidane-ield Kifle, Meshafe-Sewasiw iegis, p. 245. Almeida defines it in a slifhtly different manner, Historia de etthiopia Alta, BK, II. Ch. 18. Iyesusjo'a's alleged question to Tekre-Haymanot on his return from Tigre constitutes the best defintiion for the term: "O figliuolo mio, che é questo che ti sta sulla testa e sul collo? Dove I'hai trovato?", Conti Rossini, Il 'Gedle Takla Haymanot', p. 134.

5. Almeida describes the ceremony and the special prayers for the occasion, loc. cit. 
investiture and they seem to indicate that the monastic habits were conferred upon the novice on only one occasion:-

"Abba Tomas ... took the holy 'Askema' of the angels, and the ' $\mathrm{QOb}$ ' and the 'Ginat', and invested the monastic habits (upon Tekle-siyon)".I

In many of these traditions, however, even the terms used to describe the four vestments are inconsistent and only the more generic term of "monastic habits" is usually given. 2 This inconsistency of language in the description of such essential elements of Ethiopian monastic life clearly indicates the relati vely recent date of the institution of the rules of gradual investment. The controversy in the traditions we have about Iyesus Mo'a and Tekle-Haymanot is also very largely a result of this uncertainty of language. The following passage can best illustrate this point: "There came Abba Iyesus Mo'a and said to

1. Gadle Tekle-Sijyon, Add. 16257, MS.B. N. f. $6^{\mathrm{a}}$. The saint probabiy lived in the 15th century. The 'Qemis' is missing in the list here and in many other such passages. Even in Almeda's time the 'Qemis, Qinat and Qob were granted at the same time. Only the 'Askema' required a special occasion, loc. cit.

2. Gedle Yafgirenne-Egzi' p. 16. Gedle Filippos (DA), p. 190. Gedle Aron, p. 126, Gedle Beselote-ikika'el. p. 14. Gedle Anorewos, p. 69. Gedle Samue'el

(7aldibba) p. 2 . 
Abba Yohanni, 'Father, confer upon me the Askema of the monks', and he conferred it upon him. And Iyesus-Mo'a stayed (at Debre-Damo) for a long time ... He then went and entered a place called Haiq ... without receiving the Askema and the कृob..."1

The same contradiction is repeated in the life of Iyesus-Mo'a himself. ${ }^{2}$ The two versions of the life of Tekle-Haymanot deny that Iyesus-Mo'a had received the 'Askema' and the 'Gob' from Yohanni. These symbols of monastic excellence, we are told, were only conferred upon him by his own former disciple Tekle-Haymanot on his return from Debre-Damo. 3 This is also partly accepted by Ijesus-Mo'a's hagiographer who, however, contests that Iyesus-mo'a had already been invested with the 'gob' and it was only the 'Askema' which was later given to him by Tekle-Haymanot at his own request:"Son menachismétait toutefois parfait et il ne lui manquait rien à l'exception de l'Askema', et I'Askema' il la reçut des

1. Gedle Aregawi, pp. 85-6.

2. Gedle Iyesus-kio'a, p. 21. Here again Yohanni is said at one place to have already given him "the 'Askema' and the 'Qob' of the angels"; then IyesusMo'a is said to have left Yohanni "without receiving the 'Askema'", p. 37. This indicates an imperfect and direct borrowing by wesus-Mo'a's hagiographer (late 15th century) from Gedle Aregali.

3. Conti Rossini, on. cit., p. 108. Budge, op. cit., pp. 71, 76-7. 
mains de son fils Tekle-Haymanot qui fut

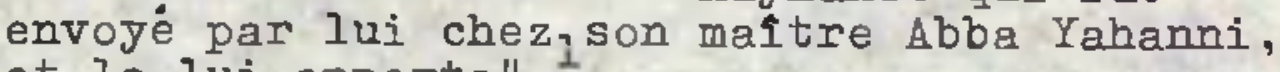
et la lui apporta".

There is however no satisfactory reason to believe that Tekle-Haymanot conferred even the Askema on his former master. Iyesus-Mo'a's profession as a monk was already complete even before Tekle-Haymanot's first arrival from Shewa in Debre Haiq. Already before his departure to Tigre many including himself had received the monastic habits from Iyesus-10'a. This is accepted by all the traditions. Only the Gedle Aregani partially contradicts this, when it reports that Tekle-Eaymanot arrived at Debre-Damo in Tigre "dressed like a soldier". This is however contradicted with its own assertion that he had previously stayed with Iyesus-Mo'a who had already been conferring monastic habits on his disciples. ${ }^{2}$ It is most unlikely that Tekle-Haymanot could have left for Debre-Damo without first receiving the monastic habits from Iyesus-

1. Gedle Iyesus-Mo'a, Pp. 38-40 (tr.) for the whole story. The singling out of the 'Gob' here as the minimum stage of "perfect ordination" strongly suggests that the rules that Almeida described in the 17th century were already taking shape in the late 15th century. In the quotation above I have altered the translator's "Scapulaire" for the more precise "Askema".

2. Gedle Aregawi, p. 85. 
Ho'a. This Debre-Damo tradition seems to be the original source of all the controversy, and was apparently invented by an over-zealous scribe of the monastery to stress the historical fact that both Iyesus-Mo'a and Tekle-Haymanot derived their monastic origin from the Eouse of Abuna Aregawi. The story was then enxiously adopted hy the descendents of Tekle-Haymanot because it brought them one step nearer to Debre-Damo. The Gedle Iyesus-Mo'a itself was only composed much later and thus partially accepted the tradition. Nevertheless, no satisfactory evidence seems to be available to show that Tekle-Haymanot did in fact confer any of the monastic habits on Iyesus-Mo'a. Based on an earlier but confused source in the hagiographical records of Debre-Damo, this tradition was only too readily adopted by the House of Tekle-Haymanot in an attempt to give a secure basis for the growing dominance of Debre-Libanos of Shewa in the 15th century. This vital process of the transformation of hagiographical traditions is more than confirmed by a similar attempt elsewhere to show the seniority of Filippos of Debre-Asbo 
over his contemporary Aron of Debre Daret. ${ }^{l}$ It is also quite apparent that this controversy about Iyesus-Mo'a and Tekle-Haymanot was further complicated by applying to the 13th century the rules of gradual investiture which apparently developed in Ethiopian monasticism only later. 2

Tekle-Faymanot's stay at Debre-Haiq was not long and he soon moved further south to Shewa. This is a major landmark in the history of organized mission work of the Ethiopian Church, and it is significant that according to the traditions it was in fact IyesusMo'a who persuaded Tekle-Haymanot to return to his native land. Fully equipped with much learning and monastic reputation Tekle-Haymanot returned to Shewa

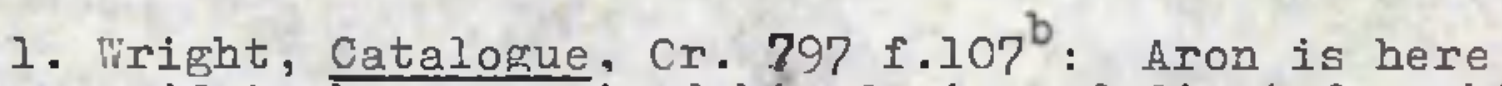
said to have received his Qemis and inat from his accepted master Beșelote-liki el, and his $60 \mathrm{~b}$ and Askema from Filippos, cf. also or.769, MS. Bli. ff.540-55a. But since we have the Gedl of each of these monks we can control the alterations in this case.

2. No chronological study of the development of these rules is possible here mainly because, as we have said above, the hagiographical traditions available do not seem to have been affected by these rules in general. The question is only raised in cases of important rivalries among the major monastic groups. But it seems most likely that in the 15th century, when these controversies were raised about IM and TH the rules of gradual investiture as described by Almeida were taking shape. 
as an emissary of the Church which was at the time undergoing an important period of revival in Tigre and in Amhara. ${ }^{I}$ His own special role was to transmit this spirit of revival to the Christian communities of Shewa, and, for the first time in the history of the Church there, to establish a permanent centre of Christian learning and monasticism through which the Church would soon make its influence felt on the pagan people of Shewa, Damot and Gojjam. Many of the evangelical achievements in Shewa and Damot attributed to him personally seem, however, to be apocryphal, and were almost completely the work of his disciples in the eventful years of the 14th century.

At first Tekle-Haymanot probably went to his own native district of sỉlalish. ${ }^{2}$ His return after a

1. cf. Conti Rossini, op. cit., p. 108. The DebreLibanos version is not clear about the role of Iyesus-Mo'a in asking Tekle-Haymanot to go to Shewa and characteristically attributes it to Abba Yohanni of Debre-Damo, Budge, OD. cit.p. 76 (text).

2.... It is unlikely that Tekle Hayman fol given in both versions of his Gedl, Conti Rossini, op. cit., pp. 108-9. Budge, op. cit., pp. 78-8 (text). This was a route frequented in the 15 th century when the Gedl was first completed probably in the reign of Yishaq, Conti Rossini, op. cit., 123. Frecisely in this reign Abba Gyorgis of 
long absence in the holy places of Tigre and Lake Haiq must have created a great sensation particularly among his own relatives. For Tekle-Haymanot himself the relative position of weakness of the Church of Shewa may have greatly impressed him and it seems that he soon took it as a personal challenge. This was also a period when the prestige of the Christian Amhara was keenly felt in Shewa, particularly since the establishment of the Amhara Dynasty by YikunnoAmlak in 1270. These new developments opened tremendous possibilities for evangelisłlCwork and Tekle-Haymanot set out preaching in the surrounding area of the Shoan Plateau.

His early preaching probably involved some travelling but it does not seem that he himself moved out of the central area between Șilalīsh and Grarya,

/ Footnote 2 cont. from previous page.

Sagla seems to have used this route on his way to Debre-Iibanos, Gedle Abba Gyorsis. MS. Haiq, f.27 . The Debre-Iibanos version takes TH even further west to Debre-Dada in Saint, although this was apparently established only after his death, Budge, op. cit.. pp. 77-8. It is most likely that $T H$ himself followed a route much more to the east, : Haiq - Menz - Tegulet - Keteta - Sílalísh where there was an almost unbroken chain of Christian settlements. There was also a tradition that this route was used in the 13 th century. Gedle sewistos, ff. 54,57 . 
where he finally settled. ${ }^{\perp}$ Before he established his monastic community at Debre-Asbo he probably moved from place to place in Shewa for sometime. In many of these districts which were still dominated by pagan worship his activities may have brought him into conflict with many of the inhabitants of Keteta and Gïrarya. The memory of these conflicts must have then furnished the scribes of Debre-Libanos with the basis for their fabulous tales of Tekle-Haymanot's miraculous activities culmulating in the conversion of Mote-Lami. But Tekle-Haymanot himself seems to have been specially pre-occupied with the spiritual stagnation of Shewan Christendom, and he particularly addressed himself to his fellow Christians.

The intellectual content of his teaching has been given little attention by his hagiographers, and

1. Both versions of his Gedl tell us of his evangelisłic exploits beyond these areas, especially in Damot, Conti Rossini, op. cit.. pp. 105-7. Budge, op. cit. , pp. 43-59 (text). But they both attribute this to the period before his travels to Haiq and Tigre. This is almost impossible in the cultural milieu of Shewan Christiandom at the time. The Saint must have also been in his sixties when he returned from Haiq. This may have been the reason for his hagiographers to transfer his mission work to his more youthful days. His movements were limited to the Shewan plateau after his return from Haiq, Conti Rossine, op. cit., pp. 108-22. Budge, op. cit., pp. 79-87 (text). 
we have as yet no way of studying this in detail. But one can imagine that, fresh from his long and edifying monastic experience in Tigre and Háq, TekleHaymanot found Christian life in Shewa much more complacent towards its pagan environment. His early teachings were therefore probably aimed at removing this state of indifference in the religious life of the Christian communities. He exhorted his audience to be much more rigorous in the observance of the prescriptions of the church, and he set an example for them by establishing a completely different community of his own with its own rules and regulations. In the wider Christian context this was not specially original of Tekle-Haymanot. But it greatly impressed his fellow Shewans, who had had no direct experience of monastic life before. Tekle-Haymanot offereā a spiritual challenge to the Christians, a new religion to their pagan neighbours, and a new life and monastic career to the younger members of the Christian families who soon began joining him. Some of these early followers of Tekle-Haymanot may have been his own younger relatives, and the group was probably mobile 
at first. ${ }^{1}$ His influence had spread considerably even before he finally decided to settle at DebreAsbo.

According to his hagiographer(s) TekleHaymanot obtained the site of his monastery with the help of a local chief recently converted by him. This was done in the face of serious opposition by the pagan inhabitants of Grarya.? The main significance of this tradition is that the site was in a pagan area. Its general location and the physical characteristics of the surrounding region indicate that Tekle-Haymanot had a definite reason for his choice of the place. Debre-Asbo was directly due north-west of his native district of Sïlalish. Apart from his evident desire to establish his community outside his own district, it appears that Tekle-Haymanot also considered the future possibilities of his mission in choosing an area towards the west. Sĩlalïsh was

1. Mentioned as his relatives are zēna-lüarqos and Gewistos, Budge, or. cit.. p. 81 (text); Gedle Zena-1.iargos, f. I8; Gedle cewistos, ff. 4-5. There is however a general tendency in the later hagiographers to relate_most of the 14th century church leaders, Gedle Zèna-liargos, ff. $1^{a}-3$. Gedle Samu'êl (megeg) f. ?.

2. Conti Rossini, op. cit.. pp. 109-110. Budge, op. cit., pp. 80-85 (text). 
itself a frontier area on the eastern edge of the plateau overlooking the river basin of the Awash and the vast desert lowlands bejond. The whole of this area had long been exposed to a very slow process of Luslim expansion and by the 13th century the broken country immediately to the east and north-east of Sïlaliss, between the slopes of the plateau and the left bank of the Awash, was apparently the home of the so-called "wahzumite Sultanate of Shewa". It was also precisely in this period of the return of Tekle-Haymanot to Shewa that the Valasma rulers of Ifat ahd incorporated this internally divided liuslim community under their direct control. ${ }^{1}$ Conditions were not suitable for an immediate establishment of an effective monastic community in this direction. Ever since Christian families began migrating south of the headwaters of the Jema River, their settlement had always been in the central Shoan plateau, which forms a great watershed between the basins of the Blue Nile and the River Awash. We have seen that there were Christian communities in the Muger area

1. Cf. Supra, pp.237-8. Neither version of TH's Gedl, both composed at a time of unquestioned Christian predominance, gives any attention to the Muslim Factor in his life. This was one of the reasons that led Almeida to date TH between the 7 th and 8 th centuries, op. cit., Book II, Ch. 18 . 
further west already before Tekle-Haymanots settlement in Girarya. I Although still dominated by pagan worship, Tekle-Haymanot's new abode was not at all unknown to Christians before. The site of Debre-Asbo is also strikingly similar to that of Șīlalish. Iike its eastern counterpart, it is on the edge of the plateau overlooking a wide panorama as far as the mountains of Gojjam beyond the river Nile to the west, and to the north the mountains of Amhara across the easter tributaries of the Abbay. The country immediately below is intersected by the numerous tributaries of the River Jēma. To the south-west is the district consisting of the river basin of the Muger from which it also derived its name. Further still in the same direction, was the region of the head waters of the River Awash and the river basin of Guder, beyond which lay medieval Damot. Located in this area, Debre-Asbo was very well placed for its future offensives against the pagans of the region. It was clearly chosen to serve a double purpose. Tucked into a cliff difficult of access it could pass unnoticed by the hostile pagan neighbourhood, and being

1. Supra, pp. 227-8. Conti Rossini curiously locates liuger "a nord di Jëma". Conti Rossini, op. cit., p. 134, n. 5 . 
within easy reach of the plateau the small community could gradually spread its influence on the local people.

It was however as a solitary retreat that it must have first impressed Tekle-Haymanot. This was specially so because of the long preparation required to undertake active exangelisficwork. For this Tekle Haymanot needed to gather around bim a sufficient number of disciples and instruct them properly for the purpose. In the cultural milieu of the church in shewa at the time it is unlikely that he could have received much heilp from the local clergy. It may therefore be that on his return to Shewa he was accompanied by some of the individuals who had joined him in Tigre and Haiq. ${ }^{1}$

1. The growth of Debre-Asbo founced by him in his 60 's cannot be fully explained without the help of his early companions in the north. The role of such non-Shewans is of course played down by the subsequent growth of a strong local group vying for the leadership of the community. There are tantelizing indications of a struggle for the succession on the death of Tekle-Haymanot: after a short reign of Elsa'i, whose origin is not given, there is a miraculous selection of the Shewan Filippos to the chair, Conti Rossini, op. cit.. p. 122. Budge, op. cit., pp. 95-6 (text). Anorewos also seems to have been a candidate, Gedle Anorewos, p. 75 . He left for Tigre on the appointment of the next Abbot. He may not have been the only one to do 
Helped by such younger companions, Tekle-Haymanot began to train the young men who joined him during his round trip of some of the Christian communities. The process must have started before his settlement at Debre-Asbo. But while his small group was still mobile and completely dependent on the sedentary communities, he must have found it difficult to ensure the necessary degree of discipline and sense of urgency among his new followers. This increased the need for a secluded area not only for the pursuit of strictly monastic ways of life but also for instituting a permanent programme of religious training.

A monastic community was specially relevant to the circumstances in Shewa. As we have briefly seen above, the position of the church there was very weak and the frontiers between Christian and pagan ways of life were probably difficult to demonstrate. In such a society any attempts to create better standards from

Footnote I cont. from previous page

this and the foundation of Debre Dada in Amara Saint may also represent a similar exodus, $c f$. Budge, or. cit., pp. 77-8 (text). The comminity of Bertelomewos in Janamore in North Angot may also be of a similar origin, cf. Lidete-Abew, OR. 769, MS.BM. f. 4. 
within were bound to il. The creation of a completely separate community acting, as it were, as a miniature Christian society, had better chances of success, both for the personal salvation of its individual members and for the training ground of eventual religious leaders for the local people. This was indeed the dual purpose which Tekle-Haymanot and his early companions intended for their new community of Debre-Asbo.

At first the monastery of Debre-Asbo only consisted of a small cave divided into two to make room for a church, and the living quarters of Tekle-Haymanot and his disciples:

\section{"He kept the Tabot (consecrated) in the name of St. Mary in half the cave, which he partitioned with a curtain of straw. He lived with his fifteen disciples in the remaining half ..."l}

Hemmed in the densely wooded slppes of the plateau, the young community lived on the wild fruits of the forest. They began to have some contact with the local people, who could not understand their strange ways of

1. Conti Rossini, op. cit., p. 115. Budge, op. cit.. p. 80 (text). 
monastic life. ${ }^{I}$ Tekle-Haymanot and his disciples probably used these early contacts for teaching the new religion to the local people. This could have obtained for them their first converts. There are many traditions of such conversions which are said to have provoked the opposition of the pagan religious leaders. 2 Tekle-Haymanot's reputation also followed him to Debre-Asbo, and when the news of his settlement in Girarya spread among the Christians many came to join him:-

"quando ebbero sentita la sua fama, gli homini che abitavano lontane regioni venivano presso I'abuna Takla-Haymanot, dalle sue mani predevano il giogo del monachismo, e stavano col santo abuna".3

The sudden growth of the community at first presented some economic and organizational problems. Tekle-

1. There are some caricatures in the hagiographies about the people's idea of the novelty of monastic life. A group of shepherd boys who showed Fillipos the way to Debre-Asbo also warned him:- "We heard our fathers say, "those monks, they eat human beings'", Gedle Filippos, p. 188 (text). Cf. also Budge, op. cit., p. 81 (text). Gedle Anorewos, p. 77 (text).

2. Budge, op. cit..p. 85 (text). Gedle Tekeste-Birhan, MS. Dima, ff. 2-3a.

3. Ibid., p. 138. Budge, op. cit., pp. 84-87 (text). Gedle Filinpos (D.A), p. 188 (text). Gedle Anorewos, p. 68 (text). 
Haymanot's disciples began clearing the forests and cultivating the land; and a simple monastic organisation soon began to take shape. ${ }^{I}$

Tekle-Haymanot lived for about 29 years after he established Debre-Asbo.? The last three decades of his life were most fruitful years during which he created an effective centre of Christian propoganda in Shewa. Almost all the future leaders of the church there and in the newly conquered areas further south and in Gojjam, derived their origin from Tekle-Haymanot's new community of Debre-Asbo. He revived the religious consciousness of his fellow Christians and raised the relative degree of Christian learning among them. Cnce he had started the process many of his early disciples seem to have followed his example in establishing their own communities even before his death. 3 By the time he died the position of the Church in the districts of Keteta and Grartja, and

1. Conti Rossini, op. cit., p. 115. Budge, loc. cit. Gedle Anorewos, p. 70 .

2. Budge, op. cit., p. 96 (text). Since he is believed to have died in 1313 Debre-Asbo was probably established in about 1284 A.D.. This fits in perfectly with the chronology given in Gedle Filippos, p. 246 (text).

3. Gedle Zena-Margos, ff. 14-17. Gedle Gewistos, f. 69. 
in the whole of the Shewan plateau, was very secure, and it was ready to take some advantage of the expansionist policies of King Amde-Sĩjon (1314 - 44). Amde-Șijon succeeded Wedim-Re'ad only one year after the death of Tekle-Haymanot. His predecessor's realm had already included the central shewan plateau, where the religious activities of the saint had been conducted, and it was from this area that the new king led his successful campaigns against the Muslims to the east and south-east. Already before the campaigns of 1332, he had also reduced Damot and Hadja to vassal states. These military conquests did not, however, mean an immediate Christianisation of the inhabitants. But they tremendously boosted Christian morale and prestige, and contacts between the Christian communities and the new subject areas became open and more frequent. The numerous captives of war were reduced to slavery; some were distributed among the conquering troops, and others were probably sold to the Christian settlers in the north. The contingents frequently levied from the conquered areas always took part in the campaigns of the king side by side with his Christian troops. As such, they were increasingly exposed to Christian influence in a religious sense also. All these offered invaluable opportunities 
for the expansion of the Church. But the 14th century was not the only occasion for the Ethiopian Church to be provided with such opportunities of which she often failed to take full advantage. It is very clear that the Church was not aspet sufficiently well-organized for such a great task.

We have already made a distinction between the seculgr and monastic clergy in the Ethiopian church. Before monastic institutions were developed in Amhara and Shewa, any semblance of Christian teaching was done only by the secular clergy, whose religious training suited them for routine services only. Their essential function was merely to serve the religious needs of the troops or colonists. The conversion of the conquered peoples was always left for time to solve. As long as the military dominance of the Christians lasted the inhabitants of the conquered areas were slowly and imperfectly absorbed into the new religious frame-work. This seems to be the general pattern in which the Ethiopian church always secured its members in the new areas, and the influence of Christianity lay only in its position as the religion of the dominant political group. It is not at all clear what, if anything, the EgJptian bishops did to change this state of affairs before the fourteenth 
century. From the condition of the church in Ambara and Shewa in the thirteenth century it is apparent that they did little or nothing more than ordaining priests and deacons to maintain the precarious existence of the secular clergy in the distant courners of their extensive diocese. Abuna Ya'iqub, the second metropolitan in the long reign of Amde-Sīyon, hovever, presents an altogether different picture.

Bishor Ya'ioob and his Programes of Evangelization His name is first mentioned in a contemporary note of $1339 / 40$ at the library of the island monastery of Haiq, and he apparently came to Ethiopia in $1337 . .^{1}$ From the traditions we have about him he emerges as a

1. Compendium of llomilies, MS. Haiq, Colophon. Ya'ĩqob ruled for seven years until he was deported by SeyfeAr'ad (1344-71) soon after his accession, probably in 1344, Gedle Filippos (D.A.) pp. 227, 229 (text). Conti Rossini's reason for dating the expulsion in 1347 A.D. is not convincing, "I'agiografia Etiopica e gli Atti di Yafqi-renne-Eqzi', in ARIV, 1936-7, p. $417, n .2$. The date is most unlikely for those days since the next bishop was already in Ethiopia in 1348, Kolmodin, Traditions de Tsazzerra et Hazzega, 1914, A . Conti Rossini, "Pergemene di Debre Damo", in $\mathrm{RSO},{ }^{2} I X, 1940$, p. 52, n. 2. Ya'qob succeeded Abuna Yohannes and arrived in tthiopia before Ewostatewos left for Egrpt in the reign of Patriarch Benjamin $(1327-39)$, Gedle Ewostateros (text) pp. 54-5, 89. There is also a tradition that the ethiopian chair was vacant for some time in Benjamin's reign, Gedle Zena-Marqos, f. $12 a$. 
man with a more than average gift for organization. He was also fully committed not only to ensuring a more rigorous application of the rule of the church, in the daily life of the Christians, but also to evangelizing the non-Christian provinces of the Kingdom. At the time of his advent to Ethiopia, Amde-șejon was at the zenith of his power and Ya'iqob intended touse this opportunity in the service of the church, and drew up plans for systematic missionary work in the region. His attempts were made much simpler by the work already done by Iyesuskio'a and Tekle-Haymanot in the provinces of Amhara and Shewa.

At the community of Debre-Asbo there was apparently a struggle for succession on the death of Tekle-Haymanot. His immediate successor, Elsa'i ruled for a short period of time and Filippos took over on his death only three months later. This has made the name of Fillipos most renowned in the traditions of Debre-Iibanos, only second to that of Tekle-Haymanot himself. In his long tenure of office of twenty-eight years Debre-Asbo emerged from a relatively obscure private centre of monastic life into one of great significance in the history of the church as a whole. Affer the apparent struggle for succession which probably 
induced some of the early members to leave Debre-Asbo, the community went on growing, and new accommodation had to be built for the fresh arrivals. ${ }^{1}$

However it was the advent of Abuna Ya'iqob that dramatically changed the importance of the community. The Egyptian bishop saw that the success of his intended evangelical programme would depend on the co-operation of the local clergy. His problems were very clear, and the following words put in his mouth by the hagiographers also relate the solitary position of his predecessors:-

"I have been thinking for a long time to establish the law of God. But 1 am alone in this big country with no-one to help me in teaching the people who are numerous".

To free himself from this position of helplessness Ya'iqob set about reorganizing the clergy on his side. This involved a major decision. As an integral part of the Royal Court, the Egyptian bishops had always been surrounded by the secular clergy. Ya'igob had to break this historic connection and bring his chair back to its natural monastic ambience. This radical

1. Gedle Filippos (DA), p. 193.

2. Ibid., p. 194 . 
move alienated him from the court. ${ }^{1}$ Its effect on the position of the Egyptian bishops in Ethiopia was probably short-lived, and his immediate successors may have opted for a happier compromise. But it left an indelible mark on the organization of the Fthiopian church. Ya'iqob's re-organization of the monastic groups in Shewa and Amhara is variously told in the traditions of the church, and it is only natural that the spirit of rivalry among these communities should be reflected in the fories, ${ }^{2}$ His immediate plan was to establish permanent centres of Christian teaching in

1. Cf. Supra, pp. 224-5

2. The story is told in the Debre-Libanos cycle of hagiographies and in Gedle Aron, pp. 126-7 (text). According to the latter, Beselote-lika'el was made "Head of the 12 Shepherds of Ethiopia". In his own Gedl, however, he was already dead before Ya'igob's arrival in Ethiopia, Gedle Beselote-rika'el. p. 53 (text). The position of Filippos is exagrerated by apocryphal stories that he was even invited to become a bishop for Shewa, Gedle Filippos, pp. 194-8. Cf. also ibid, p. 204, Budge, op. cit., p. 84 (text). The geographical delimitations of the sphere of influence of Debre Asbo are essentially based on Ya'Iqob's reorganization; but in their present form they show the cumulative effect of the post-15th century history of the monastery, Iidete-Abew, OR.769, MS.BM. ff. 10-12. A more readable copy is available at Debre-Libanos, and the Patriarchal Library at Debre-STige also has the tradition in Rules for the Administration of Debre-Libanos, pp. 121-5, 139-40. A comparative study of these successive editions of the same tradition is most helpful in the identification of historical place names. 
the new pagan areas conquered by Amde-Sijyon. The province of Shewa was most affected by the king's latest military successes and it was also in this direction that the Egyptian bishop felt the need for immediate action. He divided the area among Tekle-Haymanot's disciples whom he urged to preach the Word of God in their various districts:-

"(The Holy Spirit) ... inspired him to appoint preachers to strengthen the rules of the Holy Church and keep (God's flock) in the teachings of Christ. Each of them was to keep to his assigned area without trespassing in that of his neighbour according to the instructions of the Apostles". I

Tekle-Haymanot's descendants, amont whom Ya'ígob made this arrangement, are said to have been welve in number, including Filippos. Among these we have the Gedl of only three of them and a complete review of the traditional activities of all cannot be made at the moment. It is however very clear from the geographical setting that the bishop intended to cover all the corners of the Province of Shewa and sent his emissaries in different directions from the central plateau:-

a) to the east in the direction of the l.uslim frontiers, the following were assigned:

1. Gedle Filippos, p. 193. 
Yohannes for Kil'at ${ }^{l}$

Qevistos for Mehagil?

Tadēwos for Silalish ${ }^{3}$ and

riatyan for Fețegar; 4

b) to the north-west beyond the western edge

of the plateau were assigned:

Anorēwos "the junior" for Moret and "iegda, 5 and Merqorēwos for Merhabite; ${ }^{6}$

1. Gedle Filipoos, p. 197. The place is often mentioned together with Sermat with which it apparently had common frontiers, Perruchon, Histoire des fuerres d'Amae-siyon, pp. $280,329$.

2. Gedle Filippos, loc. cit. Cf. also OR. 769, f. $12^{\mathrm{a}}$. In his own Gedlesermat was also his district, Gedle Eewistos, ff. $68^{b}-9^{a}, 105^{b}-6$. Sermat seems to be an ancient name for what is today the central part of Bulga, cf. OR, 769, f. $7^{b}$, Chronica de Susenyos, p. 18-20 (text). A river of this name is also mentioned in the region, Gedie Gewistos, f. 83.

3. Gedle Filippos, loc. cit. OR. 769, ff. $10^{\mathrm{b}}-11^{\mathrm{a}}$. For the location of Sî́laísh Supre, p.

4. Gedle Filippos, loc. cit. OR, $269, \mathrm{f} .1 \mathrm{l}^{\mathrm{a}}$. This area was immediately south of Șilalish on the plateau, Gedle Gewistos, ff: 4-5. It includes what are today the districts of Minjar, Shenkora, and Ada, cf., Futuh al Habash, tr. Basset, pp. 96-116. Rules for the Administration of Debre Libanos. Nis. Debre-Sige, p. 123 .

5. Gedle Filippos, loc. cit. OR, 769, f. $10^{\mathrm{b}}$. Wegda is still the name of the edge of the plateau overlooking the precipitous districts of Tegulet to the 
c) to the extensive new areas in the south and south-west were sent; Anorēwos "the elder" for "Tereb and Sigaj ${ }^{l}$ Adhani for Damot ${ }^{2}$ Iyosyas for wej, 3 and

Footnotes 5 and 6 cont. from previous page

5. north and lioret to the south. Noret borders on Insaro to the South and the River Addabay to the west. Anorewos was a disciple of Zena-karqos and his appelation "the iunior" is derived from this, Gedle Zena-Marcos, ff. 19-20a.

6. Gedle Filippos, loc. cit. OR, 769 , f. $11^{b}$. Merhabite is still the name of the district between the rivers Wenchit and Addabay before they join to form the Jema in Dera.

1. Gedle Filippos, loc. cit. OR. 769, f. 10. Gedle Anorewos, p. 76. wereb and Șigaja (= Șigaga) were in the district of Endegibtain, ibid, p:93. Gedle Zena-narqos, f. $44^{\mathrm{a}}$. Endegíbțañas in the Guder Basin, south-west of Ginde-Beret, cf. Chronica de Susenyos, pp. 32 etc.

2. Gedle Filippos, loc. cit. OR, 769, f. $11^{\mathrm{b}}$. For Damot cf. Supra, p.

3. Gedle Filippos, loc. cit. OR, 769 , f. $12^{\mathrm{a}}$. appears to be the area immediately to the south of the head waters, and west of the upper_course of the River Awash, including north Guragèland, Futub al Habasha, pp. 215, 234, 242. Chronica de Susenjas, p. 36 . 
Yosef for Enar'ít. ${ }^{1}$

These were all descendents of Tekle-Haymanot and the whole region south of the Jema River ${ }^{2}$ was thus left for them to evangelize. In the fourteenth century, when there were no other monastic groups in the region Ya'Iqob had no other alternative, and shewa remained an inexhaustible sphere of influence for the House of

1. Gedle Filippos, loc. cit. Or. F69, f. $12^{\mathrm{b}}$. Enar'it and tharya seem interchancheable. The upper court of the Great Ghibbie is still called Ghibbie Bnarta. A kingdom of Fnarya apparently existed immediately to the north of what would later be the fanous Kingdom of Kaffa. Enarya is the area where Motelami, the legendary king of Damot, is said to have withdrawn on being conquered by Yî́kunno-Amlak, Guidi, "Strofe e brevi testi amarici", in MSOS, Vol. I (1907), p. 182. Cf. also Chronica de Susenyos, pp. 156, 191-7. Almeida, Some Records, pp. 11: 18-19. Most likely the origin of the iater kingdom of Kafa should be sought in Medieval Enarya.

2. The l2th unit in Ya'iqob's delimitation is said to have been Dimbi, assigned to one Gebre-Kristos. In more recent editions of the story the place is called "Dembya, also called Amara Tabor", Or. 769 , f. 11. The accompanying notes seem to favour an identification north of the Jema or in Begemdir. But this is very unikely for the 14th c., and Ya'iqob's organization of Gedle Filippos, pp. 1978. A more satisfactory identification must be sought in Southern Shewa, in Gurageland, for instance, where Gebre Kristos is said to have had some parishes. A land grant by Amde-Șiyon (1314-44) mentions Dinbi together with Wereb and Enar'it, and seems to confirm a southern identification, Wright, Catalogue, Or. 821 , ff. $106^{b}-107^{a}$. 


\section{3 ît}

Tekle-Haymanot. But despite later traditions of DebreLibanos, it was not with Lebre-Asbo alone that the Egyptian bishop began to work. As we have seen above, one of the first things he did on his arrival in Ethiopia was to create amicable relations with the monastery of Debre-Gol, and we have traditions of a similar organization of the disciples of Beșelote-likika'ēl in Ambara. ${ }^{1}$

Beșelote-Mika'èl was also a descendant of Iyesus-Mo'a, but of the second generation. Some disciples of Iyesus-ino'a, other than Tekle-Haymanot, also seem to have withdrawn from Haiq and founded small monestic communities in Amhara. The most important among these was the community of Debre-Gol. It was still a private hermitage when its founder Anorewos, "the priest", was joined by Beṣelote-kika'èl probably in the second half of the reign of Widim Re-'ad (1296-1314). ${ }^{2}$ After having

1. Cf. Supra, p. 224 Gedle Aron, pp. 126-7. The chronological difficulties of this tradition have been mentioned above, p.340 n. 2 . The organizational characteristics - "12 Shepheras of Ethiopia, 72 disciples" - are also suspect. But an attempt at the revival of the Christian movement in Amhara also fits very well the traditions we have about Ya'iqob.

2. Gedle Beselote-líka'èl (text) p. 14. There is also a mentign of other commuties in the area, pp. 8-10. 
received the monastic habits from Anorewos, BeșeloteMika'èl travelled to Tigre and stayed at Debre-Damo for some time. Iike Iyesus-Ho'a and Tekle-Haymanot before him he appears to have made extensive use of this ancient centre of Christian learning in Tthiopia:-

"He stayed here reading the books of the old and New Testaments, and pondering over their meanings". 1

He visited many other commities in Tigre, and on his return to Amhara he made Debre-Gol an important monastic centre. Much of the story of his life concerns his

/Footnote 2 cont. from previous page

Beselote-lik'aēl tried to join one of these while still very young. His mother appealed to WídimRe'ad who was her relative and the king returned him to his parents by force. That Anorewos may have been a disciple of Iyesus-ko'a is implied in later traditions connecting Beselote-likik'el with Haiq, Gedle Iyesus-lio'a, pp. 28-31 (tr.). The curious appelation "Anorewos, the Friest" does in fact suggest that he was a retired secular priest who may have visited Haiq, obtained his monastic habits, and retreated to Debre-Gol.

I. Gedle Beselote-Mika'èl, p. 19. Curious revelations are attributed to him, pp. 20-1. These have striking similarities with the apocryphal work of the still little known author Behayle-lika'el, Meshafe MistireSemay we-midr, ed. in part and tr. by Férruchon, J. in 으, Vol. I, pp. 1-97. Budge, The Book of the Mysteries of Heaven and Earth, 1935 (complete eâ. and $t r$.$) . The connection becomes even more intriguing$ since the author at times calls himself Beselotelika'èl also, Ferruchon, op. cit., p. X, n: 7 . 
famous conflicts with Abune Yohannēs and king Amde-Șijon. ${ }^{1}$ But by the time Ya'ígob came to Ethiopia, BeșeloteMika'ēl had died in exile and Aron was left as the most senior of his disciples. It was with Aron and Filippos of Debre-Asbo that the Egyptian bishop now began to work, in an attempt to unite the descendants of Iyesus-Mo'a in a common struggle against non-Christian elements both within the outside the Ethiopian church. He saw in these leaders the only hope, not only for the expansion of the church, but also for the regeneration of strictly Christian ways of life within the church itself. Fis leadership in this was completely followed throughout his short term of office. We have seen above how they co-operated with him in staging a frantic attack on the king for his non-Christian matrimonial habits. They also took up their evangeligtic assignments with a similar jouthful enthusiasm.

From the purely hagiographical records at our disposal, it is very difficult to give an adequate reconstruction of the pre-Christian beliefs of the regions in which Tekle-Haymanot and his descendants began to work. What one gathers is a general picture

\section{Supra, pp. 219-24}


of animistic practices and nature worship:

"At that time the people of that district [ZIm, west of Lebre-Iibanos] worshipped the rocks, trees, or rivers. They did not know God except very few (among them). They lived by eating, drinking, and commiting adultery all their lives".l

The religious leaders of these pagan communities assume a character analogous to that of witch doctors. They had a very strong power over their people and some curious rituals are associated with them in the hagiographies :-

"(Tekle-Haymanot) came to a hill called Bilat. This was the headquarters of the sorcerers and here they sacrificed the blood of cows and goats (to the devils). ... There lived their king and the witch doctors, the diviners, and all the men of magic worshipped him. They stayed in his palace at the foot of the hill ... waiting for his words. If he has good words for them it presages good luck; if he makes bad pronouncements evil befalls them. Because of this they, have made him king over themselves".

I. Gedle Filippos, p. 175. Other references to similar practices are abundant, cf. Conti Rossini, Il 'Gedle Takla Haymanot', p. 104. Budge, The Iife of Takla Haymanot, $p \cdot 30$ (text). Gedle Zena-Marcos, ff. $110-12^{a}, 13^{a}$. Gedle Samu el (Wegeg). ff. $81^{\circ}, 116^{b}$. For a review of the pre-Christian Kushitic religionis practices see Infra, $p p \cdot 4.98$, etc.

2. Budge, op. cit., pp. 40-1 (text). Cf. also Gedle F/note cont... 
This pagan priesthood offered the greatest resistance to the work of the disciples of Tekle-Haymanot in the south. Their countries were only recently opened to Christian influence in a religious sense, and they naturally staged a long and desperate struggle against the establishment of churches and monasteries among their peoples. After the military successes of AndeSijzon, the local chiefs had long accepted the fact of Christian political dominance and were reconciled to the idea of Christian expansion. Their religious leaders nevertheless continued their hostile policies on their own. The systematic programe of mission work inaugurated by Abuna Ya'Íqob specially provoked such organized hostilities.

It was an ancient custom of the Christian kings to send some of the clergy to their frontier military

/Footnote 2 cont. from previous page.

Filippos, pp. 179-81. Gedle Anorewos, pp. 76-8, 80-1, 94-7. Gedle Gewistos, ff. 712, 83-4. There are also references to some kind of fire cult, Conti Rossini, op. cit., p. 106. Budge, op. cit., p. 52 (text), Gedle Gewistos, f. 71a. The worship of the serpent-god which often appears in the early traditions of the peoples of the Aksumite Kingdom also finds a place in some of these traditions about Amhara, Shewa, Damot, the Gojjam in the 14 th century, Budge, op. cit., pp. 77, 79. Conti Rossini, op. cit., pp. 107,-109-10. Gedle Anorewos, p. 9415. Gedle Zeyohannis, MS. Kïbran, f'́19-20. 
colonies. These were secular priests, and their primary function was to meet the religious needs of the Christian troops themselves. With the development of monastic institutions, however, and with Ya'íqob's reorganization of the disciples of Tekle-Haymanot in particular, a new and powerful element was added to the process of Christian expansion. A prominent monastic leader, with special evangelical responsibilities began to accompany the Christian troops stationed in an area. ${ }^{1}$ Hewas in charge of the secular priests and co-ordinated their work according to the evangelistleneeds of his province. He established a monastic community of his own, where he trained more of his followers for the religious leadersinip, and which he used as a centre of his activities in general. From this centre he travelled widely in the area, preaching, baptizing new converts, and building churches at convenient places. Ya'iqob's programe of missionary work had the approval of King Amde-Șijon, who naturally placed his royal authority

1. Christian troops were stationed in the area where Anorewos was operating. On one occasion he was accused of undermining the frontier defence of the Kingdom by accepting some of the soldiers as novices, Gedle Anorewos, pp. 89-90 (text). This refers to the reign of Seyfe-Ar'ad (1344-7I); and it is most likely that the practice also existed before him. 
behind it. ${ }^{\prime}$ Besides his frontier troops, the local chiefs were also under some obligation to ensure the security of the king's religious emissaries. This background of royal protection clearly accounts for the sudden development in evangelisticactivities in the new areas, and for the traditions of early association between the preachers and some of the local chiefly families. 2 A clear picture of this regional missionary organization emerges from the traditions we have about the life of Anorēwos of Wereb.

Te have seen above that Anorewos was assigned to teach in the district of Wereb. 3 His first preoccupation on his arrival in the region was to look for a suitable place for establishing his monastic centre. This seems to have taken some time, during which he

1. Gedle Filippos, p. 197 (text); Gedle Gēistos, ff. $105^{0}-6^{3}$.

2. In the hagiographies the monks could only enlist the help of the local chiefs through their spectacular miracles, Budge, op. cit., pp. 45-53 (text). Conti Rossini, op. cit., p. 106. Gedle Anorewos, pp. 78-81, 94-6. Gedle cevistos, ff. 94-1012.

3. Supra, p.343,n.1. It is interesting that his assignment was to the immediate_south-west of his native_district of kuger, Gedle Anoréwos, p. 67. Gedle Samu'e-l (of Wegaq), f. प्रa. This also seems to be the case with Qewistos, Zena-liarqos, Anorewos "the junior", and probably also of the other preachers. 
moved from place to place, preaching and baptising some of the local people, for whom he also built churches:

"And he began teaching (the people) ... saying 'It is better to believe in God than in mortal human beings'. He told them much about Truth from the Scriptures. He gave them penance and baptized them in the name of the Holy Trinity. He also provided them with "Tabots" and built churches for them in their country..."I

Anorewos continued his search for a convenient place to establish his monastery. It is characteristic of these hagiographical traditions that he finally obtained the site with the help of a local chief.? Beragban (later called Zekaryas) is said to have been the chief of the district of Șigaga. Having heard about the religious activities of Anorewos in the nearby districts, Beragban invited the saint to come to his district and establish his monastic centre. Anorewos accepted the invitation, but on his arrival there he was met by an organized resistance of the local religious leaders. Beraghan took the Christian side, and the

1. Gedle Anorewos, p. 77.

2. Ibid., pp. 78-81. Similar traditions of early associations with local chiefs are abundant, Conti Rossini, op. cit., pp. 104-2, 109-10; Budge op. cit.. pp. 43-58 (text); Gedle kewistos, ff. 77-81, 83-4, 94-1-1. Gedle Zena-iarqos, f́. $15 b_{-1}$. 
issue was decided by force:-

"Beraghan took his arrow and went to the woods. He found there three 'men of magic' sitting at the foot of an oak tree. He shot at one of them who fell and died; the second fled away, and he captured the third, tieo up his hands backwards, and took him to Abuna Anoréwos. Then (Anorewos) saw him he wondered and said, 'After all a man of magic is a human being!' And at that time (the chief) took a knife and slew (his Captive) at the feet of (Anorewos).

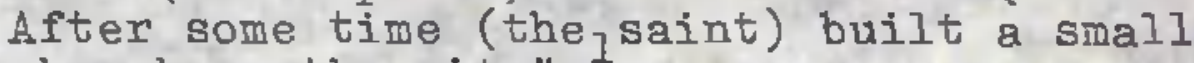
church on the site".

This gruesome story is a distant echo of the

bitterness of the struggle which confronted the Ethiopian Church in its early attempts to extend its influence in this direction. The bitterness of the conflict seems to have been further promoted by the insistence of the preachers on building their churches on the sacred places of the pagan clergy. ${ }^{2}$ It was also on such a site that Beraghan helped Anorewos to establish his monastery of Debre-șigaga. 3

The community of Debre-șīgaga grew fast and

1. Gedle Anorēwos, p. 79.

2. The theme is repeated in various traditions, Conti Rossini, op. cit., p. 104. Budge, op. cit.. pp. 37, 40,78. Gedie Gewistos, loc. cit. Gedle Zenalierqos, loc. cit.

3. Gedle Anorēwos, p. 80 . 
many new disciples joined Anorewos including some of his own relatives from the north. ${ }^{1}$ From here Anorewos continued his preaching in the surrounding area. He also seems to have assigned evangelistic duties to some of his own disciples:-

"He called one of his disciples whose name was Dawit, a respectable man and a great master of the scriptures, and said to him, 'Come, my son. Go to the Country of Ademet at a place called Bezírgoy. Take some priests and deacons with you and prepare the Holy Commumion until I come".?

The evangeliskicactivities of Anorewos seem to have extended far beyond Endegíbtan and the traditions attribute to him much pioneering work in 'Enarit to the south-west and Damot to the west. 3 But since we have no other hagiographical records for this region, this tradition of the descendents of Anorëwos cannot be

1. Ibid., p. 8I. Four sons of his sister (in Weleqa) and a son of his brother (in fuger) are specially mentioned. The latter is called Gebre-Nazrawi and is remembered as a leading monastic leader. It seems quite possible to identify him with his name sake commemorated on Tahsas 5, Synaxaire, in FO, Vol. XV, pp. 603-10. Hére also he is made a monastic descendent of Anorewos but of the second generation. The tradition (ibid., p. 607) associating him with an evangelical effort in Hadya makes the identification quite secure.

2. Gedle Anorewos, p. 94.

3. Ibid., pp. 85, 89. 
controlled. Nevertheless it seems quite clear that before the end of the third quarter of the l4th century Ya'iqob's evangelical programes had borne fruit and the presence of the church was already felt in the outlying provinces of the kingdom in this direction.

A similar work was being done on the liuslim frontier bejond the eastern edge of the Shewan plateau. ${ }^{1}$ Tie have seen above that there were Christian comunities in the region of Șïlalish already in the Zagwe period, and the immediate result of the advent of the new dynasty had been the consolidation of Christian power in Amhara and Shewa. On the religious side a similar development of Christian influence was soon promoted by the activities of Tekle Haymanot in the central Shewan plateau. By the time Tekle-Haymanot started his teaching, the region beyond the eastern slopes of the plateau was undergoing a tremendous political upheavel, culminating in the final ascendancy of Ifat over all the other kuslin communities. This, however, did not affect the Christians on the plateau and on its eastern edge. Here, Tekle-Haymanot

1. In Ya'íqob's time the parish divisions in this direction seern to have been, from north to south, Kel'at (Yohannes), Sermat and Mehagil (Gewistos), Silalish (Tadewos) and Fetegar (katijas). Of these $f$ have only Gedie Qewistos at my disposal pertaining to this period. 
was preaching among his fellow Christians and their pagan neighbours, moving from one community to another. It was probably on one of these occasion that qowistog came under bis iffluence. 1

In Gedle Tekle-Haymanot, Gewistos is only mentioned in a list which has the generic title of "disciples of Tekle-Haymanot", and there are no clear references to him as a resident member of the community of Debre-Asbo.? According to his own Gedl he received his monastic babit from Tekle-Haymanot during the latter's visit to the church of Nibgē Maryam recently built by Qewisțos in Sïlalish. 3 Here also there is no mention of him staying at the new monastery of Grarya. This seems to indicate that Qewisțos came under the influence of Tekle-Haymanot before the establishment of Debre Asbo. After these early associations with his master

1. Gewistos is said to have been a cousin of the Saint only six months younger, Gedle cewistos, ff. $44^{\mathrm{b}}-8^{\mathrm{a}}$, 52a. But he is also said to have been killed in the reign of Amde-sizyon for his part in the monastic attack of the king's unorthodox matrimonial habits which probably took place in 1341, ibid., ff. 106-9. This is chronologically impossible and he must have been a much younger disciple of Tekle-Haymanot.

2. Budge, op. cit., pp. 88-9 (text).

3. Gedle ewistos, ff. $101^{b}-2^{a}$. 
he seems to have returned to his native district of Silalish and eventually established his own community at Nibge. ${ }^{1}$

In the region of the eastern slopes of the plateau, Ifat was still the dominant political power, and the community of Nibgē could only have a strictly local significance for about two decades. In the meantime, however, it became an increasingly important religious centre among the local Christians and Qewistos consolidated his reputation as a monastic leader and as the disciple of Tekle-Haymanot. Nỉbē reflected in the east the spirit of Christian revival propagated by Tekle-Haymanot at Debre-Asbo, with inich Qewistos probably kept a close contact. This was probably increasingly felt, not only by the Christians but also by their líuslim and pagan neighbours. Although Christian and lifuslim communities had long been living side by side in these frontier districts, the do not seem to have completely rid the area of its ancient pagan ways of life. The evangeligłicactivities of gewisțos outside

1. The traditions of his visits to Tigrē and Jerusalem, ibid., ff. 60-8i, and his alleged preaching in Sermat before his monastic profession are almost certainly apocryphal. 
his Christian group probably started among these marginal communities. The traditions about his early contacts with these people present them as given to magico-pagan practices of a very bybrid character, but strikingly similar to those which Tekle-Haymanot and his disciples confronted in the west and south-west:-

"He found the inhabitants of the country worshipping the devils at the foot of a 'Kobel' (?) tree. They were sitting there eating, drinking and amusing themselves in the fashion of the Huslims. They fanned the fire with their hands and held hot flames in their mouths and chanted saying "O people of Gelan and Yey, see what your God Qorke (can) do! ..." And they brought for (Qorkē a daily present of) two fat cows, five sheep, five goats, and twenty-one baskets of white (wheat?) bread. All these were eaten by the functionaries of the gods ..."l

It was only after Amde-Sïyon's initial successes on Haq ed-Din I and Deradir, ${ }^{2}$ however, that the community of Nibge seems to have taken further advances towards the east. The military prestige of the Christian kingdom impressed the frontier peoples. There is a clear indi-

1. Gedle Gewistos, f. $71^{a}$. The passage is about a people living near a place called "Mt. Yey". From the comparative topography given in the life itself, f. $75^{\mathrm{a}}$, Mt. Yey seems to be somewhere east of Keteta and therefore to the immediate north-east of Nibge. The indirect mention of Muslims is interesting, and indicates superficial islamic influences on the practices of the people who were otherwise unmistakably pagan.

2. Cf. Supra, pp. $252-6$ 
cation that among these Christian and Muslim frontiersmen very close ethnic, linguistic and even probably family connections existed; ${ }^{l}$ and their religious associations often depended on the political fortunes of the day. A tradition about the conversion of a local chief in the area amply illustrates the point:-

"(His convert told Qewistos): 'I was (originally) a Christian living in the country of Feteqar. A Muslim chief took me away while still ten jears old (together with my mother) ... The son of another chief married her ... and gave me his sister to wife from whom I had this son ... He also appointed me chief of this district and my mother ... used to teach me in secret the rules of the Christians. I have always been a Christian at heart while observing Islam in public".?

The essential message of this story is that the growing political power of Amde-șiyon was being reflected in the intensive evangelishicactivities of the descendents of Tekle-Haymanot long stationed in the region. The influence of the church developed, and more churches were being built. 3 The rulers of

1. Cf. Cerulli, E. "Il Sultanato di Scioa", pp. 32-4.

2. Gedle gewistos, f. 77 .

3. Ibid., f. 81; more Christian clerics are said to have come from Fețeqar, Zim and from Tegda to help Gewistos in his work, for a time. Bf. the tradition collected by Azais and Chambard at Fentale, Cino années de Recherches Archéologiques en fthiopie. $1931, \mathrm{p} .145$. 
the kingdom of Ifat deeply resented this expansion of the church, and it provided them with additional grievances against the growing power of Amde-Șiyon. Sabr ad-Din's inimical attitude to these religious activities played a considerable part in the hostilities of 1332 . On the eve of the war Amde-șiyon accused the ruler of Ifat of taking strong repressive measures against the Christians in the area:-

"He sent to him saying, 'This thing that I hear about you, is it true or not? Did you burn the church of God and kill many Christians? Did you take away the rest of the Christians and convert them into your religiot?'"l

This mention of churches and Christian communities doubtless refers to the region of the eastern slopes of the shewan plateau and constitutes an important confirmation of the hagiographista traditions of the church.. The religious content of the struggle of 1332 was furnished by the atterpts of Ifat, and indeed of all the Muslims in the region against Amde-\$ijon, to stop this tide of active expansion of the Ethiopian church. During the war many of the Christians in the frontier area were converted (or reconverted?) to Islam, and after the war Amde-șijon decreed strong measures

1. Perruchon, J., Histoire des guerres d'Amde-Seyon, pp. 282, 299 (text), 331-2, 344 (tr.). 
against them. On his way back from Adal, he ordered Jemaldin, his new governor of Ifat, to deliver to the Christian Court all such "apostates":-

"Le roi des infidèles ... amena au roi 'AmdeSeyon les rénégats que $l$ 'on $¥$ avait trouves et qui étaient des prêtres, des diacres et des soldats de son armee. 'Amde-Seyon ... leur fit donner a chaqun trente coups de fouet, fit imprimer sur leur poitrine et leurs epaules une mention constatant qu'ils étaient devenus esclaves e leur fit mettre un collier de fer au cou et des chaines aux

Those who were thus punished only constituted part of the elusive frontiersmen who had characteristically changed sides during the hostilities; and Jemaldin's failure to deliver still more of them to the king's judgement cost him both his freedom and his new appointment as ruler of Ifat. 2

After 1332 the Christians enjoyed a greater freedom of action in the area. On the advent of Abuna Ya'iqob, Qewistos was confirmed as head of the Churches of Sermat and Mehagìi, and his other colleagues Yahannis, Tadewos, and Matyas were also assigned for Kel'at,

1. Ibid., pp. 433-4 (text), 478-9 (tr.).

2. Ibid., pp. 434, 479. Jemaldin was arrested and his brother Nasr ad-Din appointed in his place. 
Șilalish, and Fetegar respectively. ${ }^{I}$ Besides greatly enhancing the prestige of these preachers as monastic leaders this act of the Egyptian bishop seems to have intensified their work. The traditions indicate the extension of the influence of the church even across the Hawash:-

"And the chief of Fentale (recently converted by Qewistos) crossed the River Hawash, fought with the rulers of the "uslims and defeated them ... He destroyed their place of worship and built a church in the name of St. George ... and many of the Muslims believed".

The region was no longer a forbidden ground for Christian religious activities, and the disciples of Tekle-Haymanot were free to spread the Christian teaching, particularly through the local chiefs. Essentially, however, the loyalties of these frontier people to the church were political, and the church could not flourish beyond the last fringes of theplateau. Apart from the strong

\section{Supra, p. 342 .}

2. Gedle Qewistos, f. $101^{a}$. The chief is said to have been a brother of a powerful lady who offered a great resistance to Qewistos' work in the area. She had a great influence among the local people between the Rivers Sermat and Awash. Ibid., ff. 83-4, 94-101. It is interesting to compare the position of this lady with Prof. Cerulli's comments on female rulers in the area, "Il sultanato di Scioa", cit., pp. 21-2. 
militancy of Islam, the semi-desert conditions of the area were also unfavourable for this development.

We have already examined the traditions of the religious conflicts between 'Amode-Sigon and his successor Sejfe-Ara'd on the one hand, and Abuna Ya'iqob and his monastic allies on the other. I The exiles inflicted upon the Ethiopian church leaders by these kings on that occasion marked an important stage of the evangelization of the Ethiopian region. This followed two general patterns:

a) the banished monks tried to convert the local people of their temporary abodes of exile; and

b) some of the younger monks went further away from their place of exile and settled in new areas altogether.

The areas where these monks were temporarily exiled seem to have followed two general directions. At the initial period of the conflict, in the life-time of Amde-Șiyon, all the traditions we have (with only one exception) indicate that the monks were sent northwards

1. Supra, $p p \cdot 222-5$ 
to Amhara and Tigre. ${ }^{l}$ Amde-Șijon banished the leading disciples of Tekle-Haymanot northwards out of Shewa, 2 and those of Beșelote-Nika'ël north of Amhara. ${ }^{3}$ The exiles to Tigrē, where some churches are attribute to Aron, 4 are not relevant to our story of evangelization. In the regions of Amhara and Begemir, however, these places of refuge served not only as centres of spreading Christianity among the local people, but also as a

1. The exception referred to is the alleged exile of Beșelote-Mika'él (d. before 1337) by Amde-Siyon to Dara and Lake Zway, Gedle Beselote-lika'el, pp. 3034 (text). The conflict with the kings was conducted on two different occasions:- On the first occasion, before_1337, Beselote-Mika'èl led the clergy against Amde-Sijyon. He was exiled to Tigre on two occasions and he finally died there. The conflict started again on the advent of Bishop Ya'iqob. Amde-Sijyon again exiled the monks to Tigre in 1341. The $\frac{\dot{y}}{13}$ were recalled on his death in 1344 . Soon afterwards, however, they quarrelled with his successor, SeyfeAr'ad. It was probably on this occasion that the monks began to be exiled to the south, and BeseloteMika'el's alleged participation in this later event may have only been based on the experiences of his descendants led by Aron.

2. Frobably both Anorewos and Filippos were first exiled together to Welega, Gedle Anorewos, pp. 84-5. Gedle Filippos, p. 242. Filippos was later sent further north to Tigre, Ibid., pp. 214-15.

3. Aron and many of his followers left Debre Gol northwards to Angot and Tigre, then back to Wag_and Lasta, and to Debre-Getin across the upper Tekezze, Gedle Aron, pp. 133-6:

4. Ibid., p. 133. 


\section{$3 i v$}

launching pad for further evangelical work in Gojjam and in the Lake Tana region.

Anorewos of Wereb spent his first three years of exile in the district of Weleqa where he is said to have preached among the local people:-

"... He converted many of the people of Weleqa into the worship of God".1

He was not the earliest preacher in the district where his own sister was married to a local christian already before his exile. 2 Apart from early traditions involving an ancestor of Tekle-Haymant ${ }^{3}$, another prominent monastic leader called "Ze-'Amanu'ēl of Weleqa" is also mentioned elsewhere in connection with the region in an earlier context of the 14 th century. 4 But it seems that many parts of the district were still pagan, and both Anorewos and Filippos appear to have

1. Gedie Anerewos, pp. 84-5.

2. Ibid., p. 81 .

3. Supra, p. 229,n.3

4. Gedle Beselote-likika'èl, pp. 43, 45-6. 'Amde-Seyon mentions "a monk called 'Amanue'l" as having sent his blessing and encouragement to the expedition of 1332, Ferruchon, op. cit.. p. 311 (text); it seems quite possible to identify 'Amde-Siyon's "'amanu'el" with Ze-'Amanu'el of Weleqa; a district in Amhara. 
helped in its evangelization. ${ }^{l}$

In the second period of the conflict, in the reign of Seyfe-Ar'ad, the exiles took place in a southern or southeastern direction, into the newly conquered areas beyond the River Awash. Here the most important place seems to be a locality called Dara. It is mentioned in the hagiographies of the descendants of both TekleHaymanot and Beșelote-Míl'èl and it appears that all these monastic leaders were first sent there at the same time. 2 But only Aron and his followers stayed there for a period of about seven years. 3 It is also in Gedle Aron that we possers an interesting description of the area:"The soldiers (of the king) brought them to the land of Zengo ... in the neighbouring of Astren, near Dara and Bosato, facing Lema. Gwatr was also near them and Zway was visible from far. And there ruled the Gerad of

1. Cf. Gedle Filippos, pp. 242, 246 (text).

2. Gedle Filippos, pp. 231, 240. Gedle Anorewos, pp. 878. Gedle Aron, pp. 145-50. Gedle Beșelote-lika'el, $\mathrm{pp} \cdot 30-31$.

3. Gedle Aron, p. 149. Filippos and Anorewos were both transferred to an island in Lake Zway after a period of three months, Gedle Filippos, loc. cit. Gedle Anorewos, loc. cit. 
Bali". 1

The inhabitants of the area were apparently

Muslims and are remembered in these traditions as having

been very hostile to the exiles:-

"... those who lived there were hislims and they did not know Christ. The were murderers, and the king sent (his enemies) to them so that they take his revenge for him".

1. Gedle Aron, p. 145. Some of these places are perfectly identifiable. Al-'Umari has a Muslim state called Dara bordering on Bali, op. cit., pp. 1, 18-19. The general direction given for it is also similar in Gedle Filippos which places it, however, in Devaro, p. 240. It is also said elsewhere that it was inhabited by lusulims, Gedle Beselote-Iika'el, pp. 30-31. Gragn's chronicler has a place called "Darah" on the frontiers between Dewaro and Bali, Futuh alHabasha, tr. F. 387. The identification of Dara with a district east of Lake Tana is misleading, Almeida, Some Records of Ethiopia, p. 233. Gwatr is also mentioned elsewhere as being near Dewaro, Gedle Estifanos, MS. Gunda-Gundi, ff. 82, 86. Gedle Abekerezun, p. 26. It is probabiy the same district as Djaoutir, a frontier district of Christian Dewaro, Futuh al-Habasha, tr. p. 134, n. 3. The area where the monks were exiled was also a week's journey east of R. Awash, Gedle Aron, p. 150. The additional mention of Zway and the Gerad of Bali suggests that the place was between Dewaro and Bali. It is precisely here that an Ethiopian religious scholar located the place of Aron's exile, Aleqa Lemma, lieshafeTizita, ed. Kengistu Lemma, Ad̉is Ababa, I967, pp. 36-37.

2. Gedle Beselotefikika'ēl, p. 30. Cf. also Gedle Filippos, p. 231 . Gedle Anorewos, p. 88. 
Aron and his followers were forced to stay here for seven long years, and although they suffered many casualties, they eventually made their peace with the local people. They cleared a piece of land and transformed it into a garden on the fruits of which they managed to live. ${ }^{1}$ They preached among their neighbours and it appears that they left some churches behind them at the end of their exile:-

"... they prayed on the churches they built in Dara and Zengo and left some monks and priests there".c

Filippos and Anorëwos were transferred to Lake Zway. They were taken to one of the islands and the hagiographical traditions about this exile provide the earliest description of the lake and the people who lived there in the 14th century:-

"The lake was famous for its great depth and width, and no one can enter it without Tiebel(?). They took them into an island inhabited by pagans who did not have any religion and who ate the flesh of both properly slain and dead animals".

1. Gedle Aron, pp. 148-9.

2. Ibid., p. 150. Cf. also Gedle Beselote-ika'èl, Ioc. cit.

3. Ibid., p. 33. The description of the inhabitants of the island(s) fits what is still believed about the low-caste Fuga of the region, w. A. Shack, The Gurage, 1966, pp. 9-10. 
The monks are believed to have converted some of these peoples and it seems doubtless that the island monastery of Lake Zway had its origin in this early mission work. ${ }^{1}$ According to these traditions the monks were soon transferred from the lake region to the area further south and south-west, where they are also said to have preached. ${ }^{2}$ By the middle of the Fourteenth Century, therefore, the Ethiopian Chruch had already begun to make direct contacts with what is today a predominantiy Sidama country.

1. Gedle Filippos, pp. 231-4. Gedle Anorëwos pp. 88-9. Abba Sinoda (a. before 1433 A.D.), founder of DebreSimona in Gojjam, went to school in Lake Zway and was given the monastic habit by one Endryas, at the island monastery, Gedle Sinoda, MS. Dima, ff. $3^{a}-5^{a}$. This means that already in the end of the l4th century a monastic community has flourished there. Since then we have continuous references to it in both Christian and Puslim documents, Alvarez, The Prester John of the Indies, pp. 435-6. Futuh al-Habasha, tr. Basset, p. 371 . Almeida, Some Records, p. 36. Antoine d'Abbadie, Géopraphie d'thiorie, pp. 60-67. Blundell, H.F., "Exploration in the Abbay Basin, Abyssinia", in GJ, XXVII, No. 6, June, 1906, p. 531.

2. Gedle Filippos, p. 235. Gedle Anorëwos, p. 89. The place is said to be Gemasge in Damot which seems to indicate a general direction towards the upper Omo and Ghibiërivers. Cf. also Gedle Beselot-Mika'èl, pp. 34-55. 
Early lissionary work around Lake Tana

I have said above that the communities established in Ambara during these exiles also served as a stepping stone for further mission work in Gojjam and in the Lake Tana area. This was made possible by 'Amde-Sifyon's successful military activities in the area shortly after his accession to power. A l4th century note relates the king's victories over the "Negese-Gozim" soon after the year 1316/7. ${ }^{1}$ His chronicler mentions in addition successful campaigns againgt frojjam and Wegera sometime before $1332 . ?$ It is probably to one of these early expeditions that we also have a reference tn a hagiographical tradition:-

"The king sent (his men) to bring him a tabot from the monastery of Sana because he wI shed to set out on an expedition. They took for him a tabot consecrated in the name of Qirqos. Having taken this he went to war and defeated ${ }_{3}$ the rebels (who were) his enemies ..."

1. The Four Gospels, MS(IN), Haiq, f. 25 . Cf. also Guidi, I. "Le canzioni Ge'ez-Amarigna in onore di Abissini", in RRAL, V. 1889, pp. 62-3.

2. Perruchon, op. cit.. p. 309 .

3. Gedle Yafairenne-Egzi', ed. and tr. by I Tajnberg, in OCA, No. 106, 1936, pp. 18-22. Conti Rossini, "L'agiografia etiopica e gli Atti del Santo

$\mathrm{F} /$ note cont.... 
The first Christian influence in Gojjam came from the direction of the south-eastern corner of lake Tana. The island church of Sana Qirgos has the earliest tradition. Its alleged foundation in the 4 th century A.D. is almost certainly apocryphal. ${ }^{1}$ There seems to be no doubt, however, that a Christian community existed

/Footnote 3 cont. from previous page.

Yafqirenne-Eqzi" in ARIV, Vol. XCVI, 1936-7, Pt. 2, pp. 414-5, 424. The early date of this incident is quite clear from a close examination of the Gedl: Yafqirenne-Eqzi' was still a young member of the community as he is referred to as "my brother" by the king's messenger described as a mere "deacon", p. 20. This tallies very well with the chronological notes we have about the saint who died at an advanced age in 1376, Conti Rossini, op. cit., p. 420. He was born one year before the arrival of Abuna Yohannes in Ethiopia. This bishop is also mentioned in the note commemorating the king's success in Gojjam. Yohannes came as a result of Yagba-Sijyon's letters to Egypt in 1290, Quatremere, lémoires, II, 1811, pp. 268-73. He apparently onl y reached Ethiopia in the reign of Widim-ie'ad (1299-1314), when we have the earliest references to him, Budge, The Iife of TH, p. 84 (text). Gedle gewistos: $\mathrm{f}^{\mathrm{a}}$. $68^{\mathrm{a}}$. He was accused of simony by Beselote-nikai in the early part of Amde-Sigon's reign, Gedle BeseloteIlika'el, pp. 22-4.

1. Meshafe-ridane-..ihret, extract ed and tr. by Conti Rossini in "Il convento di Tsana in Abissinia e le sue laudi della vergine" in RRAI, Ser. V, Vol. XIX, 1910, pp. 602-3 (text), 617-8 (tr.). Cheesman, R.E., Lake Tana and the Blue Nile, $1936, p .172$. 
in the area already before the ond of the Zagwe dynasty. I About the end of the second decade of the 14th century Amde-Sigon had firmly consolidated his power in the region between the River Tekezze in the east and Lake Tana, and the stage was set for the expansion of the church further afield.

\section{Yafqĩrenne-Eqzi' joined the comunity of} Sana Qirqos in the first years of Amde-Sijon's reign.? On his arrival there the community was fairly well established. But its reputation as an important centre of monastic activities and Christian learning was a

I. It seems that 'Amde-Siyon's success was only a culmination of earlier attempts at Christian expansion in this direction. We have early traditions about Christian activities already in the Aksumite period, Conti Rossini, "Il Convento di Tsano", cit. pp. 581-2. Idem. "Il libro della leggende dello Echege Filippos", cit. pp. 706-7. The Zagwe Kings aIso seem to have had cotact with Gojjam in this direction, Perruchon, R. Le vie de Lalibela, p. 117. Conti Rossini, Gli Atti di Ne'akuto Le' ab', 1943, po. 37-8. The traditions of some churches in the Iake Tana region also connect them with 'Amde-Siyon's grandfather, The Book of kiracles of St. Mary, MS. Daga, beginning of the ins. Cheosman, op. cit., pp. 107-9.

2. The saint was born in Tigre, Gedle YafqIrene-Eozi, pp. 14, 16. For the place of his birth, cf. Conti Rossini, "L'agiografia etiopica", cit., pp. $412, n .3$ and 413, n. 1 . He was already ordained monk by one Adhani in Tigre. He is elsewhere said to have been the disciple of Medhanine-Egzi', Idem. Gedle Filippos (Bizen), table p. 156. Basset; Etudes. p. 10. 
relatively recent development. The modest position occupied by Sana at the time is suggested in the stories of the early life of Yafqirenne-Eqzi. On his advent to the lake region, the activities of the monastery were still firmly controlled by the ruler of Gojjam, whose special permission was required to admit the young monk from Tigre into the island. 2 It was only after 'AmdeSiyon'ssuccessful campaigns that the position appears to have changed. Şana Qirqos became the natural recipient of the King's favours, 3 and soon asserted itself by gradually extending its supremacy over all the other islands. The local rulers of Gojjam and Dembya now seem to give some protection to the monks living in

1. Gedle Aron, pp. 121, 152-3. This place is also mentioned as being somewhere in the lake region, Gedle Yafqirenne-Eqzi', p. 66.

2. Ibid., p. 16. The ruler is called "Zanakimir, King of Gojjam". Cf. Guidi, I. "Le canzioni", cit. pp. 62-3. Gedle Tekle-Haymanot, MS (17th c.) Kibran, end of $\bar{S}$. Her Zinkimir is King of Gojjam about 1323/A A.D. Conti Rossini, Gli Atti di Ne'akutoIe' $\mathrm{ab}$ pp. 37-8 (text), where he is called Sere-Gimis, "the enemy of God". From all these it appears that a notorious ruler of that name strongly resisted the expansion of the Christian kingdom into Gojjam. The indications seem to show that he was 'AmdeȘīyon's contemporary.

3. Gedle Yafcïrenne-Iqzi', pp. 20, 22. 
the islands. ${ }^{1}$ This was apparently followed, however, by the monks of Șana Eirqos venturing into the mainland and the still unoccupied islands in the lake.

Local opposition to the expansion of the church was still considerable on the mainland south of the lake. On his first attempt to establish himself in the district of Beda, Yafqirenne-Eqzi' was forced to return to the islands:-

"And then came the messengers of Wïdīm, King of Gozam and said to him, 'Why are you staying in the district of Beda? Return to your place ... ' Having heard the message the saint refused to go .... and they wanted to take him back by force ..."

This local opposition appears to have been even stronger in the region north and north-west of the lake. The most serious resistance to the Christian advance here

1. Cases of such co-operation are reported in the early part of the Saint's career in Lake Tana, ibid, pp. 26,28 .

2. Ibid., p. 24. Beda seems to be the same district which still bears that name on the mainland just opposite and south of the island of Kibran. In a l6th century land grant "the chief of Bed" is mentioned together with "the King of Gozam", The Four Gospels, KS. Kibran, $f=2380$. Wídim seems to be the successor of Zankimir as kine of Gojjam. The same name was borne by an officer who commanded 'Amde-Sijyon's cavalry contingent called Gojjam in 1332 , Ferrushon, Histoire des guerres d'Amde-Siyon. pp. $289,383$. 
came from the Felasha who were predominant in the mountainous districts between the lake and the Tekezze River. The early compaigns of 'Amde-Șīyon had resulted in the consolidation of his power in Gojjam and in the districts immediately to the north and east of the lake. But his conquest of the mountain Felasha tribeshad apparently been only temporary and, probably also provoked by the resultant activities of the Chnnch in the area, the Felashrose in an open rebellion against the king on the eve of his campaigns in Adal in 1332:-

"He sent other contingents called Damot, Seqelt, Gonder, and Hadya (consisting of) mounted soldiers and footmen and well trained in varfare ...; their comander (was) Begemdír Sega-Kristos. He sent them to the country of the rebels to fight ... (the people of) Simen, Wegera, Selemt, and Segede. Originally these people were Christians but now the denied Christ like the Jews who crucified him. For this reason (the king) sent an army to destroythem ..." "l

1. Ibid., pp. 293, 339-40. It is curious that the chroniclers of both Amdo-Sijyon and Zer'a-Ya'iqob considered the Felasha as Christian apostates, cf. Les Chroniques de Zar'a Ya'egob et de Ba'eda Maryam, pp. 96-97. The hagiographical traditidns are, however, unanimous in attributing Jewish religion practices to them, Gedle Yafairenne-Egzi, p. 56 . Conti Rossini, "Appunti di storia e letteratura Falascia", in RSO, VIII (1920), p. 571. Id., "Hote di agiografia: Gebre Iyesus", in RSO, XVI (1938), pp. 446-8. In this latter work their origin 
This did not represent a "Revolte de Begemder". Ferruchon reached this conclusion by a casual misunderstanding of the terro "Begemdir" which was only part of the title of Sega-Kristos, who seems to have been the governor of the district of that name at the time. ${ }^{l}$ only the Felasha rebelled against the Christian kingdom in 1332 , and Begemdir Șega-Kristos was sent to suppress them with an army which incluced Gonder, a contingent of local extraction still lojal to the king. The expedition

/Footnote I cont. from previous page.

is taken to the time of the destruction of Jerusalem. Some information about their existence in Ethiopia seems to have reached liedieval Europe, cf. Conti Rossini, "I'itenerario di Beniamino da Tudela e I'Etiopia", in ZA, XXVII (1912), pp. 360-363. Cerulli, Etiopi in Palestina, I (1943), pp. 234-6.

1. It is consistently used as such in the documents, Ibid., loc. cit., and 281. This is further confirmed by two land grants of the early 15 th century where a Princess held the title Begemdir (or Megemdir); The Four Gospels, HS. Kibran, ff. 3a, 238a. The Trovince of Begemdir now covers the whole area vest of the Tekezze and north of the lake and borders with the Sudan. It the medieval context, however, it only referred to the area between the River Bashilo and the upper course of the Tekezze on the east and south-eastern shores of the lake. 
was apparently successful and the Felasha revolt was put down for a time. The king's success in his kuslim campaigns further enhanced his power throughout his kingdom, and we have no case of major Felasha risings on record for at least fifty years. It seems, in fact, that these years saw a speedy development in the establishment of the church in this direction.

The island monastery of Șana Qirqos had been the major centre of Christian activities in the lake region. In the reign of 'Amde-sijyon its influence at the royal courtuas apparently considerable. Abba Ya'iqob, the second abbot of the community since Yafqïrenne-Egzi's arrival in Șana, seems to have had very good connections at the court and was probably appointed from there. He was later sent to Egypt as a member of the delegation to fetch a new bishop, apparently Abuna Ya'iqob about 1337.1 It is not clear what part the the community of Șana played in the conflicts between Abuna Ya'Iqob and his monastic allies on the one hand, and 'Amde-sijyon and Syfe-Ara'd on the other. But the series of exiles which 'Amde-Gijon imposed upon the

1. Gedle Yafqirenne-Egzi', pp. 26, 38. For the date of the bishop's arrival see Supra p. $337, \mathrm{n} \cdot 1$. 
monks in 1341 eventually led to the establishment of monastic centres in the lake region, other than Șana Qirqos, and considerably strengthened the Christian mission work in Gojjam and in the Felasha country. The activities of the followers of Abba Aron and Filippos of Debre-Asbo were particularly significant in this.

We have already seen how, after some wandering in Tigre and Lasta, Aron finglly established himself at Debre-Qețin. ${ }^{l}$ The site was on a hill overlooking the western bank of $R$. Tekezze on its upper course immediately west of Lalibela. Aron and his followers built a church and settled in what is today the south-eastern corner of Begëmdir. 2 Thelr influence was soon felt around the country and many of the local people seem to have joined them :-

"(The reputation of Aron) spread in all the districts of Meqet, Asasa, and the countries of Wadla and Dawnt. The whole of Begemdir was full of his news from Amhara to "iwegera ... and many received the monastic habits in his hands $z^{\text {and }}$ he taught them the ways of God

\section{Supra, p. $364, n \cdot 3$.}

2. It seems that the church was hewn out of the rock, Gedle Aron, D. 136. Cf. also A. Coqot, in AE, V, 1963, p. 272, No. 65.

3. Gedle Aron, loc. cit. 
The district of Gaynt, west of $R$. Bashilo and south of the monastery was apparently still pagan and Aron baptized many of the inhabitants there, His work was interrupted by another period of exile, this time south of the River Awash. I On his return from there about seven Jears later, Aron's activities were redoubled and his influence was felt even more widely. He travelled to his own native land of Gembya, further west, and built churches and established communities.? His own seat remained at Debre-getin where he built a new rockhewn church ${ }^{3}$ on a nearby hill called Debre-Daret which became the centre of his activities. The monastic community of Abba Aron had a great reputation and even a daughter and a brother of King seyfe-Ara'd were amons its residents. 4

\section{Supra, pp. 366-r.}

2. Gedle Aron, pp. 152-3.

3. It is quite clear here that it was a rock church:"He finished hewing the rock in three years". For identification of this site cf. Caquet, op. cit.. p. 274, No. 64 .

4. Gedle Aron, pp. 137-8, 140. His refusal to give up these princes was one of the reasons for Aron's conflict with the King. Aron gave the Princess the monastic name of Barbara, and her career is 
The dispersal of the leading members of Debre-Asbo also contributed in this vital process of the expansion of the church/ in this direction. Some of them are said to have settled eventually in the districts of Dembya and Begemdir, and on the islands of Lake Tana. I Abba Zekaryas, a disciple of Filippos, established his community on the island of Gelila about the end of the reign of Amde-Sijon. 2 These fresh

/Footnote 4 cont. from previous page

confirmed by a contemporary note of $1390 / 1$, in a MS. of the Four Goapals belonging to herself, $S$. Grebaut, "Note sur la princesse Zir-Ganēla" in JA, 1928, pp. 142-4. The identity of the king's brother is however still obscure. A son of 'Amde-Sigyon, Abba Yasay, is the traditional founder of handabba on the northern shore of Lake Tana, Cheesman, op. cit., p. 199. But it is not certain where he first received this monastic ordination.

1. Basset, R. Etudes sur I'histoire d'Fthiopie, pp. 10 (text), $100(t r)$. The date of the MS he used is mid-18th century, ibid., pp. 5-6; and as such it has some chronological set-backs of which the most conspicuous is its mention of Tekle-'Alfa (16th century) among the l4th century monastic leaders.

2. Ibid., pp. 10-11 (text), 100 (tr.). This is also confirmed by Gedle Yafgirenne-Eqzi', pp. 104-8, 112. Gelila was "uninhabited" when Yafqirenne-Eqzi' first visited it, ibid., p. 28. Zekaryas seems to have come many years after YE. But he appears to be the senior of the two in terms of age and monastic experience. 
reinforcements increased Christian activities in the area and further advances were made in the pagan districts south of the lake. This new development comes out very clearly in the story of the life of Abba Ze-Yohannis, who settled on the island of Kibran in the reign of Seyfe-Ara' ad.

\section{Zeyohannès originally came from the district} of Merhabitē in north-western Shewa. He joined the monastery of Debre-Asbo and was professed a monk by Hizkyas who became abbot in 1341 when Filippos was exiled to Tigre. ${ }^{I}$ It is not clear why he left DebreAsbo but after moving about in the country for sometime the traditions about his life take hin to the region of Lake Tana. ${ }^{2}$ He first stopped in the district of Dera

1. Gedle Zeyohannis, MS. Kībran, ff. $3^{\mathrm{a}}, 12^{\mathrm{a}}$. Basset's text makes him a disciple of Filippos, loc. cit. Together with other traditions it also makes him settle in Kibran in the reign of 'Amde-Siyon, cf. Gedle-Zeyohannis, ff. 20b-2l; Gedle Tekle-Fiamanot, I.S (17c.), Fibran, end of the liss. But this contradicts his accepted monastic ordination by Hïkyas, and it seems doubtless that his advent to the island was in Seyfe-Ara'd's reign (1344-71). Seyfe-Ara'd is in fact the earliest king mentioned in early (15th c.) historical notes at the monastery, The Four Gospels, MS. Kirban, ff. 3a, 235b-37.

2. It is interesting that the Gedl does not mention his alleged exile with Filippos given in Basset's text. 
on the south-eastern shore of the lake where the people were already Christians. He is said to have made friends with a Christian family of fishermen who helped him cross over to Kïbran:

"There are no people (his friends told Seyohannis) living on that island. But we often spend the night there when we (intend to) catch many fish".1

This contradicts the tradition in the Iife of YafqirenneEqzi, according to which some clerics were already settled in the island and were part of the community of Sana Eirqos. ${ }^{2}$ The hagiographers of Zeyohannis also indirectly imply elsewhere that some hermits were atready living on the island before him..$^{3}$ These hermits may

Footnote cont. from previous page

His itineraries are uncertain and the usual hagiographical story of the Saint's "flight in the clouds" makes his alleged visit to Tigre, Hamasen and Jerusalem very suspect, Gedle Ze-yohannis, ff. $13^{b}-14^{2}$

1. Ibid., f. $16^{\mathrm{a}}$

2. Gedle Yafairenne-Eqzi', p. 24. The island is here called "Fobra" and differs from the etymology given in Gedle Zeyohannis, loc. cit.

3. Ibid., f. $18^{\mathrm{a}}$. 
have originally been members of Șana. It is also most probable that Zejohanis himself was first connected with the same community when he started his career in Kibran. ${ }^{1}$

The most interesting part of the story of Zeyohannis's life is the tradition about his attempts to evangelize the mainland south of the lake. With the unsuccessful attempts of Yafqirenne-Eqzi' to settle in the district of $\mathrm{Bed}^{2}$ before him, this tradition seems to offer another stage in the gradual expansion of the church of Gojjam.

The pagan people "south of the island" are said to have been under "the ruler of Agew" called Jan-Chuhay. Zeyohannis crossed over to the mainland and began preaching in Zege and the adjoining districts, When Jan-Chuhay heard of the religious activities of the monk in his territory, he put him in prison from where he was only freed with the intervention of officials of the Christian kingdom:-

1. liany of the land grants to Kibran since the early 15th Ce. celarly show that the Nỉbure-id of Sana still held a position of considerable authority on the community of Kibran, hhe Four Gospels, IS.

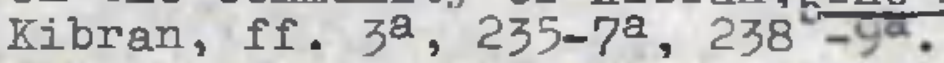

\section{Supra, p. 374, n. 2}


"(Jan-Chuhay) ordered his men to arrest him and beat him ... And Zeyohannis remained a prisoner in Amedamit. Then King 'Amde-Șigon heard (this) and sent many soldiers (to Jan-Chuhay) saying, 'If you do not release this monk, there shall be no peace between you and me'. The king ordered (his messengers) to kill Jan-Chuhay if he refused ... and they killed him $\ldots$ and released Zeyohannis". 1

This seems to suggest that local resistance to the new religion was persistent, and the power of the Christian state was once again required to suppress it. As in the other frontier areas, the degree of political control which the Christian kingdom possessed always determined the speed of advance of the church. In the case of the rich kingdom of Gojjan, the end result of these early efforts was particularly successful. But as we shall soon see the vital process of the complete integration of Gojjam in theChristian kingdom was further promoted by evangelical activities conducted from other directions accompanied with considerable Christian settlement from Shewa and Amhara. We must now turn

1. Gedle Zeyohamnis, ff. $20^{b}-21^{a}$. The people are said to have worshipped a serpent whom Zeyohannis killed by praying to his God. The conflict with Janchuhay started in this, ff. 19-20. The ruler is elsewhere given as being the king of Gojjam, Zinkimir, Gedle Tekle-raymanot, MS. (I7th C.), Kibran, end of MS. 
to the area north and north-east of the lake, where the Felasha were becoming restive once again, after more than fifty Jears of apparent calm.

\section{The Evangelization of the Felasha}

This period of about fifty years had been one of continuous Christian pressure on the ancient habitat of the Felasha. During the first half of the 14th century, this pressure came from Begemfir in the south, and the rich plains of Dembya north of Lake Tana. During the whole of this period no major traffic seems to have as jet been opened directly between the district of Shre in Tigre and the lake region. The whole region between Dembye and Begemdir in the south, and the Tekezge river in the east and north, was Felasha country and a forbidden ground for Christian movement. The itineraries of Yafqirenne-Eqzi', on his way from Tigré to Șana QIrqos at the beginning of 'amde-sijyon's reign, are not given in his Gedl; but it is probable that they followed the ancient route from Tigre to Lalibela, and then went vestwards across the upper course of the River Tekezze to Lake Tana, via Begemdir. This was exactly the route followed by Abba Aron of 
Debre-Daret towards the end of the same reign. ${ }^{1}$

The energetic campaigns of 'Amde-șiyon pushed this Felasha frontier considerably northwards into the heart of Wegera, and into the mountain districts to the immediate north of Begemdir. This increasingly impelled the Felasha to recoil into the inaccessible mountain districts of Șegede, Șelemt, sīmēn, and northern Vegera. 2 An active process of religious expansion followed the conquests of the Christian king. In the early part of Yafqīrenne-Eqzi''s career in Lake Mana, the areas immediately to the north and east of the lake were already Christianized. 3 Towards the end of the reign of 'Amde-Șifon, the Christian pressure on Felasha country was increased. Unlike the extensive areas south

1. Gedle Aron, pp. 135-6. The traditions about early Aksumite missions to Begemdis and Amhara point to the same route. In the Zagtve period when Lalibels was the seat of government this was probably the main route.

2. It is interesting that Almeida was told that Dembja was originally part of Felasha country, Some Records of Ethiopia, p. 54. It may also be that ifegera in the 14th c. extended much more to the south than the present district of that name.

3. Gedle Yafqirenne-Eqzi', pp. 28, 30. The Kentiba of Dembya and his people help the saint durint his self-exile in the island of Gelila; pp. 66, 80, 94 , 108, Fogera, Gembya, Fido, and infraz, all on the eastern sice of the lake, are mentioned as having Christian communities. 
of Ambara, where all the mission work is attributed to the descendants of Iyesus-lio'a, both Tigre and Ambara clerics worked side by side in the Christian mission among the Belasha. In the reign of Seyfe-Ara'd we have references to the intensive activities of Tigre clerics in the area, particularly at the monastic centres of Zezo and Weyna. ${ }^{1}$ But it was the advent of Abba Gebre-Iyesus in Infraz that specially represented a new factor in the history of monastic development in Ethiopia.

Gebre-Iyesus was one of the early disciples of Ewostatewos and is said to have accompanied his master to Egypt, the Foly Land, and Cyprus. 2 Ewosțatewos had left Ethiopia soon after the arrival of Abuna Ya'iqob about 1337, and many of his surviving followers returned home on his death in irmenia about 1352. The story of his eventful life belongs to another chapter and will be fully considered later. 3 But the "House of Ewostatewos", which he founded in Sera'è and Hamasēn, also played a

1. Gedle Yafoirenne-Eqzī'

2. Conti Rossini, "Note di agiografia etiopica: GebreIyesus" cit. pp. 44l-3.

3. Infra., pp. $40 \%$, etc. 
significant part in the expansion of the church. In Felasha country the role of his disciple Gebre-Iyesus was very considerable.

Gebre-Iyesus was apparently born in Thg, a frontier district between Tigre and Lasta. ${ }^{l}$ He travelled to Tigre and eventually joined the growing community of Ewostatēwos whom he accompanied on his self-exile abroad. On his departure Ewostatēwos entrusted his community to the leadership of one of his senior disciples Absadi who made his centre at Debre-iuaryam of Qohayin.? It was probably here that Gebre-Iyesus and his colleagues first stopped on their return from Armenia. They have a tradition that, some time before his death, Ewostatēwos had assigned them to teach in different places in Etbiopia. 3

1. His conscientious hagiographer discloses that the original Gedl of Gebre-IJesus was lost during the Gragn war. lis origin, as well as the rest of the story of his life are based on traditions collected frommemory, Conti Rossini, op. cit., p. 441 .

2. Gedle Ewostatēwos, pp. 73-6, 115-7, 135-6, 176. Gedle Filippos (Bizen), p. 157, note on $f$. I7r.

3. Conti Rossini, op. cit., p. 443. The asignments are said to have been given to his "twelve disciples". This arrangement is not mentioned in Gedle Ewostatewos. According to this Gedl many followed him on his 
dccording to this arrangement, Gebre-Iyesus is said to have been allocated the district of Enfraz, east of Iake Tana. After some unsuccessful attempts to establish himself in Tigre, he moved sathwards probably via his district of 7 ag and Lasta to Enfraz. From the story of his activities in this district it is quite clear that Enfraz was inhabited by the Felasha. He established his centre at Debre-San among them. Of all the traditions we have about the l4th century effort to spread Christian treaching in this region, the story of Gebre-Iyesus is unique in its explicit mention of a direct mission work among "the Jews of Ethiopia":-

"Credettero, ricevettero il battesimo, entrarono nella sua predicazione, persino i figli dei Guidei ..."

The cultural impact of the Christian church on the Felasha

/Footnote 3 cont. from previous page.

travels abroad but only two are mentioned by name, Tewodros, p. 97; and Bekimos, p. Il3. Bekimos later settled at Serabi where he ordained Filippos, the famous founder of Debre-Bizen, Gedle Filippos. pp. 78-9. Lerqorewos who is also believed to have travelled with the master later established himself at Debre-Dimah, Gedle iergorewos, pp. 32-3.

1. Conti Rossini, op. cit., p. 446. 
went even deeper, and we have a report in precisely this period that a renegade Christian monk called Qozimos left his monastery in Veyna, joined the Felasha community in Sïmen, and copied the old Testament for them. 1 quite apart from the conversion of some of the Felasha to Christianity their close contact with the Ethiopian Church began to enrich their own religious legacy, and much of their literary and organizational borrowings may date from the mid-14th century.? Apart from some territorial gains in Dembya and in the districts north of Begëmdir, 'Amde-șijon's repressive measures against the Felasha in 1332 did not result in a complete annexation of the Felasha country. The most important result appears to have been the withdrawal of the centre of Felasha resistance further north. It was in the district of simēn that a serious rising took place sometime in the reign of King Dawit

1. Gedle Yafqïrenne-Egzi', p. 56.

2. Conti Rossini, "Appunti di Storia e tetteratura Falascia", cit., pp. 577-8, 584-93. For the striking similarities wich the or sanization of the Felasha religious institutions displays with that of the Ethiopian Church see Leslau, IJ. Falasha Anthology, 1951, pp. xxi-xxvi, and xoxvi-xliii. 
(1380 - 1412). ${ }^{1}$ The revolt appears to have been a general reaction to the growing Christian domination, and both secular and monastic leaders were conspicuous among its victims. Gozimos, the renegade monk mentioned above, is particularly mentioned as having led the movement :-

"Fartirono, e misero compo contro il lientiba del Dambya: 2 Combatterono e lo vinsero. (II Kentiba) accorojossi con loro. Indi (cormos) usci (dal $\mathcal{S}$ emen), incendio numerose chiese, parvenne alla contrada di 'Enfraz ed uccise abba Gedlos, Abba Yohannes Kama e abba Tense'a kiadhen con trentasei loro figlio spirituali ... Gli altri, poi, che morirono, furono innumerevoli pertutta 'nfraz, monaci e monche ... Poscia egli
uccise molti capi e ufficiali ..."3

The new Felashe resurgence over powered the local Christian troops, and kine Dawit had to send fresh

1. The story of this revolt is told in Gedle YafäirenneEgzi' (text) pp. 50-8. Conti Rossini also published the extract in his "Appunti di storia e letteratura Falascia", cit., pp. 567-77. From the text the revolts seem to have taken place not very long after Yafqirrene-Egzi''s death in 1376. It is most likely that it belongs to the last jears of the l4th century.

2. Here Conti Rossini substitutes a pronoun with "Kentiba" and thus suggests that the ruler of Dembya ahd cooperated with the Falasha after his first defeat. This seems to me very arbitrary, and the pronoun clearly refers to Qozimos who is the chief concern of the whole extract.

3. Ibid:, pp. 571-2 (text), pp. 576-7 (tr.). Gedle Yafqirenne-Eqzi', p. 5 (text). 
auxiliaries to them under the command of Akhadom, Governor of Tipray. The expedition was successful, and the Felasha revolt was once again suppressed. There are very clear indications that, after this incident, serious attempts were roade to integrate Felasha country into the characteristic feudal system of the Christian Kingdom. This was particularly the case in the reign of King Yishaq (1413-29). Fe have seen earlier in the last chapter how a policy of "divide and mule" was successfully directed towards the Ralasma family of Ifat by 'Amde-Siyon and SeyfeAra'd. Yíshaq pursued an exactly similar policy towards the local chiefs of Felasha country. ${ }^{1}$

The king appointed a strong Felasha chief, Bet-Ajir, as Governor of simen and part of Dembya. Under Bet-ajir he appointed the chief's own nephew Beâagosh to serve as a liason officer with the rojal court. Bedagosh regularly visited the court and his special responsibility was to ensure that his uncle duly paid the tributes of the king. On one occaspion he went to his uncle to remind him to send his tributes. Betajir refused to obey and mistreated his unpatriotic

1. Tarike-Negest, paper MS. Dehre-Șīie, pp. 53-4. 
nephew. Then he was summoned to appear at the kins's court he declined to show up. On this open act of revolt King Yíshaq personally lee an expedition against him:-

"And the king came and struck his tent in Megera. Betajir did not notice his arrival. They made war from morning to evening. After that Betajir escaped; but the soldiers of the king surrounded him, and cut off his head". I

After this victory the king generously compensated Bedagosh for his loyalty and granted him a large fief in Vegera. Friendly groups among the Felasha chiefs were similarly rewarded for their co-operation during the hostilities. ${ }^{2}$ Never-the-less, Yëshaq fully

1. Ibid., p. 54. Cf. also Basset, R. Etudes sur I'bistoire d'ithiopie, pp. 11, 101. For the name of the chief, see Conti Rossini, "Appunti di storia ...". cit., p. 567, n. 2 .

2. "The 24 elders of Belew Amba" are particularly referred to as having been rewarded by the king for their co-operation against the Felasha, TarikeNegest, loc. cit. The Book of the History of the Tings, MS. Debre-șige, p. 45. Also Basset's short text reports the same, although he altered it in the translation by changing the word Ser'o to Se'aro. The spearhead of the ancient Christian [originally Bejal people, the Belew, had apparently been established in the refion of Velqayit, Conti Rossini, "Schizzo etmico e storico delle popolazioni Entree", cit., pp. 76, 84. They probably had old rivalries with the local Felasha, and may have given Yishaq a willing help against them. 
realised the essentially religious nature of the Felasha question. For him the only solution to this chronic problem lay in bringing an end to the religiots difference and in imposing Christianity on the "rebelling infidels". With this in mind he passed a decree from which the Felasha are sometimes said to have derived their name:"'He who is baptizec in the Christian religion, may inherit the land of his father; otherwise let him be a felasi'. Since then the House of Isra'el have been called Felashoch (= exiles). And the King built many churches in Dembja and Tegera".

This seems to have served as another stage for further Christian expansion in Felasha country. But the "Jews of Ethiopia" continued their hostilities to the Church, and the Felasha question was still alive to the end of our period. 2

The Establishment of the Church in Goj,jam

The reigns of Dawit and Yīshaq were also

1. Tarike-Negest, loc. cit. Basset, op. cit., pp. 12, 101. l.iar Yishaq, lus. Dima, ff. 1710-2a.

2. This is fairly well documented, Les Chroniques de Zar'a Ya'egob, cit., pp. 96-7, 17 $72-3$. Haflevy, J. Ia Guerre de Sersa-Dengel Contre les Falashas. 1907, pp. 17, 54-55. Gedle Telkle-Hawaryat, ed. and tr. Conti Rossini, pp. 103-7 (text). Kolmodin, Traditions, $\mathrm{A}_{25} ; \mathrm{A}_{32}{ }^{\circ}$ Futuh al-Habasha, tr. Basset, pp. 456-9. 
marked by a similar expansion of the Ethiopian Church in eastern Gojjam. Tie have seen above the pioneer work of Yafqīrenne-Eqzi' and Zeyohannis in the districts immediately south of lake Tana. These activities were conducted among the Agew population who appear to have constituted the medieval kingdom of Gojjam. ${ }^{1}$ It is impossible here to estimate how far inland the power of this kingdom extended; but it seems clear that its centre lay between the lake and the central highlands of Agew-midir. The earliest attempts at Christian expansion in Gojjam came from the direction of the lake. This is fairly well confirmed by the lack of any acceptable clerical traditions in eastern Gojjam which refer to a period earlier than the reign of Dawit. The Christian troops of 'Amde-șiyon in his early expeditions against Gojjam ${ }^{2}$ seem to have never crossed the middle Abbay from the direction of Ambara in the west. They were probably oonducted through the

1. "Jan-Chuhay, the ruler of Agew" is elsewhere mentioned as "Zinkimir, Fing of Gozam" in the traditions of Kỉbran, cf. Gedle Zeyohannis, ff. 19-21. Cf. Gedle Tekle-Haymanot, "T. Thran, end of the MS. Elsewhere the same area south of the lake and the islands in the southern half of the lake are sajd to have been under "the king of Gozim", Gedle Yafaírenne-Eazi', pp. $16,24,26$.

2. Supra, fe. 370 
Christian district of Begemiir to the south-eastern corner of the lake, north of the Nile, which was also probably controlled by "the king of Gozim" at first. 1 It was probably in this region on both sides of the Nile that the first hostilities were conducted leading to the eventual recognition of 'Amde-Sijyon as over-lord of the kingdom of Gojjan. The clerical attempts to extend the influence of the Church on the eastern shores of the lake, in the islands of the lake, and further inland to the south of it, followed precisely the same direction. But the Agew population south of the lake continuously resisted these religious activities. The mountain of Adedamit is the furthest point inland where even hagiographical traditions take Zeyohannjis as a prisoner of "the ruler of Agew".2 The "Kings of Gozim" were probably still pagan at least until the end of the reign of King Dawit. 3 Until the advent of Christian

1. His acciaimed control of the southern islands including Sana in the south-east (ibid., loc. cit) cannot have been maintained by a fleet of straw boats alone.

2. Supra, p.384 Amedamit is still the name of a high mountain range about 32 miles south of the lake.

3. In a land grant of King Dawit dated July/1412 A.D. we have "M'ate-Gone" as king of Gozam, Phe Four 
clerics in eastern Gojjam across the Abbay, the sionary activities of the island monasteries could not penetrate the Agew barrier. This seems to be quite clear from a close study of the traditions of Debre-Dima, ${ }^{\text {I Debre- }}$

Footnote 3 cont. from previous page

GospeIs, MS. Kibran, f. $3^{a}$. Before him in the reign

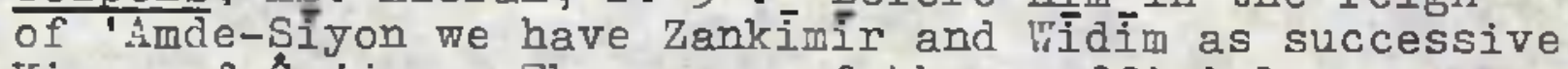
Kings of Gojjam. The names of these officials gradually become clearly Semitic, and Christian:Anbesa Dawit, Chronique de Ba'ede líaryam, ed. \& tr. $\mathrm{J}$ - Perruchon, pp. 160-1; Serse- aryam and TekleSilyon, both in the reign of líbne Dingil, The Four Gospels, MS Mîbran, ff. 5b, 236b-238. From a comparative study of Agew dialects Conti Rossini has also concluded that the "Semitic" influence on the Awiya and Damot dialects is most recent, Etiopia e senti d'Etiopia. 1937, p. 136.

1. The traditions about Tekeste-Bİrhan, founder of Dima, derive his origin from Debre-Asbo, Tekeste-BIrhan. paper MS. Dima, F. $2^{a}$. He is said to have followed Filippos on exile to Tigre whence his master sent him to Gojjam, Gedle Filippos, irs. Debre-Dima, ff. $35^{b}-37^{a}$. Here his original name is given as Bekimos which also appears in the text edited by Turaiev but in quite a different context, Gedle Filippos, pp. 222-3. Basset's short text mentions one TekesteBirhan of Debre Sot as Filippos' fellow exile, tudes, p. 10. A place called Tot is also included in the very uncertain itineraries of the founder of Dima, Tekeste-Birhan, ff. $3^{0}-4^{a}$. He is said to have been still active in the reign of Dawit, and his successor Tomas ruled for 20 years, apparently in both Dawit and Yíshaq's reigns, ibid.. ff. 79 , $16^{6}-17$, Zena-liemhiran, in qeleminto s, Jis. Dima, f. $2^{a}$. 
Simona, ${ }^{I}$ and Debre-werq, ${ }^{2}$ which have been the principal monastic centres in the area.

The most interesting element in these traditions is that they represent two new directions of Christian activities in Gojjam, from Begemdir in the north (across the Nile), and from Amhara in the west. Since the reign of King Dawit these commuities on the eastern edge of the Gojjam plateau definitely represented the advance points of Christian expansion into the interior. This movement seems to have been considerably promoted by some Christian families beginning to settle in eastern

1. Abba Sinoda, its founder, was born in Wej- in Shewa and studied at the island monastery of Lake Zway. He had already been in Gojjam and established Debre Simona in the reign of Yishaq, and died on an island of Iake Tana, where he was exiled for political reasons in the reizn of Hizbe-Nagn (1430-33), Gedle Simona, HS. Dima, ff. 2-3, 5a, 17b, 20-25.

2. The traditions of Debre-Werq have been affected most by relatively recent monastic rivalries in the region: an Aksumite foundation is claimed, Cohen, "Debre "Verq", in "ílanges Rene Basset, I (1923), p. 150. Gedle Serse-Fetros, f. 13. Its later building in Dawit's reign by Serse-Petros is said to have only been a restoration, ibid., ff. 13-16. Serse-petros is then said to have lived until the reign of Be'ede-liaryam (1468-78) f. $28^{\circ}$. In his monastic genealogy he is also made at least three generations younger than Abba Sinoda of Debre-Simona, Tarike-ifenekosat, in Compendium of Homilies, MS. Debre-ierq, ff. io ${ }^{2}$. 
Gojjam. Apart from the monastic leaders themselves, ${ }^{1}$ we also have some indications that secular Christian families were beginning to settle in the area. ${ }^{2}$ These early settlements ushered in a vital process which would soon result in the almost complete transformation of eastern Gojjam into a distinctively Christian and Amhara country. 3

The settlement of Iyesus-lio'a at the island church of Debre-Haiq in 1249, took place at an opportune

1. For Tekeste-Bírhan and Sinoda we have traditions of their Shewan origin. Serse-fetros is said_to have been born from a Christian family in Enebse, a district in Gojjam north of Debre-ierq and his monastic ancestry is traced back to Gebre-Iyesusb of Enfraz in Begemdir, Gedle Serse-Petros, ff. $5^{b}$, 18. Tarike-Menekosat, loc.cit. He is also associated, however, with a certain community of inskabeidusan in Amhara, Gedle Serse-Fetros, f. 32 . He died in Shewa, ibid., ff. 6l-3; cr. also hezgebeGedam, MS. Debre-Werq, see under his name. The present Abbot I met insisted that Serse-petros' parents were Christian settlers from Lenz in Shewa.

2. Gedle Tekle-'Alfa, ed. and tr. $彐$. Cerulli, 1943, p. 10 (text). The saint's father was originally from Shewa, and the family settled at iresen Amba in Gojjard in Yishaq's reign.

3. The process was already complete in the beginning of the l6th century. It_probably started with the conversion of the "ilegase-Gozim", and the close association of his family with the central Christian court afterwards. This is fairly clear from the reign of Zera'-Ya'qob onvards, Cf. Alvarez, op. cit. pp. 425-8, 458-9. 
moment. Immediately followed by the rise of the new dynasty - which had its centres in Amhara and Shewa the establishment of the earliest monastic school at Debre-Haiq provided an essential factor in the process of Christian expansion in the Ethiopian region. Compared with the previous nine centuries of Rthiopian Christendom, the achievements of the new dynasty were particularly remarkable in this respect. At the beginning of our period, during the last quarter of the 13th century, the Christians south of Lasta had only occupied a long and very narrow crescent running from the south-eastern corner of Begëmdir to the upper waters of the lluger, along the high ridge forming the watershed of the Nile and Awash basins. At its Shewan end the crescent was very much broken by intervening pagan communities. Tekle-Haymanol's career helped fill up these gaps in the central Shewan plateau, and with the reign of 'Amde-Ṣijon this crescent became elongated at its two ends, spreading into yet more areas, which had previously been non-Christian. The achievements of his immediate successors lay in widening this narrow Christian corridor extending to the heart of Felasha country in the north-west and medieval Damot in the south-west. The Church played a significant role in 
40.

this development, and by the beginning of the 15th century the central part of the kingdom, south of the provinces of Tigre and Last, had grown into a circle consisting of Showa, Amhara and eastern Gojjam. The political boundaries of the kingdom extended much further than the frontiers of the Church. This reflected both the relative strength of the non-Christian commanities, and the internal weakness of the Ethiopian Church. Zera'-Ya'qob's religious and administrative reforms were particularly aimed at solving these essential problems. 
CHAPTER FIVE

ZER'A-YA'QOB AND THE GROWTH OF RETIGIOUS NATIONATISM

$(1380-1477)$

The degcendents of Yikunno-Amlak, until the last quarter of the fourteenth century, were primarily engaged in the establishment of the dynagty, and the expension of the kingdom. This afforded them little time for $\theta$ serious thought on the internal organization of the church and its relations with the monarchy. In the meantime monasticiam underwent a rapid development which found ample expression in the evangelization of the Ethiopion region ${ }^{\text {, }}$ ond in the reform movements which were perticularly active in the reigns of 'Amde-Siyon $\left(1314\right.$ - 44) and Seyfe-Ar'ad $(1344-71)^{2}$. Another outcome of this development was the emergence of strong monastic groups of which the House of Ewostatewos is of great significance to the theme of this chapter.

\section{Ewosṭatêwos}

The traditions about the origins of Ewosțatēwos

1. Supra, pp. 337 , ete.

2. Suprs, pp. 219-2,6. 
(c. $1273-1352)^{1}$ are not very clear, but he is siid to have been a nephew of Hbba Deniēl of Ger'alta, under whom he later studied? ${ }^{2}$ He wos professed monk by his uncle, probably in the community of Ger'alta. He apparently left this community soon afterwards and established his own in Sero' $\mathrm{e}^{3}$. There he was joined by mony students ${ }^{4}$ and tought vigorously until the arrival of Abune Ya'qob whom he met on his way to the king's court in sbout 1337. Soon after this Ewosṭatēwos left the country, visited Cairo where he met Patriarch Benjamin (1327 - 39), and passed vio the Holy Land to Cyprus and Armenia where he

1. Gedle Ewostatēwos has been edited by B. Turaiev in bis collection Honumenta Aethiodiae Hagiologia, Fasc. III, Petropoli, 1905. A Latin translation is available in C.S.C.O., Script. Aeth. Series altera, Vol. 21, 1906, pp. 1-97. My reference below are to the edited text.

2. Ibid, p.7. Here Daniēl is only mentioned by name and the place where he had his community is not stated. In the spiritual generlogies, however, be is consistently referred to as Deniel of the Community of St. Mary in Ger'alta, cf. Gedle Filippos (Bizen), ed. \& Tr. Conti Rossini, p.156 (table). Cf. IstigubI'. MS. Debre-Werq, ff. $1-3$.

3. "And then he went out to preach...", Gedle E'wostatôwos. p.26. Following this the centre of bis monastic activities is said to have been in Sera's, pp.35, 38-41, 58, 62-3. Gedle Filippos (Bizen), pp. 7i-73.

4. Of these the principals were ibsadi, Bekimos and Merqorēwos, Ibid, pp. 78,84,88; Gedle Ewostatēwos. pp. $31,68,1 \overline{13 .}$ Gebre-Iyesus came from Lasta or Tigre and joined him, Conti Rossini, "Note di agiografis etiopice", in R.S.O., XVI (1938), pp. 44l-2. 
died fourteen years later 1 .

It is quite clear from the traditions about his career that Ewosțatêwos left the country as a result of religious controversies in Ethiopia. Immediately before his departure there was an attempt on his life, organized by a rival group of the clergy in Sera' $e^{2}$. At the court of the Patriarch in Cairo he was accused by his fellow Ethiopi an pilgrims of refusing to communicate with them and of observing the Sabbath as well as Sunday ${ }^{3}$. The question of the Sabbath was central in the conflict, and Ewostatêtwos admitted the charge. He defended his position by resorting to the Ten Commandments and to the Apostolic Cenons ${ }^{4}$. He bitterly complained to the Patriarch, who apporently asked him to be reconciled with

1. Gedie Evostatêwos, pp. 79-129. The duration of his stay abrood $1 \mathrm{~s}$ given in Gedle Filippos (Bizen), p.99. Conti Rossini "Note di ggiografia etiopica" cit. p.443. He must have viated Cairo between 1337, the date of Ya'gob's arrival in Ethiopia, and 1339, the date of the end of Patriarch Benjamin's reign. He was still alive when 'Amde-SIyon died in 1344, Gedle Ewostatêwos. p.108. It seems, therefore, that be died in about 1352. Amother tradition states that he died at 79, Istrqubi' f. $2 a$.

2. Gedle kwosţatêwog, p. 57.

3. Ibid, p.89.

4. Ibid, pp. 90-91. Conti Rossini, "Il 'Sēmodos' Etiopico", in R.R.A.L. Ser. VIII, Vol.III, 1942, pp. 44-7. 
his countrymen:-

"I came to your country ... so that I may die for the word of God, for I have found no rest in this World. In Ethiopia they said to me, 'Break the Sabbath and the (other) rest Days like us' and I refused. And here you say to me 'Be one with us in prayer' while you do not observe the rest Days." 1.

His reception in Egypt was clearly unfevourable, and he passed on to Jerusalem, apparently suffering some acts of local persecution on the way ${ }^{2}$.

When be left Ethiopia, Ewosțatêwos was accompanied by some of his followers, but be entrusted the leadership of the rest of the community to his senior disciple, Abba Absadi ${ }^{3}$. However, his absence greatly weakened the community and, already on the eve of bis departure, some of his followers are said to have defected from him 4 .

1. Gedle Ewostatêwos, p.91.

2. At the monastery of Scete where Ewostatewos and his followers bad called on their way to Jerusalem he is said to have been put in fetters and, "(These) cruel people opposed him for the Law and Commandments (of God)" Ibid, p.96.

3. Ibid, pp. 73-76. Cont1 Rossint, "Un santo Eritreo : Buruke-'Amlok", in R.R.A.I. Ser. VI, Vol. XIV, 1938, pp. 21-22. According to 8 tradition collected by Ellero Absadi originally came from Ageme and was buried at Enda Miesqel at the present site of Enda Medhenē-slem in veqele,, "Note Sull'Lnderta", in R.S.E. I (1941), pp. 157-8. Conti Rossini apparently bad a copy of Gedle Absedi which is still unpublished, oo.cit. p.7, n.l.

4. Gedle Ewosțatēwos, p.69. 
Absadi had a difficult task in keeping the small group intact, and only on the return of some of Ewosțatēwos' compenions from abroed did his efforts begin to bear fruit. Bekimos ${ }^{1}$, Merqorēwos ${ }^{2}$ and Gebre-Iyesus ${ }^{3}$ went with their mester to irmenis and returned home only after his death. An srmenian monk who had joined Ewosțatêwos abroed came with them and became en active member of the community in Ethiopia ${ }^{4}$. According to their hagiographical traditions, all the followers of Ewosṭatēwos soon gathered around $\Delta$ bsadi and establisbed the community of Debre Maryam in Qobeyรin ${ }^{5}$. Other communities were also founded by the leading members, and a chain of monastic groups, collectively known as the "Seven Disciples of Ewosțatewos", was soon established ${ }^{6}$. Apart from that of Gebre-Iyesus,

1. Ibid, p. 113, Gedle Filippos (Bizen), p. 70 .

2. Gedle Ewostatēwos, p. 68, Gedle Veraorēwos, ed. \& Tr. Conti Rossini, pp. 32-3 (text).

3. Conti Rossini, "Note di 8giografia etiopica", cit. pp. 443-4.

4. Gedle iwostatewos, pp. 112-3. snother member of the community, Buruk- Amlak, is also given o foreign origin, Conti Rossini, "Un Santo Eritreo", cit. pp. 10, 22.

5. Gedle Éwosțatēwos, pp. 116-7, 136.

6. Conti hossini, op.cit., pp. 1-3. 
who proceeded to Enfraz in Begemdir 1 , two of the communities were in nortbern ligre and the remaining four in Sera'e and Hamassen. Thus the geographical distribution of the House of Ewosțatēwos was more beavily represented in the northern provinces of the Kingdom. The regional character of the movement gave a greater homogeneity to the Houge of Ewosṭatēwos, and for the same reason too, the kings were more deeply concerned about it. A recent tradition about Ewosțatêwos and Anorêwos of Shewg puts this in good relief. The two monastic leaders, we are told, once met at the royal court of King 'Amde-Sigon. They began to discuss the question of the Sabbath in violent terms, and this was reported to 'Amde-ṢIyon. The king summoned his fellow Shewan, Anorewos, to his presence and had him flogged because "you will divide my Kingdom by your religious disputes"?

1. Supra, pp. 387-9.

2. Mel'ake BIrhan SIgẽ, Meshafe-Tarik. MS. B.30, National Library, Addis Ababa, pp: 45-46. Cf. also TarikeNerhest, MS. Debre-Marqos, ff. 29b-3la. Another tradition, which also appears to be of recent formulation, reports that iwostatēwos had visited Showa and met 'Amde-ŞIyon there, G. Ellero, "Note aull'Enderta", cit. p.166: Another only takes him to Lesta, Gedle Mercorêwos, p.21. Cf. Conti Rossini, "Il libro delle leggende", cit., p.709. 
It is probable that the controversy on the Sabbath in the Ethiopian Church was much older than the fourteenth century. In a report on Ethiopia, Bishop Sawros once requested Patriarch Cyril (1077 - 92) to write to the Ethiopions "forbidding them to observe the customs of the Old Testrment"1. Apart from the customs of circumcision $^{2}$ and marriage ${ }^{3}$, the bishop may have also had

1. Sawirua, History of the Patriarchg of Alexandria. Vol. II, part 3, p. 3 bo.

2. As early as the reign of Patriarch Yosef ( 830 - 49) there is a reference to Ethiopian insistence on circumcision. In an attempt to explain St. Paul's point on circumcision ( $I$ Corinth. VII, 8) Bishop Yohannis apparently created locol suspicions obout himself and was forced to leave the country for some time. On his return to Ethiopia after some negotiations, trouble started once agein and a petition was submitted to the king that the bishop should be circuncised: "for all the inhabitants of the country are circumcised except him". When he was examined later, it was found that he was properly circumcised, Sawirus, History of the Potriarchs, in P.O., X (1915), pp. 508-11. At a Council beld in 1238, Patriarch Cyril ruled that "customs established in Coptic churches shall not be changed, such as circumcision before baptism", O.H.E., Khst Burmester, "The Canons of Cyril III ibn Laklak", cit., pp. 106-7. Maqrizi also reports that "Le's Cóptes, controiphent oux autres ohretiens, ont l'usage de lo circoncision", Les Fetes des Coptes, ed. \& tr. R. Griveau, in .P.O., $x(1915), p .325$. Wansleb, L'Historie de l'Eglie d'blexandrie, Paris 1677, pp. 78-9.

3. Beșelote-Mikg'ẽl's parents planned for him to merry his (láte?) brother's wife, Gedie Beselote-iike'ēl, p. 12 (text). Cf. Alvarez, op.cit., p.108; cf. also, Liber Aksumge, ed. Conti Rossini, pp. 71-72. 
the Sabbath in mind. However, the early position of the Alexandrian Church 1tself is not very clear on this point, and the Sabboth seems to be held with a great deal of honour in its Coptic and Arabic literature. But in Ibn al-Hssal's Collection of Canons compiled in 1238 the observance of the Sabbath is clearly rejected as a Jewish custom ${ }^{1}$. At least from this period onwards, it is quite evident that the Egyptian bishops were determined to impose the official Alexandrian line on the Ethiopiens.

The "House of Ewostatewos".

Ewosţatêwos taught against the Alexandrian position on the Sabbath. It seems that at first he could gather little active support for his cause and left the country in self-exile. when bis disciples returned fourteen jears later, they, apparently come with even stronger views on the subject, and with new idess of better organization. During their sojourn in the Levant they probably had much access to the literature of the early Christion

1. Muyser, J. "Le Samdi et le Dimanche dans I'Eglise et la litterature Coptes", appendix to Togo Mina, Le Martyre d'Apa Edime. Cairo, 1937, pp. 89-111. 
church, and they may have brought their own copies of religious books back with them. The traditions of great love for books which we have about the leading members of the movement probably arise from this ${ }^{1}$. An active literary development appears to have token place among them during this period ${ }^{2}$, and not only did it strengthen their own position but also seems to have served in time as a decisive landmark in the cultural renaissance of the whole of the Ethiopian Church. The memory of the exile and death of Ewosțatewos gave his followers a strong sense of unity, and they continued to defend his position on the Sabbath, for which they were excommunicated:-

"I discipoli di Mra'qaba Eqzi' osservavano

i Sabati, sabato e domenica; ma non entraravano nella dimora reale ne nella dimora dei metropoliti, e non prendeveno il secerdozio, perche nella reggio non vigeva l'osservanzo del sabato, e nella

1. Conti Rossini, "Un sento Eritreo: Buruk-'Amlak", cit. p.7, n.1.

2. Gedle Filippos (Bizen), p.104. They co-operated among themselves to bring about this and there seems to have developed $\theta$ healthy sense of competition among the leaders. According to a tradition preserved bere Absedi once copied Angese BIrhan for Filippos. The latter wanted more and requested absadi to copy for him another work, BIhêre YohannIs. When Absedi besitated to do it some hard feeling was created between the two. Hnother tradition bas it that Filippos had all the Books of the Old Testament copied in 1378/9, Kolmodin, Treditions, cit. 1913, A 23. 
dimore dei patriarchi il Sebato era abolito, e lo mettevano in commune con gli altri cinque groini per compiere $i$ lavori, e riguardavano come Giudei coloro che lo osservavano, li anatemizzavano e non consentivano loro di entrare nella chiesa." 1.

The opponents of Ewosțatēwos among the local clergy actively persecuted his followers and expelled them from the settled areas. The difficulties which they had to face in this eorly period are quite evident from their traditions. On one occasion, the first compantons of Ewosțatewos, Absadi and Merqorēwos, are said to have met at a place called MIdre-GodaI' and to have prayed together for God'a guidance about whether to proceed. On snother occasion Filippos (c. 1323 - 1406), who later founded Debre-Bizen, accomprnied Absadi on a visit to his aged father, Tomas, who advised them to go in different directions and to start, each of them, $\theta$ community of his own. ${ }^{2}$ It is apparent that, in their search for suitable ploces, they were forced to withdraw into frontier aress.

1. Zer'a-Ys'qob, liashafa Berhan. Vol. II (tr.) ed. \& tr. Conti Rossini ond L. Ricci, in C.S.C.0. Vol. 262, Script. Aeth. Tomus 52, p.82. Ma'qebe-Equi' was the nome of Ewostatewos before bis ordination as monk by his uncle Daniel, Gedle iwostatewos, pp. 6, 23.

2. Gedle Filippon, p. 88. 
This seemg to have determined the location of the first major communities established by the followers of Ewosțatêwos: Debre-Maryam and Debre-DImah in Qohayīn and Dembelos respectivel ${ }^{1}$, Debre-Bizen on the esstern edge of the Hamasēn plateau, and Gebre-Iyesug' community of Debre-Sen among the Felashe in Enfraz ${ }^{2}$. Once established in these peripheral areas, however, they soon evolved a meticulous organization of their own in complete defiance of the rest of the Ethiopian church.

1. In about the same period as the eatablishment of these two commuities, these frontier areas were being gradually occupied by the Christian tribes of AdkemeMelga, Conti Rossini "Studi su populazioni dell' Etiopia", pp. 89, 92 (extract). The itineraries of Filippos before bis settlement at Bizen also indicate that the disciples of Ewostatewos were forced to wander in distant forests and uninhabited areas. Only a little to the wegt of the present site of Debre-Maryam, which Conti kossini cells "il selvaggio distretto di Cohrin", Filippos is seid to have once visited Dubenē described ag $h . . .8$ barren land ... where there are no people, no food or water, and no cattle are seen in it", Gedle Fillippes, p.81. Fillippos was met by a hostile Group of people there, and Conti kossini identifies these with the Qunama, Ibid, p.154, note on F.14r. Cf. also p. 157, note on F.17\%.

2. In the traditions about him be is said to have first established bimself at a site in rigrē, where he bad a revelation that the site was not assigned for him and that be should travel to Enfraz, Conti Rossini, "Note di agiografis etiopica in Gebre-Iyesus", cit. p.444. This is probably an allusion to a hostile reception in Tigre. For bis evangelical work among the felasha supra, pp.387-q. 
Zer'a-Ya'qob provides us with an excellent contemporary description of their curious orgenization 1 . They consisted of three major communities, namely DebreMaryam, Debre-Brzen and Deqi-Yrta ${ }^{2}$. Each of these had a number of smeller monasteries and convents under its supervision and the total number of their inmates was considerable $e^{3}$. Since all the members of a House of Ewosţatêwos were deborred from receiving holy Orders at the honds of the Egyptian bishop ${ }^{4}$, these communities lived

1. Mașhafa Berhan, II (tr.). pp. 83-4. Cf. also Dillmann, Uber die Regierung. insbesondere die Kirchen ordnung des Konige Zerg-Jacob, Berlin, 1884, pp. 45-7.

2. Cf. Liber Akgumae, p. 26 (text).

3. Zer'a-Yaqob gives a short statistical survey: DebreMaryan consisted of 81 monasteries and 23 convents; Debre Bizen bad 8 monasteries and 3 convents with a total number of 1146 nuns; and Degi-Yrta 6 monasteries, Ibid, p.84. Iwenty-five churches are elsewhere said to have been built by Filippos and administered together with Bizen, Gedle Filippos, p. 107.

4. Ewostatēwos bimself was duly ordained, apparently before he established his distinctive school, Gedle Ewostatowos, pp. 22, 25. 'Ler'a-Yagob, op.cit., pp. 82-3. No traditions of such ordinations are given about Filippos and his successor Yohonnis whose Gedls have been jointly published by Conti Rossini. Zer'g-Ya'qob simply refers to the head of Debre-Bizen as a lay brother, Ibid. p.84. 
in an almost complete independence from the rest of the church. However they apparently needed a small number of ordained priests, whom they admitted into their group only after giving them penance for having been members of other commities. These priests were mainly required to celebrate mass for the group. In all other matters, however, each of the communities was headed by a lay brother with absolute powers over the religious conduct of the members. Despite his lack of sacerdotal powers, he fully exercised the outhority of an ordinory abbot. Fe conferred the monestic habit on the novices in the community; confessions had to be individually reported to him and he fixed all penances given by the priests. Debre-Bizen also had additional rules of its own for its dependent convents. The head of this community appointed a Mother Superior for each convent and invested her with full powers, almost similar to his own. She had powers of conferring the monastic habit on the novices in her convent, and confessions were made through ber. She was in regular communication with the bead of Debre-Bizen through a lay brother, who reported all the confessions back to his master, and penances were fixed by the latter as in the case of the dependent monasteries. 
This structure of the organization of the followers of Ewostatēwos had already taken shape towards the end of the fourteenth century. Despite the official excommunication pronounced againgt them, they hod olready obtained a firm footing in the outlying districts, where the direct influence of the Church was minimal. Just like any other monastic group, they bad gradually acquired much prestige among the local people. They probably got on increaging number of recruits from among the Christians in the area, especially from the poor and orphaned". phey may also have gained some converts from among their pagon neighbours ${ }^{2}$. It seems quite clear, however, thot in the last decode of the fourteenth century their influence in what is today the heart of the Eritrean plateau had already been securely established along a widening crescent between Debre-Maryam of QohoyIn, Debre-Nierqorēwos of Dembelas, Imba-Derḥo 3 and

1. Gedle Filippos, pp. 91-3.

2. Such conversions are claimed among the pagan Barya Pastoralists, Ibid, pp. 107-8, 162 note on $F .43^{1}$.

3. One of the earliest sites, remembered as having been the place where Filippos was welcomed by the local Christians on his way to Bizen, is Geremi in Hamesēn, which Conti Rosgini identifies as being a little north of Emba-Derho, Ibid, pp. 91, 158. Another community established by 8 contemporary of Filippos, Abba Matyas, was at ShImagille, also identified by Conti Rossini as being s smell villoge a little north of Asmers, Ibio, pp. 120,163 . 
Bizen.

The anti-Sabbath party within the Ethiopian church was greatly alarmed by this rapid success. As the champion of the official Alexandrian doctrine on the Sabbath, this party had the full support of the kings, and the great mojority of the monasteries belonged to it. Moreover the Egyptian bishop bimself personally led the onslought against the followers of Ewogţatêwos Indeed it was not a mere accident that the greatest advance of the fortunes of the House of Ewostatêwos coincided with the vacancy of the episcopal seat for a period of ten yegrs.

Abune Selgma $(1348-88)^{1}$ was not succeeded until

1. Selama came in 1 Year of Grace (-1348) and died in 40 Year of Grace $(=1388)$, Liber Aksumae, ed. Conti Rossini, in C.S.C.O., Script. Aeth. ser. altera, t. VIII, Farigi, 1909, p.67 (text). Kolmodin, J., Praditions de Tsazzega et Hazzega, Upsala, 1913, A 23 . From the great number of translations attributed to him, Selama was no doubt the greatest Egyptian bishop Ethiopia ever had. For his contributions to kthiopic literature see Guidi, I. (Breve) Storia della lettersture etiodica, pp. 68-70. Lantscboot, d'Ethiopie $(1348-88)$ et son role de troducteur", in Converno di studi Etionici, Roma, 1960, pp. 397-401. The Ethiopion Church grotefully remembers him as "Abba Selama, the Translator", and the following lines are part of an eulogy read out every year on the day of his deeth: "From your lips (which are) sweeter than the scent of myrrh ...., (There) came forth Books from Arabic into Ge'ez". Ś.ynaxaire, in P.0., IX, 19, p.563. 
1398/9 when Bertelomêwos came as the new Nietropolitan of Ethiopis?. The defiance of the followers of Ewosțatewos was clearly the most important issue in the Ethiopian church at the time, and the first public act attributed to the new bishop is his energetic attempt to bring an end to the problem. The anti-Sabbatb faction hed no doubt awaited his arrival with much eagerness and provided him with up-to-date reports on the growing influence of the followers of Ewostatêwos in northern Ethiopia. The dangerous implications of this for the unity of his diocese were clearly understood by Bishop Bertelomewwos and he asked for the help of King Dawit (1380 - 1412) in bringing the recalcitrent House of Ewosṭatêwos back to strict Alexandrian digcipline. In $1400^{2}$, not long after the arrival of the bishop, Dawit 1. Kolmodin, $\frac{\text { op.cit. }}{A_{23}}$ and $\mathbb{A}_{50}$, n.9. It is not exactly terminated. He is mentioned as having still been in office in the reign of Yishaq (1413-1429), Ser'a-Ya'qob, Meshafe-Birhan, II (text), p.131. His name appears in a land grant dated 84 Year of Grace (=1431/2 A.D.), The Four Gospels, MS., Haiq (IM), f.22b. He is mentioned elsewhere with Zer'a-Ya'qob $(1434-68)$, Gedle Filippos, MS. Dobre-Libanos, F.73b. The King's name appears with that of Epis-Qopos Mika'el in 1436 A. D. Which is probably the terminal point for the reign of Bertelomêwos. Compendium of Homilieg. MS., H8iq, end of MS.

2. The jeer given is 52 Year of Groce $=1399 / 1400$ A.D. but Filiopos is said to bave gone to Amhara in April so that $1400^{\circ}$ is preferable, Gedle Filippos, p. 117. Kolmodin, op.cit., $A_{23}$. 
sent messengers to fetch the leading figures of the

Ewosțatêwos party:-

"There came to us men with handsome

looks, and they are finely dressed.

we have never seen their like since

we ascended this Nountain ... They

said to ug, 'we have a message from

the King and the Bishop'. They

look strange and their language is

incomprehensible." 1.

These were the king's messengers to Debre-Bizen, and

some of them were probably Amhara courtiers whose

language the fiamosen monks could not understand. Their

orders were to summon Abbo Filippos for a theological

discussion on the Sabbath. Similar envoys were

opporently sent to 811 the Ewostethion communities as

well, and a number of other "Disciples of Abune ria'qebe-

Eqqui' "accompanied Filippos to the Metropoliten's court

in Ambera." 2

1. Gedle Filippos. p. 111 .

2. Kolmodin, loc.cit. Their number is here given as having been 12, begides Filippos. His own hagiographer(s) roises the number to 120 , Gedle Filippos. p.112. The nomer in Kolmodin's list are exactly similar to those of "the twelve teachers of Ethiopia" who are elsewhere said to have called at Bizen in search of Filippos' instructions ond spiritual guidence, Ibid, p.I0'7. It is clearly a case of intermal rivalry among the Ewostathions for primacy. It is epparent that the early companions of Éwostatewos had died by this time, and only the second seneration of Ewostathion leaders are represented in this tradition. Cónti hossini has, 
King Dawit was evidently anxious to avoid a direct personal involvement in the matter, and fully authorized the Metropolitan to deal with Filippos and his fellow Ewosțathiana: "Punish him (i.e. Filippos) as you see fit, until he accepts (your instructions)"1. The bishop ss well os his principal courtiers were the declared opponents of the House of Ewosțatēwos and the outcome of the religious discussion was a foregone conclusion. Nevertheless Filippos ond his colleogues courageously defended the sobbath at the Assembly in much the same way as Ewosṭatēwos had done at the court of Patriarch Benjamin over balf a century earlier ${ }^{2}$. They strongly refused to

Footnote 2 cont. from previous page.

however, estimated that Absadi died in C. 1405 H.D., and Merqorēwos in c.1419, Ibid, p.157, not on F.17V. Both dates seem to be too late. This is certainly so in the case of Merqorewos who, according to his very late ( 17 th c.) hagiographer(s), was already 33 years old in 1318 , and died in the seventh year of the reign of YIshaq, In 1419, Gedle Merqorēwos, pp. 20-21, 27, 34-5, 37, 39, 47 (text). Absadi was also represented at the Council of 1399/1400 by Tewelde-Madhin of Debre-Maryam, most probably a reference to the same monk remembered elsewhere as bis disciple, Conti Rossini, "Un sonto Eritreo: Buruk 'Amlak", cit., pp. 37-8.

1. Gedle Filippog, p.

2. The whole story of this agsembly is related in Gedle Filippos, pp. 111-120. 
accept the bishop's ruling thot they drop the observance of the Sabbath, and they were all put in fetters at bis orders. They were told thot they would be freed only when they changed their views. Aqabē-Se'at SereqeBIrhan of the island monastery of Debre-Haiq, an intimate councillor and a great confidente of king Dowit ${ }^{1}$, was at the head of the anti-iwosṭatewos movement in Amhara. He apparently played an important role in the Assembly, and in carrying out the disciplinary messures taken on Filippos and his colleagues at the court of the Metropolitan. Later, when most of the Iwostathians continued their defience of the orders of Bertelomewos Sereqe-BIrhan was given the custody of Filippos and kept him under close guerd in the island of Debre Haiq?

1. First mentioned ag the spiritual father of Aqabe-Se'at BInyom, who apparently succeeded him, The Four Gospels. MS., Haiq (IM), f.22 $2^{\circ}$. He was abbot of flaiq ran young Giyorgis of Gascha entered the school there, Geale Giyorgis of Gascha, MS, Haiq, ff.4b-5a. He was greatly respected by King Dawit who consulted him on important matters of state, Cerulli, $k$. Il libro Etiopico dei Miracoli di Maria, Rome, 1943, pp. 79-86. It is interesting to note thet he is mentioned as having been married, Gedle Filippos. pp. 119. The Agabe-se'st whom Alvarez met, Negede-Iyesus, was also married and had children, op.cit. pp. 108, 270-1, 378-9. Negede-Iyegus and his son were killed during the Gragn wars, Futuh alHabasha, tr. Basset, p.202. Etudes, p. 105.

2. Gedle rilippos. p.118. 
Filippos was detained in Ambara for a period of four jears. His haglographer complains of some defection among the followers of bwostgtewos in this period, and Matyas of ShimagIlē and Zekaryas of Berberē are specially mentioned in this connection ${ }^{1}$. It is apperent that, from the start, there had been no complete unanimity among the Lwosţathian leaders. Lind, faced with the hardabips of detention in Amhara, some of them probably took the earliest opportunity to have their excommunication lifted, and to live on peaceful terms with the Metropolitan. This apparently created a lasting feud particularly among the descendents of Filippos of Debre-Bizen ond Matyas of Shimagille $\mathbf{e}^{2}$.

But on the whole the number of defections was very insignificant, and the great majority of his colleagues followed Filippos in holding fest to the teachings of

1. Ibid, pp. 112, 117. Ewostatêwos in said to hove bad a disciple called Matēwos of Debre-Berberē and Zekaryas wos probably bis pupil. The moster bimself is seid to hove stajed at Berberē for seven years, IstrgubI'. MS., Debre-werq, ff. lb-2a. Cf. also Gedle rilippos p.156, Trbles.

2. On his way back from Ambara Filippos met Matyas at Sehert. It was an unheppy encounter and Filippos is said to have solemnly pronounced a curse on Matyas whose descendents continued to be under its spell ever ofter, Ibid, p.120. 
Ewosṭatēwos. In fact, Filippos' sojourn in Ambera opened a new period for the House of Ewostyatewos and it seems to have won many more allies among the powerful ottendants and influential clergy of the royol court. The Egyption bishop, on the other hand, lost his most loyal supporter among the Ethiopian hierarchy at the death of Aqabe-Se'at Sereqe-BIrhan of Debre-Haiq in about 1403. Immedietely afterwords, orders came to the island monastery of Debre-Haiq for the release of Filippos ${ }^{1}$. The orders presumably came from the royal court, and it is unlikely that they had the approval of the bishop. It is apparent that Filippos's old gge $^{2}$ ond his unswerving leadership had won much respect and odmiration in umbara, and the Ewosțatêwos lobby at the royal court had been growing fast. In 1403 the Christion army had been

1. Filippos was released in 56 Year of Grace $=1403 / 4$, Kolmodin, op.cit., A $3^{\circ}$. This hoppened shortly ofter Sereqe-Birhon's deata, Gedle Filippos, pp. 118-9.

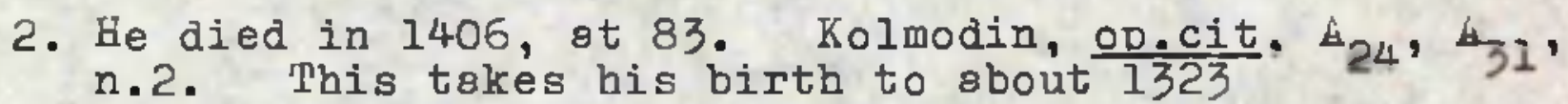
n.2. Phis tokes his birth to about 1323 tollies with the tradition that he was born in the reign of "our king 'Amde-Siyon, son of WIdFmRe'ad", and before Ewosțotēwos' self-exile, Gedle Filippos, pp. 69, 73 . 
victorious in Adal, killed the Muslim King sa'ad ad-Din, and sacked the distent port of Zeils?. The public rejoicings thet followed no doubt assumed a highly nationalistic and anti-Muslim character, and very little attention wag probably given to the wishes of the Egyptian bishop. The presence at court of military leaders from Serg'ē and Homasēn may hove also increased the pressure for the release of Filippos ${ }^{2}$. His hagiographer reports that, at the time of his release, both King Dawit and one of the Queens, igzi'-KIbra, sent messages of good will to Filippos, entrusting themselves to his prayers ${ }^{3}$. Zera'-Yaqob substantially confirms this sudden chenge of heart in favour of the House of Ewosțtêwos:-

"Mio padre Dawit, re d'etiopa ... invio dei messeggeri affinche raccogliessero i discepoli di Mo'qoba Égzi' dolla loro dispersione e li facessero rientrare nelle loro chiese. I messi del re cosi fecero; ed i discepoli di ma'qaba Egzi' ritornarono nei loro luoghi. Il re commando altresi ai discepoli di Me'qaba Egzi' di osservare entrambi i Sabati, come gli hpostoli avevano prescritto nel sinodo." 4.

1. Supre, p. $290, n \cdot 2$.

2. Geale Hilippos, p. 65.

3. Ibid, p.118.

4. Moghefa Berban, II, p.82. 
It is only natural that Zer'a-Ya'qob should attribute his father's action to a mere feeling of sympathy towards the followers of Liwosțatewwos dispersed everywhere in exile, dying of hunger and thirst, and unjustly persecuted solely for the couse of observing the Sobbath. It is, however, quite clear that Dawit's change of policy towards the House of Ewosṭotēwos was only a result of their strengthening politicel and religious influence in the kingdom. The political moves of Dowit at the time were in fact highly characteristic of the relations between the monarch in Ethiopia and the Egyption bishops on all similar occasions. At the beginning of the controversy the king did everything to facilitate the public trial and discipline of Filippos and his colleagues at the court of the Metropolitan. At the same time, however, he systematically avoided a direct involvement in the proceedings, which be left entirely in the hands of the Egyptian prelate. When the Ewostathians continued to be unrepentant and local pressures for their freedom became considerable, the king mede political capital out of the situation and personally intervened with on act of clemency towarda Filippos and his followers. Be permitted them to observe the sabbath as they insisted, and decreed that they 
should not be persecuted for this. They were now free to re-occupy their previous churches and monosteries ond to establish other communities wherever they could. But he maintained, at the same time, that both at the rojel court and in $\theta 1$ the non-Ewosțetbian churches the official Alexandrion position on the Sabboth should be observed, and that the leadership of the EgJption bishop should be strictly followed. King Dowit was clearly snxious to please both parties, but his timid approsch to the problem did not bring about a permanent solution. Neither the diehords among the Ewosțathians, nor the anti-Sabboth party, were fully satisfied by his balf-measure. The most drostic effect of bis intervention was only to undermine the prestige of Bishop Bertelomewos and weaken the position of his ardent supporters who were completely loyal to Alexandria.

The House of Ewosţatêwos emerged from the struggle with tremendoug auccess. Its stgtug wes suddenly tronsformed from one of on actively persecuted minority sect into that of a respectable school. It wag not only tolereted, but also fully protected by a special decree. lowerds the end of the reign of $\mathrm{king}$ Dawit, the Ewostathions seem to have acquired complete freedom of movement throughout the kingdom. This provided 
them with much scope for expansion, and their treditions attribute much of their internal development to this period. Even the distent community of Debre-San among the Felasha, which had been virtually isolated from northern Ethiopis during tbe conflict, seems to have felt the impact of Dawit's decree in 1404. Cebre-Iyesus, its founder, is soid to have sent out some of his followers to establish themselves further south ${ }^{1}$. A similar expansion of Ëwostathion communities is also apparent in northern Ethiopia. On his way back from his

1. From his diaciples, three are remembered in this tradition. Natewos succeeded him ag abbot of DebreSan; Fiqitor went out to Gedame Beres to live in solitude; and Endryas was ordered by his dying master to move out to a new area and start his own community, Conti Rossini, "Note di ogiogrefia etiopica i Gabra Iyssus", cit. p.450. The MS. used by Conti Rossini probably did not mention the nome of the area where indryas was recommended to go and his translation only hos "Vai verso un paese nuovo". In more recent MSS the place is given as the land of Niwag (-ZFwaj3), OR.705, BM, f.154; and Zrway, SInksar, MS. Debre-Werq, Hamle 20. This specific 1dentification with ZIway appears to be suspect and seems to derive from the attempts in Debre-Werq traditions to associate the famous $\mathrm{Abb}$ SInode of Debre-Șimone (E. Gojam) with Endryas, disciple of Gebre-Iyesus, Istigubr', MS. Debre-Werq, ff. 1b-2a. In his own Gedl sinoda is said to have been a disciple of Endryas of Ziway but there is no mention of any connections with Debre-San at all, Gedle Sinoda, MS. Dime, f.3a. Debre-Werq itself derives its origin from a fourth generation descendant of Gebre-Iyesus of Debre-San, Istigubi', loc.cit., Gedle Serse-Eetros, MS. Debre-Werq, ff. 24b-5a, $30 b-318$. 
detention in Ambara, Filippos is said to bove been welcomed by the local people at various stages along his route and to bave been invited to establish new churches. As a result a chain of smell communities seems to have started in the Eritrean region, along the main road from Amhora to Bizen ${ }^{1}$. It has been said above that even before the advent of Abune Bertelomewos the Ewostathiang had been firmly established along the western edge of the Eritrean pleteau. Soon after 1404, a number of communities were newly established on the eastern side as well, and the whole Eritrean region became once and for all on exclusive domain of the House of Ewosṭatēwos.

The fingl success of the Ewostathians in their conflict with the Egyptian bishop had far reaching consequences in the whole of the Ethiopian church. For themselves, their most important achievement ley in their acquisition of complete freedom to observe the Sabbath. But there was no way to ensure that the royal

1. Meters ond Egela are specially mentioned as the site where new communities were established. Both pleces are in what is today the district of Akele-Guzay, Gedle Filippos, p.120. 
decree protecting the custom only applied to them. Thus, olthough Dawit clearly intended the decree to cover only the House of Ewosṭotêwos, his official toleration of the Sabbath was highly subversive of the basic Alexandrion objection to the "customs of the old Testament", which the Egyptian bishops claimed were preserved in the Ethiopion church. As on essential part of the Christian tradition, the Old Testament had always hod a great influence on the thinking and religious practice of the Ethiopians. In the absence of much literary development omong them in the early Christian centuries, only the Bible provided the Ethiopions with the necessery guidelines, and from it they drew not only their religion, but also much of their cultural and political inspiration. As regards the Sabbath in perticular, both the Apostolic canons ${ }^{1}$, and

1. Les Canons des Apôtres. ed. \& Tr..J. \& A. Perier in P.0., VIII (1912), p.99: Exemption of slaves from work on Saturdays and sundays: "o'est, en effet, le Samedi que Dieu se reposs, apres avoir acheve l'univers; quant au dimenche, c'est le jour de le resurrection du seigneur"; p.134: Fasting forbidden on saturdays and Sundays - except the saturday of the Passion Week, cf. also The Ethiopic Didascalig. tr. J.M. Harden, 1920, p.127, Sawirus, History of the Patrierchs of Alexendria, (Christodulus $1046-77$ ), in PO, Vol. p.253. Muyser, J. "Le Samedi et le Dimanche dana 1'Eglise et la litterature Copte", cit. pp. 89-91. 
the monastic rules of St. Pacomius ${ }^{1}$ concurred in giving it a special plece beside the Lord's Day? . This had apparently led to the observance of the Sabbath being an important monastic practice in Ethiopia ${ }^{3}$. The Egyptian bishops always campaigned against it, and already in the beginning of the fourteenth century they had succeeded in obtaining the support of the kings, and the obedience of most of their congregations. It is quite clear that, when he started his coreer, Ewosţatêwos was only leading 8 minority group in active protest against what he considered to be the Alexandrian "innovation". By then, the great majority of the ithiopian monasteries -

1. Muyser, op.cit., pp. 92, 95-111. For the early introduction of these rules into Ethiopic literature see Cerulli, E. Storis della letterature etiopica, pp. 25-6.

2. For a detailed review of this problem in the Early Church, see articles on the Sabbath in A Dictionary of Christian Antiquities. Iondon 1908. The Jewish Encrclopgedia, New York, 1935.

3. The date of the Ethiopian adoption of this and other "customs of the Old Testament" is still an object of discussion. For a balanced view of the controversy see Ullendorff, E., "Bebraic-Jedulshelements in Abyssinien (Nonophysite) Christianity", in JSS, I (1956), pp. 216-56. Rodinson, M., "Sur la question des 'influences juives' en Itbiopie", in JSS, IX (1964), pp. 11-19. 
particularly the royal churches and the newly established communities in Amhorg and Shewa - had been brought into line with the Alexondrian bon on the Sabboth. It is apporent, however, that much of this religious conformity was only due to fears of excommunication and to the kings' full support of the Egyptien bishop. But when, in 1404, King Dawit finally decided to give protection to the Ewosţathians he dealt a serious blow to the power of the Egyptian bishop in Ethiopia.

fbune Berteloméwos and his successors never recovered from this momentous setback in their position as heads of the Ethiopian Church. Dawit's decree in favour of the House of Ewostatēwos was, in effect, also on official encouragement of other dissenters. It is further apparent that the controversy over the Sabbath was only symptomatic of the divergencies in religious practice that had developed between the Alexandrian and the Ethiopian churches over the centuries. The literary development which the Ethiopion church hod been undergoing since the thirteenth century ${ }^{1}$ had provided the

1. Guidi, I. (Breve) storia della letterature Etiopica Roma, 1932 pp. 8-10. Conti Rossini, "II 'Senedos' etiopico" in R.R.A.I., Ser. VII, Vol. III (1942), pp. 41-44. Cerulli, s. Storis delia letteratura etionics, Roma, 1956, pp. 67-70. 
Ethiopions with fresh means of self-expression through which they were beginning to assert themselves. The organized protest and final success of the Ewosțathians sparked off a restless period of religious controversies which lasted throughout the reigns of Dawit and his sons. Nevertheless, only Zera'-Ya'qob (r. 1434 - 68) understood the conflict in its true noture as a national movement, and he readily adopted it in the fabric of the religious nationalism of medieval Ethiopia of which he was the principal author.

Zer's-Yg'aob, and the Council of Debre-listmaa.

By a strange coincidence Zer'a-Ya'qob was born in 1399, within a few months of the first council called by Abune Bertelomēwos to discuss the Sabbath ${ }^{1}$. He was the

1. Zer'a-Ya'qob himself says that be was 50 years old in the 15th Year of his reign, Meshafe-Tefut, MS. Inst. Archeol. Addis. It is also said elsewhere that be "acceded to the throne when he was 35 years old; others say he was 40", Tarike-Negest. MS. Debre-S5gē, p.54. Other traditiong record his birth in $60 \mathrm{Year}$ of Grace (a 1407/8 A.D.), Liber Aksumae, p. 67 (text).

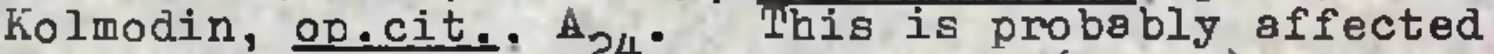
by the alleged prophesy of Filippos (Bizen) about bim, Gedle Flipoos, p.118. 
youngest son of Dawit and Queen Eqzi'-Kibrs ${ }^{1}$. An interesting tradition obout his youth? ${ }^{\text {? }}$ seems to offer $a$ useful background to his extraordinary career of intensive literary and religious activities. However, despite the fresh light it throws on the struggle for succession among Dawit's sons, the tradition tends to be hagiographical in character. While Zer'B-Yo'qob was still a little boy, we are told, many saintly monks foretold bis future greatness. This aroused against him the jealousy and hotred of his brothers, particularly Tewodros ${ }^{3}$.

1. It is not known exactly how many queens Dawit had, but his children were born of different women, Yegella Tarik, MS. Debre-Sigē, f.28. The names of three of hisqueens are aváilable: Dingil Sewena, Gedle Vieraorēwos. p.39; Siyon-Mogesa, mother of Tewódros, Sinksar, ed. \& tr. Guidi, in PO, I (1904), pp. 695-6. YIsheg may have also been ber son. Hizbe-Nagn was probably of Laota origin on his motber's side, The Four Gospels, MS. Lalibela: Gebriēl, f.9 $9^{\circ}$ Egzi-KYbra was probably Dawit's youngest queen, and lived as late as 1455 , Wright, Cotalogue, Or.481, ff. $154^{a}, 208^{\circ}$.

2. Tarike-Negest, MS. Debre-Șigē, pp. 54-55.

3. Tewodros was Dowit's first son, MelkI'a-Dawit Nigus, appendix to Gedle Serge-Petros. Ms. Debre-Werq. He succeeded Dawit in October 1412, but died only nine months later, Gedle Gizorgis of Gasçha, MS. Haiq, f.27. He died east of the River Awash, probobly during an expedition in Adel, Sapeto, G. Viagkio e liissione Cattolica fre i Mense. Roma, $1857, \mathrm{pp} .437-8$. He is remembered in the Church os a sointly man, Sinksar, ed. \& tr. Guidi, in P.0., I (1904), pp. 695-6: $\frac{\text { Bermudez }}{2}$ relates the tradition that Tewedros gave a district called Nazret in Tigre ss fief to the Egyptian bishop, La Croze Veyssiere, Histoire du Christianism d'Ethiopie et d'Hrmenie, 1739, pp. 125-6. The Portuguese Expedition 
Greatly elerwed by this and concerned for her gon's safety, Eqzi'-Kİbra entrusted him to one of her relatives, a monk of apparently TIgrex axigin. The monk took the boy 8way from court incognito, settled in Akgum and began to give bim a religious training. Soon afterwards the monk died and Zer'B-Y日'qob left Aksum on his own and joined the monastery of Debre-Abbay in Shrre, still incosnito. He remained there until all his brothers had reigned in succession and died. On this occasion troopa were sent in search of the bidden prince, who was only discovered with much difficulty. He was then brought back to court and crowned by force?.

Footnote 3 cont. from previous pege.

to Abygainia in 1541, as narrated by Castanhoso and Bermudez, tr. Whiteway, R.S., Hakluyt Society, 1902, p.160. Probably based on the same tradition, Bruce has painted on altogether different picture of the reign, Provels to discover the sources of the Nile, Vol. II (1790), pp. 64-5. Attempts have been made to identify this king with his nomesake in an apocryphal work of an unknown date. There are however no convincing reasons for this, Basset, R. Les Apocryphes Ethiopiens: XI. Fikare-Iyesus, 1909, pp. 9-12, 25-6.

1. cf. also Gedle Zena-Maraos. MS. Debre-SIgē, ff. $109 b-110^{a}$. 
This is invaluable os providing a religious background for Zer'e-Yo'qob's cвreer, but the story is very improbable in its details. The considerable leaming which Zer'a-Yo'qob later displayed, and the depth of his personal involvement in the reorganization of the church during bis reign, are indeed bighly inaicative that he had very close contacts with the church before his accession to the throne. He may have even spent much of his early life in monastic surroundings. It is unlikely, however, that he went into hiding. In fact it is apparent that he was very much in the running for the crown particularly after the death of King YIshaq $(1413$ - 30). His struggle for the succession with HIzbe-Hagn $(1430$ - 33) and his two sons is wellremembered in some traditions and will be discussed elsewhere in greater detail1. It suffices here to point out that Zer'a-Ya'qob himself relates that be was brought down from the royal prison of lount Gishen only on the eve of bis accession to the throne ${ }^{2}$.

In many ways the advent to power of 'Zer'a-Ya'qob in 1434 was a godsend to the ithiopion Church. It was

1. Infra, pp. 549, cte.

2. Maghafa Berhan, II (text 7, p.157). 
almost exactly a century earlier, in about 1337, that Ewosṭatêwos had left his country in self-exile. Since then his small following in Etbiopia had rapidy grown in strength and hed taken full control of the northern part of the kingdom. The issues raised by him and his followers had revealed, much more clearly than ever before, that the slexendrion and Lthiopian churches were at variance on many points of religious practice. In an attempt to remove these differences, the igyptian bishops bad insisted on strict disciplinary messures, and their stern action bad almost broken the Ethiopian church into two contending parties. Apert from these internal conflicts, the by-product of its rapid expension in the ethiopion region since the thirteenth century, hed also presented the church with even more serious problems. As the area under the political control of the kingdom steodily increased, so did the number of churches and monestic commuties among the newly conquered peoples. An increasing number of people with veried cultural and religious backgrounds began to adopt the Christion religion, and by the middle of the fifteenth century the odditional responsibilities of the church were clearly beyond its educational and organizational facilities. A drastic re-organization of the 
institutions of the church, and a complete retbinking of its role in the kingdom, had to be made. Zer'aYa'qob came to power at this crucial period, and set himself the vital task of reforming the Ethiopian Church. His attention was first drawn to the problem of settling the internal conflicts among the Ethiopion clergy and to the creation of a perfect union within the Church. The hottest issue that had divided the clergy for as long as he could remember was that of the Sabbath. Complete freedom to observe it had been granted by his father to the House of Ewostatewos in 1404. Since then the custom hod apparently spread among other communities, despite the protests of the Egyptian bishop. It was gaining ground even at the rojal court. This seems to be quite clear from the story of the life of Abbo Giyorgis of Gascha ${ }^{1}$.

1. Gedle Abbe Giyorgia of Gascha, MS. Haiq. This is a 19th C. copy of which the original is said to be at Gascha, where a community has been established at the site of his tomb. For the location and short description of the site see St. "right, "Notes on some cave churches in the province of Wallo", in AE, II (1957), pp. 12-13. Stephen Wright odopts a l4th C. date for the saint, erroneously seid to heve been 'imde-siyon's contemporary in en l8th C. compilation of the royal chronicles, Basset, R. Etudes sur l'histoire d'Ethiopie, 1882, pp. 5-6, 10, 99. Gijorgis died in the 12th year of the reign of Yrshaq, which was also the first year of the 14th Grand Cycle, equivalent to 1425 ش.D., Gedle Abbs Gi.7orgis, ff. 46b - 7a. Cf. also Lotenberg, 
Gigorgis was born at Segla, probably some time before the beginning of the reign of Dowit ${ }^{1}$. His fother, HIzbe-ȘIyon, was one of the chaplains at the royal court where young Giyorgis apporently spent most of his early days ${ }^{2}$. Hizbe-Şiyon sent his son to school in the island monsstery of Hoiq where the priegts were reputed to be "very wise, and proficient in (the art of) reading and exposition of books"3. The abbot of the monastery wos then Sereqe-BIrhan, the great anti-Sobbath leader until

Footnote 1 cont. from previous page. Catalogue des manuacripts éthiopiens, N.113. It is apporent that the Gedle was composed soon after Giyorgis' death, not later than the reign of 'Zer'a-Ya'qob the last king mentioned, Gedle Abba Giyorgis, ff. $31 \mathrm{~b}$, $37 b-38$.

1. According to 8 late and dubious tradition it is said that "Abba Giyorgis was born in the reign of King Dawit, ... son of Seyfe-Ar'ad", Mar YIshag, MS. Dima, f. 17Ib. His mother is said to have been from Weleqa in Ambara where Seglo was located, Gedle tbbo Giyorgis, f.4a. The place nome is also given as Shegla which is soid to be the same aite as Gascha, Ibid, f.15a. l'hus the names of Giyorgis of Segla and Gijorgis of Gascha are a reference to the same person, cf. Conti Rossini, "Due capitoli del libro del mistero di Giyorgis do Sagla", in R.S.E., VI (1948), pp. 13-16.

2. Gedle Ebbs Giyorgis, f. 4b.

3. Ibid, ff. $4 b-5 a$. 
bis death in c. $1403^{\uparrow}$. Giyorgis apporently stayed ot

Debre-Haiq for a long period and when his father

retired into a monastery he replaced him as a secular priest of the royol court ${ }^{2}$. He was a very tolented scholar, and a prolific writer. A number of doctrinal, and service books are attributed to him ${ }^{3}$. Both Dawit

1. Supra: p. 422

2. Gedie Lbba Gizorgis. f.15. Zer'a-Ya'gob makes a reference to "Giyorgis... (one of the) Priests of the Court", Miashafa Berhon. II (text), p. 131. It was Dillmenn who first identified this priest with Gijorgis of segla, Ueber die Kegierung. insbesondere die Kirchenordnung, Berlin, 1884, p.8 and n.l. Cf. olso Cerulli, Il libro etionico dei mirecoli di Varia, 1943, pp. 114-5.

3. Among thege are Arganone-Widase written in the reign of Dowit; Wrdase-liesqel, and Feshafe-Sibhat (also called Meshafe-BIrban), Gedle Abba Gi 7orgis, ff. 18b - 198. Other pryaers in the nomes of the Apostles are also attributed to him, Ibid, f. 26b. Cf. also W. Wright, Catalogue of Ethionian Manuscripts at the British Museum. No. 337, section 2. He is even said to have been authorized by the igyptian bishop to compose anaphores which the loc日l clergy apparently refused to accept, Ibid, f.2lb. His monumental work, however, is his great doctringl compilation Meshafe-lisstir completed in the loth year of the reign of Yshaq, Ibid, $f .33 a$. Mar YIshag. MS. Dima, f. 172B. Zotenberg, od.cit. No.113. Conti Kossini, "Due capitoli del libro del mistero di Giorgis da 8agla", cit. pp. 13-16. snother book he is reputed to heve composed is Meghofe-je'stat (= The Book of Hours), Gedle livesus-10 $0^{1}$. p. 35 (text) Basset, Etudes, pp. 10, 99. lhis is different from the Horoloxium apparently translated from the Coptic and Arabic into Ge'ez at a very early date, Cerulí, E. Staria della letterature etionica, 1956, pp. 32-33. The identity of Gizorgis lieshafe-Se atot is not very clear. I was able to examine an early (15th century) MS. believed to be the Meshafe-Se'etat, and specially brought from Gascho 
and YIshaq admired and respected him. He once beld the important post of Iijibure-Ed (= sbbot) of Debre-Damo in Dawit's reign 1 , and Yishaq loter appointed him head of the community of Abba Beșelote-Mika'el in Ambara?.

Abba Giyorgis was thus a prominent ecclesiastical courtier of Kinge Dawit and Yishoq, and hod obtained his education at Debre-Haiq, the citadel of the proEgyptian and anti-Sabbath party until 1404. Within the following two decodes, however, he became the most vociferous protagonist of the Sabbath. There can be no better exumple of the decisive change of public opinion

Footnote 3 cont. from previous page.

for Liqe-Liqawint Hayle-Mesqel, head of the (Menelik) Memorial Church in Addis Abba. It is a mere collection of sundry prayers and doctrinal treatises attributed to Giyorgis, but of which the connection with the Book of Hours currently in use is not, I think, apparent. I quote it below as Meshofe-Selot.

1. Gedle übba Gizorgis, ff. $19 b-20$.

2. Ibid, ff. $38 \mathrm{~b}-390$. It is bere, at Gascha, that his community is still located. It was also here that he received his monastic habits from Abba Tewodros, $a$ spiritual descendant of Beselote-Mike'ēl (d. before 1337), Ibid, f. 28a. A monastic generlogy given elsewhere makes him a 7 th generation descendent of Iyesus No'a:- Selama, Bnorêwos, Beselote-Mika'ell, \&'bel, E'frēm, Tēwodros, Gijorgis, Meshafe-Selot, MS. Gascha, f. $59 \mathrm{~b}$. 
on the subject among the clergy at the time than Gijorgis' championship of the Sabbath despite his Haiq background. The observance of the Sabbath hod long been deeply entrenched in the religious practice of the bithiopians, and, when Dawit's protection of the House of Ewosțatêwos removed their last fears of Alexandrian discipline, on increasing number of communities readopted the custom without any further inhibitiona. Gijorgis taught the legitimacy of observing the Sabbath together with the Lord's Day, and devoted an important section of his Meshafe-Mistir to it ${ }^{1}$. He rigorously practised what he was preaching and apporently come into conflict with the community of Debre-Libanos on this issue. His hegiographer tells us thot Gigorgis had made a vow to recieve his monastic habit from Yohannis Keme, abbot of the community of Tekle-Haymenot. On one occasion Giyorgia visited Debre-Libanos with this in mind. As soon as be reached there, however, he quarrelled violently with the commity and returned without fulfilling his vows because:

"(They) used to break the First Sabbath, and be found them building a church on it." 2.

1. Zotenberg, op.cit. p. 129, section $z$. Gedle Giporgis, ff. $39 \mathrm{~b}-40$.

2. Ibid, f.27b. This reference to Debre-Libanos finds confirmation elsewhere. The abbot at the time was indeed Yohannis Kems, and it was in his time thet YIshaq the building of the first big church at the present site 
The royal court wos effectively infiltrated by the proSabbath faction even before Zer'g-Ya'qob'g accession, and Abba Giyorgis was its most influential agent in the reigns of Dowit and Yishaq. As a promising young scholar, one of bis first assignments at court was to give religious instruction to the royal princes:-
"Whey took (Giyorgis) ond brought him to the inner enclosure of the royal court, and mede bim one of the priests of the court in ploce of his father who became a monk. And ... for some time (after this) be taught the children of the king, Zer'a-Abrham and the others." 1.

One of his doctrinal treatises, FIkerē-Higmanot, was specially composed for a certain prince called Tēwodros, probably Dawit's first son ${ }^{2}$. Probably, too, Zer'a-Yaqob's

Footnote 2 cont. from previous ogpe.

of Debre Libanos, Gedle Merha-Kristos, MS. DebreIibanos, pp. 51, 53-4. Rules for the Administration of Debre Libanos. MS. Debre-Șige, pp. 88-89. Cerulli, E., "Gli abbeti di Dabra Liboños", in Orientalia, XIII (1944), pp. $141-3$.

1. Gedle Lbbo Gizorgis, f.15. The king referred to is Dawit. To my knowledge there is no reference anywhere else to a son of Dawit's called Zer'a-Abrham.

2. Ibid, f. 29b. Giyorgis was on very good terms with Têwodros. During one of his doctringl disputations at court Abbo Giyorgis had apparently displeased $\mathrm{king}$ Dawit who sent him to prison where he remained until the king's death. As soon as be took over as king of Ethiopia, Tēwodros released him, Ibid, f.27. 
close association with the pro-Sabbath clergy started in the private school at the royal court.

The traditional records of the monasteries have been drastically affected by the need to conform with the later decision of Zer'a-Yagob to enforce the observance of the Sabboth in the Ethiopian church, and it is very difficult to determine which communities stood firm on the side of the losing party, during the actual controversy. Only few ond equivocal indications have survived to show which monastic groups remained persistently loyal to Alexondrio, until the Egyptian bishops themselves acquiesced to the entreaties of Zer'a-Yaqob. We have already seen above that Debre-Haiq, particularly when Sereqe-BIrhan wos the abbot, stood firmly behind Bishop Bertelomêwos, and it may be that Abba Giyorgis did not carry the whole community with him in his defection to the opposite camp. It seems quite clear also that another important community in the pro-Egyptian party was Debre Libanos of Shewa. Pogether with the tradition about Anorēwos' disputation with Ewosțatêwos on this issue ${ }^{1}$, the conflict of Abba Giyorgis with Yohannis Keme ${ }^{2}$ constitutes an important piece of contemporary evidence

\footnotetext{
1. Supra, p.4-07, n.2

2. Supre, p. 440 .
} 
for the anti-Sabbath persuasions of Debre Libanos at the time. The relationship between Debre-Libanos and Bishop Yaqob (c. 1337 - 44) was particularly close, and according to its own traditions the community owed much of its later influence to his reorganization of the monasteries in Shews". His immediate successor Abune Selama $(1348$ - 88) ig also remembered with much gratitude for hoving liberated Filippos from the exile inflicted upon him by King Seyfe-4r'ad (1344 - 71). Filippos later died at the court of the bishop? ${ }^{2}$. It is apparent that, largely becouse of these early associations, Debre-Libanos always displayed much readiness to follow the leadership of the Egyption bishops and, as we shall soon see, it remained a devoted ally of Alexendria, even when relations between the Potriarchate and Ethiopis were highly stroined. In its opposition to the Sabbath, Debre-Iibanog probably carried with it all the other communities deriving their monastic origin from Tekle-Haymanot, particularly in Shewa. From some isolated references at our disposel, on interesting pattern seems to emerge about the identity of the conflicting parties in the controversy. Thus, we are told that, on

1. Supra, pp.337, ck.

2. Gedie Filippos (Asbo), pp. 236, 244, 246. 
one occasion, Samu'ẽl of Waldrbba refused to see hbba Giyorgis when the latter deliberately trovelled all the way from Damo to Debre-Abbay to meet the famous ascetic leader. The hagiographer gives an altogether different resson for the refussl of the saint; but it may very well be that Samu'ēl had some reservations about the religious views of the young scholsr from the royal court who had just been appointed Nibure-E'd of Debre-Damo by King Dawit. That there was a religious content in the decision of Samu'el is suggested by the hagiographer himself in his description of the reaction of sbba Gijorgis. Unoffected by the rebuff he received from the old saint, Giyorgis burried back "to preach the Faith to the people of Damo"1. Lnother monastic group in ShIrē which opposed the Sabbath was probably the commuity of Samu'ẽl of Qoyeșa? . It wes here thot Estifanos, the founder of the so-called Stephanite "heresy", first took

1. The incident is related in Gedle Abba Gizoreis, ff. 19b 20. According to the hagiographer, Samu'el refused to see him becouse of the large number of attendants that Giyorgis bed taken with him on his visit to Debre-Abbay.

2. For the location and a short description of the community see Ellero, G. "I conventi dello Scire", in B.S.G.I., IV (1939), p. 838, and the sketch map on p. 837. 
his monastic habit. Esṭifonos was expelled from the community in 1428/9 A.D. 1, and one of the accusations later edvanced against him was that "he observes the Seventh Dey and breaks Sundeys, and be travels (on them)"? Both Samu'el of Waldfbbe and semu'el of Qoyeşa were students of liedhanine-Egzi' of Debre-Bankol, and they seem to have presented a united front in Shrrē against the Sabbath.

It is quite clear that Zer'a-Yaqob ascended the throne with definite pro-Sabbath convictions. Apart from his own religious convictions, however, his support of the Sobbath Party was olso a sensible political decision. The only mainstay of the opposite party was the Egyption bishop, and he could pose no serious obstacles to the will of the King. The monasteries which supported the bishop were politically weak, both as individual units and os on organized group. Unevenly distributed throughout the kingdom, their sole unifying force was their loyalty to the Egyptian bishop, and they displayed no compact regiongl front. The House of Ewostgtewos, on

1. The date is given $\theta \mathrm{S} 81$ Years of Grace $=1428 / 9$ A.D., Gedle Abekerezun, ed. Conti Kossini in C.S.C.O., Vol. 56, Script. seth. Tome 25, 1954, p. 13.

2. Gedle Estifanos, MS. No.2., Institute of Archoeology, Addis ibrbo, f. 62 . Cf. Blso ff. 25-26. 
the other hond, presented on altogether different picture. l'hey had successfully defied the power of the Egyptian bishops for a hundred years and, left to their own resources, they hod evolved a superb organization independently of the rest of the Ethiopion Church. The official protection which Dowit granted them in 1404 had only made them more defiant towards Alexandria. Before this time it bad been the bishops who had taken the initiative to exclude the Ewostathians from the church, and to deny them the secrament of ordination. This last act had been responsible for the creation of the communities of loy brothers by the followers of Ewosṭatewos ${ }^{1}$. In his decree of 1404 it is apparent thot Dawit also made it possible for them to receive Holy Orders. By thot time, however, their characteristic grouping into communities, completely run and dominated by lay brothers, had become an established tradition among them, and they declined to receive Holy Orders. They simply refused to accept that ordination by the Egyptian bishop wag on essentiol institution for the structure of their monastic organization. Only for the celebration of the liess and for bearing confessions did they require

1. Supra, $p p \cdot 410-1$. 
ordeined priests, ond these, they apparently recruited from other communities on their own terms:-

"(I discepoli di Ewostatēwos) ... si stabilirono di loro arbitrio un ordinamento che non era conforme ogli ottentun libri della legge: si interdysero di recevere il sacerdozio, si constiturono un abate laico, un monaco che non erg prete, il quale loro insegnava e loro dettava regole in tutto l'ordinomento loro; che di loro ovesse ricevuto il sacerdozio lo espellevano dalla loro communita ... Quanto ai preti, ai diaconi e ai monoci venuti da eltri posti ... imponevano loro una penitenza per essere stati in altri posti; e ... li introducevano nella loro communita e nella loro chiesa. Su quei preti e disconi e su tutti $i$ monaci commandava quel monaco laico che avevano messo comme abate ... (e lui) legrva e scioglieva senzo aver lo podesta sacerdotale e governava la chiess ... transgredendo lo legge del Signore." 1.

Thus within the three decades between Dawit's decree in 1404 and Zer'a-Yagob's accession in 1434, the controversy had ossumed a much more serious charocter than at the time of Ewosțatēwos, and was no longer a mere quarrel over the Sabbath. Excluded from the church for their observance of a "custom of the Old Testament", the disciples of Ewostatēwos had been forced to challenge the most cardinal basis of the organization of the Christian church, and to dispense with the sacrament of ordination in their organization. It is interesting, however, that

1. Maşhefa Berhan, II (tr.), p. 83 . 
nowhere in his description does Zer'a-Yagob accuse the House of Ewosţatēwos of authorizing their lay brothers to celebrate mass, or to give penance without the intervention of an ordained priest. It is quite clear from this that, although they occupied a subordinate position in the hierarchy of the Ewostathian monastic organization, duly ordained priests and deacons always constituted part of the community. Throughout the whole period of the controversy, only this slender chonnel of communication had remained between the House of Ewostatêwos and the rest of their fellow Christians in Ethiopia, and Zer'a-Ya'qob effectively used it for his complete reunification of the Fthiopian church.

Berteloméwos (1399 - 1436?) hed been too deeply involved in the conflict, and there was very little chance of 8 peaceful settlement to the controversy until the end of the bishop's reign. In 1438, he was succeeded by two Egyptian prelstes - Bishops liks'ēl Bnd Gebríêl whose names have become inseparably connected with that of Zer'a-Ya'qob in the ecclesiastic traditions of Ethiopia ${ }^{1}$.

1. Liber Aksumee, p. 67 (text). Kolmodin, op.cit., $\mathbf{A}_{24}$ Cerulli, E., Il Libro Etiopico dei Miracoli di Maria, p.91. They were also accompanied by a third prelate of a lower rank, Eppisqoppos Yohannis, Conti Rossini, "Pergamene di Debre Dammo", in R.S.O., XIX $(1940), \mathrm{p} .52, \mathrm{n} .5$. 
The king sought their full co-operation in his plans to restore the unity of the Ethiopion church. He assessed the situation with much clarity and suggested a simple way out of the problem. He believed that the only real opposition to the Sabbath in the country came from the episcopel court. Once this was removed the traditionel affinity of the Ethiopians with the Old Testament would suffice to restore complete unanimity in Ethiopia. This would also remove the only obstacle to the full rehabilitation of the House of Ewostatēwos, and would naturally lead to their acceptance of the more important Christion institution of Holy Orders. The alternative to this sensible course of action was the perpetuation of the schism, with all its adverse effects on the strength and unity of the Christion kingdom. Surely, these derk prospects appeared to Zer'a-Ya'qob too dear a price to pay for the observance of the Sabbath, of which the legitimacy was well attested by the Old Testament and the Apostolic conons.

The two bishops were ot first adomant agoinst the king's persuasions. His approach was clearly gentle and tactful, and he gave them ample time to consider the problem. In the meantime, however, he made no secret of his pro-Sabbath feelings, and probably started pacifying 
the Ewosţathian communities on his own. Hie went to the ancient city of Hiksum in 1436 for his formal coronation and stayed there for three years ${ }^{1}$. It was probably during this sojourn in Tigrē that Bishops Mike'el and Gebrīēl came to Ethiopia and the were probably welcomed by the king in the ancient city. It is apporent that, right from the beginning, Zer'aYo'qob's advent to power brought in much relief and expectation among the Ewosțathions, who received assurances that "there has come to the throne a king who favours your rules"2. The swostathian communities in northern bithiopia hove a tradition that they made a joint present to Zer'a-Ya'qob, which probably refers to the time of his coronation and his three-year stag in Aksum. Abba Nob, probably Zer'a-Ya'qob's Nibure-E'd of DebreDomo ${ }^{3}$, advised them to hand in their present through the abbot of Debre-Maryem, the most important Ewosṭathian commuity at that time. This Ewosțathion lesder referred

1. Terike-Nerest, MS. Debre-Șgē, p. 55.

2. Gedle Abba Yonas, ed. \& Tr. Conti Kossini under the title "Gli Atti di Abba Yonas", in R.R.A.L., Sc. Mor. Ser. V., Vol. XII (1903), p. 1999.

3. On this ecclesiostic see Les Chroniaues de Z8r'a-Ya'edob et de $\mathrm{Ba}$ 'eda Marysm, pp. 11-12. Cerulli, E. "Il Libro dei Mirbcolo Diopico di Merie, pp. 107-8, 111-2. Gedle Abba Yonas, p. 180, n.1. 
to was called Abba Gebre-Kristos, and the king is said to have had "much good will towards him"1.

$$
\text { Zer' } 8-Y_{a}^{\prime} \text { gob had made bis perce with the House of }
$$

Ewostatewos long before his Egyptian bishops could make up their minds. Already in 1442 he sent a book to the Ethiopian community in Jerusalem with the following message, "I hereby send you this book of Sinodos so that you may get Consolation from it on the days of the First Sabbath and on sundrys"2. In the meantime discussions were under way ot various levels, but it was not until eight years later, in 1450, that Zer'a-Yaqob convened 8 Council at his new church of Debre-Mețmeq ${ }^{3}$ in Shewa.

1. Ibid, p.199. The community of Debre-Haiq in Ambara also seem to have paid the king a similor homage at the time of his accession to power, for which be is later said to have exempted them from some taxes: "I exempted them because in the first year of my reign they came to see me while I was in the land of Dego", The Four Gospels, MS. (IM), Haiq, ff. 132b-133a. 'It was at Dego in shewa that he was first crowned, Ies chroniques de Zar'B-Y日'eoob et de Ba'eda Maryam, pp. 54,87 .

2. Ludolf, H. Commentarius ad suam Historiam Aethiopicam. Frankfurt, $1691, \mathrm{p} .303$. It is dated in the $8 \mathrm{th}$ year of the king's reign, p.301. Cf. also Tisserant et Grebant, Codices Aethiopici. Veticani et Borgiani. Barberinianus Orientalis 2 Rossianus 865 . Vatican library 1935. MS. Borg, sitiop. 2, ff. 3-4v.

3. 'This was a church built by Zer'a-Ya'qob in Tegwilet at the news of the demolition of an Egyptian monastery of the same name at the hands of the Muslims, Les chronicues de Zer'a Ya'eqob, pp. 55-57. Cerulli, Il libro etiopico del liracoli, pp. 124-5, 202-3. 
The two bishops, the followers of Ewosțatewos, and the abbots of the leading monasteries attended the council ${ }^{1}$. l'he debate bad already been exhousted in the previous years, and it oppears that the gathering was principally intended for the formel reconcilistion of the Ewostathians with the Egyption bishops and their Ethiopion followers. The bishops formally authorized the observance of the Sabbath in the Ethiopian church, and the Ewostathians agreed to receive Holy Orders through their hands:

"Il Signore... rivelo la gloria dei sabbati ai nostri padri, i santi e venerandi metropoliti abba Miks'ēl e abbo Gabre'ēl, cosa che non aveva rivelato ai metropoliti d'Etiopia che ereno venuti prime di loro ... (I Metropoliti) furono d'accordo con noi circa l'osservanzo dei due sabati, e con le loro mani scrissero che li si dovesse osservare... I discepoli di Ma'qaba Egzi furono consacrati sacerdoti e di tra essi furono eletti gli abati per cissun monastero." 2 .

1. Zer'a-Ya'qob, Meshafa Berhon, II (tr.) pp. 86-7. Gedle Abba Yonas. pp. 198-200. The place of the Council is not given bere. Another tradition of an apparently late composition reports that it was held at DebreBerhon, Gedle Zeno-Margos, M.S. Debre-Sigē, f.107. It is said here that "(AIl the great) teachers of the country of Ethiopia were assembled, and they entered into the presence of the bishops." The hagiogrspher is very anxious to associote the community of Zena-Miarqos with the successful sabbath party, and paints a very dramatic picture of the proceedings of the Council.

2. Zer'a-Yo'qob, op.cit., loc.cit. 
Unlike his fother, Dowit, who left entirely to the Egyptian bishop the conduct of the anti-íwosţatēwos assembly fifty years earlier, 'Zer'a-Ya'qob himself presided over the Council of Debre-MIțaq, and played a decisive role in bringing about $\theta$ definite settlement of the most important controversy thot had divided the Ethiopian church for over a centurg ${ }^{1}$.

1. Otber doctrinal issues of much less political importance were also discussed at the Council among the decision of which Zer's-Ya'qob lists two - "le persone della Triniṫे e ... l'unità della Divinità", Ibidg, p.87. These were hotly discussed, it appears, since the reign of Dawit. Abba Giyorgis devoted a large section of his Meshofe-MIstir to them, Zotenberg, op.cit.. pp. 127-8. Gedle Abbe Gijorgis, ff. 2b-3. Even the Egyptian bishop, Bertelomewos, was once suspected by the clergy of denying the Three Fersons of the Trinity. King Yisshaq sent a committee which included Giyorgis to investigate the charge and the bishop was cleared, 'Zer'a-Yg'qob, op.cit.. p.74. The heresy was carried on to the reign of Zer'B-Ya'qob by Zemika'el, asqa and Gemalyal, Ibid, pp. 71-76. Gemalyal was already a notorious theologian before the death of Abba Giyorgis in 1426, Gedle Abba Gizorgis, f.388. Besides their opposition to the Cult of St. Mary the stephanites ore also accused of unorthodox views on the Trinity, Ler'aYa'qob, Dos Mashefo Milad und liashofo Sellase, ed. $\mathrm{K}$. Wendt, Vol.1, pp. 13-14, 38. This is not apparent, bowever, in their own declaration of their Mrinitarian

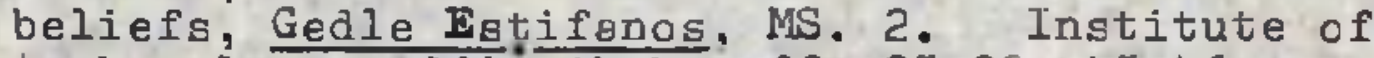
Arcbaeology, sddis Ababr, ff. 25-26, $45-46$. 
The successful outcome of the Council of DebreMrțmaq, in 1450 was a great help in Zer'a-Ya'qob's militant programme of strengthening the power of his kingdom. He invoked the highest symbols of Lthiopian Christion traditions to enhance the position of the monerchy in Church and state, and to fortify the unity of bis Christian subjects. Perhaps the most dromotic example of this deliberate policy was his revival of the old custom of formal coronation in the ancient city of Aksum. In 1436, two years after he took over as king of Ethiopia in Shewa, he trovelled to Tigrē, and underwent the customary rites

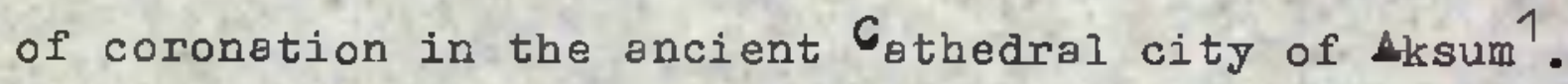
The same formalities of sacral enthronement were probably used every time a new king was proclaimed in the Chrigtion kingdom ${ }^{2}$. I'he special significance of 'Zer'a-Ya'qob's

1. Les Chroniaues de Zer'g-Yg'eoob et de Bo'ede Merysm, pp. 49-52, 83. It is significont that Neshafe-iksum enters the reign of Zer'a-Ya'gob from this date -

89 Year of Grace; liber hksumae. ed. Conti Kossini, pp. 4-5, 67. Hemesēn traditions collected by Kolmodin simply say that the king was there in that year, op.cit. $A_{24}$, Torike-Nerest, MS. Debre-ȘIge, pp. 54-55.

2. The best description of the ceremony on such occasions is ovailable in OR.817, MS.BM., ff.llb-12. Cf. also Chronica de Susenzos Rei de Ethiopia, ed. Pereira, pp. 123-4. according to some traditions similar formalities were undertaken in places other than sksum. Lalibela was enthroned in the same way in Bugna, Perruchon, J. Vie de Lolibela. roi d'Ethiopie, 1892, pp. 107-8. \& slightly different description is given about the coronstion of one of bis predecessors in Lasta, Gedle 
decision was his particular insistence that the ceremony of his corongtion be conducted at iksum șiyon.

ȘIyon, a term figurgtively applied to St. Mary, is also used in reference to the kingdom as a symbol of the special identity of Christion Etbiopia, surrounded by a hostile Nuslim and pogen world in north-east Africa ${ }^{1}$.

Footnote 2 cont. from previoug page.

YImribs-Kristos: MS. Lalibela f.28b. Be'ide Maryom, son and successor of Zer'a-Ya'qob, was crowned in the same woy os his fother but in Ambara. Officials from uksum were specially brought for the ceremony. Later the king planned to reconfirm the ceremony by going to Aksum. But hostilities from Adal made it difficult, Les Chroniaues de $28 r^{\prime} a-Y_{8}^{\prime}$ eaob, etc. pp. 124-6, 149-50. It is also apperent that a more localized, tribal ceremony was held in smbara at the accession of the kings. Apsrt from the secrecy with which it was undertaken, and the sacral use of woollen blankets, nothing is as yet known about this tribal custom, Ibid, pp. 176-7.

1. Amde-SIyon's accusation of Sebredin on the eve of their hostilities in 1332 was that he "coveted the throne of Lavid and he says 'I shall reign in SIyon'", Perruchon, J. Historite des guerres d'Amde Seyon, p:281. kmano who refused to pay tribute to Amde-SIyon is referred to as "s rebel against the king of Siyon", ibid, p.287. Referring to Amde-SIyon's messege of congratulation to his highland Christian subjects following his successes in adal the chronicler writes, "he sent messengers to the country of his kingdom which is Styon", Ibid, p.301. 
It is used in much the same way as the biblical concept of Mount Zion ${ }^{1}$, from which it is derived, and constitutes an integrel part of the Legend of the Queen of Sheba. The bistorical connection between the Christian kingdom and the Queen of Shebr is still uniknown. Cosmos, who visited the kingdom of Aksum on the eve of Koleb's expedition to South Argbia refers to the Queen of Sheba "of the Homerite country", but be does not at all connect her with the western side of the Red Sea except to say that she obtained many of her rare presents to King Solomon from the land of Ethiopia ${ }^{2}$. Hbout three centuries later, however, a chronicler of the Alexandrian church mekes a reference to "Abyssinio which is a vest country, namely, the kingdom of Saba from which the queen of the south came to Solomon, the Son of David the King"3. Sbu Salih who wrote in the beginning of the thirteenth century repeats the same point, but also provides an important

1. Johnson, H.R. Sacral Kingship in Ancient Israel, Cardiff University Press, 1955, pp. 27-29, 61-64.

2. The Christian Todorraphy of Cosmas Indicopleustes, tr. Mccrindle, 1897, pp. 51-52.

3. This is in the story of the life of Patriarch Cosmas (c. 920-32), The History of the Fatriarchs, Vol. II, pt. 2, p.118. 
addition:-
"The Abysinians possess also the Ark of the Covenent, in which are the two tables of stone, inscribed by the finger of God with the commandments which he ordained for the children of Israel ... And the Ark is attended and carried by a large number of Israelites descended from the family of the prophet David..." 1 .

Essentially, the Krbre-Nesest, which is the Ethiopic version of the legend of the Queen of Sheba, olso transmits the same tradition. Indeed it is interesting that according to its Ethiopion compilers the Arabic version of the tradition first apperred in Ethiopio in 1225, not much after Abu Salih wrote his book. It is apparent, however, that even before the first compilation of the KIbre-Negest in the first years of the reign of Amde-Siryon (1314-44), the tradition wos widely diffused in Christisn Ltbiopia?, and had gradually been transformed from a mere tradition of the Jewish origin of the Ethiopian State into an account of the origin of the Christion tribea of the

1. The Churches and Monasteries of igypt, ed. \& tr. B.T.i. Evetts, Oxford, 1895, pp. 287-8.

2. Conti Rossini, "Aethiopice (II)", in Rso, X (1925), pp. 506-8. Storie d'itiodia. 1928, pp. 253-7. Cerulli, E. Storis delle letteraturs d'Etiopia, 1956, pp. 45-48. An English tronslation of the KIbre-Negest was made by E.A.W. Budge under the title The vueen of Shebr and Her Only Son Menyelek (I), London, 1922. 
Etbiopion highlonds ${ }^{1}$. As the repository of the irk of the Covenant, also celled SIyon, the ancient city of Aksum was the focel point of this tradition and its tribal ramifications. Zer'a-Ya'qob was the first king of the new dynasty who is known to have been formally crowned there, and in doing this he sought to invest the monarchy witb oll the religious ond political symbols of Ancient Aksum.

Eorly Contacts with Christion Europe.

The pragmatic ospect of this policy was, on the other hand, his programme of strengthening his military and political control of northern Ethiopia. The major routes to flexandria and the Holy Iand ran through these northern provinces, and the rulers of the Christian kingdom had always been anxious to establish a secure and a more direct outlet in this direction. Ëver since the new dynasty came to power, the kings had been highly sensitive to any problems of security on these routes.

1. Many of the different tribes, particularly of northern Ethiopia, begin their tribal history by connecting their ancegtors with the Queen of Sheba, ber son, or his companions from Jerusalem, cf. Conti Rossini, Studi su popolazioni dell'Ethiopia, pp. 59-60, (extract). Kolmodin, op.cit., Tr.3-Tr. ${ }^{\text {. }}$ 
Some time between 1270 and 1277 a local rebel in Tigre intercepted YǏkunno-Amlak's envoys to Cairo and confiscated the presents sent to Sultan Baybars ${ }^{1}$. It is not clear whet YIkunno-smlak did on that occasion, but it is apporent that until the advent of 'mmde-sigon (131444) his immediate successors had had very little power in the northern provinces. 'Amde-ȘIyon personally led a successful expedition in the $\theta$ reo, estoblished a non-TIgre military colony at Amba-Sengyata, the native district of the rebel leader Ya'abbike-Egz', and conducted his troops as far as the coast of the Red Sea?. He appointed a new set of local chiefs in the highland districts and, to ensure that they maintained a direct contect with his court, he placed first his Tigre Queen, BIllēn-Saba, and some time later one of bis own sons, BahIr-Seged, at the head of the administration of the northern provinces. He inougurated a new period for the complete reunification of the Christion kingdom, and his successors embarked on a more aggressive policy on this

1. Mufaddal, Histoire des Soultang Mamluks, ed. \& tr. Blocket, in PO, XIV (1913), p.387.

2. The Four Gospelg, MS. (IM), Hiiq, f.25 . Liber Aksume, pp. 30-31. Gedie Ewostatewos, p.53. For f fuller discussion of tbis see supra, pp.137-40 
front. 'Amde-ȘIyon is the first among the Ethiopian kings whose nomes are recorded as benefoctors of the librery collection of the Ethiopian community in Jerusalem ${ }^{1}$, and from the reign of his son and successor, Seyfe-Ar'ad (1344 - 71), we begin to have very clear reports of ithiopians residing in Egyptian monasteries ${ }^{2}$. But together with their need to strengthen their traditional contacts with the Patriarchate and the Holy Land, the Ethiopians were now looking at a much wider horizon, and had begun to entertsin strong hopes of establishing relations with the Christian nations of

1. Tisserant et Grebout, Codices Aethiopici, Vaticani et Borgiani. Barberinianus Oxientalis 2 rossianus 865 , City of Vatican, 1935, MS. Borg. Etiop. 3 cf. Cerulli, E. Etiodi in Palesting, p.130.

2. A MS of the New Testament donated by Seyfe-irr'ad to the Etbiopian Community at the monastery of Qusqwam is among the Ethiopic collections of the Bibliotheque Nationele, Zotenberg, oo.cit. No.32. During their flight to Egypt the Holy Family are said to have resided at the site, Abu Salih, op.cit. pp. 224-6; Wansleb, op.cit., p.22. As such, it is the centre of many Ethiopion religious traditions, Cerulli, Il libro etiopico dei mirscoli di Mioria, pp. 206-212. It seems that in Egypt the Ethiopian monks resided mainly at Qusqwam, Har Zuwaila (in Cajro), and the monastery of Scete (Asqetis). At each of these places they had an Etbiopion bead, but it is apparent from a ahort note belonging to the reign of Potriarch Yobennis (1484 1524) that the Jerusalem group had supremecy over the rest, Zotenberg, op.cit. No.35. 
Europe. Hlthough they have left no traces on the traditions of the kingdom, the Wars of the Crusades could have hordly been unknown to the Christions of Ethiopia. Only the relotive weakness of the kingdom before the thirteenth century, and the need to maintain friendly relotions with the new and strong Ayyubid dynosty in sigpt, hod precluded the Ethiopians taking a close interest in the religioug struggle of the Dastern liediterranean. Thus even the daring maritime expedition of Reginald of Chatillon in the Red Ser, and his sacking of sydab on the African coast, has not obtained a place in the traditional recollections of the highland Christians of Ethiopia . However, with the revival of the Christian kingdom, and particularly after the brilliant career of 'Amde-ȘIyon, the position was drastically changed. News of the Christian exponsion and conquest in the Ethiopion region no doubt percolsted through to surope. Not only did Europeen geogrophic notions about the Christians, south of Ëgpt, considerobly improve as a result, but the Christions of Ethiopia also began to be thought of as possible allies in the preparation for another Crusade

1. Cerulli, Etiopi in Palestina, I, pp. 20-26. Cf. also D. Newbold, The crusaders in the Red Sea and the Sudan", in SNR, Vol. XXVI, pt. 2, 1945, pp. 220-4. 
after the fall of 'Akkab in $1291^{1}$. One of the proposals for such an alliance wos made by a man who knew the conditions of the region from very close quarters. Guillaume Adom, a Dominicen monk who wag later Archbishop of Sultaniygah, had been in the island of Socotra for many months, and hod been making unsuccessful attempts to travel to Ethiopia on many occasions. His plans for "exterminating the Soracens", first submitted in 1317 , were very ambitious, and envisgged the blockade of the eastern trade at the Gulf of Aden, with the military co-operation of the Christians of Ethiopia. In another report presented to ring Fhilip of France in 1332 he mentions a strong Christian people "who are now living enclosed by mountrins in the direction of egypt", no doubt 8 reference to the Christion subjects of 'AmdeSiryon ${ }^{2}$. The desire to establish contacts was not only a

1. Cerulii, op.cit., pp. 91-98.

2. Ibid.pp. 95, 97, 99-100. Crawford, O.G.S. Ethiopian Itineraries, pp. 4-5. A short biographical note on adam is given in Becueil des historiens des Croisodes, documents armeniens, Vol.II (1906). p.523, note 8 . $\dot{A}$ much fuller account is given in Ch. Kohler, "Documents relatifs 8 Guilloume idom, Árchiveque de Sultanieh, puis d'Antiveri et son entourage ( 1318 - 46)", in Revue de l'Orient Latin, $X(1903-4)$, pp. 16-17. In 1329, the date given for his death in the Recueil and adopted also by Crawford, he wes only transferred to intivari where he was still ruling in 1346, Ibid, pp. 47, 49-56. 
Europeen concern, and Etbiopian pilgrims in Falestine expressed their unreserved enthusiasm for breaking the long isolation of their country from the Christian world. Niccolo do Poggibongi, who travelled in the east in the jears $1345-7$, met a number of Ethiopians in Jerusalem and has this to say obout their readiness to communicate with Christian Europe:

"(Gli Cristiani di TIopia) ... volentieri si congiungerebono con noi Latini, ma lo Soldano di Babilonia non lossa mai passare nullo Latino verso loro solamente perche non trattino di fargli guerra." 1.

The vigilance of the Mamlukes in keeping out Buropean Christians from Ethiopia is a constant theme in the reports of travellers of the fourteenth and fifteenth centuries $^{2}$. There was real concern in Cairo about the possible damage Christian Europe could do to the commercial and territorial interests of Egypt, with the use of the growing power of the kingdom. These fears were fully confirmed by the increasingly ggressive attitude that 'Amde-Sigon'a successors had begun to assume on their northern frontiers. Traditions of uneasy relations with

1. Golubovich, G. Bibliotheca bio-bibliografia della l'erra Santa e dell'Oriente Francescano, Tom $V(1929)$, p.18. Cerulli, E. oo.cit., 133.

2. Ibid, pp. 150-1, 163-4, 249. Potvin, Ch. Oeuvres de Ghillebert de Lannoy Vopageur. diplomote. et moraliste, Louvain, 1878, pp. 129-30. 
Egypt are available for the reign of seyfe-Ar'ad. The last forty-two years (1340 - 82) of the Babri Mamluk dynasty were $a$ period of general decline and internal conflict in Egyption history ${ }^{1}$. During these years the Copts were on object of a widespread persecution, particularly in the reign of Al-Salih $(1351-54)^{2}$. sccording to one tradition ${ }^{3}$, Fatriarch Margos (1348 - 63) sent word to Seyfe-Ar'ad announcing his imprisonment by the Sulten end soliciting his help. Seyfe-kr'ad at once mobilized $\theta$ huge army and began moving towerds upper Egypt. At the news of the impending attack of his soutbern frontiers by the Ethiopian army, the Sultan released the Potriarch and made him send a delegation to Sejfe-kr'ad osking him to return to his country. A highpowered delegation was accordingly sent consisting of a certain sbba Yohannis and anotber bishop accompanied by some priests and Muslim officials, who carried the Sultan's

1. Hitti, P. The History of the Arabs, (ed. 1961), pp. 681-2.

2. Renandot, Eu., Historia Potriarchorum Alexandrilnorum. Paris 1713, pp. 507-11. Quetremere, Et. Mémoires géogrophiques et historiques sur l'Egypte. Vol.II (1811), pp. 251-4. Atijah, A.D. The Crusade in the Later Midale AEes, London, 1938, p.350.

3. Torike-Negest, MS. Debre-Șige, pp. 50-51, 58. 
presents to the Ethiopion king. The latter happily welcomed the envoys, accepted perce on condition that no more persecutions should be conducted against the Christians, and marched back to his kingdom, toking with him Abba Yohannis whom he forced to remain in Ethiopia. Another version of the same story ${ }^{1}$ attributes the delegation to quite a different reason. Ethiopian Muslims, persecuted by Seyfe-Ar'ad, had oppealed for Egyptian intervention, and it was in response to this call that the envoys went to Ethiopia. However, it is quite possible tbat the two incidents were not completely unconnected, and there are other traditions indicating that the king was in northern Etbiopia at the time with a very large army $^{2}$.

1. J. Perruchon, "Notes sure l'Histoire d'Etbiopie", in RS, I (1893), pp. 177-82. Budge, E.4.W. The Book of the Soints of the Ethiodian Church, 1928, Vol.1, pp. 177-9. For the text see SInkIser, OR, 667, MS. BM (17th C.), f.52. Here the Patriarchal envoys are identified with Abbo YohannIs, Egyptian Bishop of Jerusalem, and Qêrilos, eppisqoppos of Ahnas.. Yohannis later died in Ethiopia in October 1390. In the DebreSige MS. he is simply referred to as Abba Yohannis, "of the Country of Ethiopia".

2. The army was so large that an epidemic broke out in Aksum where they bod camped. The king then led his men to Debre-Libanos of Shimezana further north, Conti Rossini, "L'evangelo d'oro di Dabra Libanos" cit. p.177, n.2. The king is elsewhere said to have visited the old monestic leader, Medbanine-Ëgzi' at Debre-Bankol, Basset, Etudes sur i'histoire d'Ethiopie, 1882, p.100. Cf. olso Liber Aksumbe. pp. 2l-2 (text), and p.24 (tr.), n. 4 . 
More reliable sources indicate that King Dawit (1380 - 1412) took the offensive against Egypt much further thon his father ever did. Maqrizi ${ }^{1}$ reports that in 1381 news arrived in Cairo that "une armée envoyée par David, fils de Seife-hrad, roi d'Abyssinie, étoit entrée sur le territoire d'Assouan, avoit fait mainbasse sur les Arobes, et commis des ravages afreux sur les terres de l'islomisme". "Phe Amir sent for Patriarch Matēwos $(1378$ - 1408) and ordered bim to write at once to the Ethiopians to stop their hostilities. The Patriarch at firgt refused to co-operate. Finally be agreed to send the letter required by the Sultan, who also sent his own delegation, led by the Amir of the important Nediterranean port of Domietta. This account of the irab historian also finds on invaluable confirmation in the reports of a contemporary European traveller. In 1432 Bertrandon de la Brocquière met a Napolitan called Pietro at the port of Pera, near Constantinople. Fietro had just been to Ethiopia where he hod stayed for some years. He had been married to an Ethiopian and knew the country very well, and his reports on Ethiopio during the reign of YIshaq (1413 - 30) are remorkobly authentic.

1. Extract in Quartremere, Mémoires, cit. II, pp. 276-7. 
Pietro gave Bertrandon the following description of the expedition of Yrshaq's father, Dawit, in the Nile Valley:-

"... quent le Roy de Cypre conquist Alixsndrie, le grant pere de celluy Seigneur qui est aujourdhuy se partit de sondit pays pour venir en Jherusalem et avoit en sa compsigne trois millions de gens. Et quant il vint sur lo rivyer du Nil, nouvelles lui vindrent que ledit roy avoit habendonne ladite vilie d'Hlixandrie ... il fist adviser combien de gens il avoit, et trouvant l'en qu'il en avoit perdu deux millions de mortalité et de choult, et conclud de s'en retourner ... en soy retournant, il conquist deux royaumes. Et de tout ce qu'il conqueste, il fait les plus jeunes Crestiens, et tout le demeurant il fait mourir." 1.

The invasion and seven days' occupation of Alexandria by Pierre de Lusignan, king of Cyprus, took ploce in $1365^{2}$, about sixteen years before Maqrizi's date for the expedition of Dowit in the Nile Valley. Except for this slight chronological discrepancy, there is 8 perfect agreement between Pietro and Maqrizi's accounts. The Ghristians of Egypt paid very dearly for the adventures of Pierres I de Lusignan in the form of exorbitant taxes and popular persecution ${ }^{3}$. This is probably why the

1. Schefer, Ch. Le Voyege d'outremer de Bertrandon de la Brocquiere, Paris, 1892, p.148.

2. Atiyoh, Aziz Suryal, The Crusade in the Later Middle bses, 1938 , pp. 350-76.

3. Ibid, p. 377 . 
Italian traveller considered the Ethiopian offensive in the Nile Valley, on behalf of the Christians, as related to the Cypriot invosion. A whole cycle of traditionol accounts is availoble about Dawit's attempt to attack Mamluk Egypt, and, freed from their hagiographical trappings, these traditions easentially agree with both Pietro and Maqrizi. Like Pietro some of them indicate that the King's aim was to reach Jerusalem ${ }^{1}$. Naqrizi's point thet the Ethiopian army had reached the territory of iswan is also reported by the Ethiopic traditiong?. There seems to be little doubt that, on

1. "And then Dowit II, King of Ethiopia, went to Jerusalem", Mar YIshoa, MS. Dima, f.17lb. "And then Dawit II thought and wished to go to Jerusalem. He looked for men who knew the way, and who would guide him there", Gedle serse-Petros, MS. Debre-verq, f.47a. This Dawit was the first Ethiopian king to beer the name. Be is called Dowit II in deference to the Legend of the Queen of Shebr and the first Dowit is King David of Isra'el. Perruchon did not apperently realise this when he attributed a document sbout this Dewit (1380-1412) to the reign of Libne-DingIl $(1508-40)$ who also bore the name Dowit II, "Notes pour l'Histoire d'Ethiopie", in $\underline{\mathrm{RS}}$, VI (1898); pp. 157-71.

2. One version has it that the egyptian Sultan sent the Patriarch to persuade Dawit to march back, and they met at Aswon, "which is the frontier between Ethiopia and Egypt", Meshefe-Tefut, MS. Institute of urchoeology, Addis Ababa. His itinerories are given elsewhere as follows: Hagere-Nagran, "on the borders of the sudan", the Nile volley, "and he reoched the land of Kuse which is in Upper Egypt and camped there", Gedle Serse-Petrros, f.48. According to $\theta 17$ th $C$. version Dawit's huge passed through Sera'ō, Homasēn, and into SInnar where the Patriarch's message of peace reached them, Gedle Mercorewos, ed. Conti Rossini, pp. 42-44. 
the eve of the advent of the Burji dynasty of Mamluk Egypt, King Dawit had in fact led his troops beyond the northern frontiers of his kingdom, and created much havoc among the Muslim inhobitants of the area. The effect of this action was certainly felt in the $\mathrm{Nile}$ Valley, and as for north as the Egyptian frontiers. Five years after the campaign when Barquq (1382-89), the founder of the new dynasty, was well on the saddle of power, peaceful relations were re-established and Dawit sent a rich gift to the sultan, consisting of twenty-one camel loads of Ethiopian curiosities ${ }^{1}$.

The readiness displayed by Seyfe-kr'ad and Dawit to come to a direct military confrontation with Egypt increased Mamluk determination to isolate Ethiopia from Christian Europe. But it also seems to have made a strong impact on European travellers in Paleatine, and the attempts to create relations with the kingdom become particularly active from this period onwards. Ethiopian

1. "Il etoit composé de tous les genres d'objects precieux que I'on trouve en Hbyssinie. On remarquoit surtout plusieurs chandieres, remplies d'or, troveillé en grains de la grosseur des pois", Maqrizi, Extract in vusrtremère, op.cit., p.277. 
pilgrims were found in the monasteries of Egypt, in the Holy Places of Polestine, and in Cyprus ${ }^{1}$, snd they served as an important link between ithiopia and the rest of the Christian world. European travellers in Palestine tronsmitted exaggerated notions of the decisive role the kingdom could play in a united Christian front against the Muslim powers of the bastern Miediterranean. But even these were bosed on outhentic reports they collected among the Ethiopians they met in the course of their travels ${ }^{2}$. The Mamluk "iron curtain" was never

1. In Ethiopic traditions the presence of a community in Cyprus is represented in Gedle Lwostotēwos ed. B. Turaiev, pp. 101-119. See also Conti Rossini, "Sulla communita abissina di Cipro", in RSF, II (1942), pp. 98-99. Cerulli, E. Etiopi in Palestina. I'(1943), pp. 33-37. In the second half of the l5th C. a smell Ethiopion community was also formed in Lebanon, ibid. pp. 325-333.

2. A constant theme in the accounts of European travellers since the 14th $\mathrm{C}$. is the absolute control which the Ethiopians were believed to hove over the flow of the Nile, Ibid, pp. 116-9. This early tradition, was current both among the sthiopians themselves and the Egyptian Muslims, Al-Umari, Niasalik, tr. GaudefroyDemombynes, p.30 and n.l. Ethiopic hagiographies insist that one of the stretegies used by Dowit during his compaign vs. Egypt was to divert the flow of the river, Gedle Serse-Petros. f.48a. Meshafe-Tefut, MS. Institute of ArcheologJ, iddis Ababa. Tarike-Nerest, MS. Debre-Marqos, ff. 3i-32. Pietro, who was in Ethiopia in Yishaq's reign reported in 1432 "... s'il plaisoit su Prestre Jehon, il fleroit bien aller la rivyere sutre port", Schefer, op.cit., p.146. Even 
completely closed, and by the turn of the fourteenth century, when the Chriatian kingdom begen to show a favourable response, isolated individuals from Europe could also penetrate the Ethiopian highlands.

The earliest known message to Ethiopia from a European monarch is the letter of King Henry IV, dated 1400, and addressed to the "King of abyssinia, Prester John"1. Before his coronation as Henry IV, the Earl of

Rootnote 2 cont. from previous page.

'Zer's-Yg'qobnto the same point in a letter be wrote to Jagmeq, Al-sekbawi, Al-Tibr al-Nasbuk, Cairo, 1896, p.70. This tradition was seriously considered by the strategists of the later Crusades, Hayton, "La Flor des estoires de le Terre d'Orient", in Recuell des historiens des Croisodes: Document's Armeniens, VI, 1906, pp. 232, 241, 247. Blochet, li., ed. "Neuf Chapitres du 'Songe du viel Pellerin' de Philippe de liezieres relatif a l'orient", in ROC. IV, 1889, pp. 373-4. Cerulli, op.cit., pp. 92-99, 155-61.

1. The Latin text of the letter is published with a short description in Royal and Historical Letters during the Reign of Henry IV. King of England and of France, and Lord of Ireland, ed. F.C. Hingeston, Vol.1 (1399-1404), London, 1860, pp. 419-422. Cerulli, oo.cit. pp. 201-2. For the European legend of the Prester John, see Harinescu, C., "Le Pretre Jean, son pays, explication de son nom", in Bull. Sect. Hist. Acod. Roumsine, tome X (1923), pp. 25-40, and also t. XXVI (1945), pp. 203-22. La Ronciere, Ch. de, La Decouverte de I'Afriaue au Moyen Are, in Mem. Soc. Geog. igypte, t. V (1925), pp. 57-60. Slessarev, $\sqrt{ }$. Prester John. The Letter and the Logend. Minneapolis, 1959 . Beginning in the 14th C. the name Frester John has been applied by curopean writers to the kings of sthiopie, Cerulli, E. "Il volo di Astolfo sull'Etiopia nell' "Crlando Furioso", in K.R.A.I., Ser.6, Vol.VIII (1932) $\mathrm{p.21}$. Id. Etiopi in FId. Etiopi in I I (1943), pp. $77-79,97^{3}-98$. Ser.6, Vol.VIII $(1932),{ }^{\mathrm{p}} \cdot 21$.
I $(1943)$, pp. $77-79,97-98^{2}$ 
Derby had been to the Holy Land in 1392-3, and had apparently heard of the Ethio-Egyptian hostilities in the early part of the reign of King Dawit (1380 - 1412). In fact, be complimented Dawit on his desire to liberate the Holy Sepulchre from the Muslims, and expressed his own hope of returning once again to Palestine. Apperently, for security reasons, the bearer of the letter was instructed to convey in person lenry's real intentions, and it seems that he aimed at concluding an alliance for Dowit's participation in a crusade. It is not known if Henry's letter ever reoched Ethiopio. However, Ethiopian traditions attribute very active external relationa to the reign of King Dawit:-

"And the people of Kom, and Constantinople and syria, and hrmenia, and Egypt sent to Dawit II, King of Ethiopio, saying '... the rulers of the Musling rose against us, to destroy (our) Faith in Christ so that we may not call his Name and that we may not worship His venerable Cross...' ..." 2 .

1. Apporently to avoid its possible interception by the Mamluks the letter was entrusted to the Archbishop John of Sultanigyah, on the eastern land route. snother resson for the choice of this route seems to be the king's attempt to facilitate the reception of Domenican preachers from the diocese of Sultaniyya in which Ethiopia seems to heve been included by the Papal Bull of John XXII. According to the Archbishop himself, however, the missionary programme was still unfulfilled in 1402, Ibid, pp. 207-8. Cf. also Conti Kossini, "Sulle missioni domenicane in Etiopia nel secolo XÍ", in R.R.A.I., Ser.7, Vol.I (1940), pp. 71-98.

2. Meshafe-Tẽfut, MS. Institute of ArcheologJ, Hdis Ababa. 
Soon ofter King Henry's letter, the first Ethiopian Embassy to Lurope is reported, in $1402^{1}$. Led by $a$ Florentine called Antonio Bertoli, the Embassy also included some Ethiopians and thus began a new chapter of intermittent, but direct, contret with Europe which was given a particular impetus in the reigns of YIshaq and Ser'a-Yo'qob.

Maqrizi accuses King YIshaq of writing to Europe proposing a grand Christian alliance ageinst Islam ${ }^{2}$. According to Taghri Birdi (1409 - 70) YIshaq sent his envoys on the occasion of the Mamluk conquest of the kingdom of Cyprus ${ }^{3}$. Soon efterwards, in 1427, Alphonso $V$ of Aragon received a delegation from Yrshaq in the

1. Cerulii, od.cit., p.208. An itinerary dated in Dewit's reign and believed to bave been the work of this embassy is published with Prof. I. Guidi's introduction by Jorga, N., "Cenni culle relazioni tra l'Abissinia e $I^{\prime}$ 'Europa Cattolica nei secoli XIV-XV", in Centanario della nascita di Michele Amari, Palermo, 1910, Vol. I, pp. 142, 144-50. La Ronciere, op.cit., t.VI (1925), pp. 113-5. Crawford, Ethiopian Itineraries, pp. 28-37. In 1407 five לthiopian pilgrims were in Bologna, Jorga, N. "Notes et Extraits pour servir a l'histoire des croisades", in Rev. Or. Irt. IV (1896), p.291.

2. Historia Regum Islamiticorum in Abyssinie, ed. \& tr. Rinck, Leiden, 1790, p.8.

3. History of Egypt $(1382-1469)$. tr. W. Popper, part 4, p.60. The date of this conquest is 1424-6, Hitti, o. cit., pp. 697-9. 
city of Valentia". Probably the same envoys also called at other European courts. King Dawit had already received some Itolian craftsmen consisting mainly of Florentines ${ }^{2}$. IIshaq also had at his court a former Mamluk official in Upper Egypt and an Egyptian Christian with whose belp he was reorganizing his army and the administration of his kingdom ${ }^{3}$. It is opparent that, more than anything else, the purpose of his delegations sent out to Europe, was to ask for more artisans and military experts. In a letter (Deptember 1450) addressed to Zer'a-Ya'qob Alphonso refers to the men he had already sent to Ethiopia:-

"... Ia perdicio de quelli tredici homini, mostri in diverse arte, $1 i$ quali dimandeti ad noi ya fa uno grande tempo per lo serenissimo uestro fratre, li mandabamo, e essendo in

1. La Roncière, op.cit., pp. 115-6.

2. Conti Rossini, "Un codice illustrato eritreo del secolo XV", in Africe Itoliana, I (1927), p.88. Cerulli, E'. Il libro etiopico dei miracoli di Maria, 1943, pp. 87-93. Pietro Rombulo who was later sent by Zer'8-Ya'qob on a mission to Rome and Naples first went to Ethiopis towards the end of Dawit's reign, "rasselli, C. "Un Italiano in Etiopia nel secolo XV", in $\underline{\text { RSE }}, I^{\prime}(1941)$, p.176.

3. Maqrizi, oo.cit., pp. 7-8. 
Camino, per non potere passere morero." 1 The embassy of the Duke of Berry was much luckier. Consisting of the Nopolitan Pietro, a Spaniard and a Frenchmen, they apparently succeeded in reaching Ethiopio through Egypt in the reign of YIshaq. In 1432, two years after his companions had lost their lives on the way, Pietro was at Pero telling his story to Bertrandon de la Brocquiere? ${ }^{2}$ He was apparently busy recruiting craftsmen and even persuaded Bertrandon to go back with him to Ethiopia ${ }^{3}$. Pietro hed already been in the country for some time before, and it seems that his mission was a result of Yishaq's embassy to Europe in 1427. It was probably this embasy of King YIshaq that the Hamlukes intercepted in 1429 on its way back to Ethiopia ${ }^{4}$. It

1. Creone, F. "La Politica Orientale di Alfonso di Aragone", in Archivio Storico per le Provincie Napolitane, Vol.27 (1902), p.40. Alphonso's embessy to Yighaq was led by his own confessor, Josnne Bonibe, who spoke Arabic. Their instructions were to proceed first to Jeruselem then to Ethiopia vis Egypt, studying in the meantime the routes and military conditions of the country, La Ronciere, loc.cit.

2. Schefer, op.cit., pp. 142-48.

3. La Roncière, op.cit.. p.117.

4. Maqrizi, Extract in Quartremère, Némoires géographiques et historiques sur l'Egyote, II (1811), pp. 277-8. Taghri Birdi, History of Egyot (1382 - 1469). tr. W. Popper, pt. IV, pp. 59-6I. Wiet, G. "Les relations egypto-obyssines sous les Sultans Mamlouks", in B.S.A.C.. IV (1938), pp. 127-8. Vacca, V., "Le relazioni dell' Abissinia con ' 'tgitto nel secolo' XV", in Atti del $3^{\circ}$ 
was led by a Persion merchant, Al-Tabrizi. Before his mission to Europe, Al-Tabrizi had settled in Ethiopia for some time and had attracted the king's attention for his resourceful pursuit of a mixed commercial enterprise. He kept a jeweller's shop and was also engaged in long distance trade importing arms and other goods from Egypt and Arabie. YIshaq hed apparently taken bim into his confidence and entrusted to him his vital mission to the Christian princes of Europe. Two Ethiopian monks accompanied him. It is apporent that on their way out they avoided the lower valley of the Nile and proceeded, according to Maqrizi, "au travers du desert, aufdelà des Oasis ..." and took a boat from a North African port. This was a long and arduous route, and they decided to return through Egypt in disguise. Betrayed by one of kl-Tabrizi's slaves, they were arrested while disembarking in Alexandria. All their goods were confiscated, ond Al-Tabrizi executed at a public square in Cairo, with the herald crying "This is the punishment of those who carry arms to the enemy,

Footnote 4 cont. from previous dage. Congresso di Studi Coloniali, 1937, Vol. VI, pp. $218-2 \overline{3}$. 
and who play with two religions."1

Zer'a-Ya'aob and his Foreign Relations.

Like Dawit and YIshaq before him, Zer'a-Ya'qob pursued an active foreign policy. An essential part of this programme was his attempt to strengthen his control of northern Ethiopia, and to secure a direct outlet to the Red Sea. For over a century before his advent to power, the Christisn tribes of Hamosēn and Sers'ē had undergone on active period of territorial exponsion in what is today the Eritrean plateau. This had also been accompanied by the religious movement of the House of Ewostatēwos and the establishment of their monastic centres in the outlying areas ${ }^{2}$. One of these monasteries was Debre-Bizen, first built in $1390 / 1^{3}$, "at a day'a distance from the (sea) of Ertra" ${ }^{4}$. Situated on the eastern edge of the Eritrean plateau, and overlooking the mejor route between the Dablak Islands and the

1. The configcated goods are described by Maqrizi os "... un grand nombre d'babits, sur lesquels on voyait des croix en borderie, et le nom du Hațy, ecrit en lettres d'or. C'etoient ceux que devoient porter les soldats..." quartromere, loc.cit.

2. Suora, pp. $411-2$

3. Kolmodin, Traditions, cit. ${ }_{23}$.

4. Gedle Filippos (Bizen), ed. Conti Rossini, p.91. 
highland provinces, Bizen represented the movement of Christion exponsion cherecteristic of the fourteenth century. In the early period of its development its dependence on the kingdom for protection againgt its non-Cbriatian neighbours was probably minimal. Thia seems to explain the hagiographical tradition that peaceful relations with the Muslims of the coastal areas could only be achieved through a bi-lateral agreement between Abba Filippos, its founder, and "the ruler of the sea who resides in the country of Delk"1. During the whole period of the excommunication of the Ewostathiana, who gradually took control of the Eritrean region, their religious influence was an ominous force and a potential donger to the unity of the Christian kingdom. It seems quite possible to discern this delicate situation, not only in Dowit's revision of his early anti-Ewosṭatēwos policy ${ }^{2}$, but also in Zer'a-Yg'qob's complete identification with their religious views.

His pacification of the lwostathian monasteries and his re-unification of the Church in 1450 ploced Zer'B-Yo'qob in an excellent position to undertake a more

1. Ibid, p.106.

2. Supra, $p p \cdot 423-5$ 
radical policy in the biritrean region than any of his predecessors. In $1448 / 9$ he established military colonies in the districts of the Eritrean plateau. The colonists were recruited from a Shewan tribe called Maya ${ }^{1}$, and their reception by the local people was clearly hostile. A bagiographical tredition of the late 15th century puts this in very good relief:"... the earth trembled on their arrival, and those who inhabit (the earth) were distressed. .... All the people left the country and fled out of fear ..." 2 .

This was part of a general policy adopted by Zer'a-Ya'qob throughout his Empire, and was aimed at strengthening the defence of his Kingdom and ensuring a more direct military control of the provinces ${ }^{3}$. In the Eiritrean plateau, however, it was closely connected with his militant foreign policy, and assumed a particular importance. He grouped together the districts of ShIre, Ser'a ê, Hamasen and Bur and placed them under one

1. Kolmodin, op.cit. $A_{24}$. The Maya were a pastoral people in the Shewan district of Wej. Armed with poisoned arrows their warriors were formidable among the Christion army in the hors of Gragn, Futuh al-Habsshe, tr. Basset, p.82, n.3; Gedie Yones, ed. \& tr. Conti Rossini, pp. 181-3.

2. Ibid, p.244; cf. Kolmodin, op.cit. Tr.20-2I*

3. Les Chroniques de Zar'a Ya'eaob et de Ba'ede Maryam, pp. 45-48. 
administration entrusted to the Bahrr-Negegh ${ }^{1}$. These administrative and military rearrangements were only a prelude to $\theta$ more aggressive move against the formerly independent Muslim rulers of the islands of MIșwwa and Dahlak. In 1449/50, only one year after the establishment of the military colonies in the bighland districts, Zer'a-Ya'qob started building his own sea-port at Grrar, on the mainlend opposite the island of Mrșwwa?

It is apparent that Yishaq had also made a similar attempt before him ${ }^{3}$. Zer'a-Ya'qob intended, however, a more permanent and effective occupation of the coastal districts. No doubt this Christian activity was looked at with much hostility by the local Muslims, and probably it led to armed conflicts. In the end, it is reported that the iglands of MIșiwa and Dahlak were pillaged in 1464/5, and the Qsdi lost his life in the encounter ${ }^{4}$.

An exactly similar pattern of development characterized

1. Ibid, pp. 47-8.

2. Kolmodin, op.cit., $\mathbb{A}_{25}, \mathbb{A}_{32}, \mathbb{N} .5$.

3. Nisiwwa is mentioned among numerous other places where the king seems to have conducted military campaigns, Guidi, I, "Le canzoni Ge'ez-Amarina in onore di he abissini", in RRAL, Ser.4, Vol.V (1899), p.57.

4. Kolmodin, 으.cit., $\mathbb{A}_{25}$. 
Zer'a-Ya'qob's relations with the Mamluk sultans of Egypt. It appears that towards the beginning of his reign he made a serious attempt to be on good terms with them. According to Maqrizi ${ }^{1}$, Zer'a-Yg'qob wrote to Sultan Barsbay (1422 - 38) in the jear 1437/8. The letter expressed friendly sentiments towards the ruler of sigpt, whom he entreated to protect his Christian subjects and to respect their churches. This friendly message was also accompanied with a present "composé d'or, de civette et autres objets précieux". Only three jears later, however, Patriarch Yohannis XI (1428 53) wrote to Zer'a-Yagob announcing the demolition of the famous church of Mitmaq (a1-Magtas) on the orders of the same sultan ${ }^{2}$. When the news reoched bim, Zer'oYa'qob held a public mourning with his bishops, and immediately provided for the building of a new church, to be named Debre-Mițmaq (after the Igyptian church), at Eguba in Tegwilet, where he was camping at the time ${ }^{3}$. He then sent envoys to sultan Jaqmaq ( 1438 - 53) with a strongly worded letter. The message reached Cairo in

1. Extract in Quortremère, Mémoires. II, pp. 278-9.

2. Cerulli, E. Il libro śtionico del Miracoli di Maria. p. 124; Les Chronique de Zar'a Ya eqob, p.56. 3. Ibid, pp. 56-57, 87-88. 
November $1443^{1}$. Zer'o-Yo'qob declared to the Sultan that the current persecutions ageinst the Copts were a breach of the complete freedom of worship granted them by previous Muglim rulers. Te complained strongly of the general insecurity of the Christions, whose possessions were unjustly taken from them, and whose churches were openly desecrated by the populace with the full knowledge of the government officiols. He reminded the sultan too, that he bod bïmself many Muslim subjects ond be was very kind to them. Unlike the restrictions on the Christians in Egypt, luslims in Ethiopis dressed as they wished, rode well-harnessed horses and mules, and lived in peace. Not even the Jiziza was levied on them². This, Zer'aYa'qob declared, was a great sacrifice to hia treasury for, if he collected Jiziye from his Muslim subjects his wealth would have considerably increased. Zer'o-Ya'qob also made a reference to the Nile, which, he said, rose in his realms, and it wos within his power to divert its course. He degisted from doing it only for the fear of God and in consideration of the buman sufferings thot would result from it. Finally be reminded Jaqmaq that his

1. Al-Sakhawi, Al-Tibr al-Nasbuk, Cairo, 1896, pp. 67-72. Wiet, G., on.cit., pp. 124-5.

2. It is not clear whot Zer'a-Ya'gob meant by this. the tributes poid by the Nuslims, cf. supro, pp.160,-161 
father Dawit, had corresponded with Burquq and they had established peace and friendship between them ${ }^{1}$. He now asked for the preservation of the traditional amicable relotions between the two countries based on mutusl respect.

In reply to this message Jaqmaq sent an envoy to Ethiopis with complimentary gifts to the king ${ }^{2}$. The envoy also carried o letter which rejected Zer'o-Ys'qob's demand for the building and renewal of the churches in Eggpt as extravagant. Disappointed at this reply, the king detained the envoy in Ethiopia. Relations between the two countries were ot such a low ebb when Zer'aYa'gob's final victory over the liuslim king of sol, shmad Badlay, in 1445 further increased Jaqmaq's fury against his Christion subjects. The intermittent struggle with Bodlay started in earnest in $1443^{3}$, and was not

1. A reference, no doubt, to Dawit's message in 1386 , supre, p. $469, \mathrm{n} \cdot 1$

2. The envoy's nome is given as Yabya b. khmad b. Shadibek, Al-Sakbawi, op.cit., pp. 71-72.

3. Mhis early conflict is not mentioned in the king's chronicles, and is very little known. It took place 9 yeers and 2 months after the advent of Zer'a-Ya'qob to the throne. It apparently consisted of a surprise attack by Badlay on an unspecified Christian district where churches were burnt and many spoils corried away. It was a Muslim success, Cerulli, "L'Etiopio del secolo XV in nuovi documenti storici", in sfrice Italiane, V $(1933)$, pp. 83-4, 88, 96. 
completed until Badlay was defeated and killed in 1445 at the Battle of Gomit in Dewaro?. Characteristically, 'Ler'a-Ya'qob fully exploited the propaganda value of this success and, incorporated in the compilations of the miracles of st. Mary, it has become perbaps the best known military campaign in the history of the Christian Kingdom ${ }^{2}$. The Egyptian envoy was still in detention at the time of the Christion victory, and opparently suffered a number of indignities on the occasion. In retaliation, Jaqmaq colled Petriarch Yohonnis and had him severely beaten, and threatened bim even with death. He then sent onother messege to Etbiopia demanding the release of

1. This is widely known, Les Chroniques de Zar'a Ya'eaob, pp. 57-67, 88-90; Daw Washafa Milod und kiashada jellosé, ed $\mathrm{k}$. Wendt, I. (ig62), po: $15-20$; Conti kosinin, "II convento di Sona" in RRAL, Ser.5, Vol. XIX (1910), pp. 594-5; Cerulli, ov.cit., pp. 84-87, and 96, n.2.

2. All the above stories on the campaigns published by Cerulii, quoted above, were taken from the Miracles of St. Mery, Il Libro Ltiopico dei Miracoli di Merie, p.94. According to the chronicler the remains of Badlay s mutilated body were displayed in public in various ports of the country, and his personel possessions distributed among the major royal churches, to be kept as souvenirs and displayed in public on the anniversaries of the victory, Leg Chroniques de Zar's-Ya'eaob, pp. 65-66, 117. The visitor to Deore-Werq is shown a finely worked shirt in iron chrin and a belmet which local monastic traditions claim belonged to Badlay and were sent there by Zer'a-Ya'qob, Gedle Serse-Petros, f. $50^{b}$. 
his envoy. Frobably the Patriarch was also made to send his own request on behalf of the vislim diplomat. After "nearly four years" as Al- Sakbowi has it, Zer'aYa'qob finally agreed to send his deteinee back to EgJpt ${ }^{1}$.

The news of Zer' $\theta-Y g$ 'qob's success over his Muslim adversary in Adal, and his quarrel with the Momluk sultan, reached Europe, and was received with much satisfaction. In a letter dated 3rd July 1448 Jean de Lastic, the Grand Moster of Rhodes, told Charles VII, King of France:-

"... le prêtre Jean, empreur des Indes, d'après ce qui nous été rapporté sur des temoignages veridiques par certains prêtres indiens venus ici है Rbodes, a fait éprouver de grandes partes et un terrible carngge aux sarrasins, ses voisins, surtout à ceux qui se vantent de descendre de Mahomet..." 2 .

The House of Walasma, from which Badlay derived bis origin, claimed Quraish or Hashemite descent from the Hijaz ${ }^{3}$, and

1. Al-Sakbawi, op.cit., p.72; Wiet, op.cit., p.125. It Was probably after the return of this envoy that Jaqmaq forbade the Patriarch to have any direct communicationa with Ethiopis except with special permission. The order was given in 1448, Al Sakhawi, op.cit., p.210; Wiet, op.cit., p.122, n.2.

2. Marquis de Lastic, Chronique de la Moison de Lastic, Vol. I, 1919., pp. 329-30; Lo Ronciere, op.cit., p.119.

3. Naqrizi, Historie Regum Islaiaiticorum in Abyssinia, cit, o.jli Etiopian, in liRAL, Ser.6, vol.Iv (1931), pp. $42-43$. 
the last phrase quoted above seems to refer to his defeat in 1445. The Grand Master also recounts Zer'aYa'qob's quarrel with the Mamluk Sultan, and givea some of the contents of the king's letter to Jaqmaq in 1443 with a remarkable degree of exactitude. But carried oway by his Crusader's spirit, and probably also by the patriotism of his Ethiopian informants, he declares that the Prester John would soon devastate Egypt, Arabia and Syria. Nore important still, he also refers to the long detention of an Egyptian Ambassador in Ethiopia. In reprisal ageinat this, Jaqmaq had also arrested, we are told, an Ethiopion envoy ${ }^{1}$ on his way back from the Holy Land. Jean Germain, bishop of Chalon-sur-Sône, probably had the same information from similor sources and he repeated many of the Grand Master's points about the Prester John, in $1452^{2}$.

The Ethiopion informents of the Grond Master of Rhodeg were probably isolated individuals who bad crossed over to the Rhode Islands from the Holy Land. But their

1. Bccording to Al-Sekbawi Jeqmaq detained for a short time Zer'a-Ya'qob's officiel who had accompanied Yahya back to Eggpt, op.cit., p.72.

2. Shefer, Ch. "Les discours du voyage d'outremer au très victorieux roi Charles VII, prononcé en 1452 par Jean Germain, evêque de Châlon" in Rev. Or. Lat., III (1895), p. 326; Cerulli, E. Etiodi in Palestina, I (1943), pp. 247-9. 
report of Christian wilitary success in Ethiopia greatly facilitated Zer'a-Yo'qob's official mission to Europe in 1450. This time, the Ethiopian mission was entrusted to a Sicilian, Pietro Rombulo, who had been in Ethiopia since the lost years of Dewit's reign 1 . He had previously carried out a successful trode mission to India on behalf of the king, and he was now sent back to Europe ag Zer'a-Ya'qob's ambassador. He was accompanied by an Ethiopian priest, Fire-Mika'el, and two other individuels ${ }^{2}$. The principal object of the mission was apporently Fietro's own homeland where, Alphonso of Aragon, who had already established good relations with Yishaq, also ruled as king of Naples and Sicily.

In bis letter to Zer'a-Ya'qob, Alphonso says that the Ethiopian Hission came to his court "essendo pero prime con nostro senyore lo Yapa" ${ }^{3}$. This itinerery is

1. Trasselli, C., "Un Italiano in Etiopia nel secolo XV : Pietro Rombuio di Messina", in RSE, I (1941), p.176.

2. Creone, F. "La Politica Orientale di Alfonso di hragone", cit. pp. 71-2, 75-6. Alphonso's letter only mentions one other member of the delegation, fnomer Jandi, elsewhere referred to as "Baumar moro". A third delegate, probably an ithiopion Christion, called lemetrio is mentioned in en entry of Alphonso's financial aid to the mission, Minieri, R.C., "Alcun fatti di Alfonso di Aragone dal 15 Aprile $1437^{\prime}$ al 31 Meggio $1458^{\prime \prime}$, in Archievo storico per le Province Napolitane, V́r, (1889), p. 257.

3. Creone, op.cite, p.64. 
fully confirmed by two short but valuable documents

recently published by Charles-Martial de Witte. Pietro, Fire-Mika'ēl, and "Abumar E'lzend" were given an oudience by Pope Nicolag V (1447 - 55), and proceeded to Naples with a papal escort and a letter of safe conduct. But the purpose of the visit to Rome is not clearly known. Zer'a-Ya'qob's strong monophysite stand rules out any theological and doctrinal reasons for bis envoys colling at the pepel court? ${ }^{2}$. Right from the

1. Ch. M. de Witte, "Une ambassade Gthiopienne ̀̀ Rome en 1450", in Orientalia Christiana Feriodica, XXI (1956) pp. 295-7. Tbe letter of safe conduct is dated May 20th, 1450. Abumar Elzend is the Anomer Jandi or "Baumer, moro" of the Napolitan documents; de Witte reconstructs the nome as Bbu Omar al-Zendi, and suggests that he may bave been a Muslim business associate of Pietro Rombulo, ibid, pp. 288-9.

2. After a close investigation of the chronicles and the writings of Zer's-Ya'qob, Dillmenn had olresdy concluded in the last century that the king could not have had a favourable attitude towards the Council of Florence, Ueberdie Regieruns, Insbesonders die kirchenordung des Konigs Zar a Iacob, Berlin 1884, pp. 69-70. More recent studies of the history of the Council of Florence have only confirmed this conclusion, and they show that no official delegation of the Ethiopian Church took port in the Council, Creone, op.cit., pp. 56-64; Cerulli, L. "L'Etiopio del secolo XV nel nuovi documenti storici", in Africe Italiona, V (1933), pp. 58-80; Id. "Eugenio IV e gli stiopi al Concilio di Firenze nel 1441", in RRAL, Ser. VII, Vol. IX (1933), pp. 347-68; Hofmann, G. "La 'Chiesa' Copta ed Etiopica nel Concilio di Rirenze", in Ie Civilte Cattolica, II (1942), pp. 141-6, 228-35; Gill, J., The Council of Florence, 1959, pp. 321-7. 
beginning of their contact with European Christians, the Ethiopians had always been impressed by the political and military aspects of an overall Christion solidarity against the Muslim powers of the Near lest, and the advantages of sharing in the superior technical advancement of Europern nations. This had been the underlying motive of the policies of both Dawit and YIshaq, who sent their embossies to Europe ogking for technical aid. Zer'a-Ya'qob was only doing the some thing in 1450. With the advice of his Italian ambassador, Pietro rombulo, the king did not hesitate to appeal for technical assistance even through the popacy which was a strong European atate in its own right ${ }^{1}$.

$$
\text { Zer'g-Y甘'qob's mission to Alphonso was apparently }
$$

successful. Hlthough he was himself in dire need of more skilled labour, $\dot{A l p h o n s o}$ wrote to Zer'a-Ya'qob, he was sending him the artisans and masong he requested, to pleare "his dearest friend and brother"? Pietro and his companions are also arid elsewhere to have taken to Ethiopia "molti nostri artigieni che ornassero l'Eitiopia colle loro arti .... ${ }^{3}$. Evidence for their safe arrival

1. Creone, op.cit., pp. 72-3, 87-88.

2. Ibid, p.40.

3. Trasselli, op.cit., p.176. 
in Ethiopis is scant, and neither his own writings nor his Chroniclers make a reference to Zer'o-Ya'qob's relations with Europe. Nevertbeless, in the traditions of the Church, both the reign of his fother Dawit, and his own, are noted for the arrival in Ethiopia of numerous relics, including a piece of the True Cross. These relics are believed to have been deposited at Gishen, the Mountain Prison of the royal Princes. Zer'a-Ya'qob is said to have entrusted the safe-keeping of these treasures to the locel clergy with the following messege:"(The Kings of the Fronks) sent Us a piece of the True Cross. Enclosed within a golden box, it is placed inside another cross of gold of marvellous workmanship, and which can stand erect on $\theta$ golden stond, provided for it by the wise men of the Franks." 1.

1. OR. 481, MS.BM., ff. $208 b$ - 209a. Together with the piece of the True Cross the king is said to have sent to Gishen many other relics from the remains of the saints of the early Christion Church. A whole cycle of hagiographical traditions has developed around these relics, ollegedly brought in the reigns of Dowit ond Zer'B-Y8'qob, the possession of which is cloimed by various monasteries, Gedle Tekeste-BIrhan, MS. Debre-Dima, f. $1^{8}, 16^{b}-17$; Gedle Serse-Petros, MS. Debre-werq, ff. $47^{-}$- 50; M. Cohen "Dabrs Dorq", in Mélanges René Basset. I (1923), pp. 148-50; Vieshafe-Tefut, Wis. Institute of nrcheology, sddis Ababa; c. al iso Basset, R., Etudes, p. 95; Cerulli, E., Etiopi in Pglesting: I (1943), pp. 267-8. 
It is probable that the story of the importation of these objects from Christion Lurope in the reign of Zer' $\mathrm{g}-\mathrm{Ya}^{\prime} \mathrm{qob}$ largely refers to the mission led by Pletro Rombulo . Hlthough the advent of Europeans in Ethiopio in this period has left very little trace in Ethiopian documents, there can be no doubt that in the first half of the fifteentb century, precarious, but none the less continuous, relations were established between Europe and E'thiopia. The most authentic pieces of evidence for this are the map known as Egyptus Novelo (c. 1454) and Fre Mouro's Mieppomondo of 1460, which could only have been

1. Soon after the departure of the Ethiopion mission from Rome a certain Georges Sur was given a letter of safe conduct from Pope Nicolas V, dated 2lst January 1451, to go to Ethiopia with a companion, Ch.-M. de Witte, op.cit., pp. 290-1, 297-8. Two other missions are also reported os having been sent by $\mathrm{King} A l$ phonso to Zer'g-YB'qob: Michele Jesiderio with a letter dated 18th Jenugry 1452 , and Antonio Martinez with onother letter datea 3rd July 1453; Creone, op.cit., pp. 76-80; La Ronciere, on.cit. p.121. There is no trace of these missions in Ethiopia. Giovanni Battista da Imola who went to Ethiopia in 1482, and returned safely to Jerusalem in 1483, reported that he met there ten Italians who bad been in the country for 25 jears. This takes the date of their arrival to c. 1457, in Zer'a-Ya'qob's reign. Hmong them were a Napolitan called Gabriele, a Catalan called Conzalvo, and a certain Ijos Bortutho who is particulorly said to hove gone to Lthiopio with a papal letter, Suriano, F., Il Trattato di Terra Santa e dell'Oriente, ed.' G.' Golubovich, Mileno, 1900, p.86; Somigli, T. Ftionia Francescana nei documenti dei secoli XVII e XVIII, Pt. 1, 1928, p. LXXVVII. 


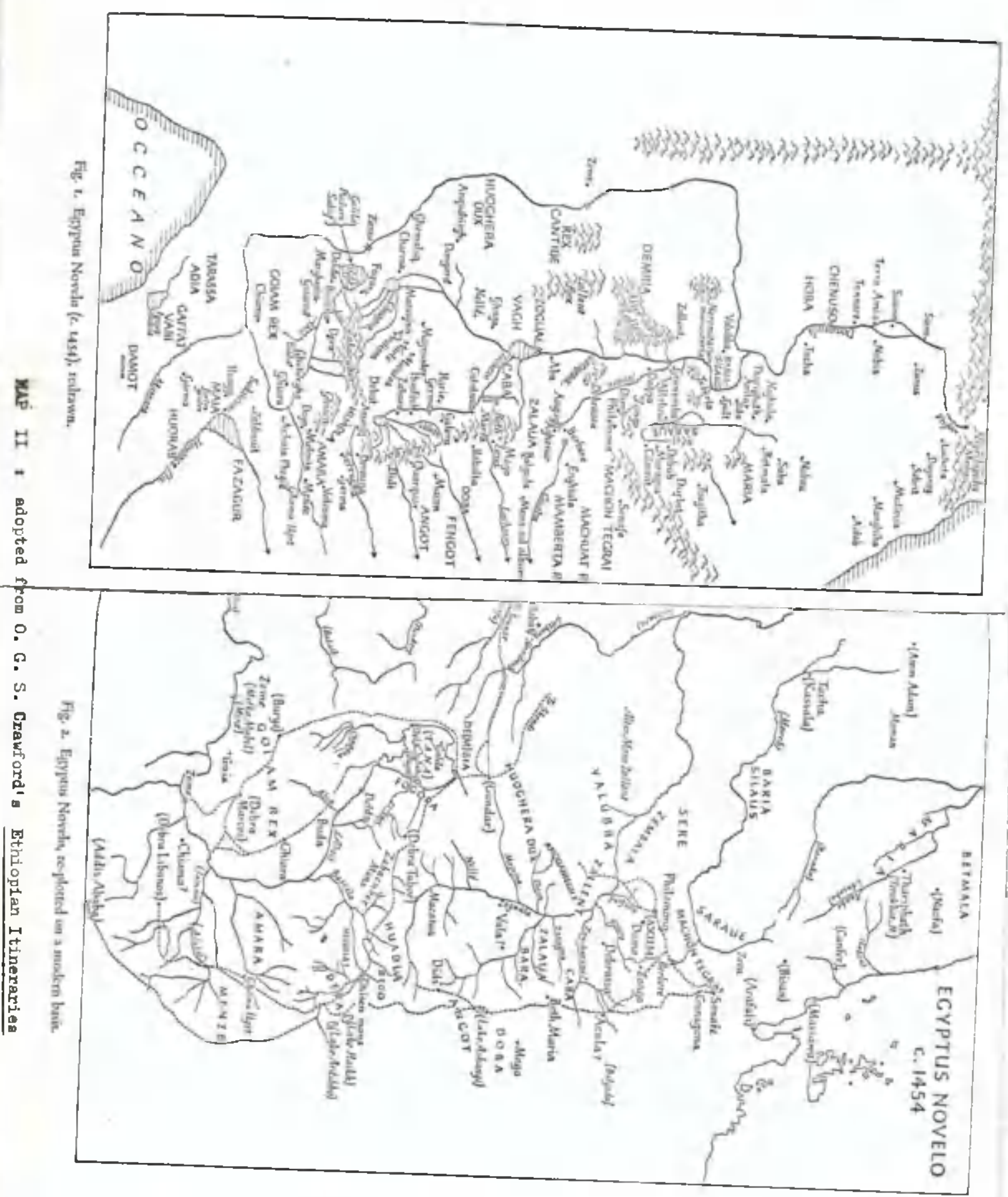


the outcome of meny years of geographical knowledge about the Ethiopion highlonds ${ }^{1}$.

Religious Reforms.

Zer'a-Ya'qob felt, more deeply than any Ethiopian monarch before him, the solitary position of his kingdom in a religious sense:

"Our country Ethiopia (is surrounded by) pagang and Nuslime in the east as well as in the west." 2.

This ides engaged his mind throughout his reign, and he attributed the religious imperfections of his own people to the bod influence of their non-Christian environment. It seems that after the Council of Debre-Mittmaq his major preoccupation was to reorganize the itbiopian Church, and to make full use of its resources in an attempt to stamp out alien religious practices among his Cbristian subjects.

Zer'a-Ya'qob's energetic activities of religious reform are a serious reflection on how small the impact of the

1. Berchet, G. "Lettera sulle cognizioni che $i$ Veneziani avevano suil' 'bissinia", in BSGI, II (1869), pp. 151-70; La Ronciere, op.cit. pp. 123-35; cf. also Conti Rossini, "Un Codice illustreto eritreo del secolo XV", in Africe Italiana. I (1927), pp. 83-97.

2. Mașhafa Berhan, Vol. I (text), p. 151. 
Church had been in the extensive provinces of the Kingdom. This was certainly the outcome of the peculiar way in which the Christion teaching had spread in the Lthiopian region. During the great period of Christian expansion, from the last quarter of the thirteenth century onwerds, the church had been carried wherever military colonies were established. It is apporent that, with the exception of Islam, which was given a recognized status in Muslim dominated areas, the Christian kingdom did not at all respect the religious institutions of its pagen subjects, who were automatically presumed to be a huge preserve for the church, $\theta$ a soon as they were conquered militarily. Their land with all its people and other resources was divided and distributed as fiefs among the Christion political and military officiels, thus constituting $\theta$ number of administrative units ${ }^{1}$. In each of these units, smoll secular churches were built for the Christion army of occupation. Particularly in the early years of large-scale conquests and military occupation, the Christian settlers formed a completely separate class of their own. The churches built for them were merely one of the distinguishing features of

\section{Supren, pp.187, ete.}


this dominant class, which alone they were basically mant to serve. For the most part the educational standarda of the priegts and deacons, who ataffed these churches in the outlying provinces, enabled them only to officiate ot the routine religious ceremonies and to preserve the liturgical traditions of the church. Apart from this, they were quite incapable of transmitting the spirit of the Chrigtian teaching even within the Christion settler commities. For them, as well as for their congregations, the Christion church seems to have had very little content other than the regular and formal services impressively performed on the prescribed days. Under these circumstances it is opporent that they were unsuited to the tagk of spreading Christian teaching among the subjected pagan peoples. We have seen above the attempts of Bishop Ya'qob (c. 1337 - 44) to organize the monastic degcendants of Iyesus-lo'a in Ambara and Shews during the reign of 'Amde-Syyon'. These monasteries no doubt helped to produce many more recruits for the Church service, and, wherever the monasteries were established Christian religious pressure on the conquered peoples was considerably intensified.

1. Supra, pp. 337 , ete. 
Nevertheless, although the monastic schools certainly produced a relotively greater number of priests and deacons, their output was much less than could suffice for the needs of the extensive Empire. Largely for linguistic reasons, almost all the recruits for the church service, who could obtain religious instruction in Ethiopic, apparently had to be of TIgrē or Amhara origin. This eligibility to the divine service also seems to have hod ethnic undertones ${ }^{1}$. These important considerations contributed greatly in limiting the number of candidateg for Holy Oraers. But, more important still, the troining programmes of the monasteries organized by Bishop Ya'qob do not seem to have brought about ang apprecieble improvement in the evangelical spirit and educational standards of the churchmen who left their dependant schools. Only the major monasteries themselves, and the royal churches, seem to hove been well-provided with clerics of considerable learning. The ordinary member of the clergy hardly made

1. For the special place given to priestly families even within the Christian communities, see supra, pp. D'Abbsdie collected an interesting tracition, in this respect, obout the reign of Be'Ide-Maryom (1468-78), when "il fallait être fils de lévi pour être prôtro ou diacre", Conti Rossini, "Il libro delle leggende...", in RRAI, Ser. 5, Vol. XXVI, (19I7), p. 71l. 
ony more progress than reading the regular service books, and reciting the prescribed prayers; and it was these members of the predominsntly secular clergy who represented the church in the distant pagan provinces.

The pagan peoples looked at the impressive ceremonies of the church as just another curious religious cult, pertaining to their conquerors. Ihe clergy, as the living agents of this cult, seemed to them not very different functionslly from the pagon priestbood who officiated in their own religious practices. In the early stages of Christion conquest and settlement, probably very few omong the conquered peoples joined the church. And whenever such "conversions" did toke place, they probably had little significance other than a simple adoption of on alien cult, without necessarily giving up all the manifestations of their notive beliefs and proctices. For an ambitious local chief of a pagan community, on association with his Christian conquerors, in their curious religious practices, was a clever political decision, which could only bring him political advancement. On a more personel level, his "conversion" made very little demand on bim or on his household. Given very little spirituol guidance by the local clergy, who were ultimately and essentially part of the same Kusbitic 
background as himself, the new "convert" continued in much the some way ag before, and lost almost none of his traditional loyalties to his pagan gods and their priesthood. It is apperent that, throughout the early and late medieval period of Ethiopion history, the Christion Church underwent on essentially similar process of expansion; and, although it gradually dispossessed the pagan clergy of much of their politicel and economic power, the Church seems to have never had a complete claim over the souls ond loyalties of the newly "converted" pagan peoples. It is apparent, too, that the same problems confronted Zer'aYa'qob in the middle of the fifteenth century. According to his own bistorical diegnoses, "... che accade ciò fu quando mancarono sacerdoti che insegnassero e Satano ridusse in servitu la gente." 1

There are numerous references to the pre-Christian religious proctices of the Kushitic peoples of the Ethiopian plateau in the hagiographical traditions of the Ethiopion Church ${ }^{2}$. It is, however, impossible to determine in precise terms the religious fromework of the people from these references. Enough linguistic

1. Mashafa Berhen, II (tr.), p.29.

2. Supre, pp.347-8 
evidence is still lacking to moke possible the identification of the religious terms preserved in the available traditions. There is an interesting reference to a pagan god in a story of the life of a fifteenth century local saint of Muger (Shewa):-

"And (the seint) said to the witchdoctor .... 'whom do you worship; who is your god?' The witchdoctor replied, 'Our god is be whom they call Gor ..., he is also called Diagoror ...' 1 .

The name of this object of pagan worship also seems to appear in various forms - jar, dero, yaro - in the kushitic language of BIlēn, Gonga, and kafficho respectively $y^{2}$. The areas which were graduelly token over by the Christian kingdom were originally the homeland of the Kushites, and there seems to have been a basic uniformity of religious beliefs and practices over the Ethiopian plateau. The general features of Kushitic pagan worship ${ }^{3}$ seem to be based on a sky god, with

1. Gedle l'ekle Hawaryet, ed. Conti Rossini, in CSCO script. Aetb. serie altera, t.24 (1910), pp. 117-8.

2. Conti Rossini, "Appunti sulla lingua awiya del Danghela" in G.S.A. I. XVIII (1905), pp. 110-1. He particularly identifies gor with the Sidama form Yero, Storia d'Etiodia, pp. 80-86.

3. Conti Rossini provides the best description, ibid, pp. 78-89; "Appunti sulla lingua awiys del Danghela", cit, pp. 108-122; Etiodio e kenti d'Etiopio, 1937, pp. $37 q-82$. 
numerous good and bad spirits inhabiting the mountalns, trees, rivers and lakes. Proyers and sacrifices were offered to these spirits, through hereditary priestly fomilies which seem to bove shered much of the sanctity of the gods of which they were the intermediaries, and as such they seem to hove wielded much power over their peoples. They could cause good and evil in accordance with the wishes of the spirits manifested in various forms of natural phenomena such as fire, storm, fomine, Iife and death. The smallest details of the daily life of the people were presumed to be under the control of these spirits, who had to be continuously pacified through the pagan clergy. They were believed to have power of life and death:-

"And (Neqawzey) says to us, 'If you fulfil my wishes you shall live, and I'll bless you; if you refuse to obey me you shall die with all your sons, your daughters, and your wives." 1 .

This was a world where every family lived in a continuous state of fear and uncertainty, where an angry spirit could strike hard at the slightest divergence from traditional forms of ritual worship. It was largely ${ }^{2}$

1. Gelde Tekle-Howaryat, p. 115.

2. The rulers of pre-Chriatian Akgum, and probably also some of their subjects, had adopted the worship of the South Arabian gods, Conti Rossini, Storia d'Etiopia, pp. 141-2. 
on this Kusbitic religious substratum that Christianity was superimposed in the Ethiopian highlands. From the description of Zer'a-Yo'qob in the fifteentb century, the establishment of the Church does not seem to have removed much of the beliefs and superstitions of the old pagan times. The dichotomy between Good and Evil God and Satan - in Ethiopian Christian cosmology did not at ell rule out the existence nor the strong arbitrary powers of evil spirits in the world. All pagan worship, in Zer'a-Yo'qob's view, was a worship of these spirits, which were only the manifestations of the molign forces of the Fallen angels. The pagans sought to placate these evil forces through the agency of their religious leaders - the desk, fetent, dino, gwidelē, meaawzē - whom Zer'a-Yo'qob considered as mere sorcerers?". It was

1. The precise meaning of these terms, frequently uoed by Zer'a-Ya'qob in his writings, and in the hagiographies of his period, is still uncertain and must awsit future linguistic investigation. It seems, however, that they referred not to the deities or the spirits themselves, but to their buman agents. Sometimes the king suggests thot each term referred to different regions: "In Shewa he who (divines) in this woy they call desk, in Angot dino, and in Gojjam SIgwi. And there are (other) sorcerers in all Ethiopia", Das Mishofa Milad und Mashafa Sellase. II (text), p.49. Conti Rossini thinks that the form of the word Tefent suggests that it hos on Agew origin, "Appunti sulle lingua awiye del Danghela", cit. pp. $112-3$. 
also, apparently, common practice among the Christians, particularly in the regions south of Angot, to consult these men whose powers to do considerable harm seem to have been widely accepted!. More common still, apparently, was the use of mogical prayers by members of the Christion community including the clergy ${ }^{2}$. 'Zer'a-Ya'qob was determined to abolish all these practices, and energetically set out reorganizing the Ethiopian church for the task.

He realised the enormity of the problem and had apparently drawn up bis reformprogrammes even before bis accession to the throne. For the first time since the establisbment of the new dynasty in 1270, Zer'a-Yaqob

1. Some of the king's wives and their children were once accused of doing this, Les Chroniques de Zar'a-Yeleqob et de Ba'eda Maryam, p. 6, 98; Das Mashafa Milad, cit. II, pp. 95-6. Fears of the evi powers of these pagan priests were apparently widespread even among the Christion clergy, and Zer' $\mathrm{B}-\mathrm{Ya}^{\prime} \mathrm{gob}$ needed to reassure them, ibid, pp. 44-5; Niashafo Berhan, II (text), pp. 23-4. References to the spirit Zar in the reminiacences of a notable scholar of the Ethiopian Church indicate that current attitude to these matters is still basically the same, Aleqa Lemma, Meshafe-TIzIta, ed. Mengistu Lemma, Addis Ababa, 1967, pp: $32,50-2$, 72 .

2. Zer'a-Ya'qob refers to clerical members of the court who practised this in the reigns of his brothers, Das Hashefa Milad, cit. Vol. I, p.19; see also lieshafa Berhan. II (Text), p. 49. 


\section{3}

asked the Alexandrian Patriarchate for more than one EgJptian bishop, and he received Bishops Mika'el and Gebri'el in 1438, together with Abba Yohanniss who was an eppisqoppos and of a lower rank? The most dire problem of the Church in the extensive Christian kingdom, as has been said obove, was the lack of a sufficient number of priests and deacons, and the king assigned his bishops to the two most needy provinces, Mika'ēl in Amhara and Gebri'el in Shewa? . Stationed in their respective posts, they performed the most important task of the Egyptian bishop in Ethiopia, namely ordaining

1. Supre, p.448. Thia was the first time for the Patriarch to send two Egyptian bishops to Ethiopis at one time. Wansleb, who gathered much of his information from the MSS. of the Coptic Church, relates that there were four bishoprics in the kingdom of Niexsmiteis, L'Historle de l'Eglise d'Alexandrie. 1677, pp. 29-30. More recentiy quatremere sought to identify Niexamiteis with Aksum, Némoires, II (1811), p.36. But no other references of many bishoprics headed by Egyptiang in Ethiopia are available and the identification is most uncertain. In the History of the Patriarchs we always have reports of one metropolitan sent to Ethiopia at a time, cf. Abu Salib, Churches and Monesteries, cit. pp. 285-6.

2. Neshafe-Tefut, MS. Institute of Archeology, Addis Ababa; ce. also Cerulli, Il libro etiopico dei miracoli di Niaria, p.117. ubba Merba-Krlstos (1409-97) abbot of Debre Libanos $(1463$ - 97) was ordained priest by Gebri'el at a place called Berara, Gedle Herhahristos MS. Debre Libanos, pp. 87-90. 
priests and deacons. In itself, the very presence of two bishops in the country created a tremendous sensation among the monasteries and a strong sense of mission seems to have developed in the Ethiopian church in general. The basis of Zer'a-Yo'qob's policy lay in bis success in involving the major monasteries of the country in his religious programme, by a strange combination of economic preferment and legal coercion. I'his wes particularly the case after the Council of Debre-Mițaq, when be could pull together the educational resources of all the established comwunities throughout his kingdom. In on attempt to make the best use of these communities he apparently divided the kingdom into 8 number of religious spheres of influence, which be distributed among the principal monasteries. The Ewosțathian communities in northern Ethiopia, and the flourishing monastery founded by Tekle-Heymenot at DebreAsbo, which Zer'o-Y8'gob renamed Debre-Libanos ${ }^{1}$, seem to have been the most important units in this arrangement. Debre-Maryam in Ser'ae, and Debre Bizen in Homasēn were at the bead of the monastic groups of the House of Ewostgatewos, and the king gave them large tracts of land

1. Les Chroniques de Zar'a Ya'eqob, cit., p.91. 
"so that they may preach and teach the orthodox Faith"1 It is also apparent thot Zer'a-Ya'qob recruited some Ewosṭathions to teach and establish themselves in southern Ethiopia, and we have references to Ewosțathian communities in Endegebțan, in south-western shewa, hitherto the exclusive domain of the House of lekle Hajmanot?

For the extensive provinces of Shewa and Ambara, Zer'a-Ya'qob utilized the facilities of Debre-Libanos. He built new churches in these areas and staffed them with recruits from Debre-Iibanos ${ }^{3}$. On one occasion the king received reports that the local people of a small district of Muger practised pagsn worship, sacrificing cows and sheep for the serpent god inbabiting a tree. He immedistely ordered that a church be built on the site, and Debre-Libanos supplied him with priests and descons, apporently led by sbba Gebre-indiryos, a notable member of the Tekle-Hajmanot community at the time ${ }^{4}$.

1. Wright, Catalogue, Or. $481, f .208^{\mathrm{a}}$.

2. Gedle Ewostatēwos, pp. 151, 165-7. The traditions related here indicate the hostility of Debre Libanos to the establishment of the Ewostatbians here. It is most probable that they refer to the reign of Zer'aYa'qob, whose sole preoccupation was to spread the teaching of the Church, and cut across old conventional spheres of influence whenever necessary.

3. Les Chroniques de Zar'a Ya'egob et de Ba'eda Maryam, pp. 53-4; Gedle Merho-Kristos, His. Debre-1icosor, pp. 153-4. 4. Ibid, pD. 128-130. 
Many other members of the community were olso active in the erea, preaching and establishing churches. It is interesting to note that the earliest tradition of some conversions among the Gafat belongs to this period:-

"(Meb'a-SIyen) had been wondering about the Gafat and he thought 'when will they believe, where will they be baptized? will it be in my lifetime, or will it be after my deoth?' And while he was contemplating in this way he met many Gafat men going to our king Zer'a-Ya'qob to be complimented for their (recent) conversion and their boptism in the neme of the Trinity." 1.

1. Gedle Meb'a-Siyon, ed. \& tr. Budge, E.A.Q., in his The Lives of Maba-sigon and Gabre hristos, London 1898, pp. 25 (text), 79 (tr.). The Gafat were a Semitic speaking group, apparently inbabiting the inaccessible districts overlooking the Nile gorge between the Jemma river and as far west a the Guder on the Shewan and Damot side. Zorzi's informants located the Gafat around the sources of the Awash river. Crowfoot, op.cit., pp. 161, 183, 187; cf. also Alvarez, The Prester John of the Indies, p.458. Bermudez was detained there by Gelawdewos, La Croze Veyaiere, Histoire du Christianisme d'Ethionie. et d'srmenie, 1739, p.197, 223-4; Witewa7, R.S., like Portuguese Expedition in Abyssinia in 1541, pp. 217, 232-3. It seems that largely because of the later expansion of the Galla the Gafat gradually moved to southern Gojjam, Chronica de Susenzos, ed. Pereira, Esteves, Iisbon, 1892, pp. 12, 23, 25-8, 30. Almeida clearly considered them as newcomers to Gojjam, some Records, p. 56. Professor Leslau's valuable linguistic studies are based on information gathered in their new babitat of Wemberma, in Gojjom. He has recently published a document purporting to be the bistory of the Gafat, "A short chronicle on the Gafat", in RSO, XII (1966), pp. 189-198. The converts to the Church in Zer'a-Ya'qob's time must have been very few, and in the 16 th $\mathrm{C}$. both Alvarez and Bermudez described them as a pagan people in senergl. 
The districts of Muger and Endegịtan had been witbin the kingdom since the thirteenth and fourteenth centuries, but it was apparently in Zer'a-Ya'qob's reign that a strong offensive against local pagan worship was conducted in these areas. The king personally directed these activities, and epparently encouraged baptism by rewarding new converts, who automatically joined the privileged class of the Christian settlers in their country. The assimilation of his pegen subjects into the Christion community and the creation of a religiously homogeneous society was Zer'B-Ya'qob's bighest ideal, and he sought to realize it through his own personel direction of the Church. Every little detail of the work and administration of the Church was, for him, an affair of state and be passed numerous decrees to regulate the religious conduct of his people.

The major part of his decrees underlined the responsibilities of the clergy in teaching ond guiding the people ${ }^{1}$. On Saturdays and Sundays every Chriatian was expected to go to the neorest church, where the priests had to teach the people "the Worship of God, His Command-

1. Mashafe Berhon (text), I, pp. 109-114, 149; II, pp. 28-30, 48-53; Das Mashofa Vilad und Miashafa Sellase (text), I, p.65; II, pp. 25-26. 
ments, and the observance of His Sobbaths"?. When a church was too far from the settlement of a group of Christian fomilies, a priest had to be sent to them every Fridoy and spend the weekend there, giving them religious instruction. On these occssions the priest was to be fed and looked after by the community. Every Christion had to bove his own Fother Confessor who looked after his spirituol well-being, and without whose recommendation participation at the Holy Communion was forbidden? ${ }^{2}$ A serious problem in many churches was the lack of a sufficient number of religioug books, and the king specially encouraged the establishment of a library in every $\mathrm{church}^{3}$. Zer'a-Ya'qob expected the full co-operation of the clergy in his religious programmes and enacted strict disciplinery measures againgt anyone amongst them who failed to follow his directiong:-

"Il ordonno aux chouns de piller les meisons et de àisir les bìens des prêtres qui ne se conformient pas à ces prescriptions et qui ne donnersient pos cet enseignement dons leurs eglises." 4.

1. Maghafa Berhan, I, p.149.

2. Ibid, pp. 48-53; Des Maghafa Milad. I, p.65.

3. Miashafa Berhan, II, p.33.

4. Ies Chroniques de Zar'a-Ya'edob et de Ba'eda Maryam, p. 82; cf. also Mashafa berhan, II (text), p. 28, n.10. 


\section{$5: 4$}

He declared the abolition of all forms of pagan worship in bis kingdom. Consultation with witch doctors, and offering sacrifices to pagon gods were forbidden on pain of death ${ }^{1}$. The use of magical prajers was also made punishable in the same way ${ }^{2}$. Zer'a-Ya'qob required from his people a clear and an unequivocal expression of their beliefs in the teachings of the Church, and their public rejection of nonChristion practices. Thus he decreed that every Christian should bear the names of "the Father, the Son, and the Holy Ghost" branded on his forehead". The sign of the cross also had to be affixed on all the belongings of the Christions, on their dress, their

1. Das Mashofe Milad. II, p.47 (text); cf. also I (text), p.42; Maghafs Derhan. I, (text), pp. 26-7, $11 \overline{8}$.

2. Mashafa Berhan, II, p.49 (text).

3. Ibid. p.29 (text); cf. also p.17 (tr.), n.4 and 5 . Here Zar'a-Yo'qob reports that the Egyption Christians bore the sign of the Cross tattooed on their hands; and he argues that his prescription is the more orthodox, and quotes Revelation XIV, 1 and XXII, 3-4. His chronicler gives two additional requirements, that everyone was asked to have the words "I deny the devil" branded on his right arm, and "I deny the cursed desk: I am the slave of Mary", on his left arm, Les úbroniques de Zar'8-Ya'aob, p.6. 
instruments of war, ond even on their plougha. To ensure a complete regimentation of the life of his subjects the king insisted on the strict observance of numerous fasting and boly degs?

It is apparent that Zer'a-Ya'qob entrusted the implementation of his religious programmes to the chief priests of the various districts, and required the abbots of the mejor monasteries to make round tours of their parishes. On these tours of inspection they were accompanied by the king's troops. 'This emerges quite clearly from the excellent biography of HerhaKrIstos, abbot of Debre Libanos (1462 - 96):-

"Zer'a-Ya'qob said to (Merha-kristos), '... go, and look after the administration of the Churches, and preach the Fith in 811 the lond.' ... (sind at that time) the Faith of the people of Muger was not strong as yet, and for this reason (Merha-Kristos) went down to the country of Muger with the messengers of the king." 2 .

1. Ibid, pp. 75-6; Das Mashafa Milad. II (text), pp. 102-5; Mashafa Berhan, II (text), pp. 44-7, 159-161, 167-72.

2. Gedle Merho-KrIstog, MS. Debre-Libanos, p.127. MerhaKristos (1407 - 96) was the son of a rich family in Wej, Whewa. Ordained descon by Bishop Bertelomêwos ( 1399 - 1436?), be joined Debre-Libonos, where the abbot Yohannis Kemo invested him with the monastic habit, while still a very young man. He was made a personal attendant of the abbot who later died in his care. Bishop Gebri'ēl (1438 - 58?) ordained him priest at the recommendetion of the next abbot, inafryes, When the latter was disgraced and exiled by Zer'a-Ya'qob in 1462, Merba-Kristos was appointed in his 
The presence of the king's troops in bis porty enobled the abbot to exercise much authority during his round visits. On the occssion of his trip to Muser, NerhaKristos is said to have "burned their books of magic", and when confronted with a more serious opposition be sent the leaders to Zer'a-Ya'qob himself. At the royal court, "the king ... ordered his men to flog them"1. It seems that thia was a general pattern throughout the kingdom, and Zer'a-Ya'qob's personol involvement in the expension of the church tended to give much political influence and arbitrary power to his ecclesiastical appointees in the provinces. Abba Tekle-Hawaryat, who also preached in Muger, is said to bave flogged 8 witch

Footnote 2 cont. from previous page.

place, ibid, pp. 108-9. He wos on very good terms with Be ide Niaryam ( 1468 - 78), whom he accompanied on his cempeigns against the Dob'a; ibid. 158-77; Les Chroniques de Zar'a-Ya'eqob et de Ba eda Maryam. pp. 133, 147. He was still abbot when be died in the second year of the reign of Na'od (1494-1508), Gedle Kerha-Kristos, p. 346; cf. 8lso Cerulli, E., "Gli abbati di Dabra Libanos", cit. pp. 145-9.

1. Gedle Merho-KrIstos, pp. 135-7. It is apparent that the clergy of the provincial churches put up a very strong resistance againat the strict control of their activities by the king's direct appointees, and there ore reports of violent closhes during these tours of inspection. 
doctor in public, and to hove expelled many others from the highland districts overlooking the Blue Nile gorge, by burning down their houses". These acts of violence hod the king's blessing and were apparently committed to demonstrate the powerlessness of the pagan gods and their human agents.

Political Unrest in the Kingdom.

$$
\text { Zer'a-Ya'qob was a despot. In his enthusiasm to }
$$
create a uniform religious proctice among his subjects, he applied very harsh rules:

"If you see anyone sacrificing to Baten, kill him with a spear, or with a staff, or with stones ..." 2 .

'fhis arbitrary disposition characterized the second half of his reign. In bis chronicles, and in the hagiographical traditions of the period, many of the punishments inflicted by the king are frequently given religious motives. However, it is possible to detect thot serious political reactions were staged against the king's highhanded rule towards the beginning of the 1450 s.

1. Gedle Tekle-Hawaryat, pp. 115-123.

2. Das Mashefa Milod und Mashafa Sellase. II (text), p.47. "Whoever is found in possession of magical prayers... shall be punished like on idolator, and his property shall be given to the church", Mashafa Berhan. II (text), p.49. 
His own Bitweded and son-in-low, 'Lmde-Mesqel, is accused of "rebellious schemes ... unbecoming to relate" Another secular official, Șasergwê Amba-Iyesus, and Abba Nob, Nibure-Ed of Debre-Damos are mentioned as hia accomplices? ${ }^{2}$. A former Bitweded, Isayiyas, was also committed to prison and was physically tortured, probably on the same ocasion ${ }^{3}$. A more definite story of a bighpowered revolt $\theta$ geinst Zer' $\mathrm{B}-\mathrm{Yg}^{\prime} \mathrm{qob}$ is told in one of his own books ${ }^{4}$. Here the leaders of the revolt are naturally kept ononymous, but they are described as being

1. Les Chroniques de Zar'a Ya'eqob et de Ba'eda Maryom: p.10. l'he chronicle also tries to avoid the real issue in enother passage, "And they exiled ('AmdeMesqel) when he did tresson on the king. I do not know the secrets of the matter. Publicly, he was accused of taking another woman to wife, while be was married to a Princess", pp. 94-95.

2. Ibid, pp. 11-12, 95. l'be mention of Abba Nob seems to provide a usefui chronological term of reference. A certain Nibure-Ed Nob is mentioned elsewhere os being involved in Zer'a-Ya'qob's programme of rehabilitating the House of Ewostatêwos, and Conti Kossini has identified him with the obbot of Debre-Damo, Gedle Yonas, pp. 180, n.l, 199. Yet another reference to a man of this name is provided in $\theta$ story of the viracles of St. Miary where he is accused of a private scepticism towards the new Cult of St. Mery, and Cerulli identifies him witb the same person, Il Libro Etiopico dei Miracoli di Mario, pp. 108, 110, ili-112.

3. Les Chroniaues de Zar'a-Ya'eaob, pp. 12-13.

4. Mashafo Berhon, II (text), pp. 19-22. 
"from smong the rulers of Ethiopia". They sought to depose Zer'a-Ya'qob and enthrone another in bis place. It is apporent that the movement had assumed very serious proportions, and the king resorted to a very unusual political act to quell the rising. We are told that the news of the revolt reached Cairo, where the Patriarch and his congregationg were greatly distressed. Patriarch YohannIs (1428 - 53) immediately sent messengers to Ethiopia with a letter of ex-communication againgt "All the army, the chiefs and rulers, big and small, men and women ... (who) desire to crown another while Zer'a-Ya'gob ... is still on his throne; these (men) and whoever wishes to take the crown (from him) ... or to kill him, or to depose him in open revolt or by secret means and by magic; and whoever joins in on evil league against him." 1.

The Patriarchal letter was read at a public gathering by Bishop Gabrie'èl, after which many of the rebels are said to have publicly confessed their sins and reconfirmed their future loyalties to the king.

Nevertheless, it is quite clear that immediately after the incident Zer'o-Ya'gob introduced a number of changes generolly intended to centralize his administrative

1. Ibid, p.19. 
control of the Empire1. Apparently this was accompanied by a great purge of mony individuals who previously beld high office in the royel court and in the provinces ${ }^{2}$. The hagiographical traditions about the life of a Shewan saint, $\Delta b$ ba Tekle-Heweryat, seem to provide an additional piece of evidence both for the noture ond the chronology of these political unrests ${ }^{3}$. At one time Tekle-Hawaryat asked for an audience with the King, and wished to speak to him about "the futile deaths of men, the arrests and the beating which take place". When the king was told of this he angrily summoned the monk and said to him:

$$
\begin{aligned}
& \text { "Is it true that you insulted me? } \\
& \text { Whom did you see me kill without legal } \\
& \text { proceedinga; and whom did you gee me } \\
& \text { punish outside the law? And why do } \\
& \text { Jou thus slander me while I am the } \\
& \text { annointed one?" } 4 \text {. }
\end{aligned}
$$

1. It is perhaps most expressive of the gravity of the political movement a שainst him that these administrative changes consisted in the appointment of his own daughters to high offices of the court, and as heads of the provinces, Les Chroniques de Ear'a Ya'egob, pp. 9-10, 13-14, 94-95. The princesses probably ren their offices from the court through their local agents who are accused of oppressing the people, ibid, pp. 95-97. The king then took a personal control of $a i l$ the provinces through a new cadre of local appointees, directly responsible to himself, ibid, pp. 14-16.

2. Cf.

3. Gedle Tekle-Hawaryat, MS. Debre-Libonos, ff. 49-50. 4. Ibid, $f \cdot 50^{\circ}$. A passing remark in the story of the life /Continued overleaf. 
Tekle-Howaryat was himself beaten and cast into prison, where he died some months later. Only thirteen years afterwards, when Be'Ide-liaryom (1468 - 78) succeeded his father, could his disciples remove the remains of TekleHawaryat to Muger, where his monastery of Debre-Șmono is still an object of pious pilgrimage. This chronological reference is particularly interesting as additionol confirmation that the abortive rising against Zer'aYa'qob took place about the beginning of $1453^{1}$.

Footnote 4 cont. from previous page.

of another contemporary local saint, from Endegibtan, also indicates that unfavourable sentiments were freely expressed about the king at the time. The Saint is shown a vision of the Fires of Hell by St. Michael who tells him, "Look, those who are crying here are men who slandered King Zer'a-Ya'qob", The Iife of Maba', Seyon, $\theta$. Budge, p. 27.

1. The incident must have taken place between 1450 and 1453. Abba Nob who took part in the revolt was still in favour in 1450. Patriarch Yohannis XI, who allegedly excommunicated the rebels died on $4 \mathrm{th}$ Maj 1453, Chaîne, M., La Chronologie des temps Chrétiens de l'Egyote et de I'Etbiopie, Paris, 1925, Tables. Tokle-Howeryat's arrest in 1454 takes the incident nearer to 1453 thon 1450. Together with that of Endrryos, abbot of Debre-Libanos (d. 1462), Tekle-Hawaryot's death as a "martyr" is also referred to in Gedle Merha-KrIstos, MS. Debre-Iibanos, p.102. 
Zer'a-Ya'aob: Lasting achievements.

Zer'a-Ya'qob displayed a strong sense of mission throughout his reign, and be set himself very high objectives:-

"And God raised Us to this orthodox throne so thet we mey disperse all idol-worshippers." 1.

Judged agrinst this high ide日l, however, hig attempts to bring about a radical change in the religious life of his people did not bear substantial results.

Perhsps the most telling illustration of this drastic foilure is the basic contradiction of his own life. Despite his eloquent commentaries on the spostolic Canons, and on the constitutions of the early Christian Church, Zer's-Y日'qob remained polygamous to the end of his days ${ }^{2}$. His superstitious fears of black magic seem

1. Das Mashaf Milaud und Mashafa Sellasê, II (text), pp. 95-96.

2. He had three queens: Zan-Hayla (also called FrreMaryam), his favourite wife and mother of his eldest doughters, Les Chroniaues de Zar'a-Ya'eqob, pp.55, 87;

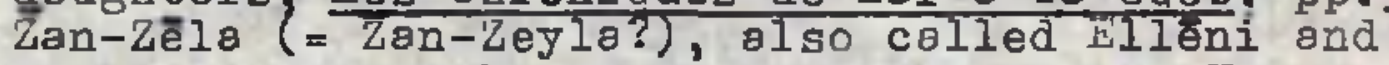
daughter of the Muslim tributary king of Hodya, ibid. pp. 16,59; another name of a queen, Ber-zeloy (= BerZeyls?) is mentioned elsewhere, Guidi, I., "Le Canzioni Ge'ez-Amarina in onore di Re Abissini", in RRAL, Ser. IV, Vol.V (1889), p.63. It is not clear whether this represents a different person or Zan-Zela. His other wife was Styon-Mogesa, mother of his successor Be'ide-Maryam, Les Chroniaues, pp. 105-7. Zer'a-Ya'qob refers to his "queens" in Des Miashofa liilad und liashafe Sellasē. II (text), p.95. Cf. also Dillmann, epecita, $p .67$. 
to have been consideroble ${ }^{1}$, and his ruthless judgements convey very little of the sense of justice in $\theta$ deeply religious man. The most lasting achievement of Zer'aYa'qob certainly lay in big encouragement of Etbiopic literature, in the development of which be actively participated ${ }^{2}$, and in his reorganization of the church. Zer'B-Ya'qob's close association with their religious activities promoted the prestige of the monosteries, and greatly incressed their economic and political influence in the kingdom. It is even apparent

1. According to bis chronicler "This king says in his own words, and it is written in his book, that evil men have cast a spell on him wherever he resides and wherever be travels", Les Chroniques, p.41. To ward off the molign effects of this, prayers were beld round the clock ot the king's residence by a select group of monks who sprinkled holy water on the premises ot regular intervals, p.40. The Patrierch's letter of excommunication also covered those who would like to get rid of the king "by secret means and through black magic".

2. A number of religious compositions are personally attributed to him, among which are Tomare-risbI't, KIhoete-jeytan, Nieghafe-BabrIy, iszi abher-Negse, Te aolbo-Mistir, Meshafe-Birhan, and Meshafe-Milad,

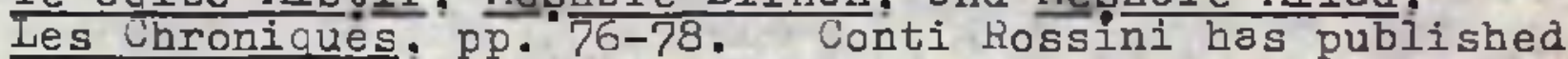
an extract from Te'aqubo-Mistir in his "Il libro di re Zar'a Ya'qob sulla custodia del Mistero", RSE, III (1943), pp. 148-66. The last two wroks have recently been published in the excellent series of the Corvus Scriptorum Christianorum Orientalium. and we have already made some use of them above. 
that the revolt of 1453 was as much against the king as against the growing wealth of some of the monasteries. It is reported by the chronicler that Zer'a-Ya'qob had granted to Debre-Libanos all the revenues collected from the rich province of Shewa. The revenues previougly belonged to the Șehafe-Lam and a number of military contingents under him ${ }^{1}$. The diversion of their former income to the monosteries was no dount resented by the troops and their leaders, and probably contributed a great deal to the political unrest of the time. The tone of the Patriarch's alleged letter of excommunication against the rebels of 1453 also points to the same conclusion:-

"If there is ony one who trespossed on the churches and monasteries built by ... Ler'a Ya'qob ... and on their land holdings and all tbeir property ... (he shall be excommunicated)." 2 .

Other land grants of considerable size in favour of the major monastic communities in northern Ethiopia are also attributed to Zer'a-Ya'qob ${ }^{3}$. It is further apparent that

1. Les Chroniques de Z8r'a-Ya'eqob, p. 101 .

2. Mashafa Berhan, II (text), p.19.

3. Liber Aksumae, ed. Conti Rossini, pp. 25-26. Ia.., "I'evangelo doro", cit., p.212. Wrigbt, Catalokue,

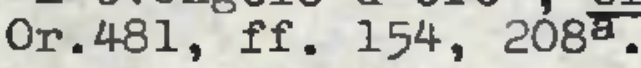


compulsory contributions in kind were collected from the Chrigtian pessantry throughout the kingdom for the support of the local churches ${ }^{1}$. Probably to ensure that his religious reforms reoched every little family, Zer'a-Ya'qob had instituted the position of the Father Confessor, which still remains one of the most distinctive features of the Ethiopian church. Despite the modest efficacy of this institution in bettering the soiritual Iife of the people, the close personal and economic relationships between the Father Confessor and the individual family remained intact: "Love (your Father Confessor) like the pupil of your eye ... ond give him from the fruits of your labour ... and share with him whatever jou have"2. The end result of these measures was the creation of a huge clerical aristocracy living almost entirely on the services of their congregation. Many of the monastic communities, which had started their religious purguits by collecting wild fruits and cultivating their own little terraces ${ }^{3}$, had become owners of large tracts of land as Gulta by the middle of the fifteenth century ${ }^{4}$. This development naturally gave the

1. Mashafa Berhan. II (text), po. 4l-3.

2. Des Mashafa Milad, cit. II (text), pp. 25-6.

3. Supra, pp. $209-14$

4. For the nature of the lond holding known as Gult, see 
monasteries much secular power and administrative responsibility over their tenant farmers, and they began to exercise a considerable political patronage in the Christian Kingdom ${ }^{1}$.

Unlike the great monastic leaders of the fourteenth century who kept strictly to their isolated hermitages, meny of the abbots of the principal monasteries became regular visitors at the court of Zer'a-Ya'qob². It is apparent thot the king required their presence around bim for religious consultations, and probably also to involve them more actively in his progrsmmes of reform and literary development. Especially towards the end

1. Puritanical monastic resctions against their acquisition of an increasing amount of wealth ond temporel power were not lacking. The most vehement protest came from the remarkable religious movement of the Deqiqo Estifanos, Gedle Egtifanos, MS.2, Inst. Arch., Lddis Ababa, ff. $22-8,59,60-61$.

2. Ies Chroniques de Zar'a Ya'eqob, pp. 27-8. Here the abbots of the major monasteries are mentioned as the king's regular courtiers. The Aaabe-Se'at of the island monestery of Haiq was specially required to stay at court with the king, ibid, pp. 7-8, 167.

The abbot of Debre-Bizen, ibba Petros, is elsewhere said to heve steyed with the king for two years, Eolmodin, oD.cit., $A_{25}$. Merba Kiristos of Debre-Libanos frequently visited $25^{\circ}$ Zer's-Ya'qob and even accompanied Be'ideNaryam on his Dob'a campaigns, Gedle Herha-KrIstos. pp. 149, 158-77. Les chroniques, cit, pp. 133-47. 
of his reign, and ofter the abortive revolt of 1453 , Zer'a-Ya'qob was always surrounded by his ecclesiastical officials. Besides enhancing the age-old role of the monarchy as the focol point of the religious and political Iife of Christian Ethiopia, this concentration of the highest clerical and secular leadership around the person of Zer'o-Yo'qob particularly made his court the centre for the increasingly articulate national selfexpression of the Ethiopians, and for their growing sense of independence, even from the Fatriarchate of Alexandrio. This national development found its highest expression, some years after the death of Zer'a-Ya'qob, in the Council of 1477 convened by his son and successor Be'Ide-Maryam $(1468$ - 78). At this council a radical proposal for the discontinuation of the spiritusl dependence on hlexandrio was put forward by a large section of the Ethiopian clexgy, and was seriously considered ${ }^{1}$.

Zer'a-Ya'qob's favourite bishops, Mika'ēl and Gebri'ēl, opporently died before $1458^{2}$, and it is not

1. The story of this important council is told in Gedle Werho-Kiristos, MS., Debre-Libanos, pp. 237-51.

2. Alvarez was told that Zer'a-Ya'gob did not have a bishop for the lest ten years of his reign, The Prester John of the Indies, II, p. 356. 
known if the king ever asked for their replacement during the remaining years of his reign. 'The two bishops had been most co-operative in his religious progrommes, ond, having their respective heodquarters in Ambara and Shewa, they were very active in ordaining priests and deacons. Probably the number of ordinations in the twenty years of their ministry in Ethiopia was very large, and the effect of the absence of a bishop was not keenly felt in Zer'a-Ya'qob's last years. Towards the end of the reign of his son, however, the shortage of priests in the kingdom had assumed serious proportions. H distont echo of this is found in a tradition collected by D'Abbadie in Begēmdir about the reign of Be'Ide Maryam: "... il n'y avait que deux prêtres dang l'église ou chapelle du Roi"l.

A strong representation was made to King Be'IdeMeryam to break relations with Alexandria and appoint Ethiopian bishops:

1. Conti Rossini. "Il libro delle leggende e tradizioni abissine dell Eccieghie Filpos", in RRAL, Ser. 5, Vol. XXVI (1917), p.711. "I'he reason given here for the shortage is oltogether different - viz. that no one could be ordained to the priesthood if he did not descend from the House of Levi, a reference to the legend of the Queen of Sheba. Most probably this is a confusion of two different traditions. 
"And they said (to the King) we have beard that (the people of) igypt have changed their Faith. 'Phey eat what is forbidden in the Law. And now let us appoint $\theta$ bishop from our country as it is said 'let him be appointed (bishop) who is chosen by the people'.." 1. Characteristically, the initiators of this radical view are kept anonymous. It seems quite possible, however, to indicate their identity from the opposite stand adopted by Debre-Libanos of Shewa in whose tradition we have the story of the Council. Merha-Kristos was the abbot of Debre-Libanos at the time and he vehemently opposed the new proposal. He based his arguments on the principal of Apostolic succession?. Merba-Kristos submitted to the King and the assembly bis own counterproposal:

\section{"Let the king send wise men, whose words are dependable, to investigete for us. If the Egyptians are still in the Orthodox}

1. Gedle Merba-kiristos, cit. p.237. Cf. Duensing, H., "The Etbiopic version of the Egyptian Church Ordinance", ed. \& tr. in Abhendlungen der Akademie der Vissenschaften, G8ttingen, Phil.-bist. Klasse, Folge 3 , No. 36, 1946, p.16 (text).

2. Gedle Merho-KrIstos, p.239. In his contention MerhaKristos reminded the assembly of the wrath of God that befell Ethiopla in the reign of Patriarch Yosef (830 49) when the Ethiopians expelled the Egyptian bishop and chose one of tbeir own, ibid, pp. 245-8. Cf. also History of the Patriarchs of Alexandria, in PO, $X$ (1913), pp. 508-9; Renandot, op.cit., pp. 273, 283-8. 
Faith let them bring us a bishop according to the tredition of our forefatbers. If they are not we shall then pray to God and ask for His guidance of what to do." 1 .

The mild tone of this suggestion was only intended to cover up the basic commitments of Debre-Libanos to the continued dependence of the Ethiopian Church on Alexandria. We have alresdy seen ${ }^{2}$ that the monastery adopted a similar position in the religious controversies before 1450, and Merha-Kristos was only expressing the traditional loyalty of the community to the Egyptian Church. It is also possible to see a gimilar consistency in the position of the anti-Egyptian party.

It is most likely that the major protagoniats of the radical view belonged to the House of Ewosṭatēwos. The tradition of Debre-Iibanos about the council only refers to them as "the other party". However their long-standing opposition to the Egyptian bishops, and their remorkable sense of independence, seem to warrant the proposed identification. Just as in the Council of Debre-Mitmeq of 1450 the "Nationalist Party" consisted of the majority of the assembled clergy ${ }^{3}$. This time,

1. Gedle Merhe-KrIstos, p. 240.

2. Supre, pp. $442-5$

3. inis is attested by the tradition of Debre-Libanos itself, "(The supporters of Merho-Kristos) numbered three bundred ... and the other party four hundred", Gedle Nierba:kristos, p. 243. 


\section{5}

however, it did not have the royal support. The DebreLibanos party was determined to win the day, and applied all the political patrongge at its disposal, outside the assembly. Ras 'Amde-rika'ēl, the most powerful official in shewa at the time ${ }^{1}$, sided with Nierha-Kristos, and arranged a private oudience for him with the King. The fate of the council was decided at this secret meeting, and the king announced bis final ruling the next day:

"We have ordered that men who are dependable go down (to Egypt), ond we shall send a thousand shekel weights of gold to be given to the Holy Sepulchre, the Patriarch of Alexandris, and the Sultan of Egypt." 2.

Despite the numerical superiority of the opposition, Be'İde-Maryam thus decided in favour of the continued dependence of the Ethiopian church on the Patriarchate of Alexandria. It is impossible to tell what Zer'aYa'qob's position in similar circumstances would have been. It must be said, bowever, that his stand in the Council of Debre-Mițmeq had been decisively nationalistic. He was also apparently reluctant to ask

1. Ras 'Amde-Mika'ēl was already a strong provincial governor of Fetegar in Zer'a-Ya'qob's reign, Les Chroniaues, p. 15 .

2. Gedle Verho-Kristos, pp. 248-9. 
for new Egyptian bishops, after the desth of Miks'ēl and Gebri'ēl, in the last ten years of his reign. The radical issue of independence from slexandria was no doubt the culmination of the religious nationalism so characteristic of the remarkable career of Zer'aYa'gob. 


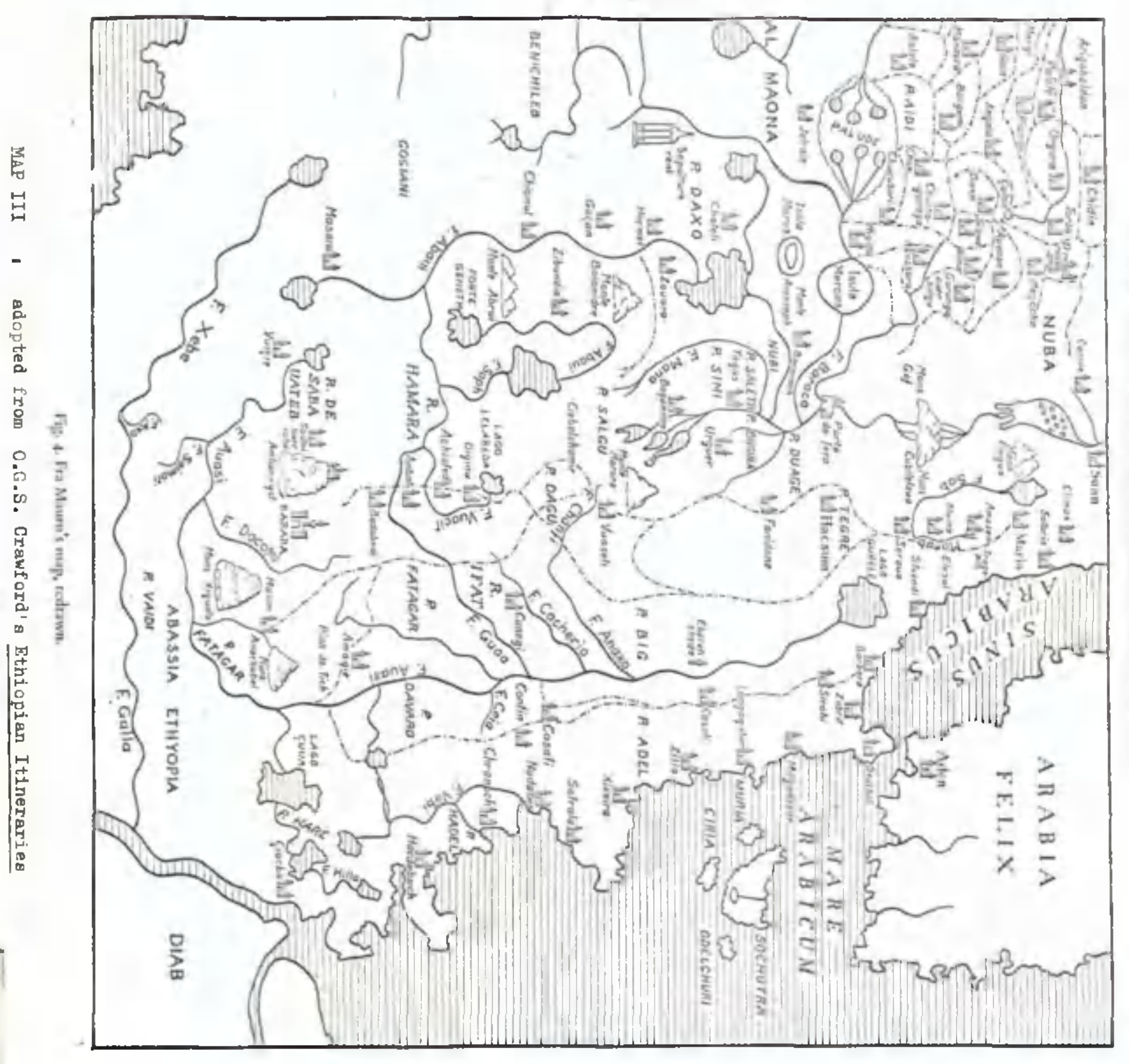


CHAPTER SIX

\section{FIPTY YEARS OF DECIINE}

(1477-1527)

The internal struggle for royal succession among the descendants of YĪkunno-'Amlak had been one of the major factors in the weakness of the dynasty in the first decade following the death of itg founder. The problem had never been entirely absent during the history of the next two centuries, and there were frequent signg of political unrest on the accession to power of many of the kings even during the fourteenth century and in the first half of the fifteenth. By the last quarter of the fifteenth century, however, problems of auccession assumed a very serious character and in the end precipitated the decline of the Chriatian Kingdom - a decline which served as an essential prelude to the remarkable military success of Ahmad Gragn.

We have already looked briefly at the constituent parts of the Royal Court during the reign of 'Amde-Síyon. Much of the struggle for succession was conducted there and, to be able to appreciate the anatomy

1. Supra, pp.133-5

2. Supre, pp. 19t-201 
of medieval Ethiopian politics, we must now consider

the development in the organization of the mobile Court. The life and pergon of the monarch constituted the focal point of the vagt Christian empire of medieval Ethiopia. This was true in more than a literal sense, and the concentric arrangement of the rojal camp was only its physical expression.

1. Material for this reconstruction hag been obtained from isolated references in the Chronicles and the abundant hagiographical traditions. Short unpublished accounts entirely devoted to the organization of the court and the description of royal officials are available in the MS collections of the British Museum, the Bodleian, and the Cambridge University Library: perhaps a copy of the earliest version is found in MS. Bruce, 88, Bodl., $f f$. $30^{\mathrm{b}}-34^{\mathrm{b}}$, described in Dillmann, A., Catalogue Codicum manuscriptorum Bibliothecae Bodleianae Oxoniensis. Pars. VII. Codicis aethiopici, oxford, 1848, No.29. The same version is also available at the BM., Wright, W., Catalogue of the Ethiopic Manuscripts in the British

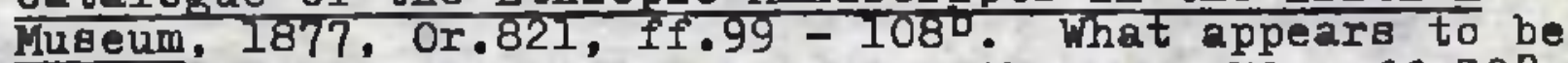
amore recent version is given in the same MS., ff.30 35. At the Cambridge University Library, OR.1873, f1. 3 - II also contains this later version, and is described by Ullendorff, E., Cataloque of the Ethiopian Menuscripte in the Cambeidge University Hibrary, pp. 62-63. It is also this later version that has been published according to different copies available in European libraries: Varenbergh, J., "Studien our abessinischen Reishsordnung (Ser'ata Mangest)", in ZA, XXY $(1915 / 6), \mathrm{pp.1}$ - 45; Guidi, I., "Contributi alI storia letteraria di Abiesinia", In RRAL, Ser.5, XXXI (1922), pp. 65-89. It is apparent, however, that what wo have in these short accounts is only a small section of a much fuller treatise on the aubject, now probably lost to us for ever. In Wright, op.cit., Or.821 ff. $3^{b}-5^{2}$, and Varenbergh, op.c1t., pp. 12-15, we only have what appears to be a ist of contents of a more complete description of the court and the institutions of the Kingdom. Contemporary accounts which have come down to us intact are the description of Zeria-Yaqob's court, 
The private quarters of the king and his family consisted of two concentric enclosures at the heart of the huge conglomeration of people assembled at the court. The inner enclosure, separated from the outer one with curtains, or with a fence in cases of a longer sojourn at the site, was exclusively set aside for the use of the king and all the tents pitched there served to his personal convenience. The king's special confidants, literally called "inner pages", officiated here and provided for his personal needs. Thirteen separate exits, each with its own name, led to the outer enclosure. The principal exit, Wīinash Dej, pro-

F/note 1 contd. from previous page.

Chroniques de Zar'a-Ya'eqob, pp. 23-45; and Alvarez' valuable description of Libne-Dingil's royal camp, The Prester John of the Indies. I, pp. 267-272; II, pp. 437-445.

1. See Figure 1, p. A distinction between the two enclosures seems to be implied in the inconsistent use of the terms Jegol and Meggareja. Jegol, used in general terms, apparently referred to the royal enclosures as a whole, but in the specific description of the arrangement of the court clearly indicates the outer enclosure only. Meggareja is what Alvarez calls "mandilate" (= Mentola'it) and referred tothe curtains drawn all around the royal tents. Here again there are inconsistencies in the use of Meggreja which sometimes also seems to be applied to the outer enclosure. The difficulties of the scribe in giving a consistent usage to these terms probably arose from what Alvarez describes as follows: "...they surround (the tents) all with (tall) curtains, which they call mandilate; ... If (the king) is going to remain several days they surround these tents with a big hedge, which will be half a league round." op.cit.. II, p. 437. 
bably opened in a weoterly direction, in a straight line with the residence of the king at the centre. On either side of this principel gate were six others, equidistant from oach other, and thus congtituting the remaining twelve exitg of the inner enclogure. The twin organization of the royal court, and of the king'g officials, into those of the Right and of the Left is basically derived from this characteristic arrengement of the six gates on oither side of the principal WIaInash Dej. Each of these exits of the inner enclosure was closely guarded by very highranking officials of the royal guard. Admittance to the royal presence was at the sole permission of the king, and the use of each entrance was prescribed for particular members of the royal court from the outer enclosure.

1. The Fthiopic descriptions do not give eny directions. There was probably no hard and fast rule about this, and the terrain of the particular site where they camped at any particular time may have affected the arrangement. Here, for purposes of clarity, I have adopted Alvarez' direction, "the principal (gate) is to the west", loc. cit.

2. Alvarez was told that the royal enclosures had a total number of 12 gates. He only gaw four, "for they let no one pass (behind)", loc.cit. The existence of a principal gate, Widinagh Dej, at the front of the court, beBides the twelve other gates is however very clear from the available Ethiopic descriptiong, cf. MS. Bruce, 88, Bodl., f.32b; Or. 821 (BM), f.104b? 
The outer enclogure itself was a direct duplicate of its inner counterpart. It had thirteen gates corresponding to those described above, and followed the same twin arrangement of the court into Right and Left. All around the fence of the outer enclosure, and particularly at the gates, were stationed numerous guarda, spec1ally assigned to cover particular sides of the court. The area within the enclosure between the Meggareja and the Jegol was very extensive, and in it were pitched many tents on either side. The treagure houses of the king, guarded and administered by a special group of officiala, formed a prominent part of the collection of tents. Hore important gtill were the tents of the Queen Mother, and those of the Queens of the Right and of the Left. Nor-

1. A partial list of the royal guarda givea a total number of over 13,000, MS. Bruce, 88, Bodl., $1.33^{\mathrm{b}}$.

2. Alvarez estimated the circumference as one league, loc.cit. The editors of his work have taken the Portuguese league as equivalent to $1 \mathrm{~g} .2$ geographical miles", op.cit., I, p.56, n.4.

3. WS., Bruce, 88 , Bodl. $1.32^{b}$. Here the various tents are collectively said to belong to the Mengist Bet, a name used by the apparently later verions for a group of tents in the outer enclosure, together with others which had similar functions such as Bereket Bet, and Mer'id Bet, ibid., f.330. Zer'a-Ya'qob's chronicler also gives them considerable prominence, Chroniquea, cit. pp. 37-38. Alvarez gives a vivid description or how they were transported, op.cit.. II, pp. 447-448. 
1

mally, the number of king's wives was three, each with her own title: the Gira-Beialtihat, the queen of the left, who camped just outside the Shilimat De.j of the inner enclosure, and used this gate to communicate with the royal tents at the centre; The Qegn-Be'altihat, the queen of the right, and the Be'alte-Shinhna, a Junior queen of the right, had their tents just outgide the Mebl'i Dej. The tents of the Queen Mother, who apparently kept some of the king's children with her, were much more in the rear and were significantly pitched near the socalled Qulf Dej (lit. = locked gate). ${ }^{2}$ Within the enclooure, the retainers of these queens only included their

1. 'Amde-SIyon had one principal queen and many wives and concubines, Histofle des guerres d'Amde-Siyon, ed. and tr. Perruchon, J., pp. 325-326; Conti Rossini, "I'evangelo d'oro", cit. pp. 202-206, and here his principal queen is given the titie of Belalte-Bihat. His son Seyfre-Ar'ad is accused of marrying three wives, Gedle Filippos, (Asbo), ed. Conti Rossini, pp. 224-225, (text). For Dawit and Zer'a-Ya'qob see supra. During h1g visit Alvarez only noticed líbne-Dīngil's Queen who camped on the left side of the court, and he believed that the king was strictly monogamous, op.cit.. p. 193. His acquaintance was probably with the King'g favourite queen Seble-Wengèl, a Tígre princess, whose courageous activities during the Muslim wars are attested by the chronicles and the Portuguese writers, and who was the mothef of Gelawdewos and Minas, both of whom relgned after the war. But a document about the preGragn part of the reign speaks of the deaths of a Be'alteShinhna (a junior queen of the Right) and another Queen Qefo, Liber Aksumae, ed. Conti Rossinif p. 69 (text). It is difficult to tell whether these were queens of his father Na'od, or of Iíbne-Díngīl.

2. These locations of the tents of the Queens of the Right and of the left are given in MS. Bruce, 88, Bodl., f.33. 
apecial guards, the zandereba, their ladies-in-waiting, and their household gervants. Besides the royal kitchens, pitched within the Jegol on both sides of the court, which were responsible for the daily banquets, each of the queens also prepared food for the King's Table in her own 2 quarters.

The royal chapela were also pitched within the 3 Jegol on both sides. It is apparent that the leading members of the Clergy serving each of these chapels also camped around them. But the most importent ecclesiastical official in court was the sqabe-Se'at, the titular head

/ F/note cont. from previous page

OR. 821 (BM), 1.106 ${ }^{2}$. As to the tents of the Queen Mother, however, no explicit mention of the site is given. But it is aald that she made use of the Qulf Dej. where I assume her tents were pitched.

1. C1. 2lso Alvarez, pq.cit., II, p. 443.

2. This is clearly brought out by zer'a-Ya'qob's chronicler, where it appears that additional contributions to the royal banquets were also supplied from other quarters, Les Chroniques, cit. pp.38-39; cf. also Alvarez, op.cit. pp. 437-438.

3. The number of the royal chapels at the court increased through the years. 'Amde-Siyon and probably also the kings before him only had a chapel dedicated to Jesus, and this was taken along even on military expeditiong, Perruchon, J., Hiatotre des guerres d'Amde-Siyon, rol d'Ethiopie, in JA, II (1889), pp. 389, 408; Gedle YePalrenne-1EgzI', ed. Wajnberg, I., pp. 18-22 (text). Dawit establighed the Chapel of the Cross, and Zer'aYa:qob that of St. Mary, Cerulli, E., Il libre etiopico del miracoli di Maria, pp. 121-122. Seyfe-'Ar'ad'a other chapel is not attested anywhere else. In the early 
of the 1sland monastery of Debre-Haiq, and his tents

were often pitched near the chapel of St. Mary, on the

R1ght. The Egyption bishop used the Megqel Dej. and

probably kept an official tent near the Chapel of the 2

Crose. Some of the hlghest military and court officials

/Footnote 3 contd. Prom the previous page

16 th century Alvarez does not mention the Chapel of Jesus, and adds another in the area of the royal kitchens," a church of St. Andrew and it is called the cook's church", op,cit., II, pp. 437-438. Outside the enclosure in a straight line with the royal tent but very far from it he mentiong "the church of the Justicea", and further still "the market square church", ibid., p. 442 .

1. Hagiographical traditions, probably of the 15th century, claim that the title was given to Iyesus-Mo'a's descendants by Yikunno-'Amlak himself, in return for the monk's epiritual help in the dynastical struggle of 1270,

Gedle Iyeaus-Mo'a, ed. and $t r . S$. Kur, pp. 23-26. It 1a, however. with Agabe-Se'at Sereqe-BIrhan (d.1403), an intimate friend of King Dawit, that the political significance of the title emerges. Zar'a-Ya'qob enhanced its importance by making Aqabe-Se'at Amha-Iyesus, his most trusted courtier, Les Chroniques de Zar'a Ya'eqob, pp. 7-8, 27-29. At the time of Alvarez visit the office had considerable influence and he calls the Cabeata, "the second man in these Kingdomg", op.cit.. I, p. 270. Gragn's chronicler refers to the same man who was killed in Gojjam, as "le qadi des Chretiens. C'est le patriarch en eecond...; il possede le quart du royaume", Futuh al-Habasha, tr. Basset, pp. 438-439. As we shall Boon see, the Aqabe-Se'at plnyed a crucial part in the succession conflicts. At the time of the visit of Alvarez he also maintained numerous tents cutside the royal enclosure, op.cit., p. 443.

2. Alvarez reports that during his visit the bishop's camp was outside the enclosure, and suggests that his camp was on the Left, loc.cit. His particular use of the Meagel Dej is however given in tise Bthiopic devcription, MS., Bruce, 88, Bodl., $1.33^{\circ}$. 
could also camp within the Jegol, though unaccompanied by their respective followers who had to camp far away, outside the enclosure, on the same side of the court as their masterg. Among these were the two highest military officials of the kingdom, the BIhtwedded of the Right and 1

of the Left. These offictals were thus given official premiges within the Jegol and, outside, on the outskirta of the whole royal camp, their numeroug troops pitched their tents and protected the kingdom. Both for their admittance into the Royal Pregence as stated above, and for their communication outalde the Jegol, each of these camping units within the enclosure utilized corresponding gates specially assigned for 1 t.

The king's numerous vassals, his district and provincial governors who camped in the extensive field outgide, each with his large following, were also admitted

1. The earliest time we have a mention of these twin officials is in the reign of Zer'a-Yaqob, Chroniques. cit. pp. 9-10, 12. This should not be taken, however as euggesting that he was the first to 1notitute them. The context in which they are mentioned clearly indicates that they were of a much older origin. Their reapective duties are described a follows, "One (of them) conducts military campaigns and the other protects the kingdom, and he camps at the outakirts of the royal camp", OR. 821 , (BM), f. $32^{\mathrm{h}}$. Alvarez reports precisoly the same thing, op.cit., pp. 270.

2. Ibid., pp. 336-337, 443-444. 
Into the Jegol through particular gates prescribed for them - either on the Right or on the Left. The two front gates - each called Sergwan Dej - on either side of the principal WIdinash Def were the most important, and were apparently in frequent use on solemn occasions. Idmittance through them is explicitly said to have been possible at the sole permission of the king. The tributary vassals of the king and his provincial governors passed through these gates to present their tributes, or whenever they needed to see their sovereign. Once admitted through, however, another permission was specially required to leave the enclogure.

The royal Court maintained its meticulous rules and characteristic organization wherever it moved, and had exactly the same functions as a fixed city. Despite

1. "They shall be admitted through the left Sergwan Dej by permission of the king; and they shall not leave without his orders... They may not enter or leave through the right Sergwan Dej without the king'g will", MS. Bruce, 88 Bodl. If. $32^{0}-33^{\circ}$. OR.821 (BM), ff. $104^{\circ}-105^{\circ}$. It is most likely that Alvarez: most gcrupulous report of the formalities of admittance into the royal enclosure is a reference to this rule, op. cit., $I, p p .282-283$.

2. Cf. 1bid., pp. 335-337, 442-444. 
1

itg mobility, it was deeply rooted in the country. Whereas

its own movemente brought it to the different parts of the

Christian Empire, the diverse elements of the king's subjects

were also represented in the vagt crowd always assembled

around the royal enclosures. This ethnic and linguistic

1. The mobile character of the Court has already been referred to above, aee pp.198, te. Yet particular sites are specially associated with some of the medieval kings, and a general southward movement of these sites can be detected from the beginning of the 14th century onwards. At one time Widim-Re'ad (1294-1314) seems to have had his court in the region of Gishe, northern Menz, cf. Gedle Beselote-Mika'el, p. 9. Both his chronicler and M-'0mori locate Amde-siyon's court at Mer'ade, where $\mathrm{Abba}$ Samuel (Waldibbal later visited Dawit, apparently in Shewa, Gedle Samu'el, $p$. 14. 'Amde-Siyon í also said to have held court at a place called sewen in Shewa, according to one tradition 3 daya' journey from Debre Asbo, Gedle Filíppos, p. 209; Gedle BeseloteMika'- $\overline{1}$, p. 25. A hundred years later the one place Is mentioned as the winter resort of King YIshaq, Gedle Abba Giyorgis of Gasicha. MS. (Haiq), ff. $38^{D}-39^{\mathrm{a}}$. HIs father Dawit is also said to have resided at Tobya, gomewhere east of Debre-Sina, Chroniques de Zar'a ${ }^{2} \mathrm{Ia}^{3} \mathrm{e} o b$. cit. p. 152. Cf. also Futuh al-Hebesha, tr. Besget, p. 272. He also had another regldence further south at Tila in Fetegar, where Zer'a-Yo'qob was born, Chroniques, cit. p. 67: Ia Ronclere has Identified this, name with the "Pian de Tich" of Fra Mauro'g map, Ia Découverte de l'afrique au moyen-âge. II (1925), p. 128. Both Zer'a-Ya qob and his son Be'Ide-Meryam also resided there at time日, and Fokindir (1478 - 94) was born there, Chroniques, cit. pp. 155-156. Zer'a-Ya'qob frequented Terwlet, ibid., pp. 55-57; be spent the last 14 yearg of his reign in his newly built residence at DebreBIrhan, ibid., pp. 78-79. A list of the wintering areas of Na'dd (1494-1508) and IÍbne-DIngIl (1508 - 40) also showg that there were particular sites favoured by the kings, Liber Aksumae, ed. Conti Rosgini, p. 69 (text). 


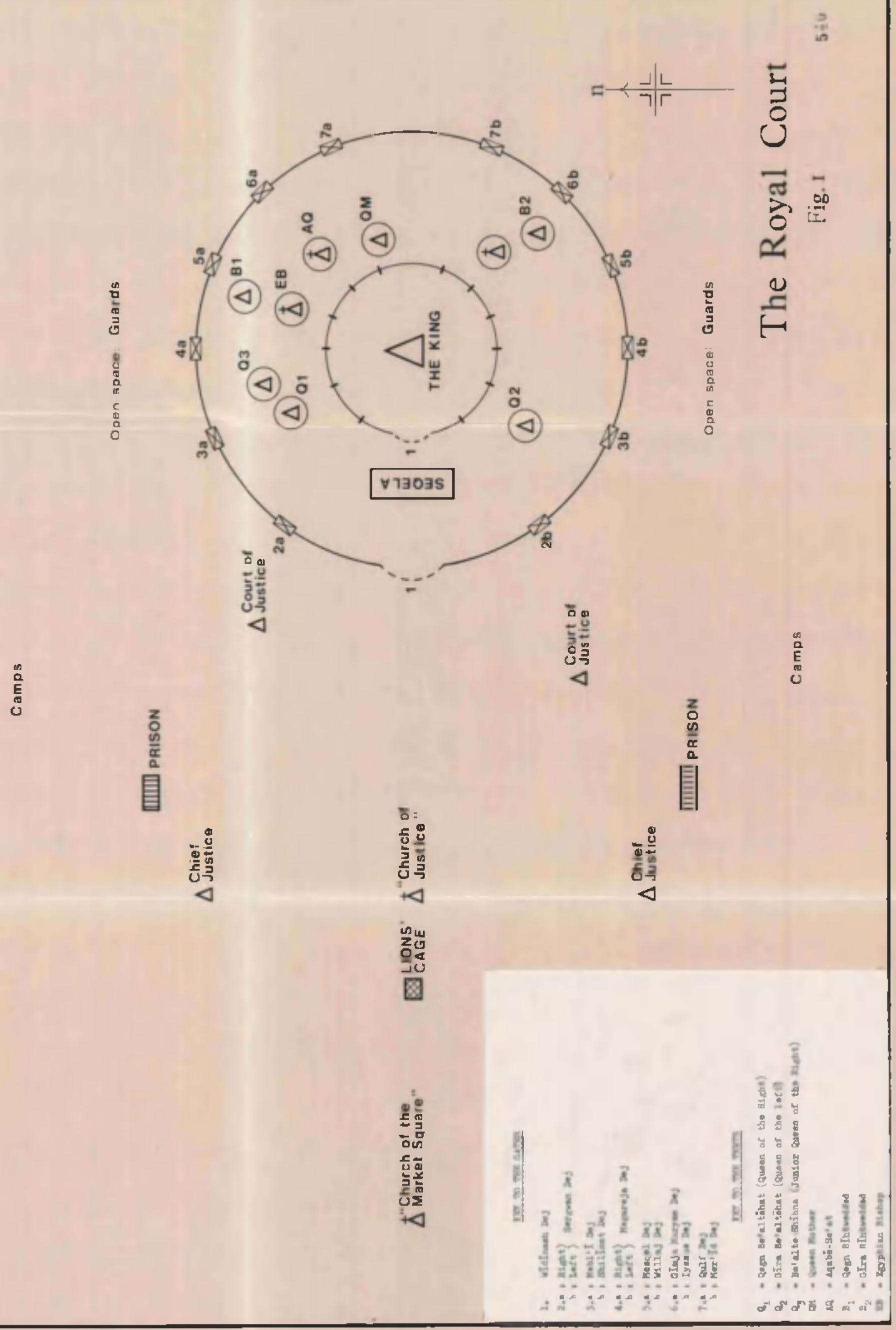


diversity is clearly brought out by Zer'a-Ya'qob's chronicler in his description of the ceremonious acclamationg of the royal troops in the presence of the king : "And they sing (his glory) each in the language of his country". The king and his family formed the nucleus of this complex assortment of ethnic and religious communities. But the geometric unity imposed on the royal Court by itg concentric arrangement belied the divergent interests of which It always consisted. Each of the camping units within the royal enclosure ${ }^{2}$ - particularly the tents of the Queens of the Right and of the Left, and those of the Queen Mother - represented a separate community of politinal interests which were reflected from the royal tents at the centre, right down to the outermost reaches of the royal camp as a whole. Essentially, this was the basis of the chronic struggle for royal succession in medieval Ethiopia.

A king was normally succeeded by one of his own sons. Except in cases where he died without male issue, this was almost always the case in the whole period

1. Chroniaues de Zer'a Ya'eqob, c1t. p. 36 .

2. Each of these units is represented by a small circle in the graphic illustration of the Royal court, Figure 1, p.54. 
1

covered by this atudy. Normally too, the eldest son

appears to have had priority of succession over his

younger brothers. But although this was generally the outcome, it was only reached after serious dynastical conflicts among the princes, and their respective oupporters. For all its unlque importance in the constitution of medieval Ethiopia, the well-known institution 2

of the royal prison of Mount Gishen was only effective in

1. One major exception - of which the true story is atill unknown - stands out against this rule. It is not clear whether Widim-Re'ad (1299-1314) assumed power on the deaths of all his nephews (= brothers?), or if any of the latter had left any successors at all, cf. supra. pp. $134-135$. Another doubtful case is the accession of Yishaq $(1413$ - 1430) on the death of hia brother Tewedros. Tewedros was a grown up men at the time of his death, and it was unusual that he did not heve sons of his own to succeed him, cf. supra, p.432, n.3.

2. For a description of this place see Alvarez, op.cit. Vol. I, pp. 237-248; Almeida, Some Records of Ethiopie 1593-1646, extracts tr. by Beckingham and Huntingford, 1954, pp. 97-102. Almeida's is a much better (probabiy eye-witness) account. According to him Lalibela built the first church on the top of the Mountain. Alvarez was, however, told that one of Lalibela's predecessors, King Yimrha, first instituted the royal prison, by divine ingpiration. Although from the rest of his account Alvarez geeme to heve extractg of the king'g Gedl read for him, Ylmrha's connection with Gishen Is not mentioned in the copy of the Gedl I was able to consult at lalibela. Congidering the frequent succesgion problems in the zagwe period (cf. supra, pp

it seems unlikely that the institution of a royal prison had ever occurred to the 8agwe kings. But the idea of a Mountain prison was not new, and Yitbrek is said to have once detained Yîunno-(Amlak on a Mountain top at Melot, in Wadla, Gedle Iresus-Mo'a, p. 20 (tr.). The organization of Gishen as a royal prison probably dates 
excluding the diatant relatives of a deceased monarch from taking active part in the atruggle for his accesion. His sons, his surviving brothers, and their immedate descendante were each a rallying point for conflicting political groups in the royal court, who vied for a handsome share in the political and economic preferment of the next reign. There is a general tendency in the official chronicles to play down such conflicta. Despite this, however, many isolated notes strongly indicate that a major struggle for power often preceded the acceasion of a new monarch in medieval Ethiopia.

/Footnote 2 contd. from previous page/

to the troubled days followigg the death of Yikunno'Amlak, cf. supra, pp.124,133-35. Iudolf, H., A New History of Ethiopie. 168, pp. 195-197. Although there are many references to the detention of "Iara'elites" on Mt. Gishen, I have not been able to obtain an Ethiopic description of the Royal Prison as such. From the days of Dawit and Zer'a-Ya'qob onwards the place is apecially noted for the many relics - a piece of the True Cross included - which these kings are believed to have received from abroad and deposited at Gishen, cf. supra, $490, n \cdot 1$ This religious legend has since completely replaced the historic importance of the site as a royal prison, of which neither the local elders nor the officials of the churches, to whom I spoke there, geem to have any recollections at all.

1. Traditional gigns of such conflicts - in the available sources - are completely absent only in the case of 'Amde-SIyon (1314-44) and his son Seyfe-Ar'ad (1344-71). A hagiographical note about the life of Patriarch Matewos (1378-1408) seems to indicate that Seyfe-Ar'ad's sons Niwaye-Karyam and Dawit - had both contested the auccesgion. Niwaye-Maryam (1371-80) took the throne, but already before the end of his reign, the Patriarch is sald to have had a revelation that Dawit would soon take over, Budge, E.A.W., The Book of the Sainte of the Bthiogion church, II, p. 454. 
Of all the descendants of Yĩkunno-'Amlak, in the male line, only the reigning monarch and his sons lived outside the royal prison of Mount Gishen. The children of a king spent the early part of their childhood in the royal court, in the care of their own mothers and the Queen Mother. When they became older, the sons were apparently sent to one of the royal estates in the country, where they were entrusted to an important official who was also governor of the area. Closely guarded, the young princes grew there, undergoing a period of training in the art of warfare and horsemanship :

"... in quel tempo (Lebna Dengel) riponeva ogni sua occupazione nel cavalcare, nel trar diarco e nel cacclar le fiere; che tale e il costume dei figli dei re, insino a quando sappiano governare 10 stato convenevolmente." 1

The site where the princes were kept probably varied according to the wishes of the king. He'Ide-Maryam grew up at Zengo near Yelebeeh, in Fetegar, a frontier site just established by his grandfather, Dawit (1380 - 1412), and

1. "La etoria di Lebna Dengel, Re d'gtiopia", ed. and tr. Conti Rossini, in RRAL, Vol. III (1894), pp. 622, 630-631. Be'ide-Maryam (1468-78) is accused voon after his accession to power, of neglecting the duties of 2 monarch in favour of the pleadure of horse-riding and hunting, Chroniques de Zar'a-Ya'qob et de Ba'eda Maryam. p. 127 . 
where his father, Zer'a-Ya'qob, was also born. It is apparent, however, that later in the 15 th century the guardianship of the royal princes was assigned to the 2

Governor of Genz - the Genz Gerad. Be'İde-Maryam's sons were brought up there, and Genz Gerad Matewos was responsible for theri. The young boys regularly visited the royal court with him, and there they had a special camping aite reserved for them, apparently in the neighbourhood of the tents of the Queen Mother and those of the Aqabegat. Small private achoola were run for them in the royal enclosure where they received religious instruction, and were taught how to read, and probably also how to write. During their stay in the country too, their retinue included

1. Ibid., pp. $67,91,155$.

2. Genz was apperently a district between the headwaters of the Rivers Gudru, Awash and Gibe, due north-west of Hadya, and east of Damot, cf. Gedle-Meb'a-Siyon, cit. pp. 25 (text), 79 (tr.). Alvarez, op.c1t.: p. 454; Futuh al Habasha, tr. Basset, pp. 83, n.2, 377-398. Zor'a-Ya qob's town of Djibat was probably in Genz, cf. supra, p. 2,94, n.1.

3. "Hiatolre d'Eskinder, d'Amde-Seyon II, et de Na'od", ed. and tr. J. Perruchon, in JA, Ser. 9, Vol.III (1894), op. 345-347. It is most likely that this Matewos was the same official - elsewhere called Zandereba Matewos who brought the good news of the birth of his first son Eskindir - to King Ba'Ide-Maryam, Chroniques, cit. pp. 155-156. Apparently he was a personal attendant of Queen Roma at first, and was later promoted to the more prestigious office of Geng Gerad.

4. MS. Bruce, 88, Bodl., f. $33^{a}$. 
prominent churchmen who continued the religious and literary instruction of the young princes. This assignment of educating the king's children was apparently given to the beat scholars of the day, and this probably accounta for the persibtent tradition of considerable religious learning reported about many of the medieval kinge and other members 1

of their family. Abba Giyorgis of Gascha, the author of many religious works, started his career as a teacher of the children of King Dawit, at the rojal court. One of Be'ide-Meryam's chroniclers was also entrusted with the anre of the king's sons, and resided with them in Genz. Probably, too, a prince could sometimes be sent to an ordinary monastic achool, where he studied as long as his father lived. For security reasons and to avoid embarrasement, his identity would only be known to the abbot and the local officials, and as soon as his father, the king, died troops would be sent to fetch the young prince to the

1. Supra, p.379 n.4. The case of zer'a-Ya'qob is wellknown. The authorship of two prayers Melki'a-Mika'el, and Melki'a-Qurban are ettributed to his son, and successor Belide-Maryam. The latter's son, Na'od, is also represented as a deeply religious man who composed Malki'a-Maryam, and Tefesihi Maryam, Cont1 Rossini, "Il Iibro delle leggende e tradizioni abissini", cit. p. 711 . Na'od is particularly gaid to have excelled in the wellknown Ethiopic religious poetry ( $Q \bar{I} \bar{e}$ ), and to have actively participated in the religious songs and chanting of the church, Gedle Merha-Krítog, pp. Tarike-Negest, MS, Debre-Sige, p, 57 .

2. Gedle Abba Giyorgis, f. 15. Cf. also supra, pp.441-2.

3. Perruchon, "Histoire dieskindir", etc. loc.cit. 
royal prison of Amba Gíshen. This last pattern seems to emerge from the story of the early life of Zer'a-Ya'qob at the achools of Aksum and Debre-Abbay.

Zer'a-Ya'qob was the youngeat gon of King Dawit. During the life time of his father, and so long 28 all his elder brothers were alive, there was probably little prospect of his eventual accession to the throne. This may have helped his mother, Egzi'-KIbra, in obtaining Dawit's permission to send the young boy to monastic schools in Aksum and Debre-Abbay, under the care of her clerical relatives or proteges. But it does not seem that he enjoyed this freedom of movement for a long time. His father died soon afterwards, when he was only 14, and his brother Tewodros apparently ordered his detention at the time of his accession to power. The chronicler ins1sts that zer'aYa'qob remained in his monastic school of Debre-Abbay incognite for the whole period of twenty years, until his own accession to power. Many historical considerations make this moot unlikely. Zer'a-Ya'qob himself speaks of "... the mountain where we were imprisoned", and from which he was only brought down on the eve of his accession

1. Tarike Negest, MS. Debre-Sige, pp. 54-55. CP. 2lso supra, pp. $432-4$

2. It is interesting to note that according to a modern traveller Debre-Abbay was also known as 'Addi Shewa, Faltlovitch, Notes d'un voyage chez les Falashas, Juif d'Abyasinie. Tous, p. 14 . 
1

in 1434. The particular mention of Tewodros'shostility also Indicates that it was at the accersion of his eldest brother, in 14I3, that he was taken to Ambe GIshen.

As has already been said above, Tewodros only ruled for nine months and was succeeded, with no apparent difficulty, by his brother, Yỉsheq (1413-30). YIshaq was in turn succeeded by his own son, Endīryas, who however died after a few montho. YIahaq probnbly had another oon (or sons), and Maqrizi mentions a certain "Salmun 1 bn Ishaq". a日 having ruled after Hizbe-Nagn. But at the time of the death of Endiryas he may have been too young to obtain atrong support from his father's army. Thus the crown passed to YIshaq'a third brother, HIzhe-Nagn. Such a transfer of power from the family of a monarch to that of his brother was always a dramatic event. It involved selecting one of the princes detained at 'Amba-GIshen, and crowning him instead of his nephewg, who immediately replaced him at the royal prison. Thus it marked an important occasion and was not settled without a verious contest among the supporters of the sons of the deceased king, and the partisans of his surviving brothers. This seems to have been the case at the time of Higbe-Nagn accession to power.

1. Maghafe-Berhan, II (text), p. 157.

2. Historia Regum Iglamaticorum in Abyesinia, p. 39. 
It is apparent that Zeria-Ya'qob, although younger than Hizbe-Nagn, was a serious contender for the succession of Endíryas. The conflict between hil supporters and those of Hizbe-Nagn probably continued, even after the succession was settled in favour of the latter. This political gituation is suggested by a hagiographical tradition about a contemporary monastic leader in eastern Gojfam :-

"A certain man accused Abba Sinoda at the court of King Hizbe-Nagn saying : 'Sinoda declares that another king, called Zer'a-Ya'qob, shall rige'... And (Hîbe-Nagn) was exceedingly angry ... and ordered (SInoda) to be brought... and to be beaten ...; He also ordered (his men) to imprison him .... and take him to (the 1sland of) Deg .... and (the king) gent his soldiers (there) ... to cut off his hands and his feet, "1

Four other men guffered similar treatment with Abba Sinoda, and all died of the mutilation.

The crisis of the royal successton flared up once again when Hizbe-Nagn died, and his army raised one of his sons to the throne. HIzbe-Nagn ruled for not more than three years, which was too short a period for the

1. Gedle Sinoda, MS. Dime, ff. 20-2I. For the Iffe and work of Sinoda, see supra. p.

2. Gedle Sinoda, $1.25^{\mathrm{b}}$.

3. The chronology of the kingdom, particularly between the beginning of the relgn of Dawit and the accession of Zer'a-Ya'qob, has been very uncertain. The traditional dating of these reigns is represented by Wright, W., Catalogue, cit. pp. VI-IX; Perruchon, J., Les Chroniques 
consolidation of his newly acquired power in his family.

/Footnote 3 contd. from previous page/

de Zarta Yaiegob, cit. p. 206, Table. It seems possible now to propose a fresh chronology of these years with the help of many additional historical notes. Dawit began his reign in 32 Year of Grace (=1379/80 A.D.), Kolmodin, Traditions, A23. He was still king in 65 Year of Grace (再1412/3 A.D.), The Four Gospelis. MS. Kibran f. $237^{\circ}$. Immediately following this, there is a land grant by King Yishaq dated 66 Years of Grace ( = 1413/4 A.D.), "in the sixth month of my reign", 1bid., f. $238^{2}$. Tewodros' short reign indicated by other gourees (Bupre. p. n. )., is also confirmed by these notes on Dawit and Yishaq. Maqrizi says that Yishaq was killed in the month of Dulkada in $833 \mathrm{A.H}$. (= August $1430 \mathrm{A.D}$.). There 1s no good reason to reject Maqrizi's report on this date nor on the circumstancesof Yisheq's death. The date goeg perfectly well with many Ethiopic traditions which give Yishaq and his son Endiryas a joint reign of 17 years, cf. MS. Bruce, 92, Bodl., f.54 . Endíryas ruled for six mbenths according to Basset, R., Etudes, p. 12; and only four months according to Maqrizi, op.cit., pp. 9, 39. It is at this point that HIzbe-Nagn began his reign. Most of the available Ethiopic chronological notes either give him 4 years on his own, or 5 years with his tro oong, cf. Basset, loc.cit. But this is too long for the interregnum of only four years between Yishaq's death and the accession of Zer'a-Ya'qob in 87 Year of Grace (=1434/5 A.D.), which seems to be a very secure date, cf. Grebaut, S., "Table de Comput et de Chronologle", in ROC. I $(1918-9)$, p. 326. From all these notes the following table of Daw1t's succession is obtained :-

Dawit (1380 - 1412)

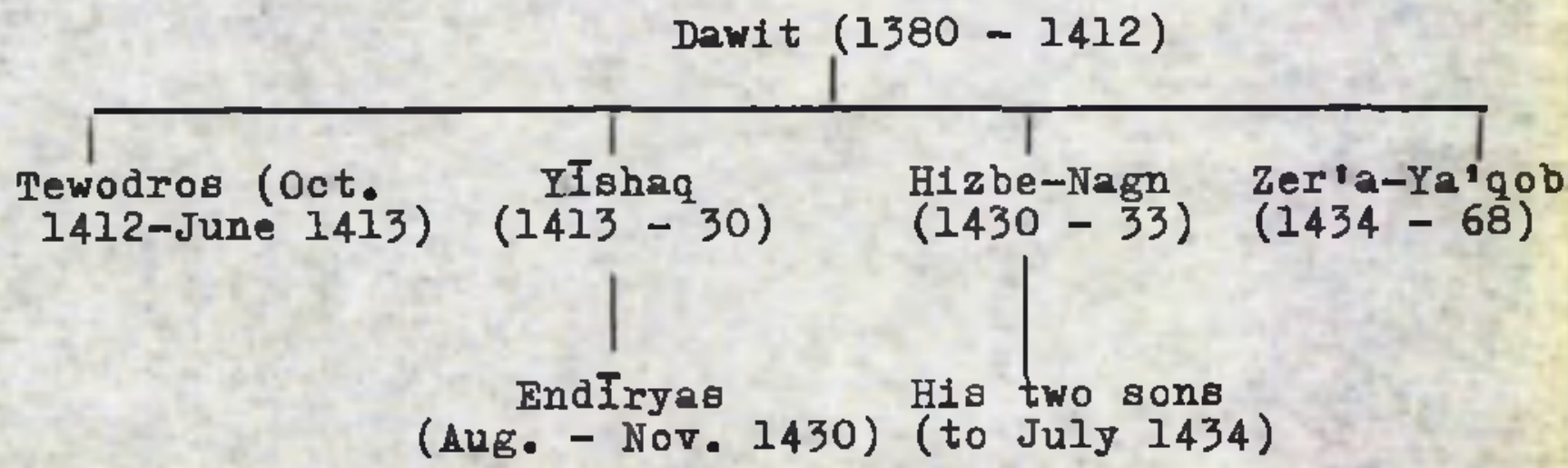


This seems to have precipitated a serious conflict among three distinct political groups at the time of his death. The first apparently consisted of a section of the Christian army, still loyal to the family of KIng YIshaq, who made a strong bid for a come-back to political power in the kingdom with one of the king's sons as their candidate. Maqrizi's invaluable mention of the short interregnum of "Salmun ibn Ishaq", on the death of Hisbe-Nagn, strongly indicates at least the existence of this third party. The second group, and probably the strongest at the time, consisted of the officials of Hizbe-Nagn who defended the continuation of the rights of his family to the crown. They apparently won the first round of the political struggle, and Míhrka-Nagn ascenced the throne for a time. But he died soon afterwards, and his followers immediately crowned his younger brother, Bedl-Nagn, who was only a very small child. It is at this atage that the supporters of Zer'a-Ya'qob became particularly strong in the conflict, and finally succeeded in bringing him to power :

"And (the wicked slaves of Hīzbe-Nagn)... crowned a omall child, Bedl-Nagn, because they wanted to rule (the country) themselves. And when God perceived their arrogant intentions, He brought forth Zer'a-Ya'qob, the Orthodor, to the throne; and those rebels and wicked glaves were jailed and fastened with iron collars and chains..."

1. Egtīgwín'I, MS. Debre-Werq, f.3. 
Magrizl also ends his contemporary account of Ethiopia with the accession of a "small boy", and the tradition just quoted above does not specify what actually happened to Bedl-Nagn himself. But most Ethiopic sources and king lists asaign to him a short reign of eight monthr. Nevertheless, the great feud between Zer'a-Ya'qob and the family

1. Op.cit., p. 41. This is almost certainly a reference to Bedl-Nagn, and the prince whom he succeeded and who ig said to have died of an epidemic, may be his brother Mihrka-Nagn. Maqrizi collected his notes about the period while he was staying in Makkah in 839 A.H. $(=1435 / 6$ A.D.), ibid., p. l. Cf. also Guidi, I.," "Sul testo dell'Ilmam d'Al-Maqrizin, in Centenario della Nascita di Michele Amari. Vol. II (1910), p. 388, n.2. Maqrizi dates the accession of the "smali boy" in 1435/6. But since he does not mention Zer'a-Yaiqob, it geems that the Arab historian was not aware of the latest developments in Ethiopia, and he simply dated the last king he had heard of to the time of his own sojourn in Makkah. Nevertheleas, his information about the troubled years following the death of YIshaq are remarkably accurate. The number of kings he gives within this period, until the advent of the "small boyn, is fully confirmed by the Ethiopic sources, except in the case of "Salmun ibn Ishaq", for whom Maqrizi is certainly preferable to the Ethiopic scribes who tend to suppress auch information. The chronological imperfections, which Maqrizi's account of these years displays, appear to have been largely due to the uncertainties of the polltical situation in Christian Ethiopia itself.

2. Cf. Basset, Etudes, p. 12. 
of Hizbe-Nagn, of which the tradition was also recorded 1

by Almeida in the seventeenth century, strongly indicates that the whole period of the reign of Bedl-Nagn - the last prince of that family - was specially marked by a protracted political struggle within the Christian kingdom.

Despite the conflicts between the supporters of rival princes, however, it is apparent that careful consultation among the high ranking (secular and ecclesiastical) officials of the kingdom was also an important factor in the determination of a successor. This no doubt accounta for the definite rules that one can detect in the available 2

king lists. A tradition about the tenth century describes the process in the following terms :-

1. Some Records, cit. pp. 101-102.

2. Cf. supra, pp.541-42. Almeida gives an interesting account of how the election of a new monarch was undertaken, and describes the general ceremony of coronation, Historia de Ethiopia alta ou Abassia. Bk. II, Ch. 2l, in C. Beccari, Rerum Aethiopicorum Scriptores Occidentales inediti, Vol.V(I9I0). Prof. CeruIII has recently published a translation of a short extract from a story of the Miracles of St. Mary regarding the life of the princes on Mt. Gishen, Storia della letteratura etiopica, 1956, pp. 127-130. 
"When the king died, the bishop, and the governors, and the generals of the royal army took counsel together, and it was said among them: 'The younger son will be far better for the kingdom than the elder'.

The reports attributed to European travellers in Ethiopia 2 in the fifteenth century, and the more authentic accounts 34

of Alvarez, and Almeida, all describe essentially the same procese. Particularly in the fourteenth and fifteenth centuries, the security of the Christian kingdom 28 against its Muslim and pagan neighbours was always an overriding factor in the choice of a monarch, and provided an important restraint to the extent of the political disputations among rival groups. It is indeed remarkable that, in precisely the same period in which he reports rapid auccessions to the throne, Maqrizi also describes the continued success of the Chrigtian army in the wars against Adal.

1. The Book of the Saints of the Ethiopian Church, tr. Budge, E.A.W., 1928, p. 667 .

2. Trasselli, C., "Un Italiano in tiopia nel XV secolo: Pletro Rombulo di Messina", in RSE. I (1941), pp. 190-191. The account of Pietro of Napoli, one of the messengers of the Duke of Berry to King Yishaq, is to be found in Ie Voyage d'outremerl de Bertrandon de la Broquiere, ed. $\mathrm{Ch}$. Scneter, Paris, 1892, pp. 146-147.

3. Op.c1t., pp. 24l-243.

4. Loc.cit.

5. Op.cit., p. 9. This was particularly the case towarda the end of the reign of Jamal ad-Din, and immediately after his assassination, ibid., pp. 35-36. Cerull1 seems to envisage a possible Christian hand in this last act, "Documenti arabi per la storia dell'Etiopia", in MRAL, Ser. 6, Vol.VI, $(1931)$, p. 47, n.2. 
The most valuable contribution of Mount GIshen to the stability of the medieval kingdom consisted in the fact that most of the rival princes themselves were not at large, and could not take an active part in the conflict. During such a crisis of royal succession, only the sons of the deceased monarch were outaide the royal prison, in the protection of their father's army, and with all the political patronage of his reign still in their hands. It was in fact largely due to this tactical advantage that the family of the deceased monarch always geems to have won the day, at the initial stage of the political struggle. The interests of the other princes were only represented by a section of the Christian army and the royal court which had special family or other connections with them. It 1s most aignificant that, in a hagiographical tradition, Zer'a-Ya'qob is made to say the following words about his advent to power :

"The troops of my relatives raised me to the throne of my father...n

Zer'a-Ya'qob's succession, like that of all other kings of medieval Ethiopia, may have certainly been promoted by his relatives in particular. But other factors also seem to have been working in hts favour in 1434. He was the only surviving son of King Dawit and was about thirty-five years

1. Gedle Zēna-Marqog, MS. Debre-Șigē, ff. $109^{b}-110^{a}$. 


\section{5}

1

of age, ho doubt much older than any of his nephew living at the time. Probably too, his reputation as a scholar prince had already opread among both the secular and clerical officials of the kingdom. Moreover, the internal political situation in the preceeding years had been particularly unstable, and this may have induced much of the Christian army and the royal court to favour a strong leaderghip. It also seems that there was a closing of ranks between the former supporters of YIshaq'B family, and those of Zer'aYa'qob against the descendants of Hİbe-Nagn. While this explains the lasting emnity between the families of Zer'a-Ya'qob and Hīzbe-Nagn, it probably also account for the absence of "Salmun ibn Ishaq" - remembered by Maqrizi from the Ethiopic list of the princes who contested the succession. "Bronght down from the mountain", in his own words, "where We were imprisoned", Zer'a-Ya'qob was crowned King of Ethiopia, and he more than succeeded in providing the personal leadership of a trong monarch which the country had lacked so much since the death of YIshaq in 1430 .

The death of a monarch was not the only occasion which brought about a struggle for the crown. There are

1. Supra, $431, n \cdot 1$.

2. Almeida, Some Recorda, c1t. pp. 101-102.

3. Mashafa Berhan. II, p. 157 (text). 
number of cases in which attempte were made to uourp power while the king was still alive. Apart from many instances in the early days of the dynasty, attempts to replace the monarch are evident even in the reigns of Dawit and Zer'a-Ya'qob, who were perhaps the most powerful kingo of medieval Ethiopia. The incident in the reign of Dawit is preserved in a story of the miracles of St. Mary. A group of local saints are said to have received a revelation that Dawit should retire and abdicate in favour of his son. They sent word to the king about their vision which troubled him a great deal. He summoned his former teacher and confidant, Aqabe-Se'at Sereqe-Birhan of Debre-Haiq, and a commander of the army. He broke to them the sad news, and they all agreed to appeal to St. Mary for help. She heard their prayers and promised the king that he would retain his crown for the rest of his life. Aqabe-Se'at Sereqe-Bİrhan died in 1403, and the incident must have taken place before this date. He was a very powerful man during the reign. Although the king's son in whose favour the abdication was pooposed is kept anonymous, the particular mention of the Aqabe-Se'at and "the commander of the king's forces" certainly imply that it was a high-powered political event. But this apparent movement against King Dawit was a failure, and the king

1. Supra, pp.132-35

2. Cerulli, E., Il libro etiopico dei miracoli di Maria, 1943, pp. 79-86.

3. Supra, pp. $420-22$. 
kept his throne for at least 10 years after this incident.

$$
\text { Zer'a-Ya'qob's relgn was also marked by some }
$$

attempts to replace $\mathrm{him}$. We have already made a reference

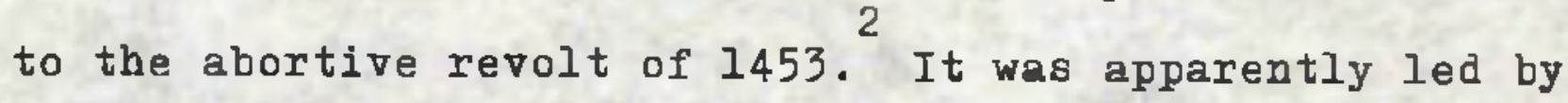
high-ranking officials of the kingdom and, as indicated above, it seems to have been motivated by political and economic grievances. But towards the end of the reign Zer'a-Ya'qob was led to belleve that even the members of his own family at the royal court were plotting against him. The report involved many of his own children and their mothers. After an ostentatious public trial held at the court the king ordered them all to be flogged, as a result of which many lost their lives. The witnesses produced against them testified that they consulted witch doctors and offered sacrifices to pagan gods, and the king'g verdict is therefore said to have been given on religious grounds. However, the victims of this latest purge in Zer'a-Ya'qob'a

1. It is most likely that this was the origin of the story that Dawit did actually abdicate, and his son Tewodros took over. Cerulli accepts this, op.cit., p. 86. But the chronology of the reigns of both Dawit and Tewodros (Eupra, p. 549 n. 3.) make it impossible.

2. Supra. pp. $512-516$

3. Les chroniques de Zar'a-Ya'eqob et de Ba'ede Maryam, pp. 4-7, 97-100, 105-107; Das Mashafa Milad und Mashafa Sellase, II (1963), pp. 95-96.

4. For the king's decrees forbidiing these practices, see supra, pp. $509-12$. 
reign included "high-ranking officials, governors, monks...", and Abba Endriyas, the Abbot of Debre-Libanos was one of them. The religious facade of the story does not stand a close examination. The political nature of the king's preoccupation is even implied in the cautious writing of the chronficler:

nThey accused them of many other things. Only the king knows the (true) story. They did not make public (the charges) other than that (the accused) worshipped desk ..."2

Zer'a-Ya'qob himself discloses a more acceptable reason for his wild fury against the princes. After describing how their mothers misled them into pagan worship and black magic, the king singles out one of his song Gelawdewos, for having ceremoniously burned copies of Tomare-Tíbílit and Meshafe-Bīrhan at a witchcraft ceremony. Gelawdêwos did this, the king writes, in return for a promise by the witch doctor of an eventual succession to the throne. The chronicler also gives a similar story about the death of

1. Les chroniques, pp. 99-100.

2. Ibid.. p. 98. For desk see supra. p. $501 \mathrm{n.1}$

3. These are two of the religious writings attributed to Zer'a-Ya'qob himself, cf. supra, p. 5ix n. 2

4. Das Mashafa Milad, cit. II (text), pp. 95-96. Gelawdēwog was probably the eldest son of Zer'a-Ya'qob Immediately before his disgrace and imprisonment, Abba Tekle-Hawaryat of Geberma (Muger) was invited to court by Gelawdewos' mother to bless and edify her young son, Gedle TekleHawaryat. MS. Debre-Libanos, f. 49a. At that time, which was probably soon after the abortive revolt of 1453 , the prince seems to have been on good terms with his father. 
Queen Siyon-Mogesa, mother of King Belĩde-Maryam (14681478). Zer'a-Ya'qob once accused her of trying to depose him in favour of her son. He had received reports, he told her, that she had been soliclting the help and prayers of many local saints for the success of her rebellious schemes. And despite her protestations of innocence, Queen SIyonMogesa was ordered to be flogged and beaten, as a result of which she died some time later. Her young son, Be'ideMaryam, was also detained for a time with his favourite slave, Mehari-Kristos, for having privately celebrated the anniversary of her death. It is apparent that these palace recriminations took place in about 1462. Be'ỉde-Maryam's later revenge on Gebre-Kristos, whom "he had stoned ... to death" ${ }^{3}$ strongly implies that they all took place as a connected serles of political incidents.

1. Les Chroniques, cit. pp. 105-107.

2. The date is obtained from the story of the life of MerhaKristos, who succeeded Endíryas as abbot of Debre-Iihanos. Merha-Kristos died in January, in the second year of the reign of Nalod (1494-1508), after 33 years and 5 months rule, Gedle Merha-Kristos, MS. Debre-Iibanos, pp. 115-117, 246. This is equivalent to 1496 A.D., and Endiryas must have been deposed and exiled in 1462. For short notices about the life of Endiryas see ibid., pp. 102, 106-107, 112; Les chroniques, pp. 90, 100 , i30; Sinkisar (Hamiè), ed. and tr. in PO, VII, pp. 345-346; Cerulli, E., "Gl1 abbati di Dabra Iibanos", cit. pp. 143-145.

3. Les Chroniques, p. 200. Gebre-Kristos was one of the three most trusted officials of Zer'a-Ya'qob at the time. They are said to have given the king false reports about the princes and other personalities including Endiryas. Be'íde-Maryam's later fury against Gebre-Krístos most probably indicates that he also had a hand in the death of Queen SIyon-Mogesa. 
Zer'a-Ya'qob lived on, and continued to rule with an iron hand for another period of six years. In terms of the concentric organization of the medieval court, the conflicts between a reigning monarch and the rest of his family can best be described as a tug-of-war between the inner and the outer enclosures of the royal camp. At times when the klngdom was ruled by powerful monarchs - Dawit and Zer'a-Ya'qob for instance - the inner enclosure always had the upper hand, and the country was thus assured of a strong leadership. When the king was weak or infantile, however, the diverse elements and political interests of the outer enclosure asserted themselves, and the Christian nation lacked the unity of purpose so essential for the defence and administration of its extensive Empire. This characterized the reigns of Zer'a-Ya'qob's grandsons after 1478. Between this year and the end of our period, the average age of the princes at the time of their accession was only eleven years. And except in the case of Na'od (1494-1508), who was already twenty when he took over, the first part of each of the reigns was ruled by a council of regents. EskIndIr (1478-94), the eldeet of Be'īde-Maryam'g baby sons, was crowned at six years of age, with no apparent problem of succession. At first, his mother Queen Romna, Aqabe-Se'at Tesfa-Giyorgis, and Bitweded 'Amde-Maka'el 
jointly assumed power as regents. 'Amde-Mike' $\bar{l} I$ was an elderly official who had held considerable power since the days of EgkIndir's grandfather. Zer'a-Ya'qob had invested him with much authority, particularly as governor of the whole of the frontier district of Fetegar. Towards the and of Be'ide-Maryam's reign, we still find him wielding great influence in the royal court, and he played a decisive role in the council of 1477 as an ally of Debre-Libanos. Of the members of the Council of regents, he was certainly the strongest and the most experienced hand in the government. It 1 most Iikely that Romna and Tesfo-Giyorgis were at first included in the Council largely because of the traditional importance of the high offices they held as QueenMother and Aqabe-Se'at respectively. From the start, however, both of them seem to have been overshadowed by the greater influence of 'Amde-Mika'êl, and the Queen-Mother soon disappeared from the political scene altogether. Even in the court of Be'Ifde Maryam, Romna was not one of the principal

1. "Histoire d'Eskender, d'Amde-Seyon, HI, et de $\mathrm{Na}$ 'od", ed. and tr. J. Perruchon, in JA, Ser.9, Vol. III (1894), pp. 338-339.

2. Les Chroniques de Zar'a Ya'egob, cit. p. 15.

3. Gedle Merha-Krístos, pp. 223, 245-249. Here he is rererred to 28 "the head of the governors, the great (man), called 'Amde-Mika'el". 
1

queens, and her position was only enhanced by giving

the king his two favourite sons, Eskindir and Enqo-Isra'ī.

She probably felt more important after this and apparently became quarrelsome among the queens in court; the king was forced to exile her in Amhara where she remalned until recalled on the coronation of her son. " Some time later, however, she abandoned the world and entered a small convent near Debre-Libahos where she died, apparently not very long afterwarde.

Unmatched by any of his colleagues, 'Amde-Mika'ēl ruled the kingdom almost single-handed. This unprecedented position of personal power held by the old man aroused an outcry againgt him. The movement was predominantly led by members of the influential clergy, but 'Amde-Mika'el had little difficulty in supressing it :

"And after gome time Abba Hasbo, Abba Amdu, and Man-Besĩdqu quarrelled with Bîhtwedded Amdu when they saw him ruling all Ethiopia on his own. For this reason (the troops) arrested all those who quarrelled with him and flogged them many times. And they imprisoned them and sent them to exile. There are some $_{5}$ who died on the way, and some who survived".5

1. The more prestigious titles of Gire-Be'altehat, QegnBe'altehat, and Be'alte-Shîhna were born by three other princesses, Zan-Seyfe, Slleni, and Dawit-Era respectively, Les Chroniques, pp. 125, 149, 176.

2. Ibid.. pp. 155-156, 161.

3. "Histoite d'Eskender", cit. pp. 338-339.

4. Gedle Merha-KrIstos, pp. 256-258.

5. "Histoire d'Eskender", cit., p. 339. 
The Bitwedded won the first round of the personal challenge organized against him. But the opposition seems to have gathered momentum over the years. As the young king grew up he apparently began to be surrounded with new officials, who increasingly looked at the old Bitwedded as the greatest obstacle to their own advancement. His ruthless suppression of his opponents had made him the most formidable f1gure in the kingdom, and a large number of court officials seem to have joined hands to bring an end to his power. From the confused traditions about this incident, it is impossible here to specify exactly the reasons for his downfall. But it is clear that his enemies alienated him from the young king who finally ordered his arrest, and exiled him to an unknown place. Sometime later he was secretly brought back to the royal court and executed.

\section{A list of the officials of King Eskindir - probably} dated 1486 - seems to suggest the identity of the personalities who promoted the movement against 'Amde-Mika'èl. At the head of the list appears Ellen1 as the Queen-Mother, and immedi-

1. The accounts we have about him are mostly short, and haglographical, Zotenberg, Cataloque, cit., No. 126, Hidar 3, and Sene 29. Wright, Catalogue, cit., Or. 667, f.60. Le Synaxaire Ethiopien, ed. and tr. Guidi, I., in $\mathrm{PO}$, I (1904), pp. 697-698.

2. Wright, Qatalogue, Or. 481, f.208. This land grant only bears Megabit 7 as its date, and the year is not given. But the land grant was probably made in the same year as another one, given in the 7 th year of the king's reign, ibid, f.92Q. Two officials - Petros and BIshile - appear in both land grants, and they held the same appointment in each. 
ately next to the three wives of the king is mentioned a certain Tesfa-Giyorgis. Tesfa-Giyorgis holds the unusual title of Mekbibe Bēte-Kristiyan and is listed prior to the Agabe-Se'at. Most probably this Tesfa-Giyorgis was the same official who was a member of the Council of Regents, together with Romna and 'Amde-Mika'el, at the beginning of the reign. Given little share in the exercise of power by his fellow regent 'Amde-Mika'ēl, Tesfa-Giyorgis was probably sympathetic to the predominantly clerical movement against him. On the overthrow of the old Bitwedded the former Agabe-Se'at probably assumed the dignified title Mekbỉbe Bētē-Kristiyan (= the Crown of the Church (lit.) ) and was succeeded in his original office by Tekle-Iyesus-Mo'a.

The new Queen-Mother was a more formidable character in the political scene. Elleni was originally a Hadya princess, married to King Zer'a-Ya'qob as early as 1445, some years before Be'Ide-Maryam was even born. When

1. Aqabe-Se'at Tekle-Iyesus-Mo'a is mentioned in the land grant quoted above, immediately next to Tesfa-Giyorgis, ibid., f.208. He also appears in the list of the abbot Of Debre-Haiq without any specific dates, The Four Gospels. MS (IM), Haiq, f.268 . Tesfa-Giyorgis is also mentioned here as the contemporary of Eskindir and is no doubt the same man as the regent, 1bid., f. $184^{\circ}$.

2. Ies Chroniques de Zar'a Ya'egob, etc. pp. 16, 59. No doubt the marriage was a political one and Elleni must have been very young. The King of Hadya had obliged King Dawit by his loyal services againgt his co-religionist Sa'ad ad-Din, ruler of Adal, Maqrizi, op.cit., p. 23. This and the increasing importance of the southern regions probably motivated the marriage. Although we have no 
Zer'a-Ya'qob died, Elleni retained her old title QegnBe'altehat in the court of his successor. Herpostion appears to have been purely cerfmonial, and she was not numbered among the four wives of the new king. Be'ideMaryam had lost his mother before he took power, and it was this role that the talented Elleni was particularly intended to play :

"Notre roi aima aussi beaucoup la reine Qan Baltehat, dont le nom était 'Eleni, car elle etait accomplie en toutes choses : elle se rendait agreable a Dieu par ses bonnes oentres et sa foi, et en faisant la prière et la communion, et elle étaint admiree de tout le monde pour son habijete a dresser la table, a grace dans les cerémonies et sa connaissance de l'écriture et de beau langage. C'est a cause de ces qualités que Baleda Maryam aima beaucoup notre reine 'Eleni et la traita comme sa propre mere."

Footnote 2 contd. from previous page /

other references to similar unions it is probable that less notable princesses may have followed Elleni to the Chriatian court. One of the complaints of the Hadya Muslims to Admad Gragn was that these marriages were forced on them, Futuh al-Habasha, tr. Basset, p. 371. Cf. also Alvarez, op.cit., p. 427.

1. Les Chroniques de Ba'eda Maryam, p. 125.

2. Besides the three mentioned above (supra p.563 n. $/$.) he had another wife who gave him a son called Tewodros, ibid., p. 156 .

3. Ibid., pp. 175-176. The best description of Queen Elleni by Alvarez is to be found in the Vatican MS. recently described by Prof. C. Beckingham, "La Regina Helena la quale e stata moglie del preteianne inanzi del avo di ques to che e hora...", "Notes on an unpublished MS. of Franceaco Alvarez", in $\Delta \mathrm{E}$, IV (1961), pp. 150-151. Thus it is clear that Zer'a-Ya'qob is meant here. She was not 
Elleni occupied this position of great influence throughout the reign of Be'ide-Maryam, and apparently gathered a huge political patronage in the whole kingdom. It is interesting that she was at first left out of the council of regents on the accession of EskIndIr. She probably had a hand in the disgrace and exile of Eskindir's mother, Romna, during the Ilfetime of Belide-Maryam. When Romna was recalled to assume the regency, there simply could not be any place for Elleni in the Council. Most likely too, there was an old misunderstanding between her and Bitwedded 'Amde-Mika'ēl, who ensured that she was excluded from all positions of authority, Certainly, Elleni's sudden re-emergence as Queen-Mother in Eskindír's court, soon after the disappearance of both Romna and 'Amde-Mika'el is very indicative of her decisive role in the political conflicts following the death of Be'Ide-Maryam. Another sign of Elleni's hostile attitude towards 'Amde-Mika'ēl and his proteges is the systematic sllence which the dominant traditions of Debre-Libanos maintain about the Queen. As has already been sid above, 'Amde-Mika' $\bar{e} l$ was a great patron of the monastery of Tekle-Haymanot. His relations with the

Footnote 3 contd. from previous page /

Be'ìde-Maryam's wife, and the general view about her in this respect is based merely on the ceremonial title she retained in the king's court, cf. Conti Rossini, "Ia gtoria di Lebna Dengel", cit. p. 631, n.l. Huntingford's notes on her are specially arbitrary, cf. Alvarex, op.cit., pp. 14, n.3, 425, n.l. 
abbot of the day, Merha-Krīstos, were very affectionate, and the hagiographer once refers to the Bitwedded as $n$ the (spiritual) son of Merha-Kristog". After his execution, 'Amde-Mika'ēl was first buxied at Debre-Libanos, and the opposition of the monastery to his unjust treatment at the royal court is still preserved in the canonization which has been conferred upon hill. Probably the same reagon motivated the diplomatic silence the scribes of DebreLibanos observed about Elleni, even after her return to power in 1486. It is also significant that not long after Elleni's death King Libne-Dingil regtored the memory of 'Amde-Mika'ēl to a place of honour by translating his remains from Debre-Libanos to the royal cemetery of Atronise-Maryam in Amhara.

Apart from its disastrous effects on the frontier defence, which will be discussed later, the removal of the strong personal rule of Bitwedded 'Amde-Mika'èl resulted in an intensive political struggle at the royal court, and in serious insubordination among the troops. Even the official

1. Gedle Merha-Krīstos, p. 223.

2. This is said to have been done 40 years after his execution, Wright, op.cit., or. 667 , f.60. This places the date at c.i525. Elieni probably died in 1522 , Alvarez, op.cit.., p. 425, n.1. The restoration of 'Ande-Mida'el'g honour was probably part of the political changes following her death, of which Alvarez was a personal witness, ibid., p. 434 . 
chronicler could not avoid writing about the royal guards of the young king in the following terms :

"His soldiers destroyed the whole world. They afflicted the poor, and (the king) did not reprimand them."I

For quite a long period after their takeover, Elleni and the new officials of the kingdom were not in complete control of the situation. There were even some religious undertones in the partisan political clashes of the time.

One of the earliest acts of 'Amde-Mida'êl as a regent was to implement the decision of Be'ide-Maryam at the council of 1477, in which he himself had played a significant role. A delegation was sent with rich gifts to the Patriarch and Sultan Qait-bay (1468-95), and they returned in 1480/1, bringing with them two bishops (Yishaq and Marqos), two ecclesiastics bearing the title of Eppisqoppos (Mika'el) and YohannIs), and one Qomos (Yosef). This was the first

1. "Histoire d'Eskender" etc. cit. p. 342.

2. Supra, pp. $523-26$

3. Gedle Merha-Kristos, pp. 251-252. Here the names of the Teading delegates are given as Segga-Ze'ab and GebreBirhan. Ibn Iyas also describes this delegation which was in Cairo in $886 \mathrm{A.H}$. (= $1481 / 2 \mathrm{A.D.})$. It was led by a high ranking dignitary and carried rich gifts to the Sultan, Quatremere, Memoires, Vol. II (1811), pp. 279-283. For the date see Kolmodin, op,cit., A53-4. Conti Rossini, "Pergamene di Dabra Damo", in $\underline{\text { RSO }}$, XIX (1940), pp. 50-51. 
time for the country to have Egyptian biships since the death of Mika'el and Gebr'èl, twenty-three years before. The occasion produced a great sensation throughout the

Christian provinces, and numerous candidates flocked towards the mainroad to Shewa to be ordained by the bishops on their way to the king's court. The great relief which was then felt in the Christian kingdom by the arrival of the bishops is described by the chronicler :

"And in his (EskindIr'a) reign came bishopg from Holy Jerusalem. The priests became many, the Churches were restored, and happiness filled all the land".

Some time later, probably in 1482, a Franciscan, Fr. Ioane de Calabria, arrived in the country with a lay companion, Giovanni da Imola. They sought an audience with

I. Yİshaq was the senior bishop and we have some traditions of such ordinations by him on the way to Shewa. The candidates were already advanced in years, and well-known for their monastic pursuits, Conti Rossini, "Besu'a Amlak e il convento della Trinita" in RRAL, Ser. 5, Vol.XI (1902), pp. 409-410; Gedle Gebre-Mesih, MS. 40, Inst. of Archeology, Addis Ababa. The Stephanite leader was already 63 when he was ordained by YIshaq.

2. "Histoire d'Eskender", cit. p. 340.

3. For this mission to Ethiopia see Surriano, F., Il Trattato di Terra Santa e dell'oriente, ed. Golubovitch, G., Milano, 1900, pp. 80-87; Somigl1, T., Etiopia Francescana nei documenti dei Secoli XVII e XVIII, Vol. I (1928), pp.Ixiii-xci. For the confused background of this mission, and for the alleged rthiopian mission to Pope Sixtus IV see Ghinzoni, P., "Un Ambasciata del Prete Gianni a Roma" in Archievo stbrico Lombardo, Vol. VI, Anno XVI (1889), pp. 145-154; Greone, F., "La Politica Orientale di Alphonso di Aragone", cit. pp. 91-92; 
the king, but they were kept waiting for eight months without any success. Finally, Giovanni de Imola returned and reached Jerusalem in 1483. He reported that the regents of the young king were unfavourable to the mission and had denied them an interview with him. At this news the head of the Franciscans in Jerusalem is said to have sent another message to Ethiopia in $1484 .^{1}$ It is not known if this message ever reached there. But an interesting document oeems to indicate that there was a change of heart towards Fr. Ioane de Calabria at the court of King Eskindir :

"And in thooe days there came Franks from Rome. One of them was a priest called Yohannis. And (the King) received them with honour. When the priests saw this they grumbled and spoke ill of him saying "The king has joined the religion of the Franks".n 2

The similarity of the name of the foreign priest, Yohannis, and that of Fr.Ioane de Calabria is particularly significant. As to the Franks referred to, both Giovannl da Imola and 4 Alvarez report the presence of many Europeans in the country

Footnote 3 contd. from previous page/

Lefevre, R., "G.B.Brocchi da Imola diplomatico pontifico e viaggiatore in Etiopia nel '400', in BSGI, Vgl. IV (1939) pp. 641-643; Ch.-M. de Witte, "Une ambassade éthiopienne a Rome en 1450", cit. p. 293, n.1.

1. Suriano, op.cit., pp. 81-83.

2. Tarike-Negest, MS., Debre-Sigē, p. 56.

3. Suriano, op.cit.. p. 86.

4. Op.cit., pp. 278-279. 
at the time. No definite conclusions can as yet be drawn from this, but it may be that after having stayed in the country for some years Fs.Ioane may have gained sympathy from one of the court officials. This may have enabled him to see the young king, which could no doubt have produced an outcry among the local clergy. Alvarez was told by Bishop Marqos that Eskīndīr had tried to change the traditional practice of the Ethiopians, particularly regarding the 1 sabbath and prohibitions of food. All these isolated notes tend to show that there was a religions aspect to the political strife in the days of Eskindír. They may also explain the hagiographical traditions of hostile relations between the king and some of the local clergy :

"There came an order from Eskindir, King of Ethiopia, asking all the priests of the Tabernacle of Wala (?) to be assembled (at the court)....., and the king became angry on a trivial point and he had them

Eskindir was still young, and all these official acts were certainly looked at as the work of his most influential courtiers. This only aggravated the rivalries and internal divisions among the officials of the royal court. The antagonistic feelings in the kingdom simmering under the surface suddenly erupted at the unexpected death

1. Op.cit., p. 357 .

2. Gedle Iyasu, MS. Debre-Libanos, 1.4 . 
of Eskindir, at the early age of only twenty-two. The chronfcler gingles out two officials - Zesillus and TakleKristos - as the leading figures in the conflicting groupings that emerged at the time. Zesillus was at the royal court when the king died. As soon as he realized this, he commanded his followers to keep the king's body at the court as long as possible, and he swiftly marched towards Mount Gishen in Amhara. There, he apparently took one of the princes - probably Eskindír's brother, Na'od - and declared him king of Ethiopia. Back at the royal court, in the meantime, ZesIllus' secret disappearance and his orders regarding the remains of Eskindir had been discovered. TekleKrIstos who was apparently the most powerful official at court at the time immediately crowned as the next king Eskindirs little son, Amde-Síyon, a boy of only seven years 2 of age or even younger. Having done this he sent Egkindir's 3 body to Atronīse-Maryam for burial, and he marched with the

1. "Histoire d'Eskender", pp. 340-341, 343-344.

2. That he was seven is given in Basset, Etudeg, p. 13. Conti Rossini, "Il libro delle leggende e tradizioni dell'Etiopia", cit. p. 7ll. This would mean that he was born when his father, Eskīndir, was only 15.

3. Many of the late compilations of the Chronicles place the tomb of Eskindir at Debre-Werq, in eastern Gojjam, where the visitor is still shown what is believed to be the king's mausoleum. If there is any truth in this, the body must have been translated there only later - from Atronise-Maryam just across the Nile, probably during the Gragn wars. A similar problem arises in the case of Dawit whose remains are said to be at Daga with 
the king's army to fight Zesillus and his partisans. ZesIllus probably had a small force at his disposal and Tekle-Kristos triumphantly marched back to the royal court, where all the followers of Zesillus were held one by one and blinded.

This did not end the civil war in the country, which apparently continued throughout the short reign of the infant king :

"Amde-SIyon (Eskindír's) son, was crowned, but he was an infant. For this reason... all the troops of the king killed one another, and they had no one to stop them. There was mourning (for the dead) in every province. The holy objects of the church were dacked. The officiala of (the kingdom of) Ethiopia destroyed one another like the fish of the river, and they became like beasts with no shelter".1

'Amde-ȘIyon's reign lasted for only six months, and even the hagiographer betrays a sense of great relief at the announcement of his death. But the early part of the next reign did not bring any immediate confort. For, $\mathrm{Na}$ 'od, who now succeeded to the throne, was the same prince who was brought forward by zesillus as his candidate only

Footnote 3 contd. from previous page/

Zer'a-Ya'qob's, Besset, op.oit,, pp. 1l-13. Zer'a-Ya'qob's body was-translated there in 1498, "Histoire d'Eskender", p. 350 .

1. Gedle Merha-Kristos, p. 285.

2. "In six months the sacrifice of the Holy Qurban ascended into heaven, and King 'Amde-Sïyon died", ibid., p. 286. 
six months before. The prince was the second son of Be'ide-Maryam and Queen Romna, only two years younger than Eskindir. It seems that, right from the beginning, the struggle for Eskindir's succession had also assumed some regional undertones. Zesillus had declared Nalod, King of Ethiopia in Amhara, and Tekle-Kristos had to march from Shewa (where the court was established) to reduce the movement. An exactly similar pattern is evident during Na'od'g successful accession to the throne six months later. He was crowned in October, 1494, in Amhara. When the news reached them, many of the officials, who had opposed him in favour of 'Amde-Siyon, apparently fled into the country and prepared themselves for armed conflicts. One of them called by the chronicler Tekka-Kristos (which is probably a misprint for Tekle-Kristos), remained in the district of Ifat, and openly rebelled against the new 2 king. To suppress these movements in the region as early as possible, Na'od marched to Shewa for Christmas, and in January, 1495, he made a formal visit to the monastery of

1. Romna is said to have had two sons : EskIndir and Engo-Isra'el, Les chroniques de Zar'a Ya'eqob et de Ba'eda Maryam, pp. 155-156, I6I. The second name was probably an early appelation for Na'od, who was certainly her son, Gedle Merha-Kristos, p. 256. Cf. also Cerulii, Il libro etiopico dei Miracoli di Marya, p. 24.

2. "Histoire d'Eskender", cit.pp. 348-349. 
Debre-Libanos.

Besides calling at his mother's tomb and paying homage to Tekle-Haymanot, $\mathrm{Na}^{\prime} \mathrm{od}$ 's visit to the monastery had a strong political motivation. This is quite evident from the tradition about the speech he is said to have made in the midst of the assembled monks :

"Pray in earnest so that Ethiopia is not
made waste. For you know (what happened
In) the last reign, and how the kingdom
was ruined. (And now pray) so that the
sheep that have gone astray may return
under one shepherd." 2 .

The king's message was very clear. He was requesting the help of the clergy to influence as many of the rebels in the Shewan region to accept him as the legitimate king. With the complete support of the clergy on his gide, Na'od began military operations against his opponents in the area. The rebel leader in Ifat, Tekka-Kristos, was captured and blinded. Many others were similarly arrested and speared 4

to death. It is apparent that Na'od put an end to the revolts against him soon afterwards. The king seems to have

1. The impressive story of this visit is told in Gedle Merha-Krītos, pp. 289-294.

2. Ibid., pp. 291-292.

3. "Histoire d'Eskender", cit., p. 349.

4. Gedle Merha-Kristos, p. 297. 
been anxious to restore normal conditions in the kingdom, and to bring to a close the atmosphere of discord that had reigned in the country, particularly after the death of Eskindir. But public recrimination and litigation about wrongs committed during the confused period probably continued to be made among the people, and Na'od had to pass a special decree forbiding them. Only land disputes, arising from the conflicts during the civil war, were 1 permitted.

Na'od's reign promised more calm and tranquility within the Christian kingdom 1tself. But serious damage had been done to the frontier defence, particularly in the direction of Fetegar, where the united command of the local troops was disrupted with the downfall of Bitwedded AmdeMika'ele ${ }^{2}$ The last decisive battle against the Muslim kingdom of Adal was fought in 1445, when Zer'a-Ya'qob defeated and killed Ahmad Badlay on the Dewaro frontiers. The military success of the kingdom at that time was apparently effective for many years, and we find the son and successor of Ahmad Badlay, Muhammad (1445-71) sending

1. "Histoire d'Eakender" p. 350.

2. Tarike-Negest, MS. Debre-Sige, pp. 56-57.

3. Supra, pp-483-4. 
a message of submission, as soon as Be'īde-Maryam succeeded his father. On the death of Muhammad, however, Adal apparently resumed hostile activities, and Be'ide-Maryam had to drop his intended visit to Aksum to hurry back to the frontiers in the south.

It is apparent that at this stage of the conflict it was particularly in the provinces of Dewaro and Bali that the Muslim pressure was increasing. Revolts among the local troops atationed in Bali are reported, and the king suppressed them by resettling the rebels en masse 3 in Gojjam. Following this, Be'Ide-Maryam directed successive campaigns to Adal from Dewaro and Bal1. The first two of these campaigns were a complete success. The third and the last, conducted in 1474, was however a great setback to the Christian army, which lost both its highest commanding officers and was practically decimated.

1. Les Chroniques, c1t., pp. 131-133. Cerulli, E., "Documenti arabi per la storia dell'Etiopia", in MRAL, Ser. 6, Vol. IV (193I), p. 48, and n.3.

2. Ies Chroniques, p. 150. Cerulli, op.cit., p. 48, n.5.

3. Les Chroniques, pp. 157-159.

4. Ibid., pp. 159, 165-167.

5. Ibid., pp. 180-182. "Histotre d'Eskender", cit., p. 345. 
It is interesting that all this time Be'ideMaryam directed his offensives againat Adal with his court established in the Wej and Gurage area, gouth of the Awagh. He seems to have had no fears about the Fetegar frontiers. There, Amde-Mika'èl had continued in the office, first given to him by Zer'a-Ya'qob, as governor of the Province. It seems, that, over the years, he had established a great reputation as a general and he had set up a strong united command for the defence of the kingdom in this direction. His downfall, in about 1485, seriously disturbed this effective system of defence. It is apparent that, with the removal of the old man, the province was divided into smaller units and distributed among petty officials who may have co-operated in bringing about his elimination. Even the chronicler of Ahmad Gragn refers to this basic change in the defence of the province:

"Au temps de l'ateul du roi d'Abyssinie, il n'y arait dans le Fetegar qu'un patrice unique qui commandait en chef..."2

EskIndir's first campaign into Adal had a mixed result. At first he successfully marched as far east as

1. Ibid., p. 15 .

2. Futuh al-Habasha, tr. Basset, p. 83. He goes on to say that in libre-Dingíl's time it was divided into seven different commands. He sees this as a point of strength, since each unit tried to excel the other in military actions. 
1

Dakkar, but suffered serious military reverses on the long way back, when he lost most of his army. It is specially significant and highly indicative of the great harm done to the Christian army by the internal political conflicts, that Eakindir could not send even a single successful expedition to Adal. The civil war during the succession of 'Amde-Siyon II and na'od considerably aggravated the weakness of the army, and the political discord among the Christian officials.

Compared with the records of his two predecessors, Na'od's achievements in the defence of his kingdom were certainly much better, and even Gragn's Muslim chronicler attributes to him many successes in Bali and Dewara. However, defections from the Christian a rmy stationed on the frontiers were rife, and the Muslim attack, particularly on

1. For this site see Cerulli, op.c1t.. pp. 42, n.1., 50, n.I. It was to the south-east of Harar.

2. "Histoire d'Eskender", cit., p. 343. Ricci, L., "Ie vite di Enbaqom e di Yohannes", in BSE. XIII (1954), p. 100. Cerulli, op.c1t., p. 49, n.I. Id. "Ltetiopia del secolo XV", cit., pp. 90-100.

3. He died during an expedition to an unknown place, Gedle Merha-Krïstos, pp. 281-284. His chronicler attributes his death to a pastoral people called "the people of the Ar'iho", against whom he had marched to revenge an official, "Histoire d'Eskender", p. 343 . Later compilations have identified these people with the Maya, Basset, Ftudes, p. 12. For the Maya see supra, p.

4. Futuh al-Habasha, tr. Basset, pp. 164-168. 
the frontier districts of Ifat and Fetegar, were considerably increased. Nalod himself lost his life while on his way to repulse a Muslim invasion in the district of Ifat. ${ }^{2}$ The first yeats of LÎbne-Díngill's reign were also marked by continuous Muslim military successes in the eatern frontiers. Even the official chroniclers do not report any Christian victory until LIbne-DIngIl had already been on the throne for eight years.

Helf a century of political strife among the warlords of the Christian kingdom provided the immediate, favourable background for the swift Muslim conquest under the able command of Ahmad Gragn. But the more basic reasons for the Christian defeat transcended the events of these fifty years, with which we have been concerned in this concluding chapter. Zer'a-Ya'qob's attempts to auperimpose a religious nationalism on his subjects had been a substantial failure. The biblical framework which he employed had been too narrow to contain the heterogenous peoples of the vast Christian empire. Only where a very long

1. Tarike-Negest, MS. Debre-Sīgē, pp. 57-58.

2. Ibid., p. 58.

3. "La storia di lebna Dengel", ed. and tr. Conti Rossini, pp. 622,632 . Cf. also Alvarez, op.cit., pp. 410-415. 
history of ethnic and religious fusion $h_{a} d$ been effected in the provinces of Tigre, Lasta, Amhara, Begemdir, eastern Gojjam, and in small isolated pockets in Shewa - could the Christian nation outlast the trying years of the Muslim invasion. 


\section{SELECT BIBLIOGRAFHY}

\section{PRIMARY SOURCES}

Ethiopic: Unoublished

1. Gedle Abba Meta'i, (Fl. 5th - 6th c.) Ms. Ialibela: Líbanos.

2. Gedle Yỉmriha-Krỉstos, Ms. Lalibela: Bete-Maryam. Yimriha was the 3rd Zagwe King. The hagiography seems to have been composed after 1270. It is, however, a useful compilation of Zagwe customs and trađitions.

3. Gedle Begī'u, (d. before 1292), Ms. Halq. He was disciple of Iyesus-Mo'a. The hagiographer claims to have been his contemporary.

4. Gedle Zena-Maraos. (FI. 14th c.), Ms. Debre-Sīgē. Disciple of Tekle-Haymanot, and founder of Debre Bisrat in Moret. The hagiography was originally composed before the wars of Gragn when the community was dispersed with mogt of the leaders extled in Gojjam, and Begémdir. Debre Bisrat was re-established in the 17th c., when many additional miracles seem to have been added to the Gedl.

5. Gedle Gewistos, (Fl. 14th c.), Ms. Debre-Libanos. Disciple of Tekle-Haymanot, and founder of Níbge Maryam in what is today Bulga, eastern Shewa. He is said to have died in exile during the controversy about the unlawful marriage of King Amae-Siyon. The Gedl is said to have been composed originally in the reign of Dawit (1380-1412), and when Bishop Selama (1348-88) was in the country. It seems, however, that many recent re-editions of it have been made.

6. Gedle Samu'ēl of Wegeg, (FI. 14th c.), Ms. DebreLibanos. Disciple of Tekle-Haymanot, and believed to the the founder of Debre Asebot on the road to Harar. Date of the composition of the Gedl impossible to tell, but the last personalities mentioned are Bishop Selama 
(d. 1388), and King Dawit (d. 1412). Cerulli who has a copy of this Gedl describes it as an "opera interesante per la storla dello Scioa nella Seconda meta del XIV", in RSO, Vol. XXII $(1946)$, p. 122, n. 6 .

7. Gedle Zeyohannis (F1. 14th c.), Ms. Kỉbran. He was originally_a monk of Debre-Iibanos in the days of Abbot Hijzijyas who took over from Filippos in 134l. Later, he moved to the island of Kibran in Lake Tana, probably in the reign of Seyfe-Ar'ad. The Gedl is most interesting for the attempts of the church to evangelize Agewnidir. There are no clues for the date of its first composition.

8. Gedle Abba Giyorgis of Gascha, (d. 1426), Ms. Haiq. Gijorgis is the famous author of Meshafe-Mistir and other works. His Gedl is an important source for the religious controversies of the first half of the 15th c. in which he actively participated. The last king mentioned by the hagiographer is Zer'a-Ya'qrob and the Gedl was probably composed in that reign, not much after Giyorgis' death.

9. Gedle Abba Sinoda, (d. before 1433), Ms. Debre-Dima. Originally a monk of an island community in Lake Zway, Sinoda moved to eastern Gojjam, and founded Debre-șimona there, probably in the reign of Yishaq (1413-30). He died of the punishment inflicted upon him by HizbeNagn (1430-3) in the island of Deq where he was exiled for political reasons. The Gedl is paritcularly interesting for the light it sheds on the struggle for succession after Yìnaq's death.

10. Gedle Tekle-Hawaryat, (d. 1455), Ms. Debre-Iihanos. Conti Rossini ed. and tr. another version of this Gedl in CSCO, Script. Aeth., Series altera, tome 24,1910 . He had concluded from his text that the saint may have lived in Zer'a-Ya'qob's reign, Ibid., pp. 99, 117. The Debre- Libanos version fully confirms this. The saint not only lived in that reign but was also disgraced and cast into prison by the king and he died in 1455, still a prisoner. 
Tekle-Hawaryat's quarrel with Zer'a-Ya'qob is also reported in other traditions, but is completely suppressed in the version which Conti Rossini had at his disposal.

11. Gedle Merha-Krístos, (1407-96), Ms. Debre-Libanos. He was abbot of Debre-Libanos in the years 1462-96, and his Gedl is an essential source for the crucial period covering the reigns of Zer'a-Ya'qob, Be'ide-Maryam, Eskindir, Amde-Síyon II, and $\mathrm{Na}$ 'od. This Gedl seems to be the most authentic hagiographical tradition of all the others described in this section. It has all the characteristics of an ordinary biography, and was composed at the auspices of the next abbot of the community, Fețros, not much after Merha-Kristos' death. The Ms. I consulted also containg some archaic forms of the Ethiopic alphabet, and seems to be of an early date.

12. Gedle Abune Habte-Maryam, (d. 1497), Ms. DebreLibanos. He was a friend and contemporary of Herha-Krístos. The Gedl is however very different from that of Merha-Kristos, and is completely devoted to the narrative of Habte-Maryam's ascetic weys of life for which he is particularly noted.

13. Gedle Iyasu, (d. after 1497), Ms. Debre-Libanos. He was at one time a companion of HabteMaryam. He quarrelled with Eskindir (1478-94), but was very friendly with Na'od (1494-1508). The Gedl sheds some light on the unstable political situations at the time. Iyasu founded the monastery of Jer Silasse, to the North East of Debre-Libanos.

14. Zēna-Memhiran Ze-Dima, in Quelēmintos, ff. 1-4. Mar-lishaq, ff. 1-4. Mss. Debre-Dima. These are short traditions about the founder, Tekeste-BIrhan, and his successors as abbots of Dima. Another short note about TekesteBïrhan is included in Godle Filippos, Ms. Dima, ff. $35^{b}-37^{a}$. 
15. Gedle Serse-Fetros, (Fl. 15th c.), Ms. Debre-Werq. Believed to be the founder of this monastery. His dates are very difficult to determine since the traditions connect him with a number of Kings from Dawit (d. 1412) to Eskindỉr (d. 1494). The Gedl is most likely of a very recent compilation, and has been drastically affected by the post-17c. monastic rivalries in the area.

Hagiographies of Stephanite leaders in the MS. Collection

of the Ingtitute of Archeology, Addis Ababa:-

16. Gedle Estifanos, Ms. No. 2. He was the founder of the remarkable "Stephanite" community, so called after him. An antagonist of the Cult of St. Mary in the reign of Zer'a-Ya'qob, he was condemned in c. 1454 and sent to exile where he died. The Gedl was apparently composed before 1499 .

17. Gedle Yisshaq, (d. before 1475) Ms. No. 36. He was Estifanos' colleague at Debre-Qoyesa where both of them received the monastic habit. Later he followed Estifianos, was condemned and exiled with him. He fled from prison and founded Gunda-Gundi which has since remained the centre of the Stephanites.

18. Gedle Gebre-Mesih, (died C. 1520), Ms. No. 40.

19. Gedle Habte-Sillasē, (died C. 1544), Ma. No. 40.

20. Gedle Tekle-Nebiyat, (died C. 1574), Ms. No. 43.

21. Gedle Isayiyas, (died C. 1589), Ms. No. 36.

22. Gedle Gebre-Krístos, (died C. 1592), Ms. No. 52.

Ethiopic: Published and/or translated

Bahayle-Mika'ēl,

Meshafe histirate-Semay WemIdr, ed. \& $t \overline{r .}$ in part by J. Perruchon in FO. Vol. I (1904), pp. 1-97. Later ed. \& tr. in full by E.A.W. Budge, The Book of the Mysteries of Heaven and Earth, London, 1935. 
Basset, R.

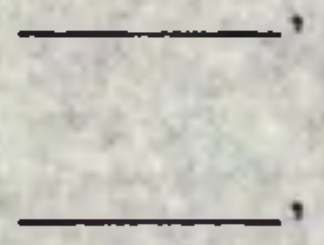

Budge, E.A.W.

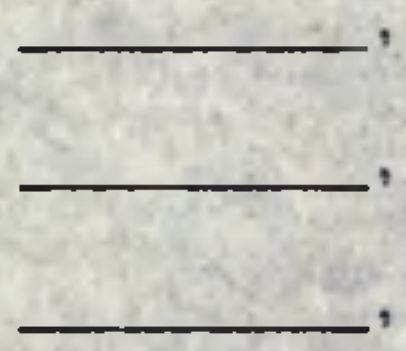

Caquot, A.

Cerulli, E.
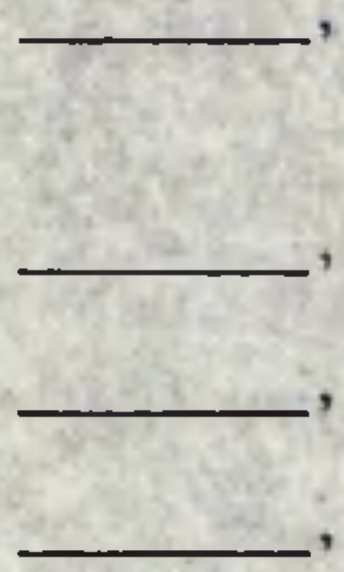

etudes sur l'hiotoire d'Ethiopie. Paris, 1882. [Extract of JA, ser. 7, Vol. DVIII, 1881].

"Vie d'Abba Yohanni", in the Bull. de Correspondance Africaine, Algere, $1884, \mathrm{pp} .433-53$.

Les Apocryphes éthioplennes, in 10 volumes, 1895-1915.

The Iife of Maba' Seyon, ed. \& tr., London, 1898 .

The Iife and Miracles of Takla Haymanot, ed. \& tr., London, 1906.

The Queen of Sheba and Her Only Son Menyelek, tr., London, 1922.

The Book of the Saints of the Ethiopian Church, tr. in 4 vols., Cambridge, 1928.

Gelde Ezra, ed. \& tr. In Á, IV (1961), pp. 69-121.

"I'Etiopia del Secolo XV in nuovi documenti storici", in Africa Italiana, V (1933), pp. 99-101.

"La Sconfitta del Sultano Badlay ibn Sa'ad ad-din in due inediti Miracoli di S. Giorgio etiopici'", In Aethiopica, Vol. II, No. 4, (1934), pp. 105-9.

Gli Atti di Tekle Alfa, ed. \& tr. in Annali, II (1943), pp. 1-89.

"Un framento degli Atti di Batergela Maryam", in RSE, III (1943), pp.|3|-8.

Il Iibro Etiopico dei Miracoli di Waria e le sue fontí nella Letteratura del Medio Evo Latino, Roma, 1943.

GIi Atti di Zena Maryam, monaca etiopica del Secolo XIV, tr.. in RSO, XXI (1946), pp. 
Cerulii, E.

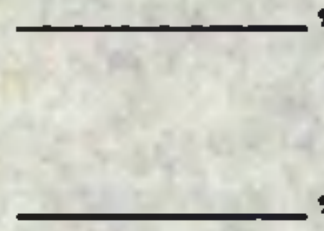

Conti Rossini, $\mathrm{C}$.
"Ia festa del Battesimo e l'eucharista in Etiopia nel secolo XV", in Analecta Bollandiana, Vol. IXVIII, $(1950), \mathrm{pp} \cdot 456-52$.

Atti di Kreatos Samra, ed. \& tr. in CSCO, vols. 163, 164, Script. Aeth. Eom. $33,34,1956$.

Scritti Teologici Etiopici dei Secoli XVI-ZVII, in studi e Testi, No. 198, 1958.

"Storia di Lebna Dengel re d'Etiopia", in RRAL, ser. 5, vol. III (1894), pp. 617-40.

Il Gadla Takla Haymanot Secondo la rodazione waldebbana, in MRAT, ser. 5, Vo1. II, pt. I (1896), pp. 97-143.

I'omelia di Yohannes, vescovo di Aksum, in Onore di Garima, in Actes du XI Congres Intern. des Orient, Paris, 1897, pp. 139-177.

"I'evangelo d'oro di Dabra Libanog", in RRAI, ser. 5, Vol. X (1901), pp. $177-219$.

Il Gadla Filipos ed il Gadla Yohanneg di Dabra Bizan, in MRAI, Vol. VIII (1901), pp. 61-170.

Besu'a Amlak e il convento della Trinitz, in RRAI, ser. 5, Vol. XI (1902), pp. 389-429.

Gli Atti di Abba Yonas, in RRAI, ser. 5, Vol. XII (1903), pp. 178-201, $236-262$.

Gadla Margorewos seu Acta Sancti Mercuri, in CSCO, Script. Aeth., Ser. altera, t. XXII, pp. 1-51 (text), $1-64$ (tr.), 1904 . 
Conti Rossini, C.
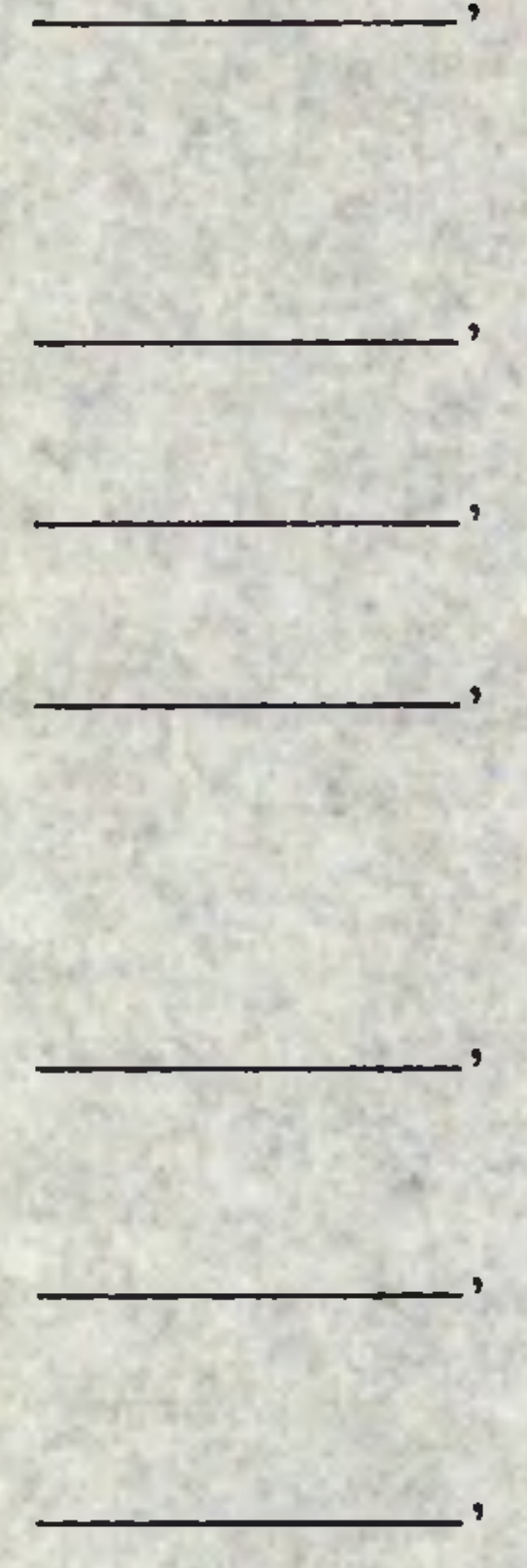

$-$

\section{,}

(1)

C.

Acta Yared et Pantalewon, in CSCO, Script. Aeth., ser. altua, t. XVII, pp. $1-60$ (text), $1-56$ (tr.), 1904. Acta S. Basalota Nika'èl et S. Anorewos, in CSCO, Script. Aeth. ser. altua, $t$. $X X, p p$. 1-ilo (text), 1-98 (tr.), 1905. I have quoted these asGedle Beselote-Mika'el, and Gedle Anorewos, repectively.

Historia regis Sarsa Dengel (halak Sagad), in CSCO, Script. Aeth. Ser. altua, t. III, pp. 1-191 (tr.), 1907.

Liber Alssumae, in CSCO, Script. Aeth. Ser altua, t. VIII, pp. $1-86$ (text), 1-104 (tr.), 1910.

Acta Sancti Abakerezun et Sancti Takla Hawaryat, in CSCO, Script. Aeth. Ser. altua, t. XXIV, pp. 1-135 (text), 1-120 (tr.), 1910. For another version of Gedle Tekle Hawaryat see No. 10 in the above list of unpublished hagiographies.

"Il libro delle leggende e tradizloni abissine dell'ecciaghiè Filpos", in RRAI, ser. 5 Vol. XXVI (1917), pp. 699-717.

"La Caduta della dinastia Zague e la versione amarica del Be'ela Negast" in RRAI, ser. $\nabla, \nabla 01$. XXXI (1922), pp. $279-314$.

"Note di agiografia etiopica ('AbiyaEgzi', 'Arkaledes e Gabra Iyesus)", in RSO, Vol. XVII (1938), pp. 409-52.

"Un santo eritreo : Buruk Amlàk", in RRAT, ser. 6, Vol. XIV (1938), pp. $1-48$.

Gli Atti del re Na'akuto La' 'ab, in Annali. Vol. II (1943), pp. 105-232. 
Conti Rossini, C.

Conzelmann, W.E.

Fotti, C.

Guidi, I.

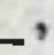

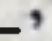

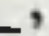

\section{,}

Pereira, F.M. Estèves de

Perruchon, $\mathrm{J}$.

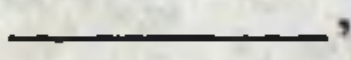

"Il libro di re Zará Ya'qob sulla custodia del Mistero", in RSE, III (1943), pp. 148-166.

"Due capitoli del libro del Mistero di Giyorgis da Sagla", in RSE, VII (1948), pp. 13-53.

Le Chronique de Galawöēwos rad d'ethiopie, Faris, 1895.

"La cronaca abreviata ded re d'Abissinia in un MS di Dabra Berhan di Gondar", in RSE, I (194I), pp. 87-123.

"Le canzoni Geez-Amarina in onore di Re Abissini", in RRAI, ser. 4, Vol. IV (1889), pp. 53-66.

Il Gadla Aragawi, in MRAL, ser. 5, Vol. II, pt. I (1896), pp. 54-96.

Il Fetha Negast o Legislazione di re, ed. \& tr., Roma, 1897-9.

See also under Le Synaxaire tthiopien below.

"Contributi alla Storia leteraria di Abissinia", in RRAL, Ser. 5, Vol. XXXI (1922), pp. 65-89.

Historia de Minas, Rei de Ethiopia, Lisbon, 1887-8.

Chronaca de Susenyos, Rei de Ethiopia, Lisbon, $1892-1900$.

Histoire des guerres d'Amde Seyon, roi d'Ethiopie, in JA, ser. $8, t$. XIV (1889), PD. 271-363, 381-493.

Vie de Lalibala, roi d'Ethiopie, paris, 1892.

Ies Chroniques de Zar'a Ya'aob et de $\mathrm{Ba}^{1}$ eda Maryam, Faris, 1893. 
Ferruchon, J.

Ricci, I.

Sentis, R. de

Turaiev, B.

Varenbergh, J.

Wajnberg, [.
Histoire d'Eskender, d'Amda-Seyon II, et de $\mathrm{Na}^{\prime} \mathrm{d}$, rois d'ethiopie, in JA, ser. 9, t. III (1894), pp. 319-66.

Le Vite di Enbaqom $\theta$ di Yohannes, abbati di Dabra Libanos di Scioa, in RSE, Vol. XIII (1954), pp. 91-120, Vol. ẌIV (1955-8), pp. 69-108.

Il Gadla Taderos de Dabra Bartarwa, in Annali Lateranensi, Vol. VI (1942), pp. 1-116.

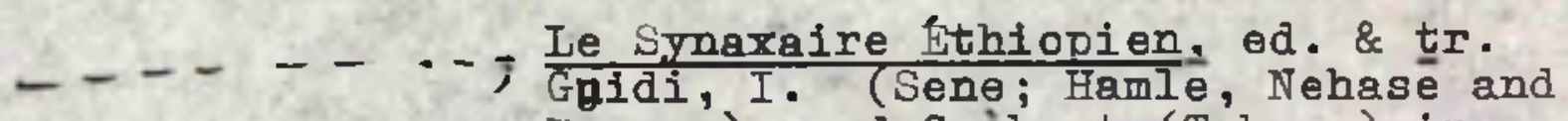
Fagume), and Grèbaut (Tahsas) in $\mathrm{EC}$, Vols. I, VII, IX, XV; XXVI, 1904-45.

Acta $S$. Aronis ot $S$. Philippi, in CSCO, Script. Aeth. ser - altera, t. XX, pp. III-26I (text), 99-234 (tr.), 1905. I have quoted these as Gedle Aron and Gedie Filippos,

respectively.

Acta S. Eustathii, the text is edited in Turaiev's collection Monumenta Aethiopiae Hagiologia, Fasc. III, Fetropoli, 1905. A Latin tr. is available in CSCO, Script. Aeth. Ser. altera, t. 21,1906, pp. 1-97. I refer to the edited text which I quote as Gedle Ewostatemos.

Acta S. Fere Mika'el et $S$. Zar'a Abraham, in CSCO, Script. Aeth., ser.altera, t. 23, 1905.

"Studien zur abessinischen Reich fordnung (Ser'ata Mangest)", in ZA, Vol. XXX (1915-6), pp. 1-45.

Das Leben des hi. Jafgerena' Egzi', in OCA, No. 106, 1936. I only refer to the edited text quoted as Gedle Yafairenne - Egzí'. 
Zer'a-Ya'qob

Arabic and Others:

Aboul Fèda

Abou Salih

Alvarez, Fr.
Meshafe-Milad, ed. by $\mathrm{K}$. Wendt under the title Das Mashafa Milad und Mashafa Sellase des Kaisers Zar'a Ya qob, in CSCO, Script. Aeth. 41, and 43. The translation of these two parts are provided - the same series, Script. Aeth. 42 and 44. I have only made use of the text.

Meshafe-Birhan, ed. \& tr. by C. Conti Rossini and L. Ricci in CSCO, script. Aeth. 47 and 48 (1964); and Script. Aeth. 51 and 52 (1965).

Góographie, tr. M. Reinaud, t. II, pt. 1, Paris, 1848.

The Churches and Monasteries of egypt and some neighbouring countries, ed. \& tr. B.T.A. Evetts, with notes by A.J. Butler, Oxford, 1895.

The Prester John of the Indies, tr. C.F. Beckingham and G.W.B. Huntingford, (Hakluyt Society, Ser. 2, Vols 114-5), Cambridge, 1961.

Arab Faqih [Chihab Futuh al-Habasha, tr. R. Basset, eddin Ahmed b. 'Abd Paris, 1897-1901. el Qader surnomme.]

Cerulli, E.

"Document arabi per la storia dell Etiopia", in MRAL, Ser. 6, Vol. IV (1931), pp. 37-101.

"Il Sultanato dello scioa nel secolo XIII secondo un nuovo documento storico", in RSE, I (1941), pp. 5-43.

"L'Etiopia mediovale in alcuni brani di Scrittori Arabi", in RSE, III (1943), pp. 272-94.

Etiopi in Palestina, 2 vols, Roma, $1943,1947$. 
Dimashqi

Ibn Haukal, Muhammad

Ibn Iyas, Muhammad ibn Ahmad

Ibn Kabar, Aba'lBarakat

Ibn Khaldun

Ibn Saba, Jean ibn d'Abou-Zakariya

Al-Khazraji, Ali ibn al-Husain

Al-Khowayter, Abdul Aziz

Maqrizi
Manuel de la Cosmographie du mojen gge, tr.M.A.F. Nehren, 1874.

Configuration de la terre, tr. J.H. Kramers, et G. Wiet, in 2 vols., Partis, 1964.

Journal d'un Bourgeois du Caire: Chronique d'Ibn Ijas, tr. G. Wiet, Vol. I (1500-1516), 1955, and Vol. II (1516-1522), 1960.

Livre de la lampe deg Ténèbres et de l'expositions (lumineuse) du Sorvice (de l'église), tr. \& ed. I. Villecourt, E. Tisserant, \& G. Wiet, in PO, XX (1929), pp. 579-733.

Histoire des Berbères et des dynasties musulmanes de l'Afrique Septentrionale, tr. de Slane, New edition, P. Casanova, Vol. II, Paris, 1927.

La Perle Préciéuge traitant des Science ecclesiastiques, ed. \& tr. J. Perier, in PO XVI (1922), pp. 593-760.

Hiatory of the Resuli.y. Dynasty of Yemen, ed. \& tr. J.M. Redhouse. 1906-8.

A critical edition of an unknown source of the life of al-Malik al-Zahir Baibarg, in 3 vols., Ph.D. Thesis, London, 1960.

Historia Regum Islamaticorum in Abysginia, ed. \& tr. F.T. Rinck, Leiden 170. [at the library of SOAS there is an Fnglish translation from the Latin version of this work by G.W.B. Huntingford, in typescript].

Les Fetes de Coptes, ed. \& tr. R. Griveau, in PO, $\bar{X}(1915)$, pp. 315-342. 
Wufazzal, Ibn Abil-Fazal

Perruchon, J
Histoire des Sultans Mamlouks, ed. \& tr. E. Blochet, in PO, Vol. XII, XIV, XX, 1919-29.

"Frtrait de la vie d'Abba Jean, $74^{\ominus}$ patriarche d'Alexandrie,

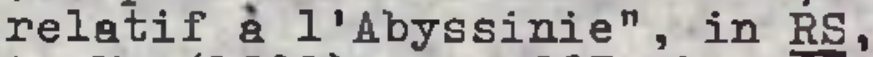
t. VI (1898), pp. 267-7I, 365-72; t. VII (1899), pp. 76-85.

Quatremère, Etienne

Memoires seographioue et historiques sur l'errote et sur quelques contries voisines, in 2 vols., Paris, 1811.

Renaudot, Eus.

\section{AI Sakhawi}

Sawirus (ibn alMukaffa), bishop of al-Asmunin

Tighri Birdi,

Tuguf Abu $-/^{i}$ Mahasin Ibn

Umarah

A ;-'Umari, Ibn Fac̣l Allah

Al-Yaqubi, 1bnWaḍigr
Historia Patriarcharum Alexandrinorum, Paris, 1717.

Al-Tibr al-Masbuk (845-57 A.…), Cairo, 1896. (The relevant parts in this work were kindly translated for me by Dr. J. Wansbrough).

History of the Patriarchs of the Egrptian Church :

Vol I (to 849 A.D.), ed. \& tr. by B.T.A. Bvetts in PO, t. I, V, $X$, and XI, 1904-15.

Vol. II (849-1102), tr. by Yassa 'Abd Al-Masih, Aziz Suryal Atiya, and O.H.E. Khs-Burmester, 1943-59.

History of Egypt, tr. W. Popper, Parts III, and IV, 1957-60.

$\frac{\text { Yaman, its earl. Medieval History, }}{\text { ed. \& tr. H.C. Bay, Iondon, } 1892 .}$

Masalik al-Absar Fi Mamaltk El Amsar : I l'Afrique moins I'tgrote, tr. by Gavefroy-Domombynes, Paris, 1927.

Historige, ed. Th. Houtsma, Vol. I, 1883 .

Livre des Pays, tr. G. Wiet, 1937. 
SECONDARY SOURCES

Abbadie, Antoine d. - Geographie de l'Ethiopie, Vol. I, Paris, 1890.

Almeida - Some Records of Ethiopia 1593-1646, Extracto tr. by C.F. Beckingham and G.W.B. Huntingford (Hakluyt Soc., Ser. 2, 107), 1954 .

Annequin, G. -Notes on Djibat and Adadi Maryam", in AE, VI (1965), ph-13-16.

Azais, R.P. and Chambard, R. - Cing annees de recherches archeologiques en Ethiopie, 2 vols.. Faris, 1932 .

Basset, R. - "Deux lettres ethiopiennes du XVI siecle", in GSAI, vol. III (1889), pp. 59-79.

- "Les inscriptions de I'lle de Dahlak", in JA, ger. 9, vol. I (1893), pp. 77-111.

Beckingham, C.F. - "Amba Geshen and Asirgarah", in JSS, II (1957), pp. 182-188.

- "A note on the topography of Ahmad Gragn's campaigns in 1542", in JSS, IV (1959), pp. $362-373$.

- "Notes on an unpublished MS. of Fr. Alvarez", in AE, IV (1961), pp. 139-154.

- "Pantaleao de Aveiro and the Ethiopian Community in Jerusalem", in ISS, VII (1962), pp. 325-338.

Berchet, G. - "Lettera sulle cognizioni che 1 Veneziani avevano dell'Abissinia", in BSGI, II (1869), pp. 151-170.

Bermudez and Castanhoso - The Bortuguese Expedition to Abyesinia in 154l, tr. R.S. Whiteway, (Hakluyt soc.), I902. 
Bruce, J. - Travels to discover the sources of the Nile in the years $1768,1769,1770,1771_{1}$ T772 and 1773 , London, 1790, 5 vold.

Budge, E.A.W. - A History of Ethiopia: Nubia and Abyssinia, in 2 vols., London, 1928.

Buxton, D.R. - "The Christian Antiquities of Northern Ethiopia", in Archeologia, vol. XCII (1947), pp. $1=42$.

Cagot, A. - "Apercu preliminaire sur le Mashafa Tefut de Geshen", in $\underline{\underline{A E}}$, I (1955), pp. 89-109.

- "Ia royaute sacrale en Ethiopie", in $\underline{\mathrm{AE}}$, II (1957), pp. 205-219.

Cerulli, E., - Note su alcune popolazioni Sidama dell'Abyssinia meridionale", in RSO, vol. X $(1923-5)$, pp. 597-692.

- Nugenio IV e gli Etiopi al Concilio di Firenze nel 1441", in RRAL, ser. 7, vol. IX (I933), pp. 347-368.

- Etiopia Occidentale, in 2 vols., Roma, 1933.

- Studi Etiopici:-

Vol.I : $\frac{\text { Ia Lingua e la atoria di }}{\text { Harar, Roma, } 1936 .}$

Vol.II : La lingua e la storia de1 Sidama, Koma, 1938.

Vol.III : Il Linguaggio dei Giangero ed alcuni lingue sidama der I'omo, Roma, 1938.

Vol. IV : Ia Lingua Caffina, Roma,

- "Gli abbati di Dabra Libanos", etc., in Orientalia, vols. XI (1943), pp. 226-253; XIII (1944), pp. 137-182; XIV (1945), pp. 143-171.

- Storia della letteratura etiopica, Roma, 1956. 
- "Punti, di vista sulla storia dell'Etiopia", in Atti del Convegno Intern di Studi Etiopici, Roma, 1960.

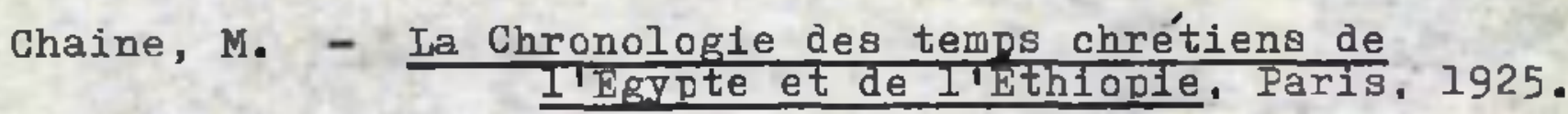

- "Un monastère Ethiopien a Rome au XV et XVI Siècles : San stefano dei Mori", in Melanges de la Faculté Orientale. Beyrouth, t. V (1910), pp. I - 36.

Cohen, M. - "Dabra Warq", in Mélanges René Basset, t.I, (1923), pp. 143-162.

- Etudes d'Ethionje méridionale, Paris, 1931.

Conti Rossini, C. - "Note etiopiche", in GSAI, vol. $\mathbb{Z}$ (1897), pp. 141-156.

- "Sulla dinastia Zague", in I'Oriente vol. II (1897), pp. 144-159.

- "Tradizione storica dei Mensa", in GSAI, voI. XIV (1901), pp. 4I-99.

- "Lettera a J. Halévy sulla caduta degli Zague", in RS, X (1902), pp. 373-377; XI (1903), pp. 325-330.

- "Per la conoscenza della lingua Cunama", in GSAI. XVI (1903), pp.187-227.

- "Al Ragali", in Boll. Soc1. Ital. d'Eaplor.geog. e Comm., 1903-4, pp. 3-62.

- "I Leggo e la legge dei Loggo Sarda", in GSAI, XVII, pt. $1(1904)$, pp. 1-63.

- "Appunti sulla lingua Khamta del l'Averghelle", in GSAI, XVII, pt. 2 (1905), pp. 183-242.

- "Appunti sulla lingua awiya del Dangla", in GSAI, XVIII (1905), pp. 103-194.

- "Sugli Habašat", in RRAL, ser. 5 , vol. XV (1906), pp. 39-59. 
- "Racconti e Canti bileni", in Actes du XIV Congrè̀ Intern. des Orient, Vol. II, Paris, 1904, pp. 331-394.

- "II convento di Tsana in Abissinia e le sue Latdi alla vergine", in RRAL, ser. 5, vol. XIX (1910), pp. 58I-62i.

- "Studi su popolazioni dell'Etiopia", in RSO, vols. III (1910), pp. 849-900; IV (1912), pp. 599-651; VI (1913), pp. 365-425.

- "Piccoli studi etiopici", in ZA, v0l. XXVII (1911), pp. 358-372.

- Li La Langue deskemant en Abyssinie,

- "Il 'Libro del Conoscimento' e le sue notizie sull'Etiopian, in BSGI, ser. 5, vol. VI (1917), pp.656-679.

- "Popoli ditiopia occidentale", in RRAL, ser. 5, Vol. XXX (1919), pp. 251-285, 319-325.

- "Appunti di Storia e letteratura Falascia", in RSO, vol. VII (1920), pp. 563-6io.

- "Nuovi appunti sui Giudei d'Abissinia", in RRAI, ser. 5, Vol. XXXI (1922), pp. $22 \mathrm{I}-240$.

- "Un codice illustrato eritreo del Secolo XV", in Africa Italiana, I (1927), pp. 83-97.

- Storia d'Etiopia, Milano, 1928.

- Etiopia e genti d'Etiopia, Firenze, 1937.

- "I'agiografia etiopica e gli Atti del Santo Yafqeranna-Egzi (secolo XIV)", in ARIV, vol. XCVI, pt. 2 (1937), pp. $403-433$. 
- "Pergamene di Debra Dammon, in RSO, Vol. XIX (1940), pp. 45-80.

- "Sulle missioni domenicalne in Etiopia nel secolo XIV", in RRAL, ser. 7, Vol. I (1940), pp. $71-98$.

- "Marco Polo e I'Rtiopia", in ARIV, Vol. XCIX, pt. 2 (1940), pp. 1021-1039.

- "Il 'Senodos' etiopico", in RRAL, ser. 7, Vol. III (1942), pp. 41-48.

- "Sul metropolita Yeshaq d'Etiopia (secolo XV-XVI)", In RRAI, ser. 8, Vol. I (1946), pp. 7-I7.

- Tabelle comparative del calendario etiopico col Calendario romano, Roma, 1948 .

Crawford, O.G.S. - Ethiopian Itineraries c.1400-1524, (Hakluyt Soc., ser. 2, vol. 109), I958.

Creone, Fr. - "La Politica Orientale di Alphonso di Aragone", in Archivio Storico per le Provincie Napolitane, voll. XXVII (I902), pí. 1-93; XXVIII (1903), pp. 154-202.

Dillmann, A. - Catalogus Codicum Manuscriptorum Orientalium qui in Museo Britanico asservantur, Pars Tertia, London, 1847 .

- Catalogus Codicum Manuscriptorum Bibliotbecal Bodelianae Oxonlengig, Pars VII, 1848.

- Die Kriegsthaten des Koniga 'Amda Syon,

- Uebeddie Regierung insbesonderre die Kirchchênordnung des Konigs Zarla Jacob. Eerlin, 1884 .

Doresse, J. - L'Empire du Prêtre-Jean, in 2 vols., Paris, 1957.

Drewes, A.J. - Inscriptions de I'Ethiopie antique,

Leiden, 1962 . 
Fllerof, G. - "I conventi dello scire e le loro leggende", in BSGI. ser. 7, vol. IV (1939), pp. $835-853$.

- "Note sull'Enderta", in RSE, Vol. I (I941).

Fumagali, G. - Bibliografia Etiopica, Milano, 1893.

Garrone, v. - "Gl Atcheme Melga", in BSGI, ser. 4, vol. v (1904), pp. 994-10Г7.

Gill, J. (S.J.) - The Council of Florence, 1959.

Ghinzoni, P., - "Un ambasoiata del Prete Gianni a Roma", in Archivio Storico Lombardo, v01. VI, Anno XVI (1889), pp. 145-154.

Grebaut, S., - "Table de Comput et de Chronologie", in ROC, I (1918/9), pp. 324-326.

- "Note sur la princess Zir-Ganēla", In JA, 1928, pp. 142-1144.

- "Disciplina Alessandrina : II Etiopi", in Codificazione Canonica Orientale, ser. I, fasc. 8, 1932, pp. 73-85.

Guidi, I. - "Le liste dei metropoliti d'Abissinia", in Bessarione, vol. VI (1899), pp. 1-17.

- "Uno Squarcio di Storia ecclessiastica", in Bessarione, vol. VIII (1900), pp. 10-25.

- "La chiesa Abissina", in OM, II (1922), pp. 123-128, 186-190, 252-256.

- (Breve) storia della leteratura etiopica, Roma, 1932.

Haberland, $\mathbb{R}$. - "The influence of the Christian Ethiopian Empire on Southern Ethiopia", in JSS, IX (1964), pp. 235-238.

- Intersuchungen 2um Athiopischen Konigtum. Wiesbaden, 1905. 
Hartmann, M. - "Der Nagasi Asham und Sein Sohn Arma", in ZDMG, vol.'49 (1895), pp. 299-300.

Hasan, Yusuf Fadl. - The Arabss of the Eastern Sudan (Th 16th C.), Ph.D. Thesis, London, 1965. This has just been published under the title The Arabs and the sudan from the Seventh to the early sixteenth century. 1967. Because of shortage of time I was not able to consult the published work.

Irvine, A.K. - "On the identity of the Habeshat in the South Arabian Inscriptions", in JSS, vol. X (1965), pp. 178-196.

Johnson, A.R. - Sacral Kingship in Ancient Israel, Cardiff University Press, 1955.

Jorga, N. - nCenni sulle relaxioni tra l'Abissinia e l'Europa Cattolica nei Secoli XIV -XV", in Centenario di M. Amari. II (1910), pp. 139-150.

Kammerer, A. - Essai sur l'histoire antique d'Abyssinie. Paris, 19z6.

- La Mer Rouge, l'Abysoinie et l'Arabie depuis l'antiquite, Cairo, 1929.

Kolmodin, J. - Traditions de Taazzega et Hazzega, in AEO, vol. 5: 1, 2, 3, Upsala, 1912-1914.

Lantschoot, A. Wan. - "Abba Salama metropolite dithiopie (1348 88) et son role de traducteur", in Atti del Convegno di Studi Etiopici. Roma, 1960, pp. 397-401.

La Ronciere, Ch.de. - Ia Découverte de l'Afrique au moyen age, in 3 vols., Cairo, 1924-7.

Lefevre, R. - "G.B. Brocchi da Imola diplomatico pontifico e viagglatore in Etiopia nell'400", in BSGI, vol. IV (1939), pp. 639-659.

- nocumenti Pontifici sui Rapporti con l'Etiopia nei oecoli XV e XVI", in RSE, V(1946), pp. 16-4l. 
Leonessa, P. Mauro da. - nUn trattato sul Calendario redatto al tempo di re "Ande-Tsion I", in RSE. III (1943), pp. 302 -

Leslau, W. - "The influence of Cushitic on the Semitic languages of Ethiopia: A problem of substratum", in Word, I (1945), pp. 59-82.

- Falasha Anthology. New Haven, 1951.

- "The influence of Sidamo on the Ethiopic language of Gurage", in Ianguage, vol. XXVIII (1952), pp. 63-81.

- "A short chronicle on the Gafat", in RSO. vol. XII (1966), pp. 189-198.

Lewis, B. - "The Fatimids and the Route to India", In Revue de la Faculte des sciences Economiques Univ. Istanbul. vol. XI (1949-50), pp. 50-54.

Littman, E. - Deutsche Aksum - Expedition, t. IV, 1913.

- "Arabische Inschritten aus Abissinien", in ZS, Bd. III (1925), pp. 236-46.

Ludolf, F. - A New History of Ethiopia, London, 1682.

- Commentarius ad Suam Historiam Aethiopicam. Frankfurt, 1691.

Monneret de Villard, U. - Storia della Nubia Cristiana. Roma, 1938.

- "Su una possibile origine delle danze liturgiche nella chisa Abissina", in OM, t. XXII (1942), pp. 389-391.

Mordini, A. - "Il convento di Gunde-Gundie", in RSE, XII (1953), pp. 29-

- "Un tissu musulman du moyen-âge provenant de Dabra Dammo", in $\underline{\text { E }}$, II (1957), pp. 75-83. 
Muyser, J. - "Le Samęi e le Dimanche dans I'Eglise et la Iittérature Copte", Appendix to Togo Mina, Le Martyre d'Apa Epima, Cairo, 1937, pp. 89-1I1.

Richard, J. - "L'extrême-orient légendaire au Moyeb-Age. Roi David et Pretre Jean", in $\underline{A E}$, II (1957), pp. 225-245.

Rodinson, M. - "Sur la question des 'influences JuIves' em Ethiopie", in JSS, vol. IX (1964), pp. $11-19$.

Rossi, E. - "Sulila storia delle isole Dahlak nel Medioevo", in Atti del $3^{\circ}$ Congresso Studi Coloniale, $1937, \mathrm{pp} .367-375$.

Sauter, R. - "Iteglise monolithe de Yaka Mika'el", in AE. II (1957), pp. 15-37.

- "Ou en est notre conaissance des Eglises rupestres dithiopien, in $\mathrm{AE}, \mathrm{V}$ (1963), pp. 235-292.

Strel6yn, S. - Catalogue des MSS Ethiopiens (Collection

Tisserant, E. and Grebaut, S. - Codices Aethiopici,

Vaticani et Borgiani, Barberinianus

Orientalis 2 Rossianus 865 , Vatican Iibrary, 1935.

Trasselli, C. - "Un Italiano in Etiopia nel XV secolo: Pietro Rombulo da Messina", in RSE, I 1941, pp. 173-202.

Trimingham, J.S. - Iglam in Ethiopia, 1952.

Mubiana, J. \& notes sur la distribution géographique des dialectes Agawn, in CAA, No. 5, 1959, pp. 1-12.

Ullendorff, E. - Catalogue of Ethiopic MSS in the Bodleian Library, Oxford, 1951 .

- "The Ethiopic MSS in the Royal Iibrary of Windsor Castlen, in RSE, vol. XII (1953), pp. 71-79. 
- The Semitic Languages of Ethiopia. London, 1955 .

- "Hebraic - Jewish elements in Abyssintan (Monophysite) Christianity", in JSS, I (1956), pp. 216-256.

- Catalogue of Fthiopic MSS in the Cambridge University Library, 1961.

Wansleb, J.M. - Histoire de I'Eglise d'Alexandrie, Parig, 1677.

Wiet, G. - "Le Relations Egypto-Abyssines sous les Sultans Mamluks", in BSAC, Vol. IV, 1938, pp. 115-140.

- "Roitlets de Dahlak", in BIE, tom. 34 (1951/2), pp. 85-95.

- "Les marchands d'épices sous les Sultans Mamluks", in $\mathrm{CHE}$, VII (1955), pp.81-147.

Witte, ch. - M. de - "Une ambassade éthlopienne à Rome en 1450", in OCP, XXI (1956), pp. 286298.

Wright, St. - "Notes on some cave churches in the Province of Wello", in $\mathrm{AE}$, II (1957), pp. 7-13.

Wright, W. - Catalogue of Ethioplc MSS in the Britisin Museum, London, 1877 .

Zanutto, Bibliografia Etiopica : Manoscritti Etiopici. Rome, 1932.

Zotenberg, H. - Catalogue des MSS ethiopieng de la Bibliotheque Nationale, Paris, 1877. 


\section{ABBREVIATIONS}

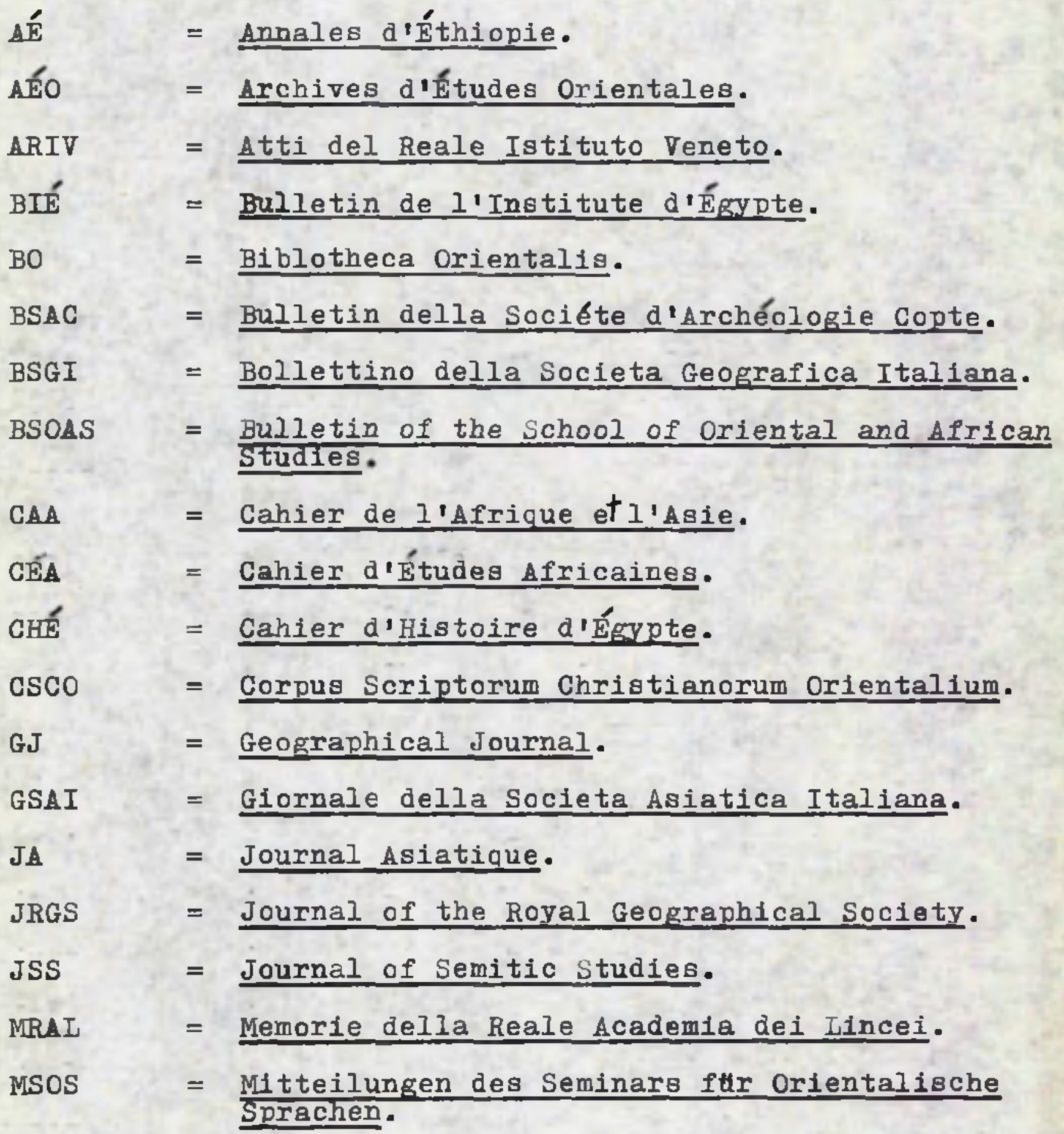




$\begin{array}{ll}\text { OCA } & =\text { Oriente Cristiana Analecta. } \\ \text { OCP } & =\text { Oriente Cristiana Periodica. } \\ \text { OM } & =\text { Oriente Moderno. } \\ \text { PO } & =\text { Patrologia Orientalis. } \\ \text { ROC } & =\text { Revue deli' Orient Chretien. } \\ \text { ROI } & =\text { Revue de l'Orient Latin. } \\ \text { RRAL } & =\text { Rendiconti della Reale Academia dei Lincei. } \\ \text { RS } & =\text { Revue Sémitique. } \\ \text { RSE } & =\text { Rassegna di Studi Etiopici. } \\ \text { RSO } & =\text { Rivista degli studi Orientali. } \\ \text { SNR } & =\text { Sudan Notes and Records. } \\ \text { ZA } & =\text { Zeitschrift fur Assyriologie. } \\ \text { ZDMG } & =\text { Zeitschrift der Deutschen Morgenlandischen } \\ \text { GS } & =\text { Gegellschaft. }\end{array}$

